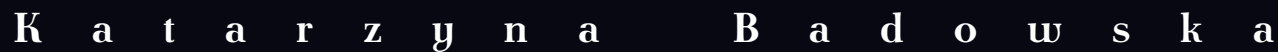

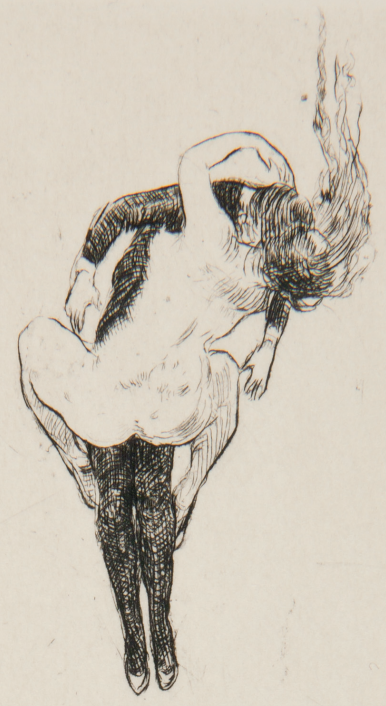

\title{
„Godzina cudu”
}

Miłość i erotyzm u tuórczości Stanisława Przybyszewskiego

\section{少}

Wydawnictuo Uniwersytetu Łódzkiego • Łódź 2011 
Katarzyna Badowska

„Godzina cudu”

\section{Miłość i erotyzm u tuórczości Stanisława Przybyszeuskiego}

Wydawnictwo Uniwersytetu Łódzkiego • Łódź 2011 
Redakcja naukowo-dydaktyczna

„Folia Litteraria Polonica”

Barbara Bogołębska, Marzena Woźniak-Łabieniec

\author{
Recenzent \\ Wojciech Gutowski \\ Opracowanie techniczne, skład i łamanie \\ Tomasz Kuc \\ Korekta \\ Małgorzata Gołab, Katarzyna Badowska \\ Projekt okładki \\ Katarzyna Badowska \\ Na okładce:
}

Konstanty Brandel, L'Araignée - Pająk, 1908, sucha igła, w zbiorach Muzeum Narodowego w Krakowie

Wydrukowano z gotowych materiałów
dostarczonych Wydawnictwu Uniwersytetu Łódzkiego

(C) Copyright by Wydawnictwo Uniwersytetu Łódzkiego, Łódź 2011

\author{
Wydawnictwo Uniwersytetu Łódzkiego \\ 90-131 Łódź, ul. Lindleya 8 \\ Wydanie I. Nakład $100+31$ egz. \\ Ark. druk. 19,0. Papier kl. III, 80 g, 70 x 100 \\ Zam. 4960/2011. Cena zł 36,- + VAT
}

ISBN 978-83-7525-597-3

https://doi.org/10.18778/7525-597-3 


\section{Spis treści}

Część I. Fenomen Przybyszeuskiego - w erotycznej aurze epoki, w oczach krytyki ................................................................................................................. 13

Erotyzm u Młodej Polsce .......................................................................................... 13

Młodopolska literatura „pornograficzna” ................................................................... 19

Literackie dojrzewanie Przybyszewskiego ………………………………………….. 26

Życie i twórczość Przybyszeuskiego na tle epoki .................................................... 32

Twórczość Przybyszeuskiego w oczach uspółczesnych ........................................ 37

Ze szkoły młodopolskiego „archicygana” ............................................................... 47

Recepcja twórczości po śmierci pisarza …………………………………………….... 50

Część II. Miłość - siła tuórcza i niszcząca. Miłosne idee, teorie, koncepcje i scenariusze .................................................................................................... 55

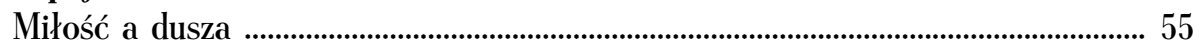

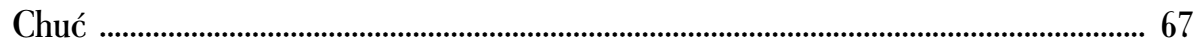

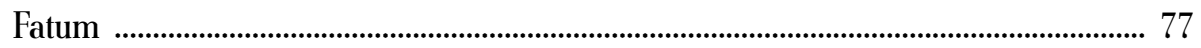

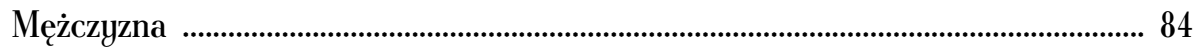

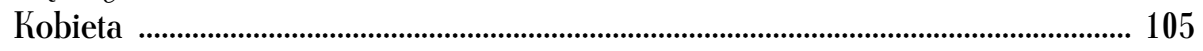

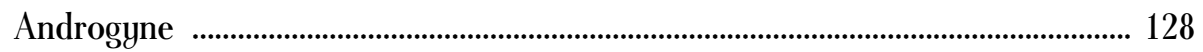

Miłość a moralność ……………………………………………………………..... 147

Miłość a cierpienie ................................................................................................ 156

Inne uczucia i stany towarzyszące miłości ………………………………………... 170

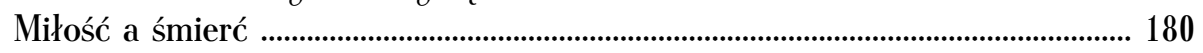

Część III. Wyobraźnia erotyczna. Obrazowanie i symbolika ............................ 191

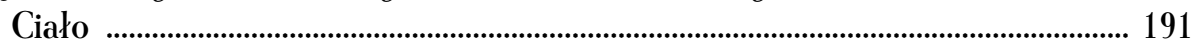

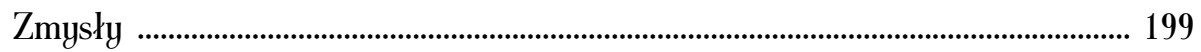

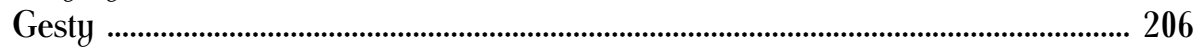

Pożądanie i akt seksualny ...................................................................................... 214

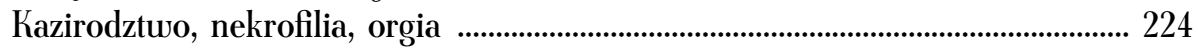

Erotyczne florarium ................................................................................................. 233 
Erotyczne bestiarium

Libido wobec sfery sacrum

Symbolika żyuiołów

Przestrzenie erotycznej wolności

Zakończenie

Wykaz skrótów najczęściej cytowanych utworów

Stanisława Przybyszeuskiego

Bibliografia 


\section{Wstęp}

Dzieła Stanisława Przybyszeuskiego, głęboko wpisane w światopogląd modernizmu, należały na przełomie XIX i XX stulecia do najgłośniejszych i najsilniej oddziałujących zjawisk polskiego, a także europejskiego, życia kulturalnego ${ }^{1}$. Nie spełniały funkcji mimetycznych, jakich w ouym okresie oczekiwała od literatury znaczna część wychowanych w pozytywizmie czytelników, a mimo to były niezuykle popularne. Bez wątpienia upływ na ich poczytność miała demoniczna, intrygująca osoba autora, ale róunież walor formalnego i ideowego nowatorstua, jaki ze sobą niosły. Dyskutowano o nich szeroko, wypowiadając krańcowo różne opinie, w których podziw i fascynacja przeplatały się z oburzeniem i zarzutami grafomanii. $\mathrm{O}$ żywym zainteresowaniu Przybyszeuskim świadczą peryfrazy, jakimi zastępowano w epoce jego nazuisko. Mówiono więc o nim genialer Pole, polski poète maudit, smutny szatan, wódz bohemy, archicygan, budziciel duszy, arcykapłan synagogi szatana, wielki dziennikarz metafizyki². A jednak jego utwory bardzo szybko skazane zostały na literacki niebyt w procesie, w którym poszlaki - w rodzaju emocjonalnych oskarżeń o „ruję i poróbstwo” oraz „zrobaczoną zmysłowość" - funkcjonowały zamiast rzetelnych naukowych dowodów. Opatrzone fiszką "gorszące i manieryczne” wypadły z czytelniczego obiegu, na długie lata przysłonięte osobowością ich autora. Dopiero od niedawna - za sprawą publikacji Wojciecha Gutouskiego, Gabrieli Matuszek, Edwarda Bonieckiego i Pawła Dybla - zaczyna się dostrzegać

${ }^{1}$ Znaczeniu osoby i tuórczości Przybyszeuskiego dla literatur i kultur obcych pośuięcono u Polsce trzy obszerne publikacje naukowe: Gabriela Matuszek, Der geniale Pole? Niemcy o Stanistawie Przybyszewskim (1892-1992), Kraków 1996; Patrycja Kawalec, Stanisław Przybyszewski w czeskim świecie literackim, Kraków 2007; Andriej Moskwin, Stanisław Przybyszewski w kulturze rosyjskiej końca XIX - początku XX wieku, Warszawa 2007. Zob. też m.in. H. Schmid, Znaczenie Stanisława Przybyszewskiego dla rozwoju eksperymentalnego teatru Wsiewołoda E. Meyerholda, „Ruch Literacki” R. 31:1990, z. 6, s. 419-433; G. Bąbiak, Między Berlinem, Praga a Warszawa. Przybyszewski - Procházka - Przesmycki, [w:] Czytanie modernizmu, red. M. Olszeuska i P. Bąbiak, Warszawa 2004, s. 11-26; R. Shenfeld, Obecność Stanisława Przybyszewskiego w literaturze hebrajskiej na przetomie XIX i XX wieku, [w:] Stulecie Młodej Polski, red. M. Podraza-Kuiatkouska, Kraków 1995, s. 377-390.

${ }^{2}$ A. Z. Makowiecki, Trzy legendy literackie, Warszawa 1980, s. 80-83. 
w Przybyszeuskim oryginalnego myśliciela ${ }^{3}$. Na razie autor Homo sapiens nie doczekał się jednak nie tylko pełnego opracowania naukowego, ale nawet ponownej edycji wszystkich suych dzieł - znaczna ich część (poza poematami prozą opracowanymi krytycznie przez Gabrielę Matuszek i opublikowanymi przez Wydawnictwo Literackie w 2003 r.) pozostaje u trudno dostępnych i zdekompletowanych wydaniach z pierwszego duudziestolecia ubiegłego wieku. Wypowiedzi o twórczości Przybyszewskiego - choć coraz liczniejsze - rozsiane są w zasadzie po artykułach, szkicach i rozprawkach, których autorzy nierzadko analizują utwory pisarza w kontekście jego przeżyć i osobowości oraz w oparciu o jego legendę. Od psychologizmu nie stronią również nowsze opracowania (np. artykuły B. Chołuj, J. Ratajczaka czy A. Sucharskiej - zob. Bibliografia), tymczasem przejście od twórcy do dzieła z konieczności prowadzić musi do sądów uogólniających i fałszywych rozstrzygnięć. Niniejsza książka jest próbą zsyntetyzowania wiedzy o problematyce miłosno-erotycznej u dorobku autora Śniegu, za podstawę bierze zaś utwór jako autonomiczną całość, co pozwala ograniczyć możliwość nadinterpretacji i zrozumieć, jak wiele sądów o pisarstuie Przybyszeuskiego nie znajduje poparcia w samym tekście. Dokumentacji badań służy obszerny materiał - przedmiotem analizy stało się sześć poematów prozą, jedenaście dramatów oraz osiem powieści (w tym dylogie i trylogie). Świadomie zrezygnowano z pogłębionego wartościowania estetycznego poszczególnych utworów.

Wybór tematu podyktowany został chęcią obiektywnego zbadania znaczenia, jakie Przybyszeuski, oskarżany o szerzenie pornografii, ale i nazywany prefreudystą, nadał problematyce miłosnej, podstawowej dla swej twórczości, jak też szeroko obecnej $w$ artystycznym dorobku całego modernizmu. Inwazja erotyki w literaturze była tendencją pouszechną w epoce. Erotyzm - pod wpływem dążeń emancypacyjnych kobiet, kryzysu tradycyjnej moralności, badania treści podświadomych, dążenia sztuki do pełnej autonomii itp. - przestał być dla artystów tematem tabu. Jako podstawowe doświadczenie egzystencjalne i metafizyczne eksponowany był zaróuno w najlepszych dziełach modernistycznych, jak i w lekturach dla czytelnika masowego. Nie ma wątpliwości, że na przełomie XIX i XX w. narodziła się nowa świadomość płci, a wraz z nią - kształtowana m.in. przez Przybyszeuskiego - nowa artystyczna postawa wobec erotyki ${ }^{4}$.

${ }^{3} \mathrm{~W}$ roku 2008 ukazały się duie ważne publikacje o kolosalnym znaczeniu dla badań nad Przybyszeuskim: W. Gutouski, Konstelacja Przybyszewskiego, Toruń 2008 oraz G. Matuszek, Stanisław Przybyszewski - pisarz nowoczesny. Eseje i proza - próba monografii, Kraków 2008.

${ }^{4}$ Zob. publikację Nowa świadomość ptci w modernizmie. Studia spod znaku gender w kulturze polskiej i rosyjskiej u schytku stulecia, red, G. Ritz et al., Kraków 2000. 
Konieczne staje się uyjaśnienie, jak rozumiane będą tutaj pojęcia miłości i erotyzmu. Od razu trzeba zastrzec, że sformułowanie ich jednoznacznych, niebudzących wątpliwości definicji nie jest możliwe, ponieważ dotyczą one skomplikowanej sfery uczuć i - jako takie - są ułaściwie niedefiniowalne. Bywa, że mimo braku typowego słownictwa erotycznego odpowiednie znaczenie uskazuje kontekst użycia słów, ich wieloznaczność i specyficzne połączenia, a także warstwa obrazowa utworu. W czasach, kiedy tworzył Przybyszeuski, pojęcie erotyzmu nie było znane. Nie notuje go ani Encyklopedia powszechna z ilustracjami $i$ mapami Samuela Orgelbranda (18 tomów, Warszawa 1898-1904), ani Wielka encyklopedia powszechna ilustrowana (48 tomów, Warszawa 1890-1912). Wymienione kompendia zawierają jedynie hasło erotomania, objaśniane jako obłęd miłosny lub choroba umysłu, kiedy to chory nieustannie myśli o przedmiocie suej miłości. Przybyszeuski nie posługiwał się także terminem seks, który nie był odnotowywany przez polskie słowniki medyczne do czasów II wojny światowej. Anna Sucharska twierdzi jednak, że pisarz przeczuwał jego zakres treściowy, gdy mówił o ptciowości (pojęcie to należy oddzielić od chuci i $p t c i)^{5}$. Niektóre kompendia epoki notowały co prawda słowo seksualny w znaczeniu płciowy, dotyczący stosunków płciowych, ale na przykład tzw. słownik warszawski zastosował przy nim kwalifikator !, oznaczający uyraz, jakiego „unikać należy”. Funkcjonował natomiast termin erotyka, którego sens naświetla bardzo enigmatycznie i ogólnikowo - jako naukę o miłości i poezję miłości - jedynie Podręczna encyklopedia powszechna, redagowana przez Adama Wiślickiego z "Przeglądu Tygodniowego”. Definicja ta o tyle pozostawia do życzenia, że odwołuje się do pojęcia miłości rozumianej $w$ drugiej połowie XIX - przynajmniej oficjalnie - wyłącznie jako jedna $\mathrm{z}$ cnót teologicznych, obok wiary i nadziei (takie jej wyjaśnienie znajdziemy we wspomnianych encyklopediach), albo jako związek małżeński służący prokreacji. Maks Nordau, niemiecki pisarz i psycholog, znienawidzony przez modernistów za konserwatywne poglądy, w tym na literaturę i sztukę, pisał:

Miłość zdrowa i naturalna zausze zdaje sobie jasno sprawę, do czego zmierza: jej dążeniem jest nic innego, jak chęć posiadania istoty kochanej, czyli dążenie do działania, mogącego dać potomków ${ }^{8}$.

\footnotetext{
${ }^{5}$ A. Sucharska, Stanisław Przybyszewski. Miłość: „Rozślizłe prześcieradło moich uczuć”, „Metafora” 1992, nr 5, s. 7-8.

${ }^{6}$ Stownik języka polskiego, red. J. Karłowicz, A. Kryński, W. Niedźwiedzki, t. 1, Warszawa 1900, s. 9.

${ }^{7}$ Podręczna encyklopedia powszechna, red. A. Wiślicki, t. 2, Warszawa 1896, s. 465.

${ }^{8}$ M. Nordau, Miłość, tłum. W.L., Warszawa 1903, s. 16.
} 
Sposoby przedstawiania uczuć miłosnych i zachowań seksualnych, ich dopuszczalne odcienie i stopień nasilenia uzależnione są nie tylko od tendencji literackich, ale róunież od ideałów estetycznych epoki, norm obyczajowych (intymności, uczuciowości, tabu), preferowanych wzorów osobowych i koncepcji osobowości ludzkiej. Dlatego uspółczesny historyk literatury musi wypracować odpowiedni materiał pojęciowy, uwzględniający czynniki upływające $w$ danym okresie na literaturę, ale nie ograniczony nimi.

W tradycji europejskiej funkcjonują cztery sposoby rozumienia miłości: seks (zmysłowość, libido), eros (miłość dążąca do prokreacji lub kreacji, tj. - jak podkreślali Grecy - tęsknota do wyższych form istnienia i więzi między ludźmi), philia (przyjaźń, miłość braterska), agape (rzym. caritas, miłość będąca poświęceniem się dla dobra innych, prawzorem jej jest miłość Boga do człowieka). Rollo May zauważa, że u każdym autentycznym przeżyciu miłości uystępują, u różnym stopniu, uspomniane cztery jej rodzaje. Eros nie może żyć bez philia, ponieważ atrakcyjność i namiętność nie są wieczne. Philia jest wypoczynkiem w obecności ukochanego, chęcią przebywania z nim; istnieje w związku z agape, czyli szacunkiem i troską o drugiego człowieka9.

Miłość może być ujmowana także $\mathrm{z}$ innego punktu uidzenia: jako fakt (zachowania seksualne, zuiązki), jako wartość (coś, co jest przez człowieka cenione), jako przeżycie (określone stany psychiczne), jako możliwość (jaka powinna być miłość, co człowiek może w niej osiągnąć) ${ }^{10}$. Miłość erotyczna (eros) polega na równowadze udziału seksu i przeżyć o podłożu uczuciouym i intelektualnym; faktami są tu zaróuno uspółżycie seksualne, jak i uspólnota doświadczeń, szacunek, przywiązanie, chęć wzajemnej pomocy. W miłości pozaseksualnej (platonicznej) doznania seksualne nie występują lub są tłumione, dominuje uczucie, afirmacja partnera. Seks natomiast jest biologicznym substratem miłości, obejmującym zachowania i emocje związane z życiem płciowym, ale także aktem samopoznania i poznania drugiej osoby, zbliżeniem ludzi, z których każdy uyposażony jest w określoną osobowość i charakter ${ }^{11}$.

W rozważaniach o tuórczości Stanisława Przybyszeuskiego zostaną uwzględnione uymienione uyżej sposoby pojmowania miłości i erotyki, ze uskazaniem na ujęcia i motywy dla pisarza specyficzne. Najogólniej można powiedzieć, że przedmiotem zainteresowania będą relacje o podłożu emocjonalnym i seksualnym, zachodzące między dwojgiem ludzi przeciunej płci.

Lektura dzieł Przybyszeuskiego pozwala stuierdzić, że pisarza cechowała wyjątkowo konsekwentna postawa artystyczna i ideowa. Autor Złotego runa do końca życia pozostał wierny rozwijanym już $\mathrm{w}$ pierwszych utworach koncepcjom na temat miłości i płci, pouracał też do raz użytych obrazów i sensów,

\footnotetext{
${ }^{9}$ R. May, Miłość $i$ wola, tłum. H. i P. Śpiewakowie, Warszawa 1978, s. 55.

${ }^{10}$ M. Gołaszewska, Imiona miłości, Kraków 1992, s. 129-130.

${ }^{11}$ Ibidem, s. 12-14.
} 
co w praktyce oznaczało nierzadko powielanie własnych pomysłów i uzorów. Starał się uykładać swoje credo zarówno w poematach, powieściach czy dramatach, jak w deklaracjach programowych i rozprawach. Dlatego wszystko, co w jego pomysłach było zrazu oryginalne i nowe, szybko znużyło czytelników monotonią. Niemniej dzięki temu cała jego twórczość składa się na spójny system myślowy, zawierający konkretną wizję świata, w której przeżycie miłosne służy poznaniu indywidualnej, lecz upisanej w transcendentalny porządek jaźni, a więc odkryciu praw rządzących istnieniem. Z uwagi na ową powtarzalność problematyki lepszym rozuiązaniem badawczym okazała się rezygnacja z chronologicznego omawiania utworów na rzecz poszukiwania uspólnych tematóu i ujęć. Analiza nie opiera się więc tutaj na opisie poszczególnych fabuł, lecz ma charakter lub teleologię syntezy: wychodzi od interpretacji poutarzających się obrazów, symboli, wątków i innych elementów kompozycyjnych, by doprowadzić do pokazania rozuijanej przez Przybyszeuskiego uizji miłości i erotyzmu. Mimo starań, próba systematyzacji nie zausze może doprowadzić do uydzielenia przejrzystych, nienakładających się na siebie motywów i typów uyobrażeń. Nieuniknione redundancje, powracanie do tych samych bądź podobnych obrazów w odmiennych kontekstach pozwala jednak odkrywać coraz to głębsze znaczenia i służy dokładniejszej, bardziej uszechstronnej interpretacji.

Wypada jeszcze wytłumaczyć się, że podjęte w rozprawie analizy dotyczyć będą tylko polskojęzycznego dorobku Przybyszeuskiego. Pisarz co prawda rozpoczynał karierę literacką od pisania po niemiecku, ku czemu zainspirowało go zapewne towarzystwo berlińskiej bohemy, nie ukrywał jednak, że traktuje ten język z rezerwą:

Jako człowiek jestem na uskroś Polakiem. Literatura niemiecka odrzuca, chuała Bogu, dzieła moje jako ustrętne i obce duchowi niemieckiemu, jako artysta nie odnoszę się do żadnego narodu, tylko do garstki ludzi, rozrzuconej po całej Europie, a do tej garstki można się naturalnie tylko w takim języku odzywać, który jest w całej Europie znany, niemieckim, francuskim lub angielskim. Przypadkowo znam język niemiecki najlepiej, dlatego piszę po niemiecku ${ }^{12}$.

[...] nigdy nie doszedłem do tego, by po niemiecku myśleć: uszystko, co w niemieckim języku pisałem, było tylko niesłychanie szybkim tłumaczeniem polskiego tekstu - tego uszystkiego, com u polskim języku myślał - polska myśl przyoblekała się z zawrotną szybkością w obcą szatę ${ }^{13}$.

$\mathrm{Z}$ decyzji, by stać się pisarzem polskim, zuierzał się w połowie $1897 \mathrm{r}$. Zenonowi Przesmyckiemu: „myślę teraz na serio rozpocząć pisać po polsku, ale koniecznie muszę się do Polski przenieść, bom sobie język popsuł

${ }^{12}$ [List do Zenona Miriama-Przesmyckiego, sierpień 1896], S. Przybyszeuski, Listy, t. 1, oprac. S. Helsztyński, Warszawa 1937, s. 130.

${ }^{13}$ S. Przybyszeuski, Moi wspótcześni, Warszawa 1959, s. 249. 
niemczyzną" ${ }^{14}$. Miesiąc później w liście do Mieczysława Zmigrydera wyznał: „Rozpocząłem w ogóle pisać po polsku. Na razie odwykłem, ale myślę, że za jakie pół roku będę tak językiem władał, że nie będę potrzebował się poustydzić. Przy usilnej pracy wyjdzie pierusza książka moja u języku polskim" ${ }^{15}$. Twórczość w języku ojczystym zaczął Przybyszewski od przełożenia suych wcześniejszych utworów niemieckich - na początek poematu Nad morzem, opublikowanego osobno w roku 1899 (w niemieckim czasopiśmie „PAN” fragmenty utworu były drukowane już w roku 1897) ${ }^{16}$.

Dzieła pisane po niemiecku historycy literatury z reguły oceniają wyżej niż ich polskie odpowiedniki. Tadeusz Żeleński, a później choćby Krzysztof Łuczyński tuierdzili, że tłumaczenia są słabsze niż pierwowzory i wychodzą utworom na niekorzyśćc ${ }^{17}$. Wydaje się jednak, że nie można traktować autoprzekładów tylko i wyłącznie jako - lepszych czy gorszych - kopii, nie poustawały bowiem mechanicznie. Przybyszewski dokonywał przeróbek, rezygnował $\mathrm{z}$ wiernego odwzorowywania stylu i formy oryginałów niemieckich, wprowadzał odmienny nastrój, w rezultacie poustawały dzieła znacznie się różniące ${ }^{18}$. Zależało mu na dbałości o znaczenie każdego słowa, o czym śuiadczy list do Adolfa Nowaczyńskiego, poświęcony tłumaczeniu drugiej części trylogii Homo sapiens. Pisał w nim:

Są rzeczy na uskroś po polsku odczute, a które zupełnie się nie dały u niemieckim języku wyrazić. A jednym polskim słowem, jednym zurotem powiem to uszystko, co powiedzieć chciałem, a po niemiecku nie mogłem. Bo to język strasznie sztyuny, obcy mej duszy ${ }^{19}$.

Ten bilingwizm nasuwa problemy badawcze, w autoprzekładzie bowiem „mogą ulec zatarciu granice między autoprzekładem a autorską przeróbką"20.

${ }^{14}$ Listy [u:] S. Helsztyński, Meteory Młodej Polski, Kraków 1969, s. 252.

15 [List do Mieczysława Zmigrydera w Warszawie, lipiec 1897] S. Przybyszeuski, Listy, t. 1 , s. 163.

${ }^{16} \mathrm{Nie}$ uiadomo z peunością, czy Nad morzem był pieruszym napisanym po polsku utworem Przybyszewskiego. Sam pisarz udzielał sprzecznych informacji. Raz twierdził, że poemat pisał jednoczesnie po polsku i po niemiecku, kiedy indziej, że wersja polska poustała na podstawie niemieckiej.

${ }_{17}$ T. Żeleński, Blaski i nędze mowy polskiej, „Wiadomości Literackie” 1928, nr 30; K. Łuczyński, Dwujęzyczna twórczość Stanisława Przybyszewskiego (1892-1900), Kielce 1982, s. $72 \mathrm{i}$ in.

${ }^{18}$ Utwory niemieckie są oszczędniejsze, cechuje je zwięzłość wysłowienia, umiar. W polszczyźnie Przybyszeuski szafouał epitetem, dążył do wydobycia maksymalnej ekspresji słowa, wykazywał skłonność do hiperbolizacji. Więcej zob. G. Matuszek, Der geniale Pole?, op. cit.

${ }^{19}$ [List do Adolfa Nowaczyńskiego w Warszawie, maj 1897] S. Przybyszeuski, Listy, t. 1, s. 151. Nawet jeśli $w$ owych słowach pobrzmiewa nuta autokreacji, to jest $w$ nich $i$ wiele prawdy, w cyzelowaniu utworów niemieckich znacząco pomagał bowiem Przybyszewskiemu poeta Richard Dehmel.

${ }^{20}$ E. Kraskouska, Dwujęzyczność a problemy przekładu, [w:] Miejsca wspólne. Szkice o komunikacji literackiej i artystycznej, red. E. Balcerzan i S. Wysłouch, Warszawa 1985, s. 197. 
Taką autorską przeróbkę można zaś traktować jako nowe dzieło, skoro sam Przybyszeuski uskazywał na jej odmienność, a nawet uyższość nad oryginałem. Tym tropem idzie Krystyna Kralkouska-Gątkouska, którą analiza autoprzekładu De profundis prowadzi do uniosku, że autor „w obu językach wykreował odrębne, oryginalne modele literackiej erotyki ${ }^{21}$ ". Analizy problematyki miłosnej w całej twórczości Przybyszeuskiego można by dokonać zatem jedynie w oparciu o drobiazgowe poróunanie dzieł niemieckich i polskich, które wykracza poza ramy niniejszego opracowania.

W pieruszej części książki zostanie omówiony kontekst literacki, filozoficzny, kulturowy i obyczajowy, w którym pojawiła się twórczość Przybyszewskiego, z zaakcentowaniem problematyki najbardziej interesującej i istotnej z punktu widzenia tematu publikacji. Kolejne części będą poświęcone wyjaśnieniu zasadniczych pojęć wprowadzonych przez Przybyszeuskiego w obręb metafizyki płci; pokazaniu przeżycia erotycznego jako z jednej strony efektu działania bezosobowego fatum, a z drugiej doświadczenia egzystencjalnego, światopoglądowego i metafizycznego; prezentacji kwestii napięcia, jakie rodzi konfrontacja naturalnych popędów (wynikających z biologicznego determinizmu) ze społecznym etosem; nakreśleniu obrazu miłości „seksualnej i mistycznej, prywatnej i kosmicznej, perwersyjnej i uyidealizowanej, witalnej i uduchowionej”"22. W części II analizy będą dotyczyły związku miłości i seksualności ze sferą duchową, mentalną i uczuciową bohaterów omawianych tekstów, przy czym nieuchronnie pojawi się problematyka życia i śmierci, sympatii i nienawiści, szczęścia i cierpienia, etyki i odpowiedzialności. Część III natomiast zaprezentuje zuiązane z erotyzmem sposoby postrzegania ciała i cielesności (własnej i partnerów), a także przedstawi symbole wykorzystane przez pisarza w obrębie badanej tematyki.

Uwzględnione zostaną upłyuuy kultury i obyczajowości Zachodu i Wschodu (tak istotnego dla literatury Młodej Polski), uspółczesnych dzieł filozoficznych, literackich i malarskich oraz osiągnięć psychologii. Dla rozjaśnienia lub poparcia stawianej tezy wypadnie przywołać wypowiedzi pisarza zamieszczone $w$ jego esejach i listach.

$\mathrm{Na}$ koniec krótka uwaga edytorska: opuszczenia w cytatach sygnalizowano z zachowaniem zastosowanego przez Przybyszeuskiego układu akapitów, uznając to za optymalne rozwiązanie dla poetyckiej, ekspresjonistycznej, poruanej konstrukcyjnie i narracyjnie prozy autora $K r z y k u$.

${ }^{21}$ K. Kralkouska-Gątkouska, Zagadki „De profundis” Stanisława Przybyszewskiego (Autoprzekład autoerotycznej powieści), [w:] Topika erotyczna w przekładzie, red. P. Fast, Katowice 1994, s. 162.

${ }^{22}$ W. Gutouski, Chuć przeciw duszy narodu. O kompleksach polskich i erotyce moderni$z m u$, „Acta Universitatis Nicolai Copernici” 1986, s. 67. 



\section{CZĘŚĆ PIERWSZA \\ Fenomen Przybyszewskiego - w erotycznej aurze epoki, w oczach krytyki}

\section{Erotyzm w Młodej Polsce}

Końcówka wieku XIX uprawomocniła literacką infiltrację zmysłowej strony miłości. Erotyczne zbliżenie przestano sygnalizować w języku aluzji; słowa pragnienie, pożądanie, rozkosz, namiętność zyskały jednoznaczne seksualne konotacje; tworzono wiersze przybierające formę opisu miłosnych piesz$\operatorname{czot}^{1}$. W odrzucaniu erotycznego konuenansu, apoteozie nagości i fizycznego spełnienia, wreszcie przewartościowaniu ról płciouych niemałą rolę odegrały piszące kobiety - Bronisława Ostrouska, Maria Komornicka, Kazimiera Zawistouska, Ewa Łuskina, wczesna Zofia Nałkouska.

Nowatorstwo literatury modernizmu uderza już przy podstawowych badaniach komparatystycznych. Decyduje o nim zerwanie pęt konwenansu i kanonu artystycznego obowiązującego w literaturze miłosnej epok poprzednich, a wyznaczanego przez style poezji grecko-rzymskiej, dworskiej i idyllicznej (sielankowej). Miejsce subtelnych wyznań, wyrażających stan emocjonalny jednego z partnerów, zajął problem dynamiki zuiązków uczuciowych. Elementy mitologiczno-retoryczne, wyszukane koncepty i komplementy, będące uyłącznie świadectwem gry literackiej, zastąpiono określeniami i opisami - nierzadko uznawanymi za drastyczne - z zakresu cielesności i fizjologii. Na bok odłożono wzorzec miłości platonicznej, uduchowionej i niespełnionej, której obiektem jest postać uymarzona lub utracona. Uczucie do wyimaginowanej i wyidealizowanej persony rozpatrywane bywało wręcz $w$ kategoriach obłąkania! ${ }^{2}$ Tęsknota do miłości doskonałej nie oznacza dla modernistów - inaczej niż dla romantyków - rezygnacji z fizycznego zaspokojenia,

${ }^{1}$ Zob. I. Sikora, Wstęp [w:] W kręgu Salome i Astarte. Młodopolskie wiersze miłosne, oprac. I. Sikora, Wrocław 1993, s. 11.

${ }^{2}$ Jako exemplum szaleństwa zafascynowanie pewnej młodej damy ideałem oficera podaje Cesare Lombroso w studium Miłość u obłąkanych, wydanym po polsku w roku 1894. 
życie seksualne nie wymaga zaś płaszczyka prokreacji, w jaki usiłowało ubrać Erosa społeczeństuo mieszczańskie.

Poutórzyć wypada za Marią Podrazą-Kwiatkouską, że prawo do ukazywania śmiałych scen erotycznych wywalczył nieco wcześniej naturalizm, ale gdy erotyzm był w nim tylko jedną z funkcji organizmu, którą można poddać obserwacji, to w Młodej Polsce urósł do siły uszechwładnej, twórczej i jednocześnie niszczącej3. Traktowany był jako doznanie absolutne, konstytuujące lub destruujące tożsamość, wyzwolone spod ocen moralnych i wchodzące w obrazoburczy dialog z tradycją chrześcijańską ${ }^{4}$ Eros stał się niebezpieczny i nierzadko otwierał perspektywę tanatologiczną.

Wojciech Gutouski podzielił młodopolskie sposoby przedstawiania miłości na trzy kręgi tematyczno-mityczne: mit chuci (miłość jest znakiem działania bezosobowego fatum, siły determinującej życie jednostki i kosmosu), mit intensyunej chwili (przeżycie miłosne jest hedonistycznym, zmysłowym absolutem i estetycznym azylem chroniącym przed naturą i historią), mit androgyne (dominują wzory miłości spirytualistycznej, pojawiają się przeżycia zmysłowe i metafizyczne $)^{5}$. Ta typologia uzmysławia dramatyczny paradoks: modernistyczny erotyzm oscyluje między „metafizyką utrzymania gatunku”, „rozpaczliuym hedonizmem” ${ }^{\mathrm{i}}$ tęsknotą za miłością absolutną, przy niemożności zjednoczenia się dusz?

Przyczyny utargnięcia erotyki do literatury modernizmu były różnorodne. Ogromne znaczenie miały zmiany kulturowo-obyczajowe $w$ drugiej połowie XIX w. Koncentrowały się one wokół następujących postulatów: zaguarantowania kobietom możliwości kształcenia się i podejmowania pracy w uybranych zawodach, co pozwoliłoby im uzyskać niezależność finansową; przyznania kobietom praw obywatelskich, a tym samym udziału we władzy; wreszcie oparcia modelu rodziny na zasadzie róuności partnerów i przeobrażenia koncepcji małżeństua jako instytucji pozwalającej mężczyźnie na absolutne podporządkowanie sobie życiowej partnerki ${ }^{8}$. Odkrycia naukowe ówczesnej etnologii

${ }^{3}$ M. Podraza-Kuiatkouska, Schopenhauer $i$ chuć, „Teksty” 1974, z. 2, s. 25.

${ }^{4}$ Zob. W. Gutouski, Mit - Eros - Sacrum. Sytuacje młodopolskie, Bydgoszcz 1999, s. 33.

${ }^{5}$ Zob. W. Gutouski, Nagie dusze i maski (O młodopolskich mitach miłości), Kraków 1992, s. 16.

${ }^{6}$ Określenia K. Wyki [w:] idem, Modernizm polski, uyd. 2. zmien. i powiększ., Kraków 1968, s. 84-92.

${ }^{7}$ Przyznać jednak należy, że w twórczości młodopolskiej obecne były również romantyczno-sentymentalne (Z. Przesmycki, M. Wolska) oraz uyrażające radość życia ujęcia miłości (L. Staff).

${ }^{8}$ Wspomnieć trzeba za Krystyna Starczeuską, że rozbiciu tradycyjnej obyczajowości sprzyjała dynamiczna ekspansja kapitalizmu w Europie. Rozwój przemysłu i zuiązana z nim migracja do wielkich skupisk miejskich, a także mobilność szukających zarobku pracouników sprzyjały nouym relacjom międzyludzkim. Kobiety, masowo zatrudniane w zakładach po uprowadzeniu na szeroką skalę produkcji maszynowej, wyszły z domu i zaczęły uniezależniać się ekonomicznie od mężczyzn, co sprzyjało stopniowemu odchodzeniu od patriarchal- 
i antropologii uskazywały na historyczną zmienność instytucji małżeństua, społeczną umouność praw i zakazów. Intensywny rozwój psychologii zurócił uwagę na ogromną rolę płci $w$ kształtowaniu osobowości ${ }^{9}$. Już John Stuart Mill rozumiał, że wolność i równość partnerów upływa korzystnie na jakość zuiązku, pozwalając rozwinąć się prawdziwej miłości między małżonkami ${ }^{10}$. Jednak typ kobiety samodzielnej, ukształtowany w wyniku ruchu emancypacyjnego, uspieranego przez liberałów i socjalistów utopijnych, większość mężczyzn przerażał, oburzał lub - zuyczajnie - śmieszył. Postęp emancypacji wzbudził potężną falę mizoginii, jako obrony przed ofensywą płci pięknej, i paradoksalnie - doprowadził do desakralizacji miłości. „,...] dopuszczam dua możliue rodzaje kobiet: dziwki i kuchty; albo miłość, albo kuchnia"11 - pisał Baudelaire, dowodząc, że stosunek do kobiet $\mathrm{w}$ drugiej połowie XIX w. podszyty był pogardą i rozpięty między olśnieniem a obrzydzeniem.

Zakwestionowanie światopoglądu pozytywistycznego, do czego drogę wskazywała literatura francuska (uyd. Kwiatów zła Baudelaire'a - 1857), oraz dążenie do autonomii sztuki, do uwolnienia jej od wszelkich reguł, uprawomocniło obrazy erotyzmu w literaturze. Doświadczenia seksualne pomagały odkrywać autentyzm życia wewnętrznego, a więc wyzwolić się od determinizmu i szukać egzystencjalnej prawdy ${ }^{12}$. Mizoginizm sprawiał natomiast, że bohaterkami dzieł stały się kobiety dominujące nad mężczyznami, kobiety-demony poniżające i dręczące partnera, porywające go w niebiosa, by za chwilę strącić $w$ przepaść. Stąd w literaturze częste, niemal szablonowe kreacje kobiety modliszki, femme fatale, motywy Salome, Judyty, Euy czy Lilith - biblijnych, legendarnych i mitycznych kobiet działających na szkodę przedstawicieli rodu męskiego.

nego modelu rodziny. Uwarunkowania ekonomiczne uymuszały z kolei przyznanie kobietom praw politycznych i społecznych. Zob. K. Starczeuska, Wzory miłości w kulturze Zachodu, Warszawa 1975.

${ }^{9}$ Zob. I. Sikora, op. cit., s. 9-10.

${ }^{10} \mathrm{~W}$ pracy $O$ poddaństwie kobiet (1868) John Stuart Mill uykazywał, że obyczajowa i prawna sytuacja kobiet jest wyłącznie efektem „prawa mocniejszego”. Kobiety „nauczone są [...] nie działać wedle własnej woli, lecz ulegać i ustępować woli obcej” - pisał (J.S. Mill, Poddaństwo kobiet, tłum. upoważnione przez autora, Toruń 1870, s. 28. Cyt za: K. Starczewska, op. cit., s. 159).

${ }^{11}$ Ch. Baudelaire, Sztuka romantyczna. Dzienniki poufne, thum. A. Kijouski, Warszawa 1971, s. 44-45. Cyt za: K. Starczeuska, op. cit., s. 164.

${ }^{12}$ Tak o uspółczesnej literaturze o miłości pisał z dezaprobatą Max Nordau: „Oto, na przykład, osobnik, który traci zmysły i szaleje na widok każdej niewiasty; oto inny, którego rękawiczka lub kwiatek, należące do ukochanej przezeń osoby, mogą przyprawić o ekstazę cichą lub o furię głośną; tu miłość symuluje uystępki, tam doprowadza człowieka do czarnej melancholii [...]. I uszystkie te przyuidzenia, dziwactua, egzaltacje, zaparcia się siebie, romantyczne entuzjazmy, namiętności, chorobliwe zachcianki i bezsensowne poryuy, uszystko to nam podawane bywa w postaci prawidłowych i naturalnych form miłości, i nikt nas nie uprzedza ani jednym słowem [...], że idzie tu jedynie o same wyjątki chorobliwe" (M. Nordau, Miłość, tłum. W.L., Warszawa 1903, s. 24-25). 
Rozwój nauk sprzyjał analizowaniu miłości z punktu widzenia przyrodniczego, psychologicznego i antropologicznego. Czytelnicy końca XIX w. rozchwytywali Fizjologię rozkoszy (1886), której część Paolo Mantegazza, profesor antropologii z Florencji, poświęcił „rozkoszom uczucia”. Inny poczytny włoski antropolog, psychiatra i kryminolog - Cesare Lombroso - analizował z kolei uypadki obłąkania z miłości, w tym fetyszyzm, ekshibicjonizm, transwestytyzm, przypadki nekrofilii i zoofilii ${ }^{13}$.

Na modernistyczny obraz miłości największy wpływ wywarły poglądy Schopenhauera (1788-1860), który definiował miłość jako dążenie do zaspokojenia popędu seksualnego i zapewnienia ciągłości gatunku. To instynkt gatunku kieruje doborem płciouym, przy czym kobieta posiada go więcej, ponieważ jej naturalnym celem jest wydawanie na świat potomstwa. I tylko do tego prowadzi złudna gra miłosna, w jaką zostaje uwikłany mężczyzna ${ }^{14}$. Nic dziunego więc, że kochanek, spełniuszy nieuświadamiane sobie zadanie, bywa rozczarowany. Nie istnieje zatem miłość jako duchowa sfera uczuć i emocji, małżeństwo zaś to tylko efekt kobiecego spisku, dzięki któremu słaba płeć usiłuje zapewnić sobie utrzymanie i wierność partnera. U Schopenhauera, podobnie jak później u Przybyszeuskiego, a także wielu antyfeministów końca XIX w., kobieta reprezentuje moce natury, biologiczny aspekt człowieczego istnienia (mężczyzna zaś stoi po stronie duchowości). Wcześnie osiąga dojrzałość, ale w konsekwencji jej umysłowość kształtuje się krócej niż męska. Dlatego - jak dowodził filozof w niewielkiej rozprawce $O$ kobietach - nie potrafi myśleć perspektywicznie, lekceważy zasady sprawiedliwości, jest próżna, a w zabieganiu o dobra materialne nierzadko posługuje się kłamstuem. To sprawia, że - niczym dziecko - potrzebuje męskiej opieki. Nie powinna więc posiadać praw cywilnych na róuni z mężczyzną, dysponować majątkiem ani wychowywać dzieci w przypadku rozstania $\mathrm{z}$ mężem ${ }^{15}$.

Przekonanie, iż motorem uszelkiego ludzkiego działania jest popęd - bezrozumny, nie ukierunkowany na konkretny cel i nigdy nie zaspokojony - prowadziło do pesymistycznego oglądu świata, potęgowanego jeszcze śuiadomością, że poznanie istoty rzeczy, a więc i sensu istnienia, nie jest możliwe: uszystko dane nam jest zjawiskowo, jako wyobrażenie. Schopenhauer odmawiał światu

${ }^{13}$ C. Lombroso, Miłość u obłakanych, tłum. M.W. [Wacław Moraczeuski? Mamert Wikszemski?], Warszawa 1894. Lombroso słynął głównie z publikacji Geniusz i obłakanie (uyd. wł. 1864, wyd. pol. 1887), w której dokonał analizy związków między uyjątkouymi zdolnościami tuórczymi a dewiacjami osobowości (ludzie genialni byli dla niego ludźmi nadurażliuymi).

${ }^{14}$ Doborem par - najułaściuszym z punktu widzenia jakości przyszłego pokolenia - steruje instynkt płciouy. Zdaniem filozofa tzu. małżeństua z rozsądku, oparte nie na prymacie instynktu, lecz statusie majątkouym czy kryterium pochodzenia, narażają gatunek, ponieważ grożą wytworzeniem słabego potomstwa.

${ }_{15}$ Zob. M. Uliński, Kobieta i mężczyzna. Dzieje refleksji filozoficzno-spotecznej, Kraków 2001. 
ładu i sensu, uznając ból i mękę za jedyne rządzące nim zasady. Stąd w życiu i literaturze, również u Przybyszeuskiego, pojawił się typ człowieka, któremu nieustannie towarzyszy poczucie braku i niezadowolenia, który nie może osiągnąć szczęścia, za jakim goni, który szuka pociechy w pozornych wartościach i zmieniających się prądach filozoficznych, by i tak zausze cierpieć. Chuilowym uyzwoleniem od egzystencjalnej męki mogła być estetyczna kontemplacja dzieł sztuki, a wyjściem skrajnym, nie potępianym uprawdzie, ale szacowanym jedynie jako namiastka oswobodzenia - samobójstwo, które przekreśla co prawda jednostkę, ale nie niweluje woli życia będącej esencją uszelkiego bytu, zatem nie dosięga ostatecznych źródeł bólu.

Ograniczenia poznania, kategorii tak istotnej dla modernistóu (zdaniem Przybyszeuskiego poznanie istoty rzeczy guarantować miała seksualna i duchowa jedność z partnerką), to róunież temat filozofii Henri Bergsona (1859-1941). Prawda o całości jest nieosiągalna, dostępne są jedynie jej przebłyski ${ }^{16}$ - przekonywał autor Ewolucji twórczej. Na dodatek intelekt poznaje fałszywie, tzn. przekształca i deformuje rzeczy, próbując je uogólniać. Ten antyracjonalizm i antyempiryzm bliski był metafizycznemu klimatowi epoki, która chętnie przyjęła Bergsonowską intuicję, guarantującą bezpośrednie postrzeganie rzeczywistości u całym jej bogactwie i pełni. Filozofia Francuza dawała poczucie wolności ludziom zmęczonym zdeterminowaniem i podleganiem koniecznościom, o jakich móuili myśliciele pozytywizmu ${ }^{17}$.

Platoński Eros, warunkujący ludzkie działanie, Schopenhauerouska wola życia, której przejawem jest cały kosmos, i Bergsonouski élan vital, jako źródło rozwoju charakterystycznego dla istot organicznych, mają wiele uspólnego z „chucią”, o której Przybyszeuski powie w Requiem aeternam, że „była na początku”. Chuć to do pewnego stopnia także wola życia z filozofii Nietzschego (1844-1900), którą późniejszy autor Śniegu poddawał oglądowi w studium pt. $Z$ psychologii jednostki twórczej (1892) ${ }^{18}$. Publikacja

${ }^{16}$ Zob. S. Borzym, Obecność ryzyka. Szkice z filozofii powszechnej, Warszawa 1998, s. 85.

${ }^{17}$ Zob. W. Tatarkiewicz, Historia filozofii, Warszawa 2003, t. 3, s. 205-214.

${ }^{18}$ Jan Tomkouski sugeruje, że Nietzsche był najbardziej rewelacyjnym odkryciem dla artystóu Młodej Polski. Szczególnie wiele zawdzięczali mu Przybyszeuski, Berent, Staff, Wyspiański, Reymont i Brzozouski. Miarą popularności autora Narodzin tragedii była inicjatyua publikacji jego dzieł zebranych w polskich przekładach. Między 1905 a 1912 r. ukazało się aż 14 tomóu pism filozofa (zob. J. Tomkouski, Młoda Polska, Warszawa 2001, s. 32). Sam Przybyszeuski $\mathrm{z}$ upływem lat dyskredytował upływ teorii Nietzschego na własne poglądy. „,...] Nietzsche suoją psychologią »naukouą imponować mi nie mógł, bom już to uszystko znał, a i uzględność jego etycznych poglądów [...] nie zrobiła na mnie żadnego urażenia - to miałem we krui. Dawno już nie wiedziałem, co dobre, co złe, co piękne lub brzydkie - przestałem już operować kategoriami”; „[...] można sobie uyobrazić moje zdumienie, kiedy nagle zrobiono ze mnie nietzscheanistę"! - pisał (S. Przybyszeuski, Moi wspótcześni, Warszawa 1959, s. 75 i 342). Przyznawał jedynie, że u autora Tako rzecze Zaratustra (uyd. pol. 1905) podziuia język, bliski duchoui Słowiańszczyzny. Tych deklaracji nie można jednak traktować poważnie. Nawet jeśli Przybyszeuski nie uległ bezkrytycznej fascynacji i oficjalnie z Nietzschem się nie identyfikouał, 
ta, jak zauważył T. Weiss, wraz z artykułami zamieszczanymi na łamach krakouskiego „Życia” w latach 1896-1899 niepomiernie przysporzyła Nietzschemu popularności w Polsce ${ }^{19}$. Myśl niemieckiego filozofa odróżniał od nauki Schopenhauera optymistyczny charakter: kult życia, witalizm, apoteoza bohaterstwa. Przybyszewski na suój własny sposób interpretował jego koncepcje, co prowadziło do wielu nieporozumień; sądzono na przykład, że autor Synagogi szatana akceptuje nietzscheańskiego nadczłowieka. Z pewnością bliskie były mu jednak zagadnienia relacji pomiędzy moralnością zbiorową a uyborami jednostki skrępowanej obyczajowością tłumu. Bezuzględnie zgadzał się natomiast $\mathrm{z}$ teorią Nietzschego, że upojenie seksualne inicjuje sztukę, jest natchnieniem do twórczości ${ }^{20}$.

W czasach modernizmu antyfeminizm był jednym z popularniejszych i bardziej inspirujących wątków nietzscheańskiej filozofii, choć uspółcześni badacze na ogół go lekceważą, nie dopatrując się w nim większego znacze$n a^{21}$. Nie uierząc $u$ róuność - $\mathrm{w}$ miłości, jak na każdym innym polu - autor Ecce homo atakował zuolenników emancypacji. „Miłość to w środkach suych wojna, w istocie suej śmiertelna nienawiść płci" - uważał ${ }^{22}$. Silna kobieta nie chce równości - gdy kocha, gotowa jest zniszczyć obiekt uczuć; dla przeciętnej przedstawicielki damskiej części ludzkości miłość oznacza jednak całkowite zdanie się na partnera: „Kobieta darowuje się, mężczyzna przyjmuje - sądzę, że żadne społeczne umowy ani też najlepsza wola na punkcie sprawiedliwości nie pokonają tego przeciwieństwa natury" - pi$\mathrm{sa}^{23}$. W jego hierarchii, na której szczycie znajduje się nadczłowiek, kobiety należą do ludzi słabych, tzn. ceniących bezpieczeństwo i pokój, litościuych i współczujących. Jednocześnie antyfeminizm Nietzschego polega na utrualaniu stereotypu kobiety jako istoty zmiennej, kapryśnej, zawistnej, uymagającej stanowczego, despotycznego wręcz traktowania.

O kobiecie jako uosobieniu żądzy, zuierzęcej formie bytu, która nie rozumie słów: prawda, obowiązek, moralność, pisał młody myśliciel z Wiednia - Otto Weininger (1880-1903). Jego dzieło Płeć $i$ charakter wpisywało się w pouszechny na przełomie XIX i XX w. nurt mizoginizmu. Według autora,

to czytał go dość gruntounie („,...] wśród uszystkich, co Nietzschego czytają, ja sam może jestem, co go całkouicie zrozumiałem" - pisał z młodzieńczą przesadą do Pauliny Pajzderskiej u 1890 r.; S. Przybyszewski, Listy, oprac. S. Helsztyński, t. 1, Warszawa 1937, s. 58), a u wielu punktach światopoglądy polskiego pisarza i niemieckiego filozofa były zbieżne.

${ }_{19}$ Zob. T. Weiss, Fryderyk Nietzsche w piśmiennictwie polskim lat 1890-1914, Wrocław 1961, s. 5-7, 35.

${ }^{20}$ Zob. B. Spannhake, „Nietzsche byt jak rumak najszlachetniejszej rasy, ale źle ujeżdżony”. Przybyszewskiego (naturalistyczna) interpretacja Nietzschego, [w:] Friedrich Nietzsche $i$ pisarze polscy, red. i tłum. W. Kunicki, Poznań 2002, s. 61.

${ }^{21}$ Zob. M. Uliński, op. cit., s. 206-207.

${ }^{22}$ F. Nietzsche, Ecce homo, tłum. L. Staff, Warszawa 1909, s. 58 (t. 14 Dziel).

${ }^{23}$ F. Nietzsche, Wiedza radosna, przeł. L. Staff, Warszawa 1910-1911, paragr. 236, s. 330 . 
wzajemny stosunek mężczyzny i kobiety to relacja podmiotu i przedmiotu oraz po Arystotelesousku pojętej formy i materii. Płeć piękna chce być jedynie pożądana i posiadana, a o jej predyspozycjach do uległości świadczy choćby... podatność na hipnozę. Egzystencję kobiety - a widzi Weininger tylko dwa typy kobiet: matkę i prostytutkę - wypełnia myśl o zbliżeniu seksualnym; w przypadku kobiet nie ma, jego zdaniem, mowy o świadomym istnieniu.

Książka ukazała się w maju 1903 r., natomiast w październiku Weininger odebrał sobie życie, co dla znających jego pisma czytelników oznaczało dopełnienie teorii ${ }^{24}$. Dla Przybyszeuskiego, którego pogląd na sferę płci był w 1903 r. w zasadzie uformowany, publikacja wiedeńczyka nie była rewelacją, choć w teoriach obu autorów daje się wykazać interesujące analogie (o wybranych będzie mowa dalej).

\section{Młodopolska literatura „pornograficzna”}

Ujęcie zagadnień erotycznych budziło guałtowne oburzenie opinii publicznej - pojawiły się zarzuty o szerzeniu deprawacji i propagowaniu wyuzdania. W wielu pseudoanalizach literackich oskarżenia o niemoralność i wszeteczeństwo prowadziły do eliminacji rzeczowych argumentów poznawczych i estetycznych. Erotyzm utożsamiany był z amoralizmem i narodową obcością; według krytyki konserwatywnej osłabiał „oblężoną twierdzę Polaka-katolika" ${ }^{25}$ - a to uszystko potęgowało ataki na zmysłowość w sztuce. Mianem pornografów i gorszycieli obdarzano Kazimierza Przerwę-Tetmajera, Stanisława Przybyszeuskiego, Stefana Żeromskiego, Gustawa Daniłouskiego, Mieczysława Srokouskiego. Andrzej Makowiecki twierdzi, że powyższymi określeniami szafowano w Młodej Polsce nadmiernie, odnosząc je do pisarzy, którzy na nie nie zasługiwali, tymczasem prozie uznawanej za

${ }^{24}$ Zob. G. Kunigiel, Otto Weininger - geniusz czy szarlatan? [ustęp], [w:] O. Weininger, Pteć $i$ charakter, tłum. O. Ortwin, Warszawa 1994, s. 8-9. Lech Sokół twierdzi, że na decyzję samobójczą Weiningera ogromny wpływ miał brak większego zainteresowania jego książką ze strony czytelników i krytyków (L. Sokół, Metafizyka płci: Strindberg, Weininger $i$ Witkacy, „Pamiętnik Literacki” R. 76: 1985, z. 4, s. 3). W rzeczyuistości dzieło dyskutowano dość szeroko, dopatrując się w nim zarówno sądów genialnych, jak kontrowersyjnych. Już w roku 1906, na kilka lat przed oficjalnym uydaniem publikacji po polsku, ukazało się jej pokaźne streszczenie przybliżające polskiemu odbiorcy myśl wiedeńczyka. Autorką 125-stronicowej książki (opartej na wcześniejszych odczytach) Mężczyzna i kobieta. Studium psychologiczne podtug dzieła Weiningera pt. „Geschlecht und Charakter” była dr Felicja Nossig.

${ }^{25}$ B. Cyuiński, Rodowody niepokornych, Warszawa 1971, s. 291. Cyt. za: W. Gutouski, Chuć przeciw duszy narodu. O kompleksach polskich i erotyce modernizmu, „Acta Universitatis Nicolai Copernici” 1986, t. 28, s. 56. 
gorszącą trudno „zarzucić tendencję do dosłownych czy też ekscytujących uyobraźnię opisów scen miłosnych" ${ }^{26}$.

$\mathrm{O}$ atmosferze przyjmowania literatury młodopolskiej zadecydowało naruszenie normy intymności. Lubię, kiedy kobieta... Tetmajera jest przecież opisem aktu seksualnego, w którym partnerka sprowadzona została do roli narzędzia w rękach kochanka. Boy zauważał:

Po dzieweczkach „w perkalikouych sukienkach w paseczki” Asnyka, po „Kocham cię, znaczy, o wolny ty duchu..." Konopnickiej, taki wiersz jak Lubię, kiedy kobieta, jak Zacisza i wiele innych były rewelacją ${ }^{27}$.

Liryce, w której nie doszukiwano się bezpośrednich związków z życiem i w której dominowała nastrojowość, impresyjność, wolno było więcej. Waż Bogusława Adamowicza mógł zadziwiać śmiałością, ale nie zasługiwał w oczach czytelników na potępienie. Obrońcy moralności nie szczędzili za to prozaików, których powieści docierały do szerszego niż poezja kręgu odbiorców. Niemniej opinie krytyków nie miały większego upływu na upodobania przeciętnych czytelników. Analizy wyborów lekturowych z końca XIX w. dowodzą, że preferowano teksty uznawane za skandalizujące. W tej grupie ogromną popularnością cieszyli się tacy autorzy obcy, jak Maupassant, Zola, Bourget, Malot i Dumas ${ }^{28}$.

Stefanowi Żeromskiemu miano deprawatora przyniosły Dzieje grzechu (1908). Nad ich główną postacią, Ewą Pobratyńską, duukrotnie przeprowadzono nawet inscenizowane „sądy” (w Petersburgu i Warszawie w 1909 r.). Bohaterka, pochodząca ze zrujnowanej rodziny szlacheckiej, ma duży temperament erotyczny. Opuszcza dom, by pielęgnować rannego w pojedynku Łukasza Niepołomskiego, w którym jest zakochana. Zostaje jego kochanką, zachodzi w ciążę, a nowo narodzone dziecko topi w kloace. Później jeszcze oddaje się w Genewie przypadkowo napotkanemu Polakowi, a obrabowana i zgwałcona znajduje w związku z bandytą satysfakcję zmysłową i poddaje się szaleńczej namiętności. Wreszcie - niczym modliszka - morduje hrabiego Szczerbica w trakcie aktu seksualnego, wbijając mu u pierś strzy-

${ }^{26}$ A.Z. Makowiecki, Ten wyuzdany fin de siècle..., [w:] idem, Wokót modernizmu. Szkice, Warszawa 1985, s. 167-169. Autor zauważył, że utwory uważane za gorszące nie mieszczą się u definicji pornografii. Sceny erotyczne nie funkcjonują w nich autonomicznie, spełniają funkcję poznawczą, a nie przeżyciową i nie zakładają erogennego odbioru.

${ }^{27}$ T. Boy-Żeleński, Wstęp, [w:] Młoda Polska. Wybór poezji, oprac. T. Żeleński, Wrocław 1947, s. XVI.

${ }^{28}$ Zob. J. Kostecki, Wybory lekturowe abonentów warszawskich wypożyczalni prywatnych na przełomie lat 80. i 90. XIX w., [w:] Przełom antypozytywistyczny w polskiej świadomości kulturowej końca XIX w., red. T. Bujnicki, J. Maciejeuski, Wrocław 1986, s. 196. 
kawkę z kurarą ${ }^{29}$. Po tej zbrodni oddaje się rozpuście z przypadkowymi mężczyznami, utrzymuje się z prostytucji, a trafiuszy do ośrodka reedukacyjnego dla upadłych kobiet, zostaje kochanką prowadzącego placówkę hrabiego Bodzanty. Ma też na koncie napad. Losy Pobratyńskiej Żeromski pokazał jednak nie w konwencji romansowej, a naturalistycznej.

Sukces niezdrowej sensacji osiągnął Kult ciała, powieść Mieczysława Srokouskiego (1873-1910), utrzymana w formie pamiętnika opisującego przeżycia miłosne. Chociaż pisarzowi uytoczono proces o obrazę moralności, popyt na książkę był tak duży, że począuszy od 1910 roku wydawano ją pięciokrotnie. Jej bohaterem i narratorem jest literat zapisujący w swoim journal intime dzieje romansu $\mathrm{z}$ piękną Hanką Złotopolską, należącą do sfery „półtora szlacheckiej”. Autor pozwolił sobie na dużą śmiałość, ze szczegółami opisując kolejne rendez-vous kochanków: w specjalnie wynajętej sali u pałacyku u Łazienkach, w obsypanej różami wannie, w powozie i hotelowym pokoju narratora, mieszkającego zaledwie piętro niżej niż narzeczony Hanki. W czasie schadzek nie dochodzi co prawda do pełnego aktu seksualnego (podczas jedynej próby literat mdleje odurzony pięknem nagiej kochanki), ale bohaterowie zrzucają kolejne warstuy odzieży i zapuszczają się pocałunkami $w$ intymne rejony własnych ciał. Oto fragment jednej z takich scen:

- Gorąco mi - szepnąłem i niecierpliwie rozchyliłem bonżurkę na piersi...

$[\ldots]$

Hanka położyła mi głowę na obnażoną pierś. Byłem uyżej od niej... ona leżała na boku i głowę miała schyloną na mojej piersi...

Całuj Hanko...

Poszła fala pocałunków jeszcze niżej...

Czułem jej drżenie... Pociągnąłem lekko sznur... rozwiązał się... bonżurkę otuierałem pomału... pomału... aż zupełnie ją rozchyliłem. Drgnęła silnie, jakby się zerwać chciała, przytrzymałem rękoma jej głowę...

Cicho... cicho... Hanko moja...

[...] Ciekawość jej oczu płynęła spod rzęs i piła, chciwie... piła. [...]

Nagle podniosła się i guałtownie przywarła ustami w moje usta. Ręka jej drżąca, biała, jak płatek lilii, zsunęła się po mojej piersi i niżej, opadła na łonie...

I każda kropla krui mojej w lawę się zmieniła... od błogosławionego ciepła białej miękkiej dłoni dziewczęcej.

O jakżeż cudownie rozkwitały mi utedy w ustach różane jagody jej piersi... Piłem oszalały ich słodycz i tak długo czułem drżące dotknięcie ciekawej jej ręki, aż zdrętwiałem z rozkoszy [...]. Męka mych pożądań ukojona - ucichła ${ }^{30}$.

${ }^{29}$ Rozkosz u pozbawianiu życia kochanków znajduje bohaterka Maski żelaznej Euy Łuskiny. W zamian za oddanie suego ciała żąda od partnera samobójstwa, ponieważ prawdziwe spełnienie przynosi jej dopiero kontakt ze zułokami i kąpiel w męskiej krui.

${ }_{30}$ M. Srokouski, Kult ciała. Dziennik człowieka samotnego, Lwów 1920 [reprint Spółdzielni Wydawniczo-Księgarskiej u Opolu 1990], s. 84-86. 
Według Andrzeja Makowieckiego Kultowi ciała - ze uzględu na kilka odważnych scen miłosnych, wielokrotnie śmielszych niż uszystko, co napisał Przybyszewski - najlepiej odpowiadała etykieta prowokacji erotycznej ${ }^{31}$. „Nawet francuska lubieżność nie zdobyła się na taką »szczerość«, nawet Boccaccio (»Dekameron«) nie śmiał się tak daleko posunąć" - grzmiał Jeske-Choiński, przyznając Srokouskiemu pierusze miejsce na polu pornografii $^{32}$. Krytycy zdawali się jednak nie zauważać parodystycznej konwencji powieści, której prześmiewczy charakter - w zakresie języka i obiegouych miłosnych obrazów - osłabia wagę podnoszonych zarzutów.

Odważył się Srokouski wykreować także rzadko obecny w polskiej literaturze typ sadisme anglaisé, jaki znajdziemy u Barbeya d'Aurevilly'ego, Villiersa de l'Isle Adama, Paul-Jeana Touleta. Jego wcieleniem jest pozornie pełen ogłady ziemianin Werycho z noweli Ich tajemnica (1908), regularnie torturujący żonę przy użyciu szpicruty i ostróg. Katusze doprowadzające kobietę do stanu wycieńczenia skutkującego omdleniem są pilnie skrywanym małżeńskim sekretem, na którego ujawnienie nie decyduje się nawet odkrywający go przez przypadek narrator. Rodzinny dramat - jakich wiele musiało się przecież rozgrywać - uycisza presja konwenansu. Tajemniczość niezdrowej relacji poza okrywającym ją milczeniem potęguje niejasne pochodzenie dręczyciela, sytuujące sadyzm jako zjawisko dla polskości nietypowe - będąc przybyszem $\mathrm{z}$ zagranicy Werycho pozostaje $\mathrm{w}$ środowisku ziemiańskim obcy i towarzysko, i kulturowo.

Atmosfera skandalu towarzyszyła odbiorowi powieści Gustawa Daniłowskiego Maria Magdalena, której fragmenty autor opublikował w 1911 roku w redagowanym przez siebie lwouskim „Życiu”. Konfiskaty duutygodnika przez prokuratora we Lwowie, uznanie utworu za nieobyczajny, obrażający moralne i religijne uczucia czytelnikóu, tylko przysporzyło mu popularności. W całości ukazał się w Warszawie w 1912 r., w ciągu kolejnych dwóch lat miał jeszcze trzy uydania. Piąta edycja - sfinansowana przez autora w $1918 \mathrm{r}$. - była niekompletna: sam Daniłouski ocenzurował powieść i zastąpił kropkami najbardziej bulwersujące czytelników ustępy. Już wcześniej zresztą żywo reagował na odbiór książki. Niejako w odpowiedzi na liczne głosy krytyczne opublikował w 1913 r. felieton Jawnogrzesznica przed sądem, w którym cytował wybrane opinie oponentów, m.in. taką, że Maria Magdalena pisana jest „warem krui rozjuszonej i spazmatycznym szlochem rozkoszy”33.

Pieruszych czytelników oburzało - częste przecież w Młodej Polsce - wplecenie wątków erotycznych w historię religijną. Maria Magdalena zaczyna bowiem wierzyć w Chrystusa i podążać za nim, ponieważ darzy go

\footnotetext{
${ }^{31}$ A.Z. Makowiecki, Ten wyuzdany fin de siècle..., s. 178-180.

${ }^{32}$ T. Jeske-Choiński, Seksualizm w powieści polskiej, Warszawa 1914, s. 24.

${ }^{33}$ G. Daniłouski, Jawnogrzesznica przed sadem, „Swiat” 1913, nr 28, s. 9-10.
} 
miłością ludzką, ziemską. Chce być dla niego kochanką. Gdy nie udaje jej się uratować go przed umęczeniem (a usiłuje tego dokonać, oferując swe ciało rzymianinowi Mucjuszowi), sama prosi o śmierć, by się z nim połączyć. Po ukrzyżowaniu Jezusa miłość Magdaleny zamienia się w szał, w histerię o charakterze religijno-erotycznym. Mistyka i seksualność przenikają się. Zauważył to Henryk Galle, kiedy pisał, że porywy egzaltacji są u bohaterki jedynie „chorobliwymi objawami zuyrodniałej zmysłowości” ${ }^{4}$. Co więcej, Jezus, w którego kreacji Daniłouski wydobył przede uszystkim pierwiastek człowieczy, nie pozostaje obojętny na zainteresowanie ze strony Magdaleny, a jego stosunek do młodej kobiety wzbudza zaniepokojenie uczniów.

Ciekawie zbudowana została też kreacja Judasza - jednym z istotnych powodów zdrady, jakiej dopuścił się on wobec Mistrza, jest bowiem u książce Daniłouskiego zazdrość o Marię Magdalenę, która w Iskariocie miała pieruszego kochanka. Podobnie miłosna motywacja biblijnego wiarołomstwa pojawia się $\mathrm{w}$ innych utworach epoki: dramatach A. Szandlerowskiego Maria $z$ Magdali i K. Tetmajera Judasz.

Poza „przygodami” heteroseksualnymi bohaterki, Daniłowski uprowadził na karty powieści - bodaj po raz pieruszy tak odważnie w literaturze polskiej - sceny relacji lesbijskich między Marią Magdaleną a jej służącą Deborą i greczynką Melitą. Zawarł też opis tańca ze striptizem. „Autor bohaterkę swą tak często rozbiera i znów odziewa, że zrazu nie wiadomo, czy z żywą osobą mamy do czynienia, czy z modelem krawieckim" - ironizował W. Rzymouski na łamach redagowanej przez Aleksandra Świętochouskiego „Prawdy”35.

Homoseksualizm, w literaturze obcej popularny i często łączony z motywami wampirycznymi, jako rodzaj transgresji seksualnej w twórczości młodopolskiej właściwie się nie pojawiał. Barierą była tu nie tyle groźba naruszenia normy obyczajowo-moralnej, bo tę przekraczano wielokrotnie i na rozmaite sposoby, lecz poparta myślą Schopenhauera i Weiningera koncepcja mężczyzny jako istoty ponad instynktami, niesprowadzalnej do fizjologii i biologiczności. Znacznie większą popularność zyskały formy nekrofilii, opisywanej jednak delikatnie i oszczędnie z obauy przed czytelniczą i recenzencką ekskomuniką. Do tej seksualnej aberracji powracał kilkakrotnie Luduik Stanisław Liciński $\mathrm{w}$ tomie małych form prozatorskich pod znamiennym, nieco usprauiedliwiającym zawartość tytułem Halucynacje. Nekropolia, której ponurą grozę wzmaga guałtowna burza, staje się miejscem pierwszej schadzki i kontaktu seksualnego bohaterów jego opowiadania $N a$ cmentarzu. Łącząc się na trumnie $w$ domu pogrzebouym, gdzie schronili się przed szalejącą wichurą, kochankowie doznają jednocześnie ekstazy erotycznej, dreszczu transcendencji, poczucia makabryczności i metafizycznej bojaźni. Towarzystwo śmierci - na

\footnotetext{
${ }^{34}$ H. Galle, Kronika literacka, „Biblioteka Warszawska” 1913, t. 3, s. 543-545.

${ }^{35}$ W. Rzymouski, Cud Magdaleny, „Prawda” 1913, nr 14, s. 7-11.
} 
prawach paradoksu - pozwala im doświadczyć głębi oraz intensywności istnienia $^{36}$. Przeżycie miłosne bywa u Licińskiego, podobnie jak u Przybyszeuskiego, mniej bądź bardziej świadomie odgrywanym spektaklem; odnajdywaniem rozkoszy u powiązaniu z lękiem i agonią, potrzebą przełamania jednostajności egzystencji i odnalezienia jej metafizycznego uymiaru. U obu autorów perwersje są manifestacją pracy psychiki, mniej zaś pragnieniem ciała.

W końcowej fazie Młodej Polski zgorszenie wywołała Kazia. Powiastka o niegrzecznej pannie, opowiadanie uydane już po śmierci jego autora - Tadeusza Nalepińskiego (1885-1918). Rzecz była jak na owe czasy tak śmiała obyczajowo, że autor zastrzegł na pieruszej stronie rękopisu: „Nie do druku!". Jednak już u 1919 r. - rok po śmierci Nalepińskiego - książkę przygotowała do publikacji jego żona Cecylia.

Kazię, dojrzewającą pannę, spędzającą czas u Babinie, modnej miejscowości kąpielowej, dokąd wysłali ją rodzice, intryguje jej własna i cudza seksualność. Dziewczyna chętnie przegląda się nago w lustrze, by z satysfakcją skonstatować, że jej przyszły mąż będzie zadowolony. Dla zabawy wraz z przyjaciółkami podgląda z drzewa literata Malickiego, całującego na mchu jakąś kobietę, a już następnego dnia zaczyna go prowokować, wykorzystując suój rodzący się sexappeal. Pod pozorem niewinnych, dziecinnych psot wciąga Malickiego w morskie fale, a suszenie się przy ognisku wykorzystuje, by zaprezentować się nago.

Kazia przypomina późniejszą Lolitę Nabokova, sprawiając urażenie doświadczonej u sztuce miłości - całuje ucho Malickiego ustami umoczonymi w koniaku, wykrada się do literata $\mathrm{w}$ nocy i bez zażenowania oświadcza: „Mam godzinę wolną. Chcesz?" ${ }^{37}$. Sama decyduje, ile siebie odda mężczyźnie: przyjmuje pocałunki i dotyk, ale nie pozwala na nic więcej. Do czasu. Nalepiński nie cofnął się przed opisem aktu seksualnego:

W tym momencie ciało jej już nie mogło dłużej ualczyć, lub - nie chciało. [...] Rozwarła się - i przyjęła kochanka w uścisku, który przeszył ją bólem, grozą, ale i radością niewyobrażalną. Piersi jej sprężyły się, by uydać ów - jedyny w życiu - krzyk ${ }^{38}$.

Obrazy charakterystyczne dla topiki erotycznej modernizmu znajdzie czytelnik również $\mathrm{w}$ prozie kobiecej - orgię i nekrofilię w kostiumie antycznym i historycznym oraz motyw miłosnego ukrzyżowania potęgującego uniesienie w opowiadaniach Euy Łuskiny z tomu Viraginitas; kobiety o ekscentrycznych, modliszkowatych upodobaniach w zbiorze Faunessy Marie Jehanne

${ }^{36}$ Zob. E. Piasecka, „Dolina mroku”. Groza i niesamowitość w prozie polskiej lat 1890-1918, Opole 2006, s. 119-121.

${ }^{37}$ T. Nalepiński, Kazia, Krakóu-Warszawa 1927, s. 61.

${ }^{38}$ Ibidem, s. 93. 
Wielopolskiej. O ile u powieściopisarzy gorszyły sceny w mniejszym bądź większym stopniu nasycone erotyzmem, to pisarki piętnowano nie za konkretne obrazy, lecz za ideologię burzącą porządek patriarchalny. Sprzeciu budziły portrety bohaterek zuracających się przeciwko tradycyjnym obowiązkom - małżeństuu oraz zasadom życia narzuconym przez religię i obyczaje. Szokowało, że kobieta może pisać o tym, o czym nie mówi się w rodzinie przyzwoitej, czyli wiernej moralności mieszczańskiej i opartej na męskim autorytecie. Nieporozumienia interpretacyjne wynikały $\mathrm{z}$ utożsamiania propagowanego w literaturze wyzwolenia $\mathrm{z}$ „wolną miłością”. Na tej podstawie do twórczości gorszącej Jeske-Choiński zaliczył u 1917 r. pouieści Eugenii Żmijeuskiej, Hanny Orlicz-Garlikouskiej, Gabrieli Zapolskiej czy Alicji Szamoty ${ }^{39}$.

Dola (1910) Eugenii Żmijeuskiej bulwersowała opinię publiczną kreacją tytułowej bohaterki - młodej kobiety, której nieuczciuy lekarz, czyhający na jej cnotę, tłumaczy słabości i niedomagania jako skutek niespełnienia seksualnego. „Pożerana płomieniami zmysłouych pożądań, zapada Dola p. Żmijeuskiej na zdrowiu, co daje autorce sposobność do popisywania się znajomością fizjologii i patologii. Z całą nagą rzeczywistością typu nowej kobiety maluje p. Żmijeuska sceny u gabinecie lekarskim, które byłyby na miejscu tylko w jakimś dziele medycznym, fachouym" - krytykował Choiński ${ }^{40}$.

Tymczasem poszukująca miłości Dola Żalińska jest tylko ofiarą XIX-wiecznego modelu wychowania, które czyniło z kobiety istotę życiowo naiwną, niezdolną do samodzielnej egzystencji. Problematykę powieści poważnie potraktowała Eliza Orzeszkowa, autorka przedmowy do książki, ale i ona nie oszczędziła Żmijeuskiej uwagi: „pragnęłabym widzieć nieco mniej fizjologii, a szczególniej patologii”" ${ }^{41}$.

Jako nowoczesne zdemoralizowane kobiety odbierano też bohaterki Orłów Alicji Szamoty (A.N. Grenieuskiej): jedna rodzi nieślubne dziecko, ale nie przyjmuje propozycji małżeńskiej uczciwego mężczyzny (który chce uznać owoc ich związku), ponieważ stwierdza, że już go nie kocha; inna opuszcza męża i dziecko i ucieka z kochankiem do Paryża, by kształcić się na gwiazdę teatralną. Czytelnicy nie mogli uybaczyć Szamocie, że daje kobietom prawo realizowania popędu płciowego ponad ustanowionymi społecznie zasadami i pozwala im przenosić osobistą wolność nawet nad szczęście dziecka.

Potrzeby seksualne pragnie realizować również Magdalena z Żaru Hanny Orlicz-Garlikouskiej (napisanego w 1916 r.), tyle że kończy jako prostytutka. Atmosfera skandalu sprzyjała, jak w wielu wcześniejszych przypadkach, sprzedaży powieści - pieruszy nakład rozszedł się w ciągu duóch miesięcy. Za to uydawca - pan Idzikouski - rozjuszony atakami na książkę miał

\footnotetext{
${ }^{39}$ Zob. T. Jeske-Choiński, Nowoczesna kobieta, Warszawa 1917.

${ }^{40}$ Ibidem, s. 9.

${ }^{41}$ E. Orzeszkowa [przedmowa], [w:] E. Żmijeuska, Dola, Warszawa 1959, s. 9.
} 
pouiedzieć autorce: „Pani zbezcześciła firmę mego ojca!”42. Tymczasem Garlikouska, nękana już ucześniej za Misterium, napisała Żar ku przestrodze. Wystrzegając się szczegółów z intymnych spotkań bohaterki z klientami, usiłowała pokazać, że kobiety są dla mężczyzn jedynie towarem, którym jako „nabywcy” mogą się wymieniać, by wreszcie bezlitośnie powiedzieć nieszczęśnicy spodziewającej się dziecka: „żeby kózka nie skakała...”3.

\section{Literackie dojrzewanie Przybyszeuskiego}

Polacy mało interesowali się uwikłaniem Przybyszeuskiego w literaturę niemiecką, którą przecież uspółtworzył, publikując w obcym języku w latach 1892-1898. Przyjęli sławę "genialnego" ${ }^{44}$ rodaka, nie analizując jej podstaw. Ale przecież pisarz dojrzeuał intelektualnie w Berlinie i tam ułaśnie - na skutek przeżyć osobistych, głównie uczuciouych, oraz poprzez zgłębianie obcej filozofii i literatury - ukształtowała się większość jego poglądów na miłość czy - szerzej - zuiązek kobiety i mężczyzny ${ }^{45}$. Toteż, choć nie jest celem tej książki tropienie zależności i inspiracji, uypada uspomnieć kilku autorów, z którymi Polak zetknął się na gruncie niemieckim - z większością osobiście u słynnym lokalu moderny Pod Czarnym Prosiakiem - i którzy fascynowali go jeszcze po powrocie do kraju.

Na czele tego grona stał szwedzki krytyk i twórca Ola Hansson, któremu w 1892 roku Przybyszewski poświęcił entuzjastyczną broszuręe ${ }^{46}$. Młodopolski artysta, żywo zainteresowany badaniem struktury duszy, cenił twórczość Hanssona za zawarte $w$ niej analizy z zakresu psychofizjologii oraz natury

\footnotetext{
${ }^{42}$ Orlicz-Garlikouska uspomina o tym we ustępie (s. 5-7) do drugiego uydania książki, które ukazało się w Warszawie w 1921 roku.

${ }^{43}$ H. Orlicz-Garlikouska, Żar, Warszawa 1921, s. 187.

${ }^{44}$ Mianem ,genialnego Polaka" po raz pieruszy obdarzył Przybyszeuskiego August Strindberg.

${ }^{45} \mathrm{~W}$ Berlinie Przybyszeuski poznał pisma Nietzschego, Schopenhauera, Bourgeta, Spencera, Zoli, Hauptmanna, Darwina, Lombrosa. Tutaj zetknął się z inspirującą twórczością Muncha, Ropsa czy Vigelanda, którzy - jak sam móuił - odkrywali głębie duszy, dostrzegając jej przejauy m.in. w sferze płciouej.

${ }^{46}$ Wszystkie teksty autora Śniegu pośuięcone innym twórcom są zresztą entuzjastyczne. Esejów krytycznych i przekładów Przybyszewski podejmował się zawsze w wyniku autentycznej fascynacji i poczucia uspólnoty w odczuwaniu świata. „Nigdy niczyich prac nie tłumaczyłem, prócz utworów Schlafa i poety, którego obecnie przekład daję! To chyba najgłębszy dowód, jak tych ludzi cenię" - notował u króciutkim uprowadzeniu do wiersza Alfreda Momberta Śnienie twórcy, którego translację zamieścił u noworoczniku literackim „Znicz” w 1903 r. Nie była to prauda - Przybyszeuski przełożył ucześniej hymn Novalisa oraz dramat Dagny Juel. Później tłumaczył jeszcze Poego, Euersa oraz Listy miłosne M. d'Alcoforado.
} 
świadomego i nieświadomego; wczytywał się w literackie opisy uczuć i stanów rodzących się w głębokich warstwach psychiki, w jakie obfitowały opowiadania ze zbioru Sensitiva amorosa. W nowelach szwedzkiego autora podpatrywał kobiety brzydzące się własnych partnerów, zaczynających nagle przypominać ich ojców, i mężczyzn, których żądza pod upływem odpowiedniej kobiety zamienia się $w$ cierpienie ${ }^{47}$. Wreszcie dzielił z Hanssonem przekonanie o fatalizmie miłości, której istota polega na przeplataniu się szczęścia i namiętności ze ustrętem, nieufnością i cierpieniem. Lektura tekstów szwedzkiego myśliciela doprowadziła Przybyszewskiego do interesujących rozważań z rekapitulującą tezą: „w kobiecie kocham siebie” ${ }^{48}$.

Zachuyt „genialnego Polaka” wzbudzała twórczość Johannesa Schlafa (1862-1941), którego opowiadania (czy raczej prozę poetycką) we własnym uyborze przetłumaczył z niemieckiego w 1907 r. Zbiór nosił tytuł Wiosna, jak rozpoczynający go tekst poświęcony problemowi nurtującemu róunież autora Dzieci szatana: genezie życia, prapoczątkowi. Schlaf stawiał tezę, że źródłem ewolucji jest "chuć za Nieznanym”" (jakież podobieństwo do słów Przybyszeuskiego z incipitu Requiem aeternam: „Na początku była chuć”), wieczna potrzeba poszukiwania, przeniknięcia niepojętego wszystkimi zmysłami. Bohater-narrator utworu głęboko odczuwa harmonię budzącej się do życia przyrody, a poczucie jedności z naturą oznacza dla niego jedność z ukochaną osobą. „Tu jesteśmy kwiatem i drzewem i trawą, jasnym niebem i złocistym polem żyta, barwą i śpiewem ptaków - tu kwitniesz, śpiewasz, jaśniejesz we mnie, a ja w Tobie" - mówi ${ }^{50}$.

Ta identyfikacja, choć bez wątpienia stanowi rodzaj androgynii, uykracza poza Duój-Jednię - bohater, będąc jednocześnie kobietą i mężczyzną, jednoczy się z naturą i odnajduje w tym stanie panteizmu satysfakcję, u Przybyszeuskiego natomiast chwila jedności kończy się smutkiem i goryczą.

Jednym z podstawouych pojęć było dla Schlafa poznanie, którego osiągnięcie usprawiedliwiało każde negatywne działanie, nawet kłamstwo i mord (Pieśń). To łączyło go z autorem Złotego runa, który pisał: „Johannes Schlaf wywołuje właśnie to, co rzadko który twórca zdołał wywołać: dreszcz najtajniejszych, zaledwie dających ogarnąć się przeczuć tego Bytu, na który zmysły zuykłego człowieka są ślepe i głuche" ${ }^{51}$.

\footnotetext{
${ }^{47}$ Zob. S. Przybyszeuski, Z psychologii jednostki twórczej. II Ola Hansson, [w:] S. Przybyszeuski, Synagoga szatana i inne eseje, oprac. G. Matuszek, Kraków 1995, s. 86.

${ }^{48}$ Eseje Przybyszewskiego o dziełach innych tuórców daleko wykraczały poza ramy recenzji czy analizy. Autor Śniegu tak głęboko wczuwał się w niektóre obce teksty, że nakładał na nie własne myśli i teorie. Podobne zjawisko M. Głowiński nazuał utożsamieniem z dziełem (zob. M. Głowiński, Ekspresja i empatia, Kraków 1997).

${ }^{49}$ J. Schlaf, Wiosna, tłum. S. Przybyszeuski, Lwóu 1907, s. 23.

${ }^{50}$ Ibidem, s. 28-29.

${ }^{51}$ Ibidem, s. 5-6 (ustęp do tomu).
} 
Umiejętność opisywania przeżyć wymykających się świadomości Przybyszeuski cenił róunież u Alfreda Momberta (1872-1942) ${ }^{52}$. Podobnie jak dla niemieckiego liryka, dla Polaka istotniejsza była ekspresja poszczególnych obrazów poetyckich niż ich logiczna spójność. Polski autor zachuycał się poza tym powieścią Knuta Hamsuna Misteria (wyd. norw. 1892, wyd. pol. 1914), która realizowała postulat badania życia weunętrznego jednostki.

Nauczycielem autora Śniegu - zułaszcza u zakresie szlifowania formy wypowiedzi - był jeden z najwybitniejszych wóuczas poetów: Richard Dehmel (1863-1920), który w odważnych erotycznych lirykach przyznawał kobiecie prawo do wszelkich rozkoszy zmysłouych (Wyznanie, Venus primitiva) i dowodził, że Bóg dał Ewie ręce, by zaspokoiła głód jabłkiem, nawet jeśli zapłaci za suój czyn cierpieniem (Boża wola ${ }^{53}$.

Tuórczość i osobowości Dehmla i Hanssona, zdaniem Stanisława Helsztyńskiego, podziałały na Przybyszeuskiego tak inspirująco, że wznieciły w nim potrzebę stworzenia dzieła stricte literackiego, czego efektem stało się rozpoczęcie $\mathrm{w} 1893 \mathrm{r}$. pracy nad pieruszym poematem Totenmesse (dosł. „mszą żałobną”, w polskiej wersji Requiem aeternam, 1900) ${ }^{54}$.

Światopogląd Przybyszeuskiego budowali też dramaturdzy - Belg Maurice Maeterlinck oraz Skandynawowie Henrik Ibsen, August Strindberg i Björnstjerne Björnson. Jak najdalszy od świadomego i celowego naśladownictwa, jak cała Młoda Polska Przybyszewski pozostawał pod upływem ich rewolucyjnych koncepcji dramaturgicznych i teatralnych, obejmujących również innowacje $u$ obrębie inscenizacji, scenografii i gry aktorskiej. Głębokie zmiany w dramacie zaczęły się uraz z nadejściem w końcu lat siedemdziesiątych XIX wieku scenicznych dzieł Ibsena i - mniej interesującego w kontekście niniejszej pracy - Richarda Wagnera. Źródłem napięć w sztukach Norwega jest - podobnie jak u Polaka - przekleństwo dziedziczności oraz konflikt między moralnością jednostki a konwenansem obyczajouym i zasadami kierującymi życiem zbiorowym. Palący społecznie problem emancypacji Ibsen zdecydowanie rozstrzygał na korzyść płci dotychczas społecznie pokrzywdzonej: Nora i Hedda Gabler (bohaterki dramatów Dom lalki oraz Hedda Gabler), wybierające samorealizację i poszukujące szczęścia poza rolą żony i matki, dały kobietom w całej Europie odwagę do opuszczania mężów ${ }^{55}$.

Konflikt płci, pojmowany już nie w kategoriach społecznych, a biologicznych, stał się obsesyjnym tematem sztuk Strindberga, z którym Przybyszeuski przyjaźnił się przez kilka miesięcy (od jesieni 1892 do wiosny 1893 r.) podczas

${ }^{52}$ A z malarzy u Edvarda Muncha.

${ }^{53}$ R. Dehmel, Poezje, tłum. A. Spaet, Lwów 1933.

${ }^{54}$ S. Helsztyński, Przybyszewski, Warszawa 1973, s. 85.

${ }^{55}$ Dramaty Ibsena czytyuała róunież Jaduiga Kasprouiczoua, która u 1901 r. porzuciła Jana Kasprowicza, by szukać namiętności u boku Przybyszeuskiego. 
pobytu $\mathrm{w}$ Berlinie ${ }^{56}$. Problem ten, typowy zresztą dla atmosfery wieku, był róunież istotnym elementem uypracowanej nieco później metafizyki Przybyszeuskiego ${ }^{57}$. Szwedzki autor silniej jednak niż Polak patrzył na kobietę przez pryzmat filozofii Schopenhauera, obwiniając ją nie tylko o unieszczęśliwienie mężczyzny, ale i całe zło świata, a tym samym podnosząc problem do rangi idei ogólnej. U Przybyszeuskiego obraz płci pięknej nie jest tak jednoznaczny: portrety kobiece są bardziej zróżnicowane i zazwyczaj kreślone nie przez trzecioosobowego narratora, lecz męski podmiot utworu. W obu przypadkach popęd płciowy jawi się natomiast jako siła fatalna, nieuchronnie prowadząca człowieka ku katastrofie. U obu tuórców motorem wydarzeń, które dałoby się wytłumaczy w kategoriach racjonalnych, były siły niepokonane - przeznaczenie, potęga dziedziczności, namiętności i instynkty. Obu towarzyszyło pragnienie uypowiedzenia najgłębszych ludzkich niepokojów, przeanalizowania meandrów człowieczej psychiki. W planie formalnym obaj zacierali pojęcia czasu i miejsca, uprowadzili rekuizyty i postacie o charakterze symbolicznym, przenosili konflikt do wnętrza bohatera i pokazali go jako istotę cierpiącą, wreszcie duże znaczenie przypisywali gestom i milczeniu. Gabriela Matuszek uskazała na jeszcze jedno, niezurykle interesujące twórcze powinowactwo - histeryczność składającą się na substancję ich pisarstwa, będącego w istocie odbiciem przetworzonych literacko własnych doświadczeń, ekspresją duszy chorej, ciemnej, podlegającej szaleństuu ${ }^{58}$.

Skandynawowie wskazywali zatem Europie nowe źródła tragizmu u życiu społecznym. Tkwią one w fizjologii, ale i duchowości człowieka, w konflikcie moralności indywidualnej z opinią publiczną, a także u niejasnym upływie dziedziczności ${ }^{59}$.

\footnotetext{
${ }^{56}$ Do opuszczenia rodzinnej Szwecji zmusiły Strindberga oskarżenia o szerzenie niemoralności.

${ }^{57}$ Mimo zapeunień Przybyszeuskiego, że nic ze Strindberga nie przejął, nie sposób zlekceważyć oczywistych zbieżności. Autorów łączą podobne typy podejmowanych konfliktów etycznych i rodzinnych, literacka analiza układów miłość - nienawiść oraz kat - ofiara, swoistego rodzaju abstrakcyjność, uniwersalność akcji, zacieranie różnic pomiędzy różnymi poziomami rzeczywistości, symbolika żywiołów (uspólna dla całego ekspresjonizmu), protest przeciwko konwencjonalności i ograniczeniom dawnego teatru oraz walka o teatr nowy, zdolny uyrazić całe doświadczenie ludzkie. Przybyszewski zapożyczył nawet tytuł jednego z dramatóu Strindberga - chodzi o tom Taniec miłości i śmierci, który ukazał się we Lwowie w 1901 r. i zawierał dramaty Złote runo oraz Goście. Irena Sławińska uważa, że łączył ich także mizoginizm, jednak Przybyszeuski mizoginem nie był, a i bohaterom jego utworów trudno zarzucić zdeklarowaną i jednoznaczną niechęć do kobiet. Zob. I. Słauińska, August Strindberg i wczesny ekspresjonizm polski, [w:] eadem, Moja gorzka europejska ojczyzna, Warszawa 1988, s. 209-215.

${ }^{58}$ G. Matuszek, Stanisław Przybyszewski - pisarz nowoczesny. Eseje i proza - próba monografii, Kraków 2008, s. 151-152. Stosunek Przybyszewskiego do Strindberga rozpatruje badaczka w kategoriach „lęku przed upływem”.

${ }^{59}$ Problem ten omówiła szerzej I. Sławińska u publikacji Tragedia w epoce Młodej Polski. Z zagadnień struktury dramatu, Toruń 1948.
} 
Oblicze dramatu, w tym dramatu Przybyszeuskiego, zmienił bezsprzecznie Maurice Maeterlinck, entuzjastycznie przyjęty w Europie niemal natychmiast po debiutanckim zbiorze wierszy Les serres chaudes (1889; Cieplarnie). W Polsce kult Belga umocniło poświęcone mu studium pióra Miriama (Z. Przesmyckiego). Tezy, jakie postawił Przesmycki na podstawie lektury Maeterlinckouskich dzieł, zdeterminowały myślenie o nowej sztuce jako o sztuce symbolicznej.

Miriam zauważył, że autor Ślepców pojmował człowieka jako istotę tragiczną, bo o dwoistej naturze: to, co świadome i zmysłowe, walczy w niej z podświadomym i ponadzmysłouym. Ludzkie działanie nie jest tylko efektem czynności umysłowych, ale i niejasnego wpływu sfery transcendentalnej. „Jest w naszej duszy morze wewnętrzne, prawdziwe mare tenebrarum, kędy szaleją dziwaczne burze tego, co nie daje się ująć w dźwięki ani opisać [...]. Chylę się z ciekawością nad instynktem [...], nad motywami nie uyrozumowanymi, nad cudami śmierci, nad tajemnicami snu, [...] nad uszystkimi nieznanymi potęgami duszy naszej; nad uszystkimi tymi momentami, gdy człowiek uymyka się własnej suej baczności" - pisał w $1891 \mathrm{r}^{60}$. Padające w wypowiedzi Maeterlincka na oznaczenie podświadomości uyrażenie mare tenebrarum (łac. „morze ciemności") chętnie przyswoił sobie później Przybyszeuski, z upodobaniem penetrujący literacko najgłębsze warstuy życia psychicznego.

Nowej koncepcji człowieka powinna odpowiadać zmieniona forma dramatyczna i teatralna. Dlatego Maeterlinck zrezygnował z budowania ciągu następujących po sobie zdarzeń na rzecz analizy sytuacji, $w$ jakiej znalazł się bohater. Słowo (dialog i monolog) dominuje nad ruchem, miejsce akcji jest odludne, odcięte od cyuilizacji, symboliczne (np. skały nad brzegiem morza, więzienie), a jej czas pozostaje nieokreślony. Podobnie u Przybyszewskiego: bohater nie ma niemal żadnego udziału u kształtowaniu własnego losu, może jedynie poddać się nadchodzącej katastrofie, a ważniejsze od samych wydarzeń są ich echa u ludzkiej psychice. Tyle że u polskiego pisarza tragedia opiera się na guałtownych uczuciach, u Maeterlincka - na bezwolnym oczekiwaniu. U obu autorów, jak zauważyła Irena Sławińska, ważną funkcję dramatyczną pełni język - pogłębia on tragizm utworu poprzez nastrój, jaki kreuje $^{61}$. Podstawą tego nastroju jest zaś wypełniające cały dramat oczekiwanie na nieuchronnie mający nadejść kataklizm.

Naturalnie zuiązki Polaka i Belga ograniczają się do rozwiązań formalnych, nie wkraczając u sferę kompozycji i treści.

$\mathrm{Z}$ oczyuistych powodów nie sposób przywołać w tej pracy uszystkich autorów, którzy przez swą twórczość kształtowali pogląd Przybyszeuskiego na

${ }^{60}$ M. Maeterlinck, Confession de poete, „L'art Moderne” 1891, z. 23. Cyt za: M. Stykowa, Teatralna recepcja Maeterlincka w okresie Młodej Polski, Wrocław 1980, s. 5.

${ }^{61}$ I. Sławińska, op. cit., s. 40. Zdaniem badaczki przemożny upłyu Maeterlincka można dostrzec u tzw. dramatach atmosfery. 
pisarstuo i literaturę. Bogactua jego lektur dowodzą najlepiej listy pisane do Arnošta Procházki, redaktora „Moderni Revue”, praskiego pisma pośuięconego nowej europejskiej sztuce, oraz uspominki zamieszczone w Moich wspótczesnych. Warto jeszcze tylko nadmienić, że Przybyszeuski czytał dramaty Franka Wedekinda, niemieckiego prekursora ekspresjonizmu, któremu u spojrzeniu na kobietę i erotyzm bliski był nietzscheanizm z jego kultem życia i przyjęciem reguł działania „poza dobrem i złem”. Interesowała go również twórczość Hannsa Heinza Euersa, którego dzieła osiągały u pieruszej ćwierci XX w. zawrotne nakłady. Niemiec był pisarzem modnym, ale i cenionym przez krytykę. Przybyszeuski nazuał go nawet jednym z proroków nadchodzącej epoki i przygotował obszerny ustęp do jego Alraune, przełożonej przez Jadwigę Przybyszewską i uydanej jako pieruszy utwór nowej serii Lektora w roku 1917. Choć polski pisarz oceniał Ewersa niżej niż Huysmansa, Villiers de l'Isle Adama, Edgara A. Poe czy Barbeya d'Aurevilly'ego, to szanował za oduagę w obnażaniu potworności ludzkiej duszy, róunoznaczne z narażeniem na społeczną krytykę. Dlatego w artykule opublikowanym na łamach „Gazety Wieczornej" bronił jego dzieła przed zarzutami zdrożności i niemoralności ${ }^{62}$.

Dzielił Przybyszewski z Euersem zainteresowanie problemem kazirodztwa (np. opowiadanie Sukkub) i demoniczną naturą kobiety (nowela Dama tyfusowa, powieść Alraune). W jego utworach - nawiązujących do niemieckiego romantyzmu oraz powieści grozy - zwracał uwagę na fabułę opartą na motywach erotycznych, sadystycznych i okultystycznych. Podobały mu się odwołania do zjawisk parapsychicznych, tajemnych kultów i prastarej wiedzy magicznej, wyznaczające cienką granicę dzielącą rzeczywistość od tego, co ponadnaturalne. Cenił niesamowite historie i drastyczne sceny, służące analizie osobliwych stanów umysłu ludzkiego. Sytuował Euersa w rzędzie autorów, którzy widzą w człowieku więcej niż tylko organizm biologiczny i uwzględniają wpływ czynników podświadomych na jego życie. We uspomnianej przedmowie do Alraune sformułował ważną tezę o znaczeniu krwi w wywoływaniu stanów ekstatycznych, prowadzących do kontaktu z Absolutem. Transgresyjną rolę życionośnej substancji, będącej transporterem sił witalnych, a więc istnienia w ogóle, dostrzegł w udręczaniu ciała dokonywanym przez flagelantów oraz zbrodni i akcie płciowym, pobudzających krew, by szalała „w rozpienionych falach”. Drogą do ekstazy jako łaski obcowania z bóstuem jest - jak móui Przybyszeuski - „straszliwa symfonia umęczonej krui i spermy" ${ }^{63}$. Krew to źródło oczyszczenia i utajemniczenia. Symbol męczeństwa i popędu płciowego. Siła kryjąca zagadki bytu i byt sam w sobie.

${ }^{62}$ Zob. S. Przybyszeuski, Moralność a sztuka - „Alraune”, „Gazeta Wieczorna” 1917, nr 3705.

${ }^{63}$ S. Przybyszeuski, Wstęp, [w:] H.H. Euers, Alraune. Dzieje istoty żyjącej, thum. J. Przybyszeuska, Lwów 1917, s. XL. Przedmowa Przybyszeuskiego u tym samym roku została uydana także oddzielnie pt. Na marginesie tworu Ewersa. 


\section{Życie i twórczość Przybyszeuskiego na tle epoki}

Przez długie dziesięciolecia funkcjonował pisarz w czytelniczym (a nierzadko i krytycznym) odbiorze głównie jako alkoholik i cygan, deprawator i skandalista, satanista i dekadent, co konstatowali sami badacze:

O Przybyszeuskim nic się porządnie nie wie, jakim był naprawdę i co wniósł do dorobku naszej kultury, ponieważ między nami a nim rozrosła się niesamowicie jakaś zła i krzyudząca legenda. [...].

W świadomości przeciętnego Polaka błąka się istotnie jakieś nieuyraźne wyobrażenie kogoś, kto odegrał co prawda jakąś podobno znacząca rolę w dziejach polskiej literatury, ale $\mathrm{w}$ istocie zmarnował się i jako człouiek, i jako pisarz, a jego dzieło zdezaktualizowało się doszczętnie i jest już jakoby dla współczesnych odbiorców absolutnie nieczytelne ${ }^{64}$.

Legenda o Przybyszeuskim nie jest bowiem legendą twórczości, ale legendą osobowości, a w takiej znaczenie większe mają działania życiowe i to uszystko, co nazywa się „teatralizacją biografii”, niż twórczość par excellence literacka ${ }^{65}$.

Od początku wiele uwagi poświęcano poruszanej przez Przybyszeuskiego problematyce płci, jednak oceniano ją przede uszystkim w kategoriach moralności. Łączono ją z dążeniem autora do ujauniania tego, co tajemne i niezbadane, a więc często zakazane i perwersyjne. Zarzucano Przybyszeuskiemu „psychozę seksualności", nadmiar seksualno-patologicznych teorii oraz nasycenie utworów wątkami osobistymi. Dopiero lata dziewięćdziesiąte XX w. zaowocowały rzetelnymi analizami, które uśuiadamiają uagę tematu. Przez niemal sto lat biografia pisarza zajmowała badaczy na róuni z jego twórczością, jeśli nie bardziej. W kolejno poustających utworach Przybyszewskiego dopatrywano się akcentów z jego życia osobistego, głóunie uczuciowego, dlatego zasadne uydaje się skrótowe prześledzenie zuiązków autora z kobietami ${ }^{66}$.

Pieruszą powierniczką przemyśleń Przybyszewskiego była starsza od niego o 16 lat Prakseda Żmudzińska, którą późniejszy pisarz - a wówczas 16-letni gimnazjalista - poznał przez kolegę ze szkoły w Wągróucu. W listach do niej relacjonował swoje lektury, z młodzieńczą egzaltacją wyrażał nadzieję na uyzwolenie narodu polskiego spod zaboru niemieckiego, wreszcie żalił się na swój indywidualizm, który nie pozwala mu rozumieć ludzi i być przez nich rozumianym. Obiektem uczuć była mniej więcej w tym samym czasie siostra innego szkolnego kolegi, róunież starsza - Helena Sztyler. Wysyłał jej wiersze do roku 1888, kiedy to dotarła do niego wiadomość o jej ślubie.

${ }^{64}$ A. Hutnikiewicz, Stanisław Przybyszewski. Legenda i rzeczywistość, [w:] idem, Portrety i szkice literackie, Warszawa 76, s. 41.

${ }^{65}$ A.Z. Makowiecki, Przybyszewski, [w:] idem, Trzy legendy literackie, Warszawa 1980, s. 86.

${ }^{66}$ Zawiłości życia miłosnego pisarza rekonstruuję u oparciu o listy oraz biografie jego i Dagny Juel. 
Już $w$ okresie berlińskim ${ }^{67}$ pełne napięć romanse, które bulwersowały nawet środowisko artystyczne, w połączeniu z plotkami o czarnych mszach zaczęły kształtować legendę Przybyszewskiego.

8 maja 1891 r. obchodzącego imieniny Przybyszeuskiego odwiedziła 19-letnia Marta Foerder, córka kupca z Wągróuca. Tego samego dnia zamieszkała z nim w jego kawalerskim pokoiku. Młody student poznał ją jeszcze w kraju, ucząc córki państua Foerderóu gry na fortepianie. Kochał się wówczas u starszej siostrze Marty - Róży.

Związek z Martą pisarz utrzymywał w tajemnicy, wielokrotnie thumacząc później w listach, że pozostawał u nim z litości dla zakochanej i oddanej mu prostej dziewczyny. Przebywając u rodziców, spotykał się - zgodnie z życzeniem matki - z Bogumiłą Łukomską, nauczycielką spod Wągróuca.

Pierusze dziecko - syna Bolesława - Marta urodziła dziewięć miesięcy i czternaście dni (22 lutego 1892) po uprowadzeniu się do mieszkania Przybyszeuskiego. Drugie - córka Mieczysława - przyszło na świat już po ślubie pisarza z Dagny Juel, wprowadzoną do winiarni Pod Czarnym Prosiakiem przez Edwarda Muncha (związek małżeński zawarto 18 sierpnia 1893 r., Mieczysława urodziła się 14 listopada 1893). Związek Przybyszeuskiego ze zjawiskowo piękną Duchą, której zazdrościli mu uszyscy mężczyźni, zniszczył jego przyjaźń ze sławnym już wówczas Strindbergiem, róunież zakochanym w Norweżce, ale pozwolił mu realizować się na niwie literackiej. Między rokiem 1894 a 1897 napisał m.in. trylogię Homo sapiens, powieść Dzieci szatana, dramat Dla szczęścia, poematy De profundis i Nad morzem, a także wiele szkiców i rozpraw, w tym o twórczości Vigelanda i tematyce demonologicznej (Synagoga szatana).

Pożycie małżeńskie nie zakończyło kontaktów z Martą, choć Dagny prawdopodobnie dość ostro namawiała męża do porzucenia „bandyckiej narzeczonej" ${ }^{68}$. Ich trzecie dziecko - Janina - urodziło się 6 lutego 1895 roku. Poczęte zostało praudopodobnie wtedy, gdy podczas pobytu żony w Kongsvinger u rodziców Przybyszeuski zamieszkał na pewien czas z dawną kochanką. 9 czerwca 1896 roku Marta Foerder popełniła samobójstwo. Była wówczas po raz czwarty w ciąży ${ }^{69}$. Przybyszewski został aresztowany jako moralny sprawca tragedii i choć uznano go za niewinnego, znajomi odsuwali się od niego, a fali plotek nie udało się poustrzymać.

${ }^{67}$ Przybyszewski wyjechał do Berlina w 1889 r. z zamiarem studiowania architektury, którą rok później porzucił dla medycyny.

${ }^{68}$ A. Sawicka, Dagny Juel Przybyszewska. Fakty i legendy, Gdańsk 2006, s. 55.

${ }^{69}$ Tezę o samobójstwie Marty Foerder podważa Wieńczysław Niemirouski, autor artykułu Stanisław Przybyszewski in Berlin (1889-1898), zamieszczonego w księdze o życiu literackim stolicy Niemiec [Literarisches Leben in Berlin (1871-1933), Berlin 1987]. Badacz na podstawie zgromadzonych dowodów tuierdzi, że kochanka Przybyszeuskiego zmarła na skutek zakażenia spowodowanego pokątnym przerwaniem kolejnej ciąży. Wiadomość za: G. Matuszek, Der geniale Pole? Niemcy o Stanistawie Przybyszewskim (1892-1992), Kraków 1996, s. 234. 
Wkrótce po przeprowadzce do kraju, w 1898 r., u życiu pisarza pojawiły się dwie kolejne kobiety: malarka Aniela Pająkówna i Jaduiga Kasprowiczowa, z której mężem - Janem Kasprowiczem - Przybyszeuski pozostawał w serdecznych stosunkach. Romansował z nimi jednocześnie, do pieruszej pisząc o Dagny delikatnie, jak przystało na człowieka wielkodusznego, do drugiej, wiecznie zazdrosnej - $\mathrm{z}$ nienawiścią. Usprawiedliwiając swe postępowanie, starał się podważyć dobre imię żony sugestiami o jej rzekomych zdradach. W atmosferze rodzinnej hipokryzji pisarz postanowił w 1901 roku wysłać Dagny z synkiem Zenonem do Tyflisu na zaproszenie Władysława Emeryka (syna przemysłowca kaukaskiego), prowadzącego przedsiębiorstwo kopalniane na Kaukazie. 5 czerwca gospodarz - z niejasnych pobudek - zastrzelił niespodziewającą się niczego Dagny, a potem popełnił samobójstwo ${ }^{70}$. Po tej tragedii Jaduiga Kasprowiczowa, porzuciuszy męża, przyjechała do Warszauy, a 11 kwietnia 1905 r. została żoną Przybyszewskiego. Dzieci urodzone z Dagny adoptował Wilhelm Westrup, mąż siostry zmarłej, natomiast Aniela Pająkówna, która 1 października 1901 r. urodziła córeczkę Stanisławę, godziła się na rolę konkubiny, nie żądając niczego od poety, wręcz przeciunie - uspierając go finansowo w każdej potrzebie.

Związek z Jadwigą nie przyniósł satysfakcji żadnej ze stron. Udręczona niewygodami i biedą pani Kasprowiczowa narzekała, posuwając się nawet do listownych utyskiwań na sue życie skierowanych do pieruszego męża. Przybyszeuski uskarżał się za to na twardą rękę, jaką druga żona - oczekująca na dodatek publicznego szkalowania Dagny - trzymała cały dom.

Dramatyczne życie uczucioue Przybyszeuskiego niezmiernie interesowało rodaków. Legenda pisarza, wyprzedzająca jego przyjazd do Krakowa we urześniu 1898 r., stworzyła u kraju podatny grunt dla zainteresowania jego osobą. O sile i natężeniu plotek oraz najrozmaitszych wieści krążących o „genialnym Polaku” świadczą m.in. niezuykle ciekawe listy Anieli Pająkóuny do przyjaciół, w których młoda malarka, a późniejsza kochanka autora Śniegu, zaintrygowana osobowością i zachowaniem nieznanego jej przybysza z zagranicy, prosi o uiadomości o nim ${ }^{71}$.

Pisarz do końca potrafił podsycać zainteresowanie swoją osobą, czego uyrazem stali się pisani pod koniec jego życia Moi wspótcześni, swoista spowiedź, w której autokreacja i dyplomacja przeważa nad szczerością $a^{72}$ Z tych autoreklamowych zabiegów coraz częściej zaczęto zdawać sobie sprawę,

${ }^{70}$ Kilka hipotetycznych powodów tragedii podaje w biografii Przybyszeuskiego S. Helsztyński, natomiast w biografii Dagny - A. Sawicka.

${ }^{71}$ Zob. K. Kolińska, Córka smutnego szatana, Warszawa 1993.

${ }^{72}$ Pierusza część Moich wspótczesnych z podtytułem Wśród obcych ukazała się u postaci książkowej w Warszawie u 1926 r., ale jej fragmenty publikowane były w prasie w 1924 i 1925 r. Część drugą - Wśród swoich - Przybyszeuski pisał do śmierci w 1927 r.; została uydana z rękopisu przez Konrada Górskiego. 
gdy minęła pierusza fascynacja osobowością Przybyszewskiego. Po latach uspominał to Krzywicki:

[...] o Przybyszeuskim rozpuszczano najrozmaitsze plotki, a im plotka była skandaliczniejsza, tym bodaj przyjemniejsza dla Przybyszeuskiego. [...] Przybyszeuski wiele robił, ażeby o nim chodziły gadki między zuykkłymi śmiertelnikami. Fama zaś pomnażała uybryki Przybyszeuskiego i przekształcała go w jakąś potęgę demoniczną, uwodzącą młodzież i ją rozpijającą, nadużywającą łatwouierności kobiecej. Mefistofeles, Don Juan, Faust, ba! kogo jeszcze więcej nie utożsamiano z Przybyszeuskim ${ }^{73}$.

Bohaterów literackich Przybyszeuskiego utożsamiano z samym autorem, a jego utwory przyjmowano jako uyznania. Najbardziej bulwersowały współczesnych akcenty osobiste w trzytomowej powieści Synowie ziemi, w której dostrzegano echa romansu pisarza z Jadwigą Kasprowiczową. Oburzeni takim ekshibicjonizmem czytelnicy Miriamouskiej „Chimery”, która drukouała książkę, w bogatej korespondencji żądali od redakcji zaprzestania publikacji niemoralnego utworu. W rezultacie na łamach pisma (w zeszytach 1-3 z 1901 r.) ukazała się jedynie niecała pierusza część powieści. Po uydaniu jej $\mathrm{w}$ formie druku zuartego w 1904 r. jeden z krytyków pisał: „Przybyszewski stale i niezmiennie opouiada tylko o sobie. Każda jego książka stanoui spowiedź publiczną, nowe kajanie się, żal, gniew, lęk, krzyk duszy własnej”"

Jakkolwiek biografistyczne podejście do literatury było w okresie Młodej Polski pouszechne ${ }^{75}$ i prowadziło do wielu nadużyć interpretacyjnych, nie sposób i dziś nie dostrzec osobistych wątków uplecionych w akcję Synów ziemi. Bohater powieści, literat Jan Czerkaski, niczym sam Przybyszewski powraca z zagranicy do Krakowa, entuzjastycznie witany przez środowisko artystyczne i pseudoartystyczne. Jest częstym gościem jednej z tamtejszych kawiarni i szybko wystawia na krakowskiej scenie swój dramat. Prywatnie cierpi z powodu zdrady, o jaką oskarża wiarołomną żonę, i wdaje się w romans z Hanką Glińską. Mówiąc o niemoralnie prowadzącej się żonie Czerkaskiego, Przybyszeuski wplótł u tekst cytat z dramatu Dagny Kiedy słońce

${ }^{73}$ L. Krzywicki, Stanisław Przybyszewski, [w:] idem, Wspomnienia, oprac. J. Wilhelmi, Warszawa 1958, t. 2, s. 441, 445. Cyt. za: A.Z. Makowiecki, Przybyszewski, s. 49.

${ }^{74}$ J. Lorentowicz, „Synowie ziemi” Przybyszewskiego, „Kurier Codzienny” 1904, nr 281, s. 2. Pozostałe części trylogii ukazały się dopiero kilka lat później: Dzień sądu u 1909, a Zmierzch w 1911.

${ }^{75}$ Lektura recenzji literackich z tego okresu nie pozostawia co do postawionej uyżej tezy wątpliwości. Krytycy i czytelnicy a priori zakładali, że podmiot autorski jest obecny u tekście. Stąd brało się odczytywanie utworów jako swoistych spowiedzi autorskich czy utożsamianie bohaterów z autorem. Miało to związek z ekspansją języka liryki na grunt pozostałych rodzajów literackich, a w obrębie powieści z przejściem od powieści auktorialnej (ugruntowanej przez realizm) do powieści personalnej, u której narracja prowadzona jest z perspektywy postaci (mowa pozornie zależna pozwalała w najprostszy sposób przedstawić rodzące się „na gorąco” przeżycia bohatera). Zob. M. Głowiński, Powieść młodopolska. Studium z poetyki historycznej, Kraków 1997. 
zachodzi: „A krew moja taka młoda i taka wiosenna, jakby młode słońce złoto swoje w mych żyłach rozpyliło" ${ }^{\text {" }}$.

Te autobiograficzne elementy poruszyły Dagny, która jeszcze na początku 1901 r. liczyła na uratowanie małżeństua z Przybyszewskim. „W tych dniach przeczytałam twoją powieść $w$ »Chimerze« - umiem już na tyle po polsku - możesz sobie uyobrazić, co się we mnie działo!" - pisała u liście do męża ${ }^{77}$.

W tym samy roku i z tego samego powodu - łatwo rozpoznawalnych wątków autobiograficznych oraz zarzutów o niemoralność - radni nakazali wycofanie z repertuaru teatru lwowskiego Ztotego runa. Czworokąt miłosny Przybyszewski - Juel - Kasprowiczowa - Kasprowicz był oczywisty także dla widzów późniejszych teatralnych realizacji dramatów młodopolskiego

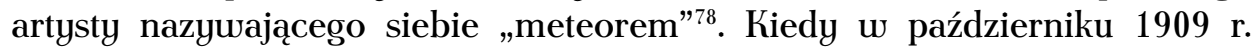
na sceniczne deski w trzech zaborach wchodziły Gody życia, krakouscy aktorzy (na czele z grającym główną rolę Solskim) ucharakteryzowali się nawet na rozpoznawalne pierwowzory. Autor był tym posunięciem głęboko wzburzony. „Jest to tak haniebna głupota i bezmyślność, że nie mam słów do dosadnego napiętnowania podobnego czynu" - ocenil ${ }^{79}$. Przeciwko biografizmowi, jednoznacznemu budowaniu analogii między „przeżyciem a tworem artysty" Przybyszeuski protestował na kartach swoich pism kilkakrotnie. Pisał: „u artysty istnieje właściwie tylko jeden sposób przeżycia - p o te n c jalny [podkr. - S.P.]: w fantazji twórczej”, „przeżycie nie było pochopem do tworu, lecz na odwrót: twór był pochopem do przeżycia" ${ }^{80}$. „Nic mnie [...] nie obchodzi, jakie zewnętrzne koleje życia ten lub ów artysta przechodził. Tę ciekawość zostawiam kamerdynerom, co przez dziurkę od klucza suego pana podpatrują. A zresztą życie zewnętrzne artysty urabia we-

${ }^{76} \mathrm{Na}$ zapożyczenie tego cytatu zurócił uwagę A.Z. Makouviecki. Badacz uskazuje też więcej zuiązków pomiędzy życiem Przybyszeuskiego a akcją Synów ziemi. A.Z. Makouiecki, Ktamstwa kompensacyjne autobiografizmu - Stanisław Przybyszewski, [w:] Autobiografizm - przemiany, formy, znaczenia, red. H. Gosk i A. Zieniewicz, Warszawa 2001, s. 104-113.

${ }^{77}$ Fragment ten cytuje u biografii Przybyszeuskiego S. Helsztyński (Przybyszewski, s. 298).

${ }^{78}$ Wątki autobiograficzne dostrzegano już na gruncie berlińskim $w$ drukowanej po niemiecku pouieści Homo sapiens. Dawało się u niej zauważyć ślady związku z Martą Foerder i niechcianych ciąży oraz wątek rywalizacji z Munchem o Dagny. (Przybyszewski kilkakrotnie nazywał siebie meteorem. W 1917 r. pisał w na poły autobiograficznym ustępie do Krzyku: „A może być, że jestem tylko meteorem, który na chuilę zabłyśnie, na chuilę ludzkość straszy i przeraża, a potem nagle ginie - szczęśliu byłbym, gdyby tak było. Droga meteorom wyznaczona jest miliard razy dłuższa aniżeli zuykłłym guiazom. [...] być meteorem to istotna moja tęsknota: zniszczyć na suej drodze kilka śuiatów, roztopić je u sobie, uzbogacić się nimi i po miliardach lat znouu powrócić, stokroć razy gorętszym blaskiem rozjaśnieć, wieścić nowe przemiany i wywroty i znouu zanikać [...]”; S. Przybyszewski, Krzyk, Lwów 1917, s. 40-41).

79 [List do Wilhelma Feldmana z 14 października 1909 r.] S. Przybyszeuski, Listy, oprac. S. Helsztyński, Warszawa 1938, t. 2, s. 468. O tym incydencie uspominają zaróuno S. Helsztyński, jak i A.Z. Makowiecki.

${ }^{80}$ S. Przybyszeuski, Moi wspótcześni, s. 17-18. 
dług swej potrzeby istota metafizyczna w artyście, ta, która tworzy, a której narzędziem tylko jest istota osobista" - przekonywat $^{81}$.

A z drugiej strony w prywatnej korespondencji przyznawał: „miałem przed oczyma jedynie moje ułasne przeżycie" ${ }^{22}$ (tak pisał w 1894 r. do Richarda Dehmla o niemieckiej wersji dramatu Dla szczęścia, prawdopodobnie mając na myśli własne rozdarcie pomiędzy Martą Foerder a Dagny Juel), „to ona jest $w$ »Am Meer « i ona znów $w$ »Epipsychidionie« - zawsze ona, ona, ona” (mowa o Dagny u liście do Ernesta Prochazki) ${ }^{83}$, „koniec »Androgyny« jest zbyt wyraźnie pisany do Ciebie" (list do Jaduigi Kasprowiczowej z 1899 r. $)^{84}$, „to dla Ciebie dopisałem w polskim »De profundis«, że się tulimy jak dwoje dzieci w stogu siana, kiedy nad nimi sroży się burza. I te zbłąkane mewy, co się z taką miłością i smutkiem wtulają w siebie, to Ty i ja" (list do Jadwigi Kasprowiczowej z 1900 r.) ${ }^{85}$.

Wbrew pozorom te dwie kategorie uypowiedzi wcale nie muszą się wykluczać. Psychologizm nie był bowiem dla pisarza tym samym co biografizm (by posłużyć się słowami Głowińskiego). Dzieło literackie to uytwór ekspresji, która uymusza na czytelniku poszukiwanie sensu u głębi tekstu. Autorskie przeżycie wyrażone w sztuce - „najbardziej autentyczne i najmniej zależne od czynników zeunętrznych" - stanowi natomiast jego istotę i wartość. „Szczerość wiąże się ze strukturą duszy, nie stanowi zaś kwestii konkretnych doświadczeń i uwikłań, jest sprawą głębinowej psychologii, nie - biografii, rozumianej jako ciąg wydarzeń rzeczywistych i niepowtarzalnych"\$6.

\section{Tuórczość Przybyszeuskiego w oczach współczesnych}

Na przełomie stuleci XIX i XX ukazała się ogromna ilość artykułów dotyczących pisarstua Przybyszeuskiego ${ }^{87}$. Mało kto - zarówno spośród najznamienitszych piór epoki, jak i zuykłych pismaków - nie zabierał głosu na jego temat. Jednak emocjonalny stosunek do biografii i dzieła dominował nad celem poznawczym. Wypowiedzi krytyczne okazywały się albo pompatycz-

\footnotetext{
${ }^{81}$ S. Przybyszeuski, Wstęp, [w:] idem, Na drogach duszy, wyd. 2, Warszawa 1902, s. 7-8.

${ }^{82}$ S. Przybyszewski, Listy, t. 1, s. 96.

${ }^{83}$ Ibidem, s. 169.

${ }^{84}$ Ibidem, s, 226.

${ }^{85}$ Ibidem, s. 257.

${ }^{86}$ M. Głowiński, Ekspresja i empatia, s. 45-50.

${ }^{87}$ Apogeum zainteresowania twórczością Przybyszeuskiego przypadło w kraju na lata $1899-1904$.
} 
nymi panegirykami, albo paszkwilami $\mathrm{w}$ niewybredny sposób szydzącymi z każdego niemal słowa autora Śniegu ${ }^{88}$.

Kolejno ukazujące się po polsku teksty Przybyszeuskiego, choćby tylko eseistyczne, niemal natychmiast zyskiwały odpowiedź krytyki. Największe zainteresowanie - z racji realizacji scenicznych - wzbudzały dramaty. Opublikowany i uystawiony po raz pieruszy u 1903 r. Śnieg do czasu śmierci autora doczekał się około osiemdziesięciu recenzji! Krytycy chętnie uypowiadali się również na temat sztuk Dla szczęścia, Złote runo i Matka. Najsurowiej oceniano powieści Przybyszeuskiego, zwłaszcza polską wersję Homo sapiens ${ }^{89}$. Przede uszystkim dlatego, że pojawiające się w nich postacie - w sposób typowy dla młodopolskich interpretacji - utożsamiano $\mathrm{z}$ autorem. Na dodatek były to postacie gorszące opinię publiczną, żyjące na marginesie społeczeństwa albo niszczące społeczne struktury: alkoholicy, samobójcy, prostytutki, abnegaci, anarchiści i ogarnięci obłędem.

Znaczenie autora Requiem aeternam było tak duże, że ogłoszona przez „Głos” w 1901 r. ankieta „Co myśli i czego chce nowe pokolenie” przekształciła się w dyskusję na jego temat. Zwolennicy pisarza uskazywali na ogólny brak ideałów i dominujący kryzys światopoglądowy, przeciwnicy opowiadali się za aktyuizmem oraz działalnością społeczną ${ }^{90}$.

Do argumentów moralnych odwoływali się przede uszystkim przeciunicy teorii i praktyki literackiej Przybyszeuskiego. Marian Zdziechouski w odczycie z 1898 r., jeszcze przed przyjazdem Przybyszewskiego do Krakowa, stwierdzał:

Mam teraz przed sobą na półce kilka tomów pouieści tegoż Przybyszeuskiego, a nie mam odwagi zabrać się do ich czytania, w tak ustrętnej, rozpaczliuie ustrętnej postaci okazał mi się kierunek tego badacza „nagiej” duszy, to delirium zrobaczonej zmysłouości, u której pogrążyły się jego żądze, jakby ślepe na błękit i słońce, niezdolne gonić za pędzącymi tam orłami ${ }^{91}$.

Z jeszcze większą pasją, nazywając Przybyszewskiego „prorokiem wykolejeńców", wypowiedział się Andrzej Niemojeuski:

\footnotetext{
${ }^{88}$ Wypowiedzi te, jak uszystkie młodopolskie teksty o literaturze i dziełach literackich, u warstuie językowej konstruowane były ekspresyjnie, na poziomie interpretacyjnym - z empatią (by posłużyć się tytułem książki M. Głowińskiego). Interpretacja góruje u nich nad informacją, a dyskurs krytyczny upodabnia się do dyskursu literackiego.

${ }^{89} \mathrm{O}$ recepcji powieści Przybyszeuskiego pisze Gabriela Matuszek w szkicu Jak czytano powieści wielkiego demoralizatora, „Pamiętnik Literacki” 1985, z. 2, s. 35-48.

${ }^{90}$ J. Dynak, Przybyszewski i „przybyszewszczyzna” w krzywym zwierciadle satyry, [w:] Stanisław Przybyszewski. W 50-lecie zgonu pisarza, red. H. Filipkowska, Wrocław 1982, s. 241.

${ }^{91}$ M. Zdziechouski, Ptazy a ptaki, [w:] idem, Szkice literackie, Warszawa 1900. Cyt. za: Programy $i$ dyskusje literackie okresu Młodej Polski, oprac. M. Podraza-Kwiatkouska, Wrocław 2000, s. 85. Tekst Zdziechouskiego po raz pieruszy ukazał się drukiem w „Przeglądzie Literackim” 1898, nr 7 pt. Spór o piękno. W uydaniu książkouym (Szkice literackie, Warszawa 1900) tytuł artykułu brzmiał już Płazy a ptaki.
} 
Dokoła Ciebie zaroiła się młódź, która wraz z Tobą piła, uwodziła cudze żony albo je strzelała. I kiedy przedtem było zaszczytem miano porządnego człowieka, teraz pijak i szubrawiec stał się tytułem honorowym. [...] Splugawiłeś uszystko, czego się dotknąłeś. Splugawiłeś każdego młodzieńca, którego wziąłeś pod suoją opiekę, splugawiłeś każdą kobietę, do której się zbliżyłeś, splugawiłeś nowy kierunek piśmiennictua, którego kapłanem samozuańczo się mianowałeś ${ }^{92}$.

Ale najwięcej zarzutów zebrał Przybyszewski od czytelników, którzy dostrzegali $w$ jego dziele jedynie zmysłową, biologiczną stronę miłości, nie rozumiejąc jej metafizycznego charakteru. W oskarżeniach o pornografię wiele zawiniło niezrozumienie jednej z podstawowych tez, wyłożonych w Requiem aeternam: „Na początku była chuć”. W zestawieniu z pozytywistycznym modelem erotyki propozycja twórcy szokowała odważnym prezentowaniem fizjologii, motywami zdrady, uwiedzenia, nekrofilii, kazirodztwa. Lutosławski tłumaczył ją dojrzewaniem wśród obcych kulturowo uzorców.

Autor, uykształcony u słynnym dziś z rozpusty Berlinie, ucale nie zna miłości polskich kochanków - tylko uprowadza do naszej poezji rozpasanie rycerzy niemieckich, zmieszane z chorobliwą romańską namiętnością cielesną - pozbawioną dziś na pruskim gruncie romańskiej subtelności, skalaną krzyżacką brutalnością ${ }^{93}$.

Twórczość Przybyszewskiego zdecydowanie odrzuciły autorytety pozytywizmu. Antoni Sygietyński, doceniając co prawda uykształcenie i talent autora Dzieci szatana, już w 1899 r. nazwał go „najciężej chorym” spośród modernistów, którzy „wciąż badają swój puls, nasłuchują tętna serca, konstatują drganie mózgu" ${ }^{4}$.

Zarzut chorobliwości w odniesieniu do kompozycji i tematyki utworów Przybyszeuskiego pojawiał się jeszcze wielokrotnie. W opublikowanym przez „Głos” felietonie pod ironicznym tytułem Wyznanie wiary modernisty krakowianie czytali:

Zamiast logicznie szeregowanych myśli, mamy tu szereg chorobliwie wybujałych wizji, obracających się prawie uyłącznie około stosunku płciowego mężczyzny do kobiety. Jest to nowy zresztą na polu literatury naszej rodzaj, który nazwałbym: literackim delirium ${ }^{95}$.

\footnotetext{
${ }^{92}$ A. Niemojeuski, Prorok wykolejeńców, „Głos” 1902, nr 5, s. 67-68.

${ }^{93}$ W. Lutosłauski, Bańki mydlane. Poglad krytyczny na tak zwany satanizm nagich a pijanych dusz, Kraków 1899, s. 11.

${ }_{94}^{4}$ A. Sygietyński, Porachunki. Neosoteryzm, „Gazeta Polska” 1899, nr 133. Cyt. za: Programy $i$ dyskusje..., s. 430.

${ }^{95}$ J.N. Szuman, Wyznanie wiary modernisty, „Głos” 1900, nr 35, s. 557. Wypouiedź Szumana dowodzi, że niezrozumienie i niechęć do twórczości Przybyszeuskiego uynikały nie tylko z odważnej tematyki, ale i nowej, trudnej w odbiorze formy.
} 
Sytuacje kreowane przez Przybyszeuskiego ocenił jako chorobliwe również Józefat Nowiński, autor uydanej u 1902 r. pieruszej monografii poświęconej twórczości pisarza:

Kończąc tę pracę, mam wrażenie takie, jakbym opuszczał posadę posługacza $u$ domu obłąkanych, gdzie nie było ani jednego okazu obłędu szlachetnego: sam obłęd haniebny ${ }^{96}$.

Piotr Chmielowski odmawiał dziełom Przybyszeuskiego psychologizmu, uważając, że rozwijają się one wyłącznie na tle fizjologicznym i patologicznym.

Wpraudzie autor maluje te orgie rozpasanej zmysłowości niby z obrzydzeniem [...], ale maluje je z taką lubością, tak często, jakby myśl jego uyłącznie w sferze stosunków zmysłowo-płciouych przebywała i z nich na żaden sposób wydobyć się nie mogła ${ }^{97}$.

Podobnie utwory Przybyszewskiego postrzegał Henryk Sienkiewicz. Na ankietę przeprowadzoną u 1903 r. przez redakcję „Kuriera Teatralnego”, a dotyczącą oceny literatury modernistycznej, autor Krzyżaków odpowiedział słynnym zarzutem o „ruję i porubstwo”. Jego wypowiedź ukazała się w druku jako pierusza, a dodatkowo uyróżniona została kursywą i większą czcionką ${ }^{98}$. Stała się ona źródłem wielu dowcipów, których autorzy opowiadali się po stronie Sienkiewicza. Przybyszeuskiego poparło jedynie krakouskie „Liberum Veto", konsekwentnie zualczające mistrza powieści historycznych ${ }^{99}$.

Wydany w tym samym roku Nowy indeks ksiażek zakazanych potępił dzieła Przybyszeuskiego (choć nie jest on uymieniony imiennie na indeksie), bo są to książki, „które może do pornograficznej literatury jeszcze nie należą, ale które ex professo starają się praktycznie pouczyć nieśuiadomych, jak sobie mają radzić i postępować, by sprośnym suym żądzom zadośćuczynić” ${ }^{100}$.

W drugim dziesięcioleciu XX w. najzagorzalszym krytykiem twórczości modernistycznej stał się Teodor Jeske-Choiński ${ }^{101}$. Przedmiotem jego guałtownych ataków były m.in. nastroje dekadenckie oraz młodopolska erotyka.

${ }^{96}$ J. Nowiński, Stanisław Przybyszewski, Warszawa 1902, s. 107.

${ }^{97}$ P. Chmielouski, Najnowsze prądy w poezji naszej, Warszawa 1901, s. 162-163.

${ }^{98} \mathrm{H}$. Sienkiewicz, Odpowiedź na ankietę w sprawie dramatu modernistycznego, „, Kurier Teatralny” 1903, nr 55; przedr. Pisma zapomniane $i$ nie wydane. Z polecenia rodziny wydał I. Chrzanowski, Luóu 1922. Jednak to właśnie Sienkiewicz sześć lat później, widząc tragiczne położenie finansowe Przybyszeuskiego, uystarał się dla niego o stypendium (na lata 1899 i 1900) Polskiej Akademii Umiejętności z fundacji swojej zmarłej żony Marii z Szetkieuiczów. Podczas wizyty w domu Przybyszeuskiego autor Krzyżaków miał nawet bawić się z małym synkiem gospodarza - Zenonem.

${ }_{99}$ Zob. J. Dynak, Przybyszewski i „przybyszewszczyzna”..., s. 240.

${ }^{100}$ W. Szczepański, Nowy indeks ksiażek zakazanych, Kraków 1903, s. 167.

${ }^{101}$ Choiński znany był również z niechęci do Żydów. 
Jak wielu czytelników, uważał, że poczynaniami bohaterów Przybyszewskiego kieruje wyłącznie popęd seksualny.

Przybyszeuski widzi, rozumie, odczuwa tylko jedną formę miłości pł c i o w e j [podkr. T.J.-Ch.], mianowicie tę, która, trawiona czarami zmysłowego pożądania, leci jak ćma u płomień, ślepa, bezwolna, oczarowana. Nie ustrzymuje jej nic. Ani religia, ani obowiązek, ani ustyd, ani uczciwość, ani obawa przed skutkami nierozwagi. Pożądam i to mi u danej chwili uystarcza - filozofuje jego miłość. Ta miłość nie zna przytłumionego szeptu budzącego się uczucia, nie zna ustydliwego rumieńca. [...] Okrutna ta ich [autorów powieści erotycznych] miłość. Wampirem jest, co wysysa z serca krew, ulewając na jej miejsce truciznę ponurego pesymizmu, chorą histeryczką jest, co obrzydza uszelką rozkosz, jawnogrzesznicą jest, co bruka z cynizmem rozpusty serce, tylko podniety ciała odczuwając, rozumiejąc ${ }^{102}$.

Choiński upatrywał zgubny upływ utworów Przybyszeuskiego m.in. w poguałceniu zasad tradycyjnej polskiej moralności. Młodopolski erotyzm, jego zdaniem zamykający życie człowieka w ramach instynktu płciowego, naruszać miał bowiem kształtowaną przez pokolenia „duszę polską” i to, co w niej święte.

Pisarz bronił się przed zarzutami o szerzeniu perwersji:

Erotomania! Erotomania! - oto okrzyk krytyków.

All right!

Jestem dumny z tego, żem temu ośmieszonemu i banalnemu uczuciu raz po raz łzami oblanemu, to znowu zęby do rozpacznych zgrzytów pobudzającemu uczuciu, które się u sztuce pod nazwą miłości rozpanoszyło, dał metafizyczny podkład, dał poza płciouym popędem samca do samiczki bolesną tragedię człowieka stworzonego na to, by wiecznie nowe żywoty płodzić, dlaczego i czemu? Dumny jestem z tego, żem poza uściskiem dłoni kochanków, w miłosnym splocie ich spojrzeń szukał praiłów bytu, starał się spojrzeć $w$ to tajemnicze mare tenebrarum, w którym nieuchwytne dla naszych zmysłów wrażenia w odbiciu cały jego obszar wypełniają, jednym słowem, żem dla oderwanego jakiegoś faktu miłosnego szukał jego znaczenia we uszechbycie ${ }^{103}$.

Reakcją na pojawienie się Przybyszeuskiego w Polsce i na jego poglądy były - poza artykułami prasowymi - niezliczone dowcipy oraz rysunkowe karykatury pojawiające się na łamach pism satyrycznych. To przede uszystkim one, z racji szerokiego adresu społecznego, kształtowały obiegowy wizerunek autora Śniegu jako dekadenta, alkoholika, uwodziciela, degenerata i szatana ${ }^{104}$.

Cieszący się dużą popularnością w Galicji „Diabeł” już w marcu 1899 r. oceniał otoczony nimbem sensacji pobyt pisarza w Krakowie i jego pierwsze wystąpienia:

${ }^{102}$ T. Jeske-Choiński, Seksualizm w powieści polskiej, s. 9, 34.

${ }^{103}$ S. Przybyszeuski, O dramacie $i$ scenie, [w:] idem, Wybór pism, oprac. R. Taborski, Wrocław 1966, s. 302-303.

${ }^{104}$ Tematem tym zajął się Józef Dynak u szkicu Przybyszewski i „przybyszewszczyzna”... 
Naród to czyta - i patrz, co się dzieje:

$\mathrm{Z}$ dniem każdym Kraków sromotniej głupieje.

$[\ldots]$

Ale nas osłoń przed najuiększą plagą:

Redakcją „Życia” i jej „duszą nagą"

Redakcja „Diabła” miała z zamieszania wokół Przybyszewskiego całkiem niezłą pożywkę. W numerze 16 z $1900 \mathrm{r}$. w rubryce sportowej zamieściła następującą „relację”:

We Luowie nieznani atleci położyli Przybyszewskiego i zabrali mu w nagrodę $25 \mathrm{złr}$. Ogólne zdziwienie nie z rezultatu walki, ale ze znalezienia przy pobitym tak wielkiej summy pieniężnej ${ }^{106}$.

W tekstach satyrycznych odnoszono się najczęściej do pojęć kluczouych dla filozofii Przybyszeuskiego; nagiej duszy i absolutu. Pierwszy termin interpretowano jako wynik zastawienia ubrania w lombardzie, który dekadenci zmuszeni byli często oduiedzać. Kontakt z absolutem trywializowano zaś jako upijanie się. Chętnie też posługiwano się leksyką z przedrostkami nad- czy meta-.

Przedmiotem niewybrednych żartów był ulubiony temat Przybyszewskiego - miłość. Satyryk „Śmigusa” skojarzył np. ze uzgórkiem łonouym termin „złote runo”, który posłużył „genialnemu Polakowi” jako tytuł jednego z dramatów.

Było sobie - „złote” runo... (mówiąc prozą: blondzłotawe!), które ukrył amor figlarz gdzieś u ogródku na murawę...

Ten, ów szukał - lecz amorka żadna rozpacz nie porusza! Bo powiada: Po to runo - tylko naga przyjść ma dusza!

W grudniu, u styczniu - rzecz za chłodna... lecz gdy ciepły przyszedł marzec - stało się!

Ach! Któż się w marcu czegokolwiek może zarzec?

Na ławeczce, $w$ altaneczce, niby zadumana wielce zrzuca dusza białe skrzydła i - zostaje w kamizelce!

${ }^{105}$ X, Hymn do losu, „Diabeł” 1899, nr 5. Cyt za: J. Dynak, Przybyszewski $i$ „przybyszewszczyzna”..., s. 237.

${ }^{106}$ Ze sportu, „Diabeł” 1900, nr 16, s. 3. Aluzja do „wielkiej summy pieniężnej” wynikała z faktu, że Przybyszeuski niemal nieustannie pożyczał pieniądze zaróuno od przyjaciół, jak i osób właściwie obcych, czego dowodzi lektura jego listów. Sparodiował tę cechę pisarza Artur Marya Suinarski, Parodie, Warszawa 1989, s. 29-32 (tu: Stanisław Przybyszeuski, Cztery listy). Autor karykaturalnie zdołał pokazać także emfazę, z jaką młodopolanin zuracał się do adresatów swych listów, w tym do kochanek. Przybyszeuski rzeczywiście został napadnięty w lipcu 1900 r., kiedy wieczorem uracał do mieszkania przy ul. Krzyżowej we Lwowie. „[...] opadło mnie trzech drabów, obrabowali doszczętnie, zbili, żem nieprzytomny leżał, i do dziś dnia mam jeszcze silne zawroty głowy" - skarżył się pisarz Anieli Pająkóunie tydzień po wypadku (S. Przybyszewski, Listy, t. 1, s. 260). O tej sprawie pisały też „Dziennik Polski” oraz „Gazeta Luouska” w numerach z 26 lipca 1900 r. 
Coraz bliżej - coraz czulej „złote runo” ręką gładzi, aż ci młodsi aniołowie odurócili uzrok swój bladzi!...

Lecz gdy zeszedł księżyc jasny - odleciała dusza naga... tylko zefir za nią utórzy bezustannie: „Blaga! Blaga!”

„Próżno ziębłam u noc marcową! Los mi rozuiał uszystką złudę: chciałam znaleźć »złote« runo - a znalazłam ciemnorude!!"107.

Ośmieszona została też figura białych pawi, jakimi bohaterowie Przybyszewskiego pragną obdarowywać kochanki.
Daj mi rękę tuą na uieki,
Pójdziem luba w świat daleki,
Na mistyczne pójdziem łąki,
Gdzie nadkwiecia kwitną pąki.
Na mistycznej wonnej trawie
Będziem karmić białe pawie,
A los hojny w ręce usunie
Nam po miękkim złotym runie ${ }^{108}$.

Tadeusz Konczyński stworzył nawet komedię Biate pawie, opartą na Złotym runie, Śniegu i poematach prozą Przybyszeuskiego.

W latach 1898-1914 nie brakowało jednak tekstów wyrażających aprobatę, a nawet zachwyt twórczością „genialnego Polaka”. Artur Górski już w programowym artykule zatytułowanym Młoda Polska ogłosił, że „dla literatury pouszechnej więcej niż Sienkiewicz znaczy Przybyszeuski”"109.

Nie brakowało również głosów broniących pisarza przed oskarżeniami o erotomanię i niemoralność. Nieraz równie guałtownych i zapalczywych jak te krytyczne.

Pogląd „modernizmu” na kobietę jest bardziej czystym, poetyckim i uzniosłym niż uszelkich „zdrowych” naturalizmów, przefiltrowanych psychologii i mieszczańsko-filisterskich [...] formułek. Wprawdzie Stanisław Przybyszeuski i „moderniści” krakouscy rozuażają byt pod postacią nieubłaganej walki odmiennych płci, [...] ale to od zdawkowej erotomanii nieco się różni. Za taki sam kosmiczny stosunek do kobiety Schopenhauer nie stracił tytułu wielkiego filozofa; za to samo Tołstoj nazywany jest wielkim, surouym moralistą, a Ryszard Wagner głębokim tragikiem rodzaju ludzkiego, miałżeby więc jeden Przybyszeuski, który to uszystko rozumie także filozoficznie [...], nosić na sobie piętno pospolitej erotomanii i pornograficznych upodobań? ${ }^{110}$

Demoralizującymi okrzyczano dzieła Przybyszeuskiego. O, rzeczyuiście! Niemoralne są one tak bardzo, jak bardzo niemiłą i nieuygodną jest brutalna ich prawda. Są aż tak

${ }^{107}$ Recenzja teatralna ze Złotego runa, „Śmigus” 1901, nr 7. Cyt za: J. Dynak, Przybyszewski $i$,przybyszewszczyzna”..., s. 243-244.

${ }^{108}$ Erjot [Roman Jungiewicz], Z teki modernisty, „Kolce” 1902, nr 3.

${ }^{109}$ A. Górski, Młoda Polska, „Życie” krak. 1898, nr 15, 16, 18, 19, 24, 25. Cyt. za: Programy $i$ dyskusje..., s. 100.

${ }^{110}$ W. Jabłonouski, Wrażenia literackie II, „Głos” 1899, nr 22, s. 509. 
niemoralne, jak niemoralnym jest życie i jak cnotliwą jest nasza skromna obłuda i jak bardzo przebiegłą i sprytną perfidia szczerości. [...] I jeśli jest uięc bezustydnym, to tym samym prawem, którym spouiednik obce czyta winy i własnych wyznaniem się kaja ${ }^{111}$.

Wielu interpretatorów dostrzegło $w$ erotyce Przybyszewskiego nie tylko sferę popędów i zmysłów, ale i tragizm uczuć.

W „Totenmesse” i we „Wigiliach” widzimy poród dwóch głównych motywów, zawartych w słowach sexus - płeć i ból is tnienia (trwoga życiowa) [podkr. Z.B.]. Motywy te poczynają odtąd służyć za głóune tło dla uszystkich utuoróu Przybyszeuskiego. [...] Nie da się zaprzeczyć, że podejmując te motyuy stał się Przybyszeuski jednym z najpotężniejszych tłumaczów treści uczuciowej naszej epoki ${ }^{112}$.

„Na początku był <Rodzaj>” - mówi we „Mszy żałobnej” - i ten punkt uyjścia zabaruia mu tragicznym erotyzmem uszystkie stosunki świata i każe patrzeć ciągle przez gazę czerwoną. Jak dla uszystkich poetóu-modernistów naszych czasów, istnieją dla niego przede uszystkim u życiu duie tajemnice: Miłość i Śmierćn ${ }^{13}$.

Nikt może w całej Europie nowoczesnej nie znalazł równie płomiennego wyrazu tęsknoty miłosnej. Pod tym uzględem zajmuje Przybyszeuski miejsce, które dotychczas nie zostało należycie ocenione przez krytykę europejską.

Miłość jego jest potęgą kosmiczną. Wszystkie zagadnienia bytu u niej mają swój początek $^{114}$.

Ale na początku XX stulecia rolę tematyki erotycznej w twórczości Przybyszeuskiego najgłębiej przeczuł (obok Stanisława Brzozouskiego) Wilhelm Presser, autor dość obszernego studium poświęconego młodopolskiemu „meteorowi”. Badacz analizował postępowanie bohaterów literackich Przybyszeuskiego, uwzględniając jego poglądy na temat „nagiej duszy”.

[...] dla Przybyszeuskiego miłość nie jest tylko „udzięcznym” tematem do powieści, jest ona dla niego czymś więcej jak tkliwo-sentymentalne gruchanie dwojga młodych dzieci, jak ukradkowe rzucanie na siebie tkliwych spojrzeń, tajemna wymiana różowych naperfumowanych liścików lub romantyczna przechadzka nad brzegiem jeziora przy blasku księżyca... [...] Przybyszeuski uważa miłość za najdonioślejsze zdarzenie w życiu człowieka, za najsilniejszy bodziec u jego życiu [...]. Zarówno jako poetę, jak i psychologa zajmuje go u pieruszym rzędzie miłość; [...]. Poeta jednak nie kręci się tylko w błędnym kole uybujałego erotyzmu, jak złośliwi tuierdzą. [...] Przybyszeuski bowiem zdołał uczucie miłosne przedstawić u tylu najrozmaitszych stopniach i napięciach, przeprowadził je przez tyle szczebli namiętności, jak rzadko który pisarz uczyni ${ }^{115}$.

${ }^{111}$ W. A. Herget, Źródta filozoficzne twórczości Przybyszewskiego, „Nowa Reforma” 1915, nr 281, s. 1-2.

${ }_{112}$ Z. Bytkouski, Stanisław Przybyszewski, Lwów 1902, s. 67-68.

${ }^{113}$ M. Krzymuska, Stanisław Przybyszewski, jego poezja, jego filozofia, [w:] eadem, Studia literackie, Warszawa 1903, s. 16-17.

${ }_{114}$ Ardens [Józef Koterbski], Wrogowie kobiety, „Biblioteka Warszauska” 1905, t. 4, z. 1, s. 71.

115 W. Presser, Stanisław Przybyszewski. Studium literackie, Luów 1903, s. 57-59, $158-159$. 
Tzw. satelici Przybyszewskiego nie uczestniczyli na ogół w polemikach na temat mistrza, jakie toczyły się na kartach pism kulturalnych i satyrycznych oraz utworów literackich. Z prozaicznego powodu: większość $\mathrm{z}$ nich nawet nie zaliczała się do ludzi sztuki, a jedynie snobowała na intelektualistów. Pozostali „po mniej lub więcej nieudanych debiutach dali za wygraną i usiąkli w burżuazję, w naród, w ludzkość, w prowincję" ${ }^{116}$. Podobne obserwacje poczynił Boy, uspominający, że wśród ludzi, którzy gromadzili się wokół Przybyszeuskiego, nie było ani jednego „firmowego” literata ${ }^{117}$. Dobór kompanów opierał się na kryterium tragicznego stosunku do życia. „Gdyby ktoś mógł mu [Przybyszeuskiemu] dać do zrozumienia, że jest pederastą, suchotnikiem, pijakiem i ułamywaczem w jednej osobie, jakże by go ujął za serce! - pisał Boy ${ }^{118}$. Cyganerię skupioną wokół autora Śniegu stanowili więc ludzie, którzy podzielali jego przekonania światopoglądowe.

Andrzej Makowiecki zauważa, że legendę Przybyszeuskiego za jego życia uspierały dwa autorytety Młodej Polski - Karol Irzykouski i Stanisław Brzozouski ${ }^{119}$. Obaj tak wypowiadali się o tematyce erotycznej u autora Śniegu:

Rewolucja literacka, jaką u schyłku naszego wieku zainicjował u nas Przybyszewski, była podniesieniem ciemnych zasłon $\mathrm{w}$ pokoju zmarłego i wpuszczeniem jasnych promieni. [...] Przybyszeuski uniósł tę zdrową porcję „niemoralności”, która jest potrzebna każdej porządnej literaturze ${ }^{120}$.

Przybyszeuski jest przede wszystkim poetą bólów, mąk i cierpień, jakie z miłości się rodzą, poetą nieubłaganego, okrutnego tragizmu miłości.

Spod pióra pewnych krytyków, którzy mówili o Przybyszewskim, wysunęło się słowo „erotomania”. Erotomanem nazywają człowieka, który lubuje się w obrazach zmysłouych przez upodobanie do nich samych; dusza Przybyszeuskiego kocha się tylko w cierpieniu, a że największe i najbardziej piekące cierpienia dostrzega w tych, o jakie nas miłość przyprawia, to już zupełnie inna sprawa ${ }^{121}$.

W końcu lat durudziestych ubiegłego wieku dla utrwalenia legendy Przybyszeuskiego duże znaczenie miały publikacje Boya, który zamierzał zweryfikować obiegowe opinie na temat autora Synagogi szatana. Żeleński najuyraźniej wypowiedział tezy o inspiratorskiej funkcji Przybyszewskiego w Młodej Polsce:

\footnotetext{
${ }_{116}$ A. Nowaczyński, Przybysz, „ABC” 1933 nr 221, 222.

117 T. Żeleński (Boy), Smutny szatan, [w:] idem, Szkice o literaturze niemoralnej, Warszawa 1990 , s. 90.

${ }^{118}$ T. Żeleński (Boy), Znaszli ten kraj?, Kraków 1962, s. 104.

${ }^{119}$ A.Z. Makowiecki, Przybyszewski, s. 55.

${ }^{120}$ K. Irzykouski, Czyn $i$ stowo. Glossy sceptyka, Lwów 1913, s. 3, 150.

${ }^{121}$ S. Brzozouski, O Stanisławie Przybyszewskim, „Wiadomości Literackie” 1928, nr 18, s. 3.
} 
Przybysz „rozbisił” naszą literaturę, dodał jej rozmachu, śmiałości, podniósł atmosferę do temperatury urzenia. Wyśmiał literaturkę sonecików i nowelek konkursouych, odnowił patetyczną koncepcję sztuki i świata ${ }^{122}$.

Określenia, jakimi Boy obdarzył Przybyszewskiego - a mówił o nim np. jako o „albatrosie Baudelaire'a”, któremu skrzydła przeszkadzały chodzić - do dzisiaj kształtują potoczną wiedzę na temat pisarza. Andrzej Makowiecki podkreśla, że próbując odkłamać legendę, „stworzył Boy legendową apologię Przybyszeuskiego" i utrualił jego obraz jako „smutnego szatana” ${ }^{23}$. Rys wzniosłości i tragizmu u życiu pisarza Boy rzeczywiście akcentował często. Oceniał go jako dobrego człowieka, który potrzebouał atmosfery nieszczęścia i tragedii, a za każde słowo płacił krwią swoją i cudzą. W jego mefistofelicznej osobowości widział skarb narodowy, remedium na kompleksy Polski, która nie miała dotychczas swojego księcia ciemności i wystrzegała się mówienia o seksualności.

Inną kategorią tekstów, w których pojawiały się opinie o Przybyszewskim i jego światopoglądzie, były utwory literackie, w których pisarz został sportretowany - najczęściej pod różnymi maskami. Wychodziły one zarówno spod piór obcych ${ }^{124}$, jak i rodzimych. Te ostatnie zebrał $\mathrm{w}$ artykule Józef Dynak ${ }^{125}$, w tym miejscu wypada jedynie uspomnieć najciekawsze, co nie znaczy, że wysokich lotów; większość wizerunków Przybyszewskiego tworzona była bowiem „przez pisarzy pomniejszych, tuzinkowych, nawet dziennikarzy" ${ }^{126}$.

Autora Śniegu rozpoznawano w Tomaszu Rydlu - pionierze „nowej nauki" i anarchiście o uwodzącej barwie głosu i demonicznej sile spojrzenia z powieści Nasi dekadenci (1899) Zofii Niedźuiedzkiej; we Włodzimierzu Kudyrko z powieści Wacława Gąsiorouskiego Moderniści (drukowanej u „Roli” w 1901 i 1902 r. oraz „Przedświcie” w 1902 r.) - modernistycz-

${ }^{122}$ T. Żeleński (Boy), Ludzie żywi, Pisma, t. 3, Warszawa 1956, s. 6.

${ }^{123}$ A.Z. Makowiecki, Przybyszewski, s. 59.

${ }^{124}$ Polski pisarz sportretowany został $\mathrm{w}$ wielu utworach literackich twórców z berlińskiej bohemy. To Kasimir der Fugenorgler u pouieści Otto Juliusa Bierbauma Stilpe. Ein Roman aus der Frosch-perspektive i Loge z dramatu Maksa Dauthendeya Maja, gdzie uystępuje wraz z Dagny ukrytą pod postacią - nomen omen - Fatinelli. Jako Spiridion Krakuschek pojauia się Przybyszeuski wraz z Eustochią (czyli Martą Foerder) i Bergljot (czyli Dagny Juel) u autobiograficznej powieści Franza Servaesa Gährungen (1898). Daje się go rozpoznać w powieściach Strindberga Kloster i Inferno. Fragment poświęcony „genialnemu Polakowi” znalazł się też u arcydziele: wydanej u 1924 roku Czarodziejskiej górze Thomasa Manna (autora debiutującego jeszcze przed rokiem 1900). Postać polskiego pisarza tropiła w tekstach literackich m.in. Gabriela Matuszek u jednym z rozdziałów książki Der geniale Pole? Niemcy o Stanisławie Przybyszewskim, Kraków 1996.

${ }^{125}$ J. Dynak, Nasi dekadenci. Literackie konterfekty Przybyszewskiego, [w:] Młoda Polska. Legendy $i$ światopoglady, red. T. Bujnicki, Katowice 1983, s. 106-130.

${ }^{126}$ Ibidem, s. 107. 
nym poecie uwodzącym grą na fortepianie, alkoholiku i nietzscheaniście; w zarozumiałym, nadużywającym alkoholu i dającym zły przykład młodzieży poecie Chmurzyńskim z Jutra Eugenii Żmijeuskiej ${ }^{127}$. Aluzje do twórczości i tez Przybyszeuskiego - w negatywnym kontekście - można było odnaleźć m.in. w Legendzie (wyd. książk. 1901) Sewera (Ignacego Maciejouskiego) i Nietocie (uyd. os. 1910) Tadeusza Micińskiego. Adolf Nowaczyński, który był jednym z inicjatorów sprowadzenia Przybyszewskiego do Polski, szybko dostrzegł destrukcyjny upływ mistrza, wyrażający się m.in. w lekceważeniu takich wartości, jak racjonalizm i utylitaryzm, i dał temu wyraz w opowiadaniu Gladiolus tavernalis (u tomie Małpie zwierciadło, 1902). Podkreśla w nim kontrast między patetyczną pozą wielbicieli nagiej duszy a ich filisterską, mieszczańską mentalnością i przestrzega przed przyjmowaniem jako stylu życia gestów pozbawionych podstaw ideowych. Cyganeria artystyczna to $w$ jego utworze ludzie mali, tchórzliwi lub podli, błyskotliwym frazesem maskujący własne niegodziwości.

Obrony „przybyszeuszczyzny” podjął się natomiast Leon Rygier w humoresce Mój wuj, jego jeleń $i$ nowe prądy (1906).

\section{Ze szkoły młodopolskiego „archicygana”}

Wpływ Przybyszeuskiego ujaunił się przede uszystkim w sferze obyczajowej i światopoglądowej, słabiej w literackiej, tym bardziej jednak warto przypomnieć utwory nawiązujące do jego koncepcji miłości.

Na Przybyszewskim wzorowali się przede uszystkim niedoświadczeni dramaturdzy, których urzekała mroczna atmosfera jego przesyconych fatalizmem utworów scenicznych. Ze szkoły „meteora” wywodzi się np. Wianek mirtowy Jerzego Żułauskiego, po raz pieruszy uystawiony we Lwowie ue urześniu 1903 r. u reżyserii Tadeusza Pawlikouskiego (wydanie książkowe 1905). Czytelnik (widz) ma tu do czynienia z trójkątem miłosnym, który od początku pozwala domyślać się tragedii. Zbliża się data ślubu Janki i Eduarda, gdy niespodziewanie do rodzinnego domu powraca $\mathrm{z}$ zagranicy Władysław, młody naukowiec wychowywany uspólnie z przyszłą panną młodą. Jankę i Władysława łączy uczucie, z którego nie zdawali sobie sprawy, dorastając razem. Najprościej byłoby zerwać zaręczyny, ale tego dziewczyna nie chce uczynić ze uzględu na rodziców - dzięki wsparciu finansowemu Eduarda kopalnia jej ojca

${ }^{127}$ Pouieść ta poustała u 1912 r., już po uyjeździe Przybyszeuskiego z kraju i zamieszkaniu $\mathrm{w}$ Monachium. W Oraczowej z tego samego utworu widziano Orzeszkową. 
może bowiem sprawnie prosperować. Obaj szlachetni zakochani są zrozpaczeni. Wreszcie $w$ dniu ślubu Janki i Edwarda Władysław popełnia samobójstuo.

Podobnie jak u Przybyszeuskiego, niespełniona miłość kończy się śmiercią jednego z bohaterów. Ale pozostali też nie zaznają szczęścia, zmuszeni do życia $\mathrm{z}$ widmem obciążającej ich tragedii.

Atmosfera niepokoju, poczucie nadchodzącej śmierci, sprzeczności natury etycznej - to cechy zaczerpnięte z twórczości Przybyszeuskiego przez Wacława Grubińskiego (1883-1973). Sam mistrz pokusił się zresztą o napisanie ustępu do wydanych uspólnie w 1906 r. dramatów Grubińskiego Na rubieży i Zacisze. „Twierdzę z całą pewnością, że imię Wacława Grubińskiego przejdzie chlubnie do literatury polskiej” - zachęcał czytelników $^{128}$.

W duuaktówce Na rubieży tragedia dokonała się już w przedakcji (co było charakterystyczne dla dramatów Przybyszeuskiego i wzorów przejmowanych z dzieł Ibsena): Antoni, wyciągnąuszy czarną gałkę w amerykańskim pojedynku o honor matki, zmuszony jest popełnić samobójstwo. Widzowie i czytelnicy są już tylko świadkami dramatycznej walki, jaką bohater toczy sam ze sobą, na jednej szali stawiając honorowy obowiązek zadania sobie śmierci, a na drugiej ogromną chęć życia u boku kochającej Anki. Nocna rozmowa kochanków toczy się w scenerii padającego śniegu. „Ja śnieg bardzo lubię, bo jest biały i robi wrażenie czegoś niezmiernie miękkiego" ${ }^{129}$ - mówi Antoni w podobnym tonie jak trzy lata wcześniej Tadeusz u Śniegu Przybyszeuskiego. O ile jednak u Przybyszeuskiego powikłanie zakończyłoby się samobójstwem jednego, a może i obojga kochanków, u Grubińskiego Anka pieszczotami odciąga Antoniego od zamiaru samobójczego i oboje postanawiają uciec, przyjmując dewizę: „niech się święcą gody życia” ${ }^{130}$.

Hedonistyczny wydźwięk mają też Kochankowie (1915), przede uszystkim zaś druga ich wersja. Dramat Grubińskiego powtarza wątek Edypa: Helena odkrywa, że jej 19-letni, poznany w Paryżu kochanek jest jej własnym synem, którego niegdyś - rozwiódłszy się - zostawiła przy ojcu. Pierwotne rozwiązanie - bohaterka zabija męża usiłującego przerwać kazirodczy związek - miało charakter melodramatyczny. W późniejszym pan Welowski po krótkiej interwencji umywa ręce, pozualając synowi i byłej żonie realizować zakazaną miłość. Mimo pewnych budujących nastrój niedopowiedzeń $w$ akcie I, zakończenie nie miało nic z metafizyki obecnej w dramatach Przybyszewskiego. Rów-

\footnotetext{
${ }^{128}$ S. Przybyszeuski, Wstęp, [w:] W. Grubiński, Na rubieży, Kraków 1906, s. 1.

${ }^{129}$ W. Grubiński, Na rubieży, s. 29.

${ }^{130}$ Ibidem, s. 41. Gody życia to tytuł dramatu napisanego przez Przybyszeuskiego w 1909 r.
} 
nież istotne dla autora Śniegu problemy etyczne zostały u Grubińskiego zniwelowane do zera.

Nie tylko tragiczna wizja miłości, ale i obecność zadziwiająco podobnych motywów łączy dorobek Przybyszewskiego z twórczością Dagny Juel, i trudno niekiedy rozstrzygnąć, które z małżonków odegrało wobec drugiego inspirującą rolę. Autor Requiem aeternam nie ukrywał, że Norweżka była jego muzą i pierwowzorem wykreowanych przez niego postaci ${ }^{131}$. Dagny natomiast zaczęła pisać już jako żona Polaka, na przełomie 1893 i 1894 r. i od męża przejęła główne założenia filozoficzne i kompozycyjne. Co więcej - tłumaczyła jego utwory na norweski, co sprzyjało zapożyczaniu rozwiązań ideowych oraz warsztatowych. Bliskie były jej formy drobne, kilku- lub kilkunastostronicowe, w których literacko rozwijała własne przeżycia. Na przykład w jednoaktówce Kiedy słońce zachodzi badacze dopatrują się echa samobójczej śmierci Marty Foerder. Ivi, bohaterka sztuki, utraciła spokój, odkąd narzeczona jej ukochanego Fina rzuciła się w morze, widząc miłość uybranka do innej kobiety. Ciężar uspomnienia o tragicznym uydarzeniu i poczucie winy dręczą Ivi u postaci nawiedzającego ją i odbierającego jej siły do życia upiora zmarłej.

Kiedy słońce zachodzi po śmierci Dagny ukazało się w przekładzie Stanisława Przybyszewskiego razem z trzyaktowym Grzechem, uważanym za najlepszą sztukę Norweżki ${ }^{132}$. Grzech przypomina Śnieg już na poziomie scenerii: jego akcja rozgrywa się $w$ wykwintnym salonie, na kominku płonie ogień, za oknem pada śnieg. W życie kochającego się małżeństua - Miriama i Hadasy - wkracza demoniczny, brutalny Leon. Zachłanną miłością zdobywa Hadasę na jedną noc, niszcząc jej spokój. Kobieta, nie chcąc żyć ze świadomością grzechu i nie mogąc wyjawić go mężoui, wypija zatrutego szampana, wcześniej podając kielich Miriamowi. Nie udaje jej się jednak ukryć zdrady - mąż domyśla się uszystkiego, czując działanie trucizny.

Podobnie jak robił to Przybyszeuski, Dagny od początku dramatu zapowiada mającą nastąpić tragedię, każąc Hadasie zapeunić męża o suej wierności i eksponować przywieziony z Indii pierścień, w którym ukryta jest trucizna.

W ramach trójkąta małżeńskiego toczy się też akcja Kruczego gniazda. Rywalkami są w dramacie rodzone siostry. Grunhild, typ femme fatale, rozstała się niegdyś z Thorem, czując, że nadmiernie ulega sile jego osobowości. Odchodząc, usłyszała od kochanka, że jest jak „zabijająca trucizna u krui

${ }^{131}$ Przykłady uprowadzenia postaci Dagny do utworów Przybyszeuskiego podaje A. Sawicka, op. cit., s. 219-220.

${ }^{132}$ D. Przybyszeuska, Kiedy słońce zachodzi, Warszawa 1902. Przybyszeuski poprzedził zbiór dedykacją: „Dzieciom moim, Zenonowi i Iuci, puściznę po matce przekazuje Ojciec”. 
i w duszy" ${ }^{133}$. Thorn szuka odpoczynku u małżeństwie z dobrą, delikatną Sygryd, nieśuiadomą jego wcześniejszych relacji z siostrą ${ }^{134}$ : „Ona jest moim szczęściem i moim białym duchem. W jej objęciu zapomnę o tym uściekłym szale" - uważa ${ }^{135}$. Ale i Thorn, i Grunhild wiedzą, że cierpień, których razem zaznali, nie ukoi żadne szczęście. Dlatego kiedy Thorn i Sygryd uracają do rodzinnego domu sióstr, odżywa dawne uczucie, które popycha Sygryd do samobójstua.

I tu także czytelnik napotyka presupozycje wydarzeń: nieszczęście zuiastują kruki i wrony krążące złowieszczo nad posiadłością oraz słowa Sygryd: „tu się wkradł jakiś upiór, jakieś widmo w ten dom”136.

\section{Recepcja tuórczości po śmierci pisarza}

Śmierć Przybyszewskiego w roku 1927 wznieciła falę uypowiedzi uspomnieniowych na łamach pism. Legendę skandalizującą zastępowano przypomnieniem o działaniach narodouych i społecznych pisarza (angażował się w sprawę polskiej szkoły w Gdańsku, pracował jako urzędnik w Poznaniu i Gdańsku) oraz o przejściu na katolicyzm i pojednaniu się z Bogiem. O znaczeniu Przybyszewskiego w ówczesnym życiu kulturalnym i literackim świadczy uydany 29 kuietnia 1928 r. numer „Wiadomości Literackich”, u całości poświęcony jego pamięci. Znalazło się tam m.in. uspomnienie Marii Dąbrouskiej, dowodzące, że lektura dzieł Przybyszewskiego była niemal pokoleniowym doświadczeniem duchowym:

Ludzie mają skłonność do przesadnego uysuwania na pieruszy plan coraz to innej sprawy życia, jakby każdą z nich po kolei chcieli tym sposobem lepiej ocenić i poznać. W czasie mojego dzieciństwa i wczesnej młodości sprawą taką była miłość pojęta jako miłość duojga, nieodpowiedzialne przed nikim i przed niczym prawo do rozwoju uczuć indywidualnych oraz kult marzenia na niekorzyść rzeczywistości. Przybyszeuski został wyrazicielem tych rzeczy, doprowadził je do pożądanej przez jego pokolenie demonicznej przesady i stał się bożyszczem czasu $^{137}$.

Popularność tekstów Przybyszeuskiego uyjaśniała Zofia Nałkouska:

\footnotetext{
${ }^{133}$ D. Przybyszeuska, Krucze gniazdo, Warszawa 1902, s. 32.

${ }^{134}$ Jak w Śniegu Przybyszeuskiego Tadeusz szukający u boki Bronki odpoczynku po burzliwym związku z Ewą.

${ }_{135}$ D. Przybuszeuska, Krucze gniazdo, s. 34.

${ }^{136}$ Ibidem, s. 28.

137 M. Dąbrowska, Piewca niedojrzałości duchowej, „Wiadomości Literackie” 1928, nr 18. Cyt. według: eadem, Pisma rozproszone, red. E. Korzenieuska, t. 2, Kraków 1964, s. $468-469$.
} 
[...] straszliwa szczerość i namiętność uyrazu - pociągają niejako czytelnika do uspółuiny, uięc i do uspółodpouiedzialności. Tymczasem karę ponosi tylko bohater książki. My zaś, którzyśmy u zbrodniach jego brali udział emocjonalnie - zarówno jak autor - pozostajemy niewinni ${ }^{138}$.

Okres międzywojenny nie przyniósł większego zainteresowania twórczością Przybyszewskiego. W opublikowanych wówczas artykułach królowały streszczenia urozmaicone osobistymi urażeniami interpretatorów. Po wojnie uwage historyków literatury poza biografią pisarza przyciągały te same zagadnienia i tematy, które rozpatrywali czytelnicy i krytycy za jego życia: naturalizm, dekadentyzm, satanizm.

W roku 1958 uydana została obszerna, interesująca i ważna monografia Stanisława Helsztyńskiego, zatytułowana Przybyszewski. Publikacja ta stanowi cenne i fundamentalne źródło wiedzy na temat biografii autora Śniegu, niemniej traktuje jego twórczość jedynie jako ilustrację i potwierdzenie życiorysu. Podobnie biografistyczną metodę obrała Krystyna Kolińska, która w książce Stachu, jego kobiety, jego dzieci (1978) działalność literacką pisarza sprowadziła w zasadzie do jednego aspektu:

Gdy zapomnimy, że za tym literackim kamuflażem stoją autentyczni bohaterowie, to utwory te będą bawić nas specyficzną stylistyką, nieprawdopodobieństwem sytuacji, kabotyństuem bohaterów, będą pachnieć tanim romansidłem za trzy grosze. Po uśuiadomieniu sobie jednak, że to uszystko działo się naprawdę, że stawka o życie była stauką prawdziwą, że literacki wyrok miał zmienić się w przyszłości w rzeczywistą tragedię rzeczywistych ludzi - kpina zmieni się w czujną uwagę ${ }^{139}$.

Za zapowiedź zmian u podejściu do twórczości Przybyszewskiego uznać należy tom zawierający artykuły wygłoszone na sesji naukowej zorganizowanej z okazji pięćdziesięciolecia zgonu pisarza. Szkice zamieścili w nim tak cenieni badacze zajmujący się Młodą Polską, jak Maria Podraza-Kwiatkouska, Andrzej Z. Makowiecki, Teresa Walas czy Marta Wyka. I choć tematykę miłości i płci podjęła uprost jedynie Bożena Wojnouska (u szkicu „Nad morzem” Stanisława Przybyszewskiego. Mistyka i płeć), pozostali krytycy podkreślali niejednoznaczność tematyki erotycznej Przybyszewskiego:

138 Z. Nałkouska, Moralność Przybyszewskiego, „Wiadomości Literackie” 1928, nr 18 , s. 6. Problem niewinności w związku z przekonaniem o deterministycznych i fatalistycznych uwarunkowaniach losu i natury ludzkiej interesował Aleksandra Świętochouskiego, którego dramat Niewinni (uyd. os. 1876) Nałkouska dobrze znała i który mógł także inspirować Przybyszeuskiego (nt. determinizmu, fatalizmu i pojęcia niewinności w utworze zob.: B. Mazan, Wczesne dramaty Aleksandra Świętochowskiego. Niewinni, Ojciec Makary, Piękna, Łódź 1991, s. 35-66).

${ }^{139}$ K. Kolińska, Stachu, jego kobiety, jego dzieci, Kraków 1978, s. 91. 
Zeusząd tu uyłania się twarz Erosa, ale jest to Eros o podwójnej twarzy. Gdy z jednej strony ukazuje oblicze pogańskie, bachiczne, rozszalałe, zbrodniczo beztroskie, zapamiętałe w „ekstazie lubieży”, to z drugiej jakże jest ono zasmucone i udręczone, uykrzywione konuulsyjnym grymasem grozy, napiętnowane chrześcijańską świadomością piekła ${ }^{140}$.

W owym tomie pokonferencyjnym, podobnie jak w innych opracowaniach wydawanych w latach osiemdziesiątych XX w., problem miłości i erotyki u twórczości Przybyszewskiego omawiany był w związku ze wzmożonym zainteresowaniem teorią „nagiej duszy”. Analizy dotyczące metafizycznych koncepcji pisarza obaliły pokutujące jeszcze mniemanie, jakoby jego erotyka była wyłącznie fascynacją biologizmem i cielesnością. Badacze uznali, że tematyka miłosna pozualała Przybyszeuskiemu dotrzeć do najgłębszych pokładów psychiki, ujawnić ukryte poza świadomością prawdy o ludzkim bycie.

Utożsamienie duszy z twórczą naturą, a przeciustawienie jej mózgowi oraz pochodzącym od niego moralności i normie społecznej daje podstawy nowej konstrukcji światopoglądowej i z niej wyprowadzonej nowej hierarchii wartościowania. Po stronie dodatnich, wywiedzionych z duszy wartości znajdzie się e r oty z m [podkr. T.W.] jako akt poznawczy, kreacyjny oraz potencjalnie odwzorouujący naturalną harmonię i pełnię $[. . .]^{141}$.

[...] nie chodzi tu przecież o erotyzm i popęd seksualny u potocznym fizjologicznym sensie, lecz o ową pieruszą zasadę bytu, o której mówią uszystkie kosmogonie świata. [...] Być może, że Przybyszeuski uyolbrzymiał, że przesadzał, że nadmiernie demonizował, popadał w egzaltację erotyczną i przeceniał rolę tego czynnika wśród tylu innych egzystencjalnych niepokojów nękających człowieka, ale niepodobna przeoczać, że i u tym szczególnym ukierunkowaniu suej twórczej pasji był on zarówno produktem tamtej epoki, jak też zaspokajał na swój sposób jej naglące potrzeby i zamówienie ${ }^{142}$.

Pojęcie „nagiej duszy” w kontekście nowożytnej duchowości dogłębnie przeanalizował w latach dziewięćdziesiątych Edward Boniecki, który pisał:

Przybyszeuskiemu zarzucano panseksualizm, a zarzut ten tak samo uysuwano wobec Freuda. Robiono to nie bez racji, ale z drugiej strony, trzeba mieć na uwadze, że płciowość to tylko jeden z wymiarów „nagiej duszy” Przybyszewskiego, u tym wypadku absolutyzowany, lecz nie wyczerpujący jej treści ${ }^{143}$.

Badacz rozważa sformułowaną przez Przybyszeuskiego koncepcję płci w kontekście kulturowym:

${ }_{140}$ T. Burek, Przybyszewski kusiciel, [w:] Stanisław Przybyszewski. W 50-lecie zgonu..., s. 15.

${ }^{141}$ T. Walas, Przybyszewski a dekadentyzm, [w:] Stanisław Przybyszewski. W 50-lecie zgonu..., s. 65.

${ }_{142}$ A. Hutnikiewicz, Stanisław Przybyszewski..., s. 50.

${ }^{143}$ E. Boniecki, Struktura „nagiej duszy”. Studium o Stanisławie Przybyszewskim, Warszawa 1993 , s. $54-55$. 
Zaproponował punkt oparcia dla kultury, którym miała być chuć. Znając późniejszą karierę psychoanalizy, należy stuierdzić, że utrafił w potrzeby kultury XX wieku i celnie obrał dla niej punkt odniesienia. Jego rozpoznanie nowoczesnego chaosu róunież było prawidłowe, co potwierdzają do dziś głosy domagające się holistycznej wizji rzeczyuistości. W odróżnieniu od Freuda, Przybyszeuski był jednak bardziej romantycznym poetą niż nowoczesnym badaczem. [...] zaproponował metafizykę płci, która wyraziła się $w$ micie początku, a więc była próbą mitycznej rekonstrukcji świata oraz przyurócenia mu ciągłości i sensu ${ }^{144}$.

Przełom w badaniach nad problematyką erotyczną w twórczości Przybyszewskiego przyniosły prace Wojciecha Gutouskiego. Rozważając - w wydanej w 1992 r. znakomitej, inspirującej monografii młodopolskiej erotyki zatytułowanej Nagie dusze $i$ maski (wznowionej w roku 1997) - charakterystyczne dla epoki mity miłości, badacz uiele uwagi poświęcił autorowi Śniegu; osadzil jego dorobek na tle literatury przełomu wieków, uskazując jednocześnie na oryginalność jego koncepcji. Jako pieruszy poddał analizie tak istotną problematykę androgynii, uskazując miejsca, w których krzyżuje się ona z mitem chuci. Scharakteryzował najczęściej pojawiające się u Przybyszeuskiego motywy miłosne i opisał rozmaite pozy przybierane w sytuacji intymnego spotkania. W kolejnych tomach studiów (zułaszcza Mit - Eros - Sacrum. Sytuacje młodopolskie) w bardzo interesujący sposób zaprezentował natomiast zuiązki erotyki Przybyszeuskiego z elementami sakralnymi i mitycznymi, podkreślając m.in. uwikłanie bohaterów w konflikt między erosem a etosem. W 2008 r. uydał osobny tom poświęcony „meteoroui Młodej Polski” (Konstelacja Przybyszewskiego), w którym pomieścił studia na temat rozmaitych aspektów jego twórczości oraz nurtujących epokę niepokojów, nieobcych i Przybyszeuskiemu.

Nieoceniony wkład do badań nad twórczością autora Requiem aeternam wniosła Gabriela Matuszek, zajmująca się analizą recepcji dzieł Przybyszewskiego w Niemczech i aktyunie działająca na rzecz wznawiania jego tekstów. W uyborze i przekładzie badaczki opublikowane zostały w 1995 r. jego wczesne eseje, a w roku 2003 ukazało się opracowane przez nią krytyczne wydanie poematów prozą (z po raz pieruszy przetłumaczonym na polski Nokturnem). Zaróuno obszerne ustępy do tych publikacji, jak i artykuły pomieszczone przez autorkę w „Roczniku Kasprowiczouskim” czy tomach zbiorowych poświęconych Młodej Polsce (np. W kręgu Młodej Polski) zawierają interesujące i nowe interpretacje. Badaczka analizowała w nich m.in. zagadnienie relacji mężczyzna - kobieta, przekonująco odpowiadając na pytanie, dlaczego porozumienie między płciami nie jest $w$ twórczości Przybyszeuskiego możliwe. Szukając źródeł mizoginizmu, stwierdziła na przykład, że strach przed kobietą jest strachem przed pustką, nicością i żarłoczną

\footnotetext{
${ }^{144}$ Ibidem, s. 49.
} 
seksualnością. Przełomem u odczytaniach twórczości „genialnego Polaka” jest jej monografia Stanisław Przybyszewski - pisarz nowoczesny, w której kompleksowo zanalizowała teksty dyskursywne, poematy i powieści Przybyszeuskiego, akcentując ich oryginalność i inspirujący upływ na literaturę nowoczesną.

Od końca lat dziewięćdziesiątych, w związku z zainteresowaniem tematyką płci, feminizmu oraz tzw. gender studies, ukazało się kilka prac omawiających erotykę modernistyczną z nowego stanowiska badawczego. W zbiorach Nowa świadomość płci w modernizmie i Ciało, płeć, literatura znalazły się m.in. teksty poświęcone Przybyszeuskiemu. I tak Grażyna Borkouska patrzy na jego dzieła przez pryzmat młodopolskiego dramatu płci: „Nie będzie przesadą stwierdzenie, że dla modernizmu przewrotem kopernikańskim jest uświadomienie różnicy płci jako tragicznego pęknięcia. [...] Płeć wprowadza dramatyczny w skutkach rozdział, skazuje na klęskę, cierpienie, niepowodzenie, fiasko, rozpacz i ból. Płeć uniemożliwia samorealizację i zamyka drogę ludzkim dążeniom do szczęścia"145.

Oryginalny punkt widzenia reprezentuje także Paweł Dybel, który pokazał zuiązek Przybyszewskiego z psychoanalizą, wskazując na możliwość interpretacji Requiem aeternam jako odbicia kompleksu Edypa ${ }^{146}$.

Mimo że przez ponad sto lat od debiutu Przybyszewskiego niemal u każdym dotyczącym go tekście krytycznym znajdowało się choćby parę słów na temat poruszanej przezeń problematyki płci i chuci, nie ukazała się do tej pory obszerniejsza praca zgłębiająca wyłącznie to zagadnienie. Próbę zsyntetyzowania i poszerzenia dotychczasowej wiedzy o erotyzmie w twórczości pisarza stanowi niniejsza książka.

${ }^{145}$ G. Borkowska, Pteć jako skaza: Przybyszewski i Nałkowska, [w:] Nowa świadomość ptci w modernizmie, red. G. Ritz, C. Binswanger, C. Scheide, Kraków 2000, s. 77.

${ }^{146}$ Zob. P. Dybel, Urwane ścieżki. Przybyszewski - Freud - Lacan, Kraków 2000. 


\section{CZECŚĆ DRUGA \\ Miłość - siła tuórcza i niszcząca. Miłosne idee, teorie, koncepcje i scenariusze}

\section{Miłość a dusza}

Wielu pieruszych badaczy i krytykóu dostrzegało w twórczości Przybyszeuskiego jedynie sferę fizjologiczną i objawy erotomanii, pomijając kontekst filozoficzny, literacki i społeczny, bez wątpienia wpływający na przełamanie przez pisarza obowiązującego w literaturze polskiej tabu seksualnego. Stosunkowo późno zauważono przyczyny, dla których akcja utworów literackich Przybyszeuskiego skupia się wokół miłosnych perypetii bohaterów, aczkolwiek autor wspominał o tych uwarunkowaniach już $w$ swoich pierwszych publikacjach po polsku - artykułach programowych (Confiteor i $O$ „nowa” sztukę), zamieszczonych w „Życiu” w 1899 r. Wyrażał w nich silne przekonanie, że artysta, wierny dyktatowi autentyzmu i absolutnej szczerości, powinien odkrywać tajemnice życia wewnętrznego, zaś najważniejszym celem prawdziwej sztuki jest dążenie do poznania duszy. Owa dusza, nazywana przez Przybyszeuskiego „nagą”, objawia się w stanach psychicznych wyzwolonych spod kontroli świadomości - jakie są udziałem ludzi dotkniętych obłędem, alkoholików, narkomanów, neurasteników - a także w chwilach osłabienia kontaktu z rzeczywistością następujących podczas miłosno-erotycznego upojenia. Przed analizą interesującego w kontekście tematu książki ostatniego z uymienionych sposobów odkrywania „nagiej duszy” niezbędne staje się uyjaśnienie genezy i znaczenia terminu, który pojawia się $\mathrm{w}$ tej pracy wielokrotnie.

Pochodzenie i autorstwo pojęcia „naga dusza” pozostaje kuestią nierozstrzygniętą. Przybyszeuski jako autora owej formuły w różnych wypowiedziach uskazywał już to siebie, już to Adama Mickiewicza. We ustępie do De profundis uyjaśniał, że stosując określenie we wczesnym etapie swej twórczości, nie wiedział jeszcze o posługiwaniu się nim przez wieszcza ${ }^{1}$.

\footnotetext{
${ }^{1}$ Zob. S. Przybyszeuski, Frontispice, [w:] idem, De profundis, Luóu 1929, s. 6, 11.
} 
Kazimierz Wyka, nie znajdując nazuy „naga dusza” w tekstach Mickiewicza, uznał, że młodopolski pisarz zafałszował jej genealogię, by pouiązać suą myśl z dziełem wielkiego poprzednika i w ten sposób dodać sobie splendo$\mathrm{ru}^{2}$. Maria Podraza-Kuiatkouska także odrzuciła możliwość mickiewiczowskich korzeni terminu, ale i zakwestionowała oryginalność jego użycia przez Przybyszeuskiego, sugerując, że pisarz przejął go - już na gruncie polskim - od krajowych krytyków zajmujących się twórczością Franza Servaesa3. Trzeba jednak wziąć pod uwagę, że nawet jeśli Servaes użył uyrażenia „naga dusza”, to prawdopodobnie później niż autor Śniegu, który u 1893 r. pisał do Dagny Juel krótko przed ślubem: „,...] chcę posiadać Ciebie tak, jak Cię nigdy nie posiadałem: Twoją nagą drżącą duszę, Twoje nagie drżące myśli [...]". Dociekania Doroty Siwickiej, a później Ewy Hoffmann-Piotrouskiej dowiodły, że Mickiewicz jednak o „nagiej duszy” mówił - użył tego sformułowania publicznie 3 maja 1842 r. na zebraniu Towarzystua Literackiego Polskiego (u przemówieniu znanym pt. Nadeszły inne czasy), z którego sprawozdania ukazały się - w dwóch wersjach - w „Dzienniku Narodouym” (nr z 3 maja 1842) oraz w „Trzecim Maju” (z 14 maja 1842). Posłużył się nim także w rozmowie z Karolem Różyckim i Sewerynem Goszczyńskim, zanotowanej przez tego drugiego w Dziennku Sprawy Bożej pod datą 23 listopada $1844^{5}$. Podobne sformułowanie pojawiło się poza tym w wersie „I ziarno duszy nagie pozostało” pochodzącym ze znanego liryku lozańskiego Widzenie. Mógł zatem Przybyszeuski zainspirować się uypowiedziami wieszcza, ale swoją „nagą duszę” wypełnił innym znaczeniem. Ponieważ rekonstrukcją sensu wyrażenia u ujęciu Mickiewiczouskim zajęły się Siwicka i Hoffmann-Piotrowska, warto tylko zurócić uwagę, że „naga dusza" obu autorów ma źródła w tradycji mistycznej. Obnażanie duszy jest bowiem istotnym elementem myślenia i obrazowania mistycznego; oznacza odrzucenie tego, co zeunętrzne, powierzchowne, ziemskie, i zbliżenie się w prostocie do Boga; nagość przynosi ewokację szczerości, otwartości, czystości i świętości. O nagości Boga i jego natury jako czystym bycie mówił m.in. Mistrz Eckhart, nadreński mistyk z przełomu XIII i XIV w. „Jeśli pamiętać, że Eckhart istotę duszy, jej głębię, szczyt utożsamił z Bogiem, co

${ }^{2}$ Zob. K. Wyka, „Naga dusza” i naturalizm, [w:] idem, Modernizm polski, Kraków 1968.

${ }^{3}$ Zob. M. Podraza-Kuiatkouska, „Naga dusza” $i$,epoka mundurów” (O Stanistawie Przybyszewskim), [w:] eadem, Somnambulicy - dekadenci - herosi. Studia i eseje o literaturze Młodej Polski, Krakóu 1985.

${ }^{4}$ S. Przybyszewski, Listy, red. S. Helsztyński, t. 3, Wrocłau 1954, s. 540. Notabene, Helsztyński błędnie datował ten list, ślub Dagny i Przybyszeuskiego został bowiem zawarty 18 sierpnia.

${ }^{5}$ Zob. D. Siwicka, „Naga dusza” i eksperyment egzystencjalny, „Pamiętnik Literacki” 1987, z. 1, s. 155-163 (oraz eadem, Ton i bicz. Mickiewicz wśród towiańczyków, Wrocław 1990); E. Hoffmann-Piotrowska, „Naga dusza” Mickiewicza-towiańczyka (przyczynek do mistycznej antropologii poety), „Przegląd Humanistyczny” 2002, z. 2, s. 71-79. Obie badaczki cytują w artykułach słowa Mickiewicza. 
Przybyszeuski poutórzył, to »nagi Bóg « i »naga dusza« stają się wyrażeniami synonimicznymi" - zauważył Edward Boniecki ${ }^{6}$, uskazując na inspiracje, jakim podlegała myśl autora Dzieci szatana.

Szukając genezy pojęcia, które zrobiło w polskiej kulturze zawrotną karierę, warto dodatkowo wziąć pod uwagę upływ - uświadamiany bądź nie - jaki mogły mieć na Przybyszeuskiego wiersze Edmonda Haraucourta, przełożone przez Antoniego Langego i opublikowane na łamach warszawskiego „Życia” w 1887 r. jako utwory z cyklu Naga dusza (tym samym tytułem dwa lata później posłużył się również Miriam, tłumacząc wiersze Haraucourta dla „Przeglądu Literackiego” - dodatku do wychodzącego w Petersburgu „Kraju”). Te filologiczne dociekania z konieczności pozostaną jednak otwarte, trudno bowiem poddawać chronologii ludzkie myśli, rodzące się $w$ podobnym kontekście kulturowym.

W końcu stulecia, coraz pouszechniej upominającego się o poszanowanie jednostkowej odrębności i wyjątkowości, ubranie wartościowane było ujemnie, jako symbol praw społecznych przygniatających indywidualność 7 . Podobnie u Przybyszeuskiego: strój, fason, którego naga dusza jest pozbawiona, to konwencje i umowy społeczne, stereotypy i schematy, jakie tłumią indywidualizm i krępują swobodną ekspresję ,ja”. Człowiek pełny, nagi - to człowiek odrzucający normy, poddający się instynktom, marzeniom i halucynacjom. Tak rozumiana istota jednostki to właśnie „dusza”. Jej poszukiwanie jest odpowiedzią na materializm empiryczny i biologiczny determinizm, uznane przez pozytywistów za podstawowe zasady rządzące rzeczywistością i poznaniem, oraz bezpośrednio wynikający z nich kryzys podmiotowości. Poszukując źródeł duchowości, Przybyszeuski zwrócił się ku Słowackiemu ${ }^{8}$ i jego Genezis z Ducha, przełamującemu utrualoną w kulturze opozycję dusza - ciało poprzez nadanie materii sensu spirytualistycznego. Zaczął od zanegowania tożsamości duszy i mózgu (rozumu), obecnej w filozofii i naukach społecznych.

Czy to, co we mnie śuiadomie myśli, wypełnia już istotę naszego „ja”?

Och nie! Stokroć razy nie!

Moja świadomość - ta świadomość na jawie - jest tylko nieskończenie maleńką uysepką na przeolbrzymim oceanie absolutnej świadomości - biedniutkim punkcikiem $w$ obrębie nagiej duszy [...] - a tę absolutną świadomość, którą nowoczesna psychologia po rozpaczliuym oporze przyjąć musiała, nazywamy: Nieśuiadomym, a ponieważ bądź co bądź trzeba jakieś naukoue pozory zachouywać: Podświadomym9.

${ }^{6}$ E. Boniecki, Struktura „nagiej duszy”. Studium o Stanisławie Przybyszewskim, Warszawa 1993, s. 124.

${ }^{7}$ Zob. M. Podraza-Kuiatkouska, „Naga dusza” $i$ „epoka mundurów”, s. 306-307.

${ }^{8}$ Zuiązkom myśli Przybyszeuskiego z filozofią Słowackiego pośuięcił interesujący artykuł Mateusz Bourkane: Stanisław Przybyszewski wobec wybranych aspektów filozofii genezyjskiej Stowackiego, „Pamiętnik Literacki” 2005, z. 3, s. 67-88.

${ }^{9}$ S. Przybyszeuski, Naokoło śmierci, Warszawa 1921, s. 13. 
Śuiadomość, rozumiana jako empiryczny i rozumowy odbiór śuiata, nie wyczerpuje definicji człowieczeństwa, nie przesądza nawet o jego konstytutywnych cechach. Przekonanie to dzielił Przybyszeuski z Karlem Du Prelem, który - uskazując na dwoistość ludzkiej natury - uznawał istnienie duszy jako substancji niezależnej od organizmu, lecz truającej przed narodzinami człowieka i po jego śmierci oraz rozprzestrzeniającej się poza obręb naszej samowiedzy. $\mathrm{O}$ składających się na osobowość niejasnych sferach życia psychicznego Du Prel pisał metaforycznie:

[...] w metafizycznej pomroce, która nas otacza, jesteśmy tak daleko od tego, aby wiedzieć, na czym polega prawda, jak ćma, która znęcona światłem gwiazdy, leci w jej kierunku ${ }^{10}$.

Prawda o człowieku kryje się za zasłoną świadomości: pod „ubraniem”, którym są schematy myślowe oraz normy i konwencje wytuorzone przez kulturę. Tkwi w nieśuiadomym, objawiającym się jedynie okazjonalnie i w specyficznych okolicznościach. Świadomość to człowiek społeczny, przyjmujący ograniczenia (zbiorowe prawidła) wyznaczane przez sytuację historyczną; człowiek pełny, wolny w ekspresji siebie - to reprezentacja nieświadomości. Zatem nieświadomość jako rzeczywistość właściwa, prawdziwa, wykraczająca poza doświadczenia zmysłowe, jest wartościowana wyżej od śuiadomości, choć razem z nią stanowi o całościowym życiu psychicznym jednostki. Dlatego ,ja” Przybyszeuskiego w przybliżeniu odpowiadałoby Freudouskiemu ego, które zajmuje miejsce między pierwotnymi potrzebami i popędami a uymogami świata zewnętrznego. Niektóre jego składniki są świadome, ale wiele jego działań opiera się na automatycznych, nieświadomych mechanizmach. W zuiązku z tym ważne jest osiągnięcie optymalnego zaspokojenia popędów przy jednoczesnym utrzymaniu dobrych relacji ze światem zewnętrznym. Zaburzenie tej harmonii jest źródłem tragizmu w życiu bohaterów Przybyszewskiego - system ideałów i wartości, zakazów i nakazów (na których straży stoi wyodrębnione przez Freuda superego) uniemożliwia realizację potrzeb dyktowanych przez nieświadomą część naszej osobowości (u Freuda: id) i osiągnięcie szczęścia.

Poszukiwanie prawdy o duszy u nieśuiadomości oznaczało zakwestionowanie tradycji kartezjańskiej, która definiowała istotę człowieka, jego „ja”, w oparciu o czynności umysłowe. Przybyszewski podważył znak równości między cogito a sum i zreinterpretował ufundowane na tym róunaniu pojęcie ego.

Kartezjanizm, wychodząc od postawy sceptycznej, poszukiwał guarantu poznania niezawodnego, opierającego się wątpliwościom. Znalazł go w samym procesie myślenia, na którym zbudował następnie przekonanie

\footnotetext{
${ }^{10}$ K. Du Prel, Spirytyzm, tłum. S. Brzozouski, Warszawa 1908, s. 41.
} 
o istnieniu jaźni. Jaźń (wynikająca z pojawiania się myśli) umożliwiała poznawanie rzeczywistości w przeciwieństuie do zmysłów, których doznania są złudne i mylące. Przeświadczenie, że fundamentów wiedzy należy szukać nie $w$ świecie zewnętrznym, lecz $w$ poznającym podmiocie, nie w materii, lecz u świadomym duchu, miało daleko idące konsekwencje, rzutujące na całą nowożytną filozoficzną teorię człowieka. Jeśli bowiem pewny jest tylko fakt myślenia, a istnienia rzeczy zewnętrznych nie da się potwierdzić (to, co myślę, może być bowiem snem, mogę też mylić się w rozumowaniu), to ludzkie ciało róunież może być złudzeniem. Jaźń myśląca kojarzona z duszą istnieje niezależnie od ciała, sprowadzonego do roli ruchomej powłoki. Radykalnie wyostrzony przez Kartezjusza dualizm duszy i ciała, obcy tradycji greckiej, z której wywodzi się europejska filozofia, doprowadzil - paradoksalnie - do postawienia hipotezy nieświadomości ${ }^{11}$. Choć bowiem prymat rozumu ideowo odpowiadał pokoleniu pozytywistów, właśnie pozytywizm strącił ,ja” z piedestału, uznając świadomość za ułaściwość każdej materii, do której zalicza się również człowiek (jako cząstka przyrody). Rozczarowanie nauką nieprzynoszącą odpowiedzi na najważniejsze egzystencjalne pytania, poczucie, że oparte na empiryzmie poznanie jest tylko namiastką prawdy ukrytej za „zasłoną Mai”, ureszcie presja społecznych zasad fałszujących rzeczywistość sprzyjały zakwestionowaniu roli świadomości ${ }^{12}$.

Zanik postaw indywidualistycznych (sankcjonowany sytuacją historyczną) i poczucie, że ludzkiego istnienia nie da się uzasadnić kategoriami biologicznymi i społecznymi, zrodziły potrzebę odnalezienia ego. Doprowadzony do skrajności kult ,ja” propagował w pieruszym okresie twórczości Maurice Barrès, którego utwory (m.in.: Człowiek wolny - 1889; Ogród Bereniki - 1891) zyskały miano „ewangelii egotyzmu”. Ten francuski pisarz (później także polityk nacjonalista) zalecał odrzucenie moralności i poszukiwanie wrażeń niezwykłych - nawet amoralnych - byle intensywnych. Najwyszukańsze wzruszenia umysłowo-uczuciowe miały jego zdaniem otworzyć jednostce drogę do autonomii wewnętrznej, dzięki której można odnaleźć jedyną nieurojoną rzeczywistość.

Próbując dotrzeć do istoty człowieka, penetrowano w modernizmie niedające się klarounie objaśnić stany psychiczne, poddawano obserwacji zachowania obyczajowo i moralnie naganne, usprawiedliwiano tłumione dotychczas potrzeby. Jednym słowem, zwrócono się ku nieświadomości. Tą drogą

${ }^{11}$ Tezę taką przyjmuje B. Dobroczyński, Idea nieświadomości w polskiej myśli psychologicznej przed Freudem, Krakóu 2005, s. 39.

${ }_{12}$ Zob. B. Szymańska, Mistycy $i$ pesymiści. Przeżycia i uczucia jako wartości $w$ filozofii polskiego modernizmu, Wrocław 1991. 


\section{- czego dowodem wcześniejszy cytat - poszedł również Przybyszeuski ${ }^{13}$. W liście do Franza Servaesa z lipca 1895 r. zwierzał się ze swoich planów penetracji ludzkiej duszy:}

Na pieruszy plan wysunę transcendentalne życie człowieka. Życie transcendentalne to nie znaczy życie duchowe ani nawet życie umysłowe (tzw. „trzeźwe” życie). Człowiek trzeźuy jest nudny. Rozum jest też nudny, ponieważ posiada zasady i granice, o które się ciągle

${ }^{13}$ Nieśuiadomość od początku była pojęciem niejednoznacznym, choć w dzisiejszych czasach pod upływem koncepcji Freuda bywa zazwyczaj definiowana jako to, co wyparte. Najbardziej rozbudowana klasyfikacja, pochodząca z publikacji Nieświadomość (1942) amerykańskiego psychologa Jamesa Millera, uwzględnia aż 16 możliwych znaczeń tego pojęcia. Pod koniec XIX i na początku XX w. teoria nieśuiadomości była już dobrze ugruntowanym elementem dyskursu filozoficzno-psychologicznego. Tylko między rokiem 1872 a $1880 \mathrm{w}$ Europie uydano sześć książek ze słowem „nieświadomość” w tytule. Tajniki życia duchowego interesowały również Polaków, co znalazło wyraz w takich publikacjach, jak Filozofia zasady bezwiednej Henryka Goldberga (1873), Świadomość i nieświadomość. Szkic psychologiczny Antoniego Złotnickiego (1888) czy Bezwiedne tradycje ludzkości Juliana Ochorowicza (1898) (dane za: B. Dobroczyński, op. cit., s. 11-13).

Termin „nieśuiadomość” pojawił się dopiero w XVIII w. Po raz pieruszy użył go w 1776 r. prof. fizjologii z Lipska Ernst Platner do opisania ciemnych percepcji obecnych w teorii Leibniza. Upouszechnili go następnie Goethe, Schiller i Schelling. Nie przyjął się za to przez długi czas utuorzony przez autora Fausta przymiotnik „nieśuiadomy”. Bardzo ważny stał się natomiast rzeczounik odprzymiotnikouy „nieświadome” („Unbewusste”), którym posługiuał się róunież Przybyszewski (w polskich tłumaczeniach obcych pism psychologicznych oddaje się tę kategorię za pomocą pojęcia „nieświadomość”, zatem i na użytek tej pracy traktować się je będzie synonimicznie). Nieuykluczone, że młodopolanin poznał ów termin dzięki publikacji Filozofia Nieświadomego (Philosophie des Unbewussten) Eduarda von Hartmanna (1869), z którą zetknął się w Berlinie.

Niemiecki filozof uznał, że każda materia obdarzona jest nieśuiadomą wolą, która realizuje się w działaniu. Owo działanie poprzedza jednak wyobrażenie celu. „Posiadać przedstawienia, a przecież nie uśuiadamiać ich sobie, uydaje się stanowić sprzeczność, jak bowiem możemy tuierdzić, że je mamy, jeśli nie jesteśmy tego śuiadomi. Jednak możemy przecież pośrednio mieć świadomość posiadania jakiegoś przedstawienia, choć róunocześnie bezpośrednio go sobie nie uśuiadamiamy" - pisał (Philosophie des Unbewussten, Berlin 1872, s. 1. Cyt za: B. Szymańska, op. cit., s. 62). Wola nie wyklucza istnienia świadomości, która przysługuje jednak tylko wybranej materii, a w planie świata jest czynnikiem utórnym, poustałym na skutek oddzielenia się od woli intelektu. Przeciustawiony rozumowi popęd, dążenie do działania o charakterze kreacyjnym, jakim jest nieśuiadoma wola, przypomina zaróuno Schopenhauerouską „ślepą wolę”, jak i chuć, o której Przybyszeuski pisał w Requiem aeternam.

Antyintelektualny charakter miały teorie poznania i metafizyki wypracowane przez wybitnego socjologa i psychologa przełomu XIX i XX w. - Edwarda Abramouskiego. Jego zdaniem, podśuiadoma część ludzkiej psychiki (terminem „podświadomość” badacz posługiwał się częściej niż słowem „nieśuiadomość”) jest niezależna od aktóu woli i operacji rozumouych. Im większa jest rola intelektu $w$ przeżyciach, tym większy ma $w$ nich udział podmiot. To, co od intelektu (a więc i podmiotu) wolne - jest rzeczywistością, rzeczą samą w sobie. W ten sposób do metafizyki prowadzą stany bezpojęciowe, jakie można osiągnąć $\mathrm{w}$ snach, nirwanie, hipnozie, $\mathrm{w}$ przeżyciach religijnych (zob. W. Tatarkiewicz, Historia filozofii, Warszawa 2003, t. 3, s. 357-358). Teraz daje się dostrzec, na jak podobnych biegunach błądziły myśli XIX-wiecznych humanistów, skoro w stanach psychicznych, wspomnianych przez Abramouskiego, także Przybyszeuski widział drogę do odsłonięcia duszy. 
obija. A więc rozumiesz: człowieka logicznego, rozumującego usuniemy, a na tronie zasiędzie człouiek bez zasad, marzyciel, fatalista i szaleniec. [...]

Ja myślę tak: w stanie trzeźwym przychodzi do głosu cała masa akcji i reakcji, które się ciągle poutarzają, ponieważ wchodzą już do przyzuyczajeń; o najgłębszej istocie człowieka, o jego tabu nie mamy najmniejszego wyobrażenia. I tego nikt dotąd nie próbował zbadać - oprócz Schlafa i mnie - chce się mieć tak zwanych zdrowych ludzi, he, he, zdrouych ludzi, tzn. idiotyczne, ujednolicone mózgi ${ }^{14}$.

Ograniczony aparat mózgouy, który Przybyszeuski nazywa „osobistym Ja", nie potrafi ogarnąć uszystkich obszarów działania duszy, ogranicza się jedynie do rozpoznawania wrażeń i logicznego ich porządkowania, koniecznego, „by się przystosować i zastosować do zewnętrznych warunków życia” ${ }^{15}$. Jest - jak obrazowo ujął Kazimierz Wyka - „czymś u rodzaju mieszaniny duszyczki filistra z naukowym i społecznym prostactwem"16. Dusza autora Śniegu to absolutna śuiadomość, czyli pełnia życia psychicznego, obejmująca procesy zachodzące pod kontrolą świadomości i nieświadomie.

Przecież ja żyję tylko małym skrawkiem mej duszy, mego istotnego „ja”, żyję ochłapami, jakie mi do mózgu dusza urzucić raczy - widzę tylko tyle, ile mi dusza widzieć pozwala [...], mimo że wiem, iż istnieje we mnie olbrzymie słońce światła - słyszę tylko tyle, ile mój mizerny organ Cortiego słyszeć mi pozuala, a przecież wiem, że tam, poza moim osobouym „ja”, szaleje i przelewa się muzyka, z której zaledwie jakiś mały tonik uyłowić jestem w stanie ${ }^{17}$.

To nieśuiadomość zawiera wiedzę prawdziwą - „kryjówki Sezama, pełne nieprzebranych skarbów i cudów”, „tam strzeże dusza swej najgłębszej tajemnicy, zagadki zagadek" ${ }^{18}$. Ta teza skutkowała przekonaniem, że próby przeniknięcia własnej duszy zausze są pozytyune, niezależnie od tego, czy jej przejawy uznaje się powszechnie za dobre lub złe, brzydkie lub piękne, moralne lub nieetyczne. Odrzucenie ograniczających norm będących wytworem kultury oznaczało $w$ istocie opowiedzenie się - jak już zauważyli badacze - za człowiekiem pierwotnym, swobodnie realizującym swe instynkty, stanowiącym medium natury. Jego najpełniejszą realizacją literacką jest bohater pouieści Homo sapiens - Eryk Falk.

O ile Przybyszewski mówiąc o świadomości, starał się korzystać z dyskursu naukowego, o tyle nieświadomość określał wyłącznie metaforycznie: jako podziemne poplątane korytarze, grobowce, labiryntowe krużganki, ocean wewnętrzny, wzburzone morze tajemnic. Nie potrafił jej zdefiniować.

${ }^{14}$ [List do Franciszka Servaesa u Berlinie, lipiec 1895] S. Przybyszeuski, Listy, oprac. S. Helsztyński, Warszawa 1937, t. 1, s. 104.

${ }^{15}$ S. Przybyszeuski, Na drogach duszy, wyd. 2, Kraków 1902, s. 19.

${ }^{16}$ K. Wyka, Modernizm polski, wyd. II zmien., Kraków 1968, s. 160.

${ }^{17}$ S. Przybyszeuski, Moi współcześni. Wśród obcych, Warszawa 1926, s. 27.

${ }^{18}$ S. Przybyszeuski, Na drogach duszy, s. 20 i 126. 
W „nagiej duszy” ukrywało się to, co ciemne i nierozpoznane, a więc i nienazwane, a zatem niemożliwe do jasnego wyeksplikowania, niewyrażal$\mathrm{ne}^{19}$. Dotarcie do tego mare tenebrarum guarantować miało jednak kontakt z Absolutem, rozwiązanie wszystkich sfinksowych zagadek, osiągnięcie gnosis. Poprzez poznanie własnej jaźni, wpisanej u porządek transcendencji, wiodła droga do odkrycia praw rządzących całym istnieniem. Sposoby na to były tylko dwa: nieświadome treści musiały przedostać się do świadomości, najczęściej $w$ chwilach osłabienia kontaktu z rzeczywistością i w nagłym akcie olśnienia ${ }^{20}$, albo ujaunić $\mathrm{w}$ przeżyciu o charakterze mistycznym ${ }^{21}$.

Rozpaczliwe pragnienie poznania jest oczywiście modernistycznym elementem odbudowywania tożsamości ,ja”, ale wiąże się też z pamięcią poprzednich wcieleń, które intuicja niekiedy odsłania. Przybyszewski wierzył bowiem, że celem duszy jest metempsychoza, prowadząca do osiągnięcia transcendencji, do suoistego „przeanielenia” (by użyć terminu Słowackiego) czy „doznania jaźni” (jak chciał Jung). Dusza ucieleśniająca się w coraz nowych wcieleniach zyskuje wzrastającą zdolność poznania. Tak pisał o tym autor Dzieci szatana:

[Dusza] raz po raz nieznaną potęgą zmuszona idzie na ziemię, wraca $\mathrm{z}$ pourotem na łono wieczności i znouu się ucieleśnia, bogatsza, silniejsza, więcej uśuiadomiona niż pieruszym razem, i tak bez końca, aż wreszcie dochodzi do świadomości całej suej potęgi, przenika najtajniejsze rzeczy, obejmuje najodleglejsze i najskrytsze zuiązki $[. . .]^{22}$.

Poznanie jest, jak u Platona, anamnezą, pewną formą przypominania, ujawniania tego, co istnieje $\mathrm{w}$ naszej duszy. Z tego można unioskować

${ }^{19}$ „Wyrazić nieuyrażalne, uchwycić nieuchwytne - oto hasło sztuki nowoczesnej” - pisał Ignacy Matuszeuski, analizując cele modernistycznej literatury (I. Matuszeuski, Słowacki $i$ nowa sztuka (modernizm), oprac. S. Sandler, Warszawa 1965, s. 142). Paradoks „wyrażania niewyrażalnego" był jednak starszy: rozwinął się w romantyzmie, gdzie uiązał się z zagadnieniem niekoherencji myślenia i mowy, a mówiąc ściślej - z możliwościami języka, który - jak pisał Mickiewicz - „kłamie głosowi”. Z czasem teza o niewyrażalności doprowadziła do rozbudowania teorii symbolizmu. W końcu XIX w. to symbol miał wyrażać to, co niemożliwe do ujęcia w słowach, a chodziło konkretnie o elementy filozoficzne (m.in. odwieczne i niezmienne byty, idee i zasady sterujące światem) oraz psychologię człowieka (stany podświadomościoue i nastrojowe). Między romantyzmem a modernizmem akcent został więc przeniesiony z signifiant na signifié. Dla modernistów nieuyrażalne było to, co niepoznawalne a zuiązane $\mathrm{z}$ naturą bytu. Problemowi niewyrażalności poświęcone zostały publikacje: Literatura wobec niewyrażalnego, red. W. Bolecki, E. Kuźma, Warszawa 1998; R. Nycz, Literatura jako trop rzeczywistości. Poetyka epifanii w nowoczesnej literaturze polskiej, Kraków 2001; A. Kluba, Autoteliczność - referencyjność - niewyrażalność. O nowoczesnej poezji polskiej 1918-1939, Wrocław 2004.

${ }^{20}$ U Junga metodą wyzwolenia człowieka z mocy nieśuviadomości jest jej integracja ze śuiadomością u procesie indywiduacji, czyli ustanawiania jaźni.

${ }^{21}$ Zob. B. Szymańska, op. cit., s. 76, 78.

${ }^{22}$ S. Przybyszeuski, $O$ „nowa” sztukę, [w:] idem, Wybór pism, oprac. R. Taborski, Wrocław 1966, s.149. 
o nieśmiertelności duszy, posiadającej prawdę już przed narodzinami człowieka. Prawda ta ulega jednak zamazaniu, gdy dusza wchodzi w ciało. Zatem wiedza może pochodzić tylko z naszego unętrza. Zmysły dostarczają jedynie wiadomości niedoskonałych, niestałych, bo opartych na mniemaniach.

Kuestia preegzystencji duszy i jej ewentualnych poprzednich wcieleń, a także zagadnienie pamięci i niejasnych motywów ludzkiego zachowania uskazują także na inspiracje Przybyszeuskiego koncepcją Plotyna, który jako pieruszy filozof kręgu cywilizacji zachodniej wyraźnie oddzielił proces myślenia od uświadamiania sobie tego procesu ${ }^{23}$. Pojmowanie nieświadomości jako spoiwa natury człowieka i kosmosu (Absolutu) sprawia, że problematyka „nagiej duszy” wykracza poza psychologię w sferę ontologii i transcendencji. Poznanie przez przypominanie zakłada bowiem pierwotny metafizyczny ogląd świata. Nieśuiadomość - jak w romantyzmie - jest nie tylko aspektem psychiki ludzkiej, ale również własnością duchowej zasady rzeczywistości pozwalającej wyjaśnić kontakt z Absolutem ${ }^{24}$. Owa prawdziwa rzeczywistość, praobrazy zachowane dzięki pamięci przeszłości, a ujawniające się fragmentarycznie, np. w snach, wykazują pokrewieństwo z Jungouskimi archetypami. Archityp (takiego pojęcia użyuał młodopolanin, zanim jeszcze szwajcarski psychoanalityk sformułował swój termin) jako najprostsza forma egzystencji przebywająca w łonie Boga (przy czym nie jest to Bóg żadnej konkretnej religii) przed przeobrażeniem się $\mathrm{w}$ ideę, a następnie łącząca kolejne ucielenia duszy, pozwala kumulować doznania ze uszystkich etapów emanacji; naturalnie dzieje się to bez udziału świadomości, archityp dostępny jest wyłącznie intuicyjnie ${ }^{25}$.

Bohaterom Przybyszeuskiego zdarzają się wizje, w których ich dusza obnaża sue początki, a każde takie objawienie potęguje pragnienie powrotu do prabytu, bo jest on stanem ukojenia, spokoju, chroniącym od metafizycznej nędzy, jaką nieuchronnie naznaczone jest ziemskie istnienie. Jana Krywłę z Dzieci nędzy „zlał pot śmiertelnego lęku, bo odsłoniła mu się przepastna

${ }^{23}$ Zob. B. Dobroczyński, op. cit., s. 45-46.

${ }^{24}$ Zob. L. Miodoński, Nieświadome w idealizmie niemieckim, [u:] Nieświadomość to odrębne królestwo..., red. I. Błocian, R. Saciuk, Toruń 2003, s. 57-58. Problem ten poruszyła także B. Szymańska, op. cit., s. 58. Przybyszeuski zdecydowanie odciął się od Schopenhauera, który zanegował absolut i przekonanie, że byt realny stanowi emanację uyższej idei i dąży do uzyskania najdoskonalszej z możliwych form, a tym samym nie przyjmował pojęcia „dusza”.

${ }^{25}$ U Junga archetypy także uyprzedzają świadomość i nie mają wyraźnego początku; pojawiły się uraz z życiem i kumulują doświadczenia całych pokoleń przodków. Jung uprowadził je dla opisania ujauniających się podczas badań nieświadomości szczególnych motywóu o charakterze mitycznym lub symbolicznym, które przychodzą do człowieka np. w snach i wizjach. Archetypy, pierwotne elementy ludzkiej psyche, nie ukazują się same w sobie, lecz - jak pisał Jung - ,jako idee i obrazy, jak uszystko inne, co staje się treścią śuiadomości” (C.G. Jung, On the Nature of the Psyche, [w:] idem, Collected Works, t. 8, par. 435. Cyt za: D. Sharp, Leksykon pojęć i idei C.G. Junga, tłum. J. Prokopiuk, Wrocław 1998, s. 38). Związkami pomiędzy koncepcją C.G. Junga a „nagą duszą" zajął się po trosze E. Boniecki. 
głębia jego duszy, odsłonił się rąbek czarnej tajemniczej kotary, jaka losy jego życia przed jego oczyma zamykała" (Dn I, 9426). Wizja nawiedza Krywłę, ponieważ wykazuje on objawy obłędu (doznaje rozszczepienia jaźni, identyfikuje się $\mathrm{z}$ wieloma biblijnymi i historycznymi postaciami, przyjmuje na siebie rolę zbawiciela własnej rodziny i całego świata), a na dodatek pochodzi ze zdegenerowanego, wymierającego rodu. Do prawdy o własnym ,ja” można dotrzeć uyłącznie w chwilach osłabienia śuiadomości - w szaleństwie, śnie, hipnozie, chorobie wywołującej gorączkę, upojeniu alkoholowym i narkotykowym. Wszelkie odchylenia prowadzą do poszerzenia percepcji. Korfini w Synach ziemi przekonuje Hankę do zażycia opium: „Jeden gram wystarczy, by uszystkie dysonanse przemienić na najczystsze harmonie, zbliżyć się do źródła życia, pierwiastka uszelkiego bytu, dokopać się do korzenia przeznaczenia”. Pod upływem narkotyku „mózg staje się jasny i bystry, ogarnia się nim uszystko to, co było dlań tajemnicą i ciemną zagadką, uszystkie mgławice i powikłania życiowe rozplątują się $w$ jasne i przejrzyste twory" (Sz II, 164) ${ }^{27}$.

Stany wyjątkowe pozwalają zajrzeć za kotarę chroniącą tajemnice duszy, potęgują doznania, są prawdą o życiu.

Idzie mi o człowieka, w którego oczach życie przepływa w swej straszliwej totalności, któremu codzienna rzeczywistość nagle objawia się $\mathrm{w}$ praistocie, ukazując mu przeraźliwe tajemnice. [...] ludzie, których ja przedstawiałem, widzieli zausze te rzeczy straszliwe. Dla mnie stan gorączkowy to jedynie wzmocniona ekstaza życia uczuciowego, uniebouzięcie i ustąpienie duszy do piekła, dla mnie halucynacja jest tym, czym dla człowieka średniowiecznego był zachuyt: środkiem do celu. [...] śuviat jest jeszcze czym innym, niż zuykłym zamtuzem, dobrym obiadem, troską finansową, czy karierą. Chciałem też pokazać, że miłość jest róunież czymś więcej, niż to, za co ją uważa przeciętna kreatura, że jest łonem macicznym i golfsztromem, korzeniem i słońcem c a ł e g o życia ${ }^{28}$ [podkr. - S.P.]

- pisał Przybyszeuski.

Najistotniejszym wymiarem „nagiej duszy” jest erotyzm. Psychika ludzka ujawnia się $\mathrm{w}$ doświadczeniu płciowym, które zaspokaja metafizyczne tęsknoty i odkrywa - poprzez androgynię - praudę o antropicznym charakterze ludzkiego bytu. Płeć „do Absolutu prowadzi, bo z niego uyszła i ku niemu podąża”"29 - twierdzi młodopolski autor.

Bohater De profundis ouładnięty miłością do swej siostry mówi:

${ }^{26}$ Lokalizując cytaty z najczęściej przywoływanych dzieł Przybyszeuskiego, użyto skrótów, których uykaz znajduje się na stronie 287; cyfra rzymska oznacza tom, arabska - stronicę, z której cytat pochodzi (według wydań umieszczonych w Bibliografii na końcu).

${ }^{27}$ Tezę, że niektóre wizje narkotyczne (zułaszcza po zażyciu meskaliny) pozwalają dotrzeć do istoty rzeczy, potwierdzają późniejsze eksperymenty, choćby Aldousa Huxleya i Carlosa Castanedy.

${ }^{28}$ [List do Alfreda Neumanna w Wiedniu, grudzień 1897] S. Przybyszeuski, Listy, t. 1, s. 173.

${ }^{29}$ S. Przybyszeuski, Szlakiem duszy polskiej, Poznań 1920, s. 142. 
Roztuorzyło się coś w mej duszy; przed mymi oczyma leżą nagie - rzeczy ukryte i zapomniane. Przypominam sobie każde słowo, którym mnie przed duudziestu laty pieściłaś, każdy ruch, każde spojrzenie, każde dotknięcie... Wszystko to, co wczoraj jeszcze było na zausze u mózgu moim pogrzebane... na zausze! (Dp 63)

Narrator Androgyne tak komentuje niepokój bohatera, oczekującego spotkania z ukochaną:

A dusza jego drżała, błądziła, jak ptak przed burzą w strasznym niepokoju, bo czuła, że nadchodzi uielki cud, że przepaście się otwierają, że już blisko chwila, w której dusza uszelkie tajnie przenika i w przepych własnej nagości patrzy. (A 444-445)

Fascynacja erotyczna pozwala odbierać świat synestezyjnie, zaciera granice między jawą a halucynacją, rozbudza uyobraźnię i intuicję, pozwalającą wkroczyć w to, co wewnętrzne. Seks inicjuje poznanie, prowadzi w głąb własnej jaźni i struktury uszechżycia, jest więc doświadczeniem egzystencjalnym. A im relacja miłosna bardziej skomplikowana, nasycona bólem, perwersyjna, im silniejsze emocje wywołuje, tym dokładniej pozwala człowiekowi dotrzeć do takich wewnętrznych obszarów, których obecności w normalnych warunkach nigdy by sobie nie uświadomił. Zatem miłość kazirodcza, nekrofilia, uleganie urokom femme fatale, uwiedzenia, zdrady itp. - których tak wiele na kartach utworów autora Śniegu - nie służą urozmaiceniu fabuły, pobudzeniu wyobraźni spragnionych sensacji czytelników, lecz są próbą odkrycia najgłębszych prawd bytu ludzkiego; odsyłają do sfery przeżyć najistotniejszych dla zakresu semantycznego utworów (choć trzeba przyznać, że dążenie do jak najpełniejszej ekspresji stanu duszy częstokroć odbijało się niekorzystnie na artystycznych walorach tekstów).

Skoro tajemnica „nagiej duszy” jest nierozstrzygalna, odkrywana fragmentarycznie w wyjątkowych stanach napięcia psychicznego, dziwić może podjęta przez Przybyszeuskiego próba jej opisania. Młodopolanin poważył się na nią prawem twórcy, w którym „daleko potężniej absolutna dusza się uśuiadamia, aniżeli w innych [ludziach]" ${ }^{30}$ i który ma dar penetracji własnego „ja”. Dzieło poustaje bowiem dzięki intuicji, a więc pamięci „nagiej duszy", docierającej do artysty w chwilach natchnienia ${ }^{31}$. Na tym argumencie

\footnotetext{
${ }^{30}$ S. Przybyszeuski, Na drogach duszy, s. 21.

${ }^{31}$ Tezę o pochodzeniu sztuki ze sfer nieśuiadomych autor postauił już u suojej pieruszej publikacji - rozprawie o Chopinie i Nietzschem. Z nieśuiadomych pokładów psychiki pochodzi także tęsknota, która rodzi się na uspomnienie utraconego przez duszę raju bytowania u boku Boga u pełni wiedzy, oraz nierozerwalny związek człouieka z ziemią rodzinną jako cząstką wieczności. Sam Przybyszewski przywoływał krajobraz rodzinnych Kujaw, by używać go jako narzędzia interpretacji dla własnej biografii i tuórczości. Traktował go - w sposób typouy dla symbolizmu - jak pejzaż wewnętrzny. G. Matuszek twierdzi, że przeżycia i pejzaże dzieciństwa ukształtowały u pisarzu późniejszy sposób odczuwania śuiata, stały się
} 
Przybyszeuski oparł walkę „o nową sztukę”, której powierzył zadanie odtwarzania stanu duszy artysty, a nie - jak było to dotychczas w myśl formuły Stendhalouskiej - literackiego kopiouania rzeczywistości. Pisał:

[...] sztuka jest odtuorzeniem tego, co jest wiecznym, niezależnym od wszelkich zmian lub przypadkowości, niezawisłym ani od czasu, ani od przestrzeni, a więc: odtuorzeniem istotności, tj. duszy ${ }^{32}$.

Skoro odrzucono dyktat rozumu, zurócono się ku uczuciom jako wartościom guarantującym prawdziwość poznania i pełnię istnienia. „Nagą duszę” konstytuują „jedynie rzeczywiste zuiązki i połączenia uczuciowe" ${ }^{33}$, zatem i odbierać trzeba ją uczuciowo, na drodze intuicyjnego wrażenia; rozum nie jest zdolny do pojmowania duszy ${ }^{34}$. Konieczność uyrażenia nieuyrażalnego oznaczała więc zmiany w strukturze utworów literackich. Odtwarzanie uczuć, myśli, uizji i snów tak, jak przejawiają się one w duszy, bez logicznego uporządkowania, doprowadziło do zuiększenia roli symbolu jako ingredientu nastroju odsyłającego do uieczności, do Absolutu, oraz zaciemniło i skomplikowało kompozycję, narażając młodopolskiego twórcę na zarzut „bełkotu” ${ }^{35}$. Projekcja tajemnic duszy „w słowa nieujętych” ${ }^{36}$ nie mogła być jednak przejrzysta, jako forma uyrazu pozostawał dla niej tylko krzyk ${ }^{37}$. Zresztą poza poematami to właśnie powieść zatytułowana $K r z y k$ okazała się najdoskonalszą realizacją postulatu uyrażania $\mathrm{w}$ dziele artystycznym treści nieświadomych ${ }^{38}$.

duchową „impregnacją” (G. Matuszek, Stanisław Przybyszewski - pisarz nowoczesny. Eseje i proza - próba monografii, Kraków 2008, s. 135, 136, 143).

${ }^{32}$ S. Przybyszeuski, Confiteor, [w:] idem, Wybór pism, s. 140-141.

${ }^{33}$ S. Przybyszeuski, Na drogach duszy, s. 25.

${ }^{34}$ Wspominał o tym aspekcie już E. Boniecki, op. cit., s. 62, 66.

${ }^{35}$ Przybyszeuski uprościł fabułę, by uydarzenia i postacie były jedynie projekcją konfliktów wewnętrznych. Odrzucił logiczne (przyczynowo-skutkowe) następstuo zdarzeń na rzecz luźnego łączenia uizji i uspomnień oraz kompilacji porządków realistycznego i symbolicznego. Wiedza narratora jest ograniczona, jedyną osobą przedstawiającą czytelnikoui śuiat utuoru jest bohater; poematy i pouieści Przybyszeuskiego są w zasadzie niespójnym monologiem weunętrznym, uygłaszanym za pomocą mouy pozornie zależnej. Poluzowanie kompozycji uyrażało się także u pozbawieniu utworu scenografii: opisów i tzu. tła zdarzeń. Zarzuty dotyczące epizodyczności i bałaganu dosięgały nie tylko Przybyszeuskiego. Można je było spotkać niemal w każdej recenzji młodopolskich utuorów, również autorstwa Reymonta czy Żeromskiego.

${ }^{36}$ S. Przybyszeuski, $O$ „nowa” sztukę, s. 150.

${ }^{37}$ Zurócili na to uwagę badacze, m.in. M. Podraza-Kuiatkouska, "Naga dusza” $i$ „epoka mundurów" oraz D. Siwicka, op. cit., s. 163.

${ }^{38}$ Bohaterem Krzyku jest artysta pragnący namalować obraz ulicy, który odda prawdę o ludzkim świecie nie tylko $w$ sferze zjawisk, ale przede uszystkim w wymiarze metafizycznym; który odsłoni zagadkę życia. Aby ogarnąć istotę rzeczyuistości, Gasztout musi usłyszeć krzyk, w którym uyrazi się tajemnica bytu, krzyk osoby na granicy śmierci (Przybyszeuski dotknął tu, uspomnianego wcześniej, wyostrzonego u modernizmie problemu twórczego uyrażenia tego, co niewyrażalne). W osiągnięciu celu pomaga mu soboutórowa postać Weryhy - zabicie go w finale powieści oznacza dla Gasztouta samobójstwo, ale i otwarcie bram 
Dopiero jednak Gabriela Matuszek w swej świetnej monografii dokonała wyraźnej rewaloryzacji prozy Przybyszeuskiego, zułaszcza zaś jego dorobku powieściowego, obfitego i interesującego, acz przez krytykę ocenianego nisko. Badaczka, doceniając nowatorstwo formalne utworów mimo wielu ich kompozycyjnych i stylistycznych niedoskonałości, sytuuje je $w$ obrębie realizacji powieści-eksperymentu oraz pieruszych w Europie powieści-dramatów ${ }^{39}$.

Wypowiedzi na temat duszy świadczą o tym, że Przybyszewski traktował ją jako coś istniejącego obiektywnie, a nie jako element retoryki czy metaforyki. Uznanie substancjalności duszy tłumaczyło zaś możliwość odrywania się jej od ciała i uyłaniania w postaci sobowtóra, którego pisarz tak chętnie uprowadzał w obszar swoich utworów. Problem ten nurtował go przez całe życie, skoro rozwinął go jeszcze w ostatniej powieści Il regno doloroso, której przedmiotem są m.in. dysputy, czy czarownice wybierają się na sabat corporaliter et realiter czy też in imaginatione et somnio ${ }^{40}$.

„Naga dusza” przypomina freudouskie id i bergsonouską „jaźń głęboką”; jest tym, co w ludziach pierwotne, żywiołowe, pozbawione upiększeń, „rozebrane" z rozumu i pięciu zmysłów. Idea jej pierwotnego bytowania w wieczności kierowała uwage ku koncepcji androgynizmu, której rewersem stała się - zułaszcza w Pentateuchu - chuć wraz ze zuiązanym z nią obszarem popędów. Marzenie o jedności jest udziałem bohaterów Przybyszeuskiego w jednakowym stopniu co żądza posiadania o naturalistycznym rodowodzie.

\section{Chuć}

Am Anfang war das Geschlecht - tak rozpoczyna się napisany po niemiecku poemat Totenmesse (1893), pierwszy czysto literacki utwór Przybyszeuskiego. Geschlecht znaczy przede uszystkim „płeć”, jednak w polskiej wersji tekstu (Requiem aeternam), poustałej siedem lat później, autor umieścił bulwersujące, nacechowane ekspresyjnie słowo „chuć”, które

nieznanego, u momencie śmierci bohaterowi udaje się bowiem usłyszeć „Ten krzyk! Ten krzyk” (K 197). W zakresie formalnym Krzyk spełnia wymogi powieści personalnej: wszystko, co czytelnik wie o śuiecie przedstawionym, uynika ze sposobu jego percepcji przez bohatera, który przez wizje i majaki kontaktuje się z ułasną nieświadomością. Powieść ta, uydana we Lwowie w grudniu 1917 r., nie będzie szerzej omawiana w tej książce, ponieważ nie wiąże się bezpośrednio z jej tematem.

${ }^{39}$ G. Matuszek, Stanistaw Przybyszewski..., s. 228-233.

${ }^{40} \mathrm{O}$ substancjalności duszy świadczyły ureszcie personifikacje, w których dośuiadczała ona tego samego, co ciało, m.in. fizycznego bólu. „Dusza krwawiła z tysiąca ran” - pisze np. Przybyszeuski w De profundis (Dp 51). Przekonanie, że dusza, mając kształt podobny do ciała, może ukazywać się jako soboutór o ciele astralnym, uyrażał wcześniej m.in. Karl Du Prel. 
Schopenhauer łączył z metafizyką. Pojęcie to - podobnie jak jego translatorski odpowiednik $w$ języku niemieckim - okazało się problematycznie wieloznaczne ${ }^{41}$.

Na początku była chuć. Nic prócz niej, a uszystko w niej. (Rae 45)

Przez sparafrazowanie prologu Ewangelii św. Jana, a więc postawienie chuci na miejscu Słowa, Przybyszewski zdegradował pierwiastek duchowy (identyfikowany z boskim planem dziejó $\mathrm{w}^{42}$ ), do rangi zasady istnienia wynosząc biologię, popęd, chaos. Budując metafizykę płci, nawiązał do mitów początku - głównie greckich i indyjskich, idei kosmogonicznego Erosa orfików oraz pierwszych greckich kosmogonii niemitologicznych ${ }^{43}$. Jak jońscy filozofowie przyrody, pytał o pierwotną materię, o początek i regułę, która wyjaśnia uszystko, o istotę bytu, o arche. Jak Heraklit widział zasadę śuiata w ogniu, Anaksymander w bezkresie, jako czymś nieskończonym i nieokreślonym, a Anaksymenes w powietrzu, podobnie Przybyszeuski dostrzegł ją w chuci. Młodopolski autor rozwinął koncepcje hilozoistów (uznających tożsamość materii i życia) i skonfrontował je z tradycją biblijną, głoszącą prymat pierwiastka duchowego. Kosmogonia Przybyszewskiego jest z pewnością prowokacyjna, nie służy jednak apoteozie erotyzmu i popędu seksualnego $w$ potocznym, fizjologicznym sensie.

${ }^{41}$ Historia terminu Geschlecht daje interesującą lekcję. Jeszcze pod koniec XVIII w. dominowało genealogiczne jego znaczenie: rodzaj (ludzki, gramatyczny) i ród. Słynna encyklopedia Brockhausa u 1893 r. jednoznacznie na pieruszy plan wysuwa już biologiczny sens pojęcia, traktując je jako określenie płci męskiej i żeńskiej (sexus masculinus i sexus femininus) - duóch form, różniących się budową narządów płciowych, wyglądem zewnętrznym oraz charakterem i życiem uczuciouym (i to od najmłodszych lat), a także rolą społeczną. U podstaw tego terminu w końcu XIX w. leży więc różnica, podczas gdy początkowo kładło ono nacisk na zuiązek i wspólnotę. Jan Papiór, który u 1990 r. dokonał tłumaczenia poematu Totenmesse $\mathrm{z}$ wersji niemieckiej (ukazało się nakładem Muzeum im. Jana Kasprouicza u Inowrocławiu), przełożył Geschlecht jako „rodzaj”, błędnie zawężając w ten sposób znaczenie słowa. „Rodzaj” w języku polskim przełomu XIX i XX w. definiowano bowiem wąsko jako „w układach historii naturalnej zbiór gatunków, we wszystkich głównych cechach między sobą zbliżonych" (Rodzaj [hasło], [w:] Encyklopedia powszechna z ilustracjami i mapami S. Orgelbranda, t. 12, Warszawa 1902, s. 630). Przybyszeuski również miał problemy terminologiczne. W Przyczynku do etyki ptci z 1908 roku (którego fragmenty z drobnymi zmianami ułączył później do tomu Szlakiem duszy polskiej) móuił o „Płci” dokładnie w takim kontekście, w jakim u Requiem aeternam występowała „chuć”. Kilka lat później we ustępie do polskiego uydania De profundis pisał: „Chuć czy też płeć - czas by był, by polskie językoznaustwo raz wreszcie ustaliło metafizyczny termin, który by odpowiadał niemieckiemu Geschlecht - francuskiemu le sexe" (Warszawa 1922, s. 28).

${ }^{42}$ Zob. W. Gutouski, Chuć przeciw duszy narodu. O kompleksach polskich i erotyce modernizmu, „Acta Universitatis Nicolai Copernici” 1986, s. 61.

${ }^{43}$ O kulturowych konotacjach i źródłach metafizyki chuci pisała G. Matuszek, Seksualizm $i$ androgynizm. $O$ erotyce w twórczości Stanisława Przybyszewskiego, „Rocznik Kasprowiczouski” 1990, s. 96-101. 
Zgodnie $\mathrm{z}$ ontogenezą, wyłożoną $\mathrm{w}$ poemacie na wzór naukowej rozprawy, chuć to „weunętrzny, organiczny, twórczy niepokój” "4 ciągły ruch, początek istnienia w ogóle i istnienia jednostkowego; to dążenie do osiągnięcia rozkoszy nieskrępowanej ograniczeniami, siła natury czyniąca z zaspokajania popędu płciowego nie tylko najuyższą potrzebę, ale i cel istnienia. „Widzę całą naturę jako apokaliptyczną apoteozę wiecznie drgającego phallosa" - mówi bohater Requiem aeternam (Rae 92), sprowadzając chuć do rangi zasady świata.

$\mathrm{W}$ procesie ewolucyjnym - zgodnym $\mathrm{w}$ zasadzie $\mathrm{z}$ koncepcją darwinowską - chuć, czyli byt pierwotny, praelement, dążąc do intensyfikacji rozkoszy i samozadowolenia, tworzyła coraz doskonalsze narządy, organa i formy. Szczyt lubieżności miała osiągnąć z chuilą wytworzenia mózgu i towarzyszących mu pięciu zmysłów, umożliwiających odbieranie każdego urażenia na kilka sposobów. Aby jeszcze spotęgować intensywność urażeń, chuć rozszczepiła zmysły, by dostarczały tysiąckrotnej rozkoszy - „Tak się dusza porodziła" (Rae 47). Jednak zamiast wzmagać odczucie przyjemności, dusza zdradziecko zuróciła się przeciuko chuci, nie chcąc służyć niskim instynktom i popędom. Zrywając pępowinę łączącą z matką-chucią, odniosła triumf połouiczny: odsunięta od kosmicznego źródła, zaczęła słabnąć, ginąćt5. Taką chorą duszą obdarzony jest bohater Requiem aeternam.

Ale choć zginąć muszę, kocham tę straszną potężną siłę, co jedyną kosmiczną potęgę zmogła, ją w siebie wchłonęła, kocham moją duszę, moją wielką umierającą duszę, co mi chuć pożarła, by bez niej umrzeć. (Rae 49)

Chuć w kosmogonicznym ujęciu Przybyszeuskiego przypomina élan vital Bergsona, pęd o charakterze kosmicznym, a także Platońskiego Erosa, warunkującego ludzkie działanie. To do pewnego stopnia wola życia z filozofii Nietzschego. Chuć ma wreszcie wiele uspólnego z „wolą” w sensie Schopenhauerouskim $^{46}$ - jest nieświadomym dążeniem, ślepą siłą, która rządzi człowiekiem bez względu na jego rozumowe pragnienia. We ustępie do uydania De profundis z 1929 r. pisarz stwierdza, że całe życie uczuciowe i etyczne podporządkowane jest chuci.

Płeć - cały ten potworny zasób kół, kółek, trybów, które się u sobie zazębiają i ten przyrząd zegarowy tworzą [...], jaki „ludzkim bytem” nazywamy, te koła, kółka [...], te uszystkie nasze namiętności, pragnienia, instynkty: ich szybsze czy też wolniejsze obroty wytuarzają nasze cnoty i zbrodnie, ich nagły przerażający rozmach jest przyczyną naszych ekstaz, upojeń,

${ }^{44}$ A. Hutnikiewicz, Stanisław Przybyszewski. Legenda i rzeczywistość, [w:] idem, Portrety i szkice literackie, Warszawa 1976, s. 50.

${ }^{45}$ Por. E. Boniecki, Struktura „nagiej duszy”, s. 51.

${ }^{46} \mathrm{Na}$ tę ostatnią zbieżność badacze uskazywali najczęściej, m.in. J. Tuczyński, Schopenhauer a Młoda Polska, Gdańsk 1969; M. Podraza-Kwiatkouska, Schopenhauer i chuć, „Teksty" 1974, z. 2, s. 25-35. 
uniebouzięć lub piekłowzięć, ale nie byłoby ruchu ani rozpędu, ani obrotu, gdyby nie było napędowego głównego koła, jakim jest Płeć [...]. (Dp 29)

Bohaterowie Przybyszeuskiego nie potrafią przeciustawić się tej sile; są zdeterminowani na sposób naturalistyczny, pragnienie intensyfikacji doznań jest nieuniknione.

Najbardziej typouym dzieckiem natury jest Eryk Falk (Homo sapiens). Kierują nim żądze i namiętności. Uwodzi młodą, niedoświadczoną Maryt i doprowadza do jej samobójstwa, dając upust podświadomym popędom. Nie potrafi zrozumieć siły, która pcha go ku dzieuczynie, i nie może nad nią zapanować.

A więc jest narzędziem jakiejś istoty czy woli, której nie zna, a która niemniej jest w nim czynna, robi z nim, co jej się podoba [...], a mózg musi przy tym uykonywać czynności pomocnicze [...].

Jeżeli np. teraz Maryt uwiedzie, to nie będzie jego winą. Zupełnie nie! On musi robić to, co nieznane $\mathrm{X}$ u nim mu robić każe. (Hs II, 106)

Na początku była podstępna, złośliwa, chochlikowata natura... [...] Ja nie wiem, czym jestem! [...] Widzę, że moje ruchy wykonują jakieś procesa w moich narządach płciouych - ot! i stało się! Co się stało? Nieszczęście! Nieszczęście! Kto to zrobił? Ja? Ja? Kto jestem Ja? Czym jestem? (Hs III, 38-39)

Eryk nie wie, czy kierujący nim imperatyw tkui w pokładach pękniętej psychiki, jest sygnaturą natury i animalnym dziedzictwem („uszyscy są zuierzętami" - orzeka, komentując grafiki uwielbianego Goi) ${ }^{47}$, czy też ma proweniencję boską, której bohater rzuca wyzwanie („Zobaczy, kto silniejszy - on, lub też ukrzyżowany Rabbi!"; Hs II, 32). Zawarte w tych wątpliwościach pytanie o człowieczą konstytucję i podmiotowość nadaje tytułowi cyklu powieściowego odcień ironii. Homo sapiens, którego rozum ustępuje przed popędem? W oksymoroniczności tej propozycji kryje się głęboka dekonstrukcja tożsamości i jednostkowości, o konsekwencjach ważkich dla całego modernizmu. Obrazouym pendant chuci jest w trylogii - co zauważyła G. Matuszek - poczucie porwania przez wir ${ }^{48}$. Obezwładniające nurty erotycznego malstromu (słowo to pojawia się w tytule części trzeciej) wciągają, zaprzepaszczają, niszczą i dezintegrują.

Popędowe, niskie, zatraceńcze elementy uczucia zostały także podkreślone u obrazie kazirodczej miłości u De profundis.

${ }^{47}$ Autor wielokrotnie akcentuje $\mathrm{w}$ pouvieści podobieństwo Falka do zuierzęcia działającego pod upływem instynktów i bodźców płynących z nieśuiadomości. Uwagi na ten temat zob. podrozdział Erotyczne bestiarium.

${ }^{48}$ G. Matuszek, Stanisław Przybyszewski..., s. 252. 
Coś rzuciło ich na siebie. Przepadli, ginęli w tej głuchej, niemej chuci krui. Na ośle p rzucili się w w i r y [podkr. - K.B.] i zatory rozpienionej ekstazy lubieży. (Dp 67)

Agaj i jej brat ulegają sterującej nimi potężnej potrzebie bez oglądania się na normy moralne. Pożądają na sposób animalistyczny i aż do samozniszczenia - $\mathrm{w}$ finale poematu popełniają samobójstwo, rzucając się $\mathrm{w}$ morze, łącząc na pourót z naturą.

Ekspansja chuci przekształca miłość $\mathrm{w}$ walkę, zgodnie z prawami natury, która tworzy po to, by unicestwiać ${ }^{49}$. Potrzeba intensyfikacji doznań wywołuje emocje niszczące i rodzi agresję przechodzącą w sadyzm. Agaj „zębami szarpała skórę na jego [brata] szyi, wgryzła się palcami w jego piersi” (Dp 49), „drgała i wpiła się kurczowo oburącz w jego włosy” (Dp 100). On „gryzł ją, błądził rozpalonemi usty po jej piersiach” (Dp 100). Nawet spojrzenie jest rodzajem guałtu: „ugrzebywał się oczyma w jej oczy” (Dp 55), „wżarła się złymi, nienawistnymi oczyma” (Dp 89). Bohaterowie drżą w konuulsjach rozkoszy i cierpienia, kaleczą ciało własne i partnera. Narrator Requiem aeternam spowiada się: „objąłem żelaznymi kleszczami Twoją szyję, wessałem się rozpalonymi ustami w Twoją pierś dziewiczą i piję z Twoich żył mleko matczyne z kruią zmięszane" (Rae 81). Ada Karska snuje przed Bieleckim następującą fantazję erotyczną: ,[...] skrępowałabym pana powrozami, żebyś się ruszać nie mógł - oczywiście nagiego... [...] Tylko niech pan sobie wystawi, że pan nawet by drgnąć nie mógł, a ja tak zbożnie, spokojnie i z taką głęboką powagą zapuszczam ostry pług moich palców u skórę pańską i uprawiam pracowicie ten kawałek żyjącej gleby, począuszy od szyi, po całej piersi" (Mc I, 117).

Związki miłosne to bolesne zbliżenia i rozstania wyrażane przez motywy rozpadu, dezintegracji, zatracenia. Życie bohaterów to terytorium instynktownych odruchów, dręczących fantazmatów, dowodzących panowania chuci rzeczywistych i imaginacyjnych zachowań orgiastycznych (w jakich ginie podmiotowość i zacierają się granice między pożerającymi i pożeranymi), wampirycznych, sadomasochistycznych i nekrofilskich.

Wyodrębniając dwa komponenty, na jakie rozszczepiła się chuć - mózg, który jest narzędziem świadomości, kategoryzuje rzeczywistość, formułuje pojęcia i idee, tworzy moralność, oraz duszę, będącą „strumieniem nieświadomego" ${ }^{50}$ i łączącą jednostkę z kosmiczną siłą libido - Przybyszeuski zilustrował nierozstrzygalny konflikt: chuć buntuje się przeciwko rygorom, jakie zaostrza możliwy dzięki niej rozwój gatunku, oznaczający przyrost śuiadomości, a tym samym hamowanie potrzeb płciouych przez zasady społeczne

${ }^{49}$ Zob. konstatacje W. Gutouskiego w książce Nagie dusze i maski (O młodopolskich mitach miłości), Kraków 1992.

${ }^{50}$ Ibidem, s. 63. 
i etyczne ${ }^{51}$. Siła natury walczy z mieszczańską kulturą represjonującą popędy utożsamiane $\mathrm{z}$ grzechem, perwersją lub buntem. Jakiś czas później to samo dobitniej sformułuje Freud, definiując kulturę ,jako źródło cierpień”. Przybyszeuski uskazuje konkretny moment, w którym napięcie między potrzebą realizacji popędów a zakazami kultury zaczęło narastać - było nim zaszczepienie judaizmu ${ }^{52}$. Wcześniej płodność i rozkosz były oznaką witalności, spontaniczności i pełni życia, łączoną z kultem, religijnością. Aby ucywilizować Płeć, włączyć ją w rytm życia społecznego, dusza - nie mogąc całkowicie wyeliminować potrzeb libidalnych - konstruuje iluzje służące doborowi płciowemu. Sprawia, że omamiony złudą piękna i dobra mężczyzna ulega uwodzącej go kobiecie przekonany, że sam świadomie ją uybrał. To miłosne uwnioślenie usprawiedliwia potrzeby ciała wartościami etycznymi.

Żyje uprawdzie [dusza] - żyje jeszcze treścią siły, którą pożarła, przetwarza jeszcze u sobie środki, które do doboru płciowego służą, może jeszcze upajać się obrazami, które żądze drażnią, może u sobie wywołać ekstazę śmiesznego okłamywania się chuci, co mniema, że może kobietę stopić w sobie [...]. (Rae 48)

Dlatego Przybyszeuski nazywa chuć naturą, „która się miłością jako środkiem posługuje" ${ }^{3}$. Poutarza tu myśl patrona młodopolskiego spojrzenia na erotyzm - Artura Schopenhauera, który móuil o miłości jako o masce, pod jaką natura ukrywa cel przedłużenia gatunku. Wojciech Gutouski zauważył, że ułaśnie ze sprzeczności między Płcią rozkiełznaną, żywiołową a Płcią uspołecznioną, pozbawioną pierwotnej instynktowności, zrodziła się w obyczajowości mieszczańskiej opozycja: erotoman, degenerat - normalny, zdrowy. Staje się ona najbardziej wyraźna w sferze przeżyć erotycznych, w której „chuć i kobieta biorą odwet za skrępowanie instynktów i ograniczenie rozkoszy" ${ }^{44}$.

Poddawanie się namiętnościom, kult Płci nie oznacza u Przybyszewskiego aprobaty dla postaw hedonistycznych. Wręcz przeciunie, w tym objawie dekadentyzmu autor Requiem aeternam dostrzegał niebezpieczeństwo dla jednostki twórczej, której życie mogło sprowadzić się jedynie do szukania środków odurzających. Akt seksualny nie ma charakteru radosnych, upojnych bachanaliów, nie jest dla bohaterów ucieczką od rzeczywistości i świadomym szukaniem przyjemności, lecz przymusem. Indywiduum staje się

${ }^{51}$ Zob. T. Walas, Stanisław Przybyszewski a dekadentyzm, [w:] Stanisław Przybyszewski. W 50-lecie zgonu pisarza, red. H. Filipkouska, Wrocław 1982, s. 59.

52 „Piękną i świętą była potęga płci, pięknym i śuiętym akt sam dla ludów nieskażonych jeszcze moralną kiłą judaizmu” - pisał u Przyczynku do etyki ptci („Nasz Kraj” 1908, z. 9, s. 167).

${ }^{53}$ S. Przybyszeuski, Na drogach duszy, s. 69.

${ }^{54}$ W. Gutouski, Nagie dusze..., s. 66-67. 
ofiarą „totalitaryzmu natury" ${ }^{55}$. Hegemonia Płci sprawia, że miłość jest doświadczeniem tragicznym i niszczącym, ponieważ dezintegruje osobowość człowieka, szamoczącego się między porywami płciouymi a regułami kultury. „Ja” zostaje więc zniewolone przez ograniczenia społeczne, które guałci, zaspokajając sue żądze, a przede uszystkim przez fatum determinujące całą przyrodę ${ }^{56}$. Euentualne odrzucenie norm zbiorowych, konstytuujących i definiujących jednostkę, oznaczałoby natomiast pogrążenie się w chaosie. W związku z tym Przybyszewski odrzucał moralne wartościowanie czynów ludzkich, ponieważ byłoby ono róunoznaczne $\mathrm{z}$ wartościowaniem natury. Można tu niewątpliwie odnaleźć ślady poglądóu Nietzschego, kuestionującego odpowiedzialność człowieka za sue postępowanie i mówiącego o występującej w życiu konieczności, której nie utożsamiał z żadną regularnością procesów, lecz raczej z fatum (losem), czyli zespołem warunków zastanych i determinujących aktywność jednostki ${ }^{57}$.

Skoro „ja” jest tylko automatem sterowanym przez chuć, nie może być mowy o jakiejkolwiek więzi emocjonalnej między uczestnikami seksualnego spotkania. Mimo chwilowego posiadania upragnionego partnera, żaden ze związków nie jest spełniony. Kochankowie szukają ekstatycznych doznań, ocierając się o cierpienie i rozpacz; potrzebują rozkoszy uykraczającej poza granice moralności i przypłacają to upadkiem lub śmiercią (jak Falk i bohater De profundis), ponieważ uświadamiają sobie, że są jedynie składnikiem irracjonalnego pędu, kształtowanym i określanym przez popędy (bywa też, że nie mogą znieść społecznych konsekwencji własnych postępków).

Proces deprecjacji i wyparcia płci jako tego, co poniżające i wstydliwe, można zaobserwować w postawie matki narratora-bohatera Requiem aeternam, którego losy stanowią suoiste exemplum dla otwierającej poemat ontogenezy z naczelnym konfliktem chuci i mózgu.

Ów bohater-narrator wiąże dręczący go rozłam między chucią a duszą z nieudanym pożyciem seksualnym rodziców, zułaszcza z momentem suego poczęcia. Według niego podłożem tych problemów małżeńskich były dysproporcje społeczne: matka, katoliczka ze zubożałej arystokratycznej familii, poślubiła bowiem prostego protestanckiego chłopa, zdolnego zapewnić jej finansowo zadowalającą egzystencję. Związek ten - nie będący nawet mezaliansem, bo zawarty bez miłości („Ojca nie kochała” - informuje narrator; Rae 61) - przypłaciła poczuciem zaprzedania siebie, swego wysokiego pochodzenia i suych ideałów. Urodę, delikatność, dumę rodową, szacunek dla wartości duchowych oddała człowiekowi nieokrzesanemu, oszczędnemu, stworzonemu po to, by pracować i przestrzegać ustanowionych przez

\footnotetext{
${ }^{55}$ Ibidem, s. 99.

${ }^{56}$ Ibidem, s. 99-100.

${ }^{57}$ Z. Kuderowicz, Nietzsche, Warszawa 1979, s. 69-103.
} 
jej warstuę praw. Współżycie fizyczne traktowała jak guałt dokonany na jej ciele i duszy, upokarzający, wywołujący wstręt i obrzydzenie. W takim „brudzie” i niechęci do partnera spłodzony został bohater.

Zmuszona do wypełniania obowiązku małżeńskiego bez pożądania, nie mogąc cieszyć się seksem z brutalnym chłopem, matka podczas zbliżenia zamieniała się $w$ kukłę. Zaczęła pogardzać tym, co cielesne. Wmóuiła sobie, że nie potrzebuje namiętności i żaru, a $w$ ramach rekompensaty rozbudowała życie wewnętrzne, szukając czegoś „tkliwego, czystego, uniebowziętego i bezpłciowego" (Rae 62). Osiągnięcie bezpłciowości okazało się jednak niemożliwe - stłamszona płeć dopomina się o swoje prawa, wywołując neurozy.

"Martwą chuć" dziedziczy po matce narrator, a efektem tej „schedy” jest agresja wobec kobiet i niemożność zbudowania truałego zuiązku. W połączeniu z piętnem mieszanego pochodzenia - skutkującym rozdarciem psychicznym między odmiennymi postawami wobec życia reprezentowanymi przez oboje rodziców - spadek ten dezintegruje osobowość bohatera. „Nigdy nie było we mnie ani miłości, ani skupienia. Jestem wyrazem odśrodkowiska, wyrazem zniszczenia i rozwiązania" - diagnozuje sam siebie (Rae $64)^{58}$. Niczym typowy dekadent utracił wiarę nie tylko w naukę i religię, ale i we uszelkie wartości. Cierpi na zanik woli, choć przypisuje sobie nieograniczone możliwości kreacji i destrukcji, jak przystało na jednostkę, która jest syntezą Chrystusa i Szatana.

By potwierdzić suą męskość, zamierza pobudzać w sobie „martwą chuć”, nurzać się w niej. Dlatego akt seksualny pojmuje jako szał, krzyk, ranienie się i pożeranie. Miarą intensywności doznań jest uczucie bólu, bez którego nie ma rozkoszy. ,[...] każdy stan mej duszy bólem i rozkoszą zarazem” - stuierdza bohater. - „Zaledwie odczuwam delikatne podrażnienie rozkoszy, a już tętni i wali młotem ból, aż nagle rozgrywa się cała orgia, w której rozkosz obłędem się staje w jadowitych kąsaniach bólu [...]" (Rae 64). Szaleństwo i chorobliwość relacji miłosnych odsłania w słowach skierowanych do kochanki: „[...] rzucam się na Ciebie, nie chcę nic czuć prócz bladej gorączki tuych członków, nic słyszeć, jeno wściekłą pogoń mej krui, i nie chcę mieć innego urażenia, prócz tego rozpalonego, szpilkującego bólu naszego d e l i rium miłości " (Rae 67; podkr. K.B.).

Ale bohaterowi idzie o coś więcej niż doznania zmysłowe. Paradoksalnie, kontakt cielesny ma doprowadzić go do „bezcielesności”, umożliwić osiągnięcie androgynii i powrót do prajedni, z której uszystko poustało; ma go przyurócić transcendencji. Tyle że cel nie zostaje osiągnięty, ponieważ kochanka nigdy nie spełnia duchouych oczekiwań mężczyzny. Gdy dla niego

\footnotetext{
${ }^{58} \mathrm{Na}$ temat rozchwianej tożsamości bohatera por. uwagi G. Matuszek u książce Stanisław Przybyszewski - pisarz nowoczesny, s. 176-177.
} 
akt seksualny jest szansą na odbudowanie jedności i przeniknięcie zagadki istnienia, ona widzi w nim jedynie sposób przedłużenia gatunku. Patrząc na ciało kochanki ułożone bezustydnie z pożądania, bohater Requiem aeternam uświadamia sobie tę praudę i przerywa zbliżenie. „Twe łono matczyne Cię oszukało - innego męża trzeba ci było odnaleźć, instynkty Twe płciowe ku innemu zurócić" - śmieje się cynicznie (Rae 61). Dlatego jego stosunek do kobiecości nosi znamiona ambiwalencji; rozpięty jest między uwielbieniem a szyderstuem i nienawiścią. Własne cierpienie i niespełnienie oraz pogarda dla tej, która wikła go u cielesność, uświadamiają mu niemożność porozumienia i brak więzi z partnerką. „Czego pragniesz? czego chcesz ode mnie? Niczego ci dać nie mogę - co wiąże nas razem? - nie wiem nawet, co mam z Tobą począć!" - monologuje (Rae 67-68).

O sile odrzucenia kochanki śuiadczy scena, u której ogarnięty halucynacjami bohater widzi ją martwą, leżącą na katafalku w świetle gromnic. Na jej twarzy dostrzega przerażający lubieżny uśmiech, który wyzwala w nim pokłady sadyzmu. Mężczyzna szarpie i kąsa trupa, wreszcie z krwawą pianą na ustach wgryza się $w$ pierś - istotę kobiecości.

Symbolicznie uśmiercając kochankę w wyobraźni, co jest reakcją na niemożność zintegrowania jej $\mathrm{z}$ weunętrznym obrazem animy, bohater daje dowód niemocy $\mathrm{w}$ uporaniu się $\mathrm{z}$ „martwą chucią”. W jego wizji kobieta unosi się $w$ trumnie i uderza go $w$ klatkę piersiową, aż siła ciosu odrzuca go daleko w tył. Chuci - wulkanu sił podświadomych - nie da się oswoić, podporządkować uyższym celom duchouym czy rozumowym, a scena przy katafalku jest rodzajem odprawionej nad własną seksualnością „mszy żałobnej", odśpiewaniem jej requiem aeternam ${ }^{59}$.

Nieprzyłączenie utraconego pierwiastka żeńskiego oznacza niemożność zintegrowania własnej jaźni, a więc odczuwania harmonii i pełni. Porażka $\mathrm{w}$ zmaganiach $\mathrm{z}$ chucią prowadzi obdarzonego nadmierną świadomością bohatera do decyzji samobójczej. Konotowana przez nią wizja mszy w wiejskim kościele także kończy się triumfem nieokiełznanej seksualności. Gdy podmiot, modląc się z wiernymi o zachowanie przed zarazą, ma przyjąć ostatnią komunię śuiętą, z rozdartego nieba - niczym Bóg podczas chrztu Chrystusa w wodach Jordanu - wyłania się w oparach siarki ,apokaliptyczna nierządnica" Astarte (Rae 91). Bohater czuje szatański, rozpustny pocałunek śmierci tej patronki onanistów, pederastów, prostytuujących się i oddających kontaktom kazirodczym, a jednocześnie poutarza ostatnie słowa Chrystusa na krzyżu: Eli, Eli lamma sabacthani... (Rae 92). Jezusową mękę

${ }^{59}$ G. Matuszek zastanawia się, że „msza żałobna” może być odprawiana za bohatera wybierającego u finale poematu samobójczą śmierć, za zmarłą kochankę, za „martwą chuć”, ale też za niemożność przeżycia miłości i odrzucenia więzów cielesności. Zob. G. Matuszek, Stanisław Przybyszewski..., s. 179. Por. też uwagi badaczki o integracji jaźni w art. Seksualizm $i$ androgynizm. 
służącą zbawieniu ludzkości sprowadza do cierpienia, jakiego sam doznaje dręczony przez seksualne majaki. Jest $u$ tym i tragizm, i szarganie świętości. Słowa konającego Chrystusa w ustach popadającego w histerię bohatera świadczą - jak interesująco skonstatował Wojciech Gutouski - „o absurdzie jednostkowego wysiłku przebóstuienia instynktów, uskazują też na słabość religijnych wzorów zbawienia wobec totalności natury-płci”60.

Do zbliżenia cielesnego prowokują zatem nakazy natury, ale i nadzieja na odtworzenie jedni gwarantującej iluminatio. Zgodnie z koncepcją Schopenhauera miłość jest twórcza dla gatunku, jednak niszczy poszczególne indywidua. Z tego powodu nie może być wolna od cierpienia. Ale - jak zauważył Paweł Dybel - bohaterowi Requiem aeternam cierpienia wywołane walką z „martwą chucią" umożliwiają bycie artystą, źródłem kreatywności są bowiem głębokie sprzeczności przysparzające bólu ${ }^{61}$. Podobne przekonanie o uwikłaniu u płeć, której właściwościami są zarówno niszczenie, jak i kreacja, Przybyszewski wyraził w esejach $Z$ psychologii jednostki twórczej.

Warto zurócić uwagę, że mimo leksykalnych wahań, widocznych w rezygnacji z nacechowanego emocjonalnie rzeczownika „chuć” dla uyciszonej „płci” (do której zmitygowały pisarza z pewnością ataki społeczne i nieporozumienia interpretacyjne), desygnat pozostał ten sam. Chuć/Płeć to warunek i pierusza przyczyna rozwoju świata, kosmiczna i twórcza potęga, z której uywodzi się uszystko, co istnieje w uymiarze fizykalnym i duchouym. Zespolenie erosa z mistyką, życia z metafizyką. Ontogeneza przedstawiona literacko już na początku drogi twórczej Przybyszeuskiego po latach zyskała po prostu swą dyskursywną uykładnię w postaci Przyczynku do etyki płci. W tekście opublikowanym na łamach „Naszego Kraju” pisarz poutórzył najważniejsze rozpoznania i twórczo - acz konsekwentnie - rozwinął suą myśl. Po raz pieruszy uwypuklił m.in. rolę miłości, uidząc u niej pieruiastek boski: „Duch święty ustąpił w Płeć i tak Płeć poczęła Miłość" - pisał, nawiązując do biblijnej tradycji Niepokalanego Poczęcia ${ }^{62}$. Płeć jeszcze wyraźniej zyskała uwznioślającą sankcję świętości ${ }^{63}$. Włączona została poza tym w klasyczną triadę dobro - piękno - prauda: ,jest płeć [...] u najuyżzzym stopniu moralną, a objawienia jej są moralne, bo są emanacją piękna" ${ }^{4}$. Autentyczność i nieskrępowanie (prawda), z jaką realizuje się Płeć, wpisują biologiczny, witalny żywioł w hierarchię etyczną i estetyczną. Najbardziej nośna znaczeniowo konkluzja

\footnotetext{
${ }^{60}$ W. Gutouski, Nagie dusze..., s. 77.

${ }^{61}$ P. Dybel, Literatura jako histeria. O „Requiem aeternam” Stanisława Przybyszewskiego, „Przegląd Artystyczno-Literacki” 2000, nr 5, s. 128-132.

${ }^{62}$ S. Przybyszeuski, Przyczynek do etyki ptci, s. 165.

${ }^{63}$ Por. uwagi na ten temat w: G. Matuszek, Stanisław Przybyszewski..., s. 81.

${ }^{64}$ S. Przybyszewski, Przyczynek do etyki ptci, s. 167. O idei piękna i prawdy w kontekście popędu płciowego por. G. Matuszek, Seksualizm i androgynizm..., s. 99-100 oraz eadem, Stanisław Przybyszewski..., s. 82.
} 
dotyczy jednak związkóu chuci i Duój-Jedni: „[...] jest Płeć androgynicznym Ojcem i Matką tego, co jest, było i będzie" ${ }^{65}$. W ten nieoczekiwany sposób spaja Przybyszeuski dwa pierwiastki, rozpatrywane przez badaczy jego twórczości jako antagonistyczne. Płeć, a więc i zbliżenie seksualne, wiedzie bowiem ku świętości i staje się guarantem odbudowania pierwotnej pełni. Dzięki zbliżeniu fizycznemu „człowiek boski i metafizyczny pierwiastek w sobie odnajduje" ${ }^{66}$. Pisarz finalnie aprobuje instynkt i akt płciouy jako niezbywalne i wartościotwórcze punkty egzystencjalnej struktury, choć w bohaterach jego utworów (przede wszystkim wczesnych) niejednokrotnie wywołują one lęk.

\section{Fatum}

Rozpoczynając, wypada poutórzyć ustalenia ucześniejsze: podstawowym czynnikiem determinującym życie bohaterów Przybyszewskiego jest chuć, uwznioślająco traktowana co prawda jako metafizyczna zasada świata, ale operująca aparatem instynktów, realizujących prawa gatunku i unicestwiających indywiduum. Do uzależnienia człowieka od natury i biologii powrócimy w rozdziale Miłość a moralność, teraz pozostaje jeszcze uzupełnić problem determinizmu o inne jego przejawy obecne w twórczości Przybyszeuskiego, głównie w dramatach i powieściach.

Obok chuci, bliskiej Schopenhauerouskiej ślepej woli, postaciami kieruje bowiem jeszcze inna siła wyższa stojąca poza nimi - fatum. Nadrzędnym motorem zdarzeń jest przeznaczenie, z którego bohaterowie doskonale zdają sobie sprawę. Dotyka ono także - a może przede uszystkim - sfery uczuć. Przybyszeuski splótł przy tym dwa źródła tragizmu - ludzkie afekty oraz konieczność, los - które w dramacie romantycznym funkcjonowały niezależnie od siebie. I nawet namiętności poddał dyktatowi przeznaczenia.

Falk, dziecko natury z powieści Homo sapiens, nie potrafi oprzeć się pokusie zobaczenia Izy, narzeczonej przyjaciela.

Wyszedł na ulicę. Coś p chało go pójść do niej, raz jeszcze ją zobaczyć, chłonąć pouietrze, którym oddychała, raz jeszcze pić czar, który wokół promieniował. (Hs I, 50; podkr. K.B.)

Potrafi racjonalnie wytłumaczyć sobie, że nie powinien dążyć do spotkania z kobietą należącą do innego mężczyzny, ale jednocześnie ma poczucie,

\footnotetext{
${ }^{65}$ S. Przybyszeuski, Przyczynek do etyki ptci, s. 166.

${ }^{66}$ Ibidem.
} 
że ktoś lub coś zaburza jasność jego myśli i krępuje jego wolę. Nie rozumie natury tej siły. „Wytłumaczcie mi teraz, co się dzieje u mojej duszy, macie przecież taką moc psychologicznych prawideł i regułek. Proszę bardzo! wytłumaczcie mi to!" (Hs I, 48) - ironizuje z ograniczeń ludzkiego poznania. Dość szybko orientuje się, że to nieubłagana konieczność związała go z Izą.

Pani stała się moim przeznaczeniem, pani stała się moją - zachłysnął się - zgubą... (Hs I, 124)

\section{Podobne wątpliwości ma Iza:}

[...] była niespokojna, słuchała z roztargnieniem. Jak to nagle nią ouładnęło? Jak mogła to zrobić? Oddać się Falkowi... (Hs I, 74)

Komplikujące się w miarę rozwoju fabuły postępowanie Falka wywołuje w nim schizofreniczne rozdarcie, poczucie ciągłej obecności alter ego ${ }^{67}$, spojone z niedającym się ukoić niepokojem:

[...] lękam się przed tym obcym człouiekiem we mnie... A tak, tak, jest coś we mnie obcego, czego nie znam, a przed czym mam śmiertelny strach. (Hs III, 30)

Poddanie się przeznaczeniu jest zatem tak dogłębne, że traci się nawet poczucie rzeczywistości i ciągłości wydarzeń. Wszystko dokonuje się poza ludzkim uyborem.

Zdradziłam, zdradziłam - co to jest? Co to znaczy? [pyta Irena siebie i swojego kochanka Przesłauskiego w Złotym runie] - Wiesz, ja będę szczerą [...]. Ja sobie wystawić tego nie mogę, że go [swojego męża Gustawa] już zdradziłam... (Zr 232)

Bohaterowie utworów Przybyszeuskiego nie czują się panami suej woli. Dośuiadczają nieznanej siły, która kieruje ich czynami i której muszą ulec. W drugiej części Homo sapiens Maryt poddaje się niszczącemu uczuciu do Falka, ponieważ wie, że nie sposób ualczyć z losem.

Wszystko było jej obojętne. Ponad sobą czuła jakieś straszne, głuche i bolesne przeznaczenie, obłok, co straszliwą ulewą gradu miał na nią spaść... (Hs II, 69)

${ }^{67}$ Por. I. Filipczak, Eryk Falk - geniusz zła czy obłakany neurastenik? („Homo sapiens” Stanisława Przybyszewskiego), „Acta Universitatis Lodziensis. Folia Litteraria Polonica” 2005, z. 7 , s. 305 . 
Bohaterowie $\mathrm{w}$ najmniejszym stopniu nie decydują o swej miłości. Nie wybierają nawet sami kochanków. Mężczyzna i kobieta już podczas pieruszego spotkania widzą w sobie miłosnych partnerów i zaczynają siebie pożądać. Nie na mocy autonomicznej decyzji czy autentycznej inklinacji, lecz dlatego że kieruje nimi wewnętrzny, nierozpoznany imperatyw. Nie istnieje etap znajomości czy przyjaźni, stopniowo przeradzającej się w głębsze uczucie, a walory osobowościowe nie mają znaczenia dla wzajemnej fascynacji. Dlatego też postacie Przybyszewskiego ułaściwie nie są zindywidualizowane, nieznacznie różnią je uyłącznie losy, w których jednakowi powtarzają się namiętność i cierpienie miłosne. W ten sposób autor stara się nadać konfliktowi człowieka z przeznaczeniem uniwersalną miarę. Postacie są marionetkami uprawianymi $\mathrm{w}$ ruch przez siły wyższe, a miejsca akcji - konwencjonalne.

Fatum greckie - jak wyjaśniał Schopenhauer - jest ukrytą koniecznością, która może zostać człowiekowi odsłonięta u przepowiedni, we wróżbie lub we śnie. U Przybyszewskiego bohaterowie z góry wiedzą, jaki los ich czeka. I nie spodziewają się niczego dobrego, ponieważ - jak mówi rezonujący Ruszczyc - „koła przeznaczenia miażdżą ludzi jak ten święty wóz indyjski... To piekielna rzecz - przeznaczenie" (Zr 181). Przeznaczenie jest więc czymś skrajnie różnym od Opatrzności, której zadaniem jest otwieranie nad człowiekiem czegoś w rodzaju parasola ochronnego.

Król z poematu Nad morzem przeczuwa zagładę, jaka spadnie na jego lud, gdy przeklnie słońce dla niewolnicy z kraju cieni. Henryk Orzelski określa siebie „śmiesznym narzędzi em obłąkańczej zemsty” (Mśc 70; podkr. K.B.), dokonanej przez Izę Szelutę na ukochanym (Mściciel). Przesłauski i Irena orientują się, że idą w przepaść i że wiadomość o ich romansie zniszczy męża Ireny, Gustawa (Złote runo).

PRZESŁAWSKI

Jestem ostatni łotr, że to robię, co robię, że ciągnę cię w przepaść - ale kocham cię - takie jest życie! (Zr 198-199)

IRENA

Zygmunt! Lękam się, boję się, my go [Gustawa] zabijemy... (Zr 228)

W wypadku dramatów katastrofa wisi w powietrzu już w momencie podniesienia kurtyny. Kolejne sceny są tylko oczekiwaniem na dopełnienie nieuniknionego. Postacie antycypują $w$ swych wypowiedziach mające nadejść nieszczęście, mówiąc aluzyjnie lub dzieląc się z innymi - i z widzem - suymi przeczuciami. W Ztotym runie już w pieruszej rozmowie z Rembouskim Ruszczyc uspomina niejasno o niszczeniu cudzego życia, co będzie ustępem do odsłonięcia wielu rodzinnych tajemnic, a precyzyjniej - ciągu zdrad. W początkowej scenie Śniegu Bronka wyznaje, że dręczy ją ,jakieś nieuchwytne uczucie lęku” (Ś 29) związane z Ewą, która okaże się kochanką 
jej męża. Hanka z Godów życia w pieruszej scenie dramatu tłumaczy muzykowi Janocie, że jego gra na skrzypcach porusza jej duszę i guałci myśli, co znajdzie przewrotny ciąg dalszy u rzeczywistym guałcie, jakiego dokona na dziewczynie Janota. Matkę otwierają następujące słowa tytułowej bohaterki oczekującej powrotu syna, praktykującego od 10 lat w belgijskich fabrykach: „Teraz za chwilę Konrad przyjechać musi. Tak się czegoś lękam. Gdyby się tylko, na Boga, nie dowiedział..." (M 11).

Niepokój, oczekiwanie katastrofy i nadejścia złego losu to elementy budowania nastroju, zaczerpnięte - jak już ponad pół wieku temu zauważyła Irena Sławińska - z osiągnięć Maeterlincka ${ }^{68}$. Właśnie do nastroju ogranicza się często tragizm dramatów Przybyszeuskiego.

Jeszcze do drugiej połowy XIX w. tragizm oznaczał aktywną walkę z losem, przeciustawianie się konieczności, ukrytemu porządkowi. Poszerzenie tego pojęcia nastąpiło za sprawą Ibsena, który uskazał na konflikty tragiczne tkwiące $w$ życiu rodzinnym oraz relacjach jednostki ze społeczeństwem. Czerpiący z dramatu Ibsena Maeterlinck poszedł jeszcze dalej - rezygnując z realizmu, interpretował tragizm nie jako mierzenie się człowieka z przeznaczeniem, lecz przyjmowanie i przeżywanie tego, co przynosi los, poddawanie się (najczęściej u cierpieniu) tajemniczej sile. Akcent został więc przeniesiony $\mathrm{z}$ dramatu zdarzeń na dramat przeżyć wewnętrznych ${ }^{69}$. Podobnie jest u Przybyszewskiego. Bohaterowie, jeden bądź kilku, znaleźli się na życiowym zakręcie już $\mathrm{w}$ przedakcji. W samym utworze tajemnica z przeszłości zostaje tylko odkryta i oddziałuje na postaci, prowadząc do katastrofy. W pieruszym akcie Dla szczęścia Helena, przeglądając listy Mlickiego, odkrywa, że została przez niego zdradzona. Cierpi tym bardziej, że trzy lata ucześniej opuściła rodziców, by pozostawać z nim w nieformalnym związku, czym naraziła się na ludzką obmowę i skazała na odsunięcie na margines społeczeństwa. Narzędziem przeznaczenia jest $w$ tym dramacie potęga femme fatale, której mężczyzna nie jest zdolny pokonać. Mlicki musi ulec niszczącemu urokowi Olgi, chociaż przyjaciel Żdżarski uprzedza go, że Helena odbierze sobie życie, jeśli zostanie porzucona. Ponura przepouiednia oczywiście się spełnia - kulminacyjną sceną tragedii jest wniesienie trumny z ciałem Heleny do domowego gniazdka Mlickiego i Olgi.

Podobny schemat zastosował Przybyszeuski w Śniegu, gdzie fatalistyczny charakter ma związek Tadeusza i Euy. Bohater, poślubiuszy Bronkę, przy której próbuje znaleźć ukojenie dla zbolałej duszy, ulega upływom dawnej kochanki, gdy tylko widzi ją ponownie. „Leci w ogień jak ćma” (Ś 62), pchany siłą instynktów i przeznaczenia. Spala się $w$ niszczącym związku

${ }^{68}$ Zob. I. Sławińska, Tragedia w epoce Młodej Polski. Z zagadnień struktury dramatu, Toruń 1948, s. 44-45.

${ }^{69}$ Ibidem, s. 31. 
z demoniczną kobietą, dającą mu tylko ból i tęsknotę, a suym odejściem popycha żonę do samobójstua.

Mimo przeświadczenia o negatyunych następstwach miłości bohaterowie nie potrafią stłumić $\mathrm{w}$ sobie uczucia i zmierzają ku nieuchronnej katastrofie. Przeznaczenie szykuje im same nieszczęścia i prowadzi do zguby ich najbliższych. Przybyszewskiego interesuje, w jaki sposób człowiek może się uporać z ciężarem przeznaczenia. Najistotniejsze jest u niego dochodzenie do prawdy o sobie i problem odpowiedzialności za krzywdę wyrządzoną innym. Rozdarcie nerwowe zostaje uprowadzone do dramatu za pomocą postaci rezonerów. Komentują oni - na wzór greckiego chóru - postępowanie miotanych namiętnościami bohaterów, radzą im i odradzają, wreszcie uypowiadają prawdy ogólne, z którymi polemizować już nie sposób. I tak projekcją przemyśleń i wątpliwości Mlickiego jest Żdżarski (Dla szczęścia), obok Rembouskiego pojawia się Ruszczyc (Złote runo), a Konradowi towarzyszy Przyjaciel (Matka) ${ }^{70}$.

Wysłannikiem losu, medium przeznaczenia bywa postać symboliczna. W Złotym runie Nieznajomy wchodzi niespodziewanie na scenę i nastawia zegar na godzinę nieszczęścia, a po chuili Irena wyznaje, że oddała się Przesłauskiemu, co popycha jej męża do samobójstwa. W Śniegu Makryna zwiastuje samobójczą śmierć Bronki; zjawienie się w Ślubach Czerwonej Krystyny z włosami $w$ barwach ognia i złymi zielonymi oczami jest zapowiedzią przybycia Krzyckiego, a wraz z tym odnowienia ran po dawnych miłościach bohaterek dramatu. Narrator poematu $Z$ cyklu Wigilii widzi w suym rywalu nie osobę, lecz „ucieleśnioną moc czegoś nieosobistego, [...] narzędzie jakiejś potęgi, która [...] wszystkich w uwięzi trzymała" (W 198).

Postaci Przybyszeuskiego - podobnie jak wcześniej Maeterlincka i u mniejszym stopniu Ibsena - nie kształtują same własnego losu. Rezygnacja i pogląd, że „przeznaczeniu nie można przeszkadzać” (Zr 180) wynikały z przekonania o niezmienności raz dokonanych zapisów. Postawę bierności zalecał m.in. Schopenhauer, ponieważ los jest uszechpotężny, a walka z nim byłaby najśmieszniejszym ze uszystkich zuchwalstw ${ }^{71}$. Dobro i zło znajdują

\footnotetext{
${ }^{70}$ Sceniczne rozpisanie osobowości jednego człowieka na postaci protagonisty i antagonisty Przybyszeuski omawiał w suoim programie teoretycznym: „Dramat staje się dramatem uczuć i przeczuć, wyrzutów sumienia, szamotania się z sobą samym, dramatem niepokoju, lęku i strachu. [...] Wyławiam z duszy działającego to uszystko, co tragedię jego życia stanowi, i tworzę nową postać, tworzę zatem projekcję wewnętrznej walki i rozterki, i mam od razu duie silne i ustawicznie na siebie oddziaływające postaci" - pisał (S. Przybyszeuski, O dramacie i scenie, [w:] idem, Wybór pism, s. 284, 297).

${ }^{71}$ Zob. J. Tuczyński, Schopenhauer a Młoda Polska, s. 167. Przybyszeuski wzorem Schopenhauera traktował wolność i konieczność jako sprzeczności, i na tym przeciustawieniu oparł koncepcję fatum. Nietzschemu natomiast udało się uniknąć fatalizmu dzięki teorii, zgodnie z którą każdy człowiek jest częścią losu. Według autora Narodzin tragedii pozorna jest zaróuno walka z losem, jak i rezygnacja wobec losu, ponieważ obie te opcje tkuią u losie. Człowiek musi samookreślić siebie nie przeciu światu zeunętrznemu, lecz w jego ramach. Ta postawa - rozumienie wolności u konieczności - przeciustawia się modernistycznemu
} 
się w świecie, są więc niezależne od woli bohaterów. Wolnej woli nie ma. Świadomość zdeterminowania $\mathrm{u}$ istnieniu wywołuje bunt przeciwko Bogu, który czyni sobie z człowieka zabawkę:

Pomyśl tylko - mówi Czerkaski do Siemiona u Synach ziemi - taki Pan Bóg boki zrywać sobie musi ze śmiechu, gdy spojrzy na takiego człowieka, któremu się zdaje, że on może coś chcieć! Człowiek, który chce! Czyż możesz sobie uystawić uspanialszego błazna?! [...] Otóż człowiek na najuyższym szczeblu rozwoju konstatuje, że w ogóle nic chcieć nie może, że jego wolna wola jest śmieszną fikcją, bastardem, spłodzonym przez Tytanię i osła, przez głuche przeczucie boskiej woli w sobie i idiotyczny mózg" (Sz IV, 44)

Fatum objawia się w utworach Przybyszeuskiego także w postaci irracjonalnego upłyuu przeszłości. Przeszłość mści się, poutarza, dosięga ludzi w kolejnych pokoleniach. „Postaci centralne w dramatach - jak pisze S. Mrazek - muszą realizować zasadę naśladowania pewnych spełnionych czynności, muszą podporządkować się tej irracjonalnej transcendentnej sile, która suą moc objawia poprzez prawo prawdopodobieństwa" ${ }^{2}$. Zdradzona Bronka ze Śniegu topi się w stawie, ponieważ taką śmiercią zginęła jej siostra. W Mścicielu Iza, obdarzona przez Orzelskiego nieoduzajemnionym uczuciem, rzuca się $w$ przepaść $w$ tym samym miejscu, w którym uczyniła to wcześniej jego zakochana bez wzajemności siostra. Zygmunt ze Ślubów, wskazawszy Krzyckiemu niebezpieczną drogę w góry, krąży wokół domu jak niegdyś jego ojciec po zamordowaniu kochanka żony.

W Złotym runie motywacja katastrofy jest jeszcze bardziej złożona. Tutaj, zgodnie z zasadą biblijną, grzechy ojców mszczą się na dzieciach. Uwiedzenie mężatki przez Ruszczyca determinuje losy jego syna - Rembouski uwodzi żonę Łąckiego i sam pada ofiarą zdrady, jakiej dopuszcza się Irena. Ruszczyc komentuje te uydarzenia następująco:

Ach, to przeklęty dom - jakieś fatum nad nim zaciężyło - niedobrze, niedobrze pod tym dachem mieszkać... (Zr 255)

Jakkolwiek bohaterowie nie mają upływu na popełniane czyny, ponieważ uymusza je na nich nieznana siła - w postaci wszechwładnej chuci lub też przeznaczenia - jednak ponoszą za nie karę (zgodnie z poglądami Schopenhauera, który uważał, że samo życie jest już winą). Ruszczyc mówi u Złotym runie: „Przecież nie ma winy, tylko kara jest, kara, kara... (Zr 212).

pesymizmowi i stanowi „ustrząsający dokument heroizmu afirmacji śuiata” (H. Buczyńska-Garewicz, Metafizyczne rozważania o czasie, Kraków 2003, s. 119).

${ }^{72}$ S. Mrazek, Środki ekspresji pozasłownej w dramatach Staffa, Tetmajera i Przybyszewskiego, Kraków 1980, s. 113. 
Pojawia się tu problem „niezawinionej winy”, niezależnej od woli i wiedzy bohaterów (jak u tragedii greckiej). Nie ma ona nic uspólnego z winą tragiczną, ponieważ wyklucza wolność uyboru. Ową winą nie jest poddanie się uczuciom i namiętnościom, bo one zostają uznane za wierność sobie, lecz doprowadzenie do upadku i samobójstwa innego człowieka.

Bohaterowie, podążając za prawem naturalnym, łamią prawo moralne. Mlicki tak tłumaczy Helenie, którą opuszcza dla Olgi:

Kocham inną. Długo walczyłem z tym uczuciem, by nie robić cię nieszczęśliwą. Uległem, bom musiał ulec. Są uczucia, wobec których obowiązki i tym podobne rzeczy są czczym frazesem. (Dszcz 11)

Wszystko, co spotkało Rembouskiego (zdrada żony, samobójstwo), jest karą za cudzołóstwo jego ojca i jego samego. Guałt dokonany na Hance przez muzyka Janotę (Gody życia) ma natomiast charakter kary „metafizycznej", spadającej na bohaterkę za naruszenie praw społecznych (opuszczenie męża i dziecka dla kochanka).

Naprzeciu transcendentalnej siły nakazującej człowiekoui uypełniać zapisy przeznaczenia staje zmysł moralny. Na tym polega tragizm bohaterów Przybyszeuskiego. Muszą oni odprawić pokutę, jakiej uymaga od nich ukryty porządek rzeczy bądź ich własne sumienie (rolę takiej kary wymierzonej samej sobie spełnia samobójstwo Hanki w Godach życia oraz Izy u Mścicielu). Edward Boniecki słusznie zauważa, że prezentowany przez autora Synagogi szatana determinizm etyczny ma wiele uspólnego z determinizmem biologicznym, a więc z naturalizmem, który pisarz programowo odrzucal ${ }^{73}$.

Przeznaczenia w uydaniu Przybyszeuskiego nie należy identyfikować $\mathrm{z}$ ananke, a więc złośliwością losu, polegającą na tym, że człowiek sam sprowadza na siebie nieszczęście, którego nie chce. Nie jest to też kismet, jako że to tureckie pojęcie - pojawiające się u pisarza kilkakrotnie, przede wszystkim w Synach ziemi - łączy się z zaufaniem w moc Boga (Allacha) i poddaniem się jego woli. Pojmowanie przeznaczenia przez Przybyszewskiego bliskie było natomiast greckiemu pojęciu heimarmene, uyrażającemu przekonanie, że człowieka determinują siły bezduszne. Otaczające go moce są tak potężne, iż niedorzecznością jest mniemać, jakoby mógł stanowić o suoim losie. Koncepcja ta implikuje pesymistyczne przeświadczenie o przedmiotowości jednostki. W konflikcie przeznaczenia z ludzką świadomością i zasadami moralnymi nie ma zaś innej drogi jak tylko katastrofa. Człowiek wybiera śmierć, ponieważ nie umie pogodzić tych potężnych, lecz sprzecznych sił.

\footnotetext{
${ }^{73}$ E. Boniecki, op.cit., s. 45.
} 


\section{Mężczyzna}

Rola, jaką natura przyznała kobiecie - w przeciuieństuie do mężczyzny - w życiu płciowym, czyni niemożliwym po usze czasy pełne zrównanie płci. Jako pierwsze i najszlachetniejsze zadanie przydziela jej karmienie, pielęgnację i wychowanie dzieci [...]. Wiąże się z tym zarządzanie gospodarstwem domouym, ekonomiczne użytkowanie zarobku męża. [...] Ponadto szczególne funkcje płciowe, które przypadły kobietom, z góry czynią ich pozycję bardziej skrępouaną, na zausze odmawiają im nieograniczonej żądną miarą suobody ruchu, jaką w życiu gospodarczym i społecznym cieszy się mężczyzna ${ }^{74}$.

Podobnie jak niemiecki leksykon Brockhausa społeczną rolę kobiety opartą na stosunkach naturalnych definiuje największe polskie kompendium wiedzy, jakim w końcu XIX w. była encyklopedia Samuela Orgelbranda:

Jeżeli mężczyzna uchodzi słusznie za reprezentanta obowiązku, honoru i myśli, utedy kobieta uyraża przede uszystkim życie rodzinne, on zaś jest uyrazem publicznego i stosunków zewnętrznych.

[...] mężczyzna udziela i zapładnia, kobieta przyjmuje, poczyna, cierpi i rodzi; jemu potrzebą siła, jej powab. $[. . .]^{75}$

Kobieta, przeznaczona przez naturę głóunie na matkę, [...] otrzymała już do tego celu właściwą organizację fizyczną [...] i usposobienie psychiczne, jako to większą czułość i urażliwość, większą delikatność i bierność, a mniejsze zdolności umysłowe [...]. Nie powinna być także dopuszczaną kobieta do urzędów publicznych, jak np. sędziów, obrońców, deputowanych, ministrów, gdzie zdolność jej i usposobienie nieraz na ciężką ze szkodą dla całego społeczeństua byłyby uystawione próbę. [...] Rodzina jest podstawą społeczeństua, a kobieta podstawą rodziny. Skierowanie kobiety do innych zajęć osłabia jej przywiązanie do rodziny i podkopuje byt społeczny. Kobieta nie uypełnia uszystkich obowiązków obywatelskich, bo jednym z nich jest obrona państua, słusznie zatem, aby też i niektórych praw nie miała. [...] Powierzanie zarządu całości połouie mniej uzdolnionej może tylko być szkodliuym dla ogółu. W końcu sama natura różna duu płci nie pozwala na ich częste i długie przebywanie razem ${ }^{76}$.

Paradoksalnie podrozdział poświęcony mężczyźnie wypada zacząć od słów móuiących o kobiecie, jako że w modernistycznych publikacjach materią porównawczą i punktem odniesienia dla Mann staje się Frau. W kompendiach epoki - także tych pokaźnych, kilkunastotomouych - hasło „mężczyzna” po prostu nie istniało. Zastanawiające, zważyuszy że rolą encyklopedii od początku było gromadzenie wiedzy danych czasów, a zdefiniowane w niej pojęcia prezentować mają ogólny poziom wiedzy i doświadczenia określonego społeczeństwa. Kilkanaście, a nawet kilkadziesiąt szpalt poświęcano za

${ }^{74}$ Brockhaus' Konversations-Lexikon, wyd. 15, t. 7, Leipzig 1898, s. 228, 235 i in. Cyt. za: U. Frevert, Maż $i$ niewiasta, niewiasta $i$ mąz. O różnicach ptci $w$ czasach nowoczesnych, przeł. A. Kopacki, Warszawa 1997, s. 62-63.

${ }^{75}$ Kobieta [hasło], [w:] Encyklopedia powszechna S. Orgelbranda, Warszawa 1863, t. 14, s. 943-946.

${ }^{76}$ Kobieta [hasło], [w:] Encyklopedia powszechna z ilustracjami i mapami S. Orgelbranda, t. 8, Warszawa 1900 , s. 332-333. 
to kobietom. Można się zastanawiać, czy działo się tak dlatego, że autorami leksykonów byli w ouym czasie uyłącznie mężczyźni, którym kobiecość wydawała się daleko bardziej tajemnicza, niejasna i intrygująca niż męskość. Raczej nie. W encyklopediach wychodzących do pierwszej połowy XIX w. notka dotycząca potomka Adama ma uszak jeszcze sue stałe miejsce ${ }^{77}$. Jej stopniowe skracanie, aż do całkowitej eliminacji, znamionuje wzrastającą - im bliżej fin de siècle'u - męską potrzebę odróżnienia się od kobiecości i jej przewyższenia. Skonfliktowanie płci, wynikające ze zmian kulturowo-obyczajowych, skutkowało w obszarze dyskursu naukowo-publicznego podkreślaniem oraz uzasadnianiem odmienności niemożliwych do zniwelowania. Już samo charakteryzowanie mężczyzny jedynie poprzez różnice między nim a kobietą zawiera sugestię, że męskość to coś oczywistego, zgodnego ze standardami, więc nie wymagającego wyjaśniania (ujęcia pojęciowego), kobiecość zaś to twór wtórny, wręcz wynaturzenie. Przywołane wyżej definicje opisują kobietę jako istotę odbiegającą fizycznie i intelektualnie od męskiej normy obranej za punkt uyjścia. Wprost sytuują płeć żeńską na pozycji podrzędnej, motywowanej przede uszystkim uwarunkowaniami anatomicznymi i naturalnymi właściwościami predysponującymi do rozrodu i macierzyństwa. Mężczyzna okazuje się zatem organizmem predysponowanym do celów wyższych, bo - choć wyposażony w organy płodzenia - nie posiada naturalnych możliwości rozrodczych, a zatem jest bardziej zdystansowany wobec potrzeb ciała (sic!). Co więcej, to właśnie z możliwości zapładniania wywiedzione są takie jego cechy, jak przedsiębiorczość, kreatywność, moc, potencjał, energia, siła (fizyczna i duchowa), zdolność do obejmowania stanowisk państwouych i wojskowych ${ }^{78}$.

Paradoks polegający na tym, że definicję człowieka konstytuują cechy mężczyzny, zauważył jeden z pieruszych niemieckich socjologów - Georg Simmel (1858-1918). Kobietę charakteryzuje się przez odniesienie do mężczyzny, a nie do ogólniejszej definicji homo sapiens, co prowadzi do jej ujmowania jako istoty niesamodzielnej i pomija wiele jej istotnych cech.

${ }^{77}$ Zob. więcej U. Frevert, op. cit.

${ }^{78}$ Choć relacje między płciami nigdy nie były kuestią bezsporną, to XVIII-wieczne kompendia definiouały kobiety i mężczyzn w sposób znacznie bardziej obiektywny i zróunoważony. Różnicy upatrywano nie w płci biologicznej (sexus), lecz w roli społecznej. I tak macierzyństuo oraz uychowanie dzieci uznawano za kobiecą pracę na równi $\mathrm{z}$ męskim zarobkowaniem, a miano „mężczyzny” przysługiwało osobnikowi, który - poza przynależnością do płci męskiej - uykazywał się dojrzałością, zasługiuał na pouszechny szacunek, był gotów do wzięcia odpowiedzialności za rodzinę itp. (zob. U. Frevert, op. cit., s. 43-50). Egzystencja społeczna nie była jeszcze oparta na własnościach naturalnych. Dopiero w XIX w. poprzez płeć biologiczną zaczęto patrzeć na inne sfery istnienia: psychikę, intelekt, system nerwouy, funkcję społeczną. To przesunięcie znamionuje m.in. publikacja Benedykta Dybouskiego o znaczącym tytule $O$ kwestii tzw. kobiecej ze stanowiska nauk przyrodniczych (Lwów 1897). 
Schyłek XIX w. jak żaden okres historyczny wcześniej dobitnie pokazał, że cała kultura zachodnia ma męski charakter. Problem ten stał się jednym z podstawouych elementów teorii Simmla, który zauważył, że to mężczyźni są twórcami kultury, a niemal uszystkie jej formy - nauka, polityka, sztuka, religia - stanowią ekspresję męskości i jej służą. Socjolog dowodzik, że kultura dopasowana jest do męskich zdolności, operuje też męskimi kryteriami uartości. Męski jest nawet język i sposób móuienia o człowieku i płci. Dlatego podkreślał, że emancypacja polegająca na umożliwieniu kobietom dostępu do uykształcenia oznacza $w$ istocie jedynie dostęp do męskich form kultury. Postulował przyznanie przedstawicielkom płci żeńskiej prawa do uyrażania siebie $\mathrm{w}$ formach odpowiadających kobiecości, tak by męskie schematy ich nie ograniczały ${ }^{79}$.

Na ogół jednak autorytet naukowców uzasadniał umysłową, moralną i społeczną uyższość mężczyzn. Gloryfikację mężczyzny stanowiła na przełomie wieków przede uszystkim uspomniana już książka Ottona Weiningera Pteć $i$ charakter. Według młodego myśliciela, mężczyzna to wyższa forma życia; u przeciwieństwie do kobiety przysługują mu takie przymioty, jak wolność, śuiadomość, logika i moralność, rozum i wolna wola. Absolutny mężczyzna jest wizerunkiem Boga, tymczasem absolutna kobieta jest symbolem nicości. Osobowość, indywidualność, dusza przysługują tylko mężczyźnie. Kobieta nie potrafi posługiwać się pojęciami abstrakcyjnymi i lekceważy racjonalne zasady, ale co uięcej - brak jej samoświadomości, a więc jaźni. Nie przysługuje jej nawet antymoralizm, bo oznacza on zajęcie świadomej postawy wobec kwestii etyki, tymczasem kobieta jest tak gruboskórna i bezmyślna, że nawet zła być nie może. Jest amoralna. Ponieważ odmawia się jej urażliwości etycznej, poczucia sprawiedliwości, zaprzecza istnieniu sumienia i zdolnościom twórczym, usprawiedliwia się jej instrumentalne traktowanie. Kobiety-geniuszki „nie ma, nie było [...] i nigdy w ogóle być nie może" - stuierdza autorytatywnie Weininger ${ }^{80}$. Jak bowiem może być geniuszem istota pozbawiona duszy? Genialność jest identyczna z głębią, a głębia plus kobieta to oczywista sprzeczność. Mizoginiczne niedorzeczności wieńczy zdanie: „Mężczyzna nisko stojący stoi tedy jeszcze nieskończenie wyżej niż najuyżej stojąca kobieta, i to tak uysoko, że poróunywanie i zestawianie uydaje się tu prawie że niedopuszczalne" ${ }^{81}$.

Nietrudno i w tekstach Przybyszewskiego odnaleźć wypowiedzi w podobnym tonie, choć polski pisarz poczytyuał Weiningerowi (podobnie jak Strindbergowi) za błąd ocenianie kobiet i mężczyzn według tych samych kryteriów, niesprawiedliwie prowadzące do dezauuowania wartości tych pieruszych i apoteozy drugich. Siebie z dumą widział jako twórcę przełamującego tendencyjność

${ }^{79}$ Więcej o historycznym różnicowaniu kobiet i mężczyzn, także w kontekście socjologii Simmla, zob. M. Uliński, Kobieta i mężczyzna. Dzieje refleksji filozoficzno-spotecznej, Kraków 2001.

${ }^{80}$ O. Weininger, Pteć $i$ charakter, przeł. O. Ortwin, Warszawa 1994, s. 27.

${ }^{81}$ Ibidem, s. 146. 
poglądu na różnicę płci, aczkoluiek warto zurócić uwagę, że w jego Synach ziemi Czerkaski tak przekonywał żonę o dzielących ich różnicach:

[...] ja kieruję się rozumem, a ty instynktem - ja mam ambicję, by tworzyć, a ty - próżność samiczki, by samców ku sobie wabić - a więc jesteś niższym zuierzęciem i musisz podlegać mej woli. (Sz I, 45)

Pouyższe wprowadzenie do meritum sprawy - choć może wydawać się przydługie - jest uzasadnione nie tylko w kontekście tematu książki, ale generalnie na tle twórczości Przybyszeuskiego, w której mężczyźni istnieją niemal wyłącznie o tyle, o ile wchodzą w związki z płcią przeciwną. Dlatego celem tej części rozważań nie jest scharakteryzowanie czy poróunanie postaci męskich w twórczości autora Synagogi szatana, lecz odnalezienie paradygmatu męskości w zakresie relacji miłosnych i seksualnych.

Zacznijmy od uwagi, że mężczyzna Przybyszeuskiego nie składa suymm partnerkom daleko idących deklaracji. Nie obiecuje szczęścia, uyłączności, szczególnych miłosnych doświadczeń, emocjonalnych uniesień. A jeśli już ucieka się do zapewnień, to z mniej lub bardziej świadomego zafałszowania. Do zaoferowania ma co najwyżej ulotne chwile rozkoszy, finalnie sprowadzające zniszczenie, nienawiść i śmierć. W dodatku bardzo szybko pozwala kobietom odkryć sue prawdziwe intencje i zorientować się, że traktowane są przez niego instrumentalnie, jako obiekt do zdobycia, którego nie chce się jednak dłużej posiadaćć.

Mlicki z hipokryzją zuraca się do Heleny, która odkryła jego zuiązek z Olgą:

Miło mi bardzo, że o uszystkim wiesz i oszczędziłaś mi długich wyjaśnień... [...] ja uyjaśnień strasznie nie lubię... (Dszcz 10)

- i dalej:

[...] o ile cię znam, nie chciałabyś, bym tylko z obowiązku został przy tobie... Wątpię, czybyś chciała żyć z człowiekiem, który przez ciebie całe życie będzie cię uważał za kulę u nogi, za... za... zaporę do szczęścia. (Dszcz 12)

Usytuowanie mężczyzny $\mathrm{w}$ centrum świata powieści i poematów umożliwiła Przybyszewskiemu wypracowana przez modernistyczną prozę nowoczesna formuła snucia trzecioosobowej narracji z perspektywy bohatera prowadzącego, którym pisarz czyni ułaśnie mężczyznę, kobiecie poza dialogami rzadko udzielając głosu. Ograniczenie czytelniczej wiedzy o rzeczywistości

\footnotetext{
${ }^{82}$ Zob. J. Ratajczak, Umrzeć z miłości. Szkice o romansach młodopolskich, Wrocłau 1999, s. 72 .
} 
przedstawionej do subiektywnego punktu widzenia postaci zmusza do przyjęcia męskiej optyki jako obowiązującej u tekście. Głównym sposobem prezentacji bohaterów oraz ich poglądów pozostają w zasadzie monolog weunętrzny oraz mowa pozornie zależna, a także przejauy emocji wyrażających się w gestach i mimice. Czytelnik, wcześniej wtajemniczany u tajniki fabuły przez autorytatywnego narratora realizmu, teraz wie mniej niż postać, która na przestrzeni tekstu nie musi uszystkiego o sobie ujauniać. Technika monologizowania bliska soliloquium, a sprowadzająca się w młodopolskich realizacjach do przymusu niekończącej się refleksji połączonej z introwersją, znamionuje popularny na przełomie XIX i XX w. typ neurotyka i dekadenta, dla którego filozofowanie jest przeszkodą na drodze do czynu, ponieważ blokuje wolę. U Przybyszeuskiego atrofia woli jest zjawiskiem marginalnym, skoro postępowaniem bohaterów kieruje niezależna od nich siła. Dlatego wykreowane przez pisarza osobowości są połączeniem schyłkouca-pesymisty z nadczłowiekiem. Bohaterowie tacy, jak Eryk Falk, Henryk Bielecki czy Gordon, to ludzie bezuzględni, egoistyczni, dyktujący innym ułasne prawa, skłonni do nihilizmu, wreszcie uciekający się do zbrodni.

Rozwiązanie formalne, sprawiające, że bohater nieustannie dokonuje wiwisekcji na sobie i całym śuiecie, Przybyszeuski potrafił poza tym uykorzystać fabularnie - akcja utworów jest dla postaci drogą do poznania prawdy, uniwersalnej zasady istnienia oraz uwarunkowań rządzących ludzką kondycją. Owa fundamentalna rzeczyuistość kryje się głównie $\mathrm{w}$ zuiązkach z kobietami. Ograniczona do minimum fabuła wyostrza tylko wizerunek człowieka poddanego różnego rodzaju presjom i uyborom uczuciowym. Z uwagi na jednowątkowość, monotematyczność oraz konfesyjność powieści i poematy Przybyszeuskiego - jak wiele młodopolskich utworów, głównie z lat dziewięćdziesiątych - zyskały miano monografii bądź studium duszy ${ }^{83}$, przy czym w przypadku autora Synagogi szatana zausze była to dusza męska.

Ze światem przeżyć zredukowanym do jednego uczucia, choć nie do jednej kobiety, czytelnik ma do czynienia w przypadku bohatera pieruszej powieści młodopolskiego pisarza - Eryka Falka. Cyniczny, banalny „donżuanizm” uyklucza w jego przypadku nadmiernie rozwinięta introspekcja. Fragmenty, w których rozkłada on motywy i skutki swego postępowania na czynniki pierusze, pozwalają bowiem uidzieć w nim narzędzie amoralnej natury. Uwiedzenie narzeczonej przyjaciela, zdradę małżeńską oraz bałamucenie i porzucenie kochanki bohater tłumaczy (w niekończących się tyradach i zmaganiach psychicznych) miłosnym fatum, niemożliuym do zignorowania przymusem. W ekspozycji dokonuje deziluzji miłości, nazwanej „uczuciem ludzi pierwotnych, rodzajem patologicznej wysypki w duchouym życiu nowego człowieka"

${ }^{83}$ Zob. M. Sadlik, „Konfesje samotnych”. W kręgu prozy spowiedniczej 1884-1914, Kraków 2004, s. 177. 
(Hs I, 7). Z reminiscencji wiadomo, że jako student robił pseudonaukowe eksperymenty, rozkochując w sobie szkolną koleżankę (Janinę Kruk, z którą nadal utrzymuje kontakty seksualne), by na podstawie obserwacji jej postępującego zaangażowania uczuciowego opracować „biogenezę miłości”. Jednak nie potrafi obronić z góry przyjętej postawy dystansu. Wystarczy spotkanie z Izą Perier, a zaczyna wierzyć w uczucie w jego najuyższym - androgynicznym uymiarze. Nie mogąc zaś się u nim spełnić - ponieważ jego wybranka należała wcześniej do innego - kompensuje sobie „niedoskonałość” ukochanej, uwodząc niewinną Maryt. Intryguje go jej życiowa naiwność, pobożność, czystość, oznaczająca opór wobec natury, na który on sam nie potrafi się zdobyć. „Posiąść śuiętą... Toby była sensacja” (Hs II, 40) - myśli, a konstatacja ta koresponduje z tezą „Tylko święte rzeczy godne są dotknięcia”, jaką u Wilde'a dzieli się lord Henryk Wotton z Dorianem ${ }^{84}$.

Poszukując źródeł obezwładniającej miłosnej fascynacji, uspiera się Falk - tu potuierdzić uypadnie rozpoznania G. Matuszek - pesymistycznymi koncepcjami Schopenhauera, widzącego w miłości jedynie złudną grę pozorów zakochania, zręcznie kamuflujących prokreacyjne cele ${ }^{85}$. Stąd patrzy na uczucie przez pryzmat reakcji fizjologicznych. Aby podkreślić swą rezerwę wobec spraw natury i zdezawuować mieszczącą się w ich obrębie miłość, sięga, bezskutecznie, po broń najsilniejszą - śmiech ${ }^{86}$ :

Miłość, och tak miłość! Najpieru dziunie zmieszane, zakłopotane spojrzenia, potem śuiecące się oczy Fauna, później drżenie rąk [...] Potem! zniżanie i podnoszenie głosu jak przy skandowaniu ód Horacego, to zachryple, to jękliwie... [...] Później cały szereg bezwiednych ruchów [...] czyż to nie jest śmieszne? Czyż to nie jest śmieszne w najuyższym stopniu? (Hs I, 92-93)

Postawa Falka od początku jest konsekwentnym uyrazem niezgody na zuiązki zależnościowe ${ }^{87}$. Implikuje ją samo z niemiecka brzmiące nazwisko. Słowo Falke oznacza bowiem w języku niemieckim sokoła i konotuje takie cechy, jak siła, bezwzględność i drapieżnośćc ${ }^{88}$. W miarę rozwoju akcji powieściowej rośnie przekonanie bohatera o powołaniu do rzeczy wielkich,

${ }^{84}$ O. Wilde, Portret Doriana Graya, tłum. M. Feldmanowa, Wrocław 1996, s. 65. Miłość jako przedmiot eksperymentu psychologicznego pojawiła się we wcześniejszych niż Falk kreacjach polskich bohateróu-dekadentów: Rymszy z powieści Leo Belmonta W wieku nerwowym (1890) oraz Płoszowskiego z Bez dogmatu (1891) Henryka Sienkieuicza. Obaj bohaterouie motyuują uwiedzenie kobiety chęcią zgłębienia tajemnic uczucia.

${ }^{85}$ G. Matuszek, Stanisław Przybyszewski..., s. 244-245.

${ }^{86}$ G. Matuszek pisze, że nie mogąc zamknąć miłości u reakcjach oganizmu Falk oduołuje się następnie do idei anamnezy oraz obsesji totalności obecnej u Ibsena. Ibidem.

${ }^{87}$ Wniosek taki wysnuł J. Zieliński, analizując pierusze zdanie powieści Homo sapiens („Falk zerwał się wściekły”) oraz jego konsekwencje dla kreacji bohatera i fabuły (J. Zieliński, Pierwsze zdanie „Homo sapiens”, „Teksty” 1977, nr 4).

${ }_{88}$ Zob.: Z. Klimajówna, Nazwiska bohaterów powieści Stanisława Przybyszewskiego, „Roczniki Humanistyczne”, Lublin 1967, t. 15, z. 1, s. 80-102; K. Kralkouska-Gątkouska, 
ponadprzeciętnych i niedostępnych pospolitym jednostkom. „Ja nie jestem samem tylko ja - [...] jestem bogiem, światem, naturą [...]" (Hs II, 126) - rozważa, najuyraźniej ogarnięty manią wielkości, którą u trzeciej części powieści usiłuje realizować - bez spektakularnych efektów - w roli przywódcy partii robotniczej. Jego ambicje, wzrosłe na nieuzasadnionym niczym przekonaniu o własnej potędze kreacyjnej, mają charakter totalitarny:

[...] ja, jako geniusz, mam ten głęboki, moralny obowiązek poprawić rasę ludzką [...]. No, oczywiście przez to, że spłodzę możliuie dużo dzieci z możliwie dużo kobietami. (Hs III, 34)

Zostaje ojcem dwóch synów. Jednego płodzi ze swą żoną Izą, drugiego - z Janiną Kruk, narzeczoną Czerskiego, członka partii i społecznego agitatora. Realizuje się wyłącznie w sferze instynktów, w ekstazie płciowej upatrując szansy poznania istoty egzystencji. Poszukiwanie erotycznych urażeń w relacjach pozamałżeńskich starannie jednak ukrywa, pragnąc za uszelką cenę utrzymać związek z Izą.

Podobną filozofią miłości od początku kieruje się Bielecki. Óu „mocny człowiek" nieustannie miota się między potrzebą zniewolenia kobiety a obawą przez zaborczością z jej strony, uynikającą nie tylko z jej roli jako narzędzia natury, ale także - a może przede uszystkim - z uwarunkowań fabularnych. Otóż każda zuiązana z Bieleckim bohaterka staje się powierniczką mogącej go skompromitować tajemnicy. Łucja Szumska zna sekret fałszerstua rękopisów Górskiego, które spragniony literackiej słauy Übermensch ogłosił pod własnym nazwiskiem. Wyzwoliuszy się od niej przez morderstwo, bohater popada natychmiast w zależność od Ady Karskiej - kobiety demonicznej, przekonanej, że nic nie wiąże kochanków mocniej niż zbrodnia. Dobrani podobieństwem natur, które każą im bezwzględnie wykorzystywać innych dla własnych celów, Bielecki i Karska mogą być partnerami tylko do czasu przerodzenia się cynicznej relacji w nieodwzajemnioną miłość. Kobieta zakochana bywa zazdrosna i nieobliczalna, dlatego „mocny człowiek”, który nie bawi się w sentymenty, musi jak najszybciej usunąć ją ze swojego życia, a najprostszą ku temu drogą jest podsunięcie jej innemu (księciu Porajowi).

Niespodziewanie dla samego siebie Bielecki, zdystansowany wobec miłości wikłającej w zależność od partnerki i samego uczucia, ulega fascynacji Niną Ligęzową. Z ramion kobiety-demona przenosi się $w$ łagodne objęcia kobiety-anioła, która pozwala mu - po raz pieruszy u życiu - odnaleźć w sobie „coś świętego, coś pozaświatowego”. Ma poczucie obcowania z sacrum, które otwiera przed nim perspektywę androgynicznego zjednoczenia. Świętość ewokująca szczerość i dobro nie jest jednak zgodna z naturą

Świat postaci $w$ powieściach Stanisława Przybyszewskiego, [w:] Młoda Polska. Legendy $i$ światopoglądy, red. T. Bujnicki, Katowice 1983, s. 83. 
„nadczłowieka”. Bielecki, choć odnalazł w Ninie ucieleśnienie suej animy, musi uwodzić dalej, by potwierdzać swą siłę i realizować potrzebę dominacji. Romansuje więc z bogatą panią Tańską, okłamując sam siebie, że czyni to dla funduszy na rozwijające się pod jego redakcją pismo artystyczne.

W kreacjach obu uspomnianych bohaterów Przybyszewski osłania strategie uwodzenia. Schemat jest podobny - mężczyzna śuiatowy sprowadza na złą drogę dziewczynę niedoświadczoną, prowincjonalną, urzeczoną kosmopolityzmem i ambicjami artystycznymi zainteresowanego nią partnera. Uwieść oznacza tu nie tylko uykorzystać seksualnie bez zamiaru poślubienia, ale podważyć wartości istotne dla uwodzonej i narzucić jej własny światopogląd. Wzoru dla takiego rozwiązania Maria Podraza-Kuiatkouska szuka w Dzienniku uwodziciela Sørena Kierkegaarda (uydanym co prawda w 1843 r., ale na łamach krakouskiego „Życia” opublikowanym u roku 1899) oraz Uczniu Paula Bourgeta (1889). Demoralizacji partnerki (niszczeniu jej poglądów, podsuwaniu właściuych lektur, zniechęcaniu do praktyk religijnych itp.), służącej zdobyciu jej ciała, towarzyszy u tych powieściach - jak u Przybyszewskiego - nieustanna autoanaliza. Uwodziciel Bourgeta, podobnie jak Falk, przybiera wręcz konstrukcję sobowtórową - w obu przypadkach można mówić o podwójnej osobowości, „z których jedna działa, a druga obserwuje działającą" ${ }^{99}$.

W przeżyciach Falka trudno rozdzielić fascynację od gry i samooszustua ${ }^{90}$. W obecności Maryt kłamie mechanicznie, by nic nie przeszkodziło ich zbliżeniu. Roztacza przed nią wizję uspólnego szczęścia i tai fakt posiadania rodziny, by nakłonić ją do kontaktu seksualnego. Odgrywa rolę kusiciela, który karmi naiuną dziewczynę pięknymi słówkami, wtajemnicza w świat grzechu i namawia do ulegania zachciankom, uykraczającym poza społeczne konwenanse, które nazywa przestarzałymi zabobonami. Z celową przesadą kreśli przed nią obraz nowoczesnych relacji damsko-męskich ${ }^{91}$ :

W Europie panuje uielka wolność u stosunku mężczyzny do kobiety. Tam nie ma tych głupich przesądów, tej przedpotopowej staroświecczyzny jak u nas. [...] u Europie nie ma przepisów u sprawach miłości. Tam jest każdy sam dla siebie przepisem i prawem. (Hs II, s. 21-22)

Pobrzmiewa w tych fałszywych zapewnieniach nietzscheańskie pragnienie odrzucenia uszystkiego, co krępuje wolę i pragnienia jednostki. Ze szczególną, niemal naturalistyczną obrazowością atakuje Falk Kościół stojący

${ }^{89}$ M. Podraza-Kuiatkouska, Wolność $\boldsymbol{i}$ transcendencja. Studia i eseje o Młodej Polsce, Kraków 2001, s. 132. Badaczka zauważa, że czystość, jako cnota świętych i bohaterów, nadająca moc poskramiania bestii, rodzi pokusę skalania tego, co pozbawione zmazy, dlatego w literaturze niezuykle często występuje temat uwiedzenia osoby niewinnej. W Młodej Polsce bywał on łączony z problematyką grzechu i zła.

${ }^{90}$ Zob. W. Gutouski, Nagie dusze..., s. 276.

${ }^{91} \mathrm{Na}$ temat metod działania Falka por. I. Filipczak, op. cit., s. 308-310. 
na straży ograniczających podmiot dogmatów i kształtujący światopogląd wychowanej w klasztorze Maryt. Opisuje go jako miejsce nie uduchowienia, ale brudnej fizyczności, w którym „panuje uszechwładnie straszliwy zapach potu i ustrętnych pokarmów, nie dobrze strawionych" (Hs II, 51). Wreszcie sięga po argument, na którym sam chciałby zbudować swoją filozofię - przekonuje młodą dzieuczynę, że instynkty są upisane w naturę człowieka, a zatem nie można im się opierać i nazywać nieczystymi; wręcz przeciunie - u podążaniu za nimi kryje się piękno i prawda. Pasożytuje na uczuciach partnerki, ponieważ nie odwzajemnia ich mocy. Z dystansem obseruuje moralne zmagania i rosnące zaangażowanie Maryt, odsuwającej od siebie krążące w okolicy plotki o ślubie Falka z ,jakąś Francuzicą” (Hs II, 2). Tuż po akcie seksualnym wykrzykuje natomiast całą prawdę na temat suego życia małżeńskiego, nie troszcząc się o kochankę, którą doprowadza do samobójstua. Tragiczny finał zapowiada uspomnienie roztrzaskanej przez piorun przydrożnej wierzby, jakie nawiedza Falka wyczerpanego natężeniem emocji ${ }^{92} .,[. .$.$] miał nagle uyraźną, błyskawiczną świadomość, że zniszczył$ Maryt" - stwierdza narrator (Hs II, 126) ${ }^{93}$. Niemniej samowiedza nie wiąże się z poczuciem winy. Falk nie działa z premedytacją, lecz ulega imperatywom natury, a to pozwala mu znaleźć usprawiedliwienie dla najcięższych zbrodni. Co więcej - jak zauważa Bożena Chołuj - chętnie unika odpowiedzialności i oddaje się pod opiekę żony ${ }^{94}$.

Brutalniejszą metodę obrał Bielecki wobec Łucji. Zaczął od dostosowania jej wizerunku do standardów cyganerii, wśród której się obracał. Kazał ściąć na krótko włosy, nauczył palić papierosy, pić wódkę szklankami i oddawać mu się na każde żądanie. „Zeskrobywanie małomieszczańskiej skóry” miało i dramatyczniejszy przebieg: „spijał mnie, bił, kopał, pastwił się nade mną" - skarży się Łusia (Mc I, 39). Nawiązanie romansu dokonało się w przedakcji Mocnego człowieka, a że Przybyszeuski nie dba o logiczne uporządkowanie faktów na zasadzie przyczynowo-skutkowej, trudno orzec, w jakich warunkach nastąpiło pierwsze spotkanie bohaterów i co ich do siebie zbliżyło. Wiadomo jedynie, że Łucja Szumska przyjechała do Warszawy nieskalana, za to gotowa kochać ze wszystkich sił i nieprzygotowana na wybiegi uwodzenia, co Bielecki skrzętnie uykorzystał. Spragniona niezwykłych

\footnotetext{
${ }^{92}$ Podobny obraz - roztrzaskanej sosny - uykorzystał Żeromski w Ludziach bezdomnych dla oddania psychicznego rozdarcia Judyma.

${ }^{93}$ Jeśli wziąć pod uwagę analizy Z. Klimajóuny i K. Kralkouskiej-Gątkouskiej, to klęskę Maryt przesądza już jej nazuisko - Kauer. Kauen znaczy u języku niemieckim m.in. „gryźć wędzidło", co sugeruje, że prowincjonalna dziewczyna - jak źrebak - rwie się na suobodę. Ale słowo kauen oznacza także „boleć nad stratą”, co symbolicznie zapowiada losy postaci (zob. K. Kralkouska-Gątkouska, Świat postaci w powieściach Stanisława Przybyszewskiego, s. 85).

${ }_{94}$ B. Chołuj, Gdyby nie miłość... Rzecz o utopii Stanisława Przybyszewskiego, [w:] Ciało, pteć, literatura, red. M. Hornung, M. Jędrzejczak, T. Korsak, Warszawa 2001, s. 126.
} 
wrażeń dała się uwieść jego demonicznej naturze, nonszalancji, z jaką deptał uszystko, co ograniczało jego wolę. Zerwała z rodziną, całymi nocami pozualała się włóczyć z knajpy do knajpy, ideały („dziecinne przesady” i „staroświeckie łachmanki”) zamieniła na cynizm, przekonana, że teraz dopiero z prowincjonalnej gąski przedzierzgnęła się w kobietę. „Dotychczas była jakąś tam poczwarką, głupim podlotkiem, który pachnie bułką posmarowaną świeżym masłem, a tu nagle przez jedną noc narodziła się w niej kobieta..." - komentuje jej deprawator (Mc I, 122).

Bielecki upaja Łusi te same antywartości, którym wzorem Nietzschego hołduje Falk. Uczy odrzucania praw zewnętrznych i obowiązków, niszczenia ludzi, by żyć ich kosztem, traktowania ich jak pionki na własnej szachownicy, „wyzwolenia swego Ja z ohydnych kajdan moralności, sumienia, idiotycznej sercowości" (Mc I, 129). Suiadomość destrukcyjności tej nauki dociera do bohaterki z opóźnieniem. Ale - paradoksalnie - uczucie ustrętu i obrzydzenia, jakim napawa ją jej ułasne życie, potęguje jeszcze niezdrową, niemal masochistyczną miłość do Bieleckiego.

W obrębie dramaturgii Przybyszeuskiego - oscylującej ku symbolizmowi - naturalistycznie ujęty wątek uwiedzenia pojawił się jedynie w Topieli, nawiązującej schematem fabularnym do realizacji sentymentalnych, ale przełamującej ich konwencję pokładami tragiczności. Trzydziestoletni Skalski, typ Don Juana, próbując zdobyć Ludmiłę (imię typowe dla XVIII-wiecznych tekstów sielankowych), nie sili się na wyrafinowany flirt. Jego komplementy grzeszą banałem i prostactuem, mieszczącym się jednak w granicach staropolskiej obyczajowości szlacheckiej. „Twoim pachołkiem będę, podnóżkiem twoim" (T 6) - zapewnia. Na uwagę dziewczyny o duszności powietrza zwiastującej nadchodzącą burzę, odpowiada: „Mnie inna parność przygniata” (T 5). Ona - niedoświadczona i zaustydzona - zachouuje się jak pensjonarka: „Nie mów pan, nie mów; ja nic nie chcę wiedzieć - ja bardzo pana proszę, byś mi pan nic nie mówił" (T 6) - reaguje na jego zapeunienia o uczuciu. Aby złamać dzieuczęcy opór, Skalski sięga po argumenty ambicjonalne, przekonując, że pragnienie i wola uświęcają każdy postępek. „Ty - ty, z twoim hartem, z twoją samodzielną wolą, z twoją inteligencją, potrzebujesz błogosławieństua ciotek i wujów? chyba żartujesz" - prowokuje. Osiąga cel, jakim jest małżeństwo dla posagu, po czym szybko pozwala Ludmile domyślić się, że została potraktowana instrumentalnie. Rozczarowana ułasnym życiem, niewiernym mężem oraz „szerokim światem”, którego była tak ciekawa, a na który składa się „bezduszna horda niechlujnych cyników, pieczeniarzy - i parę kokot” (T 129), ureszcie dowiedziauszy się, że Skalski romansował wcześniej z jej ciotką, a w niej samej kocha się uuj - bohaterka uybiera śmierć, skacząc z okna.

Wykorzystany w tych utworach wątek uwiedzenia (stanowiący według Marii Podrazy-Kuiatkouskiej literacką próbę dotarcia do granic możliwości 
człowieka u czynieniu zła ${ }^{95}$ ) dowodzi panowania mężczyzn nad kobietami u świecie Przybyszeuskiego (jedynie z femme fatale nie mógł konkurować żaden mężczyzna). Potrzeba dominacji obejmuje oczywiście nie tylko partnerki słabe, tzn. życiowo naiwne i nie znające obłudy wielkomiejskich zuiązków, lecz również te o mocnej psychice, śuiadome ułasnej wartości i cynizmu obowiązującego w kontaktach damsko-męskich tzw. wielkiego świata. Wynika natomiast z lęku przed podporządkowaniem, wchłonięciem przez drapieżną osobowość kobiety bądź głębie uczucia. Partnerstwo nie jest możliwe, ponieważ światem ludzi - podobnie jak całą naturą - sterują prawa walki, zgodnie z zasadą "pożeram albo jestem pożerany". Bohater obawiający się zdominowania przez partnerkę szamocze się i dusi, dlatego rości sobie prawo do bycia jej panem.

Mikita w chwili wzburzenia parafrazuje słowa Nietzschego: „Idziesz do kobiet? Nie zapomnij bicza!"96:

Kobietę trzeba ujarzmić, pięścią, biczem... uyualczyć, wywalczyć trzeba miłość... (Hs I, 115)

W taki sam sposób chłodno rozumuje Bielecki, związany kontaktami erotycznymi oraz zbrodnią z demoniczną Adą Karską:

Nim słońce uzejdzie ${ }^{97}$, będziesz moją. Tylko się nie poddać, trzeba pójść z batem - z biczyskiem, mieć siebie u garści, by się nie dać opanować. [...] Posiąść i rzucić, albo też i wracać, ale bez zobowiązań, bez ckliwego sentymentalizmu - po napoleońsku... A kto wie, może mi się na co przyda, ujarzmię ją, zrobię z niej swoje narzędzie... Straszna rzecz dostać się w moc kobiety... (Mc I, 103)

Zdobywanie kobiety silnej uymaga innej strategii niż uwiedzenie osóbki, której świat ogranicza się do prowincji. Trudniej zaimponować jej wywrotowymi poglądami, dlatego mężczyzna musi zacząć od chwilowej uległości, dającej partnerce złudne poczucie wyższości i wyprowadzającej na manouce megalomanii. W rezultacie - jak dywaguje Bielecki - ona „staje się lichą aktorką, a ja suflerem, który całą rolę jej podpowiadam, ona wiernie bez namysłu, bez rozwagi uszystko jak papuga poutarza, a to, że święcie wierzy, iż to ona sama mówi: tę satysfakcję można jej pozostawić..." (Mc I, 150). W zuiązkach silniejsza od miłości jest bowiem potrzeba posiadania i zawłaszczenia.

Bohater Androgyne mówi do odnalezionej ukochanej:

${ }^{95}$ M. Podraza-Kuiatkouska, Wolność $i$ transcendencja, s. 134.

${ }^{96}$ F. Nietzsche, Tako rzecze Zaratustra, tłum. W. Berent, Warszawa 1907, s. 77.

${ }^{97}$ Nim stońce wzejdzie - mikrocytat z wiersza Zygmunta Krasińskiego Nim słońce wzejdzie, rosa wyżre oczy. Podziwiać można umiejętność uykorzystania tego fragmentu w charakterze dynamicznego i sugestywnego rozpędnika zdaniowego. 
Jestem tym, co w każdej chwili może zostać królem, rzucić u stóp swych uszystkie narody, zawładnąć nad całą ziemią, zapanować nad miliardem niewolników; każdej chwili mogę Cię kazać na krzyż wbić i znouu moją uszechpotęgą do życia powołać [...]. (A 426)

Niemniej dążąc do zdobycia kobiety, mężczyźni uciekają się niekiedy do roli niewolnika lub wiernego przyjaciela. Mikita całą noc leży niczym pies przed drzwiami Izy, by poświęcając męską godność, zyskać jej rękę (Homo sapiens). Muzyk Janota zdobywa zaufanie Hanki suym przyjacielskim nastawieniem, a jednocześnie hipnotyzuje ją grą na fortepianie i guałci, gdy dziewczyna traci przytomność (Gody życia). Uwodzić nie trzeba jedynie androgynicznej połówki, partnerzy rozpoznający się bowiem z istnienia prabytowego, jako na zawsze sobie przeznaczeni, prędzej czy później ulegną kosmicznej sile, depcząc zuiązki, jakie zawarli wcześniej.

Wojciech Gutouski zauważył, że mężczyzna zdominowany przez samicę kompensuje swą słabość i zależność, przyjmując majestatyczną rolę Boga-Króla ${ }^{98}$. W pieruszej części Androgyne, dręczony niemożnością odnalezienia tajemniczej ukochanej, bohater śni, że jest królem, na którego rozkaz zwołano do pałacu najpiękniejsze dziewice. Odziany „w bisior i purpurę”, z wysokości tronu lustruje długie rzędy młodych kobiet, z których każda drży oczekiwaniem, by stać się jego niewolnicą. Przygląda się ze znawstwem natury kobiecej, ale i namysłem estety, admirującego piękno nietkniętych ciał:

Która?

Ta, której oczy płomienią, gdyby grono wilczojagody, co na dzikich porębach uyrosła?

Ta, z której łagodnych oczu raz po raz wytryśnie krwiożerczy płomień ułaskawionego tygrysa?

[...] czy ta, co jagody suych piersi w kuszące dłonie ujęła, czy ta z kształtami lśniącego węża, czy ta, co z promieni guiazd, zda się, wykuitła? (A 388)

Sen o królowaniu to wyraz marzeń bohatera o bezgranicznej władzy nad spragnionymi go kobietami, symboliczne odzwierciedlenie jego tęsknot i lęków, a zarazem próba leczenia kompleksu, odpowiedź psychiki na nieudolność i bezsiłę $\mathrm{w}$ rzeczywistości. Tylko w sennym rojeniu - poddanym dyktatowi podśuiadomości - bohater zdolen jest aranżować uydarzenia wedle własnych potrzeb. Ale psychika płata mu figla. Transgresja oniryczna pozwala co prauda poszerzyć granice miłosnych doświadczeń, jednak sen nie przynosi spełnienia, a jedynie drażni neruy. Gdy bowiem - jako król - rozjaśniuszy pałacową salę klaśnięciem $w$ dłonie, rozpoznaje ukochaną w nagiej dzieuicy wleczonej przez syryjskiego kupca, wizja się urywa. Projektowana w umyśle bohatera nagość dziewczyny to jeszcze jeden $\mathrm{z}$ objawów przepełniającego go pragnienia dominacji. Siłą doprowadzona doń kobieta jawi się oto jako

\footnotetext{
${ }^{98}$ W. Gutouski, Nagie dusze..., s. 246.
} 
gotowa do seksualnego spełnienia. Odkrywa przed władcą skarby swego ciała i poddaje mu się $\mathrm{w}$ kornym ugięciu kolan. W jej kreacji nuditas virtualis (zaustydzenie i lęk wyrażające się $\mathrm{w}$ skurczonej postawie ciała, przysłonięcie piersi ciemnymi długimi włosami) przeplata się z nuditas criminalis (bransolety w kształcie węży na ramionach i kostkach nóg, kosztouny pas wokół bioder spięty kwiatem lotosu zamiast sprzączki), stanouiąc jeszcze jeden u Przybyszeuskiego dowód ambiwalentnego traktowania miłości i kobiecości.

W kolejnym śnie bohater wciela się w postać uładcy-maga, który dzięki praktykom satanistycznym pragnie stworzyć kochankę $w$ jej cielesnej formie:

Przez trzy dni i trzy noce przygotowywał się do potężnego zaklęcia. Trzy dni i trzy noce ugłębiał się i odczytywał znaczenie tajemnych znaków, spisanych w książkach, zamkniętych na siedm pieczęci; pisał i wbijał sobie w pamięć ukryte runy, które wywoływały nieznane potęgi; trzy dni i trzy noce upajał się jadowitymi wywarami roślin, co kwitną w tajemnych czarach nocy świętojańskiej, aż ureszcie uczuł taką moc i potęgę, że mógłby przyspieszać dowolnie uzrost roślin, rzeki w biegu zatrzymywać, a nawet pioruny na ziemię ściągać. (A 390-391)

To już czarownik-szaman, zgłębiający tajemne księgi zaklęć, świadom psychoaktywnej i halucynogennej mocy rzadkich substancji roślinnych, poszerzających wrota percepcji i dodających poczucia mocy. Panowanie nad potężnymi siłami przyrody przygotouuje go do wielkiego czynu tworzenia, uykraczającego poza naturalne możliwości człowieka. Bohater widzi siebie jako spadkobiercę i naśladowcę upadłego anioła Samyazy ${ }^{99}$, przed buntem przeciu Bogu najpotężniejszego w niebie, a po zejściu na ziemię spółkującego z kobietami i przekazującego ludziom tajemną wiedzę.

I w godzinie wielkiego cudu ubrał się w kosztowne szaty praojca swego, Samyazy, włosy przewiązał na siedm węzłów zuiązaną przepaską, wziął miecz do ręki, wykreślił koło, wpisał w nie tajemne znaki, stanął $w$ jego środku naprzeciu wielkiego zuierciadła i zawołał wielkim głosem:

- O Asztaroth! Asztaroth! (A 391)

Litania z trzykrotnym wezwaniem do bogini rozpusty i płodności („matki miłości") uzmocniona zostaje innymi praktykami magicznymi. Bohater zajmuje miejsce $\mathrm{w}$ centrum koła, przeciustawiając się $\mathrm{w}$ ten sposób siłom władającym Kosmosem ${ }^{100}$ i tworząc przestrzeń nietykalną, świętą (topos hieros), symbolizującą pełnię i doskonałość. Figurę, która nie ma początku ni końca, a więc oznacza jedno i wieczność, wykreśla za pomocą miecza, narzędzia odstraszającego złe duchy i wyrażającego siłę, a wraz z urzecionem

${ }^{99}$ Wiadomości o tym aniele pochodzą z apokryficznej Księgi Henocha. Jego imię ma kilka obocznych wersji: Samyaza, Semjaza, Shemyaza, Semihazah i in. Niekiedy kojarzony bywa on z Szatanem.

${ }^{100}$ Zob. M. Lurker, Przesłanie symboli w mitach, kulturach i religiach, tłum. R. Wojnakowski, Kraków 1994, s. 152-168. 
(symbolem żeńskim) tworzącego przeciwieństwo śmierć - płodność ${ }^{101}$. Poza mieczem, w tradycji zastrzeżonym dla rycerzy zwalczających ciemne moce w obronie sił światła, używa lustra - rekwizytu, któremu od wieków przypisywano magiczne - głównie apotropaiczne - właściwości. W zwierciadle wyczarouuje wymarzoną kochankę jak Tuardowski Barbarę Radziwiłłównę, a porównanie to nie uydaje się nadużyciem, zważyuszy popularność opowieści o polskim czarnoksiężniku w literaturze XVIII i XIX w. ${ }^{102}$. Staje naprzeciu lustra, by przyglądając się swemu odbiciu, według niego ukształtować wymarzoną istotę. W ten oto sposób zwierciadło staje się medium bliźniaczości (soboutórowości?), a bohater uzurpuje sobie boskie prawo kreacji na ułasne podobieństwo, pośuiadczone u Księdze Rodzaju. Symbolika genezyjska zadziwiająco łączy się tu jednak z obrazowaniem apokaliptycznym. Księgi zamknięte na siedem pieczęci, których znaczenie mężczyzna musi zgłębić, by zyskać moc tuorzenia, to przecież oczywiste nawiązanie do siedmiu pieczęci, które otwiera Baranek według wizji z Objawienia św. Jana (rozdziały 6 i 8). Siódemka jest zresztą w Apokalipsie znacznie bardziej nośna znaczeniowo. W tekście tym siedem listów zostaje wysłanych do siedmiu Kościołów, tajemnicze wizje mówią o siedmiu grzmotach, siedmiu trąbach, siedmiu czasach gniewu oraz tyluż wzgórzach, plagach itd. Liczba „siedem” oznacza całość i doskonałość, wartości, na których opiera się istota androgynii. Ten sam jej sens wyraża akt stworzenia, którego Bóg dokonał w ciągu siedmiu dni, traktowanych jako pełny cykl czasu.

Złamaniu pieczęci towarzyszą w Piśmie Świętym guałtowne zjawiska przyrodnicze: trzęsienia ziemi, zaćmienie słońca, spadanie gwiazd, grzmoty, błyskawice. Podobnie jest w Androgyne:

Rozległ się straszny grzmot, jakby jakaś planeta oberwała się i runęła na ziemię - zerwał się wściekły orkan wichru, piekielne chichoty i uycia szarpały mu mózg na strzępy i naraz widzi w strasznym przerażeniu, jak się wokół zuierciadła tworzy świetlista mgła, krąży, wiruje, przetwarza się w kształty; coraz jaśniej rysują się linie i zarysy, krąglą się, nabierają ciała, tętnią kruią, dyszą ciepłem i żarem życia...

Fala błyskawic zapieniła się i opadła w ciemnej komnacie, piorun uderzył w olbrzymie zuierciadło, rozległ się krzyk, a na szyję opadła mu w namiętnym, dzikim rozpasaniu ta, której szukał, której pragnął, dla której duszę swą zaprzepaścił... (A 392)

Kompilacja praktyk satanistycznych i działań na pograniczu sacrum przynosi rezultaty. Bohater eksterioryzuje z siebie kobietę - wytwór pragnień, wyobrażeń

${ }^{101}$ Zob. Miecz [hasło], [w:] J. E. Cirlot, Słownik symboli, tłum. I. Kania, Kraków 2006, s. $253-255$.

${ }^{102}$ Poza słynną klasycystyczną Barbara Radziwiłłówna Alojzego Felińskiego oraz Mickiewiczouską Panią Twardowska ów polski Faust pojauiał się jako bohater m.in. w dramatach Jana N. Kamińskiego (Twardowski na Krzemionkach), Kazimierza W. Wójcickiego (Zwierciadło Twardowskiego), Juliana Korsaka (Twardowski czarnoksiężnik). 
i tęsknot. Sny, w których przybliża się do obiektu marzeń, dezintegrują jednak jego psychikę, coraz bardziej oddalając od życia realnego. $W$ rezultacie $w$ kolejnych majakach mężczyzna to gubi się $w$ thumie lubieżnych kobiecych ciał, to znów dowodzi suej hegemonii patrząc na kochankę przybitą do krzyża.

W rytmie posiadania i utraty toczy się także baśniowa, nasycona symboliką mistyczną opowieść Nad morzem, którą znakomicie zinterpretował Wojciech Gutouski. Jej bohater-narrator, król, któremu wojounicy przywożą z dalekiej wyprawy piękną dziewicę, włada uyłącznie krainą słońca, mimo deklaracji swej omnipotencji. Królestwo cienia, z którego pochodzi niewolnica, a więc sfera podśuiadomości, okazuje się dla niego tajemnicą. Dostrzegając w nieznajomej ideał kobiety i swą animę, dokonuje jej apoteozy i pragnie jej służyć. Ten czyn rozdziera jego osobowość między rolę aktywnego władcy a oddanego całkowicie kochanka, spełniającego uygórowane żądania (jak wyrzeczenie się słońca równoznaczne ze sprowadzeniem klęski na lud $)^{103}$. W drugiej części poematu bohater, któremu nie wystarcza króleuska potęga, sięga po boską moc kreacji. Marzy o przywołaniu, przyobleczeniu w ciało wywiedzionego z ułasnej uyobraźni (i duszy) ideału. Poutarza gest i słowa Demiurga, stwarzającego na swoje podobieństwo pieruszego człowieka:

„Stań się!”

I poustałaś!

[...] a łaska moja płynęła na Ciebie, płynęła, aż moc Tuoja mojej się zróunała.

Dałem Ci moc i piękno, i byłaś tym na ziemi, czym ja byłem na niebie. (Nm 313-314)

Słowa bohaterów kreujących się na stwórców suych kochanek dowodzą dominacji pierwiastka męskiego nad żeńskim lub wręcz traktowania kobiecości jedynie jako czynnika uzupełniającego w męskich koncepcjach egzystencjalnych. Bohater $Z$ cyklu Wigilii wyznaje:

Moje potężne oko, oko uszechświatów uyłoniło Cię z ciemności. Na moje potężne Stań się! przybrałaś kształty i postać. Tchnąłem na Cię Świętego Ducha mych uczuć i myśli. Byłaś głupią zabawką, a zrobiłem z Ciebie fetysza i idol święty. (W 205)

Świadomość, że to duch mężczyzny powołał kobietę do życia w ciele, ma róunież bohaterka Androgyne.

- Tak długo błądziłam, szukałam i czekałam, czy może Tua ręka nie wyruie mnie z nicości, nie ujmie mnie $\mathrm{w}$ kształty i $\mathrm{w}$ ciało nie przetworzy...

[...] jestem ciałem Tuej myśli, jestem kształtem i ciałem Tuych tęsknot, uyrazem Tuych uczuć i ruchem Tuej woli... (A 448)

${ }^{103}$ Por. W. Gutouski, Nagie dusze..., s. 250. 
Osoba kochanki zostaje uyłoniona $\mathrm{z}$ nicości i przyobleczona w ciało mocą artysty dorównującą potędze twórczej Boga. Miłosna kreacja wyrastała bezpośrednio z nurtu romantycznego i - jak pisze Wojciech Gutouski - łączyła się z energią imaginacji oraz spotęgowaną zdolnością tworzenia zindywidualizowanych sytuacji symbolicznych. Polegała na transformacji i interioryzacji: Ja w wyobraźni tworzy na nowo partnerkę, z którą się identyfikuje $^{104}$. Owa identyfikacja ,z-innym-w-sobie” służy procesowi androgynizacji. Dotykamy tutaj reinterpretacji mitu Arystofanesa, opowiadającego o rozpadzie pierwotnej jedności rodzaju ludzkiego na dwie połowy - męską i żeńską - które szukają się po śuiecie.

[...] tęskniłem za tą chwilą, kiedym Cię ze siebie wyłonił, kiedy kształty mego ducha układały się w linie Tuego ciała, drgania mych nerwów lały w Cię życie, kiedy stałaś się istotą mego ducha, jego treścią u ciało przeistoczoną (Rae 58)

- zapewnia bohater Requiem aeternam.

Powtórna jedność otworzyć ma przed mężczyzną nieznane głębie bytu, umożliwić wgląd w siebie (w „nagą duszę”) i w naturę świata. Kobieta spełnia zatem rolę narzędzia prowadzącego do metafizycznego poznania. Król z poematu Nad morzem tak zuraca się do ukochanej niewolnicy:

Ty, która mi rozrywasz pieczęcie wszelkich tajemnic i czytasz runy ukrytych sił, a po uszystkich szałach mego życia roztaczasz się tęczą łaski od jednego nieba do drugiego [...]. (Nm 285)

\section{O oczarowanym bohaterze Androgyne narrator mówi:}

Szedł z dumnie uzniesioną głową, szedł jak potężny wódz z cichym, śuiadomym suej potęgi tryumfem, bo przecież niósł słońce $\mathrm{w}$ swej piersi - niósł wszechświat: najtajniejsze zagadki i tajemnice bytu. (A 399)

Mężczyzna pragnie przy tym jedności z partnerką tylko wówczas, gdy jest w stanie całkouicie utożsamić ją z sobą samym (temat ten został szerzej omówiony w podrozdziale zatytułowanym Androgyne). Unia z istotą ukochaną możliwa jest jedynie dlatego, że osoba kochająca wykreowała ją, stworzyła z własnych marzeń, tchnęła w nią swego ducha. Szukanie imago odbywa się nie tyle w rzeczywistości, ile w wyobraźni. Nic więc dziwnego, że kobieta w tekstach Przybyszewskiego - a zułaszcza w poematach - jest raczej projekcją mężczyzny

\footnotetext{
104 Ibidem, s. 218.
} 
niż realną, zindywidualizowaną i obdarzoną świadomością postacią ${ }^{105}$. Potwierdzają to cytaty:

- Jak ja cię kocham, jasna, jedyna moja. Jesteś ziemią, pieśnią moją, jesteś uszystkim, co we mnie piękne i czyste i głębokie... (A 413)

Będę panią zausze kochał, bo muszę, bo pani jesteś moją duszą, moją głębią i śuiętością, bo pani jesteś właśnie tym we mnie, że Ja jestem Ja, a nie ktoś inny. (Hs I, 83)

Mężczyzna kocha kobietę, która otwiera mu drogę do podświadomości, która jest jego „zeksterioryzowaną duszą” ${ }^{106}$. Dlatego tak często męscy bohaterowie utworów odczuwają zuiązek ukochanych kobiet z ziemią rodzinną i sztuką, jako wartościami pierwotnymi, tkwiącymi w głębokich pokładach ich osobowości, jakby poza ich wolą:

Nagle zrozumiał. Z peunością tak było: Maryt a ziemia rodzinna to jedno.

A miała coś szerokiego, jakąś cichą, a smutną zadumę na suoim czole. Coś z tych ostrych pojedynczych kształtów płaszczyzny, którą tak bardzo ukochał. (Hs II, 39)

Kocham cię jako moją sztukę, kocham cię jako całą moją odwieczną przeszłość, kocham cię jako tchnienie mej ziemi rodzinnej, jako upojenie i zachuyt kościelnej zadumy [...]. (W 180)

Nie rozumiał całego zuiązku - zdawało mu się czasem, że ona - to jego ziemia w całej suej wiosennej tęsknocie [...]. (A 385)

W przypadku artysty problem ten jest bardziej skomplikowany. Otóż poprzez możliwy dzięki kobiecie - wyłącznie tej, u której mężczyzna rozpoznaje animę - kontakt z własną podśuiadomością artysta zyskuje moc kreacji. Sztuka bowiem rodzi się w głębokich pokładach psychiki. Identyfikacja „z-innym-w-sobie” pobudza możliwości twórcze. Dlatego Falk nazywa Izę „całą tajemnicą swojej sztuki”, a cierpiący na twórczą niemoc Bielecki marzy, że przy Ninie uda mu się napisać dzieło.

Imaginacja i kreacja z jej źródłami w podśuiadomości i pragnieniach erotycznych stały się przedmiotem teoretycznych rozważań Przybyszeuskiego we uspomnianym eseju o Oli Hanssonie.

I czemu kocham kobietę?

Każda linia, w którą jej ciało wciąż na nowo się obleka, teint jej tuarzy, tembr głosu, zapach, jaki jej ciało wysyła, to są linie, barwy i zapachy, które najgłębiej zrosły się z moim

${ }^{105}$ Refleksje na ten temat por. też. G. Matuszek, Melancholik, mistyk, narcystyczny kochanek, samotny homo dolorosus [ustęp], [w:] S. Przybyszeuski, Poematy proza, oprac. G. Matuszek, Kraków 2003, s. 29.

${ }^{106}$ Terminu tego użyła M. Podraza-Kuiatkouska w studium Somnambulicy - dekadenci - herosi, Kraków 1985. Posłużyła się nim także D. Samborska-Kukuć u szkicu Narcyz w masce tragicznej. Sobowtór jako eksterioryzacja duszy w opowiadaniu Leo Belmonta „Tamten człowiek”, „Pamiętnik Literacki” 2005, z. 3. 
najwewnętrzniejszym organicznym jestestwem, i w których moja istota znalazła najpotężniejszy wyraz. Kobieta, która potrafi potrącić te najdelikatniejsze i najtajniejsze struny mego istnienia, uślizguje się bez oporu do mego mózgu i kocham ją głębokim, nie stawiającym żadnych warunków uczuciem, jakim kocham mój kraj, co uformował moją duszę.

W kobiecie kocham siebie, moje do najuyższego stopnia spotęgowane Ja. [...] i kocham kobietę, która wywołuje we mnie tę koncentrację, kocham izotermę i izobarę moich najintensywniejszych i najgłębszych uczuć rozkoszy.

[...] kocham ją jako absolutne wyobrażenie tego uszystkiego, co daje mi najuyższe szczęście, jako wewnętrzne stopienie się tego, co jest we mnie najgłębsze i pełne najwyższej błogości ${ }^{107}$.

Rola ukochanej sprowadza się zatem do stymulowania kreatyunych zdolności artysty, a deklaracja „u kobiecie kocham siebie” jest - co oczywiste - wyrazem skrajnego narcyzmu. W swych poglądach Przybyszeuski nie był odosobniony. Poróunanie jego słów z teoriami Weiningera ujaunia daleko idące analogie:

W każdej miłości mężczyzna kocha tylko siebie samego [...], to, czym cały chce być i czym w zupełności być powinien: swoją najwewnętrzniejszą, najgłębszą istotą, wolną od przypadkowych strzępów konieczności i grud ziemskich. [...] Atoli tego jedynego celu, do którego dąży, nie ujrzy w jasnym blasku i w niezachwianej mocy na dnie własnej istoty i dlatego musi go sobie przedstawić poza sobą, aby tym łatwiej mu sprostać. Rzutuje on swój ideał istoty absolutnie cennej, którego nie może we własnym unętrzu wyodrębnić, na jakąś inną ludzką istotę; to właśnie, a nie co innego znaczy, że tę istotę kocha ${ }^{108}$.

Zacytowane pouyżej fragmenty zdają się mieć przy pobieżnej lekturze ten sam sens. Obaj autorzy interpretują miłość jako zjawisko projekcji i idealizacji. „U człowieka w ogóle sprawdza się pod uzględem psychologicznym: amo, ergo sum" - stuierdza Weininger, parafrazując słynną formułę Kartezjańską, i słowa te dałoby się odnieść także do koncepcji Przybyszewskiego. Ale wiedeńczyk dostrzega u miłości jeszcze jeden, niezbędny, acz niebezpieczny czynnik: zafałszowanie. Jego zdaniem mężczyzna poszukuje $w$ innej osobie tego, czym sam chciałby być - rzutuje swój ideał na kobietę, i to właśnie znaczy, że tę kobietę kocha ${ }^{109}$. Zatem kreuje nową partnerkę w miejsce rzeczywistej. Nie musi znać i rozumieć suej żony czy kochanki, a wręcz jest to niewskazane, oznacza bowiem przyjęcie jej wad i niedoskonałości, które zakłócają doskonałość obrazu. Miłość zdaniem Weiningera jest możliwa tylko wówczas, gdy pomija rzeczywiste cechy i pragnienia kobiety. „Dążenie do tego, żeby odnaleźć siebie w kobiecie - zamiast widzieć w niej właśnie

${ }^{107}$ S. Przybyszeuski, Z psychologii jednostki twórczej. II Ola Hansson, [w:] idem, Synagoga szatana i inne eseje, oprac. i tłum. G. Matuszek, Kraków 1995, s. 84-85.

${ }^{108}$ O. Weininger, Pteć $i$ charakter, przeł. O. Ortwin, Warszawa 1994, s. 121-122.

109 „Złożyć na jakąś jednostkę uszystko, czymby chciało się samemu być, a czym nigdy nie może się być u zupełności, uczynić z niej zbiór wszelkich wartości - to ułaśnie znaczy kochać" (Ibidem, s. 123) 
tylko kobietę - wymaga koniecznie pewnego niezważania na jej osobę empiryczną" - przyznaje ${ }^{110}$. Mężczyzna chce urzeczywistnienia ideału, iluzji. Kobieta ma się tylko dostosować, zaprzeczyć samej sobie, zrezygnować z samodzielnego życia wewnętrznego i społecznego, pozostać $w$ roli narzędzia - „przyrządu onanizacyjnego" ${ }^{111}$, rodzicielki potomstwa lub lustra, w którym partner się przegląda.

Weininger podobnie jak Przybyszeuski twierdzi, że mężczyzna jest stwórcą i w zuiązku z tym głęboko prawdziwe są przekazy kosmogoniczne, w tym z Księgi Rodzaju, ale owa kreacja sprowadza się według Ptci $i$ charakteru do przekazywania kobiecie męskich poglądów i potrzeb. Kobieta, jako istota pusta, pozbawiona świadomego istnienia, a zatem nieposiadająca wartości sama w sobie, zyskuje znaczenie jedynie poprzez kontakt z mężem lub kochankiem. To sympatia mężczyzny nadaje damskiej egzystencji sens. Co więcej - jak uważa Weininger - kobieta nie tylko łatwo poddaje się upływowi męskiemu, ale wręcz tego wpłyuu oczekuje i potrzebuje. Chce być traktowana jak rzecz, chce stać się cudzą własnością, chce należeć: do partnera lub do dziecka. To mężczyzna jest uyłącznym zuierzchnikiem i nawet tzw. zachowania dżentelmeńskie są $\mathrm{w}$ istocie poniżającym kobiety okazywaniem nierówności.

Inaczej u Przybyszeuskiego, choć uproszczona interpretacja pozwalałaby widzieć $w$ jego propozycji Narcyza próżnego, przeglądającego się w kochance, by delektować się ułasną uspaniałością. Tyle że Narcyz młodopolskiego pisarza, w przeciwieństuie do Owidiuszowego pierwowzoru, doskonale wie, że patrząc $w$ lustro (kobietę), widzi siebie. Co więcej, odbicie jest uzbogacone, otwiera nowe perspektywy, poszerza tożsamość. Bohater Przybyszewskiego przegląda się, by poznać - siebie i istotę bytu. Patrzy, bo dzięki temu „można wyjść poza powierzchnię zjawisk, dotrzeć do rzeczywistego świata idei" ${ }^{112}$. W przypadku postaci artystów, popularnych na przełomie XIX i XX wieku oraz chętnie wprowadzanych przez autora Śniegu na karty utworów, analogie do Narcyza są oczywiste. Twórca jest bouiem kimś z natury zapatrzonym w siebie, dostrzegającym cząstkę własnego ja w każdym suym dziele ${ }^{113}$.

W męskich wyobrażeniach kobieta ma szczytną powinność inspirowania partnera do rzeczy wielkich, ale w rzeczywistości nie pozwala na jedność totalną, oznaczającą całkowite zinterioryzowanie jej przez świat kochanka i dlatego drażni go swą innością. Paweł Dybel dostrzegł u takim stosunku do kobiet odkrytą przez Freuda, a następnie rozwijaną przez francuskiego psychoanalityka Jacques'a Lacana, koncepcję "stadium lustra”. Polega ona na identyfikowaniu się z własnym lustrzanym odbiciem lub z obrazem

\footnotetext{
110 Ibidem, s. 133.

111 Ibidem.

${ }^{112}$ M. Głowiński, Mity przebrane, Krakóu 1994, s. 72.

113 Zob. podrozdział Narcyz symboliczny u książce M. Głowińskiego Mity przebrane.
} 
osoby najbliższej. Wszystko, co zakłóca ,idealne Ja”, traktowane jest jako zagrożenie, na które reaguje się agresją. Dlatego bohater Requiem aeternam niszczy swe miłosne partnerki, chcąc uyzwolić własną męskość. Jego „martwa chuć" to odpowiednik agresji zuróconej przeciwko ukochanej i temu w niej, co uniemożliwia utopienie jej w świat jego wyobrażeń ${ }^{114}$. Przeszkodą w zjednoczeniu płci jest zatem obcość mężczyzny i kobiety.

Teorie Przybyszeuskiego mają swe źródło w Schopenhauerouskim pojmowaniu miłości jako metafizyki utrzymania gatunku.

Rozkoszne urojenie jest tym, co łudzi mężczyznę, że w ramionach kobiety znajdzie dzięki temu przyrzeczonemu mu pięknu rozkosz większą niż w tych każdego innego rodzaju [...]. Mniema przeto nie szczędzić trudu do suojej własnej rozkoszy i ofiary, podczas gdy dzieje się to uyłącznie dla zachowania prawidłowego typu gatunku $[. . .]^{115}$.

Mężczyzna dąży do absolutnej harmonii, unii dusz, tymczasem liczy się jedynie jako samiec. Do miłości popycha go instynkt, który zapeunia istnienie gatunku. Dopiero moment uygasania namiętności ukazuje mu, że był tylko narzędziem sterowanym prawami naturalnymi ${ }^{116}$. Jak pisze Gabriela Matuszek, akt seksualny jest chuilą najwyższej ekstazy, ale zarazem najdobitniej uświadamia mężczyźnie, że jest jedynie niewolnikiem płci, a tym samym uięźniem seksualności kobiety ${ }^{117}$. Tak mówi o tym bohater Requiem aeternam:

Była chuila, żem uczuł szczęście.

Wsłuchiwałem się $\mathrm{w}$ bolesne natężenie, z jakim się zbierały, łączyły i skupiały płciowe pieruiastki w mej duszy, z rozkoszą czułem, jak się poprzez ciało moje przeuinęły zimne dreszcze [...] ale naraz ułożyło się Twe ciało w pospolitą, bezustydną linię i $w$ jednej chwili załamało się uszystko we mnie [...].

A tyś leżała, żebrałaś Twą żądzą - milcząca, z zawartymi powiekami.

$[\ldots]$

Biedne dziecko. Tue łono matczyne Cię oszukało - innego męża trzeba ci było odnaleźć, instynkty Twe płciowe ku innemu zurócić. (Rae 60-61)

Poczucie upokorzenia przeradza się $w$ niechęć lub nawet nienawiść do tej, która topi mężczyznę $w$ bagnie pożądania i degradujących ducha przyziemnych rozkoszy, sprowadzając go do roli reproduktora („Kobieta rodzi, a mężczyzna kocha. Kobieta nie kocha nigdy, nigdy; jej wystarcza rodzenie" - Hs I, 154). Najboleśniej swoją płciowość przeżywa bohater Requiem

${ }^{114}$ Zob. P. Dybel, Urwane ścieżki. Przybyszewski - Freud - Lacan, Kraków 2000, s. 76-83.

${ }^{115}$ A. Schopenhauer, Metafizyka miłości ptciowej, przeł. A. Pańta, Gdańsk 1995, s. 127.

${ }^{116}$ Zob. K. Wyka, op. cit., s. 90.

${ }^{117}$ G. Matuszek, Między pustka transcendencji a szaleństwem zmystów. O wczesnej eseistyce Stanisława Przybyszewskiego [ustęp], [w:] S. Przybyszeuski, Synagoga szatana..., s. 25. 
aeternam. Wyraża się to oczywiście w jego stosunku do partnerek. Kobietę, która go fascynuje, najpierw narcystycznie uwielbia, poszukując androgynicznego przymierza, a zaraz potem znęca się nad nią. Nie można zapomnieć, że pogardę dla materii płciouych zaszczepiła mu matka, dla której małżeństwo z chłopem oznaczało zdewaluowanie wysokiego statusu arystokratki. Odczuwając każdy kontakt seksualny z mężem jako poniżenie, skalanie jej ciała i duszy, w akcie obrony zaczęła uypierać to, co cielesne, a więc własną kobiecość. Opowieść o poczęciu skażonym brakiem miłości i przymusem bohater przekazuje z perspektywy matki, bierze jej stronę i utożsamia się $\mathrm{z}$ nią. Jego zachowanie nosi znamiona zaburzeń $\mathrm{u}$ kształtowaniu męskiej tożsamości. Aby stać się mężczyzną, powinien bowiem odciąć się od rodzicielki, stanowiącej naturalny, pieruszy obiekt identyfikacji ${ }^{118}$. Procedurę negacji i zerwanie symbiozy z matką w celu zdobycia aprobowanej społecznie tożsamości utrudnia mu jednak brak pozytyunego uzorca męskiego, bliskiego zuiązku z ojcem. Co więcej - bohater dziedziczy po matce ustręt do płciowości, „martwą chuć”. Poczucie niespełnienia i bliżej niesprecyzowaną, ale niemożliwą do ukojenia tęsknotę rekompensuje sobie erotycznymi fantazjami - od wizji harmonijnego spoczywania w ramionach ukochanej, przez obrazy narastającego pożądania, po scenę kąsania leżącego na katafalku kobiecego trupa i podlegania kuszeniu przez wyłaniającą się z nieba „apokaliptyczną nierządnicę" (Rae 91). Owe uykreowane u uyobraźni ekstatyczne sytuacje odsłaniają silny lęk bohatera przed płciowością jako sferą, w której kobieta zawłaszcza mężczyznę. W ten oto sposób identyfikacja z rodzicielką rzutuje na jego stosunek do kobiecości w ogóle ${ }^{119}$. Przywołane przezeń we uspomnieniu i wyobraźni sceny z dzieciństwa Paweł Dybel zinterpretował jako wyraz tego, co Freud nazwał „kompleksem Edypa”. Według badacza, uczuć kazirodczych tkwiących w narratorze-bohaterze dowodzi subtelność, z jaką kreśli on postać matki, oraz urogość wobec ojca na podłożu rywalizacji ${ }^{120}$. Dla mężczyzny noszącego w sobie konflikt edypalny seks zausze pozostaje czymś niedozwolonym i przerażającym, ponieważ postrzegany jest jako czynność degradująca, kalająca i ciało, i duszę. Człowiek cierpiący na takie zaburzenia płciowe, żeby doznać erotycznej ulgi, musi poniżyć swój obiekt seksualny i to wyjaśnia agresję kierowaną w poemacie Przybyszewskiego przeciuko miłosnym partnerkom.

Bohater Requiem aeternam, podobnie jak później Falk, jest typem naznaczonym przekleństwem analizy. Sprzeczne uczucia i pragnienia pozwalają widzieć w nim naturę skłonną do schizofrenii, a przekonanie o kryzysie

${ }^{118}$ Kolejne etapy kształtowania męskiej tożsamości to w psychologii: odłączenie od matki, radykalne odróżnienie od płci przeciunej, unikanie kontaktóu fizycznych z osobą tej samej płci. Zob. E. Badinter, Tożsamość mężczyzny, tłum. G. Przewłocki, Warszawa 1993.

${ }^{119}$ Zob. interesujące uwagi P. Dybla u książce Urwane ścieżki, s. 125-130.

${ }^{120}$ Ibidem. 
poznania i uszelkich wartości sytuuje go w gronie dekadentów ${ }^{121}$. Cały świat jawi mu się jako wielka ambiwalencja, tygiel wykluczających się teorii:

A jeżeli Bóg rzeczywiście istnieje? Jeżeli dusza rzeczywiście nieśmiertelna, a u jednym kościele katolickim można naprawdę osiągnąć zbawienie?

Ale brak mi wiary, wiary, wiary.

Wiara w Charcota i w boskie dopuszczenie przy opętaniu.

Wiara u Kant-Laplace i Daruina, a róunocześnie w stworzenie świata w siedmiu dniach.

Wiara u bóstwo Chrystusa i w bluźnierstwa Straussa lub Renana.

Wiara w Niepokalane Poczęcie Marii Panny i w najpierwotniejsze fakta embriologii.

Nie! to się nie da połączyć! (Rae 79-80)

Samotność, poczucie niepełności i pragnienie poznania są tym, co pociąga mężczyzn ku płci przeciunej; stąd wynika opisywany przez Przybyszeuskiego ideał androgyne. Bolesna świadomość, że ukochana nie odpowiada całkowicie wyobrażeniom, staje się natomiast powodem cierpienia i oskarżania jej o działania na szkodę rodu męskiego. Bohaterowie Przybyszeuskiego nie są szczęśliui zaróuno bez kobiety, jak i z nią, ponieważ są ofiarami nakładających się na siebie dwóch (spośród trzech wyróżnionych przez Wojciecha Gutouskiego ${ }^{122}$ ) sprzecznych uzorów miłości - mitu chuci oraz mitu androgyne. To rozpięcie oznacza jednocześnie balansowanie między profanum i sacrum, przy czym obecność sacrum - paradoksalnie - zakłóca reguły życia codziennego podporządkowanego dyktatowi natury. Konflikt ten uzyskuje szczególne natężenie w poematach, gdzie pobudza żywioł wizyjności, stanowiący o oryginalności koncepcji Przybyszewskiego.

\section{Kobieta}

Uwaga i zainteresowania psychologiczne Przybyszeuskiego skupiają się przede uszystkim na mężczyznach pozostających pod upływem kobiet. Dlatego wszystko, co w utworach pisarza zostało powiedziane o kobiecie, nosi piętno spojrzenia postaci męskiej. Trzecioosobowy narrator nie podaje informacji o bohaterkach, ponieważ kobiety istnieją niemal wyłącznie jako obiekty pragnień czy pożądań, ich indywidualność nie ma większego znaczenia. Są to zawsze postaci drugoplanowe, ukazane poprzez pryzmat świadomości bohate-

${ }^{121}$ Dekadentów, jako typów przekonanych o upadku wszelkich wartości i naznaczonych atrofią woli, wbrew obiegowym opiniom nie ma u Przybyszewskiego wielu. Poza bohaterem Requiem aeternam (i to z peunymi zastrzeżeniami) można zaliczyć do nich Kazimierza ze Śniegu.

${ }^{122}$ Zob. W. Gutouski, Nagie dusze i maski. O wzorach tych była mowa na s. 14 niniejszej książki. 
ra - jego uspomnień, analiz i wizji. Znikoma ilość elementów realistycznych powoduje, że rysowane grubą kreską portrety służą głóunie zobrazowaniu ogólnego poglądu pisarza na kobiety i ich rolę w doświadczeniu erotycznym ${ }^{123}$. Ujęcia postaci żeńskich oscylują przy tym pomiędzy idealizacją, uwzniośleniem, zuiązanym z pragnieniem androgynicznego zjednoczenia, a deprecjacją, uydobywaniem na jaw ich popędów czy dążeń destrukcyjnych.

Gloryfikacja kobiecości towarzyszy u Przybyszeuskiego na ogół pieruszemu spotkaniu płci, wzajemnej fascynacji, która inicjuje związek. Zachwyt partnerką opiera się przy tym nie na jej walorach (fizycznych bądź duchouych), lecz jest pochodną nieuchwytnej atmosfery, jaką wokół siebie roztacza.

Pomnę: było to, jak gdyby listki z róży opadały, gdy ją wiatr muśnie - było, jak gdyby ciche perły deszczu jesiennego w ciemnej nocy łkały - było, jak gdyby się cała wieczność głębokim westchnieniem po niebie prześlizgła (Nm 291-292)

- tak, niemal na zasadzie synestezji, król z poematu Nad morzem wspomina przybycie dziewicy z krainy cienia.

Kobieta, w której bohater dostrzega swoje alter ego i w której chciałby widzieć odbicie własnej duszy u dążeniu do androgynicznej jedności, jawi się jako zwiewna i eteryczna jak na obrazach prerafaelitów. Jest drobna, delikatna, ustydliwa. Porusza się bezszelestnie, jakby unosiła się w powietrzu zamiast stąpać po ziemi. Wokół niej roztacza się blask boskiego pochodzenia. Obdarouuje mężczyznę subtelną pieszczotą, gładząc swą wąską ciepłą dłonią jego dłoń bądź - w wersji metaforycznej - jego serce. Podmiot liryczny $Z$ cyklu Wigilii u modlitewny sposób błaga kochankę:

- Przyjdź, jasna, przyjdź, połóż tue białe, miękkie ręce na mym sercu! Patrz, jestem chory i samotny, potrzebuję ciepła i miłości, przyjdź, jasna, weź u twe dobre, ciche dłonie me serce. $(\mathrm{W} 174)^{124}$

Kobieta w takim ujęciu obdarzona zostaje epitetami: „,jasna”, „Czysta”, „święta” i uyróżniona funkcją pobudzania męskich mocy kreacyjnych i intelektualych (bohater $Z$ cyklu Wigilii ceni uybraną, ponieważ ona wzbudziła w nim cierpienie i tęsknotę, które potęgują chęć poznania). Przekonanie, że wybranka potrafi wypełnić rolę pocieszycielki i sprowadzić tajemniczą

${ }^{123}$ Zob. B. Wojnouska, „Nad morzem” Stanisława Przybyszewskiego. Mistyka i płeć, [w:] Stanisław Przybyszewski. W 50-lecie..., s. 110-111.

${ }^{124}$ Podobny rodzaj anafory zastosował Stanisław Korab-Brzozouski w znanym wierszu O, przyjdź!, w którym podmiot liryczny przyzywa śmierć. Utwór Brzozouskiego został opublikowany u „Życiu” w 1898 r., dwa numery później niż poemat Przybyszewskiego. Inny przykład: „Jakby jakaś ciepła, drobna ręka chwyciła jego, nie - nie chwyciła - wtuliła, wcałowała się pieszczącymi palcami w jego dłoń” (A 378). 
łaskę, sugeruje jej przynależność do sfery sacrum. Król z poematu Nad morzem mówi o swej ukochanej: „po wszystkich szałach mego życia roztaczasz się tęczą łaski” (Nm 285), bohater Androgyne marzy, że „spłynie na niego niewidzialną łaską ciszy i ukojenia, rozleje się $\mathrm{w}$ nim zapomnieniem i duszę mu w ciche rozkosze białych snów rozśpiewa" (A 417). Pobrzmiewają tu echa nauk sanskryckich, które widzą w kobiecie czynnik ułatwiający poszukiwanie doskonałości, pełni i uyzuolenia z doczesności, a więc kierujący na ścieżkę prowadzącą do Boga (problem ten zostanie rozwinięty w podrozdziale następnym).

Niewinność kochanki wyraża się w niezuykle częstym u Przybyszewskiego porównywaniu jej do dziecka, upisującym się w popularny w epoce obraz femme fragile ${ }^{125}$ :

...Bo byłaś piękną i czystą i jasną, jak dusza dziecka, w której się święta ofiara chrztu dopełniła. (Nm 288)

Pieścił, tulił, całował, szeptał bezustannie, bezwiednie te same słowa, poutarzał te same zdania, kołysał ją i kołysał tak jak się roztkliwione dziecko kołysze w suych ramionach. (A 423)

Chryste Panie, jakie cudoune to dziecko! (Hs II, 15) - myśli Falk o Maryt.

Lidia Wiśnieuska uważa, że taki typ relacji dowodzi przekonania o niższości i infantylności kobiet, które - jak dzieci - pochodzą od mężczyzny, „dawcy żebra". Powielona tu zostaje hierarchia Boga i stworzenia. Jest to, według badaczki, jeszcze jedno oblicze Narcyza, kochającego w dziecku siebie ${ }^{126}$. Podobnie unioskuje Kralkouska-Gątkouska, pisząc o XIX-wiecznej prozie: „Kobieta ze uzględu na suój status osobnika zdefektowanego nie osiąga nigdy prawdziwej dojrzałości. Świat dorosłości jest światem mężczyzn” ${ }^{127}$.

Kobietą, której rola sprowadza się niemal wyłącznie do opiekowania się mężczyzną, jest Bronka. Przypomina ona tytułowy śnieg, chroniący oziminę przed mrozem do momentu nadejścia wiosny, dopóki „budzić się nie pocznie i z ciepłego już łona, z ziarn [...], nowe, świeże kiełki puszczać pocznie” (Ś 114). Tadeusz szuka w niej „cech letejskich, odpoczynku, destrukcji pamięci i woli”"128, wyzwolenia od dekadenckiej nudy oraz od nieokreślonej tęsknoty i męki, uleczenia serca szarpanego przez Ewę. Ale Bronka oczekuje

${ }^{125}$ Na pouiązanie bohaterek Przybyszeuskiego z charakterystycznym dla epoki motywem femme fragile zuróciła mi uwagę prof. Gabriela Matuszek.

${ }^{126}$ L. Wiśnieuska, Kobiety w literaturze (i mężczyźni), [u:] Kobiety w literaturze, oprac. L. Wiśnieuska, Bydgoszcz 1999, s. 12, 15.

${ }^{127}$ K. Kralkowska-Gątkouska, Matki, córki, mentorzy. O dyskursie edukacyjnym i emancypacyjnym w prozie XIX wieku, [w:] Przez dwa stulecia. In memoriam Artur Hutnikiewicz, Toruń 2006, s. 63.

${ }^{128}$ W. Gutouski, Pod ciężarem Ewy: totalność - obojętność - nicość, [w:] Kobiety w literaturze, s. 134. 
szczerej miłości, nie chce być jedynie „niemą poduszką pod [...] skołataną głowę" (Ś 96). Choć to ostatecznie Ewa popycha Tadeusza do zguby, namawiając go do porzucenia życia rodzinnego i oddania się aktom twórczym przesyconym tęsknotą i lękiem, to Bronka również dąży do unicestwienia - wizja stauu, u którym utonęła niegdyś jej siostra, jest zbyt silna, by miała się nie poutórzyć. Na tej podstawie Wojciech Gutouski stuierdza, że swojskie domostwo jest iluzją, zaś mężczyźni nie mają szans ucieczki przed kobietą i jej negatywnym działaniem ${ }^{129}$.

Niemożność podporządkowania kobiety, zdegradowania jej do realizatorki męskich potrzeb, przede uszystkim marzeń o Dwój-Jedni, wywoływała - jako efekt rozczarowania - wizje i zachowania gynofobiczne. Apoteoza - we wszystkich poematach prozą, a także w wielu fragmentach powieściouych i dramatycznych - nagle i sugestywnie przechodzi w lęk i nienawiść, których źródłem jest kobieca seksualność podległa prawom gatunku i niskim doznaniom zmysłowym, nie zaś rozwijaniu duchowości. Wzbudzające pożądanie ciało partnerki, u którym mężczyzna chciałby widzieć drogę „unieboustąpienia”, powrotu do prabytu, Absolutu, oznaczającego harmonijną egzystencję i kompleksowe poznanie, okazuje się narzędziem degradującym do poziomu popędów, do fizyczności ${ }^{130}$. Przybyszeuski reprezentuje ten typ mizoginii intelektualnej czy egzystencjalnej, w której kobietę obuinia się o klęskę męskich ideałów. Nie powtarzając dalszych uniosków z podrozdziałów Mężczyzna oraz Androgyne, wypada stwierdzić, że obawa przed pochłaniającym erotyzmem wyrażała się u twórczości autora Śniegu hiperbolizacją jego roli w życiu kobiety. Owa hiperbolizacja jest zasadniczym rysem mizoginizmu w wydaniu młodopolskiego pisarza, żywo zainteresowanego dziełami innych artystów uznawanych za sztandarouych mizoginistów epoki (Ropsa, Vigelanda, Muncha, Strindberga, Wedekinda), którzy niechęć do przedstawicielek płci pięknej łączyli z niezgodą na biologiczne zdeterminowanie i uzależnienie od partnerek, dostarczających mężczyznom najuyższych rozkoszy. Przybyszeuski demonizował kobiecą seksualność jako siłę bezczeszczącą duszę mężczyzny niezdolnego do opierania się pożądaniu partnerki ${ }^{131}$. Pod upływem myśli Schopenhauera, pokazującego czło-

${ }^{129}$ Ibidem, s. 135-136.

${ }^{130}$ Zgodnie z buddyzmem, im silniejszy popęd, tym niższa pozycja na skali duchowego postępu i stąd kobiety - ze uzględu na rzekomo silniejsze libido - uważane są za istoty duchowo niższe od mężczyzn. Przed kobiecą seksualnością przestrzegał „Tygodnik Ilustrowany”: „Pamiętajmy, że kobieta posiada bez poróunania uięcej płciowości od nas; są takie, które są nią przepełnione, ona się z nich przelewa, ona właściwie jest siłą nieobliczalną, niepewną nawet u mężczyźnie, kiedy jej podlega, a cóż dopiero u kobiecie, która jej podlega całe życie” (B. Lutomski, Kobieta i kobiecość, „Tygodnik Ilustrowany” 1901, nr 38, s. 738).

${ }^{131}$ Zob. G. Matuszek, Między pustka transcendencji..., s. 20, 24. Warto zaznaczyć, że obawa przed seksualnością kobiety nie oznacza u Przybyszeuskiego odrazy do żeńskich genitaliów oraz do krui menstruacyjnej, jak miało to miejsce w wielu plemionach pierwotnych, choć już 
wieka, przede wszystkim zaś kobietę, jako istotę działającą uyłącznie dla zachowania gatunku, krótkotrwałą ekstazę uznał za złudne szczęście, pod którym natura-chuć ukrywa swe prokreacyjne cele. Obawę przed seksualnością kobiety potęgowała róunież filozofia Nietzschego, a jej wyrazem stało się dosadne pytanie: „Czyż nie lepiej upaść w ręce zbrodniarza, niźli u marzenia chutliwej kobiety!" ${ }^{132}$. (W książce Poza dobrem $i$ złem oraz esejach Ludzkie, arcyludzkie czy Ecce homo Nietzsche zamieszcza obszerne dygresje o słabości, płytkości, amoralizmie i głupocie kobiet). Cielesną, a więc ciemną stronę kobiecości eksponowały także sprzyjające zachowaniom mizoginicznym publikacje naukowe, jak Kobieta jako zbrodniarka i prostytutka (1893, wyd. pol. 1895) autorskiego duetu Lombroso-Ferrero, $O$ umystowym i moralnym niedorozwoju kobiety (1900, wyd. pol. 1937) Möbiusa i von Rosen, O fizjologicznej tępocie kobiety Paula J. Möbiusa (1904), Zboczenia umysłowe na tle zaburzeń ptciowych. Psychopatia sexualis (1886, wyd. pol. 1908) Krafft-Ebinga ${ }^{133}$ czy ureszcie polskie Zwyrodnienie kobiety wspótczesnej Maksa Wolffa (Warszawa 1896).

Wiele pokrewieństua z poglądami Schopenhauera i Nietzschego uykazują teorie Weiningera. Zasadnicza myśl Ptci i charakteru sprowadza się do konstatacji, że egzystencją kobiet kierują wyłącznie pragnienia seksualne.

Tylko strona seksualna mężczyzny - nigdy aseksualna, transseksualna - działa na kobietę, i nie piękności, ale pełnego seksualnego pożądania pragnie ona od niego. [...] robi na niej wrażenie [...] tylko to, co ma on u sobie $\mathrm{z}$ fauna. Żadna książka o rzeczywistej kobiecie nie może zmilczeć, że liczy się dla niej nie mężczyzna, ale zausze le mâle (samiec) - jego seksualność $\mathrm{w}$ ściślejszym znaczeniu, phallus ${ }^{134}$.

Na kanuie pouyższego przekonania wiedeński myśliciel dzieli przedstawicielki płci żeńskiej na matki i prostytutki, a różnicę między nimi widzi u tym, że dla pieruszej chuć jest środkiem do celu, dla drugiej - celem samym u sobie. Zachowanie nierządnicy pozwala mu przy tym obalić pogląd

tam biologiczne cykle sugerouały sprzymierzenie kobiet z mroczną stroną natury. Pisarz nie potępia też seksu jako grzechu, co - nie stroniąc od paradoksu - uczynił Tołstoj w Sonacie Kreutzerowskiej (1889).

${ }^{132}$ F. Nietzche, Tako rzecze..., s. 61. Źródłem mizoginizmu była głóunie filozofia (zułaszcza Schopenhauera i Nietzschego; szerzej w I cz. pracy) oraz ruch emancypacyjny, oznaczający dla mężczyzn konkurencję i zagrażający ich przeuadze. Charakterystyczne, że demoniczne przedstawienie kobiet dominowało tam, gdzie ich działania były najsilniejsze - a więc w krajach skandynawskich.

${ }^{133}$ Krafft-Ebing pisał: „Nader często chorobliwie wzmożony popęd płciouy »usposobione ku temu dzieuczęta zmienia u Messaliny. Pożądliwość często ujawnia się w kokieterii, wyzywającym stroju, albo nawet $w$ gonieniu za mężczyznami, przekraczającym granice przyzuoitości i dobrego smaku" (R. Krafft-Ebing, Zboczenia umystowe na tle zaburzeń ptciowych. Psychopatia sexualis, tłum. A. Fabian, Warszawa 1908, s. 210).

${ }^{134}$ O. Weininger, op. cit., s. 140. 
Schopenhauera, jakoby we uszelkiej seksualności chodziło tylko o wytworzenie przyszłych pokoleń.

Obie ułaściuie nie mają żądnych żądań co do indywidualności suego płciowego dopełnienia. Pierusza bierze każdego bez uyboru mężczyznę, który jej posłuży do otrzymania dziecka; i nie potrzebuje żadnego innego, kiedy dziecko dostanie [...]. Druga oddaje się dowolnemu mężczyźnie, który jej może posłużyć do erotycznego używania: jest ono dla niej celem samym $\mathrm{w}$ sobie ${ }^{135}$.

Nietzsche sprowadza psychologię kobiety do jednego zagadnienia:

Wszystko w kobiecie jest zagadką i uszystko w kobiecie ma jedno rozuiązanie: zuie się ono brzemiennością.

Mężczyzna jest dla kobiety tylko środkiem: celem jest zausze dziecko ${ }^{136}$.

O bohaterkach-matkach mówi się u Przybyszewskiego co najmniej lekceważąco, jeśli nie pogardliwie (z zastrzeżeniem, że pisarza nie interesują kreacje matek-Polek, częste w Młodej Polsce, lecz towarzyszące na ogół fabule osnutej na tle wydarzeń narodowych). W wypowiedziach uyraża się przekonanie, że kobieta nigdy nie dojrzeje do misji, jaką wyznaczył jej mężczyzna. Ruszczyc móui do Rembouskiego: „[...] my za dużo od kobiet żądamy, my chcemy z niej zrobić kochankę, a ona tylk o jest matką - matką...” (Zr 269; podkr. K.B.). Kobieta postawiona $w$ trudnej sytuacji uyboru rezygnuje na rzecz dziecka z innych wartości. Matka przezuycięża kochankę w Godach życia: bohaterka dramatu, Hanka, porzuciuszy męża i małą córeczkę dla miłości u boku Wacława, po kilku latach - kierowana rozbudzonym instynktem macierzyńskim - usiłuje odzyskać utracone prawa rodzicielskie.

Kobiety lekkich obyczajów, wbrew obiegowym opiniom, z rzadka goszczą na kartach utworów Przybyszeuskiego. Ich profesja też nie uynika - jak chciał Weininger - z nimfomanii czy upodobania u rozpuście. Prostytutki wykreowane przez młodopolskiego autora nie czerpią z nierządu ani korzyści seksualnych, ani materialnych, jak było to na przykład u Zoli. Są produktem metafizycznej nędzy, „dziećmi szatana”, jak biedacy, zbrodniarze i anarchiści. Daleko im do ekskluzywnych pań do towarzystwa czy utrzymanek bogatych mężczyzn. Zamiast przebierać w kochankach, muszą ich szukać na ulicach i po kawiarniach. Prostytucja jest nieszczęściem, uwarunkowanym przesycającym świat złem i cierpieniem. Doskonale potwierdza to kreacja Salomei Krywło, która wkracza na drogę nierządu z powodu wydziedziczenia przez ojca o wybujałym temperamencie erotycznym, a prowokacyjnym zachowaniem usiłuje sobie radzić ze społecznym odrzuceniem (Dzieci nędzy).

\footnotetext{
135 Ibidem, s. 79.

${ }^{136}$ F. Nietzsche, Tako rzecze..., s. 75-76.
} 
Matki i nierządnice pojawiają się u Przybyszeuskiego marginalnie. Uwikłań kobiecości w ograniczenia płci dowodzą inne kreacje bohaterek.

Seks sprowadzony do procesów biologicznych degradował i upokarzał młodopolskiego mężczyznę, pozwalając na hegemonię kobiety uznanej za medium natury - wyzwolone, niezależne, powabne i zagrażające światu kultury utożsamionemu ze światem męskim ${ }^{137}$. Gynofobię uspartą na lęku przed kobiecą seksualnością - pociągającą, lecz sprowadzoną wyłącznie do zaspokajania popędów - Przybyszeuski wzmocnił dodatkowo przypisaniem płci pięknej uszelkich działań destrukcyjnych. Obawę przed pożądliwością przetransponował na poglądy deprecjonujące osobowość kobiety i kwestionujące jej duchową głębię ${ }^{138}$. Łącząc zaś w kreacjach suych bohaterek perwersję i instynkty zła, w rzeczywistości obdarzył istotę kobiecości cechami średniowiecznej czarownicy. Można u tym zabiegu odnaleźć sugestię, że czarounica jako postać historyczna jest kluczem do rozpoznania wiecznej natury kobiety ${ }^{139}$. Na drogę kultu diabła miała ją sprowadzać potrzeba „długotruałej orgii płciowej” ${ }^{140}$, i w ten oto sposób nimfomania przypisana została kobiecości w ogóle ${ }^{141}$.

Poparcie dla mizoginistycznych poglądów pisarz znalazł w niechęci średniouiecznego Kościoła do kobiet. Tertulian jako pieruszy teolog zobaczył w kobiecie bramę dla diabła. Św. Augustyn stawiał cielesność kobiety w opozycji do świata ducha - czystego i męskiego. Św. Tomasz tuierdził, że kobieta jest mniej doskonała od mężczyzny, a więc powinna mu być absolutnie posłuszna ${ }^{142}$. Poza chrześcijaństuem kobietę potępiały za jej cielesność muzułmański Koran i hebrajska Tora, a także pisma buddyjskie i hinduskie. Wszystkie wielkie religie piętnowały ją za lubieżność i deprawację, na którą podatni są mężczyźni, oraz za popełnienie grzechu pierworodnego lub jego

${ }^{137}$ W. Gutouski, Nagie dusze..., s. 59.

${ }^{138}$ Interesujące, że w scenach będących przejauem mizoginizmu bohateróu Przybyszeuski nie powołuje się na ograniczenia umysłowe kobiety, choć w tym samym czasie antropologiczne i socjologiczne teorie, m.in. Herberta Spencera, a nawet Charlesa Darwina, usiłowały dowieść, że kobieta zatrzymała się na niższym szczeblu ewolucji niż mężczyzna. Także Émile Durkheim uskazyuał na różnice $\mathrm{w}$ wielkości czaszki, a więc i poziomie inteligencji, uypadającym naturalnie na korzyść mężczyzn. Sąd o niższości intelektualnej kobiet nie jest uyrażony u Przybyszewskiego expessis verbis, jednak znaczące jest, że kobiety nie biorą udziału w dyskusjach ideowych i nie mają ambicji oraz talentów artystycznych, jakimi mogą się pochwalić ich towarzysze.

${ }^{139}$ Zob. D. Dziurzyński, Strategie mizoginistyczne Stanisława Przybyszewskiego na podstawie „Synagogi szatana”, [w:] Wiek kobiet w literaturze, red. J. Zacharska i M. Kochanouski, Białystok 2002, s. 190.

${ }^{140}$ S. Przybyszewski, Synagoga Szatana. Przyczynek do psychologii czarownicy, Warszawa 1902, s. 21.

${ }^{141}$ Problematyka kobiet-czarownic oraz ich związków erotycznych z ludźmi i szatanem wymaga odrębnego opracowania w zuiązku z interesującym Przybyszeuskiego satanizmem. Zagadnienie to nie mieści się w ramach niniejszego opracowania, skupiającego się na analizie tradycyjnych relacji uczuciouych i erotycznych.

${ }_{142}$ Zob. G. Matuszek, Między pustka transcendencji..., s. 23. 
teologicznego ekwiwalentu ${ }^{143}$. Te argumenty powtarza w Złotym runie Ruszczyc $\mathrm{w}$ rozmowie z Rembouskim:

[...] kobieta - wiesz, to inny rodzaj człowieka - my mężczyźni jej psychologii nie znamy - zupełnie nie - my się ustawicznie mylimy, bo sądzimy kobiety na podstawie naszej psychologii - ha, ha, ha - ten stary Adam w mężczyźnie zawsze głupi, och, jak on głupi... [...] Kobieta jest urodzoną zbrodniarką... Ojcowie Kościoła to wiedzieli... Tertulian nazuał ją urotami piekła [...]. Św. Anzelm mówi, że jest łaźnią szatańską, w której diabeł dusze mężczyzn kąpie [...]. (Zr 212-213)

Śladem mizoginów-poprzedników ogromny upływ na mężczyznę bohaterouie Przybyszeuskiego tłumaczą kontaktami kobiet z siłami nieczystymi, w tym z samym Szatanem. Pretekstu dostarczała postać Lilith ${ }^{144}$, matki i władczyni żeńskich demonów, pieruszej malefica, od której ma pochodzić ród kobiecy. Według Talmudu była pieruszą żoną Adama. Odmóuiła mu skonsumowania związku (nie chciała kłaść się pod mężem, jako że oboje zostali stworzeni z prochu i byli sobie róuni) i odleciała do bandy demonów, z którymi cudzołożyła. Drugim mężem Lilith miał być szatan Samael, z którym płodziła demony. W literaturze uystępowała jako postać buntownicza, broniąca suych praw do wolności i rozkoszy, femme fatale przynosząca zgubę. Szatan kierował również drugą żoną Adama, Ewą. Za jego namową zerwała owoc z drzewa wiadomości dobrego i złego i poczęstowała nim mężczyznę. Tradycja biblijna i talmudyczna upoważnia więc niejako do sądów w rodzaju:

[Szatan] Kocha kobietę, tę wieczną zasadę zła, sprawczynię uszelkich przestępstw, oduieczny zaczyn $\mathrm{zła}^{145}$.

[...] miłość to stryczek, na którym szatan dusze mężczyzn do piekła wlecze... (Zr 213)

Ukryty w kobiecie mroczny aspekt natury oraz moc niszczenia mężczyzn wyrażały poza Lilith i Ewą (tradycja judejska), a jeszcze przed zjawiskiem „kultu czarownic”, znane z przekazów religijnych, mitycznych, legendarnych i historycznych takie demony żeńskie, jak Astarte (Fenicja), bogini Kali (Indie), kobieta-wąż (Japonia), vagina dentata (Indianie Ameryki Północnej), Kirke, harpie, syreny, Chimera, Sfinks (Grecja) ${ }^{146}$. Na nowo zreinterpretowane, uplecione w obręb refleksji filozoficznej, postacie te zaczęły być wykorzystywane $\mathrm{w}$ argumentacji $\mathrm{w}$ sporach ideowych. Dekadentyzm sięgał

${ }^{143}$ Zob. D. Gilmore, Mizoginia, czyli męska choroba, tłum. J. Margański, Kraków 2003, s. $15-16$.

${ }_{144}$ Pisała o niej A. Tytkouska, Lilith: polskie dziedzictwo hebrajskiego mitu, [w:] Mity, mitologie, mityzacje nie tylko w literaturze, red. L. Wiśnieuska, Bydgoszcz 2005, s. 109-118.

${ }^{145}$ S. Przybyszewski, Synagoga Szatana. Powstanie, rozwój i dzisiejsze znaczenie, [w:] idem, Synagoga szatana..., s. 192.

${ }^{146}$ Zob. W. Gutouski, Nagie dusze..., s. 59. 
z upodobaniem po bohaterki grzeszne (przede uszystkim biblijne), których życie i działanie potwierdzałoby brud rzeczywistości oraz kryzys wartości. Te kobiece symbole destrukcji - nadużywane $w$ literaturze modernistycznej aż do zbanalizowania - są przywoływane u uyobraźni róunież przez bohaterów dzieł Przybyszewskiego. Poza kreowaniem nastroju spełniają one najczęściej rolę deprecjonujących porównań, narzucających się myślom rozczarowanych partnerkami mężczyzn. Symptomatyczne, że pisarz sprowadził starożytne kulty kobiece wyłącznie do wymiaru niszczenia, satanizując je i eliminując witalizm oraz radość życia, jaką nierzadko ze sobą niosły ${ }^{147}$.

Narrator Requiem aeternam, szamoczący się w okowach odziedziczonej po matce „martuej chuci” i nie mogący uporać się z własną seksualnością, widzi w kobiecie twór hybrydyczny: „szatańską Lilith z głową Sfinksa” oraz „bujną grzywą włosów” (Rae 80), nasuwającą skojarzenia z Gorgoną (mitologia grecka), straszliwą istotą z wężami zamiast ułosów i o zabójczym spojrzeniu; tak przerażającą, że jej wizerunek umieszczony na tarczach, zbrojach i herbach miast miał odstraszyć nieprzyjaciół. „[...] spętałaś mnie ciężkimi zwojami Twoich włosów [...]" - monologuje (Rae 80) (48. $^{14}$.

Bohater $Z$ cyklu Wigilii dopiero zdradzony przez ukochaną dostrzega, że w jego podświadomości od dawna kryła się prawda o kobiecej naturze, którą - jeszcze nieświadomie, dzięki procesowi twórczemu wyzwalającemu niesprecyzowane lęki i przeczucia tkuiące w głębokich warstuach psychiki - odsłaniał na suych obrazach. Kobieta wyłaniająca się z tego malarstua to samica zdeterminowana biologicznie i kierująca się prawami walki o przetrwanie oraz dominację, jakimi rządzi się cała natura. Dlatego bohater porównuje ją do bogiń personifikujących w różnych kręgach kulturowych infernalny aspekt bytu, a przede wszystkim obdarzonych mocą wpływania na mężczyzn: babilońsko-asyryjskiej Mylitty, patronującej dziewicom zmuszonym oddawać cnotę cudzoziemcom ${ }^{149}$; Izydy, bogini starożytnego Egiptu

\footnotetext{
${ }^{147}$ Zob. D. Dziurzyński, op. cit., s. 193.

${ }^{148}$ Biorąc pod uwagę rolę matki w kształtowaniu seksualności bohatera-narratora Requiem aeternam, jako ciekawostkę warto przywołać tekst Freuda Głowa Meduzy, w którym słynny psychoanalityk interpretuje wizerunek bogini jako uprzedmiotowienie konfliktu psychicznego. Jego zdaniem głowa Meduzy reprezentuje waginę, zułaszcza zaś oułosione narządy płcioue matki, a tym samym symbolizuje pokusę kazirodztua. Notabene, na ilustracjach Aubreya Beardsleya do dramatu Wilde'a Salome przedstawiona jest jako niesamowita, przypominająca meduzę postać z czarnymi włosami uijącymi się w wężouych splotach.

${ }^{149} \mathrm{~W}$ słouniku mitów świata pod hasłem Isztar, pośuięconym córce Mylitty, czytamy: „Najbrzydszy zuyczaj u Babilończyków - zauważa Herodot - jest następujący: każda niewiasta musi w tym kraju usiąść w świątyni Afrodyty i oddać się jakiemuś cudzoziemcowi. [...] Jeżeli niewiasta raz tam usiądzie, nie może uprzód wrócić do domu, aż jakiś cudzoziemiec rzuci jej na łono srebrną monetę i poza świątynią cieleśnie z nią się połączy. Rzucając pieniądz ma tylko powiedzieć: »Wzywam przeciu tobie boginię Mylittę«. Mylittą zaś nazywają Asyryjczycy Afrodytę" (A. Cotterell, Słownik mitów świata, tłum. W. Ceran, M. Dąbrouska i in., Katowice 1996, s. 40).
} 
(potem czczonej róunież w Grecji i Rzymie), symbolizującej tajemniczą siłę stwórczą uszystkiego, co żyje, decydującej o całokształcie życia na ziemi; Walkirii (mitologia skandynawska), dziewiczych służebnic boga Odyna, unoszących się nad polami bitewnymi, by wybierać wojouników, którzy musieli umrzeć; oraz Ateny, która „nie zaznała ciemności łona matczynego” (W 176), ponieważ uyskoczyła - uzbrojona - z głowy suego ojca Dzeusa.

Tęskniący za ukochaną, a jednocześnie przepełniony ustrętem do cudzołożnicy bohater ma w swej pracowni następującą wizję:

Stamtąd wlepiał się w me oczy nagi bezustyd kobiety-sfinksa - $\mathrm{z}$ innej strony wuiercał się w mój mózg ohydny ruch jakiejś histerycznej tanecznicy, a ze uszystkich ram czołgała się ku mnie jakaś lubieżna chuć pijanej hetery. (W 175)

W mitologicznej postaci Sfinksa, skrzydlatego potwora z ciałem lwa, a głową i piersiami kobiety, podobnie jak w postaci Chimery (potwór o głowie lwa i tułowiu kozy, z wężem zamiast ogona) znalazła odzwierciedlenie zuierzęca natura kobiet oraz umiejętność przybierania przez nie różnorodnych form. Mimo że Sfinks jest symbolem czuwania, syntezy wiedzy przeszłej, kontemplacji mistycznej, to u Przybyszeuskiego - jak i w całej Młodej Polsce - ucieleśnia zagadkę, tajemnicę zakrytą przed ludźmi. Opanowanie i drażniącą nieprzeniknioność kobiety pisarz wyraził porównaniem: „Siedziała spokojna, z zimną twarzą Sfinksa i patrzyła na niego badawczym uzrokiem" (Dp 67-68). W poemacie $Z$ cyklu Wigilii Sfinks uystępuje dodatkowo jako uosobienie tajemnicy seksu oraz pragnienia rozkoszy.

Najuiększą karierę zrobiła jednak u autora Synagogi szatana Astarte. W religiach Bliskiego i Środkowego Wschodu zwana Asztarte, a w Starym Testamencie Asztoreth, była boginią wojny i płodności oraz - co wykorzystał Przybyszeuski - miłości cielesnej. Znamienną cechą jej kultu była świątynna prostytucja. Podmiot liryczny poematów, zuracając się do niej w modlitewny sposób, określa ją jako matkę miłości, szatańską córkę wzbudzającą żądze i pragnienie rozkoszy, apokaliptyczną nierządnicę. W Requiem aeternam, pragnąc wyzwolić się od palącego pożądania róunoznacznego z cierpieniem, bohater ucieka w sacrum i wspomina mszę, której jako dziecko był świadkiem w wiejskim kościele. W chwili, gdy zamierza przyjąć „ostatnią świętą komunię" (Rae 90), pojawia się przed nim kusicielka Astarte, z rozpustną twarzą i ustami otwartymi w lubieżnym krzyku:

Ta, co kazała Onanowi szukać nowej orgii płciowej, by go oddać na pastuę strasznej śmierci ukamieniowania.

Ta, co wierny lud poprowadziła do uyzuolenia świętego grobu, by mu za nagrodę ouieńczyć czoło męczenniczą koroną syfilitycznych wrzodów.

Ta, co uysysa samicę mężoui z krui i rzuca go u sodomicznej chuci na męża - 
Ta, która silniejszą jest od porządku rzeczy, bo przeuraca uszystkie instynkty i maże sue oblicze kazirodczym nasieniem -

Astarte, Szatanie! (Rae 91)

Tę patronkę rozpustników, onanistów, homoseksualistów i oddających się zuiązkom kazirodczym bohater Androgyne obarcza odpowiedzialnością, a może właściwiej byłoby powiedzieć - winą, za rozbudzanie w mężczyznach nigdy nieugaszonej, rodzącej udrękę i tęsknotę, żądzy cielesnego użycia. Moc wezwanej magicznymi zaklęciami Astarte - moc wzbudzania „namiętnych szałów”, „nieziemskiej chuci” (A 391, 392) - pozwala mu jednak stworzyć (przyoblec w ciało) kochankę dla siebie. Przywołana w satanistycznych praktykach bogini staje się matką chrzestną kobiecości w ogóle, udzielającą suej szatańskiej natury uykreowanym przy jej pomocy przedstawicielkom „słabej” płci. Astarte demaskuje więc triumf chuci nad chrześcijańską caritas $^{150}$. W jej wizerunku natura i płeć uydają się uszechogarniające i niemożliwe do pokonania. Jej pojawienie się - mitologizujące potęgę płci ( $w$ innych młodopolskich realizacjach, choćby u Kasprowicza, tę potęgę uosabiała postać Ewy) - podkreśla słabość mężczyzny, który bezskutecznie szuka ucieczki przed chucią ${ }^{151}$.

Nawet u poemacie Nad morzem, poświęconym uwznioślającemu, mistycznemu doświadczeniu miłości, pojawiła się kobiecość niszcząca. Wspomnienie oczu utraconej ukochanej budzi w wyobraźni bohatera obraz oczu Jana Chrzciciela, któremu na życzenie Salome obcięto głowę. (Przybyszewski interesująco zastosował tu metonimię, akcentując cierpienie i bezbronność proroka oraz sadyzm Salome tylko przez obraz leżących na misie oczu, o których mówi się popularnie, że są „zuierciadłem duszy”). Wydarzenie biblijne przychodzi mężczyźnie na myśl na zasadzie skojarzeń z własną sytuacją uczuciową. Uwolniona w wizji podświadomość podpowiada, że kobieta zawsze zadaje ból:

Przede mną na złotej misie leżały oczy, dziko rozwarte - oczy, gdyby dwie uściekłe pięście ziejące zemstą, oczy Jana Chrzciciela. Z rozkoszą tygrysicy pastuiła się nad nimi córka króleuska, biła je i kłuła te oczy kochanka, które nią wzgardziły. Poiła się ich niemą rozpaczą, ich bezsilną zemstą, aż wreszcie wbiła u nie ostrą, złotą igłę. Dwie nitki krui trysnęły w górę, oczy podskoczyły w ostatnich kurczowych podrygach, krzyknęły strasznie i stanęły słupem. (Nm 323)

Salome, córka Herodiady z jej pieruszego małżeństua oraz pasierbica Heroda Antypasa, w ostatniej ćwierci XIX w. przestała być postrzegana w kategoriach biblijnych dramatis personae, a zaczęła fascynować

\footnotetext{
${ }^{150}$ W. Gutouski, Mit - Eros - Sacrum. Sytuacje mtodopolskie, Bydgoszcz 1999, s. 189.
}

${ }^{151}$ W. Gutouski, Nagie dusze..., s. 76-77. 
artystów jako figura kobiecości. Według ewangelistów Marka (Mk 6, 17-29) i Mateusza (Mt 14, 1-12), tak zachwyciła ojczyma swym tańcem, że obiecał spełnić każde jej życzenie. Za namową Herodiady zażądała głowy Jana Chrzciciela, który potępiał Heroda za związek z udową po bracie. Biblijny przekaz prezentuje Salome jako narzędzie w rękach matki (znaczenie jej greckiego imienia to: spokojna, pokojowo nastawiona, przyjacielska), tymczasem w końcu XIX w. zaczęto wydobywać demoniczne rysy jej osobowości. W śmierci św. Jana dostrzeżono zemstę za to, że nie uległ kuszeniu Salome. W dramacie Oskara Wilde’a (Salome, 1893) młoda tancerka ucieleśnia niezaspokojone pożądanie, które popycha ją do zbrodni. Podobnie u Kasprowicza (Salome, 1899): jej monolog przesycony jest erotyzmem, manifestacją namiętności, wręcz seksualnej obsesji ${ }^{152}$.

Salome utożsamiano z modliszką, owadem, którego samica dla spotęgowania rozkoszy pożera samca u trakcie kopulacji lub po niej. Już sama nazwa Mantis, uieszczka, jaką nadali jej starożytni, jest znacząca. Pojawienie się modliszki miało zuiastować głód. Pomawiano ją o „złe oko” - samo jej spojrzenie przynosiło nieszczęście temu, na kogo je zuróciła ${ }^{153}$. Rolę spojrzenia podkreślił również Przybyszewski. Kobieta, którą u powieści Homo sapiens przedstawia obraz Mikity, inspirowany osobą Izy, wygląda następująco:

W środku obrazu chciał wymalować kobietę tajemniczym uśmiechem wabiącą, zdradziecką - a ze uszystkich stron, z dołu, z góry, tysiące rąk [...] krzyczących za nią. Wątłe, nerwowe ręce artystów, grube, mięsiste ręce bankierów z pierścieniami na palcach, tysiące innych rąk - orgię pożądliwych, lubieżnych rąk... A ona z wabiącym, tajemniczym spojrzeniem. (Hs I, 61)

${ }^{152}$ Salome pojawia się $\mathrm{w}$ wielu tekstach epoki, od Herodiady Flauberta, przez Salome Wilde'a, po Na wspak Huysmansa, Herodiadę Mallarmégo, Ucztę Herodiady i Salome Kasprowicza czy wiersz Kazimiery Zawistouskiej Herodiada (w którym tytułowa postać utożsamiona jest z Salome). Okrucieństuo tej postaci, zaakcentowane przez Przybyszeuskiego, uwypukla także Marie Jehanne Wielopolska u luźno, choć wyraźnie inspirowanej przekazem biblijnym kreacji jednej z fauness - Salome de Clinchamps. Opowieść hrabiny zbudowana została na motywie rywalizacji matki i córki: porzucona przez męża za utratę figury po porodzie, Salome mści się na córce, uydając ją za księcia z egzotycznego kraju i tym samym skazując na śmierć z rąk pozostałych żon pana młodego. Postać Salome zainteresowała wielu badaczy kultury i literatury. Zob. m.in. M. Podraza-Kuiatkouska, Salome i Androgyne. Mizoginizm $i$ emancypacja, [w:] eadem, Symbolizm i symbolika w poezji Młodej Polski, Kraków 2001, s. 274-288; P. Siemaszko, Salome modernistów. Malarska i poetycka wersja kobiety fatalnej, [w:] Kobiety w literaturze. Materiały z II Międzyuczelnianej Sesji Studentów i Naukowców, Bydgoszcz 1999, s. 115-127; D. Trześniouski, „A trwanie twoje jest, jak śmierć, na zawsze - coraz straszniejsze i krwawsze...”. Modernistyczny wizerunek Salome, „Pamiętnik Literacki” 2001, z. 1, s. 7-31; M. Janion, Salome tańczy, [w:] eadem, Żyąc tracimy życie. Niepokojace tematy egzystencji, Warszawa 2001, s. 289-300; J. Ortega y Gasset, Portret Salome, [w:] idem, Szkice o miłości, tłum. K. Kamyszewa, Warszawa 1989, s. 151-158; E. Kuryluk, Salome, albo o rozkoszy, Kraków 1976.

${ }^{153}$ R. Caillois, Modliszka, [w:] idem, Odpowiedzialność $i$ styl. Eseje, thum. K. Dolatouska, Warszawa 1967. 
Prawdę oczu nieświadomie uchuycił także Borsuk z Mocnego człowieka na portrecie Ady Karskiej, malowanym z jakąś namiętną nienawiścią. Oglądający go Bielecki:

Był cały jak zahipnotyzowany oczyma kobiety z portretu, oczyma, w których artysta, jakby w zdumiewającym, nieśuiadomym jasnowidzeniu, wywlókł z przepastnych głębi, poza tysiącem masek, poza gęstymi zasłonami ukrytą istotną jej duszę: złą, przewrotną, zbrodniczą. Spoza słodkiego uśmiechu, dziewiczej czystości ust, tym potworniejszym blaskiem gorzały te oczy... (Mc I, 85)

Niszcząca kobieca siła, której świadectuem w poematach są wyłącznie męskie słowa, lęki i wizje, $\mathrm{w}$ powieściach obiektywizuje się w femme fatale uprowadzonej jako bohaterka. Pojawienie się Karskiej na powieściowej scenie antycypuje obraz na płótnie - charakteryzuje on kobietę i odsłania jej rzeczywiste intencje jeszcze przed włączeniem jej do akcji jako postaci działającej. Jak u przypadku Wilde'ouskiego Portretu Doriana Graya, malowidło ujaunia prawdę o ludzkiej istocie, demaskuje mroczną, diaboliczną naturę, skrzętnie skrywaną przed światem. Prawda obrazu szybko się potwierdza: podstawouym rysem osobowości bohaterki jest potrzeba dominacji, skutkująca okrucieństwem i dążeniami zbrodniczymi. W suym pragnieniu uyłącznego reżyserowania zdarzeń Karska przekracza człowiecze kompetencje. Świat traktuje jak kukiełkowy teatrzyk i uzurpuje sobie prawo pociągania za sznurki. Dumą i satysfakcją napawa ją podpalenie gospodarstwa własnego opiekuna, którego dokonała jako czternastolatka, a potem lasu w Tyrolu, gdzie wypoczywała jako kuracjuszka sanatorium. Pożar to dla niej - niczym dla Nerona - „boskie”, „niepojęte” (Mc II, 87) widowisko, Bieleckiemu łatwo przychodzi więc zjednanie jej dla osobistych nieetycznych planów, na których czele znajduje się podpalenie pracouni Borsuka. Pragnienie supremacji Karska przenosi także na relacje seksualne, próbując traktować marionetkowo „mocnego człowieka”, podobnie jak ona przyzuyczajonego do podporządkowywania innych własnej woli:

- Teraz już zostaniesz moim na zausze - myślała. - Teraz już cię nie puszczę. Chcę, muszę cię mieć [...].

[...] uszelka, choćby najpotworniejsza zbrodnia wydała jej się drobnostką wobec tego pragnienia, by go do siebie przywiązać. Ale z tym mu się zdradzić nie może, powoli, po cichuteńku trzeba go pętać, ostrożnie i tysiączną przebiegłością, by nie zdołał się spostrzec, jak się wikła, jak jednym nieostrożnym krokiem dostanie się do wilczego dołu. (Mc I, 238-239)

Nawet na chwilę nie przypuszcza, że niezadługo stanie się narzędziem w moim ręku, ani mu przez głowę nie przejdzie, że jest dla mnie przydrożną stacją, na której się posilę, wzmocnię, uszystko z niej zabiorę, a potem bądź zdrów, holenderski śledziu... ${ }^{154}$ (Mc I, 250)

${ }^{154}$ Bąź zdrów, holenderski śledziu - wyrażenie używane u sytuacji, gdy coś przepadło, zawiodło (zob. J. Karłowicz, A. Kryński, W. Niedźwiedzki, Słownik języka polskiego, t. 6, Warszawa 1915, s. 725). Notabene, śledzie holenderskie uważano u epoce za najsmaczniej- 
Karska ma wiele z Salome-modliszki, która prowokuje i wabi własnym ciałem, by ostatecznie wykorzystać i zniszczyć partnera. Nie tyle uwodzi, co kusi. Hipnotyzuje wzrokiem (,czuł jej oczy na swej twarzy, gdyby dotyk czujnych macek...”, „tak go dziwnie zachęcały do czegoś, wbijały u niego chwiejną, niepewną, niejasno jeszcze ukształtowaną wolę" - Mc I, 96, 105), a z jej ust nie schodzi raz wabiący, to znów zimny, zagadkowy (sfinksowy) uśmiech. To ona inicjuje kontakt seksualny - ściąga z Bieleckiego marynarkę, usuwa rękę pod jego koszulę, wreszcie zamyka drzwi od weunątrz, a klucz rzuca u ciemny kąt pokoju. W przekonaniu o ułasnej mocy psychicznej utwierdza się aktami agresji i sadyzmu. Zostawiając na ramieniu kochanka krwawe ślady swoich ostrych paznokci, usiłuje go naznaczyć już podczas pierwszego spotkania w pracowni Borsuka. Podczas pieszczot owija się wokół jego szyi niczym wąż-dusiciel i odważnie, prowokująco wyznaje:

Ja cię jeszcze kiedyś uduszę - szeptała namiętnie. - Znieść nie mogę, że ty żyjesz, to mi spokoju nie daje i jak długo żyć będziesz, nie będę go miała.

$[\ldots]$

Wiem tylko, że na myśl o tobie zgrzytam zębami z uściekłości, wiem, że ręce moje uszczepiłyby się najchętniej, jak kleszcze, w twoje gardło, kolana moje najchętniej by dusiły twoje piersi, żeby uszystkie żebra trzeszczały, najuyższą moją rozkoszą byłoby patrzeć, jak się dusisz, jak twarz tuoja zielenieje, oczy słupem stają w przedśmiertnym strachu [...]. (Mc II, 97-99)

Żądna zadawania bólu, czyni z portretu Bieleckiego fetysz, znęcając się nad nim jak nad laleczką voodoo ${ }^{155}$. Nie ma jednak mocy nad kochankiem, skoro nie odczuwa on obrażeń zadawanych jego fotografii:

[...] nie pamiętam, kiedy taką rozkosz przeżyłam. Wzięłam długą szpilkę i zaczęłam ci oczy wykłuwać - z początku jakby w przerażeniu z lękiem i wahaniem, a potem już z całą zaciekłą pasją coraz szybciej, coraz silniej wbijała się szpilka w twoje szatańskie ślepia - oczekiwałam cudu: myślałam, że teraz krew tryśnie, trysnąć musi! - Cud się nie stał - przedziurawiłam całą fotografię, podarłam na kawałki i rzuciłam do pieca. (Mc II, 98)

Podobieństwo natur oraz swoboda obyczajowa wynikająca z obcowania z bohemą i obycia w półświatku pozwalają seksualnym partnerom nie ustydzić się suej nagości. Przybyszewski - jednakże bez śmiałych detalicznych

\footnotetext{
sze (Śledź [hasło], [w:] Księga ilustrowana wiadomości pożytecznych. Popularny podręcznik encyklopedyczny $z$ dziedziny..., Warszawa 1899, s. 903).

${ }^{155}$ Wbijanie szpilek w laleczkę (symbolizującą ofiarę) jest metodą magiczną najsilniej kojarzącą się z voodoo. Ma sprowadzać na ofiarę (znajdującą się nawet setki kilometrów dalej) choroby, nieszczęścia czy śmierć, ale może też leczyć i przyciągać miłość. Kiedy szaman ubija igłę w nogę lalki, ofiara chwyta się za nogę i upada na ziemię, kiedy szaman zaciska nitkę na szyi laleczki - ofiara zaczyna się dusić itd. Praktyki te najczęściej spotykane są w Nowym Orleanie oraz Ameryce Łacińskiej.
} 
opisów - pozwala więc Karskiej i Bieleckiemu po erotycznym zbliżeniu leżeć nago na łóżku, palić papierosy, zachwycać się swoimi ciałami i planować kolejne występki. Ten ciekawy układ dominująca - dominujący kończy jednak pisarz u melodramatyczny sposób. Karska - niezależna, cyniczna, obojętna na opinie filisterskiego społeczeństwa, spędzająca dni na sączeniu absyntu w kawiarniach - okazuje słabość, zadurzając się w Bieleckim. Ginie z ręki zazdrosnego księcia Poraja, który wbija jej sztylet w serce, zrozumiauszy, że Ada oddała mu się nie z miłości, lecz $\mathrm{w}$ akcie szyderstua z jego dobroci i rozpaczy po odejściu „mocnego człowieka”.

Piękno ciała nie jest w przypadku Karskiej uzewnętrznieniem piękna duszy, a taką jedność głosili jeszcze romantycy. Wręcz przeciunie - doskonałość materialnej powłoki maskuje brzydotę i rozpad osobowości, jednocześnie dowodząc Schopenhauerouskiej tezy, że atrakcyjna powierzchowność stanowi pułapkę dla mężczyzn. Prawdę o rywalce w nagłym jasnowidzeniu odkrywa poprzednia kochanka Bieleckiego - Łucja. Podczas zakrapianego alkoholem wieczoru w kawiarni widzi Adę niemal w rozkładzie, znanym z Baudelaire'ouskiej Padliny: „Twarz Karskiej wydała jej się nagle skostniałą, obumarłą, spopielałą, z głębokich oczodołów zionął fosforyczny blask zgnilizny" (Mc I, 211). W postaci rywalki Szumska dopatruje się wampirzycy, ale przedstawiony miniopis uskazuje raczej na analogie do żywego trupa.

Cechy wampira, będącego duchem lub ożywionym ciałem zmarłego, które wychodzi z grobu, błądzi i uysysa krew żywych, a nad swą ofiarą chce panować $u$ sposób absolutny ${ }^{156}$, ma inna postać kobieca - bohaterka De profundis, Agaj. Jawi się ona jako uosobienie instynktów niszczycielskich oraz sadomasochistycznych, jako demon domagający się ofiary krwi ${ }^{157}$. Kontakty erotyczne wyzwalają w niej zachowania zwierzęce, nawet wampiryczne: „ugryzła się palcami w jego piersi” (Dp 49), „gryzła go w usta, w szyję” (Dp 91), „wżarła się zębami w skórę jego szyi i rozdarła ją" (Dp 102). Potrzeba dotarcia do trzewi partnera i upuszczenia jego krwi jest tym bardziej perwersyjna, że u Agaj płynie ta sama krew: jej wybranek jest jej bratem. Fakt ten nabiera dodatkouych znaczeń na gruncie psychoanalizy, która traktuje krążący w żyłach płyn jako ekwiwalent spermy. W ten sposób Agaj, gryząca mężczyznę i otwierająca rany na jego skórze, symbolicznie prowokuje uytrysk jego nasienia. Krew jako czynnik podniecający pojawiła się $\mathrm{w}$ podanym przez Krafft-Ebinga przypadku młodego mężczyzny obserwującego pokojówkę, która się skaleczyła: „Nie mógł się oprzeć pragnieniu wyssania jej krwi, co spowodowało

${ }^{156}$ Zob. J.-P. Roux, Krew. Mity, symbole, rzeczywistość, tłum. M. Perek, Kraków 1994, s. 251; M. Janion, Wampir. Biografia symboliczna, Gdańsk 2004.

${ }_{157}$ Picie krui - ofiary czy uroga - to rytuał odprawiany od czasów starożytnych. Jego licznych przykładów dostarcza Złota gałaź Jamesa G. Frazera (pierusze wyd. 1890), jedna z podstawouych publikacji z zakresu etnologii i antropologii. 
guałtowne podniecenie erotyczne, po którym nastąpiła ejakulacja. Odtąd szukał sposobów sprokurowania sobie świeżej krui młodej dziewczyny" ${ }^{158}$. Pod wpływem podobnych konstatacji Ludwik Krzywicki napisał cykl artykułów poświęconych „szałowi kruiożerczo-erotycznemu”, ludożerstuu i wilkołactwu ${ }^{159}$. Polski myśliciel dopatrywał się w takich zachowaniach „nienormalnego usposobienia chuciowo-uczuciowego".

Zachowania wampiryczne podpatrzył Przybyszewski u Muncha. Analizując litografię norweskiego artysty zatytułowaną Wampir (1893), pisał o diabolicznej kobiecie, która „wgryzła się w kark mężczyzny ostrymi zębami, oblała twarz jego kruią suych czerwonych włosów, objęła głowę jego silną ręką rozszalałej chuci i dusi, i gryzie - gryzie”, zaś mężczyźnie pozostaje tylko ból sprowadzony przez samicę ${ }^{160}$. Grafika ta była zdaniem pisarza doskonałym uyrazem „pesymizmu płciouego”, jednoczesnej niemożności zrzucenia jarzma kobiety i zaspokojenia żądzy, stanu, któremu intrygujący wyraz dał nieco później Stefan Grabiński w nowelach Kochanka Szamoty, $W$ domu Sary i innych.

Mimo że nienazwany $\mathrm{z}$ imienia bohater De profundis jako pieruszy przyznaje się do kazirodczej miłości i dąży do pogłębienia relacji z siostrą - a może ułaśnie dlatego - to ona przejmuje ster zuiązku. Na przemian odpycha brata i przyciąga. Wyznacza mu spotkania, na których się nie pojawia. Wyśmiewa rodzące się w nim uczucie, a jednocześnie celowo je podsyca. Prowokuje swoim zachowaniem, jest wyzywająca, szydercza i złośliwa, pełna pogardy.

- Chodź! - pouiedziała twardo i ustała od stołu.

- Dokąd?

- Czy ci to nie uszystko jedno, dokąd pójdziemy, jeżeli tylko ze mną pójdziesz? - Roześmiała się szyderczo. (Dp 65)

Agaj jest ułaściwie wyłączną reżyserką zdarzeń; na sposób demoniczny kreuje los partnera, prowadząc go do zguby, mimo iż jest jedynie wyobrażeniem, efektem zdezintegrowanej jaźni protagonisty, rodzajem snu na jawie, uyrażającym nieświadome treści jego psychiki ${ }^{161}$. A on się na to godzi: „[...]

${ }^{158}$ R. von Krafft-Ebing, Zboczenia umysłowe..., s. 77.

${ }^{159}$ L. Krzywicki, Ludożerstwo $i$ szat krwiożerczo-erotyczny, „Prawda” 1887. Idem, Wilkotactwo. Szkic psychiatryczno-antropologiczny, „Prawda” 1888. Przedruk [w:] idem, Artykuty i rozprawy 1886-1888, Dzieła, t. 3, Warszawa 1959.

${ }^{160}$ S. Przybyszeuski, Na drogach duszy, s. 47-48.

${ }^{161}$ W XIX w. dzięki badaniom parapsychologicznym, zułaszcza nad somnambulizmem, odkryto u psychice takie samodzielne siły, nad którymi człouiek nie ma uładzy. „Nasze akty woli - pisał Przybyszeuski w $Z$ psychologii jednostki twórczej - są chciane nie przez nas, ale przez człowieka siedzącego w nas, nad którym nie mamy żadnej władzy". Bardzo znany w drugiej połowie XIX w. psycholog Théodule Ribot uważał, że zjawisko halucynacji 
jestem twoim niewolnikiem, psem twoim. Możesz ze mną robić, co ci się podoba, duszę mi z ciała wyruać, jeżeli zechcesz, a jeszcze będę ci za to wdzięczny, boś ty to zrobiła, ty - ty...” (Dp 78) - deklaruje z emfazą.

Miłość Agaj dowodzi inklinacji ku destrukcji. Bohaterka przyznaje się do upodobania $\mathrm{w}$ napięciu i dysharmonii. $\mathrm{W}$ zakończeniu poematu, podążając za jej sugestią, że dobrze byłoby leżeć razem w objęciach na dnie morza, brat rzuca się do wody, z którą i ona miała się połączyć. Kochające się rodzeństwo powraca więc do pierwotnego żywiołu, do nieuformowanego chaosu.

Postaci femme fatale Przybyszewski uprowadził również do dramatów. Cechy żerującej modliszki oraz wampira odbierającego żywym siły posiada Olga, o której Zdżarski mówi: „Kogo ona pochwyci, tego nie puści... w y s s i e, odrzuci, ale nie puści..." (Dszcz, 29; podkr. K.B.). Autor nie wyjaśnia, na czym polega nieuchuytny urok kobiety fatalnej. „Uległem, bom musiał ulec” (Dszcz 11) - ucina krótko Mlicki. „Ona go opętała” - diagnozuje Zdżarski, odwołując się do szatańskiej natury kobiety i sugerując tożsamość femme fatale i czarownicy. Z półsłówek występujących w dialogach można wnosić, że mężczyznom imponuje jej oduaga u guałceniu praw i bezkompromisowość w odrzucaniu społecznych przesądów. Powód zafascynowania nią Mlickiego tak próbował wytłumaczyć Zdżarski, rezoner głóunego bohatera, były kochanek Olgi:

Olśniewa go suymi śmiałymi sądami, pochlebia mu jej piękność, jej wyniosła duma; wokół niej roi się od mężczyzn; a to go oczarowało, że właśnie ku niemu zuróciła sue względy, że on został uybrany. Przy tym umie nęcić, podrażnić, obiecuje jednym spojrzeniem więcej, ile inna nie da, choćby się całą duszą oddała. (Dszcz 27-28)

Zatem Mlicki pożąda panny Agrelli z próżności, by połechtać własne ego. Ona, znudzona uwielbieniem tłumu przeciętnych mężczyzn, uybiera tego, który zrobi na niej „względnie największe wrażenie” (Dszcz 50). Entrée tej femme fatale przygotourują wypowiedzi innych bohaterów. Następuje ono dopiero w finale drugiego aktu i doskonale wpisuje się $w$ charakterystykę przygotowaną we wcześniejszych scenach. Portret postaci od strony psychologicznej już się nie pogłębia. Jej okrucieństwo potwierdza się np. poprzez obojętność na wieść o możliwym samobójstuie porzuconej przez Mlickiego Heleny.

(a mamy z nim do czynienia w De profundis) polega na alienacji pewnych stanów śuiadomości, które „ja” - nie uważając ich za ułasne - umieszcza na zeunątrz, nadając im status odrębnej egzystencji. Przybyszeuski zaś podkreślał, że każda projekcja wewnętrzna winna mieć w utworze cechy postaci rzeczywistej i zasadę tę doskonale realizował. I tak Agaj stanowi u znacznym stopniu postać autonomiczną, a o jej fantazmatycznym statusie czytelnik dowiaduje się stopniowo. 
Podobnie pojawienie się Euy w Śniegu poprzedza jej ustępna charakterystyka dokonana przez mieszkańców podupadającego arystokratycznego dworu, w którym toczy się akcja dramatu. „Chciała być niewolnicą, a musiała być panią" (Ś 35) - mówi Tadeusz, niegdyś silnie związany z nią uczuciowo. Ewa najdobitniej ze wszystkich bohaterek Przybyszeuskiego reprezentuje fatalizm miłości. Mimo chwilowego odpoczynku u boku poślubionej Bronki, Tadeusz wraca do dawnej kochanki opanowanej przez „obłędne pragnienie zniszczenia” (Ś 34), choć po zakończonym kilka lat ucześniej zuiązku z nią pozostało mu „serce [...] suche jak wiór, dusza obolała" (Ś 33). Rozstanie spotęgowało tęsknotę, której dał upust, stylizując wnętrze mieszkalne tak, by stanowiło kopię mieszkania Euy, i wieszając w suej pracowni obraz jej autorstwa. Niesamowity upływ kobiety fatalnej jest właściwie niewytłumaczalny - dlatego nie można go zracjonalizować i pokonać („Lecisz w ogień jak ćma” - komentuje Ewa stan Tadeusza; Ś 62). Z tego powodu Bronka upatruje w przyjaciółce groźnej rywalki. Mówi do niej:

Widzisz, mogłaby być kobieta piękną, o, najpiękniejszą ze uszystkich kobiet na śuiecie, a nigdy bym się nie lękała, bo wiem, że Tadeusz ani okiem na taką piękność nie rzuci. Ale tyś inaczej piękna. Przy tobie budzą się tęsknoty i pragnienia, których się nie znało. Ty możesz przykuć i ciągnąć za sobą człowieka, choć nie uiesz, że ktoś u twoje ślady idzie, a on znów nie uie, dokąd go twój urok zaprowadzi... a jednak idzie na ślepo... przed siebie... dalej... dalej... (Ś 87)

Ewa jest tęsknotą za tym, czego nikt „nie rozumiał ani nie zrozumie” (Ś 105), wewnętrznym niepokojem, „który gna, gna i gna człowieka na oślep, po trupach, po ofiarach swej zbrodni, przed siebie naprzód..." (Ś 104). By poutórnie zdobyć Tadeusza, kusi go wizją życia intensywnego - pięknego przez immanentną mękę. Eliminacja Bronki nie zakłóca spokoju jej sumienia, więcej - jest konieczną, lecz niewartą litości ofiarą. Ewa reprezentuje kuszącą siłę, potęgę naginania innych do swej woli. Jak w przypadku pozostałych demonicznych bohaterek Przybyszeuskiego głóunym rysem jej osobowości jest potrzeba dominacji. Femme fatale nieuchronnie wiedzie mężczyznę do upadku, mimo deklaracji miłości do niego. Przynosi rozpacz i cierpienie. Z kolei zafascynowany mężczyzna, nawet jeśli przeczuwa negatywne skutki zuiązku, nie jest w stanie się uwolnić. Staje się marionetką uzależnioną od posunięć partnerki.

Mizoginizm oraz pragnienie absolutnego posiadania kobiety, panowania nad jej ciałem i duszą znalazły odzwierciedlenie w obsesji dziewictwa, przenikającej całą twórczość Przybyszeuskiego. Wielu badaczy (m.in. M. Podraza-Kuiatkouska i G. Matuszek) dostrzega w niej element biograficzny - nieumiejętność pogodzenia się z faktem, że w chwili ślubu z pisarzem Dagny Juel nie była virgo intacta. 
Próby tłumaczenia sobie utraty hymenu jako sprawy błahej zawodzą, ponieważ każdy mężczyzna chce być pieruszym i jedynym dla kobiety, na zausze wpisanym w jej życie ${ }^{162}$.

[...] jest coś, co starzy ludzie dauniej cnotą czystości nazywali [...] - dziś to już jest starzyzną. Cnota czystości nabrała komicznego znaczenia. [...] I my, ludzie postępowi, śmiejemy się z owej cnoty - w teorii, proszę pani... bo [...] chciałbym uidzieć tego mężczyznę, który by przenosił kobietę, co z rąk do rąk przechodziła, nad kobietę tak czystą i jasną [...]. (Dszcz 41)

Najzagorzalszym wyrazicielem tej postawy jest Gordon w Dzieciach szata$n a$, który suoje anarchistyczne, szatańskie działania usprawiedliwia po części tym, że nie był pieruszym kochankiem Heleny. Nie poślubił ukochanej i odtrącił ją, ponieważ wcześniej jej ciało posiadł ktoś inny, tymczasem „pierusze szczęście jest róunocześnie jedyną chwilą, w której chuć jest piękna” (Ds 9):

Kobieta zausze należy do pieruszego, śuiadomie czy nieśuiadomie, ognistą plamą wżera się pieruszy raz na zausze u jej duszę, a posiąść kobietę, w której duszy jest pieruszy - to ustyd. (Ds 9)

Pragnienie bycia pieruszym wynika z przekonania, że inicjacja seksualna przekształca dziewicę $\mathrm{w}$ kobietę, a sprawcą „narodzenia tego najwyższego piękna” (Ds 23) jest mężczyzna. Co więcej, prawdziwe stopienie dusz bywa możliwe uyłącznie z kobietą czystą. Dlatego Gordon tłumaczy Helenie:

[...] dusza moja nie potrafi stopić cię w sobie, bo tylko ta miłość jest piękna dla mnie, która zdoła stopić kobietę w duszy mężczyzny. (Ds 24)

Idzie zatem o coś więcej niż zraniona męska duma, niż prawo całkowitej ułasności, potrzeba naznaczenia kobiety. Czystość ciała róuna się czystości duszy, dlatego cielesne zjednoczenie ma moc duchowego misterium tylko wtedy, jeśli zachodzi z kobietą niepokalaną. Dokonany przez innego

${ }^{162}$ Dziewictwo kobiety jako warunek szczęśliwego zuiązku wyszczególnione zostało nawet u Przewodniku zakochanych, złożonym do druku w 1903 r. Jego autor pisze: „Otóż od kobiety, uzględem której żywimy poważne, stałe zamiary, powinniśmy przede uszystkiem żądać bezuzględnie czystej przeszłości. Tak zwane błędy młodości czy błędy miłości u przeszłości jej, aczkolwiek może nawet uspaniałomyślnie przez narzeczonego uybaczone i zapomniane - mszczą się prędzej czy później. Stanowią one zausze nieuidzialny mur, dzielący małżonków od siebie. A jeżeli nawet urazy »za przeszłość« mąż nie żywi, musi się w sercu jego obudzić, o ile sam jest honorowym i uczciwym człowiekiem, pewne uczucie lekceważenia, przeradzającego się nierzadko u pogardę dla suej towarzyszki, która u skalanej szacie, »w umiętej sukni godowej« przystępuje do tego ogniska, którego, o ironio!, czystości ma strzec i być jego westalką!" (M.A. Zawadzki, Przewodnik zakochanych, czyli Jak zdobyć szczęście w miłości i powodzenie u kobiet, Warszawa 2007, s. 16). 
mężczyznę akt defloracji staje się dla bohaterów Przybyszeuskiego źródłem cierpienia, ponieważ uyklucza androgynię, a więc osiągnięcie pełni, doskonałości, szczęścia; „[...] ta pozostawiona na ciele kobiety blizna stanie się zaporą uniemożliwiającą harmonijne miłosne relacje" ${ }^{163}$. Na tym problemie osnuta została niemal w całości akcja Wniebowstapienia. Pamięć bohatera o poprzednim partnerze uybranki sprawia, że - jak informuje pierusze zdanie poematu - „musieli się rozłączyć...”. Widmo „tego trzeciego”, choć nieobecnego, zatruwa związek i mąci spokój kochanków. W wieczornym zadumaniu ukochanej doszukuje się bohater tęsknoty za tym pieruszym, „który u niej kobietę stworzyl” (Wn 144). W jej pożądaniu - uspomnienia o dawnych rozkoszach. Nie wierzy u miłosne zapeunienia, bo „mętne resztki na dnie jej duszy - to uszystko, co dla niego zostało" (Wn 144). Nieufność i zazdrość doprowadzają związek do destrukcji: „Przestali mówić ze sobą, przestali patrzeć na siebie, bali się dotknięcia suych rąk - a nawet w ich milczeniu szalały obłędy zwątpień, bezwiary i nienawiści” (Wn 145).

Mlicki z dramatu Dla szczęścia na próżno usiłuje sobie wmówić, że Olga, z którą zamierza się ożenić, dla niego „pozostanie czystą i dziewiczą, choć [...] już należała do innego" (Dszcz 19). W rzeczywistości cierpi, myśląc o swoich poprzednikach. Wątpliwości celowo podsyca w nim Zdżarski:

[...] cóż ona temu winna, że cię ktoś uprzedził, że oddała serce sue, zanim mogła przeczuwać, że jakiś Mlicki istnieje? Cóż do diabła ona temu winna, że ten ktoś żądał pochuytnej rękojmi jej miłości [...]. Więc nie zuażam na nic: żenię się. Naraz odzywa się samiec. [...] Czujesz, że to uszystko, co kobieta po raz pieruszy daje, to uszystko, co u duszy kobiety jest tylko przeczuciem, obawą dziwną a tajemniczą, pełną strachu i pragnienia [...] u duszy twej [...] żony - dawno przekwitło [...]. (Dszcz 20)

Podobnie jak Mlicki reaguje Falk, bohater powieści Homo sapiens. Mimo iż zazdrość o poprzednika nie prowadzi go, jak Gordona, do wyrzeczenia się uczucia i nie przeszkadza mu uczynić suą prawowitą małżonką kobiety, która zaznała już rozkoszy cielesnych, nie daje się jednak zepchnąć w niepamięć. Co więcej, uskazuje mu drogę usprawiedliwiania późniejszych zdrad chęcią zrewanżowania się żonie za oddanie czystości innemu. „[...] bo przecież są chwile, że człowiek tak intensyunie nienawidzi kobietę, że z bólu, niemej wściekłości, chorobliwej potrzeby zemsty pragnie ją pokalać przez stosunek z inną kobietą" - wykłada swoją filozofię, pokrętnie tłumaczącą przymus cudzołóstua (Hs III, 61). Kocha Izę, ale zadręcza się myślą, że była wcześniej narzeczoną Mikity; pożądanie przeplata się u niego ze ustrętem i odtrąceniem. Tylko Bieleckiemu udaje się miłosna unia z panią Ligęzową, zuiązaną węzłem małżeńskim z innym. Nie jednak dzięki uybaczeniu i zapomnieniu, lecz zamarciu pożycia seksualnego między Niną i jej mężem. „On

${ }^{163}$ G. Matuszek, Melancholik, mistyk..., s. 18. 
jej jeszcze chyba nigdy nie posiadł [...] - to zdumiewające: tak mężatka nie wygląda" (Mc II, 44) - rozmyśla Bielecki, widząc po raz pieruszy swą przyszłą kochankę, która jawi mu się jako istota zawieszona na etapie między dorastającą dziewczyną a młodą kobietą.

Jak zauważa Gabriela Matuszek ${ }^{164}$, cielesna „skaza” pozostawiona przez pieruszego kochanka zakłóca idealny obraz partnerki i prowokuje ataki męskiej agresji: „Aż do krwi siekł ją szyderstwem, a w mózgu jej wypalał krwawe plamy obelgą i hańbiącym słowem" - opisuje narrator psychiczne tortury, jakim poddaje ukochaną bohater Wniebowstapienia. Oddanie dziewictua ucześniej poznanemu mężczyźnie bohaterouie Przybyszeuskiego bezuzględnie kategoryzują jako zdradę. Prowadzi to do paradoksu - kobieta zdradza mężczyznę, jeszcze zanim go pozna. Każdy akt cudzołóstwa, jakiego się dopuszcza, zasługuje zaś na karę: „Oszalałem; chuyciłem ją, szarpałem, owinąłem jej włosy naokoło ręki, wlokłem ją poprzez atelier, aż nagle, nie wiedząc, co robię, kopnąłem ją gdyby thumok łachmanów w kąt" (W 197) - opowiada bohater poematu $Z$ cyklu Wigilii, aranżując w wyobraźni brutalną zemstę na cudzołożnej kochance. Pragnienie zamordowania ukochanej zostaje podsycone przez uspomnienie widzianego we dworze ojca krwawego sądu dokonanego przez samców nad bocianicą, która przyjęła do suego gniazda nowego ptaka. Będąca rodzajem memento przypowieść o niewiernej bocianicy ilustruje tezę, że nielojalność leży u naturze płci pięknej. Uzupełnia ją anegdota o zdradzonym hrabim, przywołana przez Czerkaskiego w Synach ziemi. Występują $\mathrm{w}$ niej nieznajdujące potwierdzenia $\mathrm{w}$ uykreowanych przez Przybyszeuskiego sytuacjach fabularnych poglądy, jakoby inicjatorką zdrady zausze była kobieta, a uwodzicielskie talenty mężczyzn stanowiły jedynie mit:

Nie ma zresztą mężczyzny, który by był zdolny uwieść kobietę - to nonsens, to infernalna orgia głupoty: mężczyzna nigdy nie robi pieruszego kroku - to słynne „perskie oczko” robi zawsze kobieta. (Sz I, 37)

Zdrada kobiety, oznaczająca niemożność zapanowania nad seksualnością, rodzi ból i agresję, wywołuje mizoginiczne wizje okrutnej Salome, rozpustnej Astarte czy - jak w niewielkim poemacie $\mathrm{Na}$ tym padole płaczu - sadystki pastwiącej się nad ciałem mężczyzny szpilkami do włosów ${ }^{165}$. Zmusza także bohaterów do inscenizowania w wyobraźni scen ukrzyżowania, fizycznego dręczenia i uśmiercania partnerek (zostaną one omówione w trzeciej części książki). Obrazy kobiet-wampirów i modliszek kładły przede wszystkim nacisk na zdeterminowanie ich życia przez instynkty biologiczne (seksualny i macierzyński), a ucieczka przed nimi wynikała z pojmowania natury

\footnotetext{
${ }^{164}$ Ibidem.

${ }^{165}$ Ibidem, s. 19.
} 
jako surowej, determinującej siły, w której niszczenie przeważa nad kreacją. Destrukcyjną rolę płci pięknej $\mathrm{w}$ analogii do natury obrazowo przedstawił Przybyszewski słowami Rembouskiego w Złotym runie:

[...] w Australii czy w Indiach rosną podobno drzewa, bliźnie drzewa, ha, ha [...] kochające się drzewa... [...] Otóż rośnie sobie taki smukły, silny pień, energiczny, mocny... ot, taki wielki pan! Ale tuż obok niego uyrasta drugi, smukły, wiotki, tuli się do niego, przyciska, przygarnia, omal że nie urasta u niego. Ale cóż się dzieje? Otóż temu słabemu, wiotkiemu pniowi wyrastają gałęzie - nie! - ramiona, chciwe, szatańskie ramiona. Obejmują go, wżerają się u ten silny, energiczny pień - przytulają się coraz mocniej, namiętniej, wcinają się w skórę, przerastają ją, przerzynają korę i żyły - i ten pieruszy, ten silny i modny pień usycha. - Ha, ha - wystaw sobie! Taki martuy, uschły pień w objęciach bliźniego, słabego drzewa. Widzisz, widzisz - to jest symbol miłości - to stosunek mężczyzny do kobiety... (Zr 189)

Powyższe rozważania pozwalają uyróżnić w twórczości Przybyszeuskiego następujące kategorie bohaterek, wyodrębnione na podstawie ich roli wobec mężczyzn: poddane miłosnej idealizacji, poddane demonizacji, pocieszycielki, matki i prostytutki. Żeby owa galeria była kompletna, wypada jeszcze uspomnieć o kobietach słabych, niesamodzielnych, uciekających się pod opiekę mężczyzn i oczekujących od nich usparcia $\mathrm{w}$ uporaniu się $\mathrm{z}$ niekorzystną sytuacją, w jakiej akurat się znalazły. To trzy kochanki: Helena z Dla szczęścia, Hanka z Synów ziemi oraz Łusia z Mocnego człowieka. Pierusza, by „na wiarę” związać się z Mlickim, zmuszona była zerwać kontakt z rodziną, odejście kochanka otwiera więc przed nią uzbudzającą paniczny lęk perspektywę pozostawienia samej sobie, przed którą dziewczyna histerycznie się broni: „Zmarnieję bez niego. Nie mam domu, nie mam rodziców; cały świat się mnie wyparł. Na całym świecie Stefan, tylko Stefan, jedyny Stefan!...” (Dszcz 30). Gotowa jest upokorzyć się, by zatrzymać Mlickiego: „Zostań, zostań! twoim psem będę, rób ze mną, co chcesz! bij, zabij! - rób, co chcesz, tylko nie opuszczaj mnie!" (Dszcz 57) - błaga. Hanka Bielska oczekuje, że Czerkaski, dla którego opuściła męża i córeczkę, pomoże jej zapomnieć o powracającej wciąż w myślach, dręczącej przeszłości; że ułatui jej pogodzenie się ze stratą:

- Jasiek przy mnie - Jasiek!

Teraz mogę spokojnie patrzeć życiu u jego straszną, bólem pouykręcaną, szyderstwem i uściekłością śmiesznie pouykrzyuianą mordę [...]. (Sz II, 107)

Nadzieje bohaterki są uyłącznie rodzajem autosugestii - Czerkaski nie ma mocy tłumienia jej instynktu macierzyńskiego. Wybierając się u podróż powrotną do dziecka, Hanka również nie liczy na własne siły, lecz oddaje się chętnie pod opiekę innego mężczyzny: pianisty Miłosza Zaremby. Pozwala mu się zwodzić, ufając w błędne informacje, których jej 
dostarcza, i na wpół świadoma niemal biernie reaguje na dokonany przez niego guałt na sobie.

Zdeprawowana Łucja Szumska nie ma sił, by samodzielnie uwolnić się od Bieleckiego, lecz udaje się do Górskiego:

[...] gdym pana u tym całym obcym tłumie ujrzała, [...] coś we mnie głośno krzyczało, że u panu jest mój ratunek...

[...] chciałabym się wyruać z tego życia, a nie mogę: jestem bez woli, bez sił... Bielecki mnie doszczętnie zmarnował, uyssał, zatruł mi duszę. [...] I tak pomyślałam, że pan, pan jeden ze swoją dobrocią... (Mc I, 44)

Na podstawie kreacji tych trzech bohaterek Przybyszeuski - na ogół nieczuły na realia społeczne - uykazał różnice między pozycją żony a statusem kochanki. Helena, Hanka i Łucja marzą o formalnym zuiązku guarantującym stabilność i bezpieczeństwo - uczuciowe, towarzyskie, finansowe. Miano ,żony” broniłoby je przed ostracyzmem i zapewniało szacunek otoczenia (potrzebuje go przede wszystkim Bielska, o czym świadczy sen, w którym pogardzają nią damy z tzw. dobrego towarzystwa, zbierające fundusze na cele charytatyune; we śnie tym Czerkaski broni Hankę przed afrontami, publicznie nazywając ją żoną), a także tak ważne poczucie posiadania i przynależności do kogoś. Tak ujmuje to narrator z perspektywy Łusi:

[...] obudziło się u niej pragnienie, by posiąść Henryka, by jej tylko przynależał, by cały śuiat szanował ją jako jego żonę, a nie jako przygodną kochankę. - Ho, ho, jakie to piękne w literaturze: kochanka! A w życiu plugawione, bezczeszczone, poniewierane.

Gorycz w niej wzbierała.

Przed żoną z czcią i pokorą się słaniają, a czyjaś kochanka - oho: dla wszystkich suka, którą psiarstuo obuąchuje. (Mc I, 194)

W dramacie Dla szczęścia problem małżeństwa i konkubinatu łączy się z poruszonym marginalnie zagadnieniem sytuacji ekonomicznej kobiet oraz ich nieprzygotowaniem do pracy u celu samodzielnego utrzymania. Poważne braki w edukacji oraz bariery społeczne uniemożliwiały im dostęp do wielu zawodów, dlatego tym, które nie pasowały do roli guwernantki lub robotnicy, pozostawała częstokroć prostytucja. Perspektywę zarobkowania jako nierządnica aluzyjnie roztacza Zdżarski przed opuszczoną przez Mlickiego Heleną. Zacytowany poniżej fragment to wyjątkouy w stricte literackiej twórczości Przybyszeuskiego przypadek odwołania do XIX-wiecznych realiów, w których emancypacja była kwestią palącą.

[...] Tak! będzie się pani musiała obejrzeć za zarobkiem. - O, o, to trudna rzecz... Pani zepsute dziecko bogatych rodziców, uychowana w zbytku i pieszczotach - pani będzie wędrować od jednego pryncypała do drugiego... a pani znajdzie zarobek, bo pani jest przystojna, 
bardzo przystojna... rozumie pani, co to znaczy?... trzeba być bardzo przystojną, by otrzymać pracę... (Dszcz 44-45)

W utworach Przybyszewskiego nie ma kobiet naprawdę dobrych i mądrych, zdolnych do głębokich poświęceń w imię wyższych wartości (ich patronką mogłaby być biblijna Judyta). Żadna z nich nie stanowi dla suego partnera ostoi, nie zapeunia duchowego usparcia, spokoju i zadowolenia. Na typ Beatrycze czy Madonny nie ma miejsca w ramach światopoglądu pisarza. W świadomości bohaterów z góry tkwi założenie, że miłość nie przyniesie im niczego dobrego. Każdy z nich instynktownie wyczuwa „te słodkie rączki Dalilii, sięgające po ten włosek, w którym cała jego moc tkwiła" (Mc I, 146). Obwinianie kobiet za upadek mężczyzn jest ważnym powodem, dla którego w związkach opisywanych przez Przybyszeuskiego prawdziwe partnerstwo jest nieosiągalne, a uczucie nigdy nie może być szczęśliwe. Dodatkowo rozpięcie obrazu kobiety między odmianą demonizującą a idealizującą sprawia, że płeć piękna ujęta zostaje wyłącznie w relacji do mężczyzn; jej wizerunek jest efektem - by użyć określenia krytyki feministycznej - „męskocentrycznego” spojrzenia. W twórczości autora Śniegu kobieta istnieje zatem wyłącznie jako obiekt, niezbędny składnik świata męskiego - oswajany i infantylizowany (w wersji anielskiej) oraz pozbawiany moralności i duchowości (u wersji szatańskiej), co ma uykazać jego niższość.

Warto jeszcze raz zaakcentować, że kreśląc kobiece portrety, pisarz nie odwołuje się ani do XIX-wiecznych realiów społecznych z narastającym ruchem emancypacyjnym, ani bezpośrednio do tradycji (np. biblijnej), z których na zasadzie symbolu czerpał określenia suych bohaterek. Postaci kobiet zaprzęgnięte zostały u niego w służbę tez światopoglądowych i odkrywanych dopiero meandrów psychologii głębi, zaś mityczne przekazy dostarczały uzoru kobiecości niebezpiecznej: agresywnej, sprzymierzonej z siłami natury i szatana, zbuntowanej przeciwko dominacji mężczyzn, a przy tym zniewalającej pięknem.

\section{Androgyne}

Sens androgyniczności, czyli stanu obupłciowości somatycznej i psychicznej ( $w$ jednym ciele koegzystują dwie płcie), zawiera się w samym terminie seks, uywodzącym się od łacińskiego słowa secare, które znaczy „odcinać”, „odłączyć od całości”. Według mitu opartego na wierzeniach orfickich i opowiedzianego przez Arystofanesa w słynnej Uczcie Platońskiej, bogowie greccy, aby osłabić istniejącą przed wiekami jednostkę ludzką łączącą w sobie płeć 
męską i żeńską, przecięli ją na dwie odrębne istoty ${ }^{166}$. Jedynie ponowne połączenie odmiennych płci może zaspokoić tęsknotę za utraconą pełnią.

Doskonałość człowieka duupłciowego polegała na zespoleniu przeciwieństu i różnic. Jej wyrazem była budowa fizyczna zbliżona do kuli.

Otóż cała postać człowieka każdego była krągła, piersi i plecy miała naokoło, miała też cztery ręce i nogi u tej samej ilości, i duie tuarze na okrągłej, walcowatej szyi, tuarze zgoła do siebie podobne. Obie patrzyły w strony przeciune $\mathrm{z}$ powierzchni jednej głowy. Czworo było uszu, dwie okolice ustydliwe i tam dalej, jak sobie to każdy łatwo podług tego sam uyobrazić potrafi ${ }^{167}$.

Opowieść Arystofanesa nie była jedynym źródłem mitu Androgyne i jego późniejszych reinterpretacji. Duój-Jednia pojawiała się bowiem zawsze tam, gdzie byt utożsamiano z doskonałością, pełnią. W tym sensie androgynia upisuje się $w$ ontologię. Jak skonstatował Mircea Eliade, uszystko, co istnieje, musi być pełne, winno zatem zawierać coincidentia oppositorum na wszelkich poziomach. Znajduje to potwierdzenie w androgynii bogów, w obrzędach symbolicznej androgynizacji i w kosmogoniach, które wywodzą początek świata od kosmogonicznego jaja lub od prapełni w kształcie koła. Bóstwa androgyniczne występowały w wielu religiach (u dawnych Germanów, na Bliskim Wschodzie, w Indiach, Chinach, w Afryce, Ameryce, Melanezji, Australii; np. irański Zurwan, frygijski Agdistis), a wyrazem ich mocy tuórczej był biseksualizm. Także liczne pisma żydouskie przedstawiają Adama jako androgyna, który z prawej strony miał być mężczyzną, a z lewej - kobietą, dopóki Bóg nie rozciął go na dwie połowy ${ }^{168}$. Oto opis z egzegetycznego midrasza „Bereszit Rabba”, bez wątpienia nasuwający skojarzenia z Platońską wersją istoty androgynicznej:

Adam i Eua zostali stworzeni oduróceni plecami do siebie obejmując się ramionami: wtedy Bóg rozdzielił ich, rozcinając na dwoje jednym uderzeniem siekiery ${ }^{169}$.

Oddzielenie płci odpowiada popełnieniu grzechu pierworodnego. Pierwsi ludzie nagle uświadomili sobie suą nagość, tzn. odkryli różnice fizyczne między sobą, i zaustydzili się suej odmienności. Żeby odzyskać harmonię, męż-

${ }^{166} \mathrm{~W}$ toku opowieści Arystofanes odkrywa, że przepołowiona przez bogów istota nie musiała składać się uyłącznie z części męskiej i żeńskiej - mogła być także uformowana z części męsko-męskiej lub żeńsko-żeńskiej, a człouiek zlepiony niegdyś z osobnikiem tej samej płci ma teraz skłonności homoseksualne.

${ }^{167}$ Platon, Uczta, oprac. W. Wituicki, Warszawa 1984, s. 79.

${ }^{168}$ M. Eliade, Sacrum, mit, historia. Wybór esejów, tłum. A. Tatarkiewicz, Warszawa 1970, s. 226, 230, 231.

${ }^{169}$ Cyt. za: M. Eliade, op. cit., s. 107. 
czyzna i kobieta muszą odbudować stan jedności w wielości. W judaizmie jest to jednak wątek poboczny. Mnogość i różnorodność w obrębie Bytu-Jedni - ujmowanego w kategoriach nie tylko ludzkich, lecz również kosmicznych - była istotnym problemem głównie dla filozofii i religii indyjskiej, zułaszcza myśli zawartych w Wedach, Bramanach i Upaniszadach.

Konieczność dopełnienia człowieka widziało także chrześcijaństwo. „Nie jest dobrze, żeby mężczyzna był sam" (Rdz 2, 18) - powiedział Bóg, rozpoczynając historię ludzkości, zapisaną na pieruszych stronach Pisma Świętego.

Mit Androgyne od początku był częścią zarówno filozofii, jak i literatury. Najdoskonalszym osnutym wokół niego utworem była wydana w 1835 r. Serafita Honoré Balzaka, wywodząca się jednak nie tyle z ontogenez pierwotnych, co z teorii Swedenborga, dotyczących człowieka doskonałego.

Europejski dekadentyzm zdegradował symbol androgyna, traktując go uyłącznie jako hermafrodytę, istotę, w której obie płci koegzystują anatomicznie i fizjologicznie ${ }^{170}$. W jego kreacji podkreślano konflikt tożsamości, uynikający z niezgodności płci biologicznej i psychicznej albo wręcz przeciunie - doskonałość seksualną, nieograniczone możliwości erotyczne, jak w Pannie de Maupin T. Gautiera czy L'androgyne J. Péladana. Pomijano natomiast problem nowej śuiadomości, jaka wytwarza się w scaleniu duu płci. Źródeł takich kreacji dostarczał opowiedziany w Owidiuszowych Przemianach mit o pięknym Hermafrodycie, w którym od pierwszego wejrzenia zakochała się wodna nimfa Salmacys. Najada ujrzała młodzieńca nad jeziorem i zapragnęła go. Wyznała swą miłość, ale została odrzucona - zaustydzony Hermafrodyt zagrozil, że odejdzie. Wtedy użyła fortelu: udała, że się oddala, a gdy mężczyzna zanurzył się w wodzie, zwabiony jej świeżością i przejrzystością, uskoczyła za nim. Na własnym gruncie od razu zyskała przewagę. Objąuszy wybranka w mocnym uścisku, którego nie był w stanie zerwać, wezwała na pomoc bogów: „Niech mnie z nim, jego ze mną już nic nie rozdzieli!” $(4,382)^{171}$. Dua ciała połączyły się $w$ jedno - ni męskie, ni kobiece, ni bezpłciowe:

Jedna postać spojone ich ciała poulekła.

$[\ldots]$

Tak silnymi oboje sprzęgłszy się uploty,

Jeden kształt, lecz podwójny dwie wzięły istoty.

Nie męskie, nie kobiece rozpoznać $w$ nim ciało,

I żadne, i duojakie zarazem się stało ${ }^{172} \cdot(4,384-390)$

W wyniku tego połączenia Hermafrodyt utracił pełnię męskości, nawet jego głos „zniewieściał”. Nastąpiła synteza negatywna. Młodzieniec

\footnotetext{
${ }^{170}$ Zob. ibidem, s. 220.

${ }^{171}$ Ouidiusz, Przemiany, tłum. B. Kiciński, Kraków 2002, s. 92.

${ }^{172}$ Ibidem.
} 
nie odczuwa rozkoszy jedności, nie ma poczucia mistycznego zuiązku, jest nieszczęśliuuy i przeklina swój los. Chce pozostać mężczyzną, ale u połowie już jest kobietą. Integracja ciał nie prowadzi do unii dusz. Kobiecość narusza, zniewala i guałci męskość. A przecież bohater mitu od początku jest istotą duupłciową, na co wskazuje jego imię złożone z imion rodziców: Hermesa i Afrodyty. To imię determinuje jego los, określa przyszłość. Z drugiej strony, Hermafrodyt podśuiadomie pragnął nimfy, skoro skoczył do wody, która była jej żywiołem. Nieśuiadomie uypełnił sue przeznaczenie, zanurzył się w Innym ${ }^{173}$. Jego nowa tożsamość jest jednak pęknięta, nieokreślona, i przez to tragiczna. Rozpięty między kobiecością a męskością, młodzieniec jest tworem sztucznym, uymuszonym, nieudanym. Traci identyfikację, zamiast - jak u Platona - zyskać ją. W ten sposób historia Hermafrodyta stworzyła uzorzec dla nietypowych form tożsamości seksualnej, zuiązanych choćby z transseksualizmem czy transgresją ${ }^{174}$. Zjawisko to znane było już

${ }^{173}$ K. Mróuka, Androgyn, Szczecin 2005, s. 69.

${ }^{174}$ Literatura XIX-wieczna, głównie francuska i angielska, wykorzystała figurę androgyne do opowiadania o marginesach erotycznego pożądania, niejako czyniąc z niej kontrapunkt dla konwencjonalnych relacji heteroseksualnych. Bohaterem Panny de Maupin Gautiera (1836) jest młody poeta d'Albert, który poszukuje kochanki, jaką sobie wymarzył - idealnie pięknej na podobieństwo greckich bogiń. Nie mogąc znaleźć ideału, nauiązuje romans z Różyczką, najpowabniejszą damą z otoczenia. Ona także traktuje go jak surogat, kocha bowiem innego. Kochanków łączą więc ciała, lecz nie dusze, jak w micie o Hermafrodycie i Salmacys. Po pewnym czasie d'Albert odkrywa u sobie skłonności homoseksualne - zakochuje się w poznanym dzięki Różyczce, obdarzonym kobiecym pięknem Teodorze. Tajemniczy młodzieniec jest ucieleśnieniem ideału - istotą o poduójnej płci, mężczyzną i kobietą jednocześnie. d'Albert odkrywa, że obiekt jego miłości jest kobietą, i uyznaje swe uczucia. Magdalena de Maupin - bo to ona wędruje u przebraniu Teodora, by poznać mężczyzn, zanim odda się któremuś - składa mu u darze suą cnotę, a nad ranem uymyka się do sypialni Różyczki, jest bowiem i jej prawdziwą miłością. Kobiety romansowały jeszcze zanim w ich życiu pojawił się d'Albert. Dochodziło między nimi do intymnych zbliżeń, ale Magdalena-Teodor nie odsłoniła prawdy o suej płci. Nie straciła też pragnienia męskich pieszczot. W liście do przyjaciółki zuierza się: „Moją chimerą byłoby mieć kolejno obie płcie, aby zadowolić tę podwójną naturę. Stając się na przemian to mężczyzną, to kobietą, zachowałabym dla kochanków tkliwą omdlałość, oddanie i uległość, miękkie pieszczoty, melancholijne westchnienie, słowem, uszystko co jest we mnie z kota i z kobiety. Wobec mych kochanek byłabym przedsiębiorcza, śmiała, namiętna, buńczuczna, z kapeluszem na bakier, postawą junaka i awanturnika. $\mathrm{W}$ ten sposób cała moja natura mogłaby się uyżyć i byłabym zupełnie szczęśliwa [...]" (T. Gautier, Panna de Maupin, tłum. T. Żeleński (Boy), Warszawa 1958, s. 387). W tytułowej postaci powieści zrealizowany został ideał piękna, możliwy jedynie przez połączenie cech żeńskich i męskich. Ale odrzucenie pozorów kobiecości, w której bohaterka od dawna nie czuła się dobrze, uzbudza niepokój. Podporządkowanie ciała na poły męskiej duszy sprawia, że panna de Maupin staje się - jak Hermafrodyt - kimś nieokreślonym; ma duie płcie, a nie czuje zuiązku z żadną. Boi się kochać zaróuno mężczyzn, jak i kobiety. Dlatego u finale powieści Gautiera potajemnie wyjeżdża.

Męskość uybiera także Raula de Vènérande, arystokratka z powieści Rachilde Pan Wenus (1884). Bohaterka zakochuje się $\mathrm{w}$ znieuieściałym Jakubie Silvert, który zarabia na życie robieniem sztucznych kwiatów, i przyjmuje wobec niego rolę mężczyzny. Inicjuje zbliżenia seksualne, obdarouuje ukochanego kwiatami, zakłada męskie stroje i mówi o sobie u rodzaju męskim. Jakub ulega uspierającej go finansowo Rauli i przez bierną postawę coraz bardziej 
XIX-wiecznej myśli medycznej, która także tworzyła swój dyskurs w oparciu o dziedzictuo mitologii. Na przykład Magnus Hirschfeld, niemiecki lekarz zajmujący się problemem homoseksualizmu, na przełomie wieków uyróżnił w obrębie seksualności cztery stopnie pośrednie: hermafrodytyzm, androgynizm, metatropizm i transwestytyzm ${ }^{175}$.

Na gruncie młodopolskim największym entuzjastą mitu androgyne był Przybyszeuski. Pisarz pojmował androgynizm, zgodnie $\mathrm{z}$ ideą wyłożoną w Uczcie, jako powrót do prajedni, przywrócenie utraconej pełni metafizycznej. Terenem, na którym najpełniej rozbudował jego wersję - opartą o gnozę, kabałę i tantryzm - były poematy. Wykładem istoty i sensu mistycznego złączenia kochanków stał się przede uszystkim ostatni utwór Pentateuchu, napisany w latach 1898-1899, a zatytułowany właśnie Androgyne (wydanie książkowe 1900 r., pierwodruk niemiecki - 1906 r.).

Impulsem rozbudzającym miłość $w$ bohaterze poematu (zapewne artyście) jest przewiązany czerwoną ustążką bukiet, podarowany mu po koncercie jako dowód uznania od nieznajomej kobiety. Wyobraźnia mężczyzny nasyca kwiaty erotyzmem, co potęguje potrzebę odnalezienia ich ofiarodawczyni. Jednak kobieta bardziej niż realną osobą wydaje się efemerycznym zjawiskiem czy psychicznym konstruktem bohatera, tropiącego fantazmat ${ }^{176}$. Pożądanie i determinacja wzmocnione cierpieniem oraz

zapomina o suej męskości. Rachilde rozbija zależność między (sadystycznym) mężczyzną i męskością oraz (masochistyczną) kobietą i kobiecością, pokazując mężczyznę jako słabego i pasywnego, kobietę zaś jako silną i aktyuną.

Problem seksualnych póz, które można przybierać i odrzucać, interesował róunież Huysmansa. W powieści $N a$ wspak (1884) uwypuklił atrakcyjność seksualną uynikającą z połączenia cech obu płci. Jako jedna z kochanek diuka Jana des Esseintes'a pojawia się zuinna i muskularna cyrkówka, która podczas spektaklu jawi się bohaterowi raz jako kobieta, to znów jako mężczyzna: ,[...] była kobietą, po czym nastąpił okres wahań, kiedy sąsiadowała z androgyne, w końcu uydawała się decydować, rektyfikować, stawać się kompletnie mężczyzną" (J.-K. Huysmans, Na wspak, tłum. J. Rogoziński, Warszawa 1976, s. 153). Androgynia jest tu zatem pewną możliwością, stanem momentalnym, nieukonstytuowanym. Siła Amerykanki sprawia, że cherlawy, neurotyczny des Esseintes sam sobie wydaje się zniewieściały. Nowa znajomość stuarza mu szansę rezygnacji z męskości, stania się pasywną kobietą i zdobycia doświadczenia erotycznego, które rozproszy nudę i impotencję. Ale niedługo bawi go to rozchwianie płci. Cyrkówka okazuje się bowiem w chwilach intymnych naiuną, sentymentalną i chłodną kobietą, i ani jej w głowie okazywanie suej siły. Diuk Jan z niechęcią musi więc pourócić do zapomnianej na chuilę roli aktyunego mężczyzny.

${ }^{175}$ Hermafrodytyzm oznaczał uspółistnienie organóu płciouych odmiennych płci, androgynizm - międzypłcioue wymieszanie innych cech fizycznych. Metatropizm łączył homoseksualizm i biseksualizm, a transwestytyzm był wymieszaniem cech psychicznych właściuych każdej płci. $\mathrm{O}$ androgynii mówił u tym samym czasie Richard von Krafft-Ebing, uspomniany już profesor psychiatrii na uniwersytecie $w$ Wiedniu. Rozumiał ją jako zniewieściałość mężczyzny. Z modelu Arystofanesa czerpały także teorie dotyczące rozwoju gatunków. Darwin twierdził np., że w prymitywnych organizmach koegzystowały dwie płcie.

176 Już ten fakt pozwala się domyślać związku niemożliwego do spełnienia, będącego zjawiskiem wewnętrznym. U młodopolan spotkanie z ukochaną często było naznaczone niepeunością. „Jesteś... lecz kędy? [...] jesteś - lecz gdzie?” - zastanawia się podmiot liryczny 
tęsknotą popychają go ku snom na jawie i pełnym dramaturgii wizjom, które raz podsuwają obrazy zespolenia $\mathrm{z}$ ukochaną, to znów poszerzają przepaść między partnerami. Imaginacyjna dychotomia szarpie nerwy bohatera, stanowiąc przyczynę niemożliwej do ukojenia męki. Ale mężczyzna próbuje odnaleźć kobietę na wszystkich poziomach suego życia psychicznego: śuiadomie, błąkając się po ulicach miasta w nadziei na przypadkowe spotkanie, oraz $\mathrm{w}$ fantasmagoriach, które dają upust treściom podświadomym. W jednym ze snów jako król każe zwołać najpiękniejsze dziewice suego kraju, ale nie odnajduje pośród nich obiektu swej tęsknoty. Wreszcie gdy kupiec wlecze przed tron nagą niewolnicę, w której bohater rozpoznaje ukochaną, sen ginie. Dzikie majaki następują jednak po sobie u szaleńczym pędzie. Śniąc, że jest potężnym magiem, mężczyzna wznosi modły do Asztarte, by zesłała mu uymarzoną kobietę. Zaprzedaje się szatańskiej mocy, ale w zamian ideał się ucieleśnia - ukochana wyłania się z jego duszy i opada namiętnie na jego szyję. Jednak mimo cielesnej obecności kobieta pozostaje mało realna, jest bowiem obrazem męskich marzeń, utkanym z pragnień, oczekiwań i tęsknot pożądającego; wykreowanym $\mathrm{z}$ jego inicjatyuy i na jego podobieństwo za pomocą lustra użytego jako rekwizyt uspomagający magiczne, satanistyczne zaklęcia.

W miłości dostrzega bohater obietnicę uniebowzięcia, zapowiedź „godziny cudu" ${ }^{177}$, w której odsłonią się przed nim rozwiązania wszelkich zagadek i tajemnic bytu. Stany uduchowienia i doznania o charakterze transcendentnym są zakłócane przez wizje nasycone perwersją: mężczyzna całuje narcyzy, a oplatający je wąż z brązu przemienia się w jego oczach w ukochaną otulającą go suym ciałem. Złote węże niczym bransolety, ale i okowy szatańskiej mocy, pojawiają się jeszcze w silnie nasyconej ekspresją scenie ukrzyżowania partnerki, która z uysokości krzyża lubieżnie kusi ku sobie bohatera obietnicą rozkoszy.

Odnalazłszy się, kochankouie dostępują androgynii - łączą się fizycznie i duchowo. Akt seksualny jest komunią ciał i dusz odbudowującą pierwotną pełnię. Ale „godzina cudu” przemija i więcej nie nastąpi. Ukochana odchodzi, a mężczyzna doskonale zdaje sobie sprawę z daremności i bezsensu poszukiwań. Nie musi ich zresztą podejmować, skoro wybranka jest w nim.

W drugiej części utworu bohater udaje się do miasta, które przed tysiącem lat zbudowali jego przodkowie - do Alkazaru. W owej przestrzeni - pustej i martwej, sprawiającej ponure wrażenie wykutych w skale katakumb - ma się dokonać misterium:

u wierszu Tetmajera ([inc.] Jesteś... lecz kędy?... Poezje. Seria IV. Cyt. ug K. Tetmajer, Poezje, Warszawa 1980, s. 554).

${ }^{177} W$ godzinie cudu to tytuł pieruszej części poematu. Druga nosi tytuł (jak całość) - Androgyne. 
Tu miał według przyrzeczeń suego serca mieć tą, którą już raz posiadł, którą utracił, a na nowo miał ją odtworzyć, ulepić z brył suej najskrytszej piękności, najtajniejszego bytu swej istoty. (A 437-438)

Walka żywiołów i sił natury przygotowuje mężczyznę do mającej nastąpić epifanii. Jego dusza rozpoznaje to, co wewnętrzne, ukryte, i łączy się z duszą uszechnatury, dzięki czemu na powrót widzi ukochaną. Bardzo prawdopodobne, że obraz alkazaru (w znaczeniu zamku obronnego bądź pałacu), na którego tarasie stoi upragniona kobieta, zobaczył Przybyszeuski u Micińskiego i twórczo rozwinął $w$ myśl koncepcji androgynicznych. W poemacie Pieśń triumfującej miłości z 1902 r. znajduje się bowiem zastanawiający fragment świadczący o tym, że i Micińskiemu nieobca była myśl o ponadpłciouej jedności:

[...] Alcazar purpurowieje przepychem rodyjskich marmurów, a na tarasie w złote arabeski rzeźbionym - stoi ona -

Wyciągnęła ręce na spotkanie -

$[\ldots]$

Ja - Ty - i dusza nasza - Trójca nierozdzielna - nieskończony rozpęd miłości świetlącej się ponad chaosem niebytu - Adonai!.... ${ }^{178}$

W obu przypadkach pragnienie syntezy oznacza jednocześnie pragnienie metafizycznej głębi. Ale kobieta jest tylko treścią duszy bohatera, niezależnie od tego, jak bardzo chciałby przyoblec ją w ciało. U Przybyszeuskiego potrzeba transcendencji jest silnie skorelowana z pożądaniem seksualnym. „Odeszłam od Ciebie, boś patrząc na mnie, patrzał w Twoją własną duszę - bo jestem ciałem Tuej myśli, jestem kształtem i ciałem Tuych tęsknot, wyrazem Tuych uczuć i ruchem Tuej woli..." (A 448) - tłumaczy ukochana czy raczej imitujący ją wytwór duszy bohatera. A za chwilę błaga namiętnie: „O spłyń Tuą ręką po mej piersi, po mych biodrach, chwyć mnie $u$ ramiona, podrzuć na Twą pierś, niech włos mój grzywą się najeży w dzikich pożarach Twej krui..." (A 449). Gdy ucieleśnienie ponownie zaczyna się realizować - fantom znika. Wtedy bohater ostatecznie zdaje sobie sprawę, że to „miłość nie z tego świata” (A 452). Dlatego poutarzające się wezwania kochanki „Przyjdź, przyjdź!” odbiera jako nawoływania ku śmierci. Idzie w stronę jeziora, by dzięki samobójstuu „powrócić do uspólnego łona” (A 459), stać się jednym i niepodzielnym jako On-Ona, pojąć sens bytu.

Trudno przecenić intensywność, z jaką autor akcentuje upływ sfer podświadomych na całość organizacji psychicznej. Nie sposób odróżnić, co w życiu bohatera poematu dzieje się naprawdę, a co jest materią snu i majaków na jawie. On sam zresztą nie potrafi wyznaczyć granicy między

${ }^{178}$ T. Miciński, Pieśń triumfującej miłości, [w:] idem, Poematy proza, Krakóu 1985, s. 50. 
rzeczywistością a iluzją, między myślą a wizją, niepeuny jak Calderonouski Segismundo, czy wydarzenia wokół są praudziwym bytem, czy fantasmagorią: „Chwilami zdawało mu się, że oszalał. [...] Budził się z snu, by pogrążyć się w drugim, coraz dzikszym, coraz namiętniejszym...” (A 390). Uuzględniając karierę, jaką niewiele później marzenie senne zrobiło w psychoanalizie, nie można traktować wizji bohatera Androgyne jedynie jako płodów chorej psychiki. Upatrywać w nich należy przejawu życia duszy, odbicia dręczących pragnień, zastępczego sposobu na realizację pożądań, które wielokroć nie mieszczą się $w$ ramach społecznej akceptacji. Są informacjami przekazywanymi do świadomości z przepastnych głębin nieświadomości. Dodatkowo związek snu $\mathrm{z}$ objawieniem - duchowa iluminacja czy wizje prorocze następują często właśnie podczas snu - wzmacnia epifanijny i metafizyczny uymiar poszukiwań i dążeń bohatera.

Symbole odnoszące się do podświadomości i sugerujące osadzenie akcji w psychice postaci pojawiają się w Androgyne także na innych poziomach. Kwiaty od wielbicielki, będące katalizatorem miłosnego uniesienia, to przecież - z powodu formy - archetypowy obraz duszy ${ }^{179}$. Jako wyraz niezaspokojonych, perwersyjnych, nie do końca uświadamianych pragnień przedziwne, czarowne kuiecie „w kształt łona rozkwitających dziewic”, spoglądające „żyuymi oczyma” (A 386-387) pojawia się też jako ozdoba osobliwego pałacu u pieruszym z sennych obrazów bohatera. Z podświadomością symbolicznie wiąże się również lustro użyte przez mężczyznę w quasi-czarach, a w drugiej części utworu labirynt, po jakim błądzi on w zakamarkach tajemniczego miasta - Alkazaru.

Tak przedstawia się w skrócie treść poematu. Pora teraz zrekonstruować w oparciu o całą twórczość Przybyszeuskiego stworzoną przezeń wersję androgynizmu.

Bohaterowie utworów wprost odwołują się do mitycznej historii. Mówią o "stopieniu dwóch istot w jedno kosmiczne Ja-Ty" (W 187), o kochaniu partnera jako swej „odwiecznej przeszłości” (W 180) i ,zagubionej, oderwanej połowy” (Rae 58); uspominają czas, u którym stanowili „nierozerwalne jedno" (Rae 58). Rozbudowane monologi i dokonywane przez nich autoanalizy pokazują ich jako ludzi rozdartych, poszukujących, oderwanych od czegoś potężnego i nie do końca rozpoznanego. Mają poczucie jakiegoś pozaczasowego stanu, prapoczątku, w którym tworzyli jedność. Nie znają żadnych szczegółów dotyczących tego pierwotnego, ahistorycznego świata, ale jest on dla nich rajem utraconym. Utraconym - nie znaczy jednak straconym na zausze. $\mathrm{W}$ wypowiedziach wielokrotnie pojawia się bowiem przekonanie o wpisanej w naturę konieczności powrotu do owego prastanu.

${ }^{179}$ Zob. Kwiat [hasło], [u:] J.E. Cirlot, Stownik symboli, s. 217. 
Jak blask słońca połamany przez tysiąc szkieł, odrzucony od tysiąca zuierciadeł, chcę pourócić do pierwotnej idei, z której poustałem. (Rae 82)

Piękno, niespożyte piękno jesiennej nocy nad morzem: - to Twoja piękność pra-początku, co czas i przestrzeń i mnie i Ciebie ze siebie uyłonił, piękność przed-stuorzenia, gdyśmy oboje $\mathrm{w}$ rozkosznym spouiciu spoczywali. ( $\mathrm{Nm} \mathrm{287)}$

Już nie rozpaczał. Bo wiedział, że pójdzie do niej; połączy, zleje się z nią w odwiecznym łonie, które jego i ją porodziło. (A 459)

[...] nagle zjawiasz się, pani, dziuny praobraz mej duszy, pani, idea, którą widziałem niegdyś u innym bycie, pani, która jesteś ułaściuie całą tajemnicą mojej sztuki... (Hs I, 88)

Relacje między kobietą i mężczyzną mają charakter pełnego utożsamienia; przebiegają według równania: ty to ja, rzadziej - ja to ty.

Nie będę Cię szukał, bo mam Cię u sobie, krążysz w moich żyłach, jesteś tchnieniem mej duszy, jesteś prądem mych pragnień, jesteś czarem mych snów, jesteś Mną. (A 434)

[...] widział, jak z wolna wstępowała na taras jego pałacu - Ona, Duch święty jego bytu oduiecznego, On-Ona. (A 445)

Mimo idealistycznego charakteru koncepcji Duój-Jedni, stopienie pierwiastka męskiego i kobiecego oznacza dla bohaterów złączenie nie tylko dusz, ale i ciał. Realizuje się ono w tańcu, pocałunku i ureszcie - w akcie seksualnym:

Wpadł w wir, który go porwał. Czuł, jak się zrośli, jak ona stała się częścią jego duszy, a on wirował wokół siebie samego, sam z sobą. Nie widział jej, bo była w nim. (Hs I, 72)

Całujemy się, że tchu nam braknie, że stapiamy się ze sobą i stajemy się jedną istotą. (Rae 65)

O, upojeń godzina - godzina cudu, kiedy duie dusze $w$ jedną się zleją, dua ciała $w$ jedno się splotą... (A 422)

Zaśmiała się cicho jakąś bezmierną, obłędną rozkoszą, utuliła się u niego, objęła go rękami, tarła jedwab swych włosów o jego pierś, a potem patrzała mu długo w oczy; spłynęła cała w jego oczach. Zdało mu się, że całe jej ciało wślizgło się przez jego oczy aż na dno jego duszy; obuinęło się gorącym wężem wokół jego serca; utuliło się w każde włókno jego ciała - nie miał już jej przy sobie, była w nim, rozlała się w nim, stopiła się w jego krui, długim, przeciągłym dreszczem upojenia zbiegła jego nerwy:

Kocham Cię! Kocham! Kocham! (A 427)

W pieruszym z zacytowanych fragmentów same ruchy partnerów, nadające tańczącej parze urażenie wirującego okręgu, pozwalają u nich widzieć figurę doskonałą. Sens tej sceny nabiera uyrazistości, gdy weźmie się pod uwagę, że $w$ buddyzmie okrąg cechował mandalę, diagram poświęcony bóstwom i symbolizujący transcendencję oraz pełnię. 
Zbliżenie erotyczne jest niezbędnym warunkiem androgynii, co nie oznacza, że zawsze do androgynii prowadzi. Należy podkreślić, że zespojenie duu dusz możliwe jest „tylko z kobietą czystą, która przedtem nie kochała, której nikt nie posiady" (Ds 8). Ma to związek z pouracającą u Przybyszewskiego, opisaną wcześniej obsesją dziewictua oraz z przekonaniem, iż kobieta, świadomie czy nieśuiadomie, zausze należy do suego pieruszego kochanka (ten wymóg czystości nie dotyczył mężczyzn; bohater Androgyne, Falk czy Bielecki dostępują namiastek androgynii, mimo że mieli wiele kochanek). To pierusze zastrzeżenie. Jest i kolejne. Otóż uystępujące u Przybyszeuskiego utożsamienie Ja-Ty i On-Ona tylko po części opiera się na wzajemnym dopełnianiu się partnerów, czyli zespoleniu tego, co kobiece i męskie $\mathrm{w}$ ramach coincidentia oppositorum. Bohaterowie poszukują i pożądają najczęściej istot, które są do nich podobne i które pozwalają im odkryć w sobie głębie dotychczas nieznane i nieprzeczuwane. Mężczyzna może zbudować Dwój-Jednię tylko z konkretną kobietą, którą rozpoznaje jako „część własnej rzeczywistości weunętrznej, jako istniejący poza nim, a zarazem w nim, drugi płciouy biegun” ${ }^{180}$. Obdarza uczuciem kobietę zdolną ujawnić tajemnicze pokłady jego podświadomości.

I czemu kocham kobietę?

$[\ldots]$

W kobiecie kocham siebie, moje do najwyższego stopnia spotęgowane Ja. Moje rozdrobnione, we uszystkich kątach mózgu drzemiące stany, w jakich spoczywa najgłębsza tajemnica mojej istoty, zgromadziły się, skoncentrowały wokół tej kobiety jak opiłki żelaza wokół magnesu. [...].

I kobieta, którą kocham, to jestem Ja, moje najbardziej intymne, najwewnętrzniejsze Ja, arrière-fond mej istoty, najdalsza podstawa, Ja widziane z perspektywy lotu ptaka, Ja jako punkt centralny odbijającej płaszczyzny ${ }^{181}$.

Pouyższe słowa Przybyszeuski musiał uznać za swoje credo, skoro ogłaszał je aż trzykrotnie w różnych okresach życia - po raz pieruszy jako 24-latek u eseju o Oli Hanssonie, później we ustępie do De profundis i wreszcie pod koniec życia we uspomnieniowych Moich wspótczesnych. Traktował je jako rodzaj wykładni interpretacyjnej do zrozumienia tekstów stricte literackich. Wynika z nich, że kobieta to "wieczny sprawca miłosnego wrzenia” i „czynnik wyzwalający”. Jak pisze Manfred Schluchter, od niej idzie impuls, który seksualne „ja” mężczyzny odbiera jako miłość ${ }^{182}$.

${ }^{180}$ G. Matuszek, Między pustka transcendencii..., s. 25.

${ }^{181}$ S. Przybyszeuski, Z psychologii jednostki twórczej. II. Ola Hansson, [w:] idem, Synagoga szatana..., s. 84-85.

182 M. Schluchter, Stanislaw Przybyszewski und seine deutschsprachigen Prosawerke 1892-1899, Ludwigsburg/Württ 1969, s. 48. 
Utworzenie androgynicznego monolitu możliwe jest zatem tylko dlatego, że osoba kochająca powołała ukochaną do życia demiurgicznym gestem, wykreowała z własnych marzeń, uczuć i myśli. Bohater Wigilii wyznaje:

Moje potężne oko, oko uszechśuiatóu wyłoniło Cię z ciemności. Na moje potężne „Stań się!" przybrałaś kształty i postać. Tchnąłem na Cię Świętego Ducha mych uczuć i myśli. Byłaś głupią zabauką, a zrobiłem z Ciebie fetysza i idol święty. (W 205)

Podobne słowa wkłada Przybyszeuski u usta króla z poematu Nad morzem.

Aż wreszcie nadeszła chwila, gdy przeczute tęsknotą słowo miało stać się ciałem, wola moja ogarnęła uszechświat, ustrząsnęła nim, jakby go z posad wyruać chciała, w nocy wielkiego cudu błysnąłem jak słońcem, piorunem słowa, co śuiaty tworzyło i w proch je kruszyło, i z wielką mocą krzyknąłem: „Stań się!”

I poustałaś!

A ze źródła mej potęgi spłyuała bezgraniczna łaska w Twoją duszę, [...] aż moc Twoja mojej się zrównała. (Nm 313-314)

W omówionym wcześniej poemacie Androgyne bohater podczas praktyk satanistycznych, zmierzających do ucieleśnienia kochanki, ustawia naprzeciu siebie lustro. Właśnie u zwierciadle dzięki ustawiennictuu Asztarte pojawia się postać ukochanej, ożywiona następnie energią pioruna uderzającego w taflę szkła. Kobieta zostaje stuorzona na wzór mężczyzny, jako jego odbicie. Zabieg ten w nieco zmodyfikowanej formie powtórzył Przybyszewski u powieści Homo sapiens: Falkowi podczas pieruszego spotkania z Izą „zdawało się, że wkoło niego rozciąga się gładka zwierciadlana płaszczyzna” (Hs I, 19), a u przywołanej już scenie tańca miał „uczucie czegoś niezmiernie gładkiego, chłodzącego - jakiejś miękkiej, szklistej powierzchni” (Hs I, 72). Bohater Przybyszeuskiego przegląda się w kochance niczym w lustrze. Nie widzi jej samej jako indywidualności. Potrzebuje jej uyłącznie po to, by zobaczyć „idealne Ja”. Zjauisko to ma wiele uspólnego z wypracowaną przez Jacques'a Lacana, francuskiego psychoanalityka, koncepcją „stadium lustra”. Mówi ona, że najbardziej podstawouym ludzkim dążeniem jest narcystyczna identyfikacja $\mathrm{z}$ własnym lustrzanym odbiciem bądź z obrazem osoby najbliższej, traktowanym jako organiczna część „Ja”183. Obiekt uczuć bohater wybiera narcystycznie - według wzoru własnej osoby, na podstawie podobieństwa partnerki do niego samego. Nie identyfikuje siebie z ukochaną (identyfikacja heteropatyczna lub dośrodkowa), lecz identyfikuje ukochaną ze sobą (identyfikacja idiopatyczna lub odśrodkowa). Przypisuje jej nie tylko

${ }^{183}$ Więcej o „stadium lustra” i powiązaniu go z twórczością Przybyszewskiego zob. P. Dybel, Urwane ścieżki..., s. 80. 
pewne cechy własne, ale wręcz całościowe podobieństwo do siebie samego. To podobieństwo nie oznacza oczywiście identyczności podmiotu i obiektu jako indywidualnych jednostek, ale „odnosi się do czegoś uspólnego, pozostającego w nieświadomości”" ${ }^{184}$. Dowodzą tego sceny, w których kobieta i mężczyzna doznają olśnienia, rozpoznając u widzianej po raz pieruszy osobie kogoś znanego. Zachodzi tu rodzaj miłosnego déjà vu $u^{185}$.

Wyłoniła się twarz dzieuczęcia: jasny dźwięk, jasne odbicie bladej gwiazdy u rozkipieniu ciemnych fal - nie widział jej nigdy, ale znał ją, znał... (A 383)

- mówi narrator o bohaterze „Androgyne.

To uszystko takie dziune... Dziune, że Mikita jest moim przyjacielem, że pani jest jego narzeczoną... dziwne jest uczucie, jakbym już znał panią od tysiąca lat... (Hs I, 59)

- Falk dzieli się swoimi spostrzeżeniami z Izą.

Mężczyzna pragnie złączenia nie $\mathrm{z}$ istotą odmienną, ale $\mathrm{z}$ taką, którą może zinterioryzować, która stanie się nim. Przybyszeuski dał temu uyraz już u swoim pierwszym utworze, uywodzącym początek uszelkiego życia z energii płciowej. Potwierdza to następujący fragment z Requiem aeternam:

Zausze i wiecznie tęskniłem za Tobą, za tą chwilą, w której byliśmy jedno, nierozerualnie jedno, tęskniłem za tą chwilą, kiedym Cię ze siebie wyłonił, kiedy kształty mego ducha układały się w linie Twego ciała, drgania mych nerwów lały w Cię życie, kiedy stałaś się istotą mego ducha, jego treścią w ciało przeistoczoną. (Rae 58)

Skojarzenia z opracowaną przez Junga projekcją archetypu animy nasuwają się jako oczywiste. Ukryty u mężczyźnie pierwiastek żeński ujaunia się, gdy napotka odpowiadającą mu kobietę ${ }^{186}$. Jak u nieświadomości męskiej tkwi anima, czyli archetyp kobiety, podobnie każda kobieta nosi w sobie animusa, czyli archetyp mężczyzny. Zatem każdy człowiek jest istotą męsko-żeńską, pełnią, androgynem. Ale tylko wybrany partner odpowiada nieuświadomionemu wyobrażeniu. Bliski tego poglądu był uspółczesny Przybyszeuskiemu Otto Weininger - uznający, że każdy człowiek jest mieszaniną kobiecości i męskości - gdy mówił, że bardziej „kobieca” kobieta

${ }^{184}$ J. Laplanche, J. Pontalis, Stownik psychoanalizy, tłum. E. Modzeleuska i E. Wojciechouska, Warszawa 1996, s. 78-79.

${ }^{185}$ Por. G. Borkowska, Płeć jako skaza: Przybyszewski i Natkowska, [w:] Nowa świadomość ptci w modernizmie. Studia spod znaku gender w kulturze polskiej i rosyjskiej u schytku stulecia, red. G. Ritz et al., Kraków 2000, s. 81.

${ }^{186}$ Związek androgynii u ujęciu Przybyszewskiego z koncepcją Junga zauważył już E. Boniecki, op. cit., s. 100 . 
uybiera raczej „męskiego” mężczyznę, „kobiecy” mężczyzna szuka „męskiej” kobiety, by idealnie uzupełniali się jako para ${ }^{187}$. Po odkryciach Junga relacja kobiecość - męskość ostatecznie stała się problemem psychologii. Tak pisze o niej Kazimierz Mrówka, badający związki między trzema mitami androgyne a ich późniejszymi opracowaniami literackimi:

Z punktu widzenia psychologii głębi jesteśmy istotami podwójnymi, androgynicznymi. Gdybym był tylko mężczyzną, to wówczas prawdopodobnie każda napotkana przeze mnie kobieta byłaby dla mnie absolutnym in n y m, wzbudzającym strach i przerażenie. Kobiecość, którą złożyła we mnie nieświadomość, przygotouuje mnie na spotkanie z konkretną, fizyczną, a więc niezależną ode mnie kobietą. [...] chociaż archetypy pochodzą ze sfery nieśuiadomości zbiorowej, to owo zbiorowe dziedzictwo przejawia się w nieświadomości indywidualnej każdego człowieka. Gdyby tak nie było, to musiałbym zakochać się w każdej napotkanej kobiecie [podkr. - K.M.] $]^{188}$.

Erotyka utożsamiona została z kreacją i autokreacją. Ja nie tylko tworzy Ty, ale samo zyskuje nową tożsamość, gdy rozpoznaje $w$ Ty realizację swych marzeń. Dlatego pojawiające się u Przybyszewskiego lustro to nie tylko znak pychy, próżności i pożądania, ale też filozoficzny symbol samopoznania. Miłość jest aktem budowania tożsamości. Wojciech Gutouski zauważył, że kreacja Dwój-Jedni nie polega wyłącznie na odtworzeniu uprzednio istniejącej całości. Androgynizacja prowadzi do identyfikacji „z-innym-w-sobie”, a jednocześnie do samorealizacji podmiotu, w wyniku czego powstaje nowy, integralny byt ${ }^{189}$.

Tu dochodzimy do sedna tego procesu. Jego sens polega na wyjściu poza samego siebie, poza perspektywę antropologiczną; na przekroczeniu uwikłanej $w$ historię sytuacji jednostkowej i odzyskaniu stanu pierwotnego - ponadludzkiego i ponadhistorycznego - który jest źródłem mocy i świętości. We uspółżyciu seksualnym osoba spotyka Innego i oboje mają szansę przekroczenia siebie. Wykroczenie - poprzez jedność z odmienną płcią - poza przeżycie osobiste i bezpośrednie stwarza możliwość zyskania perspektywy transsubiektywnej, a tym samym pozwala osiągnąć poznanie metafizycz$\mathrm{ne}^{190}$. Antycypowana pod koniec XIX w. kategoria Innego w nieuchronny sposób łączy Przybyszeuskiego z Lévinasem. Według autora Całości i nieskończoności, pragnienie metafizyczne to także niezaspokojona potrzeba Ja, prowokująca chęć poznania. Poszukiwanie niewiadomego oznacza zurot w kierunku Innego, którym staje się dla nas drugi człowiek. Warunkiem przekroczenia granicy między wewnętrznym i zewnętrznym jest wystąpienie inności, możliue na przykład u relacji erotycznej. Tyle że u Lévinasa miłość

${ }^{187}$ Zob. G. Kunigiel, Otto Weininger - geniusz czy szarlatan? [ustęp], [w:] O. Weininger, op. cit., Warszawa 1994, s. 12.

${ }^{188}$ K. Mróuka, Androgyn, s. 32-33.

${ }^{189}$ W. Gutouski, Nagie dusze..., s. 220.

${ }^{190}$ Zob. M. Eliade, op. cit., s. 216. 
utrzymuje inność, nie dąży - jak u Przybyszewskiego - do bezwarunkowej integracji, do stopienia u całość. Prowadzi do konfrontacji i oswaja obce, ale jest bezinteresowna i pozwala na zatrzymanie własnej tożsamości. Inny nie jest przedmiotem, który staje się mną, lecz zachouuje swą autonomię i tajemnicę ${ }^{191}$. Ale podobnie jak w myśli polskiego pisarza, twarz Innego to okno na Absolut i droga do poznania nieskończoności. W śuiadomości bohaterów Przybyszeuskiego owo pragnienie poznania, dotarcia do tajemnicy, do Absolutu, do zasady bytu jest zaś ściśle związane z ideą androgynizmu, stanowi cel połączenia płci.

Poza zrozumieniem istoty egzystencji osiągnięcie Jedni pozwalało „dotrzeć do ostatnich celóu sztuki” (W 187), ponieważ tęsknota za pełnią uruchamiała wyobraźnię, potęgując możliwości kreacyjne. Maria Podraza-Kwiatkouska zauważyła, że do jedności prowadzi tu ekstaza o charakterze dionizyjskim. Przybyszeuski inspirował się jej zdaniem Narodzinami tragedii Nietzschego, który ten typ ekstazy przeciustawiał biernemu, nirwanicznemu, typowemu dla poglądów Schopenhauera poddaniu się nastrojowi jedni (nastrój taki sugerują obrazy rozpłynięcia się $u$ naturze lub we uszechbycie) ${ }^{192}$.

Prapoczątek, rzeczywistość ostateczną i niepodzielną Przybyszewski łączy z boskością, jak zostało uspomniane u podrozdziale pośuięconym duszy i jej pochodzeniu. Po powrocie do uspólnego źródła On-Ona

będzie Bogiem uszechjedynym, znowu Bogiem, co tu na ziemi rozłamał się w kawałki i cząsteczki,

odsłonią mu się niepojęte tajemnice, rozwiążą się uszystkie cele i przyczyny bytu,

i zakróluje nad wszelką ziemią i wszem stworzeniem. (A 460)

Można w tym poglądzie odnaleźć elementy uielu tradycji, ponieważ biseksualność jako cecha bóstwa oznaczająca jego twórczą moc była często przyjmowana przez religie pierwotne. Bardziej zasadne wydaje się jednak $w$ tym miejscu odwołanie do elementów gnostycznych inspirowanych filozofią Plotyna. Wedle nich dusze ludzkie przed wyłonieniem się świata bytowały jako idee Boże i posiadały wówczas pełnię wiedzy, utraconą następnie w egzystencji cielesnej ${ }^{193}$. Interesująca jest $\mathrm{u}$ tym kontekście także gnoza początków chrześcijaństwa. Według Jana Szkota Eriugeny podział substancji rozpoczął się już w Bogu, aż stopniowo ogarnął to, co męskie i żeńskie w człowieku.

${ }^{191}$ Filozof definiuje: „Inny bouiem to ktoś, kto nie jest tożsamy ze mną, ktoś na zeunątrz mnie, transcendentny, kogo objąć i u pełni zrozumieć nie jestem w stanie, lecz z nim mogę nawiązać kontakt" (E. Lévinas, Całość i nieskończoność. Eseje o zewnętrzności, tłum. M. Kowalska, Warszawa 2002, s. 14).

${ }^{192}$ M. Podraza-Kuiatkouska, Wolność i transcendencja, s. 76-77.

${ }^{193}$ Wspomniała o tym związku B. Wojnouska, „Nad morzem” Stanisława Przybyszewskiego..., s. 123. 
Zatem proces ponownego złączenia substancji musi zacząć się od człouieka, a skończyć na wyższych płaszczyznach istnienia, aż po Boga, który jest uszystkim i Jednią ${ }^{194}$. Pisma żydouskie nawet $\mathrm{w}$ Bogu widziały istotę androgyniczną, skoro bowiem - jak można czytać u przypomnianym ucześniej „Bereszit Rabba" - Adam i Eua zostali stworzeni jako jedno, a przy tym na obraz i podobieństwo Boga, to i Bóg musi mieć naturę androgyniczną.

W gnostycznej Ewangelii według Tomasza, która poustała między 100 a 150 r. naszej ery, ale nie weszła w skład Nowego Testamentu, sam Jezus mówi o zbawieniu poprzez zniesienie uszelkich różnic, w tym poprzez połączenie płci. Zuraca się do suych uczniów:

[...] jeśli macie zuyczaj czynić dua jednością i stronę wewnętrzną czynić tak, jak stronę zewnętrzną, a stronę zeunętrzną tak, jak weunętrzną, stronę górną jak stronę dolną, i jeśli macie zuyczaj czynić to, co męskie i żeńskie jednością, aby to, co jest męskie, nie było męskim, a to, co jest żeńskie nie było żeńskim [...] - utedy wejdziecie do królestua ${ }^{195}$.

Rozdzielenie płci i potem ponowne ich zjednoczenie to fazy w porządku kosmicznym. Sam człouiek zresztą - jak zostało wykazane - jest częścią bytu u szerokim rozumieniu (wynika to $\mathrm{z}$ wyobrażenia początku śuiata jako uszechcałości, funkcjonującego we wszystkich bodaj tradycyjnych mitologiach). Jego dusza nosi pamięć poprzednich wcieleń, dzięki czemu zyskuje zdolność poznania i sięgania transcendencji. Spoiwem między kosmosem (Absolutem) a człowiekiem jest nieświadomość. Ową jedność ze światem uyrażała znana w modernizmie wedyjska formuła tat twam asi ${ }^{196}$, czyli „uszystko to jesteś ty”. Wskazuje ona na fakt, że osobowe ja (Atman) jest $\mathrm{w}$ istocie tym samym co zasada świata (Brahman). W VI w. p.n.e. podobna koncepcja narodziła się w Chinach. Kosmos opisano wówczas jako jedność Yin - siły żeńskiej, mrocznej, negatywnej i słabej - oraz Yang, siły męskiej, pozytywnej, twórczej. Siły te są nierozerwalnie połączone, a jednak krańcowo odmienne; łączą sprzeczności w jedność, czego wyrazem jest graficzny znak nieskończoności, zamknięty w figurze doskonałej - okręgu.

Powiązanie istoty ludzkiej z uszechbytem można śledzić w trzeciej części (Przybyszeuski nazywa je rapsodami) poematu prozą Nad morzem, gdzie

${ }^{194}$ M. Eliade, op. cit., s. 106-107.

${ }^{195}$ Ewangelia wedtug Tomasza, [w:] Apokryfy Nowego Testamentu, t. 1, red. M. Starowieyski, Lublin 1986, s. 126. Ronald Rolheiser, uspółczesny teolog katolicki, podaje następującą definicję: „Seksualność to święta energia dana nam przez Boga, doświadczana u każdej komórce naszego ciała jako wezwanie do przekraczania naszej niekompletności, popchnięcie ku jedności i ku temu, co poza nami. To wezwanie do celebracji, do dawania i przyjmowania radości, do znalezienia drogi pourotnej do ogrodu Edenu" (R. Rolheiser, The Holy Longing, New York 1999, s. 196). Seksualność jest Bożą energią wewnątrz człowieka, zatem seks powinien prowadzić do dośuiadczania Boga.

${ }^{196}$ Odwoływała się do niej G. Matuszek w art. Seksualizm i androgynizm, s. 111. 
jedność Ja-Ty została poszerzona do jedności pierwiastka męskiego i żeńskiego z elementem kosmicznym. W tej fantazji poetyckiej, którą za Gabrielą Matuszek można uznać za sen na jawie wyrażający nieświadome treści psychiki bohatera-narratora ${ }^{197}$, mówiące „ja” oddaje zazdrosnemu morzu suą ukochaną. Kobieta rzuca się w odmęty, uspokajając spienione fale. Jednak wbrew pozorom żywioł spaja kochanków „ślubnym pierścieniem”. Serce Oblubienicy jest bowiem sercem morza, morze zaś jest duszą Oblubieńca. Oblubienica, rzucając się $w$ wodę, potwierdza u sobie pierwiastek kobiecy, a zarazem łączy się z Oblubieńcem. Jak zauważa Wojciech Gutouski, staje się jednocześnie sobą-nim i centrum żywiołowego istnienia ${ }^{198}$. Fragment ten można uznać za ilustrację obecności sił animy w mężczyźnie i animusa w kobiecie. Morze, a więc dusza mężczyzny, byłoby odpowiednikiem nieśuiadomości, ukrytego aspektu psychiki. Sercem ożywiającym morze-duszę jest zaś upisująca się u męską nieśuiadomość kobieta. Integracja poziomów śuiadomości i nieświadomości przypomina tu opisany przez Junga proces indywiduacji. Jak w pieruszej części poematu król krainy słońca zyskuje kontakt z ułasną nieświadomością dzięki niewolnicy ze świata mroku, podobnie $w$ ostatniej bohater dotyka transcendencji poprzez utożsamienie Ja-Ty-morze.

Synteza trzech elementów zostaje zobrazowana w finale poematu przez połączenie różnych ontologicznie bytów. Łódź, w której płynie On, przemienia się $\mathrm{w}$ ptaka i razem $\mathrm{z}$ morzem unosi mężczyznę do góry. Wodny żywioł, będący podstawą jedności, wynosi zintegrowaną kobiecość i męskość poza ograniczenia. Wzbicie się ponad obłoki symbolizuje duchową i twórczą swobodę, ale przede uszystkim możliwość zbliżenia się do sfery transcendencji $\mathrm{w}$ akcie androgynizacji ${ }^{199}$.

Istota rzeczy, głębie istnienia nie zostają jednak w utworach Przybyszewskiego odkryte, choć zakończenie poematu Nad morzem stanowi pewien wyjątek. Pojawiają się raczej marzenia o pełni, a nie zapis jej realizacji. Bohaterowie jedynie doznają stanów, które mogą prowadzić do poznania, a których bez udziału drugiej istoty nigdy by nie doświadczyli.

Maria Podraza-Kwiatkouska dostrzegła, że ówcześni krytycy i literaci (róunież Przybyszewski) unikali czasownika „poznawać”, stosowanego w pozytywizmie $u$ dyskursie naukowym. W kontekście zagadki bytu używali moderniści określeń: docierać, przenikać, wnikać, obejmować, odsłonić, odkrywać itp. ${ }^{200}$ Wyrażają one fragmentaryczność i niepewność każdego ludzkiego poznania. Bohaterowie dzieł Przybyszeuskiego nie są bowiem

\footnotetext{
${ }^{197}$ G. Matuszek, Wstep [w:] S. Przybyszeuski, Poematy proza, s. 22.

${ }^{198}$ W. Gutouski, Nagie dusze..., s. 259-260.

${ }^{199}$ Zob. ibidem, s. 262-263.

${ }^{200}$ Zob. M. Podraza-Kuiatkouska, Wolność $i$ transcendencja, s. 86.
} 
w stanie przeniknąć sfery transcendencji i rozszyfrować tajemnicy pełni. Dlaczego? Ponieważ aspekt instynktowo-cielesny definitywnie wyklucza samą możliwość autentycznej konsolidacji płci, zupełnej odbudowy pierwotnej unii. Akt seksualny nie prowadzi do prajedni, ponieważ okazuje się wyrazem sił natury i dewaluuje ethos. Na takim ujęciu zaważyły zapewne silne wpływy nurtów manichejsko-gnostyckich, traktujących genitalność w sposób podejrzliwy i pejoratywny. Upatrywanie w cielesności siedliska grzechu i jej deprecjonowanie utrualało wizję małżeństwa jako instytucji służącej uyłącznie przedłużeniu gatunku i ujmującej w społeczne karby ludzką słabość do seksu. Dlatego bohater Requiem aeternam wyśmiewa pospolitość linii, w jaką układa się w pożądaniu ciało kochanki:

Ssię Tuoją duszę - usysam ją w siebie i w tej spójności dusz i ciał, w tym stopieniu się mego bytu z Twoim, w tym uzajemnym przenikaniu się naszych uczuć, myśli i pragnień, w tej nadludzkiej, bezwzględnej, niebosięgłej wolności płciowej, co pragnie nowej przyszłości i nieśmiertelności, pochuyciłem drżącymi, dyszącymi palcami to, czegom dotychczas schuycić nie mógł.

Ha, ha, ha, ha...

Znikło, rozbiegło, rozprysło się! (Rae 66; podkr. K.B.)

Bliskość wiodąca przez seks do mistycznego przeżycia jedności jest chwilowa i iluzoryczna. Pozostawia niedosyt, nadzieję na poutórzenie niezuykłej chwili i jednocześnie upokorzenie, za które mężczyzna wini kobietę. Potrzeba niszczenia i bycia niszczonym przeszkadza osiągnięciu jedności. Kochanki - autonomicznej istoty - nie da się uformować na miarę męskich pragnień i stąd biorą się prezentowane przez bohaterów postawy agresywno-destrukcyjne. Ideał Androgyne, mający rozwiązać młodopolski problem walki płci i mizoginizmu, okazał się niemożliwy do zrealizowania u zuykłym świecie. Stało się tak, ponieważ kobiecość nie zyskała u Przybyszewskiego praw takich samych jak męskość, a filozofia posiadania - jak pisze Gabriela Matuszek - zastąpiła filozofię spotkania ${ }^{201}$.

Niemożności stworzenia Dwój-Jedni upatrywać należy również w przeszkodach zeunętrznych, głównie w prawach społecznych i moralnych, które potępiają na przykład związki cudzołożne i kazirodcze (z tym ostatnim mamy do czynienia choćby u De profundis). Natomiast klęskę bohaterów Nad morzem w tworzeniu androgynicznej jedności Wojciech Gutouski widzi u nieumiejętności pogodzenia świadomości, reprezentowanej przez królestuo słońca, i nieśuiadomości, którą symbolizuje królestwo cieni, a także w miotaniu się pomiędzy uległością a dominacją ${ }^{202}$.

\footnotetext{
${ }^{201}$ G. Matuszek, Między pustka..., s. 25.

${ }^{202}$ Zob. W. Gutouski, Nagie dusze..., s. 251.
} 
Bohaterowie Przybyszewskiego nie wyrzekają się jednak nadziei zjednoczenia. Jego realizacji spodziewają się nadal, ale po śmierci, gdy pourócą do prapoczątku, z którego się wyłonili. I tak, bohater Androgyne - zaznauszy chwilowej jedni i pragnący jej powtórzenia - odpowiada na wezwania wyimaginowanej kochanki samobójstwem w jeziorze. Podmiot Requiem aeternam, zdegustowany cielesnością, dostrzegając narzędzie chuci zarówno w swej kochance, jak i w sobie, zamierza zakończyć życie strzałem z rewolweru.

[...] miałaś zebrać i skupić moje najtajniejsze siły płciowe i spotęgować je w pragnieniu nowej przyszłości -

$[\ldots]$

Tego uszystkiego nie zdołałaś i dusza ma Cię odtrąciła (Rae 94)

- monologuje z pretensją. Ale granica życia doczesnego pozwala wyzwolić się od ograniczeń ciała i otwiera nowe perspektywy, do których nie stosują się niesprzyjające połączeniu ziemskie warunki. A to zmienia optykę.

Ale teraz: $\mathrm{w}$ tej wielkiej chuili, w której się może z Tobą połączę i u jedno zleję,

$[\ldots]$

teraz daję $\mathrm{Ci}$ moją duszę z powrotem.

Ty moja ukochana, oblubienico śmierci, Ty ukochana całą bezgraniczną głębią mej pustki.

Słyszę coś, co jest głębokie jak śuiat, ciemne jak noc, a panuje ponad uszelkim bytem.

To tęsknota za tą syntezą, której rozkosze wywyższyły mnie nad uszystkich ludzi - syntezą, którą na próżno przez ciebie osiągnąć pragnąłem.

I weź, weź moją duszę, niech się rozleje w kształtach Twego ducha i pouróci razem do praidei, z której Ja Ciebie stworzyłem. (Rae 95)

Weiningera rozczarowanie biologizmem człowieczej natury doprowadziło do programowego postulatu przezwyciężenia własnej seksualności i rezygnacji z obcowania cielesnego. Według niego mężczyzna ulegający pożądaniu i kuszony przez kobietę (jako istotę wyłącznie seksualną) daje się odciągać od życia społecznego i politycznego, upada moralnie i zaniedbuje rozwój duchowy. $\mathrm{Z}$ chwilą, gdyby poustrzymał żądze i zanegował instynkt płciowy, nastąpiłoby zwycięstwo ducha i kultury nad złem i naturą, a kobieta przestałaby być potrzebna, „musiałaby umrzeć”. Ostateczna konkluzja jest okrutna: „Kobieta istnieje tylko poprzez upadek mężczyzny”, a emancypacja powinna polegać nie na uyzwoleniu spod męskiego jarzma, lecz ucieczce od kobiecości, której cechą konstytutyuną jest godny potępienia popęd płciouy ${ }^{203}$. Przybyszeuski, choć także zawiedziony barierami

${ }^{203}$ Mężczyzna musi się zmagać nie tylko z kobietami w swoim otoczeniu, ale także z pierwiastkami kobiecymi u sobie samym, zgodnie z tezą Weiningera, że nie ma człowieka, który reprezentowałby płeć czystą. 
stawianymi przez biologię, a dobitnie i boleśnie uśuiadamianymi mężczyźnie przez kobietę, u przeciuieństuie do Weiningera nie odrzuca erotycznego zbliżenia, nie dezawuuje płciowości i nie zaprzecza roli chuci ${ }^{204}$. W doznaniu seksualnym nie przestaje widzieć elementu metafizycznego zgłębiania tajemnic bytu. Niewątpliwy tragizm wynikający z dośuiadczania płciowości przełamuje konstruując ułasną wersję mitu Androgyne. Mitu, który jest marzeniem o uyzwoleniu od ograniczeń ontologicznych i poznawczych, który pozwala oswoić lęk przed siłą gatunku i materii, a jednocześnie interpretuje człowieka jako część natury, rozumianej jednak nie jako siła determinująca, lecz twórcza.

Androgynia na pourót obecna u myśli europejskich modernistów, pojmowana idealistycznie i metafizycznie, to zagadnienie bogate $w$ konteksty i zasługujące na odrębne studium, uwzględniające niezwykle interesujące teorie Jakuba Boehmego, Franza von Baadera czy Włodzimierza Sołowjowa, autora artykułów pisanych w latach 1892-1894 i wydanych pod uspólnym tytułem Sens mitośc $i^{205}$. Pod kątem problematyki Duój-Jedni warto by przeanalizować chociażby romans Hanny Orlicz-Garlikouskiej Misterium, liryki Tetmajera oraz jego Otchłań, prozę Marii Komornickiej czy dzieła Antoniego Szandlerouskiego, który samym suoim życiem łączył inicjację religijną i miłosną ${ }^{206}$.

Nie uszyscy uspółcześni chcieli uszakże docenić uzniosłość tego mitu. Andrzej Niemojewski w satyrycznych Listach człowieka szalonego (1899) prezentował ideę androgyne jako zasłonę dla zuyczajnego pożądania. W krótkiej opowieści (szkatułkowo zamkniętej w ramach opowieści większej) wyraźnie nawiązał scenerią i schematem fabularnym do Nad morzem. Bohaterem tekstu uczynił księcia, który dzięki „wniknięciu w siebie” widzi ukochaną w uyłaniającym się z morza słońcu. Ona - „dusza, prabyt, absolut, kobieta" - chyli się $w$ jego spragnione rozkoszy ramiona i... na tym proces androgynizacji się kończy.

${ }^{204}$ Zob. W. Gutouski, Konstelacja Przybyszewskiego, Toruń 2008 (w zamieszczonym w tomie szkicu Stanisław Przybyszewski i Otto Weininger - dwie metafizyki ptci badacz uskazuje wiele więcej zbieżnych i rozbieżnych punktów obu koncepcji).

${ }^{205}$ Sołoujow - co ciekawe - włączył Miłość-Erosa u obręb myśli chrześcijańskiej, a teorię androgynizmu wiązał z nauką o Sofii jako wiecznej kobiecości. Jego zdaniem Eros ma służyć przebóstuieniu i unieśmiertelnieniu kochających się osób. Ostatecznym celem miłości jest bowiem przywrócenie w człowieku obrazu Boga. Gloryfikował zbliżenie erotyczne, uznając je za siłę zdolną doprowadzić do integracji odmiennych płci. Podobnie jak Przybyszeuski, był przekonany o konieczności uduchouienia miłości erotycznej, a androgynię pojmował szeroko jako jedność z innym człowiekiem, światem przyrody i kosmosem. Duój-Jednia w uydaniu Przybyszeuskiego wykazuje zbieżności także z myślą innego rosyjskiego symbolisty - Andrieja Biełego. Otóż bohaterowie Biełego zakochani są nie tyle w realnych kobietach, co w swoich subiektywnych wizjach, w kawałku siebie. Swoje ideały weunętrznej kobiety projektują tylko na obiekty ze świata realnego.

${ }^{206}$ Jego twórczości poświęcił jeden z rozdziałów Wojciech Gutouski u swojej znakomitej monografii mitóu miłości. 
Swoistą repliką na poemat Przybyszeuskiego było opublikowane w $1903 \mathrm{r}$. opowiadanie Prusa Ze wspomnień cyklisty. Jego bohater, trzydziestoletni urzędnik Banku Kredytowego w Warszawie Anastazy Fitulski, nadmiernie fantazjuje, zaspokajając w wyobraźni niespełnione pragnienia, a potrzebę kochania przenosi na coraz to inne obiekty. Prus sprowadza metafizykę do erotomanii; przekornie sugeruje, że androgyne składa się z więcej niż dwóch połówek ${ }^{207}$ :

Kto zresztą wie, czy u przedbytowej krainie owa doskonała istota, zuana przez poetów „androgyne”, składa się nie z duu, lecz z kilku dusz ludzkich: jednej męskiej i duu lub więcej kobiecych? ${ }^{208}$

Fin de siècle zainicjował interpretowanie figury androgyne jako objawu sublimacji, narcystycznego bądź biernego homoseksualizmu, zaburzonej identyfikacji płciowej ${ }^{209}$. Na tym tle propozycja Przybyszeuskiego, odwołująca się do Platońskiego rozumienia androgyne jako ekspresji całości i boskiej doskonałości, jawi się jako wyjątkowo oryginalna. W ujęciu autora Śniegu miłość ma odkupiającą moc, zdolną zjednoczyć rozdzieloną parę. Mit o Androgyne wiąże się zaś z ubolewaniem nad stratą utraconej połowy, tęsknotą za pojednaniem i zespoleniem, a więc i z melancholią, której przyczyny Freud dostrzegł w nieuświadamianej sobie utracie obiektu miłości (studium Żałoba i melancholia z 1917 r.). Platońska opowieść pozwalałaby więc uyjaśnić melancholiczne usposobienie bohaterów Przybyszeuskiego, żyjących u ustawicznym poczuciu braku, cierpiących z nieokreślonego bliżej powodu i kontemplujących siebie zamiast zwrócić się do świata.

\section{Miłość a moralność}

Tragedia człouieka polega u Przybyszeuskiego na tym, że chociaż nie ma on upływu na swoje czyny (determinuje je natura i los), ponosi ich etyczne konsekwencje. Naprzeciu chuci i siły przeznaczenia zausze staje zmysł moralny jednostki i moralność społeczna, które bohaterowie pogwałcają, ulegając instynktom i dążąc do osobistego szczęścia.

\footnotetext{
${ }^{207}$ Zob. esej na ten temat: J. Tynecki, Eros rozczłonkowany (albo Prus wobec Androgyne); [w:] idem, Światopogląd pozytywizmu. Wybór pism, Łódź 1996, s. 249-269.

${ }^{208}$ B. Prus, Ze wspomnień cyklisty, [w:] idem, Dzieła, red. Z. Szueykouski, Warszawa 1948 , t. 24 , s. 305.

${ }^{209}$ Potwierdzenie tej tezy znaleźć można u interesującej publikacji brytyjskiej literaturoznauczyni Tracy Hargreaves (T. Hargreaves, Androgyny in Modern Literature, New York 2005).
} 
Przybyszeuski - za Nietzschem - próbował odrzucić moralność, rozumianą jako konwencje, prawa i zakazy przygniatające indywidualność, jako „instynkt stadny” w jednostce, służący zachowaniu społeczności ${ }^{210}$. Ale jego bohaterowie nie mogą się od niej uwolnić. Nadczłowiek Nietzschego świadomie uykracza poza moralność, staje się amoralny. Bohaterowie Przybyszeuskiego zostali pozbawieni wolnej woli, ale amoralni nie są. Więcej - jaskrawa świadomość wagi popełnianych czynów nadaje im rys tragizmu. Ten determinizm etyczny, stojący u sprzeczności z woluntaryzmem Nietzschego, dobitnie dowodzi, że autor Śniegu nie akceptował idei nadczłowieka ${ }^{211}$.

Konflikt między ,ja” wewnętrznym a ,ja” zbiorowym daje się zaobserwować szczególnie $\mathrm{w}$ dramatach i powieściach, pozwalających autorowi rozsnuć szkicową choćby panoramę społeczną. Szerokiego tła Przybyszeuski, uróg powieści typu balzakouskiego i stenhalouskiego, nie odmalowywał, nie uznając roli utworu jako „zwierciadła przechadzającego się po gościńcu". Niemniej do nieszczęścia często prowadzą u niego wąskie socjologiczne ramy przewidziane dla XIX-wiecznej miłości. Taka motywacja tragizmu przydaje utworom charakteru melodramatycznego. Nie można zaprzeczyć, że Przybyszeuski „niebezpiecznie balansował między tragizmem metafizyki płci a banalnością trójkąta małżeńskiego" ${ }^{212}$, skoro najczęstszym motywem, poprzez który realizował swe koncepcje, jest zdrada. Interesowała ona pisarza już u początku drogi twórczej, gdy w 1894 r. pracował nad jednym z pierwszych poematów prozą $-Z$ cyklu Wigilii. To w nim właśnie - jako tło emocjonalne dla uczuć zdradzonego przez ukochaną bohatera - zamieścił drastyczną przypowieść o bocianich samcach rozszarpujących konkurentów niewiernej samicy.

Chronologia literackich zdrad Przybyszewskiego wiedzie aż do roku 1927, a więc roku śmierci pisarza, kiedy to na deskach teatrów w Warszawie i Łodzi wystawiono Mściciela. Bohaterka tego ostatniego ogłoszonego w całości dramatu młodopolskiego twórcy oddaje się zakochanemu w niej Orzelskiemu w akcie zemsty na Jerzym, który - jako mężczyzna żonaty - odrzucił niegdyś jej miłość, obawiając się plotek i uyrzutów sumienia.

Ale po kolei. Falk, najpierw odbiuszy narzeczoną przyjaciela i poślubiuszy ją, uwodzi następnie Maryt (Homo sapiens). Helena staje w obliczu wiarołomstua Mlickiego, z którym od trzech lat pozostaje w nieformalnym związku (Dla szczęścia). W Złotym runie zazębiają się dua trójkąty małżeńskie: Gustaw Rembouski zdradził i został zdradzony. Podobnie w Synach ziemi - Czerkaski nie potrafi uybaczyć żonie odejścia z kochankiem, ale wikła się

${ }^{210}$ Zob. Z. Kuderowicz, op. cit., s. 108-109.

${ }^{211}$ Woluntaryzm Nietzschego i determinizm etyczny Przybyszeuskiego to, według Edwarda Bonieckiego, podstawowa różnica dzieląca poglądy tych twórców (E. Boniecki, op. cit., s. 45).

${ }^{212}$ M. Podraza-Kwiatkouska, Literatura Młodej Polski, Warszawa 1992, s. 122. 
w romans z Hanką Glińską, która opuszcza dla niego męża i córeczkę. Notabene, ten centralny wątek powieści musiał uydawać się Przybyszewskiemu niezmiernie ważny i wart uwagi szerokiego grona odbiorców, skoro pięć lat po uydaniu utworu w całości (we Lwowie u 1904 r.) przeniósł go na scenę jako Gody życia.

Tytułowa Matka zdradziła już u przedakcji, a jej dopiero co ujawnione cudzołóstwo staje się osią nieszczęśliwych wydarzeń. Podobnie skonstruowana jest Topiel - zamężna Eugenia uwiedziona niegdyś przez Skalskiego w milczącej rozpaczy obserwuje zabiegi byłego kochanka, próbującego zaliczyć w poczet suoich zdobyczy jej siostrzenicę Ludmilę. Tadeusz ze Śniegu poddaje się demonicznemu urokoui Euy, dla której opuszcza łagodną Bronkę. Wreszcie Bielecki, czyli „mocny człowiek”, najpieru zdradza Łucję z Adą Karską, następnie Karską z zamężną Niną Ligęzą, by ostatecznie z pobudek ekonomicznych dzielić łoże między Ninę a panią Tańską, żonę słynnego tenora (Mocny człowiek). Rytm tych związków odpowiada konstrukcji trzytomowej powieści - nowe kobiety pojawiają się stopniowo w kolejnych częściach, tak że na każdy wolumin przypada jedna zdrada tytułowego bohatera.

Cudzołóstwo, mimo że zabronione dekalogiem, mieści się jednak w granicach XIX-wiecznej moralności mieszczańskiej ${ }^{213}$, opartej przede uszystkim na pozorach. Mlicki, odchodząc od Heleny dla innej, chce co prawda zabezpieczyć finansowo byłą kochankę, jednak nie z potrzeby serca, a z obawy przed reakcją opinii publicznej. Pozostanie bowiem szanowanym obywatelem, jeśli opuszczając kobietę, która poświęciła dla niego swą reputację, wykaże gest. W przeciunym razie - zbierze gromy oburzenia. Pieniądze usprawiedliwiają niedochowanie wiary i pozwalają kupić spokój sumienia.

[...] moja złota, pomyśl tylko, co za przykra rzecz dostać się na języki tych panien i pań, żądnych równouprawnienia. We uszystkich petycjach wskazywano by na nasz stosunek - he, he, pan się ożenił, a opuszczona dama zmarniała! (Dszcz 14)

- ironicznie argumentuje $w$ rozmowie z Heleną.

Społeczeństwo odrzuca dopiero tych, którzy łamią ustanowione przezeń zasady. Porzucony Bielski musi zabronić żonie kontaktu z dzieckiem (które umowa społeczna nakazuje pozostawić przy ojcu), jeśli chce uniknąć ludz-

${ }^{213}$ Moralność mieszczańską rozumiem za Marią Ossouską jako określony zespół przekonań i dyrektyw uważanych za typowe dla mieszczaństua u różnych środowiskach europejskich w drugiej połowie XIX w. (należą do nich m.in. reakcyjność, potrzeba bezpieczeństua politycznego i ekonomicznego, oszczędność, kult pieniądza, egoizm, filisterstwo i kołtuństuo, nieurażliwość na piękno). W tym sensie nie każdy mieszczanin musi wyznawać moralność mieszczańską, a moralność mieszczańska uykracza poza klasę mieszczan (zob. M. Ossouska, Moralność mieszczańska, Wrocław 1985). 
kich oskarżeń o brak godności (Synowie ziemi, Gody życia) ${ }^{214}$. Przyjaciółka czyni zrozpaczonej matce takie wyrzuty:

Nie umiałaś się urządzić, moja droga - po co było dziecko tracić? Jakieś tam skrupuły, by się dla siebie samej czystą i uczciuą zachować: głupstwo! Szacunek dla siebie samej - Panie Jezu - kto by się w to bawił? Chodzi o to przede uszystkim, by cię ludzie szanowali, a szanują cię, dopóki domu męża nie opuścisz, by ci prawo dziecka nie mogło odebrać - a poza tym mogłaś robić, co ci się podobało. (Gż 38)

Zdrada pod bokiem męża nie jest obyczajouym uchybieniem. Publiczne przyznanie się do pozamałżeńskiej miłości - już tak. Hipokryzja jest więc w zgodzie z moralnością mieszczańską - takie zdanie ma również siostra Hanki, Wanda:

\section{WANDA}

Każda kobieta może się urządzić, jak chce, ale nie porzuca męża i dziecka.

HANKA

Ha, ha, ha... jakie to wygodne!

WANDA

Ja praw społecznych nie pisałam, więc mnie to nic nie dotyczy - ja wiem tylko, że tak jest i tak będzie - kto się spod tych praw wyłamuje, mniejsza o to, czy one są hipokrytyczne, czy nie - pozbywa się innych praw, o które potem upominać się nie może. (Gż 118)

Cynizm w życiu erotycznym i małżeńskim nie był oczywiście tworem obyczajowości XIX-wiecznej, lecz wzrósł na francuskim libertynizmie, który w XVIII w. był już synonimem rozwiązłości seksualnej i którego najdoskonalszym wyrazicielem pozostał na literackiej niwie markiz de Sade. Nic

${ }^{214}$ Cudzołóstuo żony oceniano i karano surowiej niż zdradę mężouską. Kobieta - której powołaniem jest bycie małżonką i matką oraz życie w moralnej czystości - dopuszczając się wiarołomstua, niszczyła bowiem spokój domowy, a więc cel swej egzystencji, i nie zasługiwała dłużej na szacunek rodziny. Traciła godność ułasną i dotkliuie uderzała w honor męża. Ten zaś, jeśli świadomie tolerował nielojalność partnerki, spotykał się z powszechnym lekceważeniem. W mniemaniu ogółu mąż popełniając cudzołóstwo nie upadał tak nisko, ponieważ mógł się realizować w innych dziedzinach życia, np. w życiu społecznym czy polityce. Nie cierpiał na społeczny ostracyzm i nie godził suym postępowaniem u cześć małżonki. Tę nieróuność uzasadniano prawami natury. Męską nieuierność usprawiedliwiały dodatkowo koncepcje filozoficzne. Schopenhauer twierdził, że po zaspokojeniu seksualnym miłość mężczyzny słabnie, podczas gdy przywiązanie kobiety rośnie. Stąd wniosek, że mężczyźni to istoty poligamiczne, którym z zasady trudno dochować wierności, kobiety zaś - jako monogamiczne - zasługują z powodu zdrady na większą karę. Podobne zdanie miał Nietzsche. Kobieca miłość to, według niego, całkowite zdanie się na partnera i pragnienie dawania siebie, równoznaczne $\mathrm{z}$ wiernością. $\mathrm{W}$ miłości mężczyzny - nastawionego na posiadanie - wierność nie istnieje. Dlatego obaj filozofowie proponowali wielożeństuo (zob. M. Uliński, Kobieta i mężczyzna. Dzieje refleksji filozoficzno-społecznej, Krakóu 2001, s. 203-206, 210-211). 
zatem dziwnego, że w Synach ziemi Czerkaski - zdradzony przez własną żonę i uwodzący cudzą - nosi przy sobie zbiór Sade'a pt. Justyna, czyli nieszczęścia cnoty, z którego w gronie cyganerii cytuje słowa Madame Delmonse, roztaczającej nad tytułową Justyną uroki prostytucji. To kunszt obłudy i demagogii:

Nikt nie żąda od nas cnoty, tylko maski cnoty. Jestem nierządnicą jak Messalina, a uszyscy wierzą, albo zdają się uierzyć, żem czysta jak Lukrecja. Jestem gorszą ateistką od Vaniniego, a wierzą, z uśmiechem wierzą, że jestem pobożna jak św. Teresa. Jestem fałszywa jak Tyberiusz, a z zezowatym spojrzeniem na bliźniego tuierdzą, że jestem szczera jak Sokrates. I peuną rzeczą jest, że jestem trzeźua jak Diogenes, pomimo że Apicjusz nie doróunałby mi w rozpuście. Oddałam się występkowi, ohydzie, zbrodni, ale spytaj się mych bliźnich, a powiedzą: „Delmonse jest aniołem!”. (Sz I, 17)

XIX-wieczna opinia publiczna nie była już jednak tak tolerancyjna dla pozamałżeńskich kontaktów będących tajemnicą poliszynela. Tym bardziej u Polsce, ogarniętej zaborami i zajętej walką o najdrobniejsze przejawy swobód politycznych i społecznych. Prym wiodła - inaczej niż we Francji - nie arystokracja, stanowiąca niewielki ułamek ludności, lecz mieszczaństwo. Filisterskie życie rodzinne z ubóstwem aspiracji i koncepcją szczęścia jako stanu nasycenia i stabilizacji zdusiło polot także w sferze erotyki. Obłuda i kołtuństwo dotyczyły praktyk przedślubnych: młodzi mężczyźni realizowali seksualne potrzeby, uwodząc, a następnie porzucając służące lub naiwne dziewczęta zmuszone samodzielnie walczyć o zapewnienie sobie egzystencji. Takie ofiary środowiskowych relacji były najczęściej bohaterkami dramatów i powieści Zapolskiej - Moralności pani Dulskiej, Panny Maliczewskiej czy Kaśki Kariatydy, by wymienić najsłynniejsze. W tej sytuacji małżeństuo oznaczało kontrakt zawierany dla podniesienia statusu finansowego lub społecznego panny młodej i jej rodziny. „Jak chorą jałówkę! Za siedemdziesiąt pięć reńskich. [...] Przynajmniej nie tak tanio mnie sprzedawajcie!" - irytuje się u Kisieleuskiego szalona Julka, którą ojciec zmusza do zaręczyn z człowiekiem, wobec którego ma pieniężne zobowiązania ${ }^{215}$.

Mieszczańska rodzina to pouszedniość, stagnacja, nuda. Nawet dotykające jej dramaty mają niespecjalnie wysoką temperaturę uczuciową. Dlatego Przybyszeuski szuka prawdy o człowieku i jego nagiej duszy u pozamałżeńskich i patologicznych relacjach miłosnych. Jeśli wprowadza na scenę swoich utworów rodzinę, to tylko na chwilę, by zaraz ją rozbić (najczęściej za pomocą figury „tej trzeciej” lub „tego trzeciego”), jako instytucję skostniałą, będącą wyłącznie tworem konwencji i pozbawioną więzi uczuciowych, jak czyni np. w Złotym runie czy drugiej części Mocnego człowieka. Nie

${ }^{215}$ J. A. Kisieleuski, W sieci, Kraków 2002, s. 106. 
diagnozuje choroby toczącej małżeństwo, jak robili to Rittner, Zapolska, a nawet Kisieleuski, bo nie ma ambicji realisty. Chce być psychologiem, nie obserwatorem-fotografem. Mierność małżeństwa ujaunia jednak w każdorazowej jego klęsce, kontrastując je ze zuiązkami nieformalnymi, lecz opartymi na spotkaniu dusz, które bytowały razem w praidei.

Wyniesienie miłości na szczyt piramidy wartości sprawia, że poczucie moralne jednostki nie zawsze pokrywa się u Przybyszewskiego z moralnością zbiorową, która jest systemem zakazów i nakazów uzależnionych od istniejących struktur społecznych i zmieniających się historycznie wraz z nimi. Inaczej niż dla działającego w tym samym czasie Durkheima, moralność nie jest dla autora Śniegu uyłącznie jedną z form śuiadomości społecznej, a życie psychiczne człowieka tylko w niewielkim stopniu determinuje działanie środowiska, narzucającego jednostce poglądy i przekonania. Oto przykład: w oczach opinii publicznej Hanka Glińska bezustydnie upokorzyła męża, a za odejście z kochankiem bezuzględnie powinna ponieść karę - na zausze utracić prawo widywania dziecka. Ten normatywny wyrok społeczny zakochani odczytują jako niezrozumiałą niesprawiedliwość. Łącząca ich miłość jest ich zdaniem wzniosła i czysta, ponieważ stanowi odtworzenie stanu świętości i piękna, w jakim przebywały ich dusze, zanim los kazał im się rozłączyć i „przez łono matczyne ujrzeć światło dzienne” (Sz I, 172).

Dla bohaterów Przybyszewskiego największym nakazem jest zausze miłość; podążając za nią, lekceważą kryteria etyczne, wytworzone przez obyczaj mieszczański. Dlatego Mlicki dziwi się, że w oczach innych Helena jest jego „utrzymanką” (Dla szczęścia), a Irenie dopiero Ruszczyc uśuiadamia, że zdrada, której się dopuściła, kualifikowana jest jako „hańba” (Złote runo). A mimo to przyjęcie tej wielkiej, świętej i czystej miłości nie jest wolne od wątpliwości i rodzi dylematy natury moralnej. Wyrzuty sumienia wywołuje w bohaterach jednak nie świadomość wykroczenia poza zasady porządku mieszczańskiego, lecz wyrządzona komuś krzyuda ${ }^{216}$. I tak Mlicki obwinia siebie i Olgę za śmierć Heleny (Dla szczęścia), Rembowskiego dręczy sumienie z powodu okłamywania Łąckiego (Złote runo), zaś Klara suym odejściem czuje się odpowiedzialna za złamanie Ludwika i doprowadzenie do jego samobójstua (Śluby).

Hanka Glińska przeżywa męki, zdradzając męża - dobrego, poczciwego człowieka, który uyruał ją z nieżyczliwej, dusznej atmosfery domu rodzinnego i zapewniał względne uygody całodzienną pracą. Śuiadomość,

${ }^{216}$ Przychodzi tu na myśl klasyczna koncepcja wolności Johna Stuarta Milla. Angielski filozof postulował wolność sumienia w najszerszym znaczeniu tego słowa, wolność myśli i uczucia, uyboru zajęcia, postępouania i uyrażania opinii, uważał jednak, że granicą ludzkiej swobody winna być ewentualna krzywda, jaką jednostka może uyrządzić swoim działaniem innemu człowiekowi (zob. J.S. Mill, Utylitaryzm; $O$ wolności, przeł. M. Ossouska, A. Kurlandzka, Warszawa 2006). 
że Gliński u milczeniu zmaga się z jej rosnącą nieprzystępnością, by nie robić jej przykrości wyrzutami, potęguje rozterki bohaterki. „[...] gardziła sobą, ale miłość [do Czerkaskiego - przyp. K.B.] dławiła, dusiła uszystko w jej sercu, bo kochała, bo stała się samą miłością" (Sz I, 48). Róunież Czerkaski - zapewne dlatego, że sam dośuiadczony cierpieniem wywołanym odejściem żony - uspółczuje mężowi swej kochanki. Wyobraża sobie Glińskiego szukającego zapomnienia w pracy, a w wizji wzbudzonej natłokiem męczących myśli widzi jego krwawiące oczy. Ów drastyczny obraz symbolicznie czyni z Czerkaskiego kata, który te krwawiące rany zadał. Ustawiczną udrękę z powodu krzywdy wyrządzonej mężowi Hanki i opuszczonemu wraz z nim dziecku zakochani przypłacają brakiem poczucia stabilności związku i nadwątleniem nerwów graniczącym z neurozą.

Głosu sumienia nie potrafi zagłuszyć nawet Eryk Falk, typ nadczłowieka. Świadomy, mimo wewnętrznych oporów, nieuchronności uwiedzenia Maryt, poznanej na usi podczas wizyty u matki, rozmyśla:

Pan profesor Nietzsche zapomniał o całej tradycji i kulturze, która tysiące wiekóu potrzebowała, by sumienia wytworzyć. He, he, naturalnie głupim rozumem można nawet sumienie z rachuby uyeliminować; rozumem można by, jeżeli się człowiek weźmie logicznie do rzeczy, nawet sumienie przezwyciężyć. A jednakowoż nie można. Ach, jaki śmieszny ten nadczłowiek bez sumienia. (Hs II, 30)

Uczucia do Maryt - oznaczającego de facto zdradę żony - Falk nie traktuje w kategoriach romansu, a więc związku toczącego się na uboczu małżeństwa, ponieważ ślub jest dla niego jedynie układem, ,by zapewnić żonie ekonomiczną pozycję i ochronić ją od nagabywań policyjnych" (Hs II, 34). Nie ma sankcji boskiej i wymiaru religijnego, zatem może być zawarty w urzędzie stanu cywilnego i z kobietą dowolnego wyznania. Taki wybór stoi u rażącej sprzeczności ze światopoglądem matki bohatera, która - obawiając się społecznego ostracyzmu - postanawia ukrywać w sąsiedztuie fakt, że jej syn ożenił się z luteranką. Falk dla płytkiej moralności ogółu i ludzkiego gadania ma jedynie pobłażanie. Dręczy go ten wymiar problemu, który nazuać by można wewnętrznym - odpowiedzialność człowieka przed samym sobą za czyny, które popełnia przez niego natura i które są realizacją przeznaczenia. Dylemat tym dotkliuszy, że nierozwiązywalny.

Jak ja mogę to poustrzymać, co już dawno było we mnie przygotowane i czekało tylko na sposobność, by uybuchnąć i uszystko zalać swą niszczącą lawą? [...] Mogęż przeszkodzić, że jakiś obcy wzrok wwierci się w moją duszę i wywoła takie siły, o których istnieniu nie miałem pojęcia? (Hs III, 39)

- upada u dyskursywny ton, przerażony samobójstwem Maryt, niemogącej znieść myśli, że oddała się żonatemu mężczyźnie. Falka uczynił 
Przybyszewski bohaterem najbardziej świadomym jednostkouych konsekuencji wynikających z determinizmu jako relewantnej zasady układu świata. I najbardziej nimi przerażonym.

Nagłe napady agresji lub lęku, niepokój i krótkotrwała utrata kontaktu ze światem zewnętrznym to psychofizyczna reakcja organizmu na niemoralne postępowanie „mocnego człowieka”. Ogłosiuszy jako własne dramaty zmarłego Górskiego, Henryk Bielecki musi pozbyć się Łucji, utajemniczonej w sekret sukcesu jego kariery literackiej i gotowej go wyjawić. Już na etapie planowania morderstwa odczuwa ustyd, spotęgowany pojawiającym się na zasadzie analogii uspomnieniem rzeźnika prowadzącego na ubój rozbrykane, nieświadome nadchodzącej śmierci cielę. I mimo że odsuwa od siebie podejrzenia, sprytnie aranżując zabójstwo kochanki, na zausze traci spokój. Na przemian poci się i odczuwa dreszcze, blednie, gdy u towarzystuie cyganerii wymawia się imię zmarłej, czuje ustręt do siebie i suego otoczenia. „No patrzcie: bohater, mocny człowiek rozmazgaił się, zrobił się galaretką na uspomnienie Łusi" (Mc II, 30) - ironizuje w myślach, choć wie, że hartu i mocy cynizmem nie zastąpi. Kolejne niegodziwości i zbrodnie - dokonywane bądź inicjowane przez niego (zabójstwo detektywa Kotowicza oraz Ady Karskiej, samobójstwo księcia Pomiana, śmierć babki, od której usiłował uyciągnąć pieniądze, podpalenie obrazów Borsuka, odebranie żony dawnemu przyjacielowi Ligęzie i zdradzanie jej z bogatą Tańską) - nadwątlają jego psychikę. Kulminacyjnym momentem osłabienia jest nagłe zaśnięcie, jakiego doznaje podczas pieszczot z ukochaną Niną, a „taki nagły sen przeważnie chorych lub zbrodniarzy nachodzi” (Mc III, 78). Ta niemożliwa do opanowania niemoc - wyrażająca się melancholią, depresją, lękiem i bezsilnością - jako reakcja na wyjątkowe zużycie sił odpowiada zasadzie zachowania równowagi w systemie nerwowym, o której pisał Lombroso u studium Geniusz i obłakanie.

Triumf dramatów Górskiego napełnia Bieleckiego obrzydzeniem, choć buduje jego prestiż. W dniu nominacji na dyrektora teatru - który okazuje się jednocześnie dniem odejścia i samobójstua Niny, powiadomionej o zdradzie Bieleckiego - bohater publicznie wyznaje swoje występki, poczynając od przyznania się do plagiatu. Człowiek bezuzględny i przewrotny, zdolny do zdrady i zbrodni, sam sobie wymierza sprawiedliwość pod upływem miłości do kobiety, dla której pragnie dokonać czynu wielkiego, a takim jest zmierzenie się z prawdą i przyjęcie za nią odpowiedzialności.

Obciążając wyrzutami sumienia postać projektowaną jako literacka próba weryfikacji idei nadczłowieka, Przybyszeuski wykazał utopijność nietzscheańskiej koncepcji, co podkreślali już interpretatorzy. Jednostka wyzuta z moralności przestałaby być bowiem człowiekiem i dokonała regresu do poziomu zwierzęcia, niszczącego, by przeżyć. Rozum i sumienie jako narzędzia świadomości wyodrębniające podmiot ludzki spośród świata przyrody są niewątpliwym uyróżnieniem, oznaką najwyższego stopnia 
rozwoju, który uzasadnia panowanie nad innymi gatunkami, ale wtrącają w otchłań wątpliwości. Zamiast ułatwiać, utrudniają życie. Nie służą bowiem budowaniu własnej mądrej drogi życiowej, a pozwalają jedynie rozpoznać konieczność przygotowaną człowiekowi przez los. Są narzędziami interpretacji, nie tworzenia. Bezsilne wobec przeznaczenia i działających uniwersalnie sił natury nie są zdolne poustrzymać jednostki nawet przed zachowaniami niezgodnymi $\mathrm{z}$ jej przekonaniami i krzywdzącymi innych. Śuiadomość tych ograniczeń jest źródłem tragizmu. „[...] sto razy wolałbym być bakcylem, bo ten, jeżeli niszczy, to przynajmniej nie uczuwa męczarni ani głupich wyrzutów sumienia" (Hs III, 45) - stwierdza Falk. Niemniej owe „głupie wyrzuty sumienia”, które mogłyby być uznane przez Nietzschego i jego kontynuatorów za objau słabości, w rzeczywistości konstytuują ludzką tożsamośćc17.

Pora ureszcie na podstawie powyższych analiz podjąć próbę odpowiedzi na pytanie, czym w utworach Przybyszeuskiego jest sumienie. Na pewno nie rozbrzmiewającym w człowieku głosem Boga, w którego sędziouską moc pisarz nie wierzy, choć ukryty porządek rzeczy w zasadzie pokrywa się u niego - co zauważyło wielu badaczy - z postulatami moralności chrześcijańskiej. Nie jest też, jak dla Durkheima, wytworem życia społecznego, uzewnętrznieniem nakazów i zakazów pozwalających jednostce oceniać własne działanie. Przybyszeuski przyjął koncepcję sumienia autonomicznego, niezwiązanego z prawem i regułami zewnętrznymi. Fromm nazwał je później „humanistycznym” ${ }^{218}$. To śuiadomy element psychiczno-duchowej rzeczywistości człowieka, wewnętrzny głos obecny u każdej ludzkiej istocie i niezależny od zewnętrznych nagród czy sankcji.

Zdarza się, że rolę sumienia, rezonera, który uytacza argumenty, przejmuje inny bohater, np. dla Mlickiego jest to Zdżarski (Dla szczęścia), dla Heleny i Rembouskiego - Ruszczyc (Złote runo). Spełniają oni funkcję pedagogów, którzy ostrzegają, osądzają i ganią. Przybyszeuski powołuje ich do istnienia nie dlatego, że nie dowierza zmysłowi moralnemu jednostki, lecz - jak uspomniano wcześniej - by uatrakcyjnić na scenie starcie racji,

${ }^{217}$ Jeszcze $\mathrm{z}$ innych powodów nie można mówić o tożsamości Bieleckiego czy Falka z nietzscheańskim Übermenschem. W teorii niemieckiego filozofa nadczłowiek był bezwzględny, ale wykluczał kłamstwo i nałóg jako drogę ucieczki przed niesatysfakcjonującym życiem, był przeciunikiem eskapizmu. Bohaterowie Przybyszeuskiego mają zaś słabe nerwy i ciało, a ratunku przed nędzą życia szukają w substancjach odurzających. Michał Głowiński podkreślał, że koncepcję nadczłowieka $w$ istocie kompromitowało głoszenie amoralizmu i propagowanie niszczenia przyjętych form społecznego uspółistnienia. „Kompromitowało w sposób wielce charakterystyczny, tak jak to zuykle bywa, gdy idei bardzo szerokiej i bardzo ogólnej nada się znaczenie jednostkowe i konkretne" (M. Głowiński, Mity przebrane, s. 19).

${ }^{218}$ W odróżnieniu od sumienia „autorytatywnego”, będącego głosem zinternalizowanego, zewnętrznego autorytetu, do którego Fromm zaliczył rodziców, państuo czy kogokolwiek reprezentującego prawo moralne $\mathrm{w}$ danym społeczeństwie. 
rozłożyć targające ludzką psychiką sprzeczności na kilka postaci. To właśnie Ruszczyc wypowiada niezwykle ważne ostrzeżenia:

Chcecie zniszczyć moralność, tak zwaną moralność - pytacie się, co jest dobro, a co zło, a zapominacie, że istnieje jakaś dziwna, tajemnicza, wewnętrzna moralność w każdym czynie. To, co złe, zausze się mści, bez uzględu na uszystkie rozumowania... (Zr 179)

Zabiliście głupimi teoriami sumienie, by zaspokoić wasze zbrodnicze żądze, poczęliście głosić, że miłość nie zna żadnych praw ani obowiązków, że miłość uszystko unieuinnia... To kłamstwo. Taka miłość jest zbrodnią i mści się [...]. (Zr 224)

Nie ma wątpliwości, że Przybyszewski pokazuje absurdalność moralności mieszczańskiej, ale równocześnie tak konstruuje utwory, że pogwałcenie jej zasad narusza jednocześnie z góry ustanowiony ład: los spotykający Gustawa Rembouskiego jest skutkiem postępowania jego matki, która zdradziła ojca i urodziła dziecko kochanka, a "to się tak strasznie mści”, „w siódme pokolenia mścić się będzie” (Złote runo, 254-255); guałt dokonany na Hance przez Janotę to rezultat naruszenia przez nią porządku społecznego (Gody życia).

Dla człowieka świadomego i obdarzonego zmysłem moralnym konflikt z losem kończy się katastrofą. Bohaterowie uybierają śmierć, ponieważ nie potrafią pogodzić się z rolą narzędzia wpisanego w plan przeznaczenia i natury.

\section{Miłość a cierpienie}

Bohaterowie Przybyszewskiego dla osiągnięcia szczęścia we dwoje poświęcają niemal wszystko - uporządkowaną sytuację rodzinną i społeczną, spokój sumienia, życie bliskich osób. Zadowolenia nie odnajdują u realizacji suych potrzeb duchowych i intelektualnych, w działaniach publicznych czy u poświęcaniu siebie innym. Warunkiem szczęścia jest dla nich doświadczenie miłości (którą zazwyczaj przeżywają egoistycznie), dlatego słowa „szczęście” i „miłość” stają się swoistymi synonimami.

Nie chcę się poświęcać - krzyczy Falk zakochany w narzeczonej przyjaciela - chcę być szczęśliwym! (Hs I, 144)

A cóż mnie sumienie obchodzi! - mówi Mlicki - Chcę szczęścia! (Dszcz 19)

Przybyszewski zuraca uwagę na antynomiczne przeżywanie miłości. Dla mózgu uczucie jest szansą spotęgowania percepcji, w duszy ożywia obawę bólu i przymusu: 
Bo miłość może być szczęściem. W śuiadomości osobouości miłość daje zadowolenie, tak cudownie potęguje przecież sprawność umysłu, tak uspaniale syci wrażenia zmysłowe [...]. Ale prastara dusza słonecznego splotu, co przeżyła uszystkie burze euolucji, uszystkie szały doboru płciouego, inaczej odczuwa miłość. W jej przepastnych głębiach miłość staje się straszliwym cierpieniem, gryzącym wampirem, okropną męką, bo mężczyzna nie może przecież wyzwolić się od kobiety, zaspokoić wiecznie głodnych demonów zmysłów. I w ekstazie najuyższego przeżywania szczęścia [...] nadchodzi chwila, kiedy rozpoznajemy, że całe to szczęście to tylko szczęście robactua, jakie słońce ze śmietnika wylęgło ${ }^{219}$.

Prauczucie jest doświadczeniem rozpaczy, ponieważ żądza miłosno-duchowej ekstazy nigdy nie może zostać zaspokojona. Spełnienie trua krótko, domagając się poutórzenia. Kochankouie Przybyszeuskiego (przede wszystkim z poematów) są wręcz „ekstremistami pożądania” ${ }^{220}$, sterowanymi potęgą chuci. Ból zuiązany z namiętnością nie jest więc - jak podkreśla Gabriela Matuszek - intymnym przeżyciem konkretnej jednostki, lecz kolektywnym doświadczeniem całej natury ${ }^{221}$.

Cierpienie wywołane dyktatem chuci ściągającej $\mathrm{z}$ wyżyn duchowości w bagno fizyczności, niezdolnością do androgynicznego zjednoczenia, naznaczeniem przez los oraz piętno niezawinionej winy zostało omówione wcześniej. W tym miejscu analiza obejmie pozostałe źródła bólu wykorzystane przez Przybyszewskiego w kreowaniu sytuacji miłosnych, a jej konsekuencją będzie próba odpowiedzi na pytanie o miejsce i funkcję cierpienia $\mathrm{w}$ śuiatopoglądzie pisarza.

Chwilami szczęścia - z reguły zresztą pozornego - Przybyszewski nie obdarza suych bohaterów na długo. Radość króla z kraju słońca i niewolnicy z krainy cieni tłumi przeczucie zagłady i obawa, ,że zbliżają się chmury, pełne czerwonych błyskawic, zniszczeniem brzemiennych" (Nad morzem, 27). Falk odjeżdżający z Izą do Paryża czuje jednocześnie dumę, szczęście i... smutek (Homo sapiens). O niemal sielankouym pożyciu Bronki i Tadeusza czytelnicy/widzowie dowiadują się jedynie z ich uspomnień (Śnieg). Nieliczne chwile zadowolenia, kiedy na horyzoncie uczucia nie pojawia się jeszcze zagrożenie, zakłóca lęk przed utratą miłości, niewiara u truałość szczęścia, bo - jak zabobonnie stwierdza Zygmunt nieustannie obawiający się odejścia Klary - „diablo krucha rzecz to szczęście - nie trzeba o nim móuić” (Śluby, 29). Prognozowanie miłosnego fiaska pozbawione jest racjonalnych przesłanek. U jego podstaw leżą raczej intuicyjne przeczucia, nastrój, ogólne powątpiewanie $\mathrm{u}$ przychylność losu. Jak u przypadku Mikity:

${ }^{219}$ S. Przybyszeuski, Psychiczny naturalizm (O twórczości Edvarda Muncha), [w:] idem, Synagoga szatana..., s. 96-97.

${ }^{220}$ W. Gutouski. Nagie dusze..., s. 90.

${ }^{221}$ G. Matuszek, Między pustka transcendencji..., s. 28. 
Bolesny niepokój targał mu mózg.

$[\ldots]$

Jakiż miał powód wątpić w Izę?

Żadnego, zgoła żadnego.

Więc czegóż chciał, do uszystkich diabłów? (Hs I, 65)

Uczucia bohaterów są pełne sprzeczności. Namiętności i rozkoszy towarzyszy ból i strach. Miłość nie jest jednoznaczna, wielokrotnie mówi się o niej jako o doświadczeniu negatywnym, topieli, otchłani ${ }^{222}$. Bohater Wniebowstapienia nazywa ją „jadouitą trucizną” (Wn 143), Falk - „wirem”, „który nęci, uciąga, wchłania u siebie" (Homo sapiens, I, 146), dla Agaj i jej brata jest „piekłem szczęścia i grozy” (De profundis, 91). Przesławski i Irena widzą w niej „zbrodnię”, „przepaść”, „piekło” i „stryczek szatana” (Złote runo, 208, 234, 251), dla Izy oznacza „kajdany” (Mściciel, 52), dla Zdzisława - „najstraszniejsze nieszczęście" (Dzieci nędzy II, 145). Znamienne, że znaczna część użytych określeń odwołuje się do obrazowania infernalnego, potęgującego grozę, zgodnego z demonologicznymi zainteresowaniami Przybyszewskiego oraz inspirowanego zapeune myślą Schopenhauera, mówiącego o życiu-piekle.

Przyczyną miłosnej katastrofy jest najczęściej rozbicie związku przez pojawienie się „tej trzeciej” lub „tego trzeciego”. Zdrada uderza w odrzuconych niezuykle silnie - ból podsuwa bohaterowi poematu $Z$ cyklu Wigilii myśl o zabiciu kochanki, a Mikitę (Homo sapiens), Helenę (Dla szczęścia), Rembouskiego (Ztote runo) i Bronkę (Śnieg) wiedzie do samobójstwa. Zdradzającym nowy zuiązek nie przynosi natomiast spełnienia, ponieważ ciąży na nich piętno krzyudy wyrządzonej poprzedniemu partnerowi. Mlicki histerycznie krzyczy do Olgi, dla której opuścił Helenę: „Myśmy ją zamordowali! My!... Ja i ty!...” (Dszcz 81). Irena i Przesłauski także wiedzą, że „złote runo" można zdobyć tylko kosztem innego człowieka:

PRZESŁAWSKI

[...] Inka, pomyśl - całe życie szukaliśmy tego złotego runa.

$[\ldots]$

Teraz je znaleźliśmy. Nie damy sobie go uydrzeć.

$[\ldots]$

\section{IRENA}

Ha, ha, ha!... To złote runo takie ciężkie, upadam pod jego ciężarem - a ja mu [mężowi] taką straszną krzyudę wyrządziłam. Krzywdę - krzywdę...

[...]

Złote runo, złote runo... Och, jak trudno je zdobyć.

${ }^{222}$ Termin „otchłań” w młodopolskich utworach z podstawowym wątkiem miłosnym występuje niemal jako leitmotiv. Oznacza nie tylko niszczące skutki miłości, ale też pustkę egzystencjalną, niewiarę u żadne wartości. O jego znaczeniu pisały: M. Podraza-Kuiatkouska, Pustka - otchtań - petnia, [w:] eadem, Somnambulicy, dekadenci, herosi, Kraków 1985; T. Walas, Ku otchłani (dekadentyzm w literaturze polskiej 1890-1905), Kraków 1986, a także M. Sadlik, „Konfesje samotnych” (tu rozdz. $W$ „otchłani” miłości). 
PRZESŁAWSKI

Zbrodnią! Tylko zbrodnią zdobyć je można. (Zr 234-236)

Cierpią zatem i zdradzeni, i zdradzający. Za męki związane z miłością odpouviedzialne są bowiem normy etyczne. Sumienie dręczy cudzołożników: Falka, ulegającego urokowi zaręczonej z Mikitą Izy, a następnie zdradzającego ją z młodą dziewczyną ze suych rodzinnych stron (Homo sapiens), Mlickiego, porzucającego Helenę dla Olgi (Dla szczęścia) i Rembouskiego, który nawiązuje romans z żoną jednego z podległych mu lekarzy (Złote runo). Weunętrzny opór przeciwko niewierności nie stanowi blokady wystarczającej, by zapobiec zbliżeniu fizycznemu. Bohaterowie nie są w stanie uniknąć konfliktu między pożądaniem zmysłowym i jego realizacją a normami ustanowionymi przez innych ${ }^{223}$. Sprzeczność pomiędzy kulturowymi wzorcami i pokusami płci odczuwają bardzo dotkliwie, ale zafascynowani sobą nawzajem szukają rozkoszy i najintensywniejszych dośuiadczeń nawet poza granicami moralności.

Wiarołomni cierpią, bo obdarzeni zostali niechcianym, niejako dodatkowym uczuciem. Ale - niejako na drugim biegunie - przyczyną nieszczęścia bywa u Przybyszewskiego nie intensywność uczucia, ale jego niedosyt. Na przykład Rembouski uśuiadamia sobie, że Irena nie kocha go tak, jak on ją, „a to boli, boli...” (Złote runo, 181). Symfonią braku wzajemności jest powieść Dzieci nędzy; tym tragiczniejszą, że odgrywaną w zamkniętym kole zdegenerowanego rodu Krywłów ${ }^{224}$. Jaduiga, zmęczona alkoholizmem kochającego ją Zdzisława, obdarza uczuciem jego brata - Jana, sama zaś staje się obiektem guałtownej namiętności Adama Drzazgi, spłodzonego przez starego Krywłę z chłopką. O lekceważonego przez nią półchłopskiego syna z chorobliwą zazdrością zabiega z kolei dojrzewająca Zosia, wypierająca ze śuiadomości więzy pokrewieństua łączące ją z Drzazgą.

Jan z Synów ziemi (oraz jego późniejsza kopia - Wacłau z Godów życia) i Zygmunt ze Ślubów zdobywają co prawda obiekt swych miłości, ale nieustannie muszą starać się o wzajemność i aprobatę ukochanych kobiet. Pieruszy męczy się, ponieważ nie potrafi zaspokoić uszystkich potrzeb uczuciowych Hanki, a jej dziecko traktuje jak swego rywala. Drugi jest samotny w walce o suą miłość, ponieważ Klara zmaga się z przeszłością, obuiniając się za sprowokowaną zerwaniem śmierć poprzedniego kochanka:

${ }^{223}$ Zob. B. Chołuj, op. cit., s. 124.

${ }^{224} \mathrm{Na}$ familiocentryczność dylogii u kontekście antyrodzinnych tendencji literatury młodopolskiej zuracał uwagę W. Gutouski. Badacz pisał: „Trudno uskazać w literaturze epoki bardziej negatywny portret familii: liczna rodzina zamyka się w kręgu szaleństua i traumatycznych namiętności, nie reprodukuje życia, ani nie organizuje go w trualszych strukturach, natomiast »poświęca« się intensyfikacji zniszczenia i śmierci”. W. Gutouski, Konstelacja Przybyszewskiego, s. 113-114 (szkic Rodzina jako egzystencjalna pułapka. $O$ „Dzieciach nędzy” Stanisława Przybyszewskiego). 
Miłość twoja samolubna, w sobie tylko zagłębiona. [Zygmunt czyni Klarze uyrzuty] Kochałaś i wiedziałaś, że jesteś kochaną, ale czyś ty pomyślała, że i u mojej duszy pali się słońce miłości, i wre, i kpi, grzałaś się przy nim - ale czyś ty kiedy stanęła z nim oko w oko - spojrzała u tę bezdeń płonącego morza. (Śl 107-108)

Metaforą męskich starań o kobietę jest rzeźba, nad którą pracuje Zygmunt, przelewający sue lęki w materię. Przedstawia ona olbrzyma, świętego Chrystofora, z wielkim trudem unoszącego ponad odmęty morskie ukochaną, ściąganą w dół przez przyczepionego do jej nóg potwora. Kobieta kurczowo obejmuje szyję mężczyzny, ale jej ramiona mdleją, a ciało staje się bezuładne. Zmuszając Zygmunta do nieustającej walki o siebie, Klara nieuchronnie, choć nieświadomie, zadaje mu ból. Jej winą jest nieumiejętność palenia za sobą mostów, brak daru zapomnienia. Bohaterka tak mówi o uspomnieniach, których nie jest $w$ stanie odegnać:

To jakiś ucisk na mózgu, jakieś nagłe, bolesne szarpnięcie, jakby ktoś serce kleszczami ściskał, niepokój dręczący, którego by się chciało pozbyć, a pozbyć się nie można, nie wiem zresztą, co to jest... (Śl 26).

Przeszłość zatruwająca zuiązek pojauiła się w dramatach Przybyszewskiego już wcześniej, jednak jako problem marginalny, nie osnowa akcji. W Dla szczęścia Olga czyni Mlickiemu takie uyrzuty:

Kochasz mnie i wiesz, jak cię kocham. Powinien byś być szczęśliuyy. Pouinien byś o uszystkim zapomnieć. [...] Ja byłam tak pewna, że zapomnisz, utopisz uszystko w tym szczęściu, że mnie masz przy sobie, że jestem tuoją, na zausze twoją... Stało się inaczej - inaczej... (Dszcz 63)

Podobnie u Złotym runie: warunkiem szczęścia byłoby jedynie - o czym pisał Freud - wyparcie przeszłości do sfery podświadomego.

\author{
IRENA \\ Zygmunt, obronisz mnie? Przytulisz mnie tak mocno, że o uszystkim zapomnę? \\ PRZESŁAWSKI \\ Pieścić będę, całować, na rękach nosić... \\ IRENA \\ I o uszystkim każesz mi zapomnieć? \\ PRZESŁAWSKI \\ O uszystkim. (Zr 226)
}

U Przybyszeuskiego pojawia się ten rodzaj pamięci, który Husserl nazwał retencją. Bohaterowie bezpośrednio przeżywają przeszłość, która, 
mimo że miniona, pozostaje $u$ pełni obecna i jest przeżywana jako aktualna. Podobna koncepcja przeszłości jako wielkiej przeszkody życia pojawiła się u Nietzschego. To, co dawne, nie jest zdaniem filozofa ważne samo przez się, lecz tylko ze uzględu na rolę wobec tego, co obecne. Zasadniczy staje się wątek rozumienia przeszłości jako winy. Dziecko jest niewinne, ponieważ nie ma przeszłości; dorosły z przeszłością, której nie może zapomnieć, jest obarczony winą. W ten sposób - jak interesująco zauważa Hanna Buczyńska-Garewicz - metafizyka czasu spotyka się z metafizyką moralności ${ }^{225}$.

Sposobem na uchronienie partnerów przed cierpieniem wydaje się niekiedy kłamstwo podtrzymujące iluzję. „Kto nie umie kłamać, ten niech milczy, milczy...” - radzi Ruszczyc (Złote runo, 249). Z tego powodu Mlicki jak najdłużej utrzymuje związek z Olgą u tajemnicy przed Heleną (Dla szczęścia), a Irena nie potrafi zdobyć się na wyjawienie mężowi okrutnej prawdy o swej zdradzie (Złote runo). Wybór między wewnętrznym rygorem szczerości a litościuym kłamstwem nie ma jednak znaczenia dla finału: zły czyn musi zostać ukarany ${ }^{226}$.

W dziełach Przybyszewskiego toczy się walka miłość - świat. Uczucie kochanków jest zakłócane przez to, co przychodzi z zeunątrz, najczęściej w postaci innego człowieka. Ludzie przeszkadzają miłości. By zadbać o stabilność zuiązku i zapeunić sobie szczęście, trzeba jej zazdrośnie strzec. Bohaterowie muszą więc odizolować się od otoczenia, zamknąć w wieży uczucia, uystarczać sobie nawzajem, by uniknąć pokus i rozbudzania uspomnień. Dlatego błąd popełnia Bronka, która sprowadza sobie do towarzystwa Euę, by dać Tadeuszowi więcej swobody w kontaktach z innymi i nie znudzić sobą. Jej kobieca taktyka - „Jeżeli się chce zachować miłość mężczyzny, to trzeba go raz po raz od siebie odsuwać, raz po raz samopas go puścić" (Ś 41) - ściąga na nią nieszczęście. Zamiast zbliżyć do niej męża, popycha go w ramiona rywalki. Tymczasem Kazimierz uprzedza, że „szczęście we dwoje jest zazdrosne i egoistyczne" (Ś 41), a Tadeusz, nie wiedząc jeszcze o przyjeździe suej dawnej kochanki, tłumaczy żonie: „[...] szczęście u miłości jest niezmiernie delikatne i może być zakłócone lada drobnostką. [...] Najczęściej atmosferą obcego człowieka" (Ś 49).

Miłość potrzebuje samotności we dwoje. Alegorią tej prawdy jest marmurowa rzeźba w domu Czerkaskiego:

Siedzący mężczyzna a na jego kolanach kochanka. Oplotła jego szyję rękoma, on ją przygarnął całą siłą do suych piersi - śuiat zanikł, nic nie istnieje prócz nich obojga, stracili poczucie czasu - błądzą w wieczności, są światem sami dla siebie. (Sz I, 29)

${ }^{225}$ H. Buczyńska-Garewicz, op. cit., s. 95.

${ }^{226}$ Zob. M. Podraza-Kuiatkouska, Wolność i transcendencja, s. 218. 
Główny bohater Synów ziemi, opuszczony przez żonę, ze swoją prawdziwą miłością - Hanką - wyjeżdża więc do samotni gdzieś w Poznańskiem. I tym razem pojawia się przybysz z zewnątrz, zakłócający związek. Wizyta Korfiniego, który bywał dawniej w domu Bielskich, wywołuje w Hance nieopanowaną potrzebę zdobycia informacji o pozostawionym przy mężu dziecku i popycha ją ostatecznie do powrotu.

Cierpienie bywa także skutkiem uyboru, jakiego dokonuje bohater. Walczy o spełnienie suej namiętności, mimo iż poświęcenia, na jakie musi się zdobyć, nie przychodzą łatwo, a konsekwencje podjętych decyzji okazują się trudne do przewidzenia. Bohaterowie nie mają pełnej świadomości praw rządzących światem, dlatego wyboru dokonują właściwie pomiędzy niewiadomymi. Nie zdają sobie sprawy z tego, co może ich czekać. Maryt poświęca dla miłości wiarę i spokój duszy, by u zamian zyskać cierpienie i śmierć. Falk (Homo sapiens), Mlicki (Dla szczęścia) czy Tadeusz (Śnieg) nie podejrzewają nawet, jakiego rodzaju następstwa spowoduje ich zdrada, ponieważ nie mają upływu na sue postępowanie, uypełniając jedynie nakazy przeznaczenia i chuci. W finale zdarzeń nie są już pewni, czy warto zabiegać o przedmiot pożądania ${ }^{227}$.

Osiągnięcie szczęścia wielokrotnie jest niemożliwe z powodu tęsknoty, nie tylko odniesionej do konkretnej osoby, ale przede uszystkim rozumianej jako poczucie braku czegoś nieuchuytnego, czego zuiązek z drugą osobą w żaden sposób nie może zapewnić. W utworach Przybyszeuskiego tęsknota jest motorem życia i twórczości, guarantuje ciągłe dążenie, sięganie ku sferom metafizycznym. Taką tęsknotą jest dla Tadeusza Ewa (Śnieg), taką tęsknotę przynosi miłość bohaterowi Wigilii:

I kocham cię jeszcze, boś dała mi cierpienie i tęsknotę - tęsknotę, co myśli tuórcy kojarzy, ręce ku Bogu uyciąga, mózg trawi żądzą poznania, bolesną a odwieczną tęsknotą bytu, wieczny niepokój a rozkosz. (W 180)

W poemacie Nad morzem został stworzony specyficzny ciąg synonimiczny: miłość - szczęście - smutek - tęsknota:

I znowu przeżywam wielką moc cudu, kiedy po raz pieruszy Tue spojrzenie się $u$ mą duszę wświeciło jak świetlany rozbłysk szczęścia i smutku, i wiecznej tęsknoty. (Nm 320)

Powinowactuo miłości i tęsknoty przeczy zdrowemu rozsądkowi i potocznemu doświadczeniu, dlatego bohaterowi poematu Androgyne jawi się jako niezrozumiałe:

${ }^{227}$ O uyborach, jakich dokonują bohaterowie Przybyszeuskiego, pisała Elżbieta Rzeuuska w artykule Dramaturgia Przybyszewskiego i ekspresjonizm, zamieszonym w tomie Jan August Kisielewski i problemy dramatu młodopolskiego, red. E Łoch, Rzeszów 1990. 

siach.

Wściekła tęsknota żłobiła mu głębokie bruzdy u duszy, ogień miał w głowie i pier-

A przecież miał ją [ukochaną - przyp. K.B.] u sobie, niósł słońce, uszechśuiat, niósł ją u suej piersi - i czemuż tęsknił? (A 401)

Szczęście i spontaniczność uczucia zabija w bohaterach Przybyszeuskiego uporczywa wiwisekcja dokonywana na sobie. Niekończący się przepływ myśli - roztrząsanie motywów i skutków własnego postępowania oraz świadomość ofiar poniesionych dla miłości - zatruwa związek. Próby zatrzymania kołowrotu refleksji spełzają na niczym, zaś skumulowane lęki, jak obrazowo przedstawił to pisarz w kreacji Hanki w Synach ziemi, zaczynają przypominać niebezpieczne wężouisko:

[...] mam u mózgu jakiś poplątany, pouikłany kłębek - nie! cały ogromny kłąb myśli - biada, jeżeli ktoś lub coś pochuyci za ukryty początek nitki: utedy już ją całą uysnuję i wtedy wiem, wiem, że to będzie koniec!... [...] Tam, u głębi mej duszy, wężowisko śpiących gadzin! Biada, gdy je kto przebudzi! - zagryzą, zatrują żądłami na śmierć... (Sz II, 8)

Przymus analizowania czyni z postaci wykreowanych przez młodopolskiego pisarza - by użyć określenia z powieści innego autora zainteresowanego óucześnie ludźmi grzeszącymi nadmiarem refleksji - „męczenników wyobraźni”228. Stąd powracające wizje, dotyczące przeszłości i przyszłości (jak choćby przywołane wyżej obrazy dręczące psychikę Hanki), a także fantazje, odkrywające tłumione uczucia i podsuwające scenariusze postępowania (można do nich zaliczyć na przykład mizoginistyczne wyobrażenia omówione w podrozdziale Mężczyzna). Skupienie świadomości na samej sobie sprawia, że jednostka popada u coraz większą izolację od świata. Człowiek, którego cała aktywność zwraca się ku wewnątrz, staje się niewrażliwy na otoczenie. „Jeżeli kocha, nie czyni tego, aby złożyć siebie w darze, połączyć się w owocnym związku z kimś innym niż on sam; czyni to, aby rozmyślać o swojej miłości. Jego uczucia są pozorne, ponieważ są jałowe. Rozpraszają się w próżnych kombinacjach wrażeń, nie tworząc nic zewnętrznego wobec siebie" - stwierdzał Durkheim ${ }^{229}$. Nadmierną skłonność do analizy implikował z pewnością egotyzm, charakterystyczny dla neurotycznej osobowości schyłkowca. Wynikała ona róunież z „soboutórowej egzystencji artysty”, będącego jednocześnie aktorem i suym własnym widzem ${ }^{230}$. Przewaga myślenia nad życiem cechuje nie tylko bohaterów Przybyszeuskiego, lecz „czło-

${ }^{228}$ L. Belmont, $W$ wieku nerwowym, Warszawa 1928, s. 195.

${ }^{229}$ E. Durkheim, Samobójstwo, tłum. K. Wakar, Warszawa 2006, s. 354.

${ }^{230}$ A. Lubaszeuska, Życie - Śmierci doskonałość. Młodopolska antropologia śmierci i literacki świat wartości, Kraków 1995, s. 58. 
wieka końca wieku" w ogólności. Pojawia się w kreacjach Płoszouskiego z Bez dogmatu (1891) i Rymszy z W wieku nerwowym (1890). Tezę, że nadurażliwe jednostki poprzez nieustanne dywagacje przeobrażają miłość w cierpienie, ustami jednego z bohaterów wyraziła w Szkicach z 1894 r. Maria Komornicka ${ }^{231}$, a Marcelina Kulikouska w dzienniku $Z$ dziejów duszy (1911) notowała: „Myśl ludzka, którą się człowiek nieustannie chlubi, jest jednocześnie zabójcą. Myśli to wina, że nie umiemy żyć, a zastanawiamy się tylko nad życiem"232.

Zdaje się, że postacią stworzoną wyłącznie na to, by cierpieć, jest Hanka. Początkowo owa femina dolorosa znosi męki niezrealizowanej miłości do Czerkaskiego, powiązanej z poczuciem winy wobec oszukiwanego męża. Decydując się następnie na życie z ukochanym, oznaczające jednoczesne opuszczenie córki, której prawo nakazuje pozostać przy ojcu, cierpi coraz bardziej jako matka. Przeszłość dogania i ją, by zatruć szczęście. Jej ból jest „niezawinioną winą”, wynikającą - jak pisze Edward Boniecki - z niewiedzy, z braku gnosis ${ }^{233}$. Każde przypadkowo zobaczone dziecko jest dla Hanki chodzącym wyrzutem sumienia, wzbudzającym atak paniki. W napotkanym w lesie, przemoczonym od deszczu maluchu w tachmanach, zapewne zbierającym chrust, widzi jedynie dziecko porzucone przez matkę:

[...] nie mogła tchu złapać, chwyciła się za piersi i jak w obłędzie poutarzała: - opuszczone - opuszczone - przez matkę opuszczone - Jezus Maria!...

Jedną chwilę patrzyła oniemiałymi, szeroko rozwartymi oczyma na tę drżącą kruszynę, tę słodką drobinę człeczą [...]; aż nagle uyruała się z ramion Czerkaskiego, rzuciła się ku dziecku, porwała je w swoje objęcia, całą siłą przycisnęła do siebie tę kupkę obłoconego, zmokniętego łachmana...

- Opuszczone, przez matkę porzucone dziecko! Jezus Maria!... (Sz II, 19-20)

Wyobraźnia podsuwa jej na zmianę sielski obraz malutkiej Basi ruącej na łące kwiaty, to znów dramatyczną scenę dziecięcego orszaku wiodącego na cmentarz białą trumienkę, w której spoczywa jej córka. Środka uśmierzającego cierpienie szuka bohaterka u miłości. Gorączkowa namiętność i żarliwa opieka Czerkaskiego mają przynieść jej zapomnienie i ukojenie. Miłosny

${ }^{231}$ Zob. M. Komornicka, Staszka, [w:] eadem, Szkice, Warszawa 1894, s. 110.

${ }^{232}$ M. Kulikouska, $Z$ dziejów duszy, Kraków 1911, s. 138. Cyt. za: M. Sadlik, „Konfesje samotnych”, s. 50. O takiej charakterystycznej dla dekadentyzmu „mózgowości” zob. też T. Walas, Ku otchtani...

${ }^{233}$ E. Boniecki, op. cit., s. 24. Cierpienie psychiczne obejmuje także ciało, dlatego Przybyszeuski opisuje je naturalistycznie:

[...] jakieś ostre, delikatne kleszcze wyrywały jedno włókno po drugim z jej mózgu - wiła się z bólu - chciała uciekać, ale nogi tkuily u jakimś bagnie, chciała krzyczeć, ale głos, jakby ścięty grubą warstuą lodu, uydostać się nie mógł. [...] A było to, jakby darcie żywej skóry, oranej ostrymi grabkami, siepanie twardymi rzemieniami, oplecionymi stalouym drutem (Sz II, 48-49). 
wir nie zagłusza jednak cierpienia, a rozdarcie Hanki, niezdolnej do całkowitego poświęcenia się związkowi, uzmaga jednocześnie ból bezskutecznie walczącego o nią Jana. Przeszkoda w postaci Basi, skojarzona z postępującą germanizacją dzieci w Poznańskiem, podsuwa bohaterowi myśl o pozytywnym aspekcie rzezi niewiniątek:

Przede uszystkim dzieci pouybijać - całe życie u zarodku zniszczyć, z korzeniami uyplenić to ohydne zielsko życia.

Można by jeszcze chłopaków przy życiu pozostawić - ci sami się wytracą... ale dziewczątka - wytruć, wymordować, by nie mogły żywota płodzić, by świat człowieczy istnieć przestał i męka i rozpacz - nienawiść i miłość... (Sz II, 315)

By zyskać spokój i wytchnienie od dręczących myśli, Hanka sięga po opium, o którego oczyszczającym działaniu zapeuniał ją Korfini:

Jeden gram uystarczy, by uszystkie dysonanse przemienić na najczystsze harmonie, zbliżyć się do źródła życia, pieruiastka uszelkiego bytu, dokopać się do korzenia poznania. Haplosis nazywa Plotinus ten stan. I to Haplosis mogę sobie uytworzyć za pomocą opium. Ciało drętuieje, a dusza czuwa, szybuje w bezmiarach tej jedni, z której się uszystko wyłoniło. Traci się poczucie czasu i przestrzeni, mózg staje się jasny i bystry, ogarnia się nim uszystko to, co było dlań tajemnicą i ciemną zagadką, uszystkie mgławice i powikłania życiowe rozplątują się $\mathrm{w}$ jasne i przejrzyste twory... (Sz II, 164)

Narkotyk zażyty podczas dramatycznej, osłabiającej neruy próby odzyskania córki spełnia swą rolę:

Całe fale niewysłowienie błogiego ciepła przelewały się przez nią całą. Płacz uniesienia rozpierał jej piersi, płacz niepojętego szczęścia i radości unieboustąpienia.

Nie była zdolna objąć ogromu tej błogości.

$[\ldots]$

Rozwiał się lęk i niepokój, z duszy podniosły się mgły i opary [...]. (Sz II, 250-251)

Dobroczynna moc opium nie trua jednak długo. To, co miało wyzwolić Hankę od egzystencjalnego cierpienia, wpędza ją w rozpacz. Odurzona narkotykiem, a więc w stanie osłabienia kontaktu z rzeczywistością, zostaje zgwałcona przez zakochanego w niej Miłosza Zarembę. Dotychczas niewinna, wewnętrznie czysta pomimo braku hymenu oraz ucieczki do kochanka, teraz zostaje skalana. Ta hańba dopełnia czarę nieszczęść i popycha dziewczynę do próby samobójstua, od którego ratuje ją Skirmunt, symboliczna postać uskazująca drogę do samopoznania. Dzięki radom duchowego przewodnika (rodem z hinduizmu) femina dolorosa uśuiadamia sobie boskie pochodzenie, a więc wieczną czystość własnej duszy, która błądzi wśród boleści, lecz nigdy nie zostanie zbrukana. I to przekonanie załamuje się 
jednak chuilowo pod wpływem samobójczej śmierci Czerkaskiego, na powrót utrącającej Hankę w cierpienie. Wskazania Skirmunta są uszelako na tyle silne, że pozwalają kobiecie podźuignąć się po raz kolejny, a nawet uwierzyć we własną misję przekazania poznanych prawd porzuconemu niegdyś dziecku.

Weunętrzną, duchową wolność, jaką zyskuje Hanka u finale trylogii, widzi Gabriela Matuszek w kategoriach kobiecego dojrzewania do własnej podmiotowości, która „przeciustawiona zostaje słabej, schyłkowej, zdegenerowanej męskości", stanowiąc o nowatorstwie i oryginalności powieści ${ }^{234}$. W interesującej interpretacji uskazuje badaczka na zawiłe uzależnienia, w jakie popada kobieta w patriarchalnej kulturze i jakich świadomość zyskuje stopniowo bohaterka („Jam jest to coś - można je łaskawie komuś pozostawić - można je wziąć - och! jakie to przedziunie śmieszne..." - myśli, Sz III, 82), by ostatecznie zbudować suą filozofię „antycierpienia” na przekonaniu, że udręka i ból odrywają od „uszechduszy świata, w której się rozkosz i cierpienie róunoważą, śmierć z życiem" (Sz VI, 65) (35. $^{23}$.

Bohaterowie Przybyszewskiego nie są wyłącznie ofiarami niespodziewanie dosięgającego ich cierpienia. Śuiadomie wybierają i intensyfikują doznanie bólu, w czym Magdalena Popiel dostrzegła upływ Nietzschego, który pisał:

Pragniecie o ile możności [...] usunąć cierpienie; a my? - zda się po prostu wolelibyśmy, by stało się jeszcze głębszym i gorszym, niźli bywało kiedykolwiek ${ }^{236}$.

Poszukiwanie męki jest tu $\mathrm{w}$ istocie poszukiwaniem pełni przeżyć, a więc odrzuceniem popularnej w modernizmie buddyjskiej propozycji uygaszenia uczuć i wyrzeczenia się doznań (choć bowiem Przybyszeuski wiele zawdzięczał filozofii Wschodu, nie zaakceptował Nirwany jako opcji ucieczki od świata). Upodobanie u cierpieniu jest podstawą miłosnych zuiązków Agaj i jej brata (De profundis) oraz Gordona i Heli (Dzieci szatana). W pierwszym przypadku kochankowie wiedzą, że łączy ich miłość „niedobra”, społecznie nieakceptowalna, dlatego tłumią ją, ukrywając swą wzajemność i uypierając się jej. Każde zbliżenie przyczynia się jednak do spotęgowania ich miłosnego cierpienia, które prowadzi do utraty kontaktu z rzeczywistością i chorobliwych majaczeń. Oboje ukochali ból, ponieważ guarantuje on intensyuność życia. Jednocześnie związek krwi, nasycający zakazaną miłość tak pożądaną męką, poustrzymuje ich przed ostatecznym spełnieniem.

${ }^{234}$ G. Matuszek, Stanisław Przybyszewski..., s. 286.

${ }^{235}$ Ibidem, s. 286-291.

${ }^{236}$ F. Nietzsche, Poza dobrem $i$ złem, przeł. S. Wyrzykouski, Warszawa 1907, s. 184. Cyt. za: M. Popiel, Wzniostość - retoryka cierpienia (O prozie Stanisława Przybyszewskiego), „Ruch Literacki” 1996, z. 1, s. 44. 
Kocham twoją duszę, kocham tuój straszny, głęboki smutek. [...] Ty, ty jesteś jedyny, który masz cierpienie i ból w sobie. A ty nie bronisz się przeciu tej męce. Nie bronisz się przeciu cierpieniu. Kochasz mękę i cierpienie (Dp 100)

- mówi do brata Agaj. Wybór cierpienia jest jednocześnie aktem odrzucenia filisterskiej kultury:

Mam nieskończony ustręt przed tym zdrowym rozsądkiem tych uszystkich ludzi naokół. Boże, jaki oni strach mają przed cierpieniem... Jak oni szczęścia pragną, tego głupiego szczęścia! Ból dla nich gorszy od zarazy morouej. Ha, ha, ha... te biedne żony mieszczańskie - te biedne, posażne mieszczańskie panny na uydaniu - one tylko pragną szczęścia. [...] Kocham cię, bo nienawidzisz rozsądku - a tysiąc razy chętniej rzuciłbyś się w przepaść, zaczym byś sięgnął za chwilkę szczęścia. (Dp 96-97, 100-101)

Gordonowi cierpienie daje impuls do przeprowadzenia dzieła zniszczenia - pisała G. Matuszek - dlatego pastwi się on nad sobą i innymi, odnawiając miłosną udrękę. Nieurzeczywistnione uczucie owocuje postawą anarchistyczną, a ból nosi znamiona perwersji ${ }^{237}$. „Oboje pragniecie cierpienia - mówi Ostap o Gordonie i Heli. - Fatalny jakiś pęd gna was w kierunku najuyuzdańszego cierpienia" (Ds 90).

Bohaterouie Przybyszeuskiego ustawicznie zmagają się z czymś w miłości. Walczą o jej zdobycie lub ocalenie, przekonując się, że szczęście nie istnieje, jest poza ich zasięgiem, poza zasięgiem ludzkiego doświadczenia w ogóle. Taka kreacja postaci uynika z przekonania, że najbardziej naturalnym stanem człowieka jest cierpienie. Idea bólu i rozpaczy osadzona była głęboko w światopoglądzie modernizmu. Jej patronem był Artur Schopenhauer, który twierdzil, że ból jest substancją życia tkuiącą w naturze - żyć, znaczy więc cierpieće ${ }^{238}$. Eksponowanie w sytuacjach fabularnych i przeżyciach bohaterów nieszczęścia, niespełnienia, bólu i destrukcji, ale też choroby i fizycznego rozkładu, upisuje się u szersze przekonanie Przybyszeuskiego o istnieniu przenikającej cały byt nędzy metafizycznej ${ }^{239}$. Po raz pieruszy została ona zdefiniowana u powieści Synowie ziemi:

${ }^{237}$ Zob. G. Matuszek, Nędza świata bez Boga. O „Dzieciach szatana” Stanisława Przybyszewskiego [posłowie] [u:] S. Przybyszewski, Dzieci szatana, Kraków 1993, s. 192.

${ }^{238}$ J. Tuczyński, op. cit., s. 142. To przekonanie dzielił z modernistami głóuny bohater powieściowego arcydzieła pozytywizmu - Lalki (1890) Bolesława Prusa. Wokulski wypowiada znamienną formułę egzystencjalną „Cierpię, więc jestem!...” (B. Prus, Lalka, oprac. J. Bachórz, t. 2, Wrocław 1991, s. 481), w której Bogdan Mazan uidzi nawiązania nie tylko do Kartezjusza, ale i napisanego u 1838 r. dziełka Ernesta von Feuchterslebena, zatytułowanego w polskim uydaniu Higiena duszy (1857). Zob. B. Mazan, Z obrazów Chin i Chińczyków w piśmiennictwie polskim drugiej połowy XIX wieku. „Chińskie cienie” w „Lalce” Bolesława Prusa, [w:] Pozytywizm i negatywizm. My i wy po stu latach, red. B. Mazan, Łódź 2005, s. 381-382.

${ }^{239}$ Nędzę - obok Miłości i Śmierci - winą za ból egzystencji obarczył także Kazimierz Przerwa-Tetmajer, który pisał: „Nędza, Śmierć i Miłość, to są te trzy bachantki świata, które 
[...] jest poza uszystkim i tkwi we uszystkim: w przez liszki pożartych liściach dębu, w chorym, przez jadowite owady opadniętym zuierzęciu, co już nie ma sił się bronić - $w$ dziecku, co za grzechy ojców niewinne, nieświadome ni dobrego, ni złego, cierpieć musi - za grzechy ojców, za grzechy - matek... (Sz II, 35)

Cierpienie nie dotyczy więc bytu jednostkowego i nie jest zinterioryzowaną właściwością ludzką, lecz przybywa z zeunątrz, jako ułasność całej Natury ${ }^{240}$. Wiąże się z panowaniem Szatana, który zastąpił Boga i nieustannie tworzy i niszczy życie, stojąc jednak na straży jego ciągłości. Nędza ludzka objauia się w obciążeniu człowieka mrocznym przeznaczeniem, odrzuceniu przez społeczeństwo, wykolejeniu moralnym, egzystencji na granicy obłędu i w biedzie, przeduczesnym starzeniu. Oznacza zatem, jak skonstatował Wojciech Gutowski, wanitatywny charakter istnienia naznaczonego złem i udręką, w obliczu których jednostka staje bezsilna ${ }^{241}$. Dotyczy właściuie uszystkich bohaterów Przybyszeuskiego ${ }^{242}$. Źródło ich niepouodzeń tkwi zaś w braku miłości, jakim zostali skażeni przy poczęciu. Jan, należący do upadłego, dekadenckiego rodu Krywłów, tragiczne dziedzictwo po przodkach uświadamia sobie po śmierci ojca, tyrana na prawo i lewo płodzącego dzieci ze swoimi chłopkami:

Nagle zrozumiał przyczynę nędzy całego rodu: Matka nie kochała ojca... A! teraz mu się uszystko rozjaśniło - teraz uszystko zrozumiał: tuardą, surową naturę ojca - zazdrosną nienawiść ku uszystkiemu, co płciouym szczęściem trąciło [...]. (Dn I, 8)

Spostrzeżenia Jana potwierdza opowiadanie spotkanej przez niego prostytutki, popchniętej na drogę nierządu przez matkę. Jak wcześniej u Synach ziemi, pojawia się tu przekonanie o dobroczynnej roli rzezi niewiniątek:

najstraszliuszą wyprawiają orgię. Widzę je, gdybym był malarzem, odtworzyłbym je $u$ tej chwili! Woskowa nędza o ptasich oczach i ptasiej twarzy, kościana śmierć, szkielet nagi [...] i ta Astarte, dławiąca gardło, dzika, chciwa, pragnąca, nienasycona” (K. Przerwa-Tetmajer, Otchłań. Fantazja psychologiczna, Warszawa 1901, s. 9).

${ }^{240}$ Por. G. Matuszek, Między pustka..., s. 28.

${ }^{241}$ W. Gutouski, Konstelacja Przybyszewskiego, s. 126.

${ }^{242}$ Nędzę ludzką - namacalną, odniesioną do biedy i fizycznych ułomności ludzi żyjących na marginesie społeczeństua - poznał Przybyszeuski jako uczeń gimnazjum w Toruniu. W Moich wspótczesnych pisarz uspomina spacery po zaniedbanych przedmieściach miasta i wizyty u zamku krzyżackim, wóuczas „przytułku ostatnich nędzarzy”, gdzie podpatrywał „zdziczałe, rozpustne robactwo, gnieżdżące się w tych wilgotnych, rozpadających się norach” (S. Przybyszeuski, Moi wspótcześni, Warszawa 1959, s. 52-3). Pisze dalej:

Ukochałem wóuczas nade uszystko nędzę i cierpienie.

I stałem się hardy i ,zły” - ,zły” w całkiem innym znaczeniu.

Pozostałem tym samym tkliuym, nieśmiałym i odludnym chłopakiem, jakim byłem i jakim ostatecznie pozostać miałem. Ale $w$ duszy mojej rodził się niepohamowany bunt przeciu niesprawiedliwości praw ludzkich i coraz więcej wzmagający się żal do Boga, że na to pozwalał. 
[...] matka ma prawo do życia i prawo do mnie - uydała mnie na śuiat, więc mogła swoją własnością rozporządzać, jak jej się podobało. [...] Jedno jej tylko za złe biorę, że mnie w zarodku nie zabiła. Dzieci nędzy [...] trzeba od razu niszczyć... Herod był wielkim dobroczyńcą ludzkości, kiedy kazał wyniszczyć pierworodny płód ${ }^{243}$. Rzeź betlejemska to jeden z najwięcej dobroczynnych czynów, jakie ludzkie plemię doświadczyło. (Dn I, 229)

Continuum egzystencji, motywowane przez Szatana, jest zatem przekleństwem, ponieważ służy wyłącznie temu, by człowiek ciągle cierpiał ${ }^{244}$. Z braku miłości rodzą się bowiem ludzie do miłości niezdolni, choć jej pragnący. Każde z „dzieci nędzy” na swój własny sposób usiłuje radzić sobie z cierpieniem. Hanka z Synów ziemi sięga po opium, ale ono obezwładnia. Rodzeństwo z powieści Dzieci nędzy, by ujść przed „rodzinnym katastrofizmem” ${ }^{245}$, wybiera inne sposoby: Zdzisław popada w alkoholizm („Alkohol ordynarny - niszczy duszę i uyuraca ją na ręby" - pada w powieści ocena; Dn II, 16), Jan - w obłęd, w którym widzi siebie jednocześnie jako Chrystusa i zdradliwego Judasza, Gustaw szuka pociechy $w$ buddyzmie, Zbigniew bawi się $w$ anarchistę, podrzucając ładunki wypełnione nitrogliceryną, a Sala oddaje się prostytucji.

Przybyszewski nie pokazuje uczucia stabilnego, opartego na zaufaniu i poczuciu bezpieczeństwa, ale jego celem nie było też selektywne portretowanie ludzi słabych, niewinnie skazanych na cierpienie. Dźwigany przez bohaterów ciężar nieszczęścia, choroby czy upadku wynika z naznaczenia wszelkiej egzystencji „nędzą metafizyczną”. Zło i dobro wpisane są bowiem w naturę świata i nie zależą od decyzji człowieka. Ból nie zamienia się w skargę, lecz nie ma też funkcji katharsis. Może być za to drogą do poznania własnego unętrza i indywidualnego losu, dojrzewaniem do zmierzenia się z prawdą. Dlatego bohaterowie Przybyszeuskiego obdarzeni są wyjątkowo przenikliwą świadomością, pozwalającą głęboko rozpoznać negatyune przeżycia. Doświadczenie cierpienia nobilituje, ponieważ wyodrębnia jednostki wyjątkowe, uyposażone u szczególną wrażliwość. Jak zauważa Magdalena Popiel - nadaje uszystkim postaciom wykreowanym przez Przybyszeuskiego „duchową wzniosłość”, mimo że każdorazowo prowadzi do samounicestuienia $^{246}$.

${ }^{243}$ Identyczny, paradoksalny wątek myślouvy wystąpił niewiele wcześniej w wierszu Adama Asnyka z 1890 r., ironizującym na temat „historycznej nowej szkoły”, transponowanej z Niemiec, która:

Nie poustrzyma się u zapędzie,

Aż dowiedzie, że król Herod

Dobroczyńcą był dla sierot.

(A. Asnyk, Historyczna nowa szkoła [w:] idem, Poezje zebrane, ustęp Z. Mocarska-Tycoua, Toruń 2000, s. 670)

${ }^{244}$ Zob. też M. Bourkane, Stanisław Przybyszewski wobec wybranych aspektów filozofii genezyjskiej Stowackiego, s. 71-73.

${ }^{245}$ Tego celnego terminu podkreślającego destrukcyjność i autodestrukcyjność relacji w familii Krywłów użył W. Gutouski, Konstelacja Przybyszewskiego, s. 108 i in.

${ }^{246}$ M. Popiel, op. cit., s. 45. 


\section{Inne uczucia i stany towarzyszące miłości}

U Przybyszeuskiego właściwie nie ma uczuć tradycyjnie kojarzonych z miłością. Związek dwojga bohaterów rzadko opiera się na przyjaźni, szacunku, altruizmie. Zakochani i pożądający zachowują się egoistycznie, ponieważ ważniejsze niż partner bywa dla nich samo uczucie. Dlatego też nadzuyczaj często poddają się wizjom i obrazom wywołanym przez uyobraźnię, a poważne emocje wyrażają w teatralnych pozach i pustych gestach.

O wzajemnej fascynacji nie decydują cechy indywidualne partnerów. Przybyszeuski nie prezentuje łączącej ich więzi emocjonalnej, która byłaby oparta na uspólnocie poglądów, zainteresowań czy postaw wobec życia. Nie pozwala śledzić rozwoju uczucia. Oto, co mówi na temat jego rodzenia się w jednym ze suych esejów:

Miłość ogarnia człouieka bez uzasadnionej przyczyny: może jest nią jakiś nastrój wywołany oświetleniem, w jakim przypadkowo ujrzeliśmy kobietę, zapach róż, które miała we włosach, jakiś ruch, w jaki ułożyło się jej ciało. Miłość wywołać mogą najbardziej śmieszne drobnostki, z których tylko w bardzo rzadkich przypadkach zdajemy sobie sprawę ${ }^{247}$.

Źródło olśnienia tkwi więc $\mathrm{w}$ podśuiadomości, opiera na asocjacji urażeń i wiąże z pamięcią głęboką. W Falku pociąg do Maryt budzą białe róże, jakie nosi ona we włosach, a jakie widział w dzieciństwie rozstawione wokół trumny ze zmarłym leżącym na marach. Mistyczna atmosfera towarzysząca schyłkowi życia w nietypowy sposób odżywa w miłosnym spotkaniu dzięki kwiatom. Owo uspomnienie skojarzone z zapachem jest jednocześnie antycypacją samobójstwa uwiedzionej Maryt, która topi się w rzece ${ }^{248}$.

Kuiaty inicjują pożądanie róunież u Androgyne - otrzymany po uystępie bukiet rozpala $w$ bohaterze namiętność do nieznanej kobiety, która mu go podarowała, a której odnalezienie jest możliwe dzięki jej silnej identyfikacji z kuiatami.

Sprzyjający olśnieniu upływ podświadomości ujawnia się także w chwilach, gdy kobieta i mężczyzna na zasadzie déjà vu rozpoznają w uidzianej po raz pieruszy osobie kogoś sobie znanego (być może z pierwotnej androgynicznej jedności).

${ }^{247}$ S. Przybyszeuski, Misteria (O powieści Knuta Hamsuna), [w:] idem, Synagoga szatana..., s. $109-110$.

${ }^{248}$ Śmierć bohaterki zapowiada jeszcze jedna scena wykorzystująca transpozycję wrażeń. Otóż Falk, dotknąuszy dłoni Maryt, przypomina sobie, jak podczas dziecięcej kąpieli w jeziorze czy rzece uratował od zatonięcia dzieuczynkę, co miało rozbudzić u nim mężczyznę. O montażu asocjacyjnym pisała M. Podraza-Kuiatkouska, Symbolizm $i$ symbolika..., s. $195-204$. 
Wyłoniła się twarz dziewczęcia: jasny dźuięk, jasne odbicie bladej guiazdy w rozkipieniu ciemnych fal - nie widział jej nigdy, ale znał ją, znał... (A 383)

- stwierdza narrator poematu. Z kolei Falk wyznaje Izie:

To uszystko takie dziune... Dziune, że Mikita jest moim przyjacielem, że pani jest jego narzeczoną... dziune jest uczucie, jakbym już znał panią od tysiąca lat... (Hs I, 59)

W świecie Przybyszewskiego brakuje czystej radości z bycia we dwoje, uspólnego oddawania się przyjemnościom. Bohaterowie odczuwają ciągły niepokój, miotają się między euforią a apatią. Nadejście miłości zaskakuje ich, ponieważ nie wiąże się z uczuciami pozytywnymi. Narrator Homo sapiens tak relacjonuje stan i myśli Falka:

[...] niepokój jego uzmagał się coraz silniej. Walczył z jakąś dziuną męką, która tamouała bicie jego serca.

$[\ldots]$

Czy to była miłość?

Uczuł truogę. (Hs I, 45)

Jak najdalszy od błogostanu jest także zakochany bohater Androgyne:

Jakiś straszliuy a nieskończenie cichy smutek krążył mu w żyłach, zlewał się w sercu, udrążał się u najtajniejszą szczelinę jego nerwów. (A 395)

Zauroczenie nieodłącznie pociąga za sobą smutek, tęsknotę i niepokój, które już nie opuszczą bohaterów, ponieważ od tego momentu próbują oni zdobyć przedmiot uczuć, zatrzymać go lub odzyskać. Nie wahają się upokarzać i poniżać przed istotą ukochaną, by przekonać ją o swym uczuciu.

Zostań, zostań! Tuoim psem będę, rób ze mną, co chcesz! Bij, zabij! - Rób, co chcesz, tylko nie opuszczaj mnie! (Dszcz 57)

- błaga Helena Mlickiego. Podobnie przemawia do siostry bohater De profundis:

[...] jestem twoim niewolnikiem, psem tuoim. Możesz ze mną robić, co ci się podoba, duszę mi z ciała wyruać, jeżeli zechcesz, a jeszcze będę ci za to udzięczny, boś ty to zrobiła, ty $-\mathrm{ty} . . .(\mathrm{Dp} 78)$

Dla zaspokojenia suych pragnień gotowi są nawet przystać na wieczne potępienie: 
Szatanie! Wykreśl mnie z księgi żywota, upisz mnie u księgę śmierci i hańby wiecznej, ale pozwól, że raz jeszcze uczuję tę rozkosz nad uszelkie rozkosze, jak pierś jej się u moją wpala, jak usta jej się w moje upijają, jak ręce jej dyszą na mej szyi w bolesnym upojeniu. (Nm 288-289)

Lęk przed utratą partnera towarzyszy wykreowanym przez Przybyszewskiego postaciom najczęściej. Doświadcza go Helena z dramatu Dla szczęścia, Gustaw Rembouski ze Złotego runa, Bronka ze Śniegu, Wacław Druęski z Godów życia, Iza z Mściciela, Mikita z powieści Homo sapiens, a także męscy bohaterowie poematów Nad morzem i $Z$ cyklu Wigilii. Obawa uynika przede uszystkim z pojawienia się osoby trzeciej, stanowiącej zagrożenie dla stabilności zuiązku. Reakcją obronną staje się wówczas w pieruszym rzędzie zazdrość. Z zazdrości Zygmunt uskazuje Krzyckiemu drogę w góry, gdzie przeciunik może znaleźć tylko śmierć (Śluby). Z zazdrości bohater $W i$ gilii pragnie zabić ukochaną. Z zazdrości - tym razem o przeszłość i dziecko - Wacław Drwęski zabrania Hance odwiedzania córeczki (Gody życia).

Zazdrość nie może oczywiście ocalić miłości, a u Złotym runie pokazana jest wręcz jako czynnik niszczący:

\section{IRENA}

O wszystko jesteś zazdrosny - każde moje słowo nicujesz... Wiesz, jak kocham taniec - zaprowadziłeś mnie na bal - nigdy już nie pójdę. Byłam wesołą, bawiłam się, a ty - ty, och, nie móuiłeś słowa, niczym się nie zdradziłeś, ale czy myślisz, że nie wiem, jaka burza w tobie szalała? Namiętnie lubię ślizgawkę i łyżuy. Raz sam mnie zaprowadziłeś - a potem [...] zamknąłeś się u swojej pracouni, dua dni nic do mnie nie mówiłeś - nie mówiłeś. [...]

\section{REMBOWSKI}

Inka, Inka, kocham cię za bardzo. Czy ty nie rozumiesz tej męki, gdy widzę cię w obcym objęciu - gdy widzę cię przytuloną do innego... (Zr 187-188)

Brak peuności wyraża się poza tym w obsesyjnym niemal podkreślaniu suych praw do partnera, wynikających z kochania i bycia kochanym po raz pieruszy. Przesłauski bez skrupułów wkracza w życie małżeńskie Ireny, ponieważ kochał ją, zanim poślubiła Rembouskiego:

I będziesz moją. Ja mam prawo do ciebie. Kochałem cię od dziecka. Nikogo, prócz ciebie (Zr 200)

- zapewnia despotycznie.

Dla skomplikowania problemu rodzenia się miłości, rywalami o uzględy kobiety czyni Przybyszeuski przyjaciół. Falk miota się między uczuciem do Izy a lojalnością wobec zaręczonego z nią Mikity, z którym zdobywał uspólne doświadczenia jeszcze $u$ gimnazjum, lecz ostatecznie uybiera szczęście własne. Nie mając odwagi przyznać się szkolnemu koledze do „skradzionej” 
mu miłości, obłudnie przekonuje go o obojętności wobec Izy. Zazdrosny Mikita natomiast $\mathrm{w}$ masochistyczny niemal sposób popycha narzeczoną $\mathrm{w}$ ramiona Falka poprzez testujące jej uczucia, rozpaczliwe decyzje zapraszania konkurenta do domu i pozostawiania go w kawiarni jedynie w towarzystwie ukochanej.

Jeszcze wyraźniej zdradę prowokuje bohater prozy $Z$ cyklu Wigilii. Zauważyuszy zainteresowanie partnerki innym mężczyzną - zainteresowanie, z którego ona nie zdaje sobie jeszcze sprawy - nie zaprzestaje zadających ból spotkań „w trójkącie”. W jego przekonaniu zdrada już się dokonała - w myśli kobiety. „Dawno już to wiedziałem; nie potrzebowałem żadnych dowodów. Czułem jej zdradę w sobie, poza sobą; widziałem ją w jej oczach, w każdym ruchu, wiedziałem, zaczym naocznie się o tym przekonać mogłem" (W 191) - rozważa, podobnie jak czynił to ouładnięty skrajnymi uczuciami do żony bohater o kilka lat wcześniejszej Sonaty Kreutzerowskiej Tołstoja. Potrzebę zyskania ostatecznego dowodu realizuje podczas jednego z kolejnych wieczorów, obseruując poruszenie ukochanej namiętnie akompaniującej „temu trzeciemu”, czytającemu swój poemat ${ }^{249}$. Po skończonym dziele wielkopańskim gestem nagradza oboje rozkazem pocałunku. Tak go relacjonuje:

[...] uspięła się na palce, uygięła się w kształt napiętego łuku i zatonęła wzrokiem w jego duszy. Porwał ją na ramiona, podrzucił na sue piersi, ugryzł się ustami w jej usta - pociemniało mi w oczach, schwyciłem kurczowo poręcz mego krzesła i krzyczałem jak uściekły:

- Silniej jeszcze, silniej!

$[\ldots]$

O, ta nieskończoność sytego szczęścia w jej oczach, to bezkresne oddanie się w każdym drgnięciu jej ciała.

${ }^{249}$ Obezwładniającą moc sztuki jako źródła, medium i usprawiedliwienia dla uzajemnej fascynacji akcentował Tołstoj w głośnej Sonacie Kreutzerowskiej. Pojawienie się dawnego sąsiada, znakomitego skrzypka - niejakiego Truchaczeuskiego - działa w opouiadaniu destrukcyjnie na i tak dręczone rozkładem małżeństwo Pozdnyszewów. Pani Pozdnyszew, umilająca sobie czas grą na fortepianie, stopniowo ulega urokowi przybysza podczas uspólnego muzykowania. A przynajmniej tak wydaje się jej mężowi, w niezrozumiały, prowokacyjny sposób zabiegającemu o kolejne wizyty Truchaczeuskiego: „Bardzo mi się nie spodobał od pieruszego wejrzenia. Ale dziwna rzecz, jakaś dziwna, fatalna siła zmuszała mnie do tego, by go nie odepchnąć, nie oddalić, lecz przeciunie, zbliżyć do siebie. [...] Od pieruszej chwili, kiedy wzrok jego spotkał się ze wzrokiem żony, wiedziałem, że bestia tkuiąca w obojgu, mimo uszystkich światowych konwenansów, spytała: »Czy można?«, i odrzekła: »O tak, i ouszem«". Poza popędami i bujnym temperamentem winą za zbliżenie obojga Pozdnyszew obarcza muzykę: „Stałby się pośmiewiskiem ktoś, kto by zwalczał zbliżenie na balach, zbliżenie lekarzy z pacjentkami, bliskość przy zajmowaniu się sztuką, malarstwem, a przede uszystkim - muzyką. Ludzie zajmują się we dwoje najszlachetniejszą sztuką, muzyką, do tego potrzebna jest pewna bliskość, $\mathrm{w}$ tej bliskości nie ma nic zdrożnego, i tylko głupi zazdrosny mąż może widzieć $\mathrm{u}$ tym coś niepożądanego. A przecież uszyscy wiedzą, że ułaśnie za pośrednictuem tych zajęć, zułaszcza muzykowania, dochodzi do większości uypadków cudzołóstua u naszej sferze" (L. Tołstoj, Sonata Kreutzerowska, tłum. M. Leśnieuska, Warszawa 1987 , s. $142-143,146,150)$. 
Wyszedłem, taczając się, z pokoju.

Może, że chciałem im dać czas, by się raz jeszcze sobą nasycić mogli.

Gdym wrócił, leżał u jej nóg, całował jej stopy i był szczęśliwy, och, tak szczęśliwy... (W 200-201)

Dowód miłości u postaci pocałunku uytrąca bohaterowi-narratorowi z ręki oręż do walki o ukochaną. Uzasadnione uydaje się tylko rozstanie. U Przybyszeuskiego żaden mężczyzna nie walczy aktyunie o kobietę, w której rodzi się uczucie do innego. Mikita woli zadręczać się podejrzeniami u zaciszu malarskiej pracouni (gdy Falk i Iza tańczą u kawiarni), a wreszcie u milczeniu popełnić samobójstuo, ponieuaż zazdrość ośmiesza ${ }^{250}$. Z obauy przed śmiesznością i utratą godności u milczeniu cierpi też Gliński, porzucony przez żonę w Synach ziemi. Wzoru zachowania dostarczała przywołana na kartach tej powieści anegdota o hrabim, który przyłapauszy żonę in flagranti z młodym porucznikiem, pokrywa upokorzenie wymuszonym uśmiechem, w ten sposób okazując kochankom pogardę: „Cóż z nią zrobić? [...] Zabić? Po co? niewarta tego! Pojedynek? Ha, ha - jej kochanek - to uwiedzione biedactwo, aż nadto ukarane swoim upodleniem..." (Sz I, 38) - rozważa i ostatecznie dwa tygodnie później rzuca się ze szczytu Mont Blanc.

Ale bierna akceptacja odchodzenia ukochanej nie sprowadza się do urażonej męskiej dumy; jej motywacja jest bardziej złożona. Otóż bohaterowie Przybyszeuskiego wiedzą, że miłosnemu przeznaczeniu nie można przeszkadzać, że z naturą-chucią nie da się walczyć, wreszcie - że istoty stanowiące jedność $w$ prabycie po spotkaniu na ziemi spróbują rozerwaną unię odtworzyć. Śuiadomość bezcelowości zmagań o miłość otwiera przed porzuconymi tylko dwie drogi: cierpienia u milczeniu lub szukania ukojenia w śmierci.

Aktyuną drogę uyrzutów i pretensji uybierają jednak zazdrosne kobiety. Łucja gotowa jest zdemaskować Bieleckiego-plagiatora, odkryuszy jego romans z Karską. Karska, uidząc rywalkę w pani Ligęzowej, posuwa się do ironicznych docinków i demonstracji przewagi nad „mocnym człouiekiem”. Dramatyczniej przebiega rywalizacja między szuagierkami w drugiej części Dzieci nędzy. Dorastająca Zosia, zakochana bez uzajemności w Adamie Drzazdze, zaczyna nienawidzić suej bratowej Jadwigi, w której - również bez uzajemności - kocha się Adam. Mimo że między kobietami nie dochodzi do bezpośredniego uspółzawodnictwa o mężczyznę (notabene, należącego do tej samej co one rodziny), żadna z miłości nie może zostać zrealizowana. Zosia, najmłodsza potomkini rodu Krywłów, przekonana u suym obłędzie,

${ }^{250}$ W Przewodniku zakochanych z 1903 r. M.A. Zawadzki radził, by unikać pozorów zazdrości: „Konkurent widząc, że narzeczona się bawi, że jest oblegana przez młodzież - nie powinien ukazywać nieukontentowania w spojrzeniach lub, broń Boże, wymóukach. Zazdrość nie zausze jest dobrym sprzymierzeńcem miłości. Zazdrość zaślepia i ośmiesza" (M.A. Zawadzki, Przewodnik zakochanych, s. 39). 
że Jaduiga stoi na drodze do jej szczęścia, u geście rozpaczy najpieru niszczy róże uyhodowane dla niej przez Drzazgę, a wreszcie wbija bratowej w serce nóż myśliuski.

Konieczność dzielenia się partnerem jest dla bohaterów Przybyszeuskiego nie do przyjęcia. Prawu uyłączności chcieliby podporządkować nie tylko jego ciało i uczucia, ale nawet myśli i uspomnienia. Zdżarski zrezygnował ze zdobycia Olgi, ponieważ był mu „ustrętny widok tylu pożądliuych rąk, które się po nią wyciągały" (Dla szczęścia, 23). Olga woli żyć bez Mlickiego, niż czuć, że on „w ciągłej rozpaczy rozmyśla możliwość samobójstua dawniejszej kochanki" (Dla szczęścia, 64). Wacław wprost żąda od Hanki: „[...] mnie jednego masz kochać - o uszystkim zapomnieć - o niczym nie myśleć prócz o mnie, tak jak ja nie mam innej myśli, prócz o tobie!” (Gody życia, 55-56).

Życie uczuciowe i erotyczne bohaterów Przybyszeuskiego jest do tego stopnia skomplikowane, że ujaunia się w nim emocjonalny paradoks „kocham i nienawidzę"; ich namiętności towarzyszy odraza, pożądaniu - pretensje. Kochają, bo kochać muszą, a jednocześnie nienawidzą, ponieważ miłość jest grzeszna, rani niewinnych i burzy ustalony rytm życia. Podstawą tego kompleksu jest całkowite uczuciowe uzależnienie od partnera, znamionujące związki nazywane we uspółczesnej psychologii toksycznymi. Przymus kochania, ograniczający wolność i zagrażający podmiotowości, jest źródłem negatywnych, destrukcyjnych emocji. I tak Falk nienawidzi, ponieważ czuje się zniewolony koniecznością kochania niezależnego od suej woli:

Słuchaj, Iza. Nienawidzę Cię czasami [...]. Umiem Cię tak nienawidzić, że od zmysłów odchodzę. Nienawidzę, bo tak Cię kochać muszę, bo uszystkie moje myśli do Ciebie się odnoszą, bo nie ma chuili, u której byś nie stała przed moimi oczyma. (Hs III, 28)

\section{Z tego samego powodu Irena czyni Przesłauskiemu takie uyrzuty:}

Jakiś ty straszny! A ja taka słaba, taka biedna. Oprzeć ci się nie mogę. [...] Lękam się ciebie. A on taki dobry [mówi o mężu Irena] - on uszystko czuje [...] - ach, jak ja cię nienawidzę! (Zr 200)

Bohaterowie De profundis chcieliby uwolnić się od kazirodczej miłości, ale nie potrafią.

- Nienawidzę cię, nigdy nie chcę cię już uidzieć.

- Ja też nie.

Ale gdy się zerwała, by pójść, schwycił ją za rękę.

- Przebacz mi, jestem chory. (Dp 80) 
Problem ten został dodatkowo skomplikowany w powieści Synowie ziemi. Hanka, porzuciuszy dla Czerkaskiego męża i córeczkę, nie tylko nie umie pogodzić się z narzuconą przez los miłością, lecz i utratą szansy na wychowanie dziecka. Poczucie rezygnacji z wartości, jaką jest macierzyństwo, uzbudza w niej nienawiść do ukochanego. Dręcząca bohaterkę uczuciowa ambiwalencja prowadzi do osobliwej psychomachii. Napięcie emocjonalne jest tak silne, że Hanka bezpodstawnie podejrzewa kochanka o brak miłości do niej:

Śpi, śpil Czyż on mnie na tyle nie kocha, by nie mógł czuwać, gdy cierpię, by nie mógł choć jednej godziny czuwać uraz ze mną?

$[\ldots]$

Jezu! Jezu! On mnie nie kocha. Nie! nie! Człowiek, który przed chwilą słyszał mój krzyk, a teraz tak spokojnie zasnął, nie kocha, nie, nie!

$[\ldots]$

A on śpi, szeptała nienawistnie - śpi snem spokojnych - ha, ha - tych sprawiedliwych, co tylko siedem razy na dzień grzeszą...

Nagle przeraziła się sama siebie.

- Skąd ta nienawiść?

$[\ldots]$

Nie, nie, nie! Śpij, złoto moje najdroższe!...

I już wyciągnęła ręce, by pogłaskać, by przytulić do piersi tę umęczoną głowę, a nagle, jakby płomień, co spod długo tlejącego zarzewia u górę tryśnie:

- Dziecko mi zaprzepaścił!

- Męża ci zabrał! - rechotał szatan.

$[\ldots]$

Teraz mogłaby uszystkimi siłami tłuc tę tak nieskończenie ukochaną, znienawidzoną głowę o kamienną ścianę - mogłaby deptać żelazną stopą po tym zmęczonym, w ciężkim śnie uyciągniętym cielsku - tym rozkosznym ciele, które ją z taką chciuą żądzą noc u noc obejmowało i które ona z róuną miłością tuliła, tratować je, siepać biczyskiem, rozorywać kańczugiem... (Sz II, 38-41)

Jedyne pewne dowody miłości to pamiątki. Są niezmienne, w przeciwieństuie do uczuć, i obiecują więcej niż uczucia mogą dawać. Stają się metonimią (czy może raczej substytutem) osoby, od której pochodzą, i traktowane bywają fetyszystycznie. Bohater Androgyne pieści czerwoną ustążkę zdobiącą kuiaty od nieznajomej, co staje się namiastką doświadczenia erotycznego. Kawałek materiału nabiera cech żywej istoty, zdaje się odpowiadać:

Zdawało mu się, że coś z jej istoty usiąkło u tę ustążkę. Czuł, że żyje. Gdy ją głaskał, zdawało mu się, że ręka jego spływa wzdłuż jej aksamitnego ciała; gdy ją całował, czuł zapach jej jedwabnych włosów; okręcił ją naokoło suych piersi, a czuł oplot jej wiotkich członków... (A 393)

Tasiemka podtrzymująca bukiet daje wyobrażenie o jego tajemniczej ofiarodauczyni. Bohater nigdy nie uidział pożądanej kobiety, a mimo to wie, że ma aksamitne ciało, wiotką syluetkę i jedwabiste włosy. Więcej - on może 
zapach tych włosów poczuć! Nawet jeśli owe doznania zmysłowe mają jedynie charakter życzeniowy, są na tyle silne, że pozwalają bohaterowi szukać nieznajomej wśród określonego typu kobiet i - odnaleźć ją.

Podobną rolę spełniają u Przybyszeuskiego listy. Korespondencja między kochankami nie jest ważna ze względu na przekaz treściowy, lecz z powodu emocji, jakie nadawca wzbudza w adresacie. Świadczą o tym słowa zakochanego w swej siostrze bohatera De profundis:

Drżałem i trząsłem się, gdym listu od ciebie oczekiwał. A gdym go wreszcie otrzymał, czytałem go i czytałem nieustannie. Czytałem uszystko, czegoś mi napisać nie chciała lub nie mogła, ale co w każdym słouie gorącą krwią biło - całymi tygodniami nosiłem tue listy przy sobie, pieściłem je rękoma, całowałem, tuliłem, kiedym jeszcze nie przeczuwał, że staniesz się tym dla mnie, czym dziś mi jesteś. (Dp 63-64)

Uczucia i pożądanie niejako w zastępstuie skierowane zostają zatem na zapisany ręką ukochanej papier. List staje się przedmiotem czułości także w Śniegu. Kartki od Tadeusza, zapewniające o gorącym uczuciu, Bronka nosi w staniku i całuje, znajdując w nich pociechę wobec coraz bardziej jawnej fascynacji jej męża Ewą. Z nie tak dawnej miłości pozostała jej już tylko korespondencja („najukochańsze, drogie listy” - Ś 51), potęgująca poczucie straty, ale jednocześnie dająca złudzenie, że nie uszystko zaprzepaszczone. List od Ewy jest natomiast w dramacie pułapką zastawioną na Tadeusza. „Serdeczny, gorący i wylany” (Ś 35), uysłany w dniu jego ślubu z Bronką, pozornie z zamiarem złożenia gratulacji i przeprosin za uyrządzone krzyw$\mathrm{dy}, \mathrm{w}$ istocie jest podstępną - udaną zresztą - próbą pojednania, przygotowującą grunt do dalszych spotkań.

Listy spełniają jeszcze jedną interesującą funkcję: stają się zapowiedzią nieszczęścia. Nie otwierając dostarczonej korespondencji, Helena domyśla się przyjazdu Olgi (Dla szczęścia), natomiast bohater De profundis miłość do Agaj uświadamia sobie dopiero po przeczytaniu kartki od żony, w której czyta: „Jej [Agaj] miłość taka dziwna. Ona nie kocha cię jak siostra” (Dp 45).

Miłość jest chorobą atakującą duszę i ciało. Znamionują ją takie objawy, jak gorączka, dreszcze, halucynacje, chwilowa utrata świadomości. Bohater $Z$ cyklu Wigilii nie potrafi odtworzyć momentu pożegnania ze zdradzającą go żoną. Ostatnie zdanie rozmowy, jakie pamięta, to wypowiedziane przez siebie: „Nie zobaczymy się więcej...” (W 172).

Co się potem stało - nie wiem. Ziemia usuwała mi się pod nogami, pociemniało mi w oczach; czułem, że lecę gdzieś, spadam, zaprzepaszczam się...

Przypominam sobie tylko, że zimny powiew wiatru chłodził me skronie - widocznie uyprowadziłem ją przed dom.

Gdy oprzytomniałem, byłem już u mojej pracowni. (W 172-173) 
Z miłością wiąże się specyficzne przewrażliwienie, oznaczające podatność na bodźce zmysłowe, wzmocnione podrażnieniem wyobraźni (taka nadurażliwość znamionować miała ludzi genialnych, jak pisał Lombroso w publikacji Geniusz i obtąkanie z 1864 r.). Bohaterowi Androgyne, wędrującemu po ulicach miasta w poszukiwaniu ukochanej, wydaje się, że dostrzega ją w każdej widzianej z daleka kobiecej postaci:

[...] czasami słyszał w wieczornym zmroku tuż poza sobą odgłos kroków, gdyby łopot niespokojnych skrzydeł, co lada chwilę do lotu zerwać się miały - czasami widział błyskawiczny przebłysk jakichś ciemnych oczu, co z nieznanych dali czy też pobliży u duszę mu się ugryzały - raz uczuł jej miękką, pieszczącą dłoń w swojej, gdy stanął u ciemnym kącie kościoła i chłonął smutną zadumę wieczornych modeł, ale gdy się odurócił, gdy oczyma wżerał się $\mathrm{w}$ mrok, by go $\mathrm{w}$ śuietliste szmaty rozstrzępić, widzenie pierzchało [...]. (A 386)

Potrzeba odnalezienia nieznajomej uzbudza w psychice bohatera sny o króleuskiej potędze, ale wywołuje też stany gorączkowe, wyczerpujące siły i nerwy. Coraz trudniej odróżnić mu jawę od majaczeń sennych. „Nie wiedział dokładnie, co się z nim dzieje” - stwierdza narrator (A 404). Apogeum osłabienia następuje $w$ chwili spotkania kochanków, kulminującej omdleniem bohatera ${ }^{251}$. Podobne przeczulenie nerwowe dręczy później „mocnego człowieka”. Myśląc o Ninie Ligęzowej, Bielecki ma męczące złudzenie zbliżających się i oddalających kroków, a upadek najdelikatniejszego pyłku wydaje mu się hałasem.

Chorobliwe objawy miłości dręczą najsilniej bohatera De profundis. Początkowo prowokuje je rozstanie z żoną, wymuszone koniecznością podjęcia mediacji między siostrą a matką, mieszkającymi w innym, nieokreślonym bliżej mieście. Należą do nich nieustanne fizyczne zmęczenie, przyspieszone bicie serca, uczucie zimna pomimo upału na zewnątrz, gorączka. Symptomy patologii nasilają się jeszcze, gdy bohater odkrywa w sobie kazirodczą miłość do Agaj. Drżenie jak w febrze, guałtowny napływ krui do mózgu, utrata kontaktu z rzeczywistością to tylko najłagodniejsze z nich. Znacznie niebezpieczniejszy jest brak kontroli nad własnymi czynami. Bohater nie przypomina sobie momentu pisania telegramu do żony, choć własnoręcznie nakreślił u nim dwa zdania: „Przyjeżdżaj natychmiast. Dzieje się ze mną coś strasznego" (Dp 84). Nawet książka, u której szuka uspokojenia rozpędzonych myśli, zaczyna ożywać w jego rękach. Napięcie oraz dezintegracja osobowości wynikająca z emocjonalnego rozdarcia pomiędzy miłością do żony a uczuciem do siostry owocują ostatecznie uzewnętrznieniem się jego

${ }^{251}$ Omdlenia jako skutek silnych emocji są jednym z ulubionych rozwiązań fabularnych w twórczości Przybyszeuskiego. Dla przykładu: Irena mdleje, gdy uychodząc z kochankiem, słyszy wołanie męża (Złote runo); bohater De profundis - uidząc po uyjściu Agaj swego soboutóra; Ostap po wyrzutach Heli, którą odrzuca, ponieważ była ucześniej kochanką kilku mężczyzn (Dzieci szatana). 
stanów psychicznych w postaci sobowtóra. Pojawia się on coraz częściej u miarę nasilania się kazirodczych pragnień i narastania obłędu. W którymś momencie bohater widzi go leżącego w przepaści z roztrzaskaną głową i wizja ta antycypuje samobójczą śmierć w finale utworu.

Zmęczenie fizyczne i psychiczne jako reakcja na miłość to objaw neurastenii $^{252}$. Pierusze wiąże się z dolegliwościami wegetatywnymi, przede wszystkim bólami głouy (najczęściej o charakterze ucisku zeunętrznego lub wewnętrznego) i kołataniem serca, oraz nietolerancją na wysiłek. Każdy ruch, nawet ustanie z łóżka, jest męczący. Drugie wyraża się uczuciem zniechęcenia, problemami z koncentracją i zapamiętywaniem, podatnością na podrażnienia zmysłowe. Najlżejsze bodźce stają się dla neuropaty źródłem przykrych wrażeń. „Człowiek neruouy jest jednostką hiperestetyczną, tj. cierpiącą na chorobliwą urażliwość. [...] przestał mieć pięć zmysłów, ma ich bowiem pięćset lub pięć tysięcy" - diagnozował w końcu XIX w. Mantegazza, za znamię czasu uznający „chorobliwą wrażliwość” i upatrujący źródła nerwowości we wzrastającym tempie życia, wadliuym systemie edukacyjnym oraz używkach ${ }^{253}$. Neurastenik uszystkiego ma dość, nie rozumie, co czyta, trudno mu napisać zuykły list, zapomina, co przed chuilą słyszał. Nie opuszcza go nieokreślony niepokój, wewnętrzne napięcie, jakby coś przykrego miało się wydarzyć, jakby coś mu zagrażało $^{254}$. Ów lęk wywołuje nienaturalne, wyolbrzymione reakcje. Przesada w uyrażaniu uczuć płynących z głębi duszy, miłosnych uniesień, lęków i kryzysóu odbiera im więc autentyczność; sprawia - jak pisze Paweł Dybel - że bohaterouie uydają się histerykami. Badacz zauważa jednocześnie, że histerią przesiąknięta była cała epoka, w której tworzył Przybyszewski. Ujauniała ona głębokie rozdarcie człowieka, jego niemożność identyfikowania się z kulturouymi wzorcami oraz powszechnymi normami ${ }^{255}$. Cały świat Przybyszewskiego przesycony jest guałtownością cierpienia i tęsknoty. Gesty i słowa mogące razić sztucznością u rzeczywistości odzwierciedlają nieumiejętność odnalezienia się u śuiecie. Należy przy tym zauważyć, że problematyka maski, mistyfikacji i zatraty osobowości jest znacząca w całej literaturze ekspresjonistycznej.

O niejednoznaczności problematyki erotycznej Przybyszeuskiego ciekawie pisał Tomasz Burek:

Zeusząd tu uyłania się tuarz Erosa, ale jest to Eros o podwójnej twarzy. Gdy z jednej strony ukazuje oblicze pogańskie, bachiczne [...], zapamiętałe u „ekstazie lubieży”, to z drugiej jakże jest ono zasmucone i udręczone, wykrzyuione konuulsyjnym grymasem grozy $[. . .]^{256}$.

${ }^{252}$ Terminu „neurastenia” użył po raz pieruszy u 1879 r. amerykański lekarz George Beard. W jego mniemaniu choroba ta była bliska melancholii i hipochondrii.

${ }^{253}$ P. Mantegazza, Wiek nerwowy, tłum. J. Wollerner, Złoczów 1890, s. 93, 97.

${ }^{254}$ Zob. A. Kępiński, Psychopatologia nerwic, Kraków 2002; E. Trillat, Historia histerii, tłum. Z. Podgórska-Klawe, E. Jamrozik, Wrocław 1993.

${ }^{255}$ P. Dybel, Literatura jako histeria..., s. 120.

${ }^{256}$ T. Burek, Przybyszewski kusiciel, [w:] Stanisław Przybyszewski. W 50-lecie..., s. 15. 


\section{Miłość a śmierć}

Śmierć niełatwo poddawać badawczej wiwisekcji. Po pierusze dlatego, że jej przeżycie jest nieprzekazywalne i niedostępne obserwatorom. A skoro zasadniczy moment odejścia pozostaje tajemnicą, umieranie może być opisane jedynie $w$ bardzo ograniczonym stopniu. Po drugie, fenomen śmierci w omawianym okresie to konglomerat różnorodnych nurtów modernistycznego światopoglądu, wymaga zatem przywołania wielu perspektyw soteriologicznych, propozycji religijnych i filozoficznych. Na młodopolską retorykę śmierci złożyło się bowiem zarówno przejęte z romantyzmu przekonanie, że tylko w pogardzie dla śmierci tkui nadzieja uyzwolenia (nie tylko w sensie narodowym, ale i metafizycznym), jak i zaczerpnięta z pism Schopenhauera świadomość bezwartościowości bytu i nicości ludzkiej egzystencji ${ }^{257}$. Śmierć to - obok miłości - monotemat literatury końca XIX w., powiązany z dekadenckimi niepokojami, kryzysem wiary i poznania, zainteresowaniem psychologią jednostki. Z jednej strony odsłania praudę o ograniczeniu człowieka, z drugiej - jawi się jako doświadczenie transgresywne. Jest wyrazem klęski życiowej, ale i aktem najwyższej wolności. Bogactwo jej odcieni trudno byłoby przedstawić nawet $w$ ramach bardzo obszernego studium. Hanna Ratuszna, która w wydanej w 2005 r. rozprawie podjęła analizę fenomenu śmierci u twórczości Stanisława Przybyszeuskiego ${ }^{258}$, nie zdołała wyczerpać tematu. W niniejszej publikacji zostaje on poruszony $w$ bardzo ograniczonym zakresie, sprowadzonym do zuiązków Erosa z Tanatosem - związków u literaturze modernistycznej wyjątkowo silnych i niemożliwych do zlekceważenia.

Śmierć przybiera u autora Śniegu tylko dwie postacie: morderstwa i samobójstua. Naturalny kres - spowodowany chorobą bądź starością - pozostaje całkowicie poza obrębem zainteresowań pisarza. Jest nie tyle mało frapujący literacko, co po prostu niezależny od ludzkiej woli, konieczny i bezsporny. Dlatego cierpiącemu na suchoty, a więc $w$ istocie powolnie umierającemu, artyście Górskiemu w pieruszych scenach powieści Mocny człowiek każe Przybyszeuski zażyć strychninę - by dowieść możliwości człowieczego panowania nad życiem oraz uyboru momentu i sposobu śmierci:

Posłyszał głos śmierci i uśmiechnął się.

Wołasz mnie, wołasz - musisz jeszcze trochę poczekać. Kocham cię, tęsknię bezbrzeżnie za tobą, gorąco pragnę tue wrota przekroczyć, ale panować nad sobą nawet tobie nie pozwolę.

${ }^{257}$ Zob. A. Lubaszeuska, Życie - Śmierci doskonatość, s. 54 i in.

${ }^{258}$ H. Ratuszna, Wieczność w człowieku. O młodopolskiej świadomości śmierci w twórczości Stanisława Przybyszewskiego, Toruń 2005. 
Musisz zaczekać, aż sam do ciebie przyjść zechcę - ja sam - poczekaj, aż cię zawołam: poznałem tuoje tajemnice i teraz ja jestem panem, panem nad życia ohydą i pięknością tuoją... A teraz się przejdę, jeszcze mam parę godzin czasu... (Mc I, 31)

Oczywisty zuiązek między samobójstwem a wolnością ugruntowały już rozważania filozoficzne starożytnych, przede uszystkim Seneki. Hegel uznał abdykację z życia za najistotniejszy argument na rzecz absolutnej wolności woli ${ }^{259}$. Schopenhauer twierdził, że człowiek powinien jak najszybciej opuścić ten świat, zaś śmierć traktował jak uybawienie. Dla Nietzschego naturalna śmierć była kresem nierozumnym, gdzie nędzna skorupa decyduje o tym, jak długo istnieć ma jądro. Rozważając w Wędrowcu $i$ jego cieniu sens samobójstwa jako śmierci rozumnej, Nietzsche stawia fundamentalne, obrazowo uyrażone pytanie: czy rozsądniej zatrzymać maszynę, gdy dzieło zostało wykonane, czy pozwolić jej chodzić, dopóki się nie zepsuje? ${ }^{260}$ W XX w. Landsberg, autor klasycznego studium o moralnym aspekcie samobójstwa, utrzymywał, że zadanie sobie śmierci jest szczytową możliwością egzystencji, Cioran natomiast - ogarnięty „obsesją” samobójstua - widział w nim najpotężniejszą afirmację wolności ${ }^{261}$.

Zintegrowanie gestu przerwania własnego istnienia z problematyką wolności można przedstawić $w$ dwu aspektach: po pierusze, $w$ uyborze śmierci najpełniej realizuje się wolność uyboru, po drugie - samobójcza śmierć pozuala osiągnąć wolność (od opresyjności życia) ${ }^{262}$. Młodopolska antropologia miłości kieruje uwagę ku drugiemu z uymienionych porządków. Zawiera bowiem obrazy samopoznania kulminujące rezygnacją z życia, oznaczającą realizację siebie u obliczu losu, z którym trzeba się zmierzyć. Samobójstwa popełniane przez bohaterów Przybyszewskiego są świadomym podejmowaniem odpowiedzialności za działanie. Najczęściej mają charakter kary wymierzanej sobie, nawet jeśli jest to kara za „winy niezawinione” (zob. podrozdz. Fatum). Człowiek uybiera śmierć w konflikcie losu/natury z moralnością społeczną i moralnością „wewnętrzną”, właściwą każdej jednostce. Jest to droga zgodna z filozofią Schopenhauera, który nie widział sensu $\mathrm{w}$ walce z przeznaczeniem i domagał się dobrowolnej rezygnacji z woli do życia ${ }^{263}$. O jej słuszności mówi się uprost w epilogu Tańca miłości i śmierci (Goście):

\footnotetext{
${ }^{259}$ Zob A. Lubaszeuska, op. cit., s. 118.

${ }^{260}$ Zob. J. Marx, Idea samobójstwa w filozofii, Warszawa 2003. Jeden z fragmentów Tako rzecze Zaratustra zatytułował Nietzsche $\boldsymbol{O}$ wolnej śmierci. Zapisał tam: „Moją śmierć sławię ja wam, śmierć wolną, która po mnie przyjdzie, ponieważ ja tego chcę" (F. Nietzsche, Tako rzecze Zaratustra, przeł. W. Berent, Warszawa 1990, [reprint wydania z 1907 r.], s. 83).

${ }^{261}$ E. Cioran, Zły demiurg, tłum. I. Kania, Kraków 1995.

${ }^{262}$ Por. A. Lubaszeuska, op. cit., s. 112.

${ }^{263}$ J. Tuczyński, op. cit., s. 142-143.
} 
[...] to uszystko głupstwo, to lep, na który życie ludzi bierze. Śmierć, śmierć, to jedyne - pluje się życiu u twarz i mówi się: mnie nie omamisz! I idzie się z wielką powagą i pogardą w śmierć! ( $\mathrm{G}$ 125)

Tylko śmierć może rozeruać błędne koło, w które uplecione zostało życie ludzkie ${ }^{264}$ :

Jeżeli kto sobie życie odbiera, to ma tysiąc powodów do tego, he, he - tysiąc i jeden... To tak samo jak z pijaństuem... [...] trzeba się zagłuszyć, zdusić coś u sobie... [...] ale lepsze samobójstwo, to peuniejsze i, że tak powiem, sumaryczna, ryczałtowa spłata za - za winy - mój Boże - winy? [...] Przecież nie ma winy, tylko kara jest, kara, kara... (Zr 211-212)

Przy pobieżnej lekturze Złotego runa, z którego pochodzi powyższy cytat, można odnieść wrażenie, że samobójstwo Gustawa Rembouskiego jest jedynie decyzją zdradzonego samca, który uniósł się honorem. W rzeczywistości bohater strzela do siebie, ponieważ odkrywa ukryty ład świata, bierze odpowiedzialność za własne postępowanie i postanawia spłacić winy nie tylko swoje, ale i swego ojca. Amor fati wiedzie ku śmierci także Hankę z Godów życia oraz Izę w Mścicielu. Pierusza nie jest u stanie pogodzić się z utratą dziecka i znieść myśli, że odchodząc od męża, dała innym prawo pogardzania sobą, co znalazło wyraz w dokonanym na niej gwałcie. Druga, przytłoczona ciężarem odkrytej u pełni rodzinnej przeszłości, skacze u przepaść, wymierzając sobie karę za oddanie się Orzelskiemu i unieszczęśliwienie Jerzego. Te przypadki pozwalają dostrzec, że sytuacje graniczne stwarzają jedyną możliwość samopoznania, rozeznania się w samym sobie i suych losach. Owo samopoznanie jest jednak wrogiem egzystencji - wzrastająca świadomość i samoświadomość odsłania bezduszne prawa bytu (którym zamiast człowieka rządzą natura i przeznaczenie), prowokując do rezygnacji z życia.

Niemniej przyjęcie odpowiedzialności $w$ akcie samopoznania nie jest triumfem, lecz bankructuem, pozbawionym najlżejszego choćby odcienia wielkości ${ }^{265}$. Śmierć Rembouskiego, Hanki oraz Izy to oznaka klęski, bezradności, próba zakłócenia dosięgającego ich przeznaczenia, ucieczka od zagadnień, których sami nie potrafią rozstrzygnąć. W żadnej mierze nie ma ona oczyszczającej mocy katharsis. Nie ma racji Hanna Ratuszna, która w zgonie Bieleckiego chce widzieć „okupienie popełnionych zbrodni” ${ }^{266}$. Śmierć „mocnego człowieka” nie jest ekspiacją. Nie jest nawet dobrowolna, lecz zadana ręką malarza Borsuka, okrutnie skrzyudzonego przez tytułowego bo-

\footnotetext{
${ }^{264}$ Ibidem, s. 168.

${ }^{265}$ Zob. I. Słauińska, Tragedia w epoce Młodej Polski, s. 53.

${ }^{266}$ H. Ratuszna, op. cit., s. 19.
} 
hatera. Bieleckiego stać na wyznanie swych zbrodni, na samobójstwo - nie, choć zapewne byłoby ono najbardziej przekonującym dowodem skruchy, rekapitulującym walkę bohatera z samym sobą ${ }^{267}$.

Zaproponowany przez Przybyszewskiego wariant samobójstwa jest zatem splotem wolności i rozpaczy ${ }^{268}$. Jeszcze uyraźniej można to dostrzec w melodramatycznych samobójstwach z powodu zawiedzionej miłości: Mikita z powieści Homo sapiens strzela sobie w usta, zdradzony przez narzeczoną i przyjaciela; uwiedziona i oszukana Maryt (z tego samego utworu) szuka śmierci w nurtach rzeki. Topią się róunież porzucone przez ukochanych Helena z dramatu Dla szczęścia oraz Bronka ze Śniegu. Nawet jeśli ich śmierć jest słabo umotywowana, jako że ważniejsze od niej samej jest wrażenie, jakie sprawia na pozostałych postaciach, to u jej podstaw leży przekonanie, że samobójstwo broni przed poczuciem nonsensu, pozwala ocalić (lub odzyskać) godność, nadać istnieniu wartość. Negacja siebie przechodzi zatem $\mathrm{w}$ afirmację siebie, zgodnie z tezą - wyrażoną przez Durkheima w doniosłym socjologicznym studium Samobójstwo (1897) - że im mniej zależy jednostce na sobie, tym bardziej jej na sobie zależy ${ }^{269}$. Do twórczości Przybyszeuskiego można więc odnieść ogólną myśl Anny Lubaszeuskiej: „Młoda Polska mocuje się ze śmiercią w swej poetyce i dyspucie filozoficznej, ale nie dochodzi do sformułowania tezy o absurdzie śmierci. Ouszem, prowadzi do sytuacji wywyższania się przez śmierć - osiągnięcia wolności”270.

We wszystkich dziełach Przybyszeuskiego miłość implikuje śmierć, która realizuje się przede uszystkim przez samobójstwo. Popularność samobójstu na kartach utworów młodopolskiego pisarza odpowiada ich rzeczywistemu wysokiemu natężeniu w drugiej połowie XIX w. Jak wynika z badań przywołanych przez Durkheima, w latach 1874-1878 niemal co piąty Francuz odbierał sobie życie z powodu miłości, zazdrości lub rozwiązłości. Do częstszych motywów samobójstwa należały tylko choroby umysłowe oraz „róż-

${ }^{267}$ Zapewne dlatego Bielecki sam uymierza sobie sprawiedliwość w niemym filmie nakręconym na podstawie powieści Przybyszeuskiego w 1929 r. przez Henryka Szaro, jednego z najważniejszych reżyserów polskiego kina przedwojennego, specjalizującego się w adaptacjach dzieł literackich (zrealizował m.in. Przedwiośnie, Dzieje grzechu, Ordynata Michorowskiego). Odtwórca głównej roli - Grzegorz Chmara, znakomity aktor rosyjski, związany ze słynnym moskieuskim MCHAT-em - tak móuił o granej przez siebie postaci: „Rolę Bieleckiego rozumiem jednak nieco inaczej niż ją rozumiał Przybyszewski. Jestem zdania, że demonizm tej postaci jest dziedzictuem okresu nietzscheańskiego, które zostało już za nami. Pragnę tę postać bardziej przybliżyć do życia, do prawdy". Film ten zaginął u czasie wojny. W 1997 r. odnaleziono go w Króleuskim Archiuum Filmowym w Brukseli. W 2006 r. ukazał się na płycie DVD.

${ }^{268}$ A. Lubaszeuska pisze, że synteza tych pieruiastków to cecha uspólna młodopolskich gestów samobójczych (op. cit., s. 119).

${ }^{269}$ Por. ibidem, s. 82.

${ }^{270}$ Ibidem, s. 83. 
ne zmartwienia" ( $u$ przypadku kobiet także kłopoty rodzinne) ${ }^{271}$. Przyczyn uspomnianego „nienormalnego wzrostu liczby samobójstu”"272 upatrywać można u XIX-wiecznej neurastenii, nieobcej i bohaterom Przybyszewskiego. Przypadłość ta, u której uspółcześni widzieli zaczątki choroby psychicznej, predestynuje bowiem do odczuwania rozpaczy. Wyjątkowa wrażliwość układu nerwowego sprawia, że myśli i uczucia neurastenika podlegają ciągłej gonitwie i rozchwianiu. Najbłahsze urażenia i doświadczenia uzbudzają wyolbrzymioną reakcję, prowadząc do przekroczenia granicy emocjonalnej i duchowej wytrzymałości.

Durkheim zauważył ponadto, że samobójstwo u znacznej mierze jest „zaraźliwe” ${ }^{273}$. Tendencja do tego nietypowego naśladounictua występuje u osób podatnych na wszelkie sugestie, skłonnych do roztrząsania uszystkiego, co im się przytrafia, oraz gotowych powtórzyć czyn, do którego mają już predyspozycje. Uwaga ta uydaje się interesująca przy analizowaniu motywów i sposobów, w jaki odbierają sobie życie bohaterki dramatów Śnieg oraz Mściciel. Bronka topi się w stawie, ponieważ taką samą śmiercią zginęła jej siostra. Iza rzuca się z urwiska w tym samym miejscu, w którym uczyniła to wcześniej nieszczęśliwie zakochana siostra jej adoratora. Wrażliwość nerwowa bohaterek skłania je ku poutórzeniu tragicznego końca, jaki stał się udziałem bliskich im kobiet. Wspomnienie widzianej niegdyś śmierci staje się impulsem do pożegnania się z własnym życiem. Samobójstwo realizowane jest przy tym niemal w identyczny sposób, jak gdyby było spadkiem dziedziczonym w kręgu najbliższych sobie ludzi ${ }^{274}$.

Samobójczą śmierć sugeruje zatem przeszłość. Ale nie tylko. Trafiającą na podatny grunt sugestię rezygnacji z życia podsuwają postaci symboliczne oraz rezonerzy. Bronkę $w$ krainę Tanatosa wprowadza piastunka Makryna. Wypowiadając słowa „Już czas!”, niczym Charon przeprowadza dziewczynę na drugą stronę bytu. Wcześniej u Dla szczęścia Żdżarski wyprorokował samobójstwo Heleny, przedstawiając je jako jedyną reakcję na porzucenie i uykorzystując dla ugaszenia własnego pragnienia zemsty, natomiast w Złotym runie Nieznajomy nakręcał zegar, uybijający godzinę śmierci, a Ruszczyc przekonywał Rembouskiego o zaletach samobójstua, które pozwoli-

${ }^{271}$ E. Durkheim, Samobójstwo, s. 191.

272 Ibidem, s. 14.

${ }^{273}$ Ibidem, s. 118.

${ }^{274}$ Durkheim zauważa, że tendencję do samobójstu naśladowniczych mają osoby chore umysłowo lub neurastenicy, których rodzice się zabili. Pisze: „Zdarza się często, że u rodzinach, gdzie obserwuje się poutarzane fakty samobójstwa, fakty te są prawie identyczne. Popełniane są nie tylko w tym samym wieku, ale też nawet w taki sam sposób. Raz jest to powieszenie, kiedy indziej natomiast zaczadzenie czy skok z wysokości”. Ibidem. 
łoby uciec przed bólem i jednocześnie spłacić winy wobec skrzywdzonych przez siebie osób.

Splot Erosa i Tanatosa najsilniej wyrażają samobójstwa otwierające perspektywę androgynicznego zespolenia. Traktowane są one w twórczości Przybyszeuskiego jako jedyna opcja powrotu do wymarzonej prajedni. Powrotu - jak zostało ucześniej wykazane - niemożliwego poprzez zjednoczenie seksualne, wikłające mężczyznę w ograniczenia biologiczne i uświadamiające mu, że podlega jarzmu płci. Śmierć zatem ma udzielić odpowiedzi na te potrzeby, których nie mogła zrealizować miłość. Przenosząc do stanu pierwotnego, uwalniać ma od ograniczeń ontycznych, otwierać drzwi poznania uszystkich tajemnic bytu, umożliwić kontakt z Absolutem. U jej źródeł leży poszukiwanie aspektu metafizycznego, boskiego. „Żeby rozważać możliwość samobójstua, trzeba być chciwym absolutu" - słusznie twierdzi Cioran $^{275}$.

Rezygnacja z życia jako alternatywa dla niespełniającej oczekiwań miłości pojauia się już w pieruszym poemacie Przybyszeuskiego. Jego bohater cierpiący z powodu „martwej chuci” tęskni za „czystością wyzwolenia”, ku któremu nie zdołała powieść go kochanka. W monologu skierowanym do nieobecnej kobiety tak tłumaczy decyzję o samobójstwie:

To tęsknota za tą syntezą, której rozkosze wywyższyły mnie nad wszystkich ludzi - syntezą, którą na próżno przez Ciebie osiągnąć pragnąłem. (Rae 95)

Podobny wariant przybiera śmierć bohatera Androgyne. Wierny wezwaniom kochanki, która może być jedynie wytworem jego duszy (jego animą), mężczyzna idzie nad oświetlone księżycową poświatą jezioro, by $\mathrm{w}$ jego nurtach szukać nowego życia. W owym życiu ma tworzyć jedność z kobietą poznaną w czasie egzystencji ziemskiej:

On i ona mieli pourócić do uspólnego łona, by zlać się u to jedno ognisko, w to jedno śuięte słońce.

Tam się dokona cud; wielki, nieziemski cud:

Będzie jednym i niepodzielnym,

$[\ldots]$

odsłonią mu się niepojęte tajemnice, rozwiążą się wszystkie cele i przyczyny bytu, i zakróluje nad wszelką ziemią i wszem stworzeniem.

On-Ona.

Amen. (A 459-460)

Śmierć przywołuje zatem narodziny. Jest odrodzeniem, które otwiera perspektywę wieczności. A także zdarzeniem mistycznym, jeśli wziąć pod uwagę,

${ }^{275}$ E. Cioran, Zły demiurg, thum. I. Kania, Kraków 1995, s. 51. 
że upisuje się $\mathrm{w}$ proces wielkiego życia kosmicznego, łączy jednostkę z rytmem uszechśuiata. U źródeł tej koncepcji „vita mortalis” leży Platońskie pojmowanie człowieczego kresu jako momentu narodzin ducha oraz echa buddyjskiej nirwany, oznaczającej roztopienie się istoty ludzkiej $w$ totalności bytu ${ }^{276}$. Wspólnotę substancjalną człowieka i kosmosu interesująco obrazuje scena poematu Nad morzem, u której wodne fale uspinają się pod niebo. Zuażyuszy, że Oblubienica rzuca się ucześniej w odmęty morza, symbolizującego duszę Oblubieńca („morze, co ciałem się stało” - mówi się w utuorze parafrazą Ewangelii św. Jana; Nm 333), następuje tu synteza podmiotu i przedmiotu miłości, podobnie jak w myśli Wschodu zniesienie „przeciuieństua podmiotu i przedmiotu" 277 charakteryzuje teorię ,życia u śmierci" ${ }^{278}$. On-Ona tworzą androgyniczną jedność z naturą, a dokonana synteza jest apoteozą wolności ponad uszelkimi ograniczeniami - ontycznymi, poznawczymi i metafizycznymi.

Całkowicie odmienne znaczenie ma samobójstwo w morskich odmętach uybrane przez rodzeństwo z De profundis. Chociaż i tu kobieta: „Skryła się na morzu... Sama stała się morzem..." (Dp 104), do czyniena mamy z żyuiołem destrukcyjnym. Agaj i jej brat pędzą ku otchłaniom natury, by - jak pisze Wojciech Gutouski - ich ciała mogły ulec dezintegracji w nieuformowanym żywiole. Pełnia (Ja-Ty-morze) łączy się tu z samozniszczeniem. Samobójstwo zaś - sprowokowane niezaspokojoną namiętnością - jest protestem przeciu warunkom, które nie pozwalają osiągnąć spełnienia ${ }^{279}$. Związek rodzeństwa nie jest możliwy, ponieważ lęk przed przekroczeniem sfery tabu jest zbyt silny. W śmierci bohaterowie nie szukają androgynicznego spełnienia, lecz uyzwolenia od bólu i męczących halucynacji spowodowanych miłosnym napięciem. Liczą na uyzwolenie od „teraz”, a nie „ku czemuś”. Akcentuje to kilkakrotne użycie przez Przybyszeuskiego słowa „dno” („Widzisz morze? Och, jakby było słodko i dobrze leżeć w twoim objęciu na jego dnie. [...] to za straszny ból, żyć chociaż chwilę dłużej z tym okropnym uspomnieniem, żeś z twoją siostrą poszedł na dno morza..." - mówi Agaj; Dp 101-102). Król i niewolnica z kraju cieni unosili się. Wektor linii, po której poruszają się Agaj i jej brat, uskazuje przeciuny kierunek. Ich śmierć jest upadkiem. Nie na darmo ostatnie zdanie tekstu brzmi: „Runął w dół”.

Niezamierzony efekt komiczny osiągnął Przybyszewski w końcowych fragmentach Świętego gaju (trzeciej części Mocnego człowieka), przedstawiając w mowie pozornie zależnej samobójstwo Ning Ligęzy. Przechadzającej się wzdłuż torów kolejowych bohaterce światła nadjeżdżającej z przeciwka lokomotywy wydają się... oczami ukochanego Bieleckiego. Pędzi więc na

${ }^{276}$ Zob. też A. Lubaszeuska, op. cit., s. 67-69.

277 A. Schopenhauer, Metafizyka życia i śmierci, tłum. J. Marzęcki, Łódź 1995, s. 29.

${ }^{278}$ Zob. H. Ratuszna, op. cit., s. 45.

${ }^{279}$ W. Gutouski, Nagie dusze..., s. 90-91. 
spotkanie miłości, znajdując w śmierci pod kołami pociągu szczęście i androgyniczne zespolenie:

Jedzie, pędzi, szuka mnie! Poprzez mroki, poprzez mgły przedziera się ku mnie - On - On! Jedyny mój! A móuił mi, że się odnajdziemy!

Jedną jeszcze chwilę obłąkanego szczęścia w jego objęciu.

Bliżej, coraz bliżej:

Już - już! O rozkosz! o szczęście! (Mc III, 305)

Autor Synagogi szatana wykorzystuje bogaty repertuar metod popełniania samobójstua. Jego bohaterowie wieszają się, topią, strzelają do siebie, skaczą z dużej uysokości i zażywają truciznę ${ }^{280}$. Sam moment konania dokonuje się jednak poza nurtem akcji, za kulisami. Zostaje przemilczany. Śmierć jest zapowiedziana, lecz nie opisywana ${ }^{281}$. Jej obecność wyraża się raczej nastrojem, przeczuciem. Powodu rezygnacji ze szczegółów fizycznego aspektu odchodzenia upatrywać można w zakorzenionym w młodopolskiej tanatologii - na przeciunym biegunie niż fascynacja chorobą i rozkładem - zaleceniu pięknego umierania. Wspomina o nim Grodzki w rozmowie z Falkiem:

Widziałem raz obraz, który na mnie zrobił wielkie urażenie. Wkracza jakiś pan u królestwo śmierci. Idzie w lakierkach i podkasanych spodniach. Idzie sans peur et sans reproche. $\mathrm{Z}$ wielkim szykiem. Duie lilie uyrastają $\mathrm{z}$ jednej i drugiej strony. A gdzieś $\mathrm{u}$ dole ziewa, piekielnie znudzona śmierć. [...] Nie czułbym ani na chuilę lęku, gdybym mógł sobie strzelić w łeb. Ale chcę umierać przyzuoicie i pięknie. Nie chcę, żeby się mój mózg rozpryskiwał na uszystkie strony... (Hs III, 117)

Postaci Przybyszeuskiego odbierają życie nie tylko sobie, ale też innym. Najczęściej u efekcie działań anarchistycznych, zmierzających do oczyszczenia świata z metafizycznej nędzy, a będących de facto - dokonywanym $\mathrm{w}$ ramach eksperymentu - totalnym zniszczeniem w imię Zła/Szatana ${ }^{282}$. Miłosne emocje - przed którymi przestrzegał Ochorowicz w swoich studiach z psychologii kryminalnej ${ }^{283}$ - u Przybyszeuskiego prowadzą do zbrodni

${ }^{280}$ Dane procentowe dotyczące różnych rodzajóu zadawania sobie śmierci $u$ drugiej połowie XIX w. podaje u przywoływanym już studium E. Durkheim, op. cit., s. 368.

${ }^{281}$ Inaczej niż w literaturze pozytywizmu, która lubowała się w opisach umierania, ukazujących kolejne etapy rozpadu fizycznego, ale nie stawiała pytania o sens śmierci. Por. uwagi H. Ratusznej, op. cit., s. 11 i 100, a także B. Szymańskiej, op. cit., s. 113.

${ }^{282}$ Anarchistyczny bunt przeciuko światu przedstawił Przybyszeuski w pouieściach Dzieci szatana oraz Dzieci nędzy.

${ }^{283}$ „Namiętność miłosna jest źródłem licznych zbrodni. Porywa bowiem człowieka jak potok rozhukany i unosi go ze sobą" - stwierdzał Ochorowicz, dodając, że skutkom fatalnego uczucia nie zapobiegną nawet zasady etyczne, ponieważ przestały one być hamulcem wraz z osłabieniem wiary (J. Ochorowicz, Miłość, zbrodnia, wiara i moralność. Kilka studiów z psychologii kryminalnej, Warszawa 1870, s. 109-111). 
znacznie rzadziej, a podstawowym motywem do jej popełnienia pozostaje zdrada. W bohaterze poematu $Z$ cyklu Wigilii odzywa się atawistyczny, pierwotny, zwierzęcy zew krwi, nakłaniający do zamordowania cudzołożnej ukochanej. Wewnętrzny głos nawołuje: „Zamorduj ją! Zamorduj!” (W 196), a milcząca obecność skruszonej partnerki prowokuje: „Jestem bezbronna! Zabij! Uduś!" (W 197):

Z najgłębszych otchłani mego bytu upełzywały w mózg ohydne myśli - coraz to dziksze, coraz to więcej zbrodnicze instynkta we mnie budziły - a przed moimi oczyma rozuarło się straszne piekło; zwierzęca przeszłość, pełna zbrodni, nienasyconych pragnień: przeszłość drapieżnego zuierzęcia i dzikiego człowieka. [...]

Wszystko we mnie krzyczało, nawoływało mnie do zbrodni. (W 195)

Dla zbrodni będącej karą za zdradę bohater znajduje analogię w naturze. Zawiedziony i skrzyudzony przez kochankę przywołuje z pamięci następujące uspomnienie: Pewien bocian został postrzelony u trakcie zdobywania pożywienia dla samiczki wysiadującej jaja. Gdy opiekował się nim znachor, samica przyjęła do gniazda nowego osobnika. Wyleczony bocian pokaleczył oboje, a wieczorem samicę otoczyła jeszcze cała mściwa gromada. „I nagle, jakby na tajny znak, rzuciły się na nią uszystkie bociany, w jednej chwili rozerwały ją na drobne sztuki - ochłapy jej ciała, powyrywane kawałki skrzydeł, krwią zabarwione pierze, bagno krwi znaczyło miejsce, u którym się odbył straszny sąd nad cudzołożnicą" (W 195).

Zabójstwo pozwoliłoby bohaterowi poematu wyładować emocje i przyniosłoby ulgę, jednak mężczyzna nie posuwa się do ostateczności. Decyduje o tym zapewne nie słabe natężenie uczuć, lecz fakt, że - jak skonstatowano ucześniej - okazywanie zazdrości ośmiesza zdradzanego. Kobieta ginie z rąk kochającego ją mężczyzny tylko raz - w powieści Mocny człowiek. Książę Poraj wbija sztylet w serce Ady Karskiej, nie mogąc znieść jej zainteresowania Bieleckim, a następnie popełnia samobójstwo. Także sam „mocny człowiek” pozbywa się niewygodnej kochanki, spychając ją z łodzi do morza. Czyni to jednak nie z miłości, a z uyrachowania, pragnąc uchronić przed opinią publiczną odkrytą przez Łucję tajemnicę jego literackiego sukcesu.

Zbrodnicze skutki zazdrości dotykają rywali. Zygmunt, broniąc swej miłości, uskazuje Krzyckiemu drogę na niebezpieczną perć, z której nikt jeszcze nie wrócił. Tak wyjaśnia swój postępek żonie:

\section{ZYGMUNT}

[...] gdybym czuł, że jeden $\mathrm{z}$ nas za wiele na śuiecie, gdybym jego śmiercią mógł coś okupić, pogrzebać coś, co umarło, a więcej żyue, aniżeli ty i ja... [...] nie wahałbym się ani na chwilę... 
KLARA

Zbrodnię popełnić?!

ZYGMUNT

Tak! (Śl 102)

Skierowanie śmierci - której atmosfera unosi się w powietrzu od pierwszych kwestii dramatu - na Krzyckiego pozwala ocalić pozostałych ${ }^{284}$. Wolno bowiem przypuszczać, że napięcie między małżonkami prędzej czy później doprowadziłoby do samobójstwa któregoś z nich.

Tragicznie kończy się kobieca rywalizacja u Dzieciach nędzy: dojrzewająca fizycznie i emocjonalnie Zosia, zazdrosna o uczucie Adam Drzazgi, sięga po nóż przeciwko własnej bratowej. Popełniwszy zbrodnię, wiesza się w lesie na gałęzi drzewa, która kojarzy jej się z huśtawką. Śmierć odsłania jednak i sue litościue oblicze - oddaje martuą Jadwigę u ręce kochającego ją Adama. „Nie mógł jej mieć za życia, teraz przynajmniej po śmierci ma trupa na własność, swoją wyłączną własność" - oddaje narrator tok myśli bohatera (Dn II, 293-294). Sposób, w jaki mężczyzna postępuje z nagłym darem, ma cechy rytuału, miłosnego obrzędu, niemal aktu seksualnego. Drzazga z nabożeństwem przenosi ciało na kanapę, podkłada pod głowę poduszkę, gładzi włosy. Izoluje zmarłą od reszty domowników, ponieważ „obce oczy mogłyby sprofanować, zbeszcześcić ciekawością te śuięte zułoki” (Dn II, 293). Szuka intymności, jakiej wymaga kontakt ze śuiętością. Po raz pieruszy dotyka ukochanej:

[...] wziął miednicę, nalał wody, rozpiął bluzkę, i niewidzącymi oczyma, bo wielka śuiętość chuili nie pozwoliła mu nawet płatka jej nagiego ciała widzieć - uyciągnął nóż z piersi, obmył starannie obyduie rany z krui, dźwignął z kanapy wiotkie ciało Jadwigi; a z większą czcią nie podnosi kapłan sakramentu u górę, z jaką od podnosił Jadwigę i ułożył na łóżku.

$[\ldots]$

Z jednej i drugiej strony ułożył jej piękne ramiona, przytulił sue usta do tych rasouych, małych rąk białych, zdawało mu się, że ręka drgnęła, ale ta obca siła, która nim kierowała, szepnęła mu do ucha, że to złudzenie. (Dn II, 295)

Po przygotowaniu ciała jak do pogrzebu, Drzazga dokonuje kremacji - podpala posiadłość Krywłóu wraz z ułożoną u pokoju Jaduigą.

Eros zatem zazuyczaj rozsiewa śmierć. Zamiast - jak u Platona - pomnażać i apoteozować życie, odsłania jego absurdalność i niszczy je. Miłość nosi zarazki rozkładu, które rozsadzają ją od wewnątrz. Aktualizuje obecność śmierci. Dlatego bohater $Z$ cyklu Wigilii, utożsamiając ją z tęsknotą i sztuką, zuraca się do niej oksymoroniczną apostrofą „kolebko Ty moja, grobie Ty mój" (W 181).

${ }^{284}$ H. Ratuszna, op. cit., s. $106-107$. 
Przybyszewski uniezależnia śmierć od teologii, widząc $w$ niej problem egzystencjalny, poznawczy i aksjologiczny. Nie rozpatruje jej także jako faktu społecznego, który daje się tłumaczyć w obrębie socjologii. Podobnie jak inni twórcy młodopolscy, stawia tezę o tożsamości bytowej miłości i śmierci: „Miłość, jest uięc, jak śmierć, potęgą, której niepodobna się oprzeć i która w zuiązku z tym pozostaje niejako poza dobrem i złem" - pisze Lubaszeuska ${ }^{285}$. Obie te potęgi mogą być rozpatrywane w kategoriach siły lub niemocy, zuycięstua bądź porażki. Są samospełnieniem i samounicestwieniem; wyrazem swoiście pojmowanej autokreacji i transgresji. W samobójstwach popełnianych z miłości dopatrywać się można ludzkiej ułomności lub przyuileju. Traktowane mogą być jako klęska człowieka albo afirmacja jego siły sprawczej. Jako przejaw absolutnej wolności, potrzeba wyzwolenia się z ciała, ucieczka od siebie i poza byt bądź przeciunie - pragnienie zjednoczenia się z bytem, roztopienia w materii nieorganicznej. Są dopełnieniem życia i ostatnim ogniwem procesu samorealizowania się wobec niemożności rozwiązania problemów egzystencjalnych $^{286}$. Wyzwaniem rzuconym śmierci bądź buntem przeciu życiu. Thanatos eksponuje rolę Erosa jako potęgi twórczej i płodnej, energii kreującej życie. Eros stanowi zatem oppositum kresu, ale w wersji modernistycznej jednocześnie i nieuchronnie przyzywa śmierć.

${ }^{285}$ A. Lubaszeuska, op. cit., s. 67.

${ }^{286}$ Zob. S. Kijaczko, Wobec bycia. Filozoficzny problem samobójstwa, Opole 2005. 


\section{CZĘŚĆ TRZECIA \\ Wyobraźnia erotyczna. Obrazowanie i symbolika}

\section{Ciało}

Jeszcze $w$ XIX $w$. pouszechny był pogląd, że ciało to rodzaj formy ograniczającej człowieka, naczynie dla świadomości, która je przerasta. Temu poniżeniu ciała $w$ kulturze sprzeciuili się moderniści, a ich reakcją na problemy z określeniem tożsamości stał się m.in. wybujały indywidualizm" W drugiej połowie XIX stulecia zaczęto odkrywać znaczenie ciała jako znaku, obdarzono je epitetami „rozumne” i „myślące”, choć pamiętać trzeba, że równocześnie żywe były ujęcia manichejskie, uwydatniające opozycję „duch” - „materia” i nasycone nastawieniem antyseksualnym. Pozytywne pojmowanie ciała występuje m.in. u Nietzschego, który pisał:

„Ja” powiadasz i chełpisz się z tego słowa. Lecz rzeczą większą - w co wierzyć nie chcesz - jest twe ciało i jego wielki rozum: ono nie mówi: ,ja”, ono ,ja” czyni³

Przybyszewski powiązał życie cielesne z duchowym (i kosmicznym) zarówno w swojej teorii androgynicznego zjednoczenia, jak i koncepcji metafizyki płci, co uznać uypada - za Edwardem Bonieckim - za uyraz odkrycia ciała jako wartości i nadania mu sensu egzystencjalnego ${ }^{4}$. Autor Śniegu był jednak daleki od optymizmu Nietzschego, czego dowodem jest wielokrotnie uyrażane przez niego przekonanie, że potrzeb fizycznych nie da się uzgodnić ze wzniosłym życiem wewnętrznym. Poza tym pisarz, choć zainteresowany relacją ciało - dusza, jak przed nim choćby Kartezjusz i Maine de Biran,

\footnotetext{
${ }^{1}$ Zob. E. Boniecki, Modernistyczny dramat ciała. Maria Komornicka, Warszawa 1998, s. 12.

${ }^{2}$ Ibidem, s. 5.

${ }^{3}$ F. Nietzsche, Tako rzecze Zaratustra, tłum. W. Berent, Warszawa 1907, s. 35.

${ }^{4}$ E. Boniecki, Struktura „nagiej duszy”. Studium o Stanisławie Przybyszewskim, Warszawa 1993, s. 47.
} 
a w jego czasach Husserl, nie rozuijał filozofii cielesności. Ciało sytuował po prostu w duu porządkach: epistemologicznym - jako ludzki, ograniczony, punkt widzenia świata; oraz ontologicznym - ponieważ świadomość ucielona to nasz sposób bycia w świecie. A jak je opisywał?

Marian Stala zauważył, że ciało ludzkie - jako pełnowymiarowy, obdarzony sensem obraz - zjawia się w literaturze Młodej Polski (zwłaszcza w poezji) stosunkowo rzadko, podobnie zresztą jak słowa „ciało” czy „cielesny”. To spostrzeżenie odnosi się również do twórczości Przybyszeuskiego, którego przez dziesiątki lat potępiano przecież za rzekome epatowanie cielesnością czy szerzej - fizjologią. Tymczasem bodaj najdokładniejszy z jego opisów kobiecego ciała zadziwić może swą „niewinnością”. Ten suchy, niemal anatomiczny ogląd dokonany w myślach przez bohatera jednej z powieści przypomina ocenianie towaru na targu:

Mała głowa siedziała mocno i wyzywająco na silnym, ale nie grubym karku - biust pełny, chociaż nie thusty ani obfity - dość ponętnie musiały uyglądać delikatne kości obojczyka spoza ciemnawej skóry - kościec, sądząc z ogólnej budouy, delikatny i smagły, proporcje dobre, a ta reszta - to zuykle u kobiety mało indywidualna: jedna jak druga ma to samo opolstrowanie $^{6}$, chudsze lub pełniejsze - a ta nie jest ani chudą, ani zbyt pełną. (Mc I, 148)

Kobieca fizyczność przywoływana jest zatem nie bezpośrednio, w obiektywnym ujęciu narratora, ale pośrednio - jako składnik subiektywnego przeżycia, połączonego niekiedy z marzeniem na jawie, halucynacją, snem? ${ }^{7}$. Spojrzeniu męskiemu narzuca się przede uszystkim biel ciała kobiecego oraz bijący od niego blask, najczęściej o złotawym odcieniu (symbolicznie bowiem biel kojarzona jest ze złotem). Epitet ,jasna” w odniesieniu do kochanki pojawia się $w$ utworach Przybyszeuskiego niemal obsesyjnie. $\mathrm{O}$ emanującym z ciała świetle mówi się uprost lub metaforycznie: 293)

Przyszłaś jak promień, co się z miliona lat odległej guiazdy na ziemię zabłąka. (Nm

- [...] widziałem, jak błądziłaś w zaczarowanych ogrodach wśród czarnych palm, jak błędny ognik świętojańskich nocy. (Nm 315)

Te same oczy, które mu u duszę onego wieczoru uświeciła, ta sama tuarz, bo tylko taka twarz płomieni tym światłem, co się wokół tych oczu rozlewa. (A 394)

${ }^{5}$ M. Stala, Pejzaż człowieka. Młodopolskie myśli i wyobrażenia o duszy, duchu i ciele, Krakóu 1994, s. 222, 247.

${ }^{6}$ Stownik języka polskiego A. Karłowicza i in. objaśnia hasło „polstrować” jako nabijać, wyściełać, wypychać, napychać, w odniesieniu do materacy i poduszek (Stownik języka polskiego, A. Karłowicz, A. Kryński, W. Niedźuiedzki, T. 4, Warszawa 1908, s. 541). „Opolstrowanie" można zatem uyjaśnić jako wypełnienie, zawartość, skład.

${ }^{7}$ Zob. M. Stala, op. cit., s. 247-248. 
Marian Stala zauważył, że w młodopolskich epifaniach ciała skojarzenie z symboliką bieli było motywem dominującym ${ }^{8}$, o ile jednak barwa ta miała znaczenie erotyczne bądź destrukcyjne, o tyle u autora Synagogi szatana występuje najczęściej u kontekście uduchowienia, dobra, spokoju; wyraża łagodność, niewinność i czystość kochanki, towarzyszy odświętnym chwilom objawienia i dostąpienia łaski. Wyraźnie widać to w słowach króla z poematu Nad morzem, dla którego dłoń ukochanej niewolnicy jest jedynym jasnym punktem, kontrastującym z uszechobecną ciemnością:

Korzyłem się niegdyś przed uszechpotężną ręką ludzkości. [...]

ale czymże mi ta uszechpotężna ręka ludzkości, jeśli czuję Twą białą, wąską dłoń, gdy się jaśniejąca z ciemności ku mnie uysuwa, gdy moje serce obejmuje, jak przeciągły akord rozpłakanej harfy, a ponad mętną toń mego życia rozpościera guiaździstą jaśń Tuych złotych splotów! (Nm 308)

Antynomia śuiatła i ciemności odpowiada dualistycznemu obrazoui świata w każdej religii. Wyznacza opozycyjność ducha i materii, męskości i żeńskości, świadomości i nieświadomości, życia i śmierci, łaski i grzechu. Autorowi Requiem aeternam, o czym wspominał E. Boniecki, odpowiadały tezy Mistrza Eckharta, który twierdził, że ciemność to stan duszy oczyszczonej z uszelkich doznań doczesnych, stan całkowitego oddania, zaufania Bogu i oczekiwania, aż rozbłyśnie prawdziwe światło. Bóg umieszczony został więc poza śuiadomością ( $u$ ciemności) i z nieśuiadomości należy spodziewać się objawienia ${ }^{9}$. Wyzwolenie z ciemności ku jasności to - w dużym uproszczeniu - także cel jednostki w wierzeniach manichejskich, które upłynęły na naukę chrześcijańską ${ }^{10}$. Oznacza ono dostąpienie utajemniczenia, oświecenie, zbawienie. Już zresztą filozofia antyczna głosiła metafizykę blasku, tj. naukę o jego pozaziemskim źródle - nieprzemijające idee emanują światło, a proces poznania polega na oświeceniu przez nie ${ }^{11}$. W twórczości Przybyszeuskiego światło nie ma takiego charakteru jak w malarstwie impresjonistycznym; jest elementem mitotwórczym, to „claritas neoplatoników, gnostyków, pisarzy chrześcijańskich i wielu pierwotnych kultóu religijnych" ${ }^{2}$. Łączy się z absolutem i stąd pojawiają się u autora Synagogi szatana przypuszczenia o jego pozaziemskim pochodzeniu:

\footnotetext{
${ }^{8}$ Ibidem, s. 252.

${ }^{9}$ E. Boniecki, Struktura „nagiej duszy”..., s. 82.

${ }^{10}$ M. Lurker, Przesłanie symboli $w$ mitach, kulturach i religiach, thum. R. Wojnakouski, Krakóu 1994, s. 121.

${ }^{11}$ Ibidem, s. 123.

${ }^{12}$ M. Jankowiak, Funkcja mitu w prozie Przybyszewskiego i Berenta, [w:] Problemy literatury polskiej lat 1890-1939, red. H. Kirchner i Z. Żabicki, Wrocław 1972, s. 262.
} 
[...] stało się światło, dziwne światło: jaśniejące tchnienie woni letnich nocy, zimny, jednostajny odbłysk ukrytych światów - stało się światło, jakie się tworzy przez refleksy metalicznych zuierciadeł, wewnętrzne światło, światło duszy wszechnatury. (A 445)

Światło - synestezyjnie skojarzone $\mathrm{w}$ powyższym fragmencie $\mathrm{z}$ wonią i sugestionujące istnienie nieznanych światów, dostępnych jedynie $\mathrm{w}$ zniekształconym odbiciu - jest emanacją natury, stanowiącej wspólne źródło i początek. Jednocześnie nadaje owej naturze wymiar duchowy, niemal boski. Utożsamienie śuiatła z boskością znane było bouiem już religiom starożytnym i zostało przejęte przez chrześcijaństwo. Blask jako atrybut, ale też istota bóstua występuje m.in. w psalmach oraz pismach mistyków średniowiecznych ${ }^{13}$. Emanujące z postaci światło jest oznaką świętości także u tuórczości Przybyszewskiego, tym bardziej że układa się ono w aureolę (notabene, z symbolicznego punktu widzenia znaczące jest, że aureola ma kształt kolisty; podkreśla on doskonałość, boskość, totalność, a także androgyniczność postaci, nad którą jest zawieszona):

$\mathrm{Z}$ wolna gaśnie płomienny cud, niebo dogorywa, duie guiazdy tlą mdłym blaskiem, ale widzę Cię jeszcze, widzę jaśniejącą Twą postać i złoty krąg śuiatła wokół Tuej głowy (Nm 312)

\section{bądź przywodzi na myśl skojarzenia z monstrancją:}

Tylko on, on jeden istniał, a ona była jakąś śuiętą, złocistą, olbrzymią monstrancją, wzniesioną nieuidzialnymi rękoma z najtajniejszych głębi jego duszy. Ślepł od jej blasku... (Hs I, 73)

Doświadczenie śuiętości ciała sprawia, że w Młodej Polsce jego opisowi towarzyszyło skojarzenie z ofiarą Chrystusa. Przybyszewski takiego porównania nigdy nie zastosował, niemniej biel symbolizuje u niego boską doskonałość, całościowość, a tym samym - zgodnie zresztą z tradycją - kojarzona jest $\mathrm{z}$ androgynem ${ }^{14}$. Atut jasności przysługuje u pisarza tej kobiecie, która jawi się jako partnerka miłosnej unii, zdolna poprowadzić mężczyznę ku zjednoczeniu i najwyższemu poznaniu, zaś symbolika światła stała się podstawą interesującej metafory procesu androgynizacji:

Ty jedna krążysz w moich żyłach, gdyby złoty wir pyłu słonecznego. (A 423)

Jesteś słońcem rozlanym we mnie. (A 435)

${ }^{13}$ M. Lurker, op. cit., s. 123-125.

${ }^{14}$ Biel [hasło], [w:] J.E. Cirlot, Słownik symboli, przeł. I. Kania, Kraków 2006, s. 79-80. Autor uważa, że właśnie z powodu androgynicznej symboliki bieli Balzak umieścił akcję Serafity u północnej Skandynawii, gdzie na ziemi zawsze zalega śnieg. 
Wojciech Gutowski zauważył, że pierwiastek duchowy (światło) połączony został tu z elementem cielesnym (krew), odnoszącym się do zmysłowości ${ }^{15}$. To kochanka (nosicielka pierwiastka duchowego) umożliwia bohaterowi wkroczenie na wyższy próg doznań, zapala w nim lux aeterna, oznaczające dostępność wiedzy, czyni z niego króla-słońce o spotęgowanych możliwościach.

Przybyszewski nie bada ludzkiej postaci, nie opisuje ciała całościowo, lecz posługuje się metonimią. Najważniejsza okazuje się twarz, i to uyłaniająca się nagle, niczym wizja lub epifania ${ }^{16}$.

Drgnąt.

Wyłoniła się tuarz dziewczęcia: jasny dźwięk, jasne odbicie bladej guiazdy w rozkipieniu ciemnych fal - (A 383)

Pojawienie się twarzy jest zdarzeniem wyjątkowym i niepokojącym:

Odtąd już nie mógł się pozbyć wizji tej drobnej tuarzy z ciemnymi guiazdami, co suym światłem krążyły w jego żyłach - (A 384-385)

Jako najważniejszy element twarzy funkcjonują u Przybyszewskiego oczy, podobnie jak w twórczości Kazimierza Tetmajera oraz na obrazach XIX-wiecznych symbolistów: Franza von Stucka, Fernanda Khnopffa czy Gustava Klimta. Liczy się nie tyle ich kształt czy barwa, lecz moc, z jaką oddziałują na obiekt, na który są zurócone (o sile spojrzenia i sposobach patrzenia zob. też podrozdział Zmysty). Jak w następującym fragmencie z Nad morzem:

Spostrzegłem drobną twarz kobiety, nieruchomo ku mnie zuróconą, bladą i jasną jak śuiatło miesiąca, spostrzegłem oczy - oczy... Nie pomnę ich kształtu, nie dostrzegłem ich baruy, czuję tylko, jak drobne, błagalne ręce ujęły w drżących pieszczotach moje serce, tuliły je i całowały. (Nm 321)

Na poziomie opisu oczy porównywane są do wszelkich sił kosmicznych: słońca, guiazd, nieba, morza, wiatru. Wypada w tej metaforyce widzieć nie tyle element zbanalizowanej konwencji, co przekonanie o uszechidentyczności człowieka i natury, wiarę w istnienie uspólnego źródła ludzi i żywiołów. Z tego samego powodu oczy emanują silnym blaskiem o niemal nieziemskim pochodzeniu:

${ }^{15}$ W. Gutouski, Nagie dusze i maski (O młodopolskich mitach miłości), Kraków 1992, s. 253.

${ }^{16}$ Por. M. Stala, op. cit., s. 248. 
Szczególne! Ta sama zasłona w oczach. Niby przebłysk potężnego światła, które toruje sobie drogę dopiero poprzez ciężkie opony mgły. (Hs I, 19)

Czuła nad sobą dwoje otchłannych oczu, gdyby dwie ciemne guiazdy - (Hs II, 95)

A teraz widzę Twoje oczy we mnie upatrzone, ciemne jak otchłanie niebieskie, smutne jak poszum wiatru jesiennego $w$ nagim parku, a słodkie jak jaśnienie morza $w$ ciemnych nocach. (Nm 292)

I widziałem te oczy, jak się zapalały, jak błyszczały gdyby węgle żarzące, widziałem je, świetliste białą łuną elektrycznych lamp, a często $\mathrm{w}$ pomroku stojąc nad brzegiem morza, widziałem wokół nich tęczoue mgły, jakie się widzi wokół gazowych latarni, gdy się na nie patrzy przez szronem pokryte szyby. (Nm 322-323)

W nekrofilskiej scenie z Requiem aeternam jako narzędzie prowokacji i kuszenia martwa kobieta uykorzystuje długi jak u grzechotnika język. W Androgyne tę samą rolę diabolicznego uwodzenia spełniają rzęsy zawieszonej na krzyżu kochanki:

Patrzała na niego przymrużonymi oczyma; spoza długich rzęs wybiegały lubieżne węże kuszeń i wabień [...]. (A 407)

O wiele rzadziej Przybyszeuski obiera za przedmiot opisu usta. I tu nie ma znaczenia ich krój czy wielkość. Podobnie jak spojrzenie, układ warg wyraża emocje i rozterki wewnętrzne, ale usta, kojarzone przede uszystkim z uśmiechem i pocałunkiem, mają szersze konotacje erotyczne:

- O usta wy moje,

tyle razy błądził wasz smutek na mej piersi, użerała się wasza rozpacz u me ciało, a wasza pieszczota syciła me usta słodkim jadem niewypowiedzianych żądz - tyle razy składałyście się do rozkosznych szeptów, do rozpustnych krzyków i bezładnych bluźnierstu - tyle razy drgałyście jękami lubieżnego bólu, gdym silnym ramieniem przeginał to słodkie ciało - (A 457)

Zacytowany fragment pochodzi z obszerniejszego ciągu apostrof uywołanych tęsknotą za ukochaną. Symptomatyczne, że myśląc o kochance, bohater poematu przywołuje te elementy jej ciała, które frekwencyjnie pojawiają się najczęściej w obrębie całej twórczości Przybyszewskiego. Zuraca się więc kolejno: „O oczy wy moje”, „O usta wy moje”, „O głowo ty moja”, by finalnie zakrzyknąć: „O całe ciało przenajsłodsze”.

Inną podstawową metonimią cielesną są w Młodej Polsce dłonie ${ }^{17}$. Towarzyszą im u Przybyszeuskiego określenia: „piękne” (Hs I, 123), „ciche”, „jasne” (Nm 284), „,ciepłe” (A 388), „miękkie” (W 174). O wyjątkowej subtelności i delikatności związku świadczy uczynienie z rąk ukochanej osoby

\footnotetext{
${ }^{17}$ Ibidem, s. 250.
} 
przystani dla własnego serca. Takiego schronienia pragnie bohater poematu $Z$ cyklu Wigilii; takie schronienie proponuje kochance Przesłauski:

- Przyjdź, jasna, przyjdź, połóż twe białe, miękkie ręce na mym sercu! Patrz, jestem chory i samotny, potrzebuję ciepła i miłości, przyjdź, jasna, weź u twe dobre, ciche dłonie me serce. (W 174)

[...] patrz, weź moje ręce, jakie one ciepłe, jak one cię kochają - w tych rękach będzie twemu sercu tak dobrze - Inka, Inka! (Zr 226)

Splecenie rąk jest u Przybyszewskiego bardzo częstym i niezawodnym znakiem zaangażowania emocjonalnego i duchowego porozumienia, jednak dłonie, podobnie jak wszystkie inne elementy ciała, nie mają wyłącznie waloru dodatniego. Ich ruch może być wyrazem guałtownego pożądania i niemożliwej do ukrycia namiętności, jak u zachowaniu Karskiej bądź Agaj:

Pochuyciła kurczowo jego rękę - ugryzła się palcami u jego dłoń, szczypała i drapała skórę, to znowu chuytała, głaskała i pieściła rękę: był ból i krzyk, i strach w tej obłąkanej, płonącej ręce. (Dp 64)

W kontekście ekstazy zmysłowej pojawiają się w twórczości Przybyszewskiego róunież ramiona:

[...] rzucasz mi ją w uściekły uścisk mych ramion, gibką wikliną jej członkóu oplatasz ciało moje - (A 391)

- uyobraża sobie bohater Androgyne. Wcześniej - w Requiem aeternam - uszechogarniające ramiona potwora przypominającego ośmiornicę okazywały się atrybutem i narzędziem chuci:

I bez granic rozszalała się jej [chuci] potęga. Stworzyła sobie tysiączne ramiona, którymi uszystko zagrabiała i w siebie wchłaniała, stworzyła tysiączne naczynia, lejki, otwory, potworne usta i narządy, by cały świat ussać w siebie [...]. (Rae 46)

Jeśli Przybyszeuski wędruje wzrokiem niżej niż twarz bohaterki, to nie po to, by opisywać, lecz w najlepszym wypadku nazuać. Takim rzeczounikom jak „szyja”, „piersi” czy „łono” nie przydaje określeń, jakby same u sobie niosły wystarczający ładunek semantyczny dla scharakteryzowania intymnych chwil kochanków. Pisze więc o pieszczotach Bieleckiego i Karskiej: „,...] schwycił ją, przygarnął do siebie, całował po twarzy, szyi, piersiach" (Mc II, 109). Pierś identyfikowana z kobiecością i wyjątkowo silnie nacechowana erotycznie pojawia się jedynie w Requiem aeternam, gdy bohater zbliża się do trupa młodej kobiety i ugryza w niego wampirycznie: 
[...] całouałem jej twarz, kąsałem ją, ussałem się u jej ciało i nagle wgryzłem się uściekłymi zębami, z kruawą pianą na ustach, w jej pierś. (Rae 78)

Bohaterowie pokazani są $\mathrm{w}$ miłosnym uścisku jedynie do połowy, zapewne dlatego, że opis dolnych partii ciała nie mieścił się $w$ granicach normy intymności obowiązującej na kartach dzieł literackich ${ }^{18}$. Z rzadka pojawiają się wzmianki typu: „Podwinął pod nią ramiona, ogarnął ją nogami” (Mc III, 78). Wyjątkowo brzmią słowa Bieleckiego:

- Piękne masz piersi, i oczy twoje rozlane, i biodra jakby z kości słoniowej utoczone... (Mc I 245)

Nawet stopa jako element działający na seksualną wyobraźnię mężczyzny pojauiła się bodaj tylko raz - w Wyzwoleniu, drugiej części Mocnego człowieka, gdy Nina Ligęzowa przy wyjściu z kawiarni zakłada kalosze. Elegancka toaleta włożona przez bohaterkę przy okazji wizyty w teatrze umożliwia natomiast Bieleckiemu przyjrzenie się jej odsłoniętym plecom i skonstatowanie, że Nina "skórę ma delikatną i mleczno-białą” oraz „wysoce podniecającą" (Mc II, 143).

Dotychczasoue rozważania pozwalają stwierdzić, że Przybyszeuski nie opisywał ciała u sposób perwersyjny. Najwięcej uwagi poświęcił tym motywom, które uprzywilejowane były już w romantyzmie. Nakreślone przez niego „mapy kobiecego ciała” nie są nawet w połowie tak śmiałe, jak ta, którą rysuje słowem Oblubieniec z Pieśni nad pieśniami. Obraz kochanki ogranicza się $w$ zasadzie do jej twarzy, oczu, rąk ${ }^{19}$. Ze sprzyjającymi opisowi kochanków, a nawet do niego prowokującymi, scenami intymnych zbliżeń i nagości młodopolski autor radził sobie $\mathrm{w}$ mniej lub bardziej oryginalny czy udany sposób. Na przykład Łusi, z której opada ubranie, kazał zgasić światło (pierusza część Mocnego człowieka), a Adamowi Drzazdze, rozbierającemu Jadwigę, by obmyć jej poranione ciało - zamknąć oczy (druga część Dzieci nędzy).

Ciało męskie nie stało się $\mathrm{w}$ tekstach autora Synagogi szatana pełnopraunym obiektem opisu. Przede uszystkim dlatego, że głównymi bohaterami utworów są wyłącznie mężczyźni patrzący na kobiety. Ich zewnętrzne

${ }^{18}$ O swoistej „amputacji” nóg przez Przybyszeuskiego uspomniała Krystyna Kralkouska-Gątkouska, pisząc o autoprzekładzie De profundis. W wersji niemieckojęzycznej pisarz nie pozbawił bowiem suych bohaterów kończyn dolnych (zob. K. Kralkouska-Gątkouska, $Z a$ gadki „De profundis” Stanisława Przybyszewskiego (Autoprzekład autoerotycznej powieści), [w:] Topika erotyczna w przektadzie, red. P. Fast, Katowice 1994, s. 159).

${ }^{19} \mathrm{~W}$ utworach Wacława Berenta ludzie róunież postrzegani są fragmentarycznie; zułaszcza oczy i uargi istnieją niejako niezależnie; u Przybyszeuskiego zabiegi metonimiczne nie mają jednak związku z techniką impresjonistyczną, jak to jest u Berenta. Zob. P. Hultberg, Styl wczesnej prozy fabularnej Wacława Berenta, tłum. I. Sieradzki, Wrocław 1969. 
piękno i seksualna atrakcyjność zostają jednak dostrzeżone przez partnerki. Iza zachwyca się Falkiem:

Iza ciągle patrzyła na niego. Nie słyszała, co móui - widziała tylko jego gęste włosy, jak mu na czoło spadły, oczy głębokie, szeroko rozwarte... Nie myślała nigdy, by mężczyzna mógł być tak pięknym... vraiment: beauté du diable... (Hs II, 35)

Ada Karska mówi do Bieleckiego:

Zuykle mężczyzna jest albo za krótki, albo za długi [...], ale pan jest w sam raz, uskutek czego wydajesz się pan wyższym, niż jesteś. (Mc I, 115)

A w innym miejscu:

- Gładkie i piękne masz ciało - szepnęła mu do ucha. (Mc I, 237)

Salomea nie może oprzeć się fizycznemu urokowi przyrodniego brata:

Róunie pięknego mężczyzny jeszcze nie zdarzyło się jej ujrzeć.

Smukły, mocny i z tymi uytwornymi ruchami, jakby od dziecka przywykł przebywać na książęcych salonach, rosły, a lekki - chód jego cichy, przypominający chód pantery... (Dn I, 56)

Przedmiot pożądania rzadko jest u Przybyszeuskiego przedmiotem urażeń estetycznych, jak zdarza się choćby w erotykach Tetmajera. Daleko mu do godnego zachwytu dzieła sztuki. Zapewne dlatego, że ciało traktował autor Śniegu ambiwalentnie - w każdym z jego elementów dostrzegał zarówno uwznioślającą siłę, jak i pierwiastek czysto zmysłowy, wyrażający lub uzbudzający pożądanie.

\section{Zmysły}

Zmysły są jedynym narzędziem umożliwiającym odbieranie bodźców zewnętrznych, a więc kontakt ze światem. Odgrywają także dużą rolę w pobudzaniu libido, co znalazło odzwierciedlenie w synonimicznych odpowiednikach przymiotnika „zmysłowy” - namiętny, seksualny, erotyczny, popędowy, miłosny. Wyobraźnia Przybyszeuskiego nie była szczególnie rozuinięta sensualnie, stąd też urażenia płynące z bezpośredniego doświadczania śuiata są u kreacjach jego bohaterów rzadkością. Nad empirię przedkładał pisarz poznanie intuicyjne i podświadomościowe. Spośród zmysłów zdecydowa- 
nie największe znaczenie dla kształtowania relacji międzyludzkich przypisał wzrokowi. Nie był w tym zakresie oryginalny - literackie badanie możliwości i sensów spojrzenia było wspólne XIX wiekowi, w którym uszak oko straciło funkcję narzędzia obserwacji, a stało się terenem spotkania podmiotu i Innego. Niemniej upisując się w konwencję epoki, uzyskał Przybyszeuski rezultaty różnorodne i nie mniej interesujące niż słynny „uścisk spojrzeń” Żeromskiego.

Patrzenie w jego tekstach uyraża całą gamę najróżnorodniejszych uczuć i emocji: od namiętności, czułości i tkliwości, przez smutek, lęk, niepewność, błaganie, po pogardę i nienawiść. Nie jest instrumentem rejestrowania rzeczywistości, lecz składnikiem komunikacji. Wyraża stosunek podmiotu do obiektu, co więcej - obdarzona nim osoba bezbłędnie interpretuje jego znaczenie, co pozuala uniknąć komunikacyjnych pułapek ${ }^{20}$ :

Iza nie słuchała słów jego mowy. Widziała tylko człowieka z delikatną, ściągłą twarzą, z płonącymi, głębokimi oczyma, jakby się trawiły w jakiejś nieokiełznanej namiętności. (Hs I, 33)

Czytał w niej jak w jasnowidzeniu. Widział tęsknotę $w$ jej oczach, jak do strasznego wybuchu przyczajony ból: cała jej dusza stężała u tym długim, bolesnym spojrzeniu. (Dp 66)

Spojrzenie jest istotą uwodzenia. Wyraża pożądanie, czysto seksualne potrzeby jednostki sterowanej przez chuć, ale eksponuje także porozumienie dusz, androgyniczne zespolenie. I tak femme fatale patrzy uyzywająco, prowokująco, „umie nęcić, podrażnić, obiecuje jednym spojrzeniem więcej, ile inna nie da, choćby się całą duszą oddała” (Dszcz 28), zaś dziewczyna niewinna, spragniona uczucia idealnego, spogląda „na przemian z taką nieuypowiedzianą miłością, to znowu ze strachem i lękiem”

${ }^{20}$ Miłosne spojrzenie oznaczające rozpoznanie i absolutną komunikację pojawia się także w operach Richarda Wagnera. Notabene, szczerość spojrzenia charakteryzuje u Przybyszeuskiego nawet jednostki podstępne i kłamliwe, spełnia zatem funkcję demaskacyjną. W dramacie Odwieczna baśń obłudny Kanclerz spuszcza wzrok, by Król nie przejrzał jego zdradzieckich zamiarów:

KANCLERZ

[...] panie, ja tylko nad tuym dobrem i szczęściem myślę.

KRÓL

Poutórz to samo, patrząc mi prosto w oczy!

KANCLERZ [nisko pochylony]

Nie śmiem spojrzeć u majestat słońc twoich oczu, raczej wolę pokornie ucałować tue kolana...

KRÓL [uparcie]

Spojrzyj mi w oczy...

KANCLERZ

Nie śmiem. Raczej wolę ucałować stopy mego pana i władcy. [Przyklęka u nóg króla]

KRÓL

Co za jad ukrywasz u zanadrzu tej pokory? Wyciągnij ureszcie zatrutą strzałę z szatańskiego tuego kołczana. (Ob 120-121) 
(Hs II, 42). Zafascynowani sobą bohaterowie stają się niewolnikami patrzenia na siebie, choć wzrok pali i obnaża, odziera z zasłon, jest aktem o sadystycznym odcieniu ${ }^{21}$ :

Spojrzała na niego. Twarz jej drgała. Oczy jak zalane jakimś płomieniejącym żarem. $\mathrm{Z}$ wolna chciwie wessała się oczyma w niego. Czuł jak gorące płomienie zlewały mu się w krew. (Dp 57)

Ujrzał nagle te złe, zbrodnicze oczy [...] - tak go dziunie zachęcały do czegoś, wbijały w jego chwiejną, niepewną, niejasno jeszcze ukształtowaną wolę, gdyby iglaste ostrogi, a teraz czuł dokładnie, jak się te oczy całkiem dotykalnie po nim obślizgiwały, dua śuidry wwiercały się z wolna w ciemny, chaotyczny kłąb jego myśli [...]... (Mc I, 105)

[...] odczuł zupełnie cielesny dotyk wzroku, czuł jak najwyraźniej i najoczywiściej, że czyjeś oczy na nim ciężką parnością spoczywają. (Dn II, 99)

Dla Heli widok Gordona, o którym stara się zapomnieć, jest rodzajem guałtu:

Zauważył, że Hela spogląda nań z lękiem i trwogą, i że koło ust jej zastygnął obłąkany uśmiech. Ale powoli wracała do równowagi, twarz jej skurczyła się nienawistnie:

- Guałcisz mnie; nie przypuszczałam, że cię ujrzę jeszcze. (Ds 22)

Wzrok potrafi nawet zniszczyć związek, jeśli służy kontroli i psychicznym represjom; jeśli jest niemym wyrzutem, jak w Złotym runie, gdzie Irena mówi do męża:

Nie patrz na mnie tak dziko... tuoimi oczyma mnie zabijałeś - (Zr 240)

Przenikliwy wzrok sięga aż do głębi duszy, której przypisuje się doznania zmysłowe, m.in. doświadczenie fizycznego bólu. Dusza reaguje tak, jak gdyby była ciałem ${ }^{22}$ :

Patrzeliśmy na siebie chwilę z taką siłą, jakbyśmy duszę sobie uyssać chcieli, ale nie zniosła bólu mego wzroku - spuściła oczy [...]. (W 169)

Spojrzenie jest więc instrumentem władzy, próbą sił, zmaganiem osobowości. Ma moc hipnotyczną, której dowodził popularny już u początków

${ }^{21}$ Podobnie u Żeromskiego: „Piękny brunet nie spuszczał oka z Euy. Poczęło ją to drażnić. Spojrzała na niego po swojemu, spojrzeniem młodej, cudnej, hardej dziewczyny, gniewnym i okrutnym - żeby go odtrącić o cztery mile. Ale tu, może po raz pieruszy w życiu, spotkała się z oporem nie do zuyciężenia. Głębokie oczy tego człowieka nie zlękły się i nie cofnęły. Przeciunie, podeszły śmiało, bliżej, jakby do boju. Było w tym spojrzeniu i uyzwaniu coś tygrysiego. Eua doświadczyła piekielnego wrażenia, jakby ją za gardło chuyciła ta ręka z grubymi szponami, gruba i ogromna”. (S. Żeromski, Dzieje grzechu, Kraków 2005, s. 119).

${ }^{22}$ Zob. M. Stala, op. cit., s. 231. 
XIX w. magnetyzm-mesmeryzm. Stanowi rodzaj inwazji, sposób na owładnięcie duszą obiektu i odebranie mu sił witalnych. Taką walkę na zniewalającą siłę wzroku prowadzi przede uszystkim rodzeństwo z De profundis. Narrator utworu daje jej świadectwo słowami:

Chuycili się guałtownie oczyma; oczy ich spowiły się nierozerwalnie ze sobą. (Dp 61)

Spojrzenie idzie tu $\mathrm{u}$ parze $\mathrm{z}$ dotykiem, innym ważnym narzędziem kontaktu z drugą osobą. Zetknięcie dłoni - celowe czy przypadkowe - jest zausze dla postaci przeżyciem niezuykłym, kryjącym wiele emocji (zob. też podrozdziały Ciało i Gesty). Gładzenie rąk pojawia się niezuykle często jako uyraz miłości, dlatego kojarzy się z delikatnością, spokojem, bezpieczeństwem. Dłonie emanują ciepłem, (,[...] czułem w mej dłoni gorejącą Twą rękę [...]" - Nm 320), rozumianym także metaforycznie:

Och! teraz powinna być przy nim; potrzebowałby tylko trzymać jej ręce $\mathrm{w}$ swoich, a uszystko by przeszło. Usnąłby, stanowczo usnąłby natychmiast. (Dp 44)

Dotyk bywa u Przybyszeuskiego róunież, choć rzadziej, pieszczotą erotyczną. Sadystyczną, gdy wiąże się z panowaniem chuci i polega np. na drapaniu ciała partnera, bądź subtelną, opartą na muśnięciach, gdy symbolizuje porozumienie dusz, jak w poemacie Androgyne:

Co to było?

Jakby jakaś ciepła, drobna ręka chuyciła jego, nie - nie chwyciła - wtuliła, wcałowała się pieszczącymi palcami w jego dłoń. (A 378)

Zetknięcie innych niż dłonie fragmentów ciała, które można by zakwalifikować jako dotyk, uścisk bądź przytulenie, a jeszcze nie akt seksualny, i które dostarczałoby istotnych emocjonalnie doznań, w zasadzie nie następuje. Do wyjątków należy fragment z powieści Homo sapiens, gdzie atmosferę czułości wywołuje zbliżenie twarzy:

Uczucie czegoś niezmiernie gładkiego, chłodzącego - jakiejś miękkiej, szklistej pouierzchni. Czuł ją. Przytuliła się twarzą do jego twarzy. (Hs I, 72)

Faktura i kształt dotykanej materii - jej gładkość bądź chropowatość, krągłość czy kanciastość - również tylko sporadycznie są jakościami doznawanymi. Wyjątkowo na bohatera De profundis pobudzająco działa struktura jedwabiu, z którego wykonana jest suknia Agaj, ponieważ „daje takie dziunie lubieżne uczucie w kończynach palców" (Dp 76). To jeden z nielicznych momentów, kiedy zuraca się uwagę na strój partnera. Dla Przybyszeuskiego 
realistyczne detale towarzyszące głębokim doznaniom weunętrznym nie mają bowiem znaczenia, chyba że pobudzają wspomnienia i potrzeby ukryte w głębokich warstwach psychiki.

Fascynacji drugą osobą służy za to usłuchiwanie się w jej głos, łączący w sobie gamę najczarowniejszych dźwięków. Mówienie działa jak afrodyzjak.

Dźwięk Tuego głosu spływał w mą duszę, jak gdyby go wiosenne wiatry przewiały przez zielone morze, i słyszę, słyszę go, jak morze cichego śuiatła, przetworzone w atmosferę dźwięków, co mnie owiewa nieskończenie lekkim, miękkim drżeniem. (Rae 57)

ale czym mi uszelki dźwięk, czym uszelkie upojenie pieśni i tęsknota cytr i harf, kiedy słyszę Twój głos, gdy czerwonym światłem gasnącego słońca tka bogaty przepych mych dumań, a u me sny uplata pałające żary jesiennych kuiatóu... (Nm 310)

Głos męski jest dla kobiety źródłem erotycznych doznań:

Było coś u jego głosie, co ją dziunie przykuwało. Mógł mówić o rzeczach zupełnie trywialnych, a przecież móuil z takim dziwnie przykuwającym, pieszczącym odcieniem... (Hs I, 24)

Melodyjnie płynące słowa mają moc uprawiania w hipnotyczny trans, zapeuniając mężczyźnie władzę nad partnerką-ofiarą:

[...] słuchała, syciła się cichym, monotonnym dźwiękiem jego głosu... Było coś w tym głosie, co ubezwładniało jej wolę i hipnotyzowało ją. (Hs I, 122)

Podobnie magnetyzujące działanie ma melodia fortepianowa, którą Janota podstępnie zniewala Hankę. Kochający muzykę Przybyszeuski uydobywa tutaj jej ciemną, choć uwodzicielską stronę ${ }^{23}$ :

A nigdy nic mną tak nie ustrząsnęło. To była istotnie muzyka do tańca mych myśli - więcej nawet: muzyka pańska guałciła uprost moje myśli, zmuszała je wirować, kłębić się i rozlewać u jej rytmie i takcie... (Gż 23-24)

- zuierza się Hanka Janocie. Zamiar obezwładnienia dziewczyny dostrzegła narzeczona muzyka, Stefa:

${ }^{23}$ Podobnie czynił Tołstoj we uspomnianej już Sonacie Kreutzerowskiej. ,[...] muzyka to straszna rzecz. [...] Nie działa na duszę ani uszlachetniająco, ani poniżająco, lecz drażniąco. [...] Muzyka zmusza mnie do zapomnienia o sobie, o swoim istotnym położeniu, przenosi mnie w jakieś inne, nie moje położenie: pod upływem muzyki wydaje mi się, że czuję to, czego ułaściwie nie czuję, że rozumiem to, czego nie rozumiem, że mogę to, czego nie mogę. [...] Czy można pozwolić, żeby każdy, kto chce, hipnotyzouał innego lub wielu innych, a potem robił z nimi co chce?" - zastanawia się głóuny bohater opowiadania (L. Tołstoj, Sonata Kreutzerowska, tłum. M. Leśnieuska, Warszawa 1987, s. 158-159). 
Grałeś dziś bardzo pięknie Szumana, ale obliczyłeś go na efekt. Patrzyłam na nią [Hankę] cały czas, podczas kiedy grałeś - tyś ją hipnotyzował suą grą... (Gż 61)

Taką paraliżującą moc ma - według określenia Ribota - muzyka pełna, tzn. opracouująca stany wewnętrzne i uyrażająca uczucia (w przeciwieństuie do muzyki pustej, opartej na zręcznej kombinacji tonów, dowodzącej li tylko technicznej biegłości) ${ }^{24}$. Melodia płynąca z instrumentu łączy ludzi nawet poza ich świadomością. Są w niej upojenie i ekstaza oznaczające żywioł dionizyjski, na który uskazywał Nietzsche w opozycji do apollińskiego charakteru sztuk obrazowych. Muzyka - przez wielu postawiona w XIX w. na szczycie twórczości artystycznej („Muzyka ponad uszystko” - czytamy u Verlaine'ouskiej Sztuce poetyckiej) - jest silnym narzędziem oddziaływania na uczucia i psychikę. Może wyrażać stany irracjonalne, ponieważ uymyka się pełnej kontroli rozumu (jak przekonywał choćby Schopenhauer $)^{25}$. Ze uzględu na najszersze możliwości ekspresji, jest doskonalsza od pozostałych dziedzin sztuki: „dla wszystkiego, co niepojęte [...], dla czego nie umieliśmy podać powodu, dla czego w mowie nie ma słowa, dla czego najbystrzejsze określenie jest tylko sztuczką karcianą, dla tego mamy w dźwiękach wyraz" - pisał Przybyszeuski w studium $Z$ psychologii jednostki twórczej ${ }^{26}$, które stało się elementem formułowanej przez niego teorii muzyki. Łącząc moc dźwięków z tajemnicami nagiej duszy, dokonał autor jednocześnie wyjątkowego w modernizmie, niezwykle interesującego odkrycia erototwórczej roli muzyki. A z drugiej strony róunie ważną funkcję przypisał ciszy, bo: „[...] mówić nie zausze można. Wszystkie te niesłychanie subtelne odcienie dadzą się tylko gestem wyrazić" (Hs I, 13). Milczenie we dwoje spaja dusze, sprzyja wymianie myśli:

Milczeliśmy, ale dusze nasze objęły się i splotły, i dumały, dumały [...]. (Nm 309)

[...] wtedy nie było nam potrzeba słów [mówi Jerzy do Izy] - wtedy słyszałaś moje myśli i ja twoje... (Mśc 24)

Mimo że ogromny wpłyu na poziom libido mają węch i smak ${ }^{27}$, Przybyszewski nie poświęca wiele uwagi doznaniom wywołanym przez te zmysły. Jedynie w bohaterze Androgyne woń różnorodnych kwiatów, kojarzących się z bogactuem kobiecych typów, wzbudza pożądanie erotyczne:

${ }^{24}$ Zob. T. Ribot, Logika uczuć, tłum. K. Błeszyński, Kraków 1921, s. 177.

${ }^{25}$ Zob. J. Tomkouski, Młoda Polska, Warszawa 2001, s. 37.

${ }^{26}$ S. Przybyszeuski, Z psychologii jednostki twórczej. Chopin i Nietzsche, tłum. S. Helsztyński, [w:] idem, Wybór pism, oprac. R. Taborski, Wrocław 1966, s. 21.

${ }_{27}$ Zob. C. J. Cela, Zmysty [hasło], [w:] idem, Słownik erotyzmu, tłum. K. Adamska, Warszawa 2002, s. 252. 
Widział tuberozy [...]; widział olbrzymie drzewa białych i czerwonych azalii [...]; widział orchidee $[. .$.$] i lilie z rozwartymi kielichami [...], i narcyzy, i bijony { }^{28}$, i begonie - całe powodzie różnobarunego kwiecia, upajającej woni spłynęły do jego duszy.

Miękki zapach bzów majowych rozlał się cichą rozkoszą dalekich fletni pastuszych w nocach uiosennych [...]; lubieżną rozkoszą udychały się w niego róże; [...] rozkosznym jadem usysał się w niego odurzający zapach kwiecia akacji [...], a wszystkie te zapachy miękkie i chłodne, jak oczy dziewcząt, nieświadomych swej płci - gorące i lubieżne, jak ramiona rozpasanej hetery [...]. (A 379-380)

Specyficzny rodzaj procesu skojarzeniowego towarzyszy Falkowi w chuili poznania Maryt - w jego uspomnieniu odżywa wówczas zapach róż (zob. dalej o symbolice kuiatouej). Następuje opisana m.in. przez Théodule'a Ribota korelacja pomiędzy stanami umysłouymi i wzruszeniami - aromat kwiatu wywołuje stan duszy, jaki towarzyszył ongiś tej samej woni ${ }^{29}$. W ten oto sposób zauroczenie od początku przesycone jest nastrojem i przeczuciem śmierci:

Tak, tak - ten pieruszy raz, kiedy się z Maryt zapoznał. Ta dziuna halucynacja zapachu róż i czegoś dziunie mistycznego...

Z niesłychaną szybkością przebiegło przez jego mózg dawne, dawno już ukryte uspomnienie. Widział wielki pokój; w pośrodku trumnę. Gromnice, wielkie, woskowe gromnice naokoło trumny. Cały pokój pełen białych róż, wyziewających odurzający zapach.

$[\ldots]$

Wreszcie zrobił dziune odkrycie.

Białe róże miała Maryt w swoich włosach. (Hs II, 36-37)

Wrażenia płynące $\mathrm{z}$ różnorodnych zmysłów łączą się niekiedy i nawarstwiają, tworząc ciekawy obraz zmysłowego postrzegania ukochanej istoty, jak u następującym fragmencie Nad morzem:

Och, widzieć tylko jaśnienie Tuych włosów, słyszeć najdalsze, najtajniejsze echo Tuego głosu, czuć niepojętą pieszczotę Twej dłoni, oddychać powietrzem, przez które spłynęłaś, pić tchnienie Tuego ciała... (Nm 288)

W procesie opisywania drugiej osoby ważną rolę odgrywają elementy przyrody, związane z typowym dla Młodej Polski zabiegiem psychizacji krajobrazu, oraz tzw. światoodczucie ${ }^{30}$. Oznacza to, że doświadczanie obecności partnera ma charakter kompleksowy. Jest poznawaniem człowieka i świata. Wiedzie od doznań zmysłouych do głębokich treści psychiki i odwrotnie - bywa, że podświadomość prowokuje i narzuca określone skojarzenia sensualne:

\footnotetext{
${ }^{28}$ Bijony - peonie.

${ }^{29}$ Zob. T. Ribot, op. cit., s. 17 i in.

${ }^{30}$ Zob. M. Stala, op. cit., s. 248.
} 
Widzę Cię, jak idziesz wolnym i cichym krokiem przez rozstępujący się szereg moich wodzów.

Pomnę: było to, jak gdyby listki z róży opadały, gdy ją wiatr muśnie - było, jak gdyby ciche perły deszczu jesiennego w ciemnej nocy łkały - było, jak gdyby się cała wieczność głębokim westchnieniem po niebie prześlizgła. (Nm 291-292)

Łączenie wrażeń płynących z doświadczania ukochanej osoby bliskie jest niekiedy synestezji, jak np. w słowach: „[...] przewiał wzdłuż jego czoła świetlany, nieskończenie czysty oddech liliowej dłoni..." (A 408). Taki opis postaci, uwikłany u metaforykę ulotności, delikatności oraz śuiatła, związany jest z młodopolską fascynacją bezcielesnością. W znacznej mierze został on przejęty z malarstwa prerafaelitów (ich bractwo zawiązane zostało jesienią $1848 \mathrm{r}$. w Anglii), którym najbliższa była tradycja sztuki renesansowej przed Rafaelem - świetlistej, przejrzystej, uduchowionej, pełnej znaczeń ${ }^{31}$. Podobnie jak na ich płótnach, niektóre bohaterki Przybyszewskiego są wiotkie, blade, promieniują czymś niepochwytnym, a siła ich ekspresji skoncentrowana jest $w$ oczach $^{32}$. Właśnie $w$ malarstwie prerafaelitów w całej krasie pojawił się, występujący też w powyższym cytacie, obraz lilii - kwiatu niewinności, czystości, świętości (zob. podrozdział pt. Erotyczne florarium).

Pouyższe analizy pozwalają stwierdzić, że dla bohaterów Stanisława Przybyszeuskiego poznanie sensualne jest jedynie suplementem $w$ budowaniu wiedzy o drugim człowieku. Ich urażliwość zmysłowa jest słabo rozwinięta. Wrażenia płynące z bodźców zewnętrznych nie decydują o wzajemnej fascynacji, narodzinach i rozwoju uczucia. Źródło oczarowania partnerem tkui w podświadomości, poza ludzką wolą i uyborem. Przez zminimalizowanie udziału pierwiastka zmysłowego i intelektualnego pisarz pozwolił bohaterom przeżywać dramatyczniej, bo wyłącznie w oparciu o doświadczenia wewnętrzne. Percypowanie drugiej osoby następuje w głębiach psychiki, w nurtach mare tenebrarum.

\section{Gesty}

Tytuł niniejszego podrozdziału uymaga uyjaśnienia, jest bowiem skrótem myślowym, zastosowanym dla przejrzystości wywodu i pozwalającym zorientować się u układzie książki już przy pobieżnej lekturze. Przedmiotem analizy będą

${ }^{31}$ Zob. A. Czyż, Mortęska, Drużbicki i lilie mistyczne. Symbolika roślinna w prozie polskiej wczesnego baroku, [w:] Literacka symbolika roślin, red. A. Martuszeuska, Gdańsk 1997, s. 73.

${ }^{32}$ Zob. M. Podraza-Kuiatkouska, Symbolizm i symbolika $w$ poezji Młodej Polski, Kraków 1975, s. 150-157. 
tu w istocie nie tylko gesty - rozumiane przede wszystkim jako ruchy rąk - ale także pozycje i ruchy całego ciała, a u mniejszym stopniu róunież mimika, sposoby spoglądania i dotyku (o ile nie zostały omówione w podrozdziałach Ciało i Zmysty), zatem takie komunikaty niewerbalne, które zalicza się do tzw. języka ciała. W przywoływanych zachowaniach doszukiwałam się przede uszystkim uzewnętrznienia emocji. Gest traktowałam psychologicznie - jako ekspresję, sposób uyrażania, nie badając jego kulturowych źródeł i zależności od reguł społecznych $^{33}$. Poza obszarem zainteresowania znalazły się więc gesty-znaki, gdzie forma ruchu w sposób konwencjonalny odsyła do znaczenia, jak przy powitaniach, pożegnaniach czy gratulacjach. Gest to w niniejszych rozważaniach stan duszy, uyraz emocji $u$ mniejszym stopniu poddanych kontroli intencjonalnej niż język mówiony, a zatem niekoniecznie dokonywany świadomie. Niekiedy ilustruje wypowiedzi słowne bohaterów, nawiązuje do nich bądź im towarzyszy; innym razem bywa abstrakcyjny, tzn. nie odnosi się bezpośrednio do kuestii mówionych lub następuje bez ich udziału, niejako je zastępuje.

Rozwiązaniom gestycznym zastosowanym przez Przybyszewskiego w dramatach interesujące studium poświęcił Stanisław Mrazek ${ }^{34}$. W tym miejscu zostaną poddane analizie jedynie gesty wyrażające emocje zuiązane $\mathrm{z}$ miłością i uczuciami jej towarzyszącymi, a ich źródło zostanie poszerzone o powieści (z pominięciem poematóu prozą ze uzględu na przesycający je żyuioł wizyjności).

Autor Synagogi szatana zadbał o autentyczność gestów i póz ciała odzuierciedlających życie psychiczne bohaterów, o czym śuiadczy zgodność jego rozwiązań twórczych z badaniami poczynionymi przez Darwina ${ }^{35}$. A że przeżycia postaci sprowadzają się głównie do zintensyfikowanych uczuć i namiętności, paleta wprowadzanych przez Przybyszewskiego gestów - guałtownych, o natężonej ekspresji - jest mało rozbudowana, co sprawia, że reakcje bohaterów są powtarzalne, a przez to i mało oryginalne. Od razu trzeba zaznaczyć, że mowa ciała jako sposób charakterystyki postaci ma u młodopolskiego pisarza znaczenie podrzędne wobec dialogu

${ }^{33}$ W końcu XIX w. pod upływem teorii Daruina uznawano, że służące uyrażaniu emocji niewerbalne formy komunikowania są uniwersalne, tzn. specyficzne gatunkowo, a nie kulturowo. Darwin - autor opublikowanej u 1872 r. rozprawy $O$ wyrazie uczuć u człowieka $i$ zwierzat (wyd. pol. - 1873) - twierdził m.in., że mimika uwarunkowana jest ewolucyjnie, a wyrazy twarzy to pozostałości przydatnych w swoim czasie reakcji fizjologicznych; na przykład, jeśli uczesne hominidy jadły coś, co im nie smakowało, wówczas marszczyły nos (z powodu nieprzyjemnego zapachu) i wypluwały pożywienie. Komunikując stany emocjonalne (np. uczucie obrzydzenia) mimika sprzyja zatem przetruaniu gatunków. Obecnie, choć psycholodzy i antropolodzy mówią o określonych gestach uniwersalnych, to są raczej zgodni, że formy zachowań zuiązane są z kontekstem społecznym; że język emocji jest kulturowo uwarunkowany - zależy choćby od wieku, płci, zajmowanego stanowiska.

${ }^{34}$ S. Mrazek, Środki ekspresji pozasłownej w dramatach Staffa, Tetmajera i Przybyszewskiego, Kraków 1980, s. 109-141.

${ }^{35}$ Ibidem, s. 118-119. 
i narracji w mowie pozornie zależnej. Przybyszeuski nie był behawiorystą i programowo odrzucał tradycję naturalistyczną, z której wywodzi się zabieg przedstawiania bohaterów poprzez ich działanie, zachowanie oraz reakcje podporządkowane prawom fizjologiii ${ }^{36}$. Determinanty biologiczne ustępowały u niego walorom intelektualnym i psychicznym człowieka.

Uczucie miłości czy pożądania wyraża się najczęściej w bogatej gamie dotyków: trzymaniu się za ręce, całowaniu dłoni partnera, gładzeniu jego włosów, przytulaniu głowy do jego piersi.

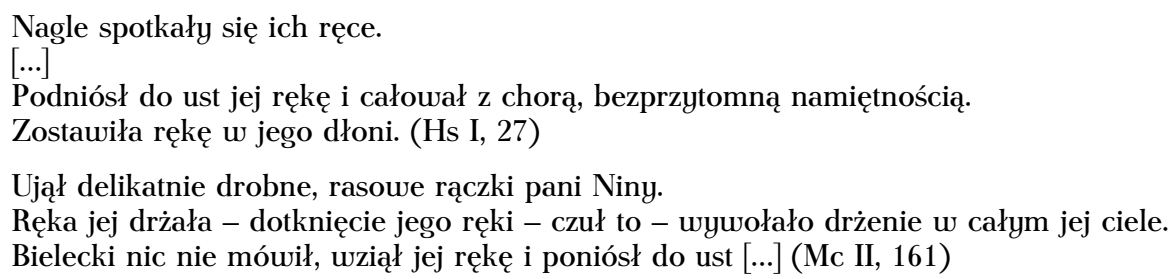

Nagle spotkały się ich ręce.

$[\ldots]$

Podniósł do ust jej rękę i całował z chorą, bezprzytomną namiętnością.

Zostawiła rękę w jego dłoni. (Hs I, 27)

Ujął delikatnie drobne, rasowe rączki pani Niny.

Ręka jej drżała - dotknięcie jego ręki - czuł to - wywołało drżenie u całym jej ciele.

Bielecki nic nie mówił, wziął jej rękę i poniósł do ust [...] (Mc II, 161)

Chora tęsknota za jej rękami, ból pragnienia, by ciało jej przytulić do siebie, tuarz suą położyć na jej piersi: tak dokładnie czuł jej rękę, jak cichym dreszczem spływa po jego ciele. (Dp 44)

Wyrażeniu uczuć służą bardzo często zestawienia gestów. Na przykład w didaskaliach do trzeciego aktu Dla szczęścia czytelnik znajduje informację, że Mlicki „chwyta jej [Olgi] ręce, całuje je i tuli ją do piersi” (Dszcz 66). Falk natomiast, okazując suą czułość Izie, „drżącymi rękoma gładził ją po twarzy, tulił ją do siebie, przyciskał namiętnie do piersi” (Hs I, 106). Tekst poboczny pokazuje także ciąg gestów wykonywanych przez Tadeusza i Bronkę. Sygnalizują one serdeczność i delikatność małżeńskiej relacji:

\author{
TADEUSZ \\ Obejmuje ja, prowadzi do kominka i sadza obok siebie \\ BRONKA \\ [...] bierze jego głowe, tuli do piersi i całuje jego oczy \\ TADEUSZ \\ Kładzie głowe na jej piersi \\ BRONKA \\ Bawi się jego włosami [...] całuje jego włosy \\ TADEUSZ \\ [...] bierze ja na kolana, ona obejmuje rękoma jego szyję (Ś 45-47)
}

\footnotetext{
${ }^{36}$ Jan Detko następująco pisał o naturalistycznym sposobie kreowania postaci: „Osobowość ludzka, bogate życie psychiczne człouieka uzeunętrznić się powinno nie za sprawą autora, ale u toku działania bohatera. Ujaunić się ono może najlepiej w sposobie reagowania bohaterów, w ich odruchach. Stałe zaś pierwiastki natury ludzkiej odkrywać powinna »relacja unaoczniająca« - »scena, dialog«” (J. Detko, Znaczenie naturalizmu, „Miesięcznik Literacki” 1976, nr 4).
} 
Jednym z gestów najczęściej przypisywanych przez Przybyszeuskiego kobiecie jest zarzucanie ramion na szyję partnera. Uścisk ten ma znaczenie ambiwalentne. Bywa dowodem miłości, manifestacją chęci bycia z ukochanym i zaufania mu, ale jednocześnie uyrazem bezradności. W wykonaniu Hanki jest błaganiem, by Mlicki jej nie opuszczał; zademonstrowany przez łkającą Irenę oznacza ostateczne oddanie się romansowi z Przesłauskim; Iza, płacząc, przytula się do Falka, by okazać uczucie, którym go darzy, i bez słów wyrazić obawę przed zranieniem Mikity.

\section{HELENA}

Ha, ha, ha! Nie opuszczaj mnie, Stefanie! Nie opuszczaj mnie! Na litość Boską, nie gub mnie! (rzuca się na jego szyję) (Dszcz 34)

IRENA (nagle zrywa się)

Niech się stanie! - w przepaść - w piekło, ale z tobą. (Rzuca mu się na szyję - tka gwattownie) (Zr 208)

Ujęli się za ręce i drżeli.

Nagle zarzuciła mu Iza ramiona na szyję i zapłakała głośno. (Hs I, 167)

Ekspresją podobnych uczuć jest u kobiet gest uyciągania rąk za odchodzącym. To znak niemej prośby o okazanie uspółczucia i zrozumienia; demonstracja miłości i błaganie o nią. W utworach scenicznych wprowadza go Przybyszeuski w momentach kulminacyjnych, dla podkreślenia dramaturgii zdarzeń. W Dla szczęścia pojawia się on u finale aktu drugiego, gdy Helena rozpaczliwie żebrze o wzajemność opuszczającego ją właśnie Mlickiego. W Ztotym runie gestem tym, czynionym tuż przed ostatecznym zapadnięciem kurtyny, Irena prosi męża o uybaczenie zdrady i uyrozumiałość. W wykonaniu Kingi w końcowej scenie pieruszego aktu Miasta uyraża on rozpacz z powodu utraty Leszkowej miłości. Natężenie emocji jest tak silne, że gest ten bezpośrednio poprzedza nagłe osłabnięcie. Helena rzuca się ku drzwiom, za którymi zniknął ukochany, i mdleje. Irena z płaczem pada na sofę. Kinga zatacza się ku ścianie i osuwa na stojące obok krzesło. Podobnie reaguje Zosia Krywło, podglądająca z ukrycia zarządzającego chłopami Adama Drzazgę. Najpieru wyciąga ku przyrodniemu bratu ręce, „które ruały się, jak skrzydła do lotu" (Dn II, 95), a potem bezsilnie opada na trawę. Za każdym razem omawiany gest nie tylko kończy rozmowę i związek kochanków, ale też zapowiada śmierć jednego z nich (Heleny, Rembouskiego, Leszka, Zosi).

Podobny sens jak obejmowanie szyi partnera i błagalne wyciąganie ku niemu rąk ma klękanie przed nim. Ten znak poddania może być etapem uwodzenia (gdy Przesławski klęka przed Ireną), oznaką szacunku i miłości (których dowód chce dać Jadwidze Jan Krywło) lub próbą zyskania przychylności interlokutora (np. w Topieli Eugenia poniża się w ten sposób przed Skalskim, by nakłonić go do zerwania z Ludmiłą). 
Napięcia uczuciowego, towarzyszącego bohaterom niemal nieustannie, dowodzą ruchy i gesty niekonieczne, uykonywane jedynie na poły świadomie, a służące temu, by zająć czymś ciało i ręce. Mlicki zakochany w Oldze, ale uwikłany w kilkuletni romans z Heleną, „gasi lampę i chodzi dokoła niespokojnie” (Dszcz 17); Ewa, „ta trzecia”, w towarzystuie Tadeusza i Bronki „patrzy nieruchomie w ogień”, „dorzuca gałęzi do ognia, jakby nie słyszała, co Tadeusz mówi”, „odwraca się znowu zamyślona do kominka”, „przeciera sobie czoło", milczy, rozgrzebuje łopatką ogień i dorzuca świeżych gałęzi" (Ś 57-63). Takie zachowanie znamionuje - zgodnie z obserwacjami Darwina - smutek „nieco łagodniejszy, lecz długotruały”, w którym cierpiące osoby pozostają nieruchome lub wykonują ruchy monotonne ${ }^{37}$.

Weunętrzny niepokój połączony z rozmyślaniem i niemożnością rozumowego ogarnięcia uydarzeń bywa symbolizowany poprzez dotykanie rękami twarzy. „W takich wypadkach podnosimy na ogół ręce do czoła, ust albo podbródka" - notował słynny ewolucjonista ${ }^{38}$. Gesty te, zwłaszcza zaś gest potarcia czoła, sygnalizują skłonność postaci do autoanalizy, ale przede uszystkim - jak zauważył Mrazek - wskazują na uczucia i stany nienazwane, zaleduie przeczuwane ${ }^{39}$. Wprowadzał je Przybyszewski także w scenach perypetii miłosnych. Ludmiła „zgarnia włosy” i „trze czoło” (T 141), uświadomiona przez Skalskiego, że jest obiektem uczuć jej własnego wuja. Beznadziejnie zakochany u bratowej Adam Drzazga:

[...] głowę wsparł ciężko na obydwóch rękach, i zdawał się nad czymś z uytężeniem myśleć.

Nagle zerwał się ze stołka, obiegał niespokojnie pokój, przystawał, tarł czoło, odgarniał włosy z czoła i znowu je, pogrążony w ciężkich myślach, wichrzył. (Dn II, 97)

Osoby głęboko zasmucone, zrozpaczone, zdaniem Darwina szukają ulgi w ruchach guałtownych, niemal frenetycznych ${ }^{40}$. Tę zależność prześledzić można i u Przybyszeuskiego. Na przykład Karska po wyznaniu Bieleckiego, że pokochał inną, „skoczyła, jakby ją prąd elektryczny zeruał”. Jej dalsza reakcja przebiega następująco:

- Precz! - krzyczała zduszonym głosem - precz!

To już było ponad jej siły.

- Precz! - zdało się, że lada chwila coś ją rozerwać musi, że na cząstki się rozsypie...

$[\ldots]$

${ }^{37}$ K. Darwin, Dzieła wybrane, t. 6 (O wyrazie uczuć u człowieka i zwierzat), Warszawa 1959, s. 129.

${ }^{38}$ Ibidem, s. 168.

${ }^{39}$ S. Mrazek, op. cit., s. 120.

${ }^{40}$ K. Darwin, op. cit., s. 129. 
Ada chciała jakiś straszny krzyk ze siebie uydobyć, ale nie mogła, wiła się na ziemi, tarzała, poczęła się czołgać na kolanach, jak ciężko zraniony zuierz, który resztką sił chce się doczołgać do suego legowiska: gdzieś, gdzie by mógł swoje rany uylizać, gdzieś, gdzie by się mógł ukryć przed uzrokiem ciekawych [...]. (Mc II, 315-316)

Zachowanie bohaterki jest ekspresją kolejno: wściekłości - bezsilności - poczucia odrzucenia - psychicznego i fizycznego osłabienia - uspokojenia - rosnącej nadziei. Policzek od Bieleckiego Karska rekompensuje sobie myślą o zakochanym w niej Poraju i to na moment wycisza jej emocje:

[...] uyciągnęła się na dywanie i poczęła, by się uspokoić, bezmyślnie z niego wełnę wyskubywać, to ją zausze uspokajało.

Przysiadła, podwinęła pod siebie nogi i złożyła ręce jak do modlituy:

Poraj! Och - przystań moja - miejsce, w którym spocznę! (Mc II, 316)

Dźwięk dzwonka do drzwi na nowo podnosi temperaturę jej uczuć:

Rzuciła się $u$ nieprzytomnym podnieceniu do drzwi, szarpnęła je:

- Jesteś, jesteś... a tak krzyczało moje serce za tobą, tak wołało - rzuciła mu się na szyję [...], wciągnęła go do pokoju, zamknęła drzwi na klucz. (Mc II 316-317)

Ekstatyczne gesty odpowiadają ekstatycznemu sposobowi wypowiedzi, a silne natężenie uczuć wiedzie bohaterkę ku oddaniu się Porajowi. Podobne falowanie emocji czytelnik obserwuje u kolejnej zdradzonej kochanki Bieleckiego - Niny Ligęzy. Z trudnością przyjmując do wiadomości wiarołomstwo ukochanego, kobieta „[...] przecierała oczy [...], tarła czoło, jakby chciała u lęku zdrętwiałe myśli do życia pobudzić" (Mc III, 294). Stopniowo jej ruchy stają się coraz guałtowniejsze. Zraniona bohaterka z obrzydzeniem ściąga z siebie odzież i biżuterię kupioną jej przez kochanka za pieniądze innej kobiety:

Pobiegła do sypialni, nie zdejmowała, ale zdzierała ze siebie ten ohydny, obrzydły szlafrok, kupiony za pieniądze pani Tańskiej - zerwała z siebie łańcuszek złoty, kunsztownej roboty, który jej Bielecki przed tygodniem na imieniny w podarunku przyniósł, rzuciła go ze ustrętem i pogardą na ziemię [...]. (Mc III, 295)

Chwile przypływu energii są przerywane przez momenty apatii. Rozebrawszy się do spódniczki i gorsetu, Nina bezwiednie siada na łóżku:

Zwiesiła ciężko suą złotą głowę na piersi: ponieważ jej głowa ciążyła, gdyby centnary ołowiu, ujęła ją oburącz w dłonie. (Mc III, 296) 
Zachowanie Karskiej i Niny jest niezależne od języka werbalnego. Gesty nie uspomagają w omówionych sytuacjach treści wypowiedzi słownej, lecz konotują i symbolizują myśli. Nie mają też statusu komunikatu, jako że ich wykonanie nie zakłada obecności odbiorcy z kręgu świata przedstawionego. Inne rozwiązanie zastosouał Przybyszeuski u powieści Dzieci nędzy. Zaskoczenie i rozpacz, jakie wzbudza u Drzazdze uiadomość o wyjeździe Jadwigi, zostają wyrażone nie poprzez guałtowne gesty, lecz niemożliwą do opanowania reakcję fizjologiczną. Znaczenia kształtuje tu - mimo pozornego bezruchu - mimika (warto dodać, że wymienione przez pisarza pobladnięcie, skurcz ust, trzepotanie powiek, pochylenie pod własnym ciężarem to stereotypowe objawy załamania, zniechęcenia i smutku, szczegółowo analizowane przez Darwina):

W tuarzy Adama zaszła dziuna zmiana: pobladł tak, że cera jego ziemista się stała, usta się wykrzywiły chorym bólem, oczy załopotały niespokojnie, silił się, by ustać, ale skurczył się tylko w sobie i chwilę zdawało się, że się do drapieżnego skoku zamierza. (Dn II, 174)

Ważna rola w wyrażaniu uczuć przypada również takim elementom pozawerbalnym, jak dźwięki paralingwistyczne, zułaszcza śmiech i płacz. Śmiech nigdy nie jest u Przybyszewskiego radosny, beztroski, lecz zawsze szyderczy, ironiczny, sarkastyczny, pokrywający smutek i niepewność. Poznając się, Bielecki i Karska wybuchają wymuszonym śmiechem, by zamaskować poruszenie emocjonalne i silne wrażenie, jakie nawzajem na sobie wywarli. Bronka udawanym uśmiechem usiłuje przekonać samą siebie, że wybuch zazdrości o Euę był nieuzasadniony. Mlicki i Olga, zaczynający śmiać się nerwowo i spazmatycznie na wieść o śmierci Heleny, jawią się nie jako ludzie bezuzględni, ale przerażeni i nawzajem pogardzający sobą za doprowadzenie do samobójstwa porzuconej dziewczyny. Tę nieszczerość, nieautentyczność śmiechu oddaje zapis wyrazów dźwiękonaśladowczych w postaci osławionego „he, he” („ha, ha”). Jego negatywną wartość podkreśla dodatkowo łatwość, z jaką przeradza się on u płacz (np. w kreacjach Bronki ze Śniegu i Hanki z Godów życia).

Istotną rolę $w$ kształtowaniu reakcji postaci odgrywają przedmioty; kontakt z nimi ma niemal cechy fetyszyzmu. Bronka, poznauszy w Euie rywalkę, szuka pocieszenia u liście, u którym Tadeusz zapeuniał ją o miłości: „leży chwilę, podnosi się z wolna na szezlongu, nasłuchuje truożnie, potem zza stanika wyjmuje list, patrzy na niego, całuje go, zakrywa twarz listem i płacze cicho" (Ś 91). Według Darwina tak właśnie manifestuje się uczucie czułości ${ }^{41}$.

Podobnie obchodzi się z listami od siostry bohater De profundis. Wyznaje on:

\footnotetext{
${ }^{41}$ Zob. S. Mrazek, op. cit., s. 119.
} 
[...] całymi tygodniami nosiłem twe listy przy sobie, pieściłem je rękoma, całouałem, tuliłem, kiedym jeszcze nie przeczuwał, że staniesz się dla mnie, czym dziś mi jesteś. (Dp 63-64)

Interesująca i oryginalna jest reakcja gestyczna Bieleckiego u odpowiedzi na opuszczenie go przez Ninę:

[...] padł na łóżko Niny, zerwał kołdrę, wtulił, wgrzebał się twarzą u poduszki, przesycone Niną, głaskał je i całował, bo zdawało mu się, że ma w rękach bogate, jeduabiste pasma jej złotych włosów, szarpał je i gryzł, bo tych włosów nie było [...]. (Mc III, 311)

Kontakt z przedmiotem jest nasyconym cierpieniem i bezradnością ekwiwalentem kontaktu bezpośredniego. Podmiot otacza rekwizyt gestami, jakie chciałby wykonywać wobec partnera. Ruch ciała komunikuje więc uczucia, ale może także służyć ich maskowaniu. Mistrzem takiej mistyfikacji jest - szczególnie u stosunku do pieruszej i drugiej kochanki - właśnie Bielecki. Nie chcąc zdradzić się ze suym zainteresowaniem dla nowo poznanej Karskiej, usiłuje udawać wobec niej obojętność. Przyłapany na upatrywaniu się w nią - by ukryć zmieszanie - najpieru uyciąga papierośnicę, a następnie z nadmierną uwagą studiuje przypadkowo leżący na podłodze szkic znajomego malarza. Podobne uybiegi stosuje wobec Łusi - by zbagatelizować sprawę fałszerstwa manuskryptów Górskiego i nadać swoim słowom pozory szczerości, udaje opanowanie, zgodnie z zasadą, że tylko winny się tłumaczy:

Nie śpieszył się.

Wstał, podszedł do stołu, przeczytał raz jeszcze uważnie telegramy, zapalił papierosa i chodził wzdłuż pokoju, chuycił wreszcie stołek i siadł naprzeciu niej. (Mc I, 158-159)

Znajomość konwencjonalnych znaczeń przypisywanych gestom pozwala bohaterom Przybyszewskiego świadomie uciekać się do określonych zachowań, by manipulować partnerem. Gdy Falk klęczy przed Maryt i tuli jej dłonie, czyni to nie z potrzeby serca, lecz w celu uwiedzenia dziewczyny. Podobnie Skalski „chwyta ręce” Ludmiły i całuje je nie po to, by dać upust emocjom i uczuciom, lecz by skłonić ofiarę do poślubienia go. Bielecki gładzący ręce Karskiej jedynie przybiera pozę troskliwego kochanka, w istocie bowiem pragnie uśpić czujność partnerki i odwrócić jej uwagę od Niny Ligęzy.

Choć jako środek charakterystyki postaci mowa ciała uystępuje niezuykle rzadko, a bohaterowie nie mają typowych dla siebie gestów, można uskazać momenty, w których reakcja gestyczna wykracza poza proste wyrażenie emocji i pozwala wyciągnąć unioski na temat osobowości 
bohatera. Na przykład Bronka, słysząc propozycję konnej przejażdżki z Tadeuszem, „rozwiązuje guałtownym ruchem włosy” i mówi: „Tak, tak... poprzez pole - poprzez lasy - och, jakie to piękne, a w tym wietrze, $w$ tym pędzie, moje włosy, patrz, tak, o tak”, po czym „rozwiewa swoje włosy, zakręca je znouu szybko, zrywa się" (Ś 101). Zabawa włosami przełamuje stereotyp Bronki jako uległej, bezwolnej i naiunej pocieszycielki Tadeusza. Daje uyobrażenie o temperamencie bohaterki, którego nie dostrzegał nawet jej własny mąż. W chwili rozmarzenia kobieta komunikuje, że ma swoje pragnienia i potrzeby, że stać ją na fantazje i szaleństwo. Dzięki mowie ciała czytelnik zyskuje wyobrażenie także o usposobieniu uprouadzanej na powieściową scenę zdarzeń Karskiej. Kokieteryjną naturę i potrzebę podobania się demaskuje jej zachowanie w kawiarni:

Osunęła się wygodnie $u$ kanapkę, założyła jedną nogę na druga, nieznacznie podniosła obcisłą suknię, spojrzała uważnie u przeciwległe lustro [...]. (Mc I, 111)

O gestach postaci wykreowanych przez Przybyszewskiego decydują przede uszystkim ich guałtowne uczucia i namiętności, przy czym trzeba zgodzić się z S. Mrazkiem, że reakcje cielesne i ruchowe nie są urozmaicone, a nawet mogą nużyć poutarzalnością ${ }^{42}$. Poddawane są też dość daleko posuniętej teatralizacji. Niemniej w prawdopodobny psychologicznie sposób ilustrują zmaganie się bohaterów z własnym „ja”, z krzyudzącymi ich wyborami innych, z przeszkodami piętrzącymi się przed miłością.

\section{Pożądanie i akt seksualny}

Schopenhauer twierdził, że miłość ma zausze podtekst seksualny: „Albowiem całe zakochanie, obojętnie pod jak eteryczną zasłoną mogłoby się ukrywać, tkui korzeniami uyłącznie w popędzie płciowym [...]" ${ }^{33}$. Zwolennikiem oddzielenia miłości od seksu był natomiast Otto Weininger.

Miłość i pożądanie są to dwa tak różne i nawzajem tak zupełnie wykluczające się stany, że w chwilach, w których człowiek rzeczywiście kocha, myśl cielesnego zjednoczenia się z ukochaną istotą jest dlań całkiem niemożliwa. [...] Chociaż nie ma uwielbienia, które by zupełnie wolne było od żądzy, nie można zaraz z tego powodu obu rzeczy utożsamiać [...]. Istnieje zatem miłość platoniczna, choćby profesorowie psychiatrii kpili sobie z tego. Powiedziałbym

\footnotetext{
${ }^{42}$ Ibidem, s. 121.

${ }^{43}$ A. Schopenhauer, Metafizyka miłości ptciowej, uybór i tłum. A. Pańta, Gdańsk 1995, s. 120 .
} 
nawet: istnieje $\mathrm{tylk}$ o platoniczna miłość. Cokolwiek bowiem poza tym nazuie się jeszcze miłością, będzie już tylko świństuem ${ }^{44}$ [podkr. - O.W.].

Bohaterowie Przybyszeuskiego suoim rodzącym się pożądaniom usiłują nadać pozory i miano miłości, broniąc się przed przyznaniem, że ich działaniami kieruje natura-chuć. Najdobitniej ilustrują to rozterki Eryka Falka, bohatera trylogii Homo sapiens. W jednej chwili zastanawia się:

Dlaczego znowu powrócił? Czegoż chciał od Maryt? Czemuż ją okłamyuał? Dlaczego grał całą tę komedię?

$[\ldots]$

To chuć, co w głębi czyhała na nową ofiarę? (Hs II, 29)

A następnie tłumaczy swoje zachowanie zakochaniem:

Jeżeli pisał gorące, o! strasznie gorące listy miłosne do swej żony, to nie kłamał, bo ją rzeczyuiście kochał, a jeżeli parę godzin później zapewniał Maryt, że ją kocha, to też, Bóg widzi, nie kłamał. (Hs II, 30-31)

Postacie z utworów Przybyszeuskiego oddają się kontaktom seksualnym niekoniecznie z miłości - Falk przychodzi do Janiny, ponieważ nie może być z Izą (Homo sapiens), Ada Karska wciąga Bieleckiego w swą grę, chcąc go uykorzystać (Mocny człowiek), bohater poematu Androgyne uspomina „cały szereg kobiet, które znał, pieścił, tulił i w namiętnych splotach z nimi się zrastał”, chociaż „żadnej z nich nie kochał” (A 395-396).

Bohaterowie nie są $w$ stanie oprzeć się rosnącemu pożądaniu, ponieważ kieruje nimi nie do końca rozpoznana siła, która zmusza ich do przekraczania norm społecznych i ustanowionych bądź przyjętych przez nich samych zasad (zob. podrozdział Chuć i Fatum). Namiętność jest najsilniejszym stymulatorem motyuującym zachowanie postaci. Jej działanie Przybyszewski ujmuje obrazowo jako „krótkie, guałtowne ustrząśnienia, jakby od uderzeń młotka” (Dp 77). Bodziec wzbudzający owo pożądanie bywa na ogół nieokreślony. Ma charakter przymusu, nie olśnienia cielesnym bądź duchouym pięknem obiektu. Płynie z natury lub podświadomości. W pieruszym przypadku uymuszają go cele gatunku, konieczność realizacji popędów. W drugim uiąże się z rozpoznawaniem w napotkanej osobie androgynicznej połówki (animy/animusa), z powrotem do początków własnych i śuiata, do stanu boskości i pełni wiedzy. Wobec tych nacechowanych naturalistycznie i metafizycznie koncepcji oryginalne uypadają rozwiązania najbłahsze, np. pociąg erotyczny budzący się nagle na widok wdzięków partnera podkreślonych strojem. Bielecki

\footnotetext{
${ }^{44}$ O. Weininger, Płeć $i$ charakter, tłum. O. Ortwin, Warszawa 1994, s. 115, 116.
} 
patrząc na zrywającą się z kanapy Łucję - bosą, jedynie w spódniczce i odsłaniającej piersi koszuli - przerywa wzajemną awanturę słowami: „Rozbroiłaś mnie; dawno cię tak piękną nie wiedziałem" (Mc I, 154). W ledwo odzianej kochance dostrzega świadome suej wartości, lecz proste dziewczątko:

[...] te roziskrzone oczy, płonąca tuarz, uspaniałe ramiona, smukła, bajeczna u rysunku ręka, podtrzymująca na piersi białą koszulę, u pasie odcinająca się czarna spódniczka i te maleńkie bose nóżki pod spodem, jak dwa gołąbki, co siadły na mostku gołębnika - o! o! gdybym był malarzem... (Mc I, 154)

Wygląd Łusi wzbudza w „mocnym człowieku” pożądanie, choć planuje on pozbycie się niewygodnej dzieuczyny. Kłamliwe uyznanie miłości ostatecznie czyni mu kobietę powolną:

Objął ją i tulił gorąco do siebie - młode, gorączką rozpalone, na upół nagie ciało poczęło działać na jego zmysły.

$[\ldots]$

Luźno zuiązana spódniczka opadła z niej, podrzucił ją na siebie, objął ramieniem jej nogi i poniósł na łóżko.

- Rzadko piękne ciało - pomyślał. (Mc I, 166)

Scenę miłosną dyskretnie kończy pisarz oględnymi informacjami narratora:

Zamknęła oczy i pociągnęła go ku sobie. [...] Zgasił lampę. (Mc I, 167)

Urok Łucji polega na jej prostocie, infantylności, którą wyraża strój. Ubranie to także erotyczny atut Agaj, tyle że bohatera De profundis roznamiętnia obraz siostry ubranej szykownie, niemal wieczorowo - w czarną jeduabną suknię, do której dodatkiem są czerwone rękawiczki. W takiej toalecie mężczyzna od początku widzi ukochaną w swoich wizjach. Eksponująca wdzięki, przylegająca do ciała kreacja pobudza jego pożądanie:

Ujrzał naraz Agaj tuż obok siebie. Czarna, jedwabna suknia przylegała gorącą pieszczotą do jej smukłej, delikatnej postaci.

$[\ldots]$

Widział ją ustawicznie tuż przy sobie, przed sobą. Obnażał ją oczyma, sycił, poił się jej pięknością i naraz zapragnął jej namiętnym, dzikim szałem. Zmysły jego poczęły się mącić w pragnących żarach. (Dp 46)

Z czasem odczucia wzrokowe uzbogacają się o wrażenia dostarczane przez zmysł dotyku. Libido narasta. Bohater mówi do siostry:

Bardzo mi się podoba twoja jedwabna suknia. To daje takie dziunie lubieżne uczucie u kończynach palców. Ten jeduab rozpyla się słodką rozkoszą u mojej krui... (Dp 76) 
Toaleta Agaj oddaje jej demoniczną naturę. Sytuuje ją wśród postaci rodem z grafik i rysunków Féliciena Ropsa, lubującego się w komponowaniu erotyki ze śmiercią i satanizmem. Oznaką śmierci, ku której kobieta wabi brata, jest czerń jej sukni. To barwa zła, mocy ciemności. Kontrastująca z nią czerwień sięgających łokci rękawiczek symbolizuje przede uszystkim uspólnotę krui kochanków. Kolor ten gra w utworze znaczeniami. Ma moc przyspieszania pulsu, podnieca i prowokuje. Jest barwą seksu, zapowiadającą niebezpieczeństwo, ustyd, grzech, a także obrazowym ekwiwalentem kazirodztwa. Wyraża aktywność życiową, tłumioną jednak w zestawieniu z funeralno-diabelską czernią. Agaj jawi się jako nieopanowana chuć, siła erotyzmu skorelowanego ze śmiercią. To wyobrażenie jest tak silne, że widząc siostrę w szarej, pospolitej sukni, mężczyzna wpada w gniew. Tylko Agaj dominująca pobudza głębie jego psychiki, uzupełnia go i ekscytuje, jest jego animą.

Przybyszewski jako pisarz nie koncentruje uwagi na opisie intymnych chwil kochanków. Stroni od dosłowności, która pobudzałaby wyobraźnię odbiorców i uzasadniała upisanie jego utworów na listę „pornograficznych”. Jeśli zapowiada akt seksualny - jak w omówionej powyżej scenie Mocnego człowieka - to skrótowo, w kilku zaledwie zdaniach, nie ogniskując uwagi na detalach ciał partnerów czy miłosnej akcji. Coitus nigdy nie został przezeń opisany - zapewne zadecydowała o tym obyczajowość epoki. Ostateczny moment zbliżenia autor pozostawiał domyślności czytelnika lub sugerował za pomocą peryfraz, np.: „Falk wziął ją” (Hs II, 125), „zuisła bezuładnie w mych objęciach” (Nm 328), „O, upojeń godzina - godzina cudu, kiedy dwie dusze $w$ jedną się zleją, dwa ciała w jedno się splotą...” (A 422).

Kochankouie Przybyszeuskiego głównie całują się i konuulsyjnie przytulają. Czują drżenie i uderzającą do głowy krew. Chwile ekstazy przywołują we uspomnieniu:

- Pomnisz noc, gdym tuliła Twą twarz w mych dłoniach, gdym obejmowała Cię gorącym oplotem mych ramion; głowa Twa spoczęła na mej piersi, a jam błądziła cichymi palcami w Tuych miękkich włosach? (A 447)

Szatanie! [...] pozwól, że raz jeszcze uczuję tę rozkosz nad uszelkie rozkosze, jak pierś jej się $\mathrm{w}$ moją wpala, jak usta jej się w moje wpijają, jak ręce jej dyszą na mej szyi w bolesnym upojeniu. (Nm 288-289)

Kochającą się parę często otulają włosy kobiety (jak na obrazach Muncha i Klimta); długie, uzburzone, jako symbol fetyszystyczny były jednym z głównych motywów secesji, wychodziły naprzeciu koncepcjom dekoracyjnym stylu ${ }^{45}$ :

\footnotetext{
${ }^{45}$ Zob. H. Hofstätter, Symbolizm, tłum. S. Błaut, Warszawa 1987, s. 270.
} 
A kiedy Cię namiętnym rzutem mych ramion na piersi podrzucam, a włosy Tue grzywą się najeżą, gibką trzciną Tuych nóg me biodra opaszesz, a usty Twoimi upijesz się $\mathrm{w}$ moje - [...] kochasz mnie wtedy? (A 426-427)

Całowała go długo, a potem objęła go rękoma, położyła głowę na jego piersi, strumień jej włosów rozlał się po całym jego ciele. (Dp 88)

Niekiedy ekwiwalentem aktu seksualnego jest dotyk ${ }^{46}$, całowanie rąk lub taniec, który łączy w androgynii Izę i Falka („Wpadł w wir, który go porwał. Czuł, jak się zrośli, jak ona stała się częścią jego duszy, a on wirował wokół siebie samego, sam z sobą" - Hs I, 72). Co więcej - zbliżenie erotyczne może obyć się całkowicie bez fizycznego kontaktu, a realizować jedynie w wymiarze wewnętrznym, nie tracąc suego seksualnego charakteru. Dusza zaznaje zmysłowej ekstazy niejako w zastępstwie blokowanego społecznym ethosem ciała, jak w pokazanej oczami bohatera-narratora scenie z poematu $Z$ cyklu Wigilii, w której recytującemu poezję mężczyźnie akompaniuje siedząca przy fortepianie kobieta:

[...] były duie dusze spojone w wściekłym uścisku, porywały się w górę, spadały w dół, a silniej i silniej splatały się ich ręce, szarpały się i gryzły, a było to, jakby się rozpętała piekielna orgia rozpasanych zmysłów, pełna krzyku, boleści i żądzy, chciwa krui i ciała. (W 199)

Bardziej dosłouny niż $\mathrm{w}$ obrazowaniu rzeczywistego aktu seksualnego bohaterów bywał Przybyszewski w opisach imitujących go widowisk, jakie na przełomie wieków oferowały klientom $w$ ramach rozrywki podrzędne kabarety i tingel-tangle $w$ wielu miastach europejskich. Z takich spektakli słynęły przede uszystkim lokale na paryskim Montmartrze i właśnie do jednego z nich zaprowadził Przybyszewski Jana Krywłę, „kiepskiego Chrystusa" z powieści Dzieci nędzy. Widząc tańczącą na scenie swoją siostrę Salomeę, bohater płaci za kilkakrotne poutórzenie nieuybrednego widowiska, by masochistycznie przeżywać nędzę i upadek tancerki-prostytutki. Pokaz - będący zuulgaryzowaną syntezą nie tylko miłości fizycznej, ale pożycia partneróu w ogóle - to demonstracja męskiej siły i kobiecej uległości.

Z początku rozkoszne, pełne tęsknot i pragnień wabienia się wzajemne, potem jeden rzut: samiczka zawisła na mocnym karku samca - parę miłosnych obrotów, a nagle w ordynarnych ruchach symbolizowany akt płciowy - jeszcze kilka znużonych okoleń, a potem samiec

\footnotetext{
${ }^{46}$ Oto interesujący przykład:
}

Ujął lekko jej rękę, siedzieli sami, nikt nie mógł ich widzieć.

Odpowiedziała guałtownym, nerwouym uściskiem.

A uścisk stawał się coraz silniejszy.

Coraz bliżej niego - opadała prawie - bliżej - bliżej: głowy ich stykały się.

Nie opierała się, czuł, jak mu się oddawała, jak kładła się w jego serce: u gorące łoże krui jego serca. (Hs I, 73) 
rzucił się wściekły na kobietę, powalił ją o ziemię, wkręcił palce $u$ jej rozpuszczone teraz, przepyszne, krucze włosy, zeruał ją z ziemi, znowu parę razy okręcił wkoło i znowu, jakby z obrzydzeniem rzucił o ziemię. (Dn I, 214)

Tym, co łączy kobietę i mężczyznę, jest zatem popęd płciouy, który z kolei - szybko zaspokojony - przeradza się w sadyzm. W takiej animalistycznej relacji partnerzy, samiec i samica, traktują się przedmiotowo:

Przywarła do jego stóp, jak psica, żebrząca o łaskę, i widocznie zdołała zmiękczyć dzikie serce samca, bo podniósł ją z ziemi i objął znouu upół. A ona uległa, pokorna, uszczęśliwiona, że ją znowu do siebie przytulił, patrzyła mu w oczy rozkochanymi ślepiami, uylękniona, a może dumna, że ma tak mocnego samca.

Ale to truało krótką tylko chwilę.

Bo po paru obrotach wygiął ją $\mathrm{w}$ tył, podrzucił na siebie i cisnął o ziemię, że zaskowyczała z bólu. (Dn I, 214-215)

Podobny przebieg ma taniec, który ogląda Gasztowt w Krzyku. Jest „namiętny, sprośny, całkiem nieprawdopodobny w suym żywiołowym rozpętaniu - bezpamiętnym rozpasaniu zmysłów" (K 148-149). I tu na estradzie występuje prostytutka - kobieta, którą bohater uchronił przed samobójczą śmiercią w nurtach rzeki. Jej ruchy przypominają kuszenie lubieżnie uygiętego węża i odsłaniają nagie ciało. I ona kończy jak Sala - ciśnięta u kąt przez tancerza. Bachiczne widowisko obrazujące „rynsztok życia” jest miarą jej upodlenia, rozwiązaniem okrutniejszym niż śmierć, potęgującym bowiem nędzę świata.

Interesującą, bo lesbijską, wersję kawiarnianego tańca dał Przybyszewski w Mocnym człowieku. Przed bywalcami krakowskiego lokalu Szotta uystępują w powieści Cesia i Miecia, artystki kabaretu o ludycznej nazuie „Sprośny Marchołt”. Prezentują wywodzącą się z Brazylii i popularną w Europie końca XIX w. żywiołową macziczę, i to w odmianie wyjątkowo zerotyzowanej. „Takiej macziczy u Paryżu nie zobaczysz” - uprzedza Bieleckiego Cesia.

Cesi twarz zaczęła się rozpalać, ramiona nabierać jakiejś giętkości i siły stali, zdawała się zapominać, że ktoś na nią patrzy, przyciskała do siebie delikatną Miecię, łamała ją jak gibką trzcinę, to znóu wtulała ją między sue nogi, przechylała się nad nią całym ciężarem tułowia, znowu podrzucała na siebie, tarły się z miłosną rozkoszą o siebie, odrzucały, przygarniały - gibkie członki nóg i ramion zdawały się nierozerwalnie splatać, znowu rozluźniać i z większym jeszcze pragnieniem się z sobą sprzęgać... (Mc I, 206-207)

Opisy zbliżeń udawanych są uyraźnie bardziej śmiałe i dosłowne niż sceny, w których następuje faktyczne zbliżenie bohaterów. Czego to dowodzi? Przede uszystkim zaprzecza pornograficznym jakoby zamiarom pisarza, uznanego bądź co bądź przez współczesnych za gorszyciela epoki. Po 
drugie, przekonuje, że autorowi szło nie tyle o konkretny obraz, co o siłę wyrazu - rzeczywiście następujący akt płciowy mógł pozostać u sferze niedopowiedzeń, nie tracąc nic ze suego znaczenia; jego sceniczna namiastka musiała być bardziej obrazowa (wulgarna?), ponieważ spełnia rolę metafory, oznacza zgniliznę życia, jest objawem metafizycznej nędzy. Idąc dalej: skoro Przybyszeuskiego nie interesowały szczegóły intymnego pożycia postaci, jaki artystyczno-filozoficzny sens nadawał scenom cielesnych zbliżeń? Otóż w centrum jego uwagi znalazło się nie samo przeżycie zmysłowe, lecz związane z nim odczucia, jak w relacji bohatera Requiem aeternam:

Gdzieś z dołu dolatywały nas dźwięki jakiejś pijanej muzyki - poprzez zieloną, gęstą umbrę dżdżyło słabe dogorywające światło - i wtedy czułem, jak drgania Twego ciała udzielały się memu, jak się wwijały wężouym czołgiem u krew moją, jak serce w coraz to mniejszych odstępach bluzgało prądy krui u tętnice, a w mózgu zadrżały dawno, dawno już nie trącane struny. (Rae 60)

Autor ucieka przed konkretem, uybiera przenośnie i pojęcia abstrakcyjne dla oznaczenia całej gamy uczuć i zachowań, nie decydując się na radykalne przełamanie obowiązującej w języku normy intymności. Wrażenie silnego przesycenia tekstów erotyzmem uynika przede uszystkim z użycia dużej liczby czasowników potęgujących dynamikę, przymiotników podkreślających doznania oraz rzeczowników odnoszących się do sfery seksu, a przy tym nie posiadających jednoznacznych definicji, jak rozkosz, lubieżność, rozpusta, szał. Miłość jest u Przybyszeuskiego paroksyzmem, ekstazą, najsilniejszym rodzajem ekspresji. Jako potwierdzenie wystarczą pierwsze z brzegu przykłady z poematów:

Wpijam me rozżarzone usta $\mathrm{w}$ Twoje piersi, aż serce me się rozpiera od szczęścia, tak mocno upragnionego [...]. Przytulam Twe smagłe ciało krwiożerczej samicy tak silnie do mego, że czuję bicie Twego serca na mej piersi i mogę liczyć uderzenia [...]. (Rae 65-66)

- O całe ciało przenajsłodsze,

raz jeszcze rozszalej się przenajśuiętszym grzechem na mym rozżarzonym ciele, zamieraj w nieludzkiej pieszczocie, rozkrzycz się $\mathrm{w}$ dzikim szale rozpusty, pień się wielkim Alelujah u ciemną otchłań, w której się pamięć zatraca. (A 458)

Metaforyka dowodzi, jak bardzo autorowi Synagogi szatana zależało na intensywności środków wyrazu, pozwalającej uwolnić dzieło od powierzchowności, konwencjonalności ${ }^{47}$. W tę koncepcję konuulsyjności wpisuje się wyraźny element sadyzmu, który Freud uznał później za podstawowy paradygmat $\mathrm{w}$ relacji męskie - żeńskie. Partnerzy miłosnego zbliżenia szarpią

${ }^{47}$ Zob. A. Sucharska, Stanisław Przybyszewski. Miłość: „Rozślizłe prześcieradło moich uczuć”, „Metafora” 1992, nr 5, s. 12. 
i kąsają sue ciała, pochłaniają się nawzajem i zagłębiają w sobie. Dotykiem zadają ból, wypalają krwawe stygmaty.

W g r ze buj ę s i ę w Ciebie, czuję, jak się Twe wiotkie członki pienią w upojeniu krzyczącej lubieży i podrywają się $w$ bolesnym eretyzmie ${ }^{48}$ rozkoszy (Rae 66; podkr. K.B.)

- snuje wyznanie bohater Requiem aeternam. Świadectwo podobnego erotycznego cierpienia odnajdujemy w De profundis:

Dusił się. Oddech jej palił go, usta jej wessały się z jękiem u jego usta: jak do biała rozpalone żelazo żarzyło się jej ciało. (Dp 49)

Istotnym aspektem następującej podczas pieszczot destrukcji ciała partnera jest uypływ krwi. Krwawe pręgi na piersi Bieleckiego zadane paznokciami Karskiej czy rany pozostawione na szyi brata przez Agaj to oznaki wyjątkowo silnych pragnień seksualnych połączonych z potrzebą niszczenia i dominacji. Jedności rozbuchanego Erosa z sadyzmem i masochizmem dał wyraz Przybyszewski $w$ interesującym utożsamieniu pieszczot z biczowaniem: ,[...] strumień krui, co się w Tuym ciele rozszalał, moje własne ciało $w$ pieniący szał smaga [...]" - ekstatycznie mówi bohater do kochanki (Rae 66) ${ }^{49}$. Każda ze stron jest tu jednocześnie biczującą i biczowaną. Role kata i ofiary stają się płynne. Sterowanie przepływem krui ma jednocześnie charakter seksualny i patologiczny, pozwala jednak doświadczyć stanów granicznych: zaznać boskości lub poczuć uspółobecność szatana. W jednym z esejów pisał Przybyszewski, że:

Biczowaniem się, upustem krui, [...] niszczeniem jej najuiększego rozpędu w płci, osiągał święty łaskę obcowania z Bogiem - i na odurót: potęgując jej moc w nieskończoność, każąc jej szaleć $w$ rozpienionych falach niszczącego żywiołu, czy to w orgiach płciowych, czy w „kruiożerczych” zbrodniach burząc jej uszelakie „naturalne” tamy i groble, starał się sługa Szatana zetknąć z suoim przepotężnym możnowładcą ${ }^{50}$.

Wywód kończy autor konkluzją unaoczniającą podobieństwo krwi i spermy, usankcjonowane później przez psychoanalizę. Pieszczoty kochanków w oczywisty sposób przypominają guałt, zwierzęce lub wampiryczne pożeranie się. W dużym stopniu potwierdzają zauważony przez psychologów zuiązek między funkcją żywienia się i funkcjami seksualnymi ${ }^{51}$. Zasada supremacji i absorpcji obejmuje poza obszarem fizyczności strefę psychiczno-duchową:

${ }^{48}$ Eretyzm - nadmierna, chorobliwa pobudliwość.

${ }^{49}$ Por. W. Gutouski, Nagie dusze..., s. 35, 245.

${ }^{50}$ S. Przybyszeuski, Na marginesie tworu Ewersa, Lwów 1917, s. 33.

${ }^{51}$ R. Caillois, Modliszka, [w:] idem, Odpowiedzialność i styl. Eseje, thum. K. Dolatouska, Warszawa 1967, s. 136. 
„ssię Twoją duszę - usysam ją w siebie" - deklaruje bohater poematu, usiłując w akcie seksualnym stopić w sobie kochankę (Rae 66). Akcenty miłosnego masochizmu zostały wplecione również $\mathrm{w}$ symbolikę religijną. Bohater poematu $Z$ cyklu Wigilii błaga ukochaną:

Przyjdź, weź hostią mego serca u twe miękkie ręce, przyjdź!

[...] w rękach twoich drga moje serce, krwawi i wzbija się w niebo. (W 174-175)

Akt seksualny ma dwa oblicza. Jest realizacją popędu płciowego, związanego z mitem chuci, ale także - przynajmniej w marzeniach i oczekiwaniach postaci - komunią dusz. W tym drugim przypadku prowadzi do odbudowania pierwotnej jedności androgynicznej, a przez to pozwala przekroczyć wąskie granice jednostkowego poznania i przeniknąć tajemnice bytu (problem ten został szerzej omówiony w podrozdziale Androgyne). Ekstaza łączy się z gnosis i pobudza możliwości kreacyjne. Dlatego bohater Requiem aeternam mówi do leżącej obok niego kochanki: „Ujrzałaś tajemnicze Saïs mego życia” (Rae 61), co znaczy: poznałaś prawdę o mnie, prawdę, która nawet dla mnie pozostaje tajemnicą ${ }^{52} \mathrm{~W}$ innym miejscu wyraża niepojęte doznania, odwołując się do sił kosmosu:

I chuyciłaś mnie u Tue ramiona, spętałaś mnie ciężkimi zwojami Twoich włosów, jedną ręką zerwałaś guiazdę, że spadła i z sykiem zatonęła w Cichym Oceanie, drugą zdajesz się chuytać krańce ziemskiego globu, by mnie ponieść u kosmiczną nieskończoność, gdzie przestrzeń staje się głupim urojeniem, a czas sam siebie w ogon gryzie, bo się rozpostrzeć nie może. (Rae 80-81)

W słowach Przybyszeuskiego powraca centralny dla religii indyjskich pogląd, iż rzeczywistość jest niepodzielną całością, zaś dostrzeżenie integracji z kosmosem stanowi zasadniczy krok w jej bezpośrednim poznaniu. Ta uniwersalność, przekraczanie granic samego siebie, ma znamiona misterium, sakramentu. Jeszcze uyraźniej można to prześledzić u poemacie Nad morzem, gdzie w analogii do mocy żywiołów pojawiła się seksualna penetracja ciała. Serce Oblubienicy (czyli serce morza) posiada cechy falliczne, zagłębia się we wnętrze ziemi niczym w waginę:

I serce rosło - rosło, jednym zamachem rozerwało gęstą noc i gdyby piorun wpadło do morza.

A teraz puka cała ziemia - drży - trzęsie się. Coraz głębiej wuierca się serce w jej ciemne wnętrze i oto rozwiera się dno morskie i uszystka krew ziemi, uszystkie rzeki, jeziora i oceany spływają do serca ziemi. (Nm 330)

\footnotetext{
${ }^{52}$ Saïs to ośrodek kultu religijnego w starożytnym Egipcie. Według legendy znajdował się tam zasłonięty obraz przedstawiający prawdę; jego odsłanianie było zabronione.
} 
Serce ziemi jest tu kosmicznym centrum, w którym zbiegają się siły naturalne, witalne, zaś wytrysk krwi, analogiczny do wytrysku nasienia, oznacza wyzwolenie energii. Znaczenie spermy $w$ aspekcie kosmicznym i kosmogonicznym uwypukla przekaz staroirański, według którego praczłowiek Gajomard został zabity, a jego nasienie zapłodniło macierzystą ziemię i przyczyniło się do uydania na świat (początkowo pod postacią rośliny) pieruszego mężczyzny i pieruszej kobiety ${ }^{53}$. Obraz fallicznej penetracji ziemi występuje także $w$ religiach indyjskich, gdzie dwa bieguny bytu przedstawiane są jako linga i joni. Linga utożsamiana jest z promieniem światła i błyskawicą, która zapładnia matkę-ziemię, a więc niejako łączy się z żeńskim „łonem” - joni. Te symbole, przywołujące dodatkowo żywioł ognia, odsyłają do najuyższego poznania, oczyszczenia; temu samemu celowi służy cielesne połączenie mężczyzny i kobiety ${ }^{54}$. Ogień ożywiający ziemię pojawia się w Nad morzem jako kontynuacja kosmicznej refleksji:

Bo znouuż podszepnęła mi tęsknota moja, że u tej czarnej nocy ujrzę ją [ukochaną] nad lśniącym lodem, że uytryśnie jako płomień, jeżeli serce jej jeszcze żądnym pragnieniem ku mnie bije.

I oto, niby ognista nitka wytrysnął naraz płomyk; $w$ jednej chwili rozrasta się $w$ krzew, rozlewa się w ognisko, leje strumienie ognistych warów na bezkresy lodowe. Błyskiem piorunu zamienia się śnieg i lód w jedno morze ognia, święte serce morza poczyna bić i znouu wyrzuca wrzące lawy ognia, swą krew: potopy rzek, jezior i oceanów chłoną pożar uszechśuiata. (Nm 331)

Ogień niszczy (topi lodowiec), ale i ożywia (budzi morze). Symbolizuje dynamiczną moc pulsującej krwi, która - o czym unikliwie pisał Wojciech Gutouski - nie wiąże się z regresem jak w micie chuci, lecz tworzeniem. Aktywność (wytrysk) skierowana jest ku górze, ma zatem walor dodatni ${ }^{55}$.

Okazuje się jednak, że w ludzkim świecie miłość jedynie przez moment umożliwia zatarcie granic między duiema śuiadomościami. Obcość kobiety i mężczyzny jest nie do pokonania. Ona realizuje wyłącznie cele gatunku. On, dążąc do stopienia dusz, ulega namiętnościom i poddaje się prawom natury, a winą za swój upadek obarcza partnerkę. Grażyna Borkowska interesująco pisze o tym, że przez ciało kobiet wiodła droga do nieba i do piekła, a u zbliżeniu miłosnym zmagały się, podobnie jak u Ropsa i Muncha, równoważne siły: dobro i zło, piękno i brzydota ${ }^{56}$. Przybyszewski demaskuje zatem akt seksualny i ocenia go negatywnie, ale - jak zauważa Maria Pod-

${ }^{53}$ Zob. M. Lurker, op. cit., s. 267.

${ }^{54}$ Ibidem, s. 265.

${ }^{55}$ Zob. W. Gutouski, Nagie dusze..., s. 261.

${ }^{56}$ G. Borkouska, Pteć jako skaza: Przybyszewski i Natkowska, [w:] Nowa świadomość ptci w modernizmie, red. G. Ritz, C. Binswanger, C. Scheide, Kraków 2000, s. 87. 
raza-Kwiatkouska - nie każe suoim bohaterom wyrzekać się go, przyjmuje to, co przynosi natura ${ }^{57}$.

Kochankowie Przybyszeuskiego, pokładający u zbliżeniu cielesnym tak wielkie nadzieje, stają się niewolnikami pożądania. Nie udaje im się przekroczyć barier ciała, są na zawsze uzależnieni od natury.

\section{Kazirodztwo, nekrofilia, orgia}

Miano deprawatora i gorszyciela przyniósł Przybyszeuskiemu nie tylko sposób ujęcia miłości heteroseksualnej, lecz także sceny, w których kreślił obraz zuiązków kazirodczych oraz dawał upust wyobraźni nekrofilskiej i orgiastycznej. Wszystkie te nietypowe zachowania seksualne, mimo iż uzbudzały zainteresouanie XIX-wiecznych antropologów, socjologów, psychiatrów i biologów, sytuowano $w$ obszarze ciemności, grzechu ${ }^{58}$. Potwierdzały je co prawda mityczne, religijne i historyczne praźródła, niemniej stanowiły wykroczenie przeciwko zasadom społecznym i boskim. Zagrażały porządkoui społecznemu i cywilizacyjnemu, dlatego opresyjna kultura nałożyła na nie piętno tabu.

Literatura polska rezygnowała $\mathrm{z}$ jawnego i dosadnego podejmowania tematu kazirodztwa, unikając szczególnie analizy naturalistycznych determinant i fizjologiczno-popędowych rozwiązań. Zastępowała go natomiast quasi-incestem, jak w Chłopach Reymonta, gdzie romans nawiązują macocha i pasierb. Gabriela Matuszek widzi w tej ostrożności dziedzictwo tradycji romantyczno-chrześcijańskiej, zułaszcza zaś mitu matki-Polki i dziewicy-ukochanej poustańca, które nie pozwalały brukać uwznioślonych zuiązków rodzinnych biologizmem i seksualnością ${ }^{59}$. Dopiero na początku XX w. polscy artyści (m.in. Miciński w Xiędzu Fauście) odważniej sięgnęli po motyw incestu. Jedną z najoryginalniejszych jego realizacji przyniósł utwór Przybyszeuskiego De profundis. Erotyczna więź zespala tu spotykające się po dwunastu latach rodzeństwo. Pisarz pokusił się o odtworzenie źródeł budzącego się dość niespodziewanie uczucia - tkwią one $u$ spędzonym wspólnie dzieciństwie. Bohater stopniowo przywołuje zepchnięte do podświadomości uspomnienia i na nowo je interpretuje. Wynika z nich, że duuznaczne relacje łączyły go z siostrą od dawna, choć

${ }^{57}$ M. Podraza-Kuiatkouska, Wolność $i$ transcendencja. Studia i eseje o Młodej Polsce, Kraków 2001, s. 155.

${ }^{58}$ G. Matuszek, Incest w literaturze przełomu XIX i XX wieku, [w:] Zrozumieć płeć II: studia interdyscyplinarne, red. A. Kuczyńska i E.K. Dzikouska, Wrocłau 2004, s. 144.

${ }^{59}$ Ibidem, s. 146. 
nigdy nie przybrały charakteru stricte seksualnego. Sięgają one czasów, gdy 12-13-letnia Agaj, bojąc się nocnej burzy, przyszła do łóżka brata, by opowiadał jej bajki. Przerażona hukiem pioruna, który uderzył u topolę przed domem, guałtownie i mocno przytuliła się do chłopca. W takim uścisku usnęli. Nad ranem, gdy kołdra opadła na podłogę, bohater po raz pieruszy ujrzał siostrę nagą. Zaczął całować jej ciało, po którym - jak ocenia to po latach - przebiegały dreszcze. Nie wiedział, czy spała, czy też z premedytacją leżała odkryta, oczekując jego reakcji. Chuil dziecięcej intymności było więcej. Podczas zabawy w chowanego Agaj ukrywała się w najciemniejszych zakamarkach i tuliła brata do siebie "tak gorąco, jak tylko kobieta tulić się może do ukochanego mężczyzny" (Dp 59). W czasie pobytu nad morzem pozwalała mu pomagać sobie przy rozbieraniu i zanosić się do wody. $\mathrm{Z}$ pozoru niewinne zachowania nabierają ukrytego sensu, obrastają w kontekst. „Tyś obudziła mężczyznę we mnie” - stwierdza bohater $\mathrm{u}$ rozmowie z siostrą (Dp 59). Interesującym punktem odniesienia dla ich romansu są spotkania z 12-letnią prostytutką, jakie nawiązuje bohater, próbując odnaleźć wcielenie dawnej Agaj i odtworzyć nastrój minionych chwil.

Po latach pożądanie seksualne wybucha z niepohamowaną siłą. Agaj usiłuje mu zaprzeczyć, jednak spojrzenie i sposób, w jaki chuyta dłoń brata, by delikatnie ją głaskać, to znów szczypać, zdradzają jej tłumione obawą pragnienie. Pieszczoty rodzeństwa stają się coraz odważniejsze. Przybierają formę kurczowych, namiętnych uścisków i wampirycznych pocałunków. Na pożegnanie, po podjęciu samobójczej decyzji, siostra rozpina gorset, podając bratu do całowania swoje piersi, a sama rozrywa zębami skórę na jego szyi. Żądza wywołuje erotyczne fantazje, nie może się jednak dopełnić. Ale nie z powodu tamy, jaką stawiają związki rodzinne. Paradoksalnie bowiem, powinowactwo krui nie jest przeszkodą, lecz spoiwem kochanków. „Dziś widzę tylko Agaj przed sobą, obcą jakąś kobietę, którą kocham ponad uszystko, może dlatego, że jest kruią z mojej krwi, ciałem mego ciała" - mówi on (Dp 62) ${ }^{60}$. „Krui moja... mężu mój]” - wtóruje ona (Dp 96). Więzy krwi stwarzają związek naturalny, organiczny, niemożliwy do zerwania, a oparty na uspólnocie i urodzonym podobieństwie partnerów. W takiej relacji łatwiej osiągnąć Dwój-Jednię, ku której dąży rodzeństwo.

Silniejszy niż tabu kazirodztua jest w De profundis zakaz cudzołóstwa. W rozmowach kilkakrotnie pouraca postać żony bohatera, a jej „nieobecna obecność" poustrzymuje brata i siostrę przed spełnieniem uystępnej miłości. Miłości, którą zasugerował ułaśnie list od żony, a szczególnie trzy jego zdania: „Jej [Agaj] miłość taka dziuna. Ona nie kocha Cię jak siostra. Nie widziałam

\footnotetext{
${ }^{60}$ Bohater De profundis przypomina Adama, z którego żebra poustała Ewa - jego kochanka, siostrzana cząstka, a według pism żydouskich także androgyniczna połówka.
} 
czegoś podobnego pomiędzy rodzeństuem" (Dp 45). Nakreślone w liście słowa pobudzają fantazje bohatera o Agaj jako kochance. Gabriela Matuszek tuierdzi, że siostra pojawia się w jego chorej uyobraźni w zastępstuie żony i matki, do której przyjechał, a której ostatecznie nie odwiedził ${ }^{61}$. W tym sensie Agaj łączy role trzech kobiet najbliższych każdemu mężczyźnie. Ale może przecież odzwierciedlać także kobiecą stronę osobowości głóunego bohatera (animę). A jest to osobowość rozbita, o czym świadczą powracające stany gorączkoue i nieustanne osłabienie, a wreszcie poczucie egzystencji soboutórowej. Tę psychiczną jedność rodzeństua $w$ interesujący sposób potwierdzają słowa Agaj, zarzucającej bratu (a może tylko go informującej), że trzeba go uwodzić jak kobietę, że stał się kobietą. Żebrzący o miłość, uległy mężczyzna podporządkouuje się w De profundis dominującej partnerce. Podobnie jak u Huysmanouskim Na wspak oraz Panu Wenus Rachilde mamy do czynienia z żonglowaniem rolami uświęconymi przez wieki formowania się kultur i społeczeństw. Aktywność tradycyjnie przypisywana jest mężczyźnie, zatem kobieta aktywna musi być „męska”. Bierność i poddanie to cechy kobiece, więc popadający w zależność mężczyzna jest „kobiecy”. Męskość i kobiecość, przeplatające się $w$ kreacji bohatera utworu, to dwa aspekty zdezintegrowanej psychiki, dla której ratunkiem byłoby androgyniczne zjednoczenie. Przeniesienia konfliktu u sferę podświadomości mogłoby dodatkowo dowodzić osadzenie akcji na pograniczu realności, majaczenia i snu. Trudno bowiem odróżnić w utworze to, co dzieje się i wypowiadane jest naprawdę, od wytworów uyobraźni bohatera. Nieuykluczone nawet, że Agaj jest wyłącznie fantomem, sukubem, jak sugerował sam autor ${ }^{62}$.

Wątek kazirodczej relacji podjął Przybyszeuski róunież u powieści Dzieci nędzy. Pożądanie splata tu dwoje dzieci starego Krywły: Salomeę i Zbigniewa. Podobnie jak w De profundis, korzenie występnego związku sięgają dzieciństua, w którym to mała Sala przysięgła należeć tylko do brata. Nie dotrzymała słowa - wydziedziczona i wypędzona z rodzinnego dworu została niejako skazana na los prostytutki. Rodzeństwo spotykające się po latach na pogrzebie ojca zachuyca się nawzajem pięknem suych ciał, nie odczuwając bariery pokrewieństwa. Wspólnota krui, zamiast ograniczać, pozwala całkowicie się zjednoczyć, dopasouać, dopełnić.

To, co mu kazano nazyuać siostrą - to całkiem obca krew - a może dlatego mu bliższa, że... że... zastanowił się.

Aha! - pomyślał - że przez przymieszkę tej krui, która w moich żyłach płynie, całkowicie mnie dopełnia.

- rozmyśla Zbigniew. I:

${ }^{61}$ Zob. G. Matuszek, Incest..., s. 156.

${ }^{62}$ S. Przybyszeuski, Frontispice, [w:] idem, De profundis, Lwów 1929, s. 30. 
Zdumiony był tym dziunym uczuciem, bo przecież nigdy przedtem żadnej kobiety nie kochał. (Dn I, 62)

W przeciwieństwie do rodzeństwa z De profundis Sala i Zbigniew żyją jak kochankowie, choć czytelnik nie poznaje szczegółów ich intymnego pożycia. Stają się także wspólnikami w anarchistycznym dziele zabijania, prowadzącym w założeniu do wyplenienia „dzieci nędzy”. Interesujące, że pociąg do niszczenia również rozbudzili w sobie jeszcze w maleńkości - jako dzieci, chcąc się przekonać, $w$ jaki sposób kona zwierzę, powiesili na drzewie kota (upisać ich można na długą listę literackich dzieci, dla których „sielskie, anielskie" dzieciństwo skończyło się wraz z romantyzmem ${ }^{63}$ ).

Świadomość występku, jakim jest pożądanie ułasnej siostry, oraz przeczucie konsekwencji kazirodczej miłości asocjuje w De profundis ze scenami kopulującej ludzkości zmierzającej na Sąd Ostateczny. Agaj i jej brat są uczestnikami pochodu potępionych, tak samo pogrążonych w rozpaczy, obarczonych poczuciem winy, targanych sprzecznymi emocjami. Intymność przeplata się z „kosmiczną totalnością" ${ }^{64}$. Eschatologia z perwersją. Postępującemu zbliżeniu rodzeństwa odpowiada spotęgowana ekstaza korowodu grzeszników. Obejmowany i całowany przez siostrę bohater widzi tłum, ,jak wije się i kłębi, gdyby poplątany splot ramion, nóg, cielsk, co się gryzły, roztrącały [...], ale się od siebie oderwać nie mogły" (Dp 49). Gdy coraz mocniej przyciska jej ciało do swego, ludzkość w szaleństwie i upojeniu kieruje ku niebu bluźnierczą apostrofę: „Zbrodniarzu! Za co nas karzesz, zbrodniarzu?” (Dp 49), oskarżając Boga o to, że sam wpisał zło w plan istnienia. Wtedy następuje kulminacja pożądania rodzeństwa:

I $w$ niewypowiedzianej truodze rzucił się na nią - ciało jej pieniło się, zębami szarpała skórę na jego szyi, ugryzła się placami w jego piersi. Ale był silniejszym. Żelaznym oplotem pokonał jej szał: dziki orkan burzy złamał się u długim, rzężącym jęku.

Trzymał ją jeszcze u silnym uścisku. Ale już opadło jej ciało bezsilne, obezuładnione. W jego rękach drgało jej serce, gdyby gasnący płomień. Przekuitły ostatnie dreszcze, a nieskończenie ciche szczęście rozlało się w jego krui. (Dp 49)

Kontynuacja wizji następuje $\mathrm{w}$ finale utworu, gdy brat i siostra podejmują decyzję o połączeniu przez samobójstwo. Po raz kolejny pojawia się orgia, rozgrywana wokół unoszącej się nad światem kobiety u szkarłatnym płaszczu - antyMadonny, symbolu chuci i chaosu, perwersyjnych rozkoszy, transgresji.

${ }^{63}$ Miłość rodzeństwa u sztuce romantyzmu to porozumienie siostrzanych dusz, absolutna harmonia, uczucie uduchouione, niewinne i delikatne, niezbrukane przez naturę (zob. M. Piwińska, Miłość romantyczna, Kraków-Wrocław 1974).

${ }^{64}$ W. Gutouski, Nagie dusze..., s. 83. 
[...] wokół kobiety jął wirować strumień ludzkich par w strasznej konuulsyjnej kopulacji.

Słyszał zuierzęce rżenie, jęki bolesnej męki rozrodczej; widział twarze, upojone do szału ekstazą nieludzkich pragnień; widział ciała, przeżarte jadem, pokryte ustrętnymi urzodami; a w dole, gdzieś u dole ujrzał siebie samego, z kruawiącymi się, potrzaskanymi skroniami, z zaciśniętymi pięśćmi; wijącego się w przedśmiertnej agonii. (Dp 104)

Człouiek to narzędzie chuci w tym swoistym dies irae. Myśl o zbliżeniu fizycznym dekonstruuje porządek rzeczywistości, a wraz z nim psychikę podmiotu, prowokuje wizje końca świata, potwierdzając, że nawet przez Przybyszeuskiego - piewcę androgynicznej jedności - akt miłosny bywa postrzegany jako skaza na duchowości człowieka.

Orgia wywołana marzeniem o kobiecie (i oznaczająca utożsamienie kobiecości z degradującym popędem płciouym, dokonane wyraziście $\mathrm{w}$ zakończeniu De profundis) stała się ucześniej udziałem bohatera Androgyne, pisarz potraktował ją jednak marginalnie. W poemacie mężczyzna doświadcza zmysłouych doznań z kobiecymi postaciami wyłaniającymi się z ornamentu zdobiącego gzyms. A może właściwiej byłoby powiedzieć - z jedną po wielokroć powieloną postacią, która uyraża różne oblicza kobiecości: od niewinności i pieruszych nieświadomych pragnień, przez żądzę aż po rozpustę.

[...] widział ramiona wyciągnięte ku niemu, postacie schodziły, zlewały się, uyskakiwały ze ścian, rzucały się na niego; piekielny śmiech, chichot, płacz, jęk, przerażające krzyki i skouyczące uycie rozległo się po sali [...]; oplotły go lubieżne ciała; zawisły mu na szyi, stłaczały go w dół, porywały go u ramiona i podrzucały u górę; rozpasała się wokół straszna orgia nagich członków, potwornych splotów, dzikich podrywów, lecz w tej samej chwili rozwiał się majak szatański... (A 407)

Orgia nie dostarcza zmysłowej przyjemności, lecz obrazuje całkowitą dezintegrację jednostki w „kłębowisku odduchowionych ciał” ${ }^{5}$. Wyraża uwięzienie przez kobiecość, a szerzej - upiorną, ciemną stronę ludzkiej egzystencji. Problem ten, zaledwie zainicjowany w Androgyne, a następnie rozwinięty w De profundis, znalazł zwieńczenie w ostatniej powieści pisarza, gdzie łączy się z praktykami satanistycznymi. Orgią kończy się w Il regno doloroso sabat z udziałem Szatana. Tak widzi ją uczestniczący w zlocie po raz pierwszy De Lancre, prokurator działający oficjalnie w imieniu inkwizycji:

[...] kłębiły się nagie cielska sprzężone i zuarte $\mathrm{z}$ sobą $\mathrm{w}$ nierozerwalnych splotach, a uśród ryków, nieludzkich rzężeń, potępieńczych skowytów, wśród konuulsji opętańców jęło mu się ćmić u oczach, czuł jeszcze, że ktoś się na niego rzuca, ciska go o ziemię, utłacza się $u$ niego, ugryza boleśnie $u$ jego ciało - czuł, jak się przewala po ziemi, by się suego wampira pozbyć, zmaga się z nim w straszliwych rozkoszach, dusi, gniecie czyjeś ciało, łamie

${ }^{65}$ W. Gutouski, Bestiarium młodopolskiej erotyki, [w:] Literacka symbolika zwierzat, red. A. Martuszeuska, Gdańsk 1993, s. 126. 
u dzikiej uściekłości rozszalałych zmysłóu czyjeś członki - słyszy jakiś przeraźliuy śmiech, jakby całe piekło zarechotało [...]... (Ird 100-101)

Chaos, ból, animalizm i wampiryzm cechują grupową kopulację, w której - jak relacjonuje jedna z czarownic - dopuszczone są kontakty kazirodcze: „Żona oddaje się kochankowi, a mąż nie odczuwa żadnej zazdrości, bo rozkoszuje się swoją córką albo bliską krewną, matka uwodzi syna bez jakiegoś lęku lub wyrzutu, brat wydziera siostrze dziewictwo" (Ird 75). Dostępujący okultystycznej inicjacji siostrzeniec De Lancre'a - de la Croix - kuszony jest natomiast orgią z udziałem... płazów, symbolizujących szatańskie moce zła, oraz poruszających się niezależnie męskich i żeńskich narządów płciouych.

Orgia, będąca przekroczeniem normy, wiedzie ku zamętowi, nabiera charakteru apokaliptycznego. Pojawia się w chuilach rozluźnienia świadomości, gdy zostają odrzucone upływy kultury. Podobnie zresztą jak inne ekscentryczne pragnienia seksualne opisane przez Przybyszeuskiego - kazirodztwo i nekrofilia.

W zakresie nekrofilii literatura Młodej Polski nie dostarczyła tylu interesujących rozwiązań, co literatury zachodnioeuropejskie, głóunie francuska i angielska. Zamiast bezpośrednio ujaunianych i realizowanych pragnień spotykamy w niej - jak zauważył Wojciech Gutouski - poetycki szyfr, w którym ekwiwalentem tendencji nekrofilskich bywają m.in. obrazy egzotycznej flory ${ }^{66}$. Do uyjątków należy scena z Requiem aeternam, w której bohater, nie mogąc zjednoczyć w sobie kochanki, widzi ją w wyobraźni jako martwą. Kobiecy trup, leżący na katafalku w ponurym świetle gromnic, wabi mężczyznę lubieżnym spojrzeniem spod przymkniętych powiek i długim językiem, poruszającym się z sykiem jak u grzechotnika. Jest niczym Eua działająca z podszeptu szatana przyjmującego postać węża. Zmusza mężczyznę, by patrzył („,chciałem się pod ziemię skryć - ale oczu oderwać nie mogłem: musiałem patrzeć”; Rae 64), uwodzi jadowitym językiem i zatruwa - pożądaniem i gniciem. Zahipnotyzowany „powabem” martwej kochanki bohater zaczyna się bowiem rozkładać:

Połączenie pomiędzy trupem a mną było tak silne, że czułem, jak mi potężne galwaniczne strumienie wyżerały oczy, z krtani mej ruały się zwierzęce ryki, w strasznej męce, w potwornych porodach.

Usta moje ułożyły się u dziuny sposób, począłem parskać, wiedziałem, że naśladuję trupa.

To gazy pośmiertne, krzyknęło coś we mnie. (Rae 74)

Upojenie ma tu ambiwalentny odcień rozkoszy pomieszanej z bólem; pożądanie przeplata się z uczuciem ustrętu i strachu ${ }^{67}$. Trup jest stroną domi-

${ }^{66}$ Ibidem, s. 150.

${ }^{67} \mathrm{~W}$. Gutouski, Miłość śmierci i energia rozkładu. O młodopolskiej wyobraźni nekrofilskiej, „Pamiętnik Literacki” 1989, R. 80, z. 1, s. 48. Szkic ten został zamieszczony róunież u książce W. Gutouskiego Konstelacja Przybyszewskiego. 
nującą, aktywniejszą. Uzależnia partnera i prowokuje, by się zbliżył („I coraz guałtouniej ruało się we mnie pożądanie hieny [...]. Wiedziałem teraz, że muszę jej dotknąć"; Rae 77). Kuszony bohater posuwa się ureszcie do nekrosadyzmu, dowodząc swym zachowaniem, że nekrofilia jest swoistym rewersem wampiryzmu.

[...] całowałem jej twarz, kąsałem ją, ussałem się w jej ciało i nagle wgryzłem się wściekłymi zębami, z kruawą pianą na ustach, w jej pierś.

Szarpałem, gryzłem trupie ciało, straszliwy śmiech, w którym się każdy nerw w konwulsjach bólu szarpał i kurczył, rozpierał mi piersi - a naraz potoczyłem się i padłem na wznak.

Stało się coś straszliuego.

Umarła kobieta poustała $w$ trumnie $w$ upiornym majestacie i szerokim ruchem rąk uderzyła mnie z guałtouną, przerażającą siłą obyduiema pięściami w piersi.

Odleciałem daleko - bez przytomności. (Rae 78-79)

Trudno rozstrzygnąć, czy mężczyzna chce podjąć kontakt seksualny z trupem. Jeśli nawet tak - to nie dla przyjemności, a dla poniżenia martwej kobiety; okazania jej pogardy jako samicy skupionej na przedłużaniu gatunku. Zresztą sam fakt uykreowania przez psychikę bohatera owej sytuacji, będącej $w$ istocie symbolicznym uśmierceniem, jest śuiadectuem zakłócenia relacji z kobietami i rozczarowania kobiecością. Nawet u uyobraźni bohater nie jest jednak zdolny zapanować nad kochanką. W marzeniach także zuycięża nieubłagany determinizm. Scenę tę Paweł Dybel proponuje interpretować psychoanalitycznie. Badacz zwraca uwagę, że obiektem agresji staje się przede uszystkim pierś trupa, utożsamiona zapewne z piersią matki, a zatem zuiązana z zakłóceniami $\mathrm{w}$ trakcie karmienia $\mathrm{w}$ dzieciństwie ${ }^{68}$. Podobnie w latach trzydziestych XX w., analizując twórczość Poego, interpretowała nekrofilię uczennica Freuda, Maria Bonaparte. Uważała ona, że mężczyźni poszukują w martuych kobietach matki, która zniknęła, kiedy byli mali. Interesujące, że w myśl psychoanalizy nekrofil jest zainteresowany matką jako ofiarą ojcouskiej agresji, w dziecięcej wizji aktu seksualnego matka jawi się bowiem jako pasywna, a więc martwa. W niniejszych rozważaniach może to mieć znaczenie o tyle, że matka bohatera Requiem aeternam w zbliżeniach z mężem - prostym chłopem - świadomie wybierała bierność, chłód, niemal pozwalała się guałcić, usiłując $\mathrm{w}$ ten sposób ochronić swą „arystokratyczną" seksualność. Rezygnując z tych rozważań - interesujących, ale z konieczności pozostających poza granicami tekstu - można poprzestać na stwierdzeniu, że pierś jest po prostu symbolem kobiecości i atrybutem erotycznym budzącym pożądanie, a zatem sadystyczne kąsanie jej przez bohatera poematu to z jednej strony - realizacja popędu seksualnego, z drugiej

${ }^{68}$ P. Dybel, Urwane ścieżki. Przybyszewski - Freud - Lacan, Kraków 2000, s. 85-86. 
- zurócenie się przeciuko istocie kobiecości, halucynacyjna próba zniszczenia jej, skoro nie sposób jej zdominować.

O osobnikach, w których trupy wywołują „poczucie rozkosznej przyjemności”, pisał Krafft-Ebing w swoich Zboczeniach umysłowych. Jeden z przywołanych przez niego przypadków przypomina sytuację nakreśloną przez Przybyszeuskiego. Wiedeński psychiatra uspomina mianowicie o prałacie, który „od czasu do czasu przychodził w Paryżu do domu publicznego i zamawiał sobie prostytutkę, leżącą na śmiertelnym łożu (lub katafalku), ubieloną na wzór trupa. $\mathrm{O}$ oznaczonej godzinie przychodził do pokoju zamienionego w żałobną komnatę w ornacie, udawał, jakby odprawiał mszę żałobną, po czym rzucał się na dzieuczynę, która przez cały czas rolę umarłej odgrywać musiała" ${ }^{69}$. Bohater poematu Przybyszeuskiego także odprawia mszę żałobną, jednak nie nad martwą kochanką, a nad „martwą chucią", którą ów trup ucieleśnia. Notabene, seksualny aspekt śmierci musiał przybierać na sile, skoro w 1901 r. francuski lekarz Alexis Epaulard podawał w swoim dziele pt. Wampiryzm, nekrofilia, nekrosadyzm, nekrofagia, że Kościół zrezygnował ze zuyczaju wystawiania zmarłych z odkrytą twarzą, by nie przyczyniać się do wzrostu zachowań nekrofilskich ${ }^{70}$.

Scena z Requiem aeternam upisuje się w znacznie ucześniejsze zainteresowanie artystów wizerunkiem kobiety śpiącej bądź pozbawionej świadomości. Odnaleźć ją można na przepojonych atmosferą tajemniczości płótnach Johanna Heinricha Füssliego (np. Koszmar), a pod koniec XIX w. w malarstwie prerafaelitów, w takich obrazach jak The Garden Court (Dworski ogród) Edwarda Burne-Jonesa, Flaming June (Ptomienna June) Frederica Leightona czy Śmierć Ofelii Johna E. Millais'a. „Jej sen, nieprzytomność czy pozorna martwota budziły w patrzących fantazmaty o spełnieniu aktu seksualnego, któremu bezwolna kobieta byłaby powolna” - zauważa Maria Janion $^{71}$. Przedstawicielka płci pięknej, na ogół przedstawiana w literaturze fin de siècle'u jako istota niszcząca, działająca na zgubę mężczyzn, teraz nie ma żadnej mocy, może więc zostać ukarana bez konsekwencji. W nieco zmienionej formie rozuiązanie takie poutórzył Przybyszeuski w Synach ziemi, gdzie odurzoną opium Hankę guałci pożądający jej muzyk. Warto zauważyć, że figuracją śmierci nie jest już - jak w średniowieczu - szkielet, lecz piękna kobieta. Schemat danse macabre został odwrócony ${ }^{72}$. Martua kochanka z Requiem aeternam nie jest rozpadającym się ciałem, lecz daleko jej także do dziewicy-trupa; skoro bowiem nie ma rozkładu, nie trzeba go

\footnotetext{
${ }^{69}$ R. von Krafft-Ebing, Zboczenia umysłowe na tle zaburzeń ptciowych. Psychopatia sexualis, tłum. A. Fabian, Warszawa 1908, s. 99-100.

${ }^{70}$ Informacja za: M. Janion, Wampir. Biografia symboliczna, Gdańsk 2004, s. 74.

${ }^{71}$ Ibidem, s. 200.

${ }^{72}$ Zob. A. Lubaszeuska, Życie - Śmierci doskonałość. Młodopolska antropologia śmierci i literacki świat wartości, Kraków 1995, s. 53.
} 
maskować pozorami uroku. O potrzebie zbliżenia fizycznego nie decydują w poemacie urażenia estetyczne, ale determinizm, który Wojciech Gutowski nazywa „magnetyzmem materii”" ${ }^{73}$. Oba uspominane rozwiązania uykorzystane zostały natomiast u powieści Synowie ziemi, gdzie Przybyszeuski po raz kolejny uprowadził obraz kobiety w trumnie - nakreślił mianowicie halucynacyjno-oniryczną wizję, w której Czerkaski zostaje zaproszony przez rajfura-kozła na porażające widowisko: spektakl z udziałem kobiecego kościotrupa. Szkielet przypominający produkcje Ropsa jest „ohydny, nieuymownie ustrętny, z wiszącymi tu i owdzie ochłapami zgniłego ścierwa" (Sz I, 75), kokieteryjnie maskowanymi wachlarzem oraz szmatą imitującą suknię. Wychodzi z trumny i ku uciesze gawiedzi zaczyna tańczyć uulgarnego kankana. To trup-nierządnica obrazowo symbolizujący „taniec miłości i śmierci", jakim jest ludzkie życie. Majak kończy się omdleniem bohatera, ale $\mathrm{w}$ suoistej formie zostaje opisany kilka stron dalej, gdy w rozmowie z Szarskim Czerkaski uspomina iluzję, jakiej uległ podczas pobytu w San Francisco. Wydawało mu się wówczas, że w spotkanej w obcym mieście kobiecie rozpoznał ukochaną Hankę. Pozwolił jej zaprowadzić się do jakiegoś mieszkania, a po chwilach upojenia ujrzał na miejscu jej twarzy jedną wielką ranę. $\mathrm{Z}$ pasją naturalisty opisuje wygląd prostytutki:

Lupus erythematosus ${ }^{74}$ rozsiadł się na twarzy na kształt motyla. Nos przeżarty tworzył korpus, a z jednej i drugiej strony twarzy rozciągały się potworne skrzydła ze strupieszałej, ropiącej się skóry.

Otchłanne, zbolałe, zgnilizną śmierci ziejące oczy wlepiły się we mnie, a cała twarz, ta potworna, łuszcząca, ropiąca się tuarz drgała kurczouym uyciem:

- Hanka! Hanka! Ha, ha, ha - raz byłam kochana! Teraz mogę zmarnieć, splugawieć na śmietnisku podwórza! (Sz I, 90)

Pojawiający się tu motyw dziewicy-trupa, dający się lokować w obrębie nekrofilii, ma uyraźne znamiona mizoginicznych lęków. Skrywa on przekonanie, że kobiece piękno jest wyłącznie pozorem przykrywającym - przede wszystkim moralne i duchowe - zepsucie; wabikiem, dzięki któremu kobieta zmusza mężczyznę do realizacji popędu płciouego. Podobny sens ma w Mocnym człowieku omówiony u podrozdziale Kobieta wizerunek demonicznej Karskiej, jawiącej się nagle z twarzą „skostniałą, obumarłą, spospielałą”, z której „głębokich oczodołów zionął fosforyczny blask zgnilizny” (Mc I, 211).

Walka z opresyjną kulturą toczy się u Przybyszewskiego w głębokich warstwach „,ja”, w nieświadomości. Incest, nekrofilia czy orgia rozgrywają się

${ }^{73}$ W. Gutouski, Nagie dusze..., s. 149.

${ }^{74}$ Lupus erythematosus eystemicus, czyli toczeń rumieniowaty układowy. To choroba autoimmunologiczna, w której system odpornościouy uszkadza tkanki oraz komórki własnego organizmu. 
w stanach somnambulicznych, na granicy realności i halucynacji. Odsłaniają zatem prawdę o człowieczej psychice: rozbitej, niezdolnej do komunikacji ze światem zewnętrznym, nakierowanej na samą siebie, niemal autotelicznej. Wizje bohaterów, dowodzące przerażenia sferą seksu, są wynikiem z jednej strony nieuświadomionych pragnień, $\mathrm{z}$ drugiej - konieczności stłumienia libido; demaskują nieumiejętność budowania właściwych relacji, nie tylko erotycznych, z drugą osobą. Są ekspresją narcystycznej jaźni poszukującej identyfikacji ,z-innym-w-sobie” bądź „siebie-w-innym” ${ }^{75}$. Nie szukając sensacji, Przybyszeuski nie wystawia patologicznych relacji seksualnych pod osąd społeczny. Skoro zresztą rozgrywają się one u sferze wyobraźni, podlegać mogą co najuyżej weryfikacji psychologicznej, nie etycznej. Społeczna kontrola przybiera jedynie postać nieuśuiadomionego oporu przed realizacją wyszukanych potrzeb. Zderza się z nią obawa przed zniewoleniem potęgą seksu i własnym animalizmem. W ten sposób dramatyczne rozpięcie między naturą a kulturą prowadzi do izolacji i autodestrukcji ${ }^{76}$, z której wyzwoleniem jest śmierć.

\section{Erotyczne florarium}

Motywy florystyczne stanowią relewantną cechę literatury - przede uszystkim liryki - młodopolskiej ${ }^{77}$. Pojawiają się w analogii do ludzkiej duszy, rozwoju i więdnięcia życia, piękna i niestałości świata, miłości i śmierci. Niemałą rolę $w$ ich wzmożonym występowaniu odegrały - jak zbadał Ireneusz Sikora - tzw. „mowy kuiatów”, zbudowane najczęściej z pytań i odpowiedzi i zmierzające do jednoznaczności, a służące głównie flirtowi towarzyskiemu. W II połowie XIX stulecia były one tak popularne, że zaczęto uydawać antologie liryków opartych na symbolicznej interpretacji roślin. W konsekwencji wytuorzyła się moda na pisanie wierszy o kwiatach. Jednak symbolika kwiatowa ma za sobą tradycję wielowiekową. Narodziła się w krajach Dalekiego i Bliskiego Wschodu; do Europy dotarła w czasie wojen krzyżowych i pielgrzymek do ziemi świętej, a następnie podlegała narodowym i obyczajouym modyfikacjom ${ }^{78}$. W całej Europie

${ }^{75}$ Zob. G. Matuszek, Incest..., s. 154.

${ }^{76}$ Zob. G. Matuszek, Incest..., 156-157.

${ }^{77}$ Duże znaczenie przypisywała im także literatura europejska końca XIX w. Jeden z najciekauszych przykładów wykorzystania motywów kuiatouych dostrzega się w powieści J.K. Huysmansa $N a$ wspak, której bohater zastępuje bezpośrednie relacje miłosne kontaktem ze specjalnie sprowadzoną do mieszkania egzotyczną florą.

${ }^{78}$ I. Sikora, Symbolika kwiatów w poezji Młodej Polski, Szczecin 1987, s. 24-32. 
- także w Polsce - twórcze podejście do natury cechowało przede uszystkim romantyków.

Moderniści szczególnie chętnie odwoływali się do flory egzotycznej, orientalnej. Duże znaczenie miała tutaj fascynacja kulturą Wschodu, którą propagowali tacy filozofowie i twórcy, jak Artur Schopenhauer, Antoni Lange czy Jerzy Żułauski. Niezuykle rzadko uskazywano jednak na pierwotne funkcje religijne i symboliczne kwiatu; aurę osobliwości tworzyła już sama orientalna nazwa ${ }^{79}$. Przybyszeuski także nie sięgał do elementów kultury, z której zapożyczał roślinę. Różnorodne określenia kwiatów pojawiające się w jego twórczości służą raczej olśnieniu czytelnika, wprowadzeniu go w krąg egzotyki i niezuykłości, która jest także wyróżnikiem erotyki w ujęciu pisarza. A właśnie do utworów erotycznych metaforyka florystyczna wkroczyła najszerzej, przy czym - jak zauważa I. Sikora - podjęcie tematu grzesznej miłości zmysłowej owocowało ciekawszymi rozwiązaniami artystycznymi, ponieważ apoteoza miłości duchowej miała przeważnie charakter stereotypowy ${ }^{80}$.

Atmosferę osobliwego upojenia i wyszukanej rozkoszy budują kwiaty u Androgyne, najciekawszym pod uzględem ilości i różnorodności motywóu florystycznych dziele Przybyszeuskiego, a może i całej Młodej Polski. Maria Kuncewiczowa pisała o poemacie, że jest to „utwór w literaturze polskiej chyba najbardziej kuiecisty; początek brzmi jak hymn na cześć kwiatów”" Ireneusz Sikora nazwał go „katalogiem ulubionych kwiatów epoki”" Kuiaty, nieokreślone gatunkowo, ale zebrane w olbrzymi bukiet, inicjują akcję poematu: uzbudzają w bohaterze namiętność do nieznanej kobiety, która mu je ofiarowała. U źródeł tego pożądania leży podświadome przeczucie, że nieznajoma - całując, obejmując i przytulając kwiaty do serca - przelała na nie cząstkę siebie, $w$ rezultacie „kwiecie przesiąkło jej oddechem, przesyciło się lubieżnym ciepłem stęsknionego ciała; może jeszcze drży cichym, namiętnym szeptem jej pragnień..." (A 379).

Uczucie wiodące do kobiety poprzez bukiet sprawia, że bohater już w pierwszej ze swoich halucynacyjnych wizji dokonuje erotyzacji flory.

Widział ogromne róże, czarne, pąsowe, białe ${ }^{83}$, chwiejące się na wysokich prętach; słaniały się i gięły, upojone swoim własnym przepychem.

\footnotetext{
${ }^{79}$ Ibidem, s. 94.

${ }^{80}$ Ibidem, s. 39-40.

${ }^{81}$ M. Kunceuiczowa, Fantasia alla polacca, Warszawa 1982, s. 145.

${ }^{82}$ I. Sikora, „Asfodele - liany - tuberozy...”. O młodopolskiej egzotyce florystycznej, [w:] idem, Labędź i lira. Studia i szkice o literaturze Młodej Polski, Zielona Góra 2001, s. 27.

${ }^{83}$ Te trzy podstawowe kolory - biały, czerwony i czarny - mogą uskazywać na zagadnienie cykliczności oraz krańcowo odmienne stany emocjonalne; pieruszy byłby symbolem urodzin i niewinności, drugi - życia i miłości, ostatni - śmierci i pesymizmu. Notabene, barwy
} 
Widział tuberozy, jak białe guiazdy betlejemskie na wiotkich łodygach; widział olbrzymie drzewa białych i czerwonych azalii, obsypane miękkim puchem kuiecia, strojne i pyszne, jak dziewicze suknie balowe; widział orchidee $\mathrm{z}$ otwartymi usty, ziejące obezwładniającym czarem i lilie z rozwartymi kielichami, pijące diamentową rosę, i narcyzy, i bijony, i begonie - całe powodzie różnobarunego kuiecia, upajającej woni spłynęły do jego duszy.

Miękki zapach bzów majowych rozlał się cichą rozkoszą dalekich fletni pastuszych w nocach wiosennych - cichymi rękami obejmowały lilie jego serce; lubieżną rozkoszą udychały się w niego róże; świetlistym blaskiem okoliła go woń tuberozy - rozkosznym jadem usysał się $w$ niego odurzający zapach kwiecia akacji, co się deszczem i błyskawicą burzy letniej przepoiły [...]. (A 379-380)

Wymienione gatunki kuiatów nie mają tu jeszcze mocy symbolu. Pojawiają się w wyobraźni bohatera nie dla walorów znaczeniowych, ale ze uzględu na kształt, baruę i zapach, transpozycja urażeń (woń kuiatóu wywołuje wrażenia słuchowe i uzrokowe) potęguje zaś odczucie ich upajającego, hipnotyzującego działania ${ }^{84}$. Warto przy tym zauważyć, że mężczyznę odurza nie tylko flora egzotyczna, ale i rodzima ${ }^{85}$. Azalie, begonie, bez (kojarzący się młodopolskim poetom nieodmiennie z majem, czasem ich kuitnienia ${ }^{86}$ ) czy akacje swą upajającą, przesyconą erotyzmem wonią także pobudzają libido. Rośliny kuszą, działają na zmysły, oszałamiają jak kobiety. Są wśród nich delikatne ,jak oczy dziewcząt, nieśuiadomych suej płci", "gorące i lubieżne, jak ramiona rozpasanej hetery", a wreszcie „jadowite i krzyczące jak oczy zdeptanej żmii" (A 380). Wizja oparta na analogii świata kobiet i świata natury pogłębia dokonaną w umyśle mężczyzny identyfikację nieznajomej i otrzymanych kuiatów. Dzięki owemu utożsamieniu bohater zyskuje obraz ukochanej i może podjąć próbę jej odnalezienia. W sposób typowy dla osobowości neurotycznej, poszukuje jej najpierw w halucynacyjnym widzeniu wśród grona niewolnic. Sceneria jest przedziwna:

Wokół pięły się podzurotnikowe bluszcze; z ciemnych krzewów wyrastały złote kiście czarownego kwiecia; pięły się kwiaty, jakich jeszcze oko ludzkie nie widziało: kwiaty

te - przeciustawione sobie, ale i splatające się ze sobą - konstytuują istotne sensy $\mathrm{w}$ dramacie Wilde'a Salome.

${ }^{84}$ Zjawisko łączenia urażeń płynących z obcowania z kwiatami i sprawiające, że „otwiera się głąb duszy”, analizował Przybyszewski także na podstawie słynnego wiersza Wincentego Koraba-Brzozouskiego Powinowactwo cieni i kwiatów o zmierzchu, uydrukowanego w numerze 4. „Życia” z 1899 r. (S. Przybszeuski, $O$ „nową” sztukę, [w:] idem, Wybór pism, oprac. R. Taborski, Wrocław 1966, s. 153-155).

${ }^{85}$ Badając symbolike kwiatową, Ireneusz Sikora zauważył, że motywy wywodzące się z flory polskiej były liczniejsze niż motyuy egzotyczne, choć podczas lektury odnosi się urażenie, jakby to kwiaty niezuykłe zdominowały wyobraźnię poetycką modernistów. Wynikało to $\mathrm{z}$ celowego nagromadzenia oryginalnych nazw roślin, co sprawiało wrażenie przepychu, bądź z zastosowania dużej liczby czasouników, sugerujących dynamikę życia flory egzotycznej. I. Sikora, Symbolika kwiatów..., s. 94-95.

${ }^{86}$ Zob. ibidem, s. 67. 
z olbrzymimi kielichami, gdyby dzuonki mosiężne, kuiaty z liściem, połyskującym barwą roztopionej miedzi, kuiaty $\mathrm{w}$ kształt łona rozkuitających dziewic, [...] to znouu łodygi, jak lilie z zamarłych serc wyrastające, to znouu płomienne języki wykuitłe z bulu, co uyglądały jak potworne czaszki ludzkie - całe nieprzerwane gąszcze najdziwaczniejszych kwiatów. Wokół, jak daleko oko sięgało, olbrzymie ciemne lasy, porosłe paprociami, storczykami, ananasami - a uszystkie te latorośla pięły się po palmach, kokosach, drzewach chlebouych, wiły się wokół nich, splatały i wiązały drzewa, przechodziły z gałęzi jednego pnącza na drugi, a z tarasu królewskiego pałacu uyglądał las owity powojami i lianami, gdyby jedno olbrzymie, potwornie splecione wężowisko. (A 386-387)

Przybyszeuski nie tylko komponuje roślinność z różnych stref klimatycznych; idzie krok dalej - dla zwiększenia odczucia egzotyki kreuje florę nieistniejącą w przyrodzie. Jej bujność i chaotyczność ewokuje intensywne przeżycia wewnętrzne, i to o negatywnym zabarwieniu emocjonalnym, kulminującym w obrazie poskręcanych lian, kojarzonych - dość pouszechnie $\mathrm{w}$ epoce $-\mathrm{z}$ zabójczym oplotem węża ${ }^{87}$. Florarium pojawiające się w projekcji bohatera odnosi się do głębi jego psychiki targanej obsesyjnymi myślami i mrocznymi lękami, uruchomionymi przez nieoczekiwane uczucie.

Ukochaną mężczyzna utożsamia w całym utworze $\mathrm{z}$ wieloma bardzo różnorodnymi kwiatami. Najpieru z tuberozą, pojawiającą się w młodopolskiej poezji wyjątkowo często, zazwyczaj jako odpowiednik zmysłowej rozkoszy miłosnej, ale też znak przemijania i śmierci (np. w wierszu E. Słońskiego Tuberozy $I^{88}$ ). Przybyszewski nawiązał do formy kwiatu, transponując weń cechy kochanki:

Tak - ona gibka i wiotka jak łodyga tuberozy, a oczy jej czyste jak te dwie białe gwiazdy na słaniającej się sennie tuberozie. (A 384)

Kształty kobiecego ciała nasunęły też skojarzenie z chwiejną, ale przy tym sprężystą i gibką trzciną:

Twarz jej tak dziunie jasna i przeźrocza, oczy jej tak wielkie i przestraszone, kształty jej tak wiotkie, jak młoda trzcina na wiosnę. (A 401)

Oba zestawienia (notabene, uwypuklające moc spojrzenia) sugerują subtelność, niewinność, uległość i delikatność kobiety, odnoszą się jednak tylko do jednej z wielu niewieścich twarzy. Wystarczy sobie uprzytomnić, że dwie splecione trzciny były atrybutem Isztar, babilońsko-syryjskiej bogini miłości i płodności ${ }^{89}$, a także zurócić uwagę na opisy poruszeń roślin w powyższych

\footnotetext{
${ }^{87}$ Por. I. Sikora, „Asfodele - liany - tuberozy...”, s. 28.

${ }^{88}$ E. Słoński, Wśród szronu, Warszawa 1910, s. 33.

${ }^{89}$ Zob. W. Kopaliński, Trzcina [hasło], [w:] idem, Stownik symboli, Warszawa 1991, s. 432.
} 
cytatach - „słaniają się” jak w erotycznym upojeniu. Za stanem hipnotycznego oszołomienia kryje się nie pokora, lecz pożądanie. Ta zależność, tu zaledwie zasugerowana, została wyrażona expressis verbis $\mathrm{w}$ jednym $\mathrm{z}$ kolejnych obrazów poematu, kiedy to bohater widzi ukochaną „żądną i spragnioną, jak pęk kuiecia makowego, słaniającą się w odurzeniach oddania się" (A 406). Ważna jest tu nie tyle purpura maku (w poezji młodopolskiej kwitnące maki kojarzono często z ustami ukochanej i namiętnym pocałunkiem ${ }^{90}$ ), ile ułaściwości jego ziarenek, mających działanie narkotyczne, odurzające i upajające. U Owidiusza mak występuje na przykład jako afrodyzjak, który wypiła Wenera na ślubie z Wulkanem ${ }^{91}$. Wprowadzona przez Przybyszeuskiego analogia u sposób oczywisty oznacza pewien rodzaj utraty świadomości, spowodowany pożądaniem.

Akcję Androgyne osnuł pisarz przede uszystkim wokół narcyzów, kuiatów należących do najbardziej zadomowionych w kulturze i literaturze wszystkich krajów, ale jako symbol przeżyć miłosnych funkcjonujących w Młodej Polsce rzadko i zazwyczaj w związku z uczuciem uduchowionym ${ }^{92}$. Autor poematu w oryginalny sposób upersonifikował narcyzy, nadając im cechy kobiece. Narrator-bohater utworu traktuje je, jakby była w nich zaklęta nieznana uielbicielka, od której otrzymał bukiet. Przychodzą mu one na myśl za każdym razem, gdy próba zdobycia obiektu pożądania kończy się fiaskiem.

Spojrzał na narcyzy: oczy ich nieruchomo w niego wlepione z jakimś wielkim smutkiem, z jakąś nieprzebraną tęsknotą. Czuł, że te milczące oczy żyją, że udrażają się wielkim pytaniem w jego oczy, szukają odpowiedzi, pragną, by do nich przemówił, by je do serca przytulił i pieścił. (A 403)

Narcyzy kompensują nieobecność upragnionej kobiety; korespondują zatem z nastrojem smutku i tęsknoty. Są jednocześnie kwiatami namiętności, ich słodka, odurzająca woń oszałamia (według wierzeń starożytnych Greków mogła nawet przyprawiać o pomieszanie zmysłów $\left.{ }^{93}\right)$. Suoiste utożsamienie ich z nieznajomą sprawia, że reagują one - w odczuciu bohatera - jak kobieta. I niczym kobieta-wampir kąsają go, domagając się krwi.

Całouał długo milczące oczy narcyzów; zdawało mu się, że wielkie, ciężkie powieki zamykają się $\mathrm{w}$ drżącym pragnieniu, rozkoszą obezuładniona głowa w tył się przechyla, rozpalone usta się otwierają, szukają jego ust, wpijają się nagle z guałtowną żądzą i ssą krew z jego warg. (A 403)

\footnotetext{
${ }^{90}$ Zob. I. Sikora, Symbolika kwiatów..., s. 65.

${ }^{91}$ W. Kopaliński, Mak [hasło], [w:] idem, op. cit., s. 217.

${ }^{92}$ Zob. I. Sikora, Symbolika kwiatów..., s. 79, 82.

${ }^{93}$ W. Kopaliński, Narcyz [hasło], [w:] idem, op. cit., s. 250.
} 
Po raz kolejny biel, barwa niewinności, ukrywa u Przybyszewskiego guałtowną namiętność. Mimo że narcyzy dotyczą u poemacie kochanki, ich symboliczne znaczenie - egoizm, autoerotyzm, przesadne umiłowanie samego siebie - doskonale odpowiada egotycznej osobowości bohatera.

Ażeby pogłębić urażenie egzotyczności, autor uprowadził do poematu Androgyne lotos, będący $\mathrm{w}$ religiach indyjskich jednym $\mathrm{z}$ najbardziej uniwersalnych symboli ${ }^{94}$. To jedna z nielicznych roślin, która znalazła miejsce w młodopolskiej sztuce razem ze swoim bogatym kontekstem kulturowym ${ }^{95}$. Przybyszeuski nawiązał tylko do znaczenia odnoszącego się do żeńskich narządów płciouych oraz do aktu seksualnego ${ }^{96}$, a jednocześnie w obrazoburczy sposób połączył je z elementami religii chrześcijańskiej. Otóż bohater utworu w swoich halucynacjach duukrotnie widzi ukochaną z kwiatem lotosu zasłaniającym intymne miejsce ${ }^{97}$ - najpieru wśród niewolnic w pałacu, potem zawieszoną na krzyżu:

Ujrzał ją w krzyż rozpiętą na ścianie u całym przepychu jej piękności; ramiona jej owiły miast naramienników złote węże, złote węże oplatały kostki nóg, a biodra opasała złota przepaska, zamknięta na łonie kuieciem lotosu, uysadzonym drogim kamieniem. (A 407)

Odbywa się tu ciekawa gra znaczeń: kwiat lotosu jest świadectuem czystości, niejako broni dostępu do sfer intymnych kobiety (lotos bywał w sztuce chrześcijańskiej atrybutem Maryi Panny), a zarazem prowokacyjnie zachęca do udarcia się do nich. Doskonale uspółbrzmi znaczeniowo z wężouymi bransoletami na ramionach i nogach kochanki - jest narzędziem kuszenia jak one.

Odchodząc, ukochana zostawia bohaterowi na białym papierze czerwone goździki (w różnych rytuałach inicjacyjnych biel i czerwień pojawiają się jako symbole pieruiastka męskiego - nasienie oraz żeńskiego - miesiączka), kuiaty, którym od XV w. przypisywano funkcję symbolu zaręczyn, ale - co ważniejsze - których nazwa jest zdrobnieniem słowa „gwóźdź”. W ich postaci dostrzeżono kształt gwoździ, służących przybijaniu Jezusa do krzyża, stąd też nadano im znaczenie symbolu śmierci krzyżowej ${ }^{98}$. Do takiej pierwotnej interpretacji odwołuje się w suym pożegnalnym liście ofiarodawczyni kwiatów.

Czytał:

Idę już, idę, daleko - och, daleko; idę na mękę i na krzyż, na który mnie sam wbiłeś. (A 429)

\footnotetext{
${ }^{94}$ Zob. M. Lurker, op. cit., s. 227.

${ }^{95}$ Za najbardziej interesujący artystycznie i filozoficznie utwór epoki poświęcony temu kwiatowi uznawany jest poemat Lotos Jerzego Żułauskiego.

${ }^{96}$ Zob. W. Kopaliński, Lotos [hasło], [w:] idem, op. cit., s. 206.

${ }^{97} \mathrm{~W}$ indyjskich Brahmanach kuiat lotosu jest obrazem łona matki, z którego wydostaje się dziecko.

${ }_{98}$ Zob. M. Lurker, op. cit., s. 240-241.
} 
Miłość jest zatem drogą krzyżową, drogą ku śmierci, i to drogą krwawą, o czym śuiadczy barwa kwiatów.

W innych utworach Przybyszewskiego flora nie odgrywa już tak znaczącej roli. Pojedyncze kwiaty pojawiają się z rzadka dla zbudowania nastroju bądź ze względu na swoją funkcję symboliczną. Zdecydowanie najczęściej przywoływana jest róża, która spośród tematów florystycznych zyskała w Młodej Polsce najuiększą popularność. Zadecydowała o tym rola, jaką róża pełniła w poezji i obyczaju różnych kręgów kulturowych. Z pączka róży miała poustać indyjska bogini szczęścia i piękna - Lakszmi; u Persji wierzono, że czerwony kolor róży pochodzi z krui słowika zakochanego u niej i zranionego o jej cierń; Anakreont głosił, że zrodziła się ze śnieżnej piany pokrywającej ciało Afrodyty, a zabarwiła na purpurowo, gdy bogini skaleczyła się, biegnąc do Adonisa; chrześcijaństuo odnosi symbolikę róży do kultu Matki Boskiej ${ }^{99}$. W różnorodnych „mowach kuiatów” róże oznaczały niezmienną miłość ${ }^{100}$, co znalazło wyraz w przystrajaniu nimi nowo zaślubionych i ich małżeńskiego łoża ${ }^{101}$. Młoda Polska u dużej mierze przejęła utrualone od wieków znaczenie kwiatu, wzbogacając je jednak o elementy nowe, oryginalne.

U Przybyszeuskiego róże nie występują nigdy jako kwiaty szczęścia, nie odnoszą się do radości towarzyszącej uczuciu miłosnemu (bo taka radość nie istnieje). Bywają raczej synonimem namiętności i pożądania, nasycają obcującego z nimi „lubieżną rozkoszą” (A 379). Jeśli w dramacie Gody życia Janota ofiarowuje Hance róże, to nie po to, by wyznać jej miłość, lecz by tym gestem podstępnie zyskać jej zaufanie, zapewnić o rzekomej trosce, a następnie wykorzystać seksualnie.

Białe róże, znacznie mniej popularne od szkarłatnych, odnosiły się w Młodej Polsce do miłości duchowej, wzniosłej. W Homo sapiens nosi je we włosach Maryt, dziewczyna niewinna, czysta, pobożna. Poprzez omówiony ucześniej mechanizm asocjacji pobudzają one libido Falka i, paradoksalnie, prowokują go do uwiedzenia „świętej”. „Toż to białe róże zrobiły, że ja pragnę?" - zastanawia się bohater (Hs II, 37). Kuiat nie łączy się więc tutaj z platonicznym charakterem erotycznych marzeń.

W symbolice religijnej, z jaką mają związek białe róże, Najświętsza Maria Panna nazywana bywa Różą Mistyczną (takie wezwanie występuje w Litanii Loretańskiej). Do tego określenia w prowokacyjny sposób nawiązał Przybyszeuski - w poemacie Androgyne uyimaginowana kochanka tak zuraca się do bohatera-narratora:

${ }^{99}$ Ibidem, s. 43.

${ }^{100}$ Wręczenie komuś róży oznacza - kolejno według Mowy kwiatów Józefa Dunin-Borkowskiego z 1856 r. oraz flirtu kwiatowego zamieszczonego w „Bluszczu” w 1897 r. - „Kocham ciebie”, „Kocham”.

${ }^{101}$ Zob. W. Kopaliński, Róża [hasło], [w:] idem, op. cit., s. 361. 
[...] drżałam, chuytałam Cię; usta me Tuych szukały; rozchylała się dla Ciebie mistyczna róża mego ciała [...]... (A 449)

W pouyższym fragmencie nastąpiła kontaminacja określeń Róża Mistyczna oraz Mistyczne Ciało Chrystusa (które oznacza przelaną krew oraz rany Syna Bożego), odnoszących się do sfer boskich, duchowych. Przybyszewski połączył sacrum z profanum - wysublimowana metafora, nadająca uczuciu rangę przeżycia religijnego, móui przecież o cielesności, o kontakcie seksualnym, a rozchylający się kielich kwiatu jest częstą w literaturze metonimią żeńskich narządów płciouych.

W podobny sposób pisarz uykorzystał symbolikę lilii - kuiatu maryjnego, reprezentującego nieskalaną dzieuiczość, czystość, bezgrzeszność. Jego uzniosłe znaczenie odniósł do cielesności, uwznioślając przez metaforę kobiece piersi:

Nie uidział jej twarzy, bo zasłoniła ją ramionami, widział tylko jej postać, widział gibkie a wiotkie kształty tuberozy z duiema białymi guiazdami, które zasłoniła liliami serca.

[...] widział, jak się słaniała, jak zdała się stać w ogniu ze ustydu i lęku; ułosy jej spłynęły ciemną falą po białych liliach [...]. (A 389-390)

Przybyszewski nie zrezygnował z aury niewinności - uyimaginowana kochanka słania się „w ogniu ze ustydu i lęku”, a jej piersi-lilie są białe (waloryzacja dodatnia). Niemniej zuiązek kuiatu z namiętnością jest bardzo uyraźny.

W obręb tematyki miłosnej Przybyszewski ułączył również symbol nieistniejącej w przyrodzie róży czarnej, jednoznacznie pesymistyczny pod względem emocjonalnym. Bohaterowi Androgyne kochanka jawi się „smutna i rozbolała jak kuiat czarnej róży u duszącym upale sierpniowej południcy" (A 406). Kolor kwiatu nieuchronnie nasuwa skojarzenia ze śmiercią. Dlatego czarna róża pojawia się we włosach kochanki króla z poematu Nad morzem, która - by odwrócić zemstę zdradzonego słońca - złożyła w ofierze sue życie. Władca opowiada:

A w Tuych jasnych włosach chwieje się czarna róża. Smutkiem Twego czoła trawiona, chuieje się u bladym jaśnieniu Tuych ułosów. (Nm 294)

W podobnym znaczeniu - dążenia ku śmierci - występuje u tekście określenie „czarne kwiecie”. Król ma wrażenie, że ukochana niewolnica wiedzie go ku zagładzie:

Ty, która mi noce burz na dni pogody przemieniasz, w głębiach snu jawy mi gasisz, w bezbrzeżne dale odsuwasz pobliża - która mi w sercu błędne ognie rozpalasz i czarne kuiecie ku życiu niecisz - (Nm 285) 
Niemniej róża występuje u Nad morzem jako synonim delikatności uczucia. Poświadczają to słowa króla, który uspomina, że pierusze spotkanie z ukochaną odczuł, ,jak gdyby listki z róży opadały, gdy ją wiatr muśnie” (Nm 291).

Innym florystycznym odpowiednikiem delikatności i wrażliwości była mimoza. W dramacie Śnieg Ewa uspokaja zaniepokojoną pojawieniem się rywalki Bronkę, porównując ją do kwiatu, który zuija listki w czasie zagrożenia, przy dotknięciu. „Och, ty mimozo moja, jakaś ty nerwowa i przeczulona..." - zauważa (Ś 80).

Spośród kwiatów wymienionych w Androgyne w kontekście wyrafinowanej rozkoszy, a nawet perwersji, Przybyszeuski przypomniał u późniejszej twórczości tylko orchidee „Z otwartymi usty, ziejące obezwładniającym czarem” (A 379), zdolne „stępione zmysły podniecić” (Mśc 34).

W podrozdziale pośuięconym mężczyźnie powiedziano, że kobieta często bywa kojarzona z ziemią rodzinną bohatera. W takim kontekście przywoływane są kasztanowce, drzewa liczne w Polsce, typowe dla jej klimatu, oraz dziewanny, zuiązane ze słowiańskimi wierzeniami magicznymi, przede uszystkim zaś z obrzędem świętojańskim (Androgyne, $Z$ cyklu Wigilii).

Autor Synagogi szatana wprowadzał motywy florystyczne w sposób wyszukany - poprzez poróunanie, symbol, alegorię. Sentymentalnych scen, w których mężczyzna obdarza kwiatami kobietę, unikał. Czytelnik znajdzie co prauda w Wyzwoleniu, drugiej części Mocnego człowieka, fragment, w którym książę Poraj zwozi do mieszkania Karskiej olbrzymie naręcza kwiatów, scena ta ma jednak głębszy sens: antycypuje wydarzenia i charakteryzuje bohaterów. Jej akcja toczy się pieruszego dnia świąt Bożego Narodzenia, Poraj zadaje więc sobie niemało trudu, by zmusić ogrodnika do otwarcia oranżerii. Wybiera rośliny najkosztowniejsze - róże, lilie, orchidee, biały bez, hiacynty i mimozy - i uypełnia nimi cały automobil. Dopiero później - podczas wnoszenia kwiatów do pokoju - okazuje się, że są wśród nich i czarne „gwoździki”. Ich symboliczne znaczenie zapowiada śmierć Karskiej z ręki księcia. Tym bardziej znacząca jest reakcja bohaterki, która na widok tych kuiatów „klasnęła w dłonie” (Mc II, 129).

Poraj wykazuje niezwykły talent florystyczny. Nie dość, że uybiera kwiaty rzadkie, delikatne, uymagające starannej hodowli i pielęgnacji, to jeszcze potrafi komponować je $\mathrm{w}$ przepiękne oryginalne bukiety.

Poraj z uielkim smakiem dobierał kolory i rodzaje kuiatów, układał je w misterne wachlarze, to znowu w rozwichrzone krzaki i naręcza, i podawał Adzie gotowe bukiety. (Mc II, 138)

Umiejętność obchodzenia się z kwiatami odsłania ogromną wrażliwość i subtelność księcia. Dostrzega to Karska, która u zamyśleniu stwierdza: „Pan sam cieplarnianym kwiatem” (Mc II, 139), mając na myśli różnice 
społeczne, obyczajowe i światopoglądowe, dzielące Poraja od takich ludzi, jak ona i Bielecki.

Adam Drzazga, prosty ekonom, by sprawić przyjemność ukochanej Jaduidze, buduje dla niej uspaniały ogród. Sprowadza kosztowne rośliny z całej Europy - olbrzymie rododendrony, drzewka azalii obsypane kwieciem, rzadkie odmiany tulipanów, hiacynty i lilie. Ozdobą klombów, a jednocześnie wyrazem głębokiej namiętności Drzazgi do bratowej, stają się przede uszystkim - zgodnie ze swoim symbolicznym znaczeniem - róże przywiezione do dworu w Dzierżanach z Drezna i Erfurtu. Uczucie, którego są nośnikiem, kieruje przeciuko nim nienawiść Zosi. Dojrzewająca Krywłówna, zazdrosna, że te róże „Adam dla Jadwigi z dalekich stron sprowadził i sam nad ich wyhodowaniem czuwał" (Dn II, 97-98), zrywa je po kryjomu i wrzuca przez okno do pokoju Drzazgi. Odgrywa się na rywalce, a zarazem komunikuje przyrodniemu bratu - jak chcą XIX-wieczne mowy kuiatów - „kocham”.

Ale ogród jest w powieściowej dylogii czymś więcej niż polem rywalizacji o uczucie. To - jak u Piśmie Śuiętym - namiastka raju, szczęścia. Pozuala Jadwidze oderwać się od ciężkiej, przesyconej nieszczęściem atmosfery majątku Krywłów i stworzyć sobie miejsce alternatywne. Dlatego tak bolesne jest dla bohaterki jego zniszczenie przez Zosię. Chociaż jako przestrzeń natury uporządkowanej, wyselekcjonowanej, ogród symbolizuje świadomośććn ${ }^{102}$, to chęć posiadania go - wynikająca z potrzeby upiększenia życia, dodania mu uroku - płynie z głębokich pokładów psychiki. Przecież Jaduiga zaczyna myśleć o posiadaniu kwiatów podczas spaceru „w całkiem zdziczałej i opustoszałej części parku" (Dn II, 81), wśród przyrody swobodnej, oznaczającej podświadomość.

Do modnej u modernizmie roli przyrody jako pejzażu weunętrznego, odpowiednika psychicznego mare tenebrarum, odwołał się Przybyszeuski także w powieści Homo sapiens. Drzewa (według Freuda jeden z typowych symboli fallicznych), którymi zachwyca się Falk, odkrywający w sobie namiętność do Izy, obrazują mianowicie męską potencję, chaos libido przekładający się na chaos bytu.

Wszedł w szpaler drzew. Był zdumiony. Takich uspaniałych drzew nigdy jeszcze nie widział. Przypatrywał się im uważnie. Widział potężne konary niby sękate szprychy tkwiące w osi koła - dziwacznie rozgałęzione, powiązane i poplątane $\mathrm{w}$ sieci... (Hs I, 44)

Charakterystyczny kształt konarów, przypominających szprychy w kole, zapowiada los bohatera (determinizm) - niejednoznaczny, poplątany,

${ }^{102}$ Zob. W. Kopaliński, Ogród [ hasło], [w:] idem, op. cit., s. 270-271; J. E. Cirlot, Ogród [hasło], [w:] idem, Stownik symboli, przeł. I. Kania, Kraków 2006, s. 283. 
grożący upadkiem. Warto zurócić uwagę, że w obrazie tym jedyny raz u Przybyszeuskiego roślinność została ściśle zidentyfikowana z postacią męską. Nawet jeśli flora pojawia się u męskiej uyobraźni, to jako element charakteryzujący kobietę bądź uczucie do niej. Metafory kwiatowe odnoszą się do kobiecej osobowości bądź figury (róża, mak, narcyz, tuberoza, mimoza), do elementów kobiecego ciała (lilia, lotos) oraz do sytuacji erotycznej, silnie nacechowanej namiętnością (róża, azalia, bez, goździk, orchidea). Wyłączenie mężczyzn poza obręb symboliki florystycznej można wiązać z mizoginistycznym odcinaniem się przez nich od świata natury (którego wyrazicielką była płeć piękna) na rzecz świata kultury. Podobnie rzecz ma się z wykorzystaniem symboliki animalistycznej, o czym za chwilę.

\section{Erotyczne bestiarium}

Młodopolska literatura chętnie sięgała po obrazy i maski ze świata fauny, by mówić o ludzkiej kondycji - najczęściej demaskować animalistyczny, a więc degradujący charakter kierujących człowiekiem namiętności i popędów ${ }^{103}$. Źródła tego zabiegu leżały oczywiście u upodobaniu modernistów do języka symboli, pozwalających „wyrazić niewyrażalne”, ale także w naturalistycznej, redukcjonistycznej interpretacji darwinowskiej koncepcji ewolucjonizmu, zgodnie z którą jednostki ludzkie podporządkowane są tym samym prawom co przyroda. „Zwierzęcość” nacechowana była w drugiej połowie XIX stulecia negatywnie, „oznaczała regres, ontologiczny upadek człowieka" ${ }^{104}$, co uyrażają między innymi słowa Nietzschego, uważającego animalizm za mało chlubny rys uspółczesnych kondycji:

Przebyliście droge od robaka do człowieka i wiele jest $\mathrm{w}$ was jeszcze $\mathrm{z}$ robaka. Byliście niegdyś małpami i dziś jest jeszcze człowiek bardziej małpą, niźli jakakolwiek małpa ${ }^{105}$.

Filozof nazywa człowieka „najlepszym drapieżnikiem” i „najokrutniejszym zuierzęciem" ${ }^{106}$, widząc $\mathrm{w}$ jego zachowaniu silne dziedzictwo animalnego instynktu, który uczy, jak przetruać i zapewnić sobie zdobycz (zdaniem Nietzschego, najlepszym rozwiązaniem jest pogodzenie się ze swoimi pierwotnymi motywacjami oraz uwolnienie pędu życia od ograniczeń kultury).

\footnotetext{
${ }^{103}$ Choć np. figurę łabędzia odnoszono do zagadnień idealizmu i duchowości.

${ }^{104}$ Gutouski, Mit - Eros - Sacrum. Sytuacje młodopolskie, Bydgoszcz 1999, s. 54.

${ }^{105}$ F. Nietzsche, Tako rzecze Zaratustra, s. 7.

${ }^{106}$ Ibidem, s. 261, 272.
} 
Echa tych teorii pobrzmiewają w pieruszej powieści Przybyszewskiego, wielokrotnie akcentującej zuierzęcość głównego bohatera. Mikita zachęca Falka do odwiedzenia Izy, bo - jak tłumaczy - obiecał „przyprowadzić jej »in natura« to dziwne zwierzę, zwane Falkiem" (Hs I, 16). Falk podejmuje grę i podczas spotkania pyta narzeczoną przyjaciela: „[...] oczekiwała pani zapeune jakieś zamorskie zuierzę?" (Hs I, 19). Pierusze intymne chuile Falk i Iza przeżywają zaś w przejeżdżającej przez „zwierzyniec” dorożce.

Przybyszeuskiemu świat ludzkich namiętności do tego stopnia przypominał świat zachowań zuierzęcych, że twórca kilkakrotnie posłużył się rozbudowaną parabolą ilustrującą odpowiednie analogie. W poemacie $Z$ cyklu Wigilii opisał okrutną, krwawą zemstę bociana na samicy, która przyjęła do gniazda nowego osobnika, a więc - w języku ludzkim - zdradziła. Dla bohatera utworu rozwiązanie podpatrzone $u$ natury jest przykładem i pokusą, by równie srogo ukarać ukochaną, która wybrała innego. Podobnie u powieści Homo sapiens Falk analizuje zaobserwowaną niegdyś walkę łosi o prawo do samicy. Jego myśli krążą w tym momencie wokół miłosnego trójkąta: on - Iza - Mikita.

Widział, jak zuierzęta uderzały na siebie olbrzymimi rosochami, jak cofały się, aby się rzucić ku sobie z strasznym rozpędem. Potem widział, jak splątały się rosochami, jak w dzikich skokach chciały je rozerwać i obracały się wkoło... [...] jeden łoś wysuobodził się i wbił drugiemu rosochy u pierś. Przebił go. Coraz głębiej wwiercał rogi, wbijał, że krew strumieniem tryskała, rozdzierał mięso i wnętrzności z dziką wściekłością. (Hs I, 145-146)

Parabole owe akcentują tragiczny, niszczący aspekt erotyzmu, nadają mu charakter siły fatalnej, ureszcie sprowadzają życie płciowe człowieka do popędowego determinizmu. Dowodzą, że ludzkie namiętności powiązane są ze świadomymi uyborami, lecz poddane instynktownym, animalnym reakcjom. Przekonanie to znalazło jeszcze dobitniejszy wyraz w kojarzeniu ze zuierzęcością obrazów pożądania i aktu płciowego, na jakie natknie się czytelnik podczas lektury Homo sapiens. Narrator powieści móui mianowicie o Mikicie, pałającym namiętnością do Izy: „Zuierzęca, ślepa, wściekła żądza ouładnęła nim" (Hs I, 108), czym jednoznacznie charakteryzuje pragnienie zmysłowe jako podświadome, bezrefleksyjne, odruchowe.

Wyraźnie negatywny wydźwięk mają teriomorficzne maski kobiece, wyrażają one bowiem obawę przed siłą chuci i seksu. Spośród nich Przybyszeuski najczęściej przywoływał popularne wśród modernistów figury tygrysicy i pantery, których symboliczne znaczenie wywodzi się jeszcze z kultów starożytnych. Dla przykładu: w Egipcie kult skupiał się wokół bogini-lwicy Sachmet i kociej bogini Bastet, w Grecji koty stanowiły atrybut Dionizosa, boga wina, płodności i orgii, natomiast $w$ mitach nordyckich ciągną rydwan Frei, bogini miłości i płodności, ale róunocześnie wojen 
i śmierci ${ }^{107}$. U autora Śniegu są nośnikami zbliżonych znaczeń - elegancji, energii, zagrożenia, jakie stanowią dla mężczyzny - nigdy jednak nie bywały traktowane przez pisarza synonimicznie i dowolnie uymieniane. Tygrysica oznacza niebezpieczną moc niekontrolowanych popędów, ciemną stronę psychiki ludzkiej, wyrażającą się w nienawiści i guałtowności, symbolizuje przyczajoną zmysłowośćc ${ }^{108}$, nieustraszoność, dzikie okrucieństwo, gniew. Te cechy odpowiadają osobowości Karskiej, dlatego Bielecki w rozmowie z kochanką zastanawia się: „Z czymże by cię poróunać można? [...] z - tygrysicą? gdy jesteś zła, to oczy twoje stają się zielone, jak oczy tygrysicy...” (Mc II, 110). To samo porównanie służy wyeksponowaniu drapieżności Agaj, o której narrator De profundis mówi:

[...] twarz jej stwardniała, patrzyła błędnie przed siebie skostniałym uzrokiem i znowu wybuchła nienawiść. Wyprężyła się jak tygrysica. (Dp 75)

Chciałoby się dopowiedzieć: wyprężyła się do skoku, do ataku. W poemacie Nad morzem figura tygrysicy odsłania uręcz krwiożerczość i bestialstwo Salome, pojawiającej się w uyobraźni bohatera-narratora:

Przede mną na złotej misie leżały oczy, dziko rozwarte - oczy, gdyby dwie wściekłe pięście ziejące zemstą, oczy Jana Chrzciciela. Z rozkoszą tygrysicy pastuiła się nad nimi córka króleuska [...]. (Nm 323)

Pantera z kolei pojawia się w twórczości Przybyszewskiego dla wyeksponowania kobiecego piękna ${ }^{109} \mathrm{i}$ gracji kobiecych ruchów - zuinnych, lecz niebezpiecznych. Jak w słowach brata zachwycającego się Agaj:

- Jakaś ty smukła i wiotka... Jak pantera - jak lśniąca, smagła pantera... A każdy twój ruch, każde twe zgięcie... (Dp 94)

Już Arystoteles zaliczył panterę do zwierząt najbardziej kobiecokształtnych; jej usposobienie określił natomiast jako nikczemne, podstępne i fałszywe. Symbolem rozwiązłości i pożądliwości cielesnej stała się ona szczególnie od czasów Dantego, który przedstawił ją u Boskiej Komedii jako zwierzę rozpusty.

${ }^{107}$ N. J. Saunders, Dusze zwierząt, tłum. Z. Daleuski, Warszawa 1996, s. 70.

${ }^{108}$ Przyczajoną kobiecą zmysłowość $\mathrm{w}$ postaci tygrysa u wejścia do wąwozu przedstawia sztych Zmystowość z cyklu Ewa i przyszłość, autorstua cenionego przez Przybyszeuskiego Maksa Klingera.

${ }^{109}$ Piękno charakteryzujące panterę podkreśla już u pieruszym poświęconym jej zdaniu jeden $\mathrm{z}$ najstarszych średniowiecznych bestiariuszy, wydany niedawno po polsku (O naturze pantery i jej znaczeniu, [w:] Bestiariusz, tłum. R. Sasor, Kraków 2005, s. 77). 
Erotyzm zagrażający mężczyźnie, agresywny, łączący zmysłowość z destrukcją, odzuierciedla metamorfoza, jakiej śuiadkiem staje się we śnie Czerkaski. Bohatera - opuszczonego przez Hankę, starającą się o odzyskanie dziecka - dręczy nieletnia prostytutka przeobrażona u dzikiego kota. Zjawa, szydząc, usiłuje zaszczepić u mężczyźnie ziarno niepeuności co do uczucia Hanki:

$[\ldots]$ jednym susem uskoczyła mu na kark - upiła drapieżne szpony u jego ciało.

A szpony kota rozdrapywały jego ciało, orały skórę na rzemienie...

$[\ldots]$

- Nie uróci Hanka, nie uróci - chichotała mała nierządnica. - Hanka bije się teraz małymi piąstkami w suą grzeszną pierś: jam biedna cudzołożnica! Wybaw mnie panie! - Ha, ha, ha... (Sz II, 327-328)

Metaforyczne odniesienia do dzikich kotów są elementem erotycznego image'u, jakiemu podlegają także mężczyźni. Kobiety bowiem dostrzegają w przeciunej płci pociągającą zuierzęcość.

Spojrzała na niego [Iza na Falka]: piękny był. Całymi godzinami mogłaby patrzeć na niego, patrzeć $\mathrm{w}$ jego wielkie, błyszczące oczy ${ }^{110}$, utkwione w nią z gorączkouym blaskiem... a kiedy raz po raz się zrywał i obiegał pokój: te zuinne, niebezpieczne ruchy smagłej pantery. (Hs I, 121)

W poemacie Androgyne Przybyszewski interesująco zestawił kobiety w analogii do zwierząt:

Ta, niedociekniona, tajemnicza, z połyskiem czarnego jedwabiu; jak pantera, przyczajona do skoku kot -

Ta, z oczyma gołębicy, a z sercem rozpustnym, łagodna jak gazela i drapieżna jak dziki

Ta, śliska jak wąż, z ciałem chłodnym, jak liście róż wodnych - (A 395-396)

Pozytywne symbole gołębicy (oznaczającej prostotę, niewinność, pojednanie, świętość, a także duszę ${ }^{111}$ ) oraz gazeli (kojarzonej z czystością,

${ }^{110}$ Wspomniano wcześniej o roli patrzenia i oczu u twórczości Kazimierza Przerwy-Tetmajera. Jako analogię do obrazu przywołanego przez Przybyszeuskiego warto więc przytoczyć fragment wiersza:

$\mathrm{Z}$ daleka patrzą na mnie tue oczy

błękitne, duże,

a chociaż takie są jasne, jak słońce,

powiek nie zmrużę.

(K. Tetmajer, $Z$ dawnej przesztości, [w:] idem, Poezje wybrane, oprac. J. Krzyżanouski, Wrocław 1968, s. 27)

${ }_{111}$ Gołąb [hasło], [w:] J.C. Cooper, Zwierzęta symboliczne i mityczne, Poznań 1998, s. $65-69$. 
łagodnością, wrażliwością, duchowością ${ }^{112}$ ) uznane zostały za pozór i wykorzystane do zdemaskowania póz przybieranych przez kobiety. Delikatność, skromność, czystość to - zgodnie z przekonaniami mizoginów, upatrujących w przedstawicielkach płci pięknej niszczycielek rodu męskiego - maski, za którymi kryją się rozpusta, okrucieństwo i perfidia. Kontrast między zewnętrznym pięknem a pustką kobiecego unętrza najdoskonalej wyraża figura pawia, do jakiej odwołuje się Czerkaski w pierwszych zdaniach powieści Synowie ziemi. Przybyszewski ukształtował myśli bohatera w ciąg asocjacyjny, prowadzący mężczyznę do przypisania cudzołożnej żonie cech, które alegorycznie uyrażał paw co najmniej od czasów baroku. Otóż rysunek ptaka, ,pysznego, zuchuałego, z roztoczonym ogonem” (Sz I, 7), zawieszony na drzwiach kawiarnianego pokoiku, gdzie Czerkaski szuka towarzystwa, nasuwa bohaterowi na myśl słowa, powracające następnie jako leitmotiv na przestrzeni całego utworu: Les paons nonchalants, les paons blancs ont fui („Pawie niedbałe, pawie białe uciekły”). Zdanie to, zaczerpnięte z wiersza Maurice'a Maeterlincka pt. Znudzenie (Ennui, 1889) ${ }^{113}$, sprzyja uspominaniu żony:

Tak, to symbol dla niej. Ona była tym pawiem, strojnym w przepych i bogactwo: pyszna, próżna, zimna - och, jaka zimna...

A przecież niedawno, zaledwie przed dwoma miesiącami, siedział tu $\mathrm{z}$ nią razem. $\mathrm{Z}$ nią razem? He, he - tak, razem, ale ona nie była przy nim. Że też był tak ślepy! Niczego nie widział!

„Les paons nonchalants, les paons blancs ont fui...” (Sz I, 7)

Białe pawie powrócą w dalszej części powieściowego cyklu, jednak nie w charakterze kobiecej maski, a jako element sztafażu - rzadka, wyszukana ozdoba ogrodu, o jakim marzy Hanka (wątek ten zostanie omówiony w podrozdziale poświęconym przestrzeni $)^{114}$.

Za jedyny symbol ornitologiczny nie dający się interpretować na niekorzyść kobiet uznać należy mewę. Ciekawe, że jest to symbol indywidualny Przybyszeuskiego, daleki od alegorii i dlatego trudny do jednoznacznego odczytania. Pojawia się najczęściej we fragmentach prezentujących partnerki bohaterów jako istoty bezradne, zagubione, niewinne. Nie bez

${ }^{112}$ Gazela [hasło], [w:] J.C. Cooper, op. cit., s. 62-63.

${ }^{113}$ Wiersz ten dał nazwę pokoikowi „Pod nonszalanckim Paonem” (lub u skrócie „Paon”) u kawiarni Turlińskiego, gdzie zbierali się znajomi Przybyszeuskiego po jego przyjeździe do Krakowa. W tym pokoiku (tu nazwanym „Pod Pawiem”) Przybyszeuski ulokował bohatera Synów ziemi.

${ }^{114}$ Białe pawie z Chin proponuje też ukochanej u darze Przesłauski w Złotym runie. Warto zaznaczyć, że ptaki te nie są uyłącznie figurą retoryczną, lecz rzeczywiście uystępują w stanie naturalnym na południu Chin, o czym uspomina B. Mazan w studium Z obrazów Chin i Chińczyków w piśmiennictwie polskim drugiej połowy XIX wieku. „Chińskie cienie” w „Lalce” Bolesława Prusa, [w:] Pozytywizm i negatywizm. My i wy po stu latach, red. B. Mazan, Łódź 2005, s. 391. 
znaczenia jest barwa upierzenia ptaka (wartościowanie pozytywne) oraz jego związek z morzem, ujmowanym u twórczości Przybyszeuskiego jako sfera swobody, nieograniczonej wolności, ontologicznego wyzwolenia.

Miłość Tua była biała i czysta i miękka jak skrzydła meuy polarnej. (Nm 298)

Płakała cicho krwią serca, płakała, jak płacze biała mewa, gdy się z daleka zabłąka i drogi z powrotem znaleźć nie może. (A 414)

Inną popularną w Młodej Polsce zuierzęcą maską był wąż, pod postacią którego ukrywał się zazwyczaj mężczyzna - ujarzmiający partnerkę seksualnie, zniewalający ją oplotem ciała, zadający jej ból, a nawet śmierć (np. Waż Bogusława Adamowicza, Waż-luxuria Marii Grossek-Koryckiej) ${ }^{115}$. U Przybyszeuskiego figura węża - oznaczającego żądzę, chuć, lubieżność i erotyczną rozkosz - odnosi się zausze do kobiety, przy czym nie ulega zatarciu falliczny charakter symbolu. W najprostszym ujęciu ruchy gada służą metaforyzacji postaci femme fatale; podkreślają ogarniające ją silne zmysłowe napięcie, którym zaraża mężczyznę. „O, nieraz uytrysły te węże z tuych oczu w spokojne głębie mego serca" - uspomina bohater utworu $Z$ cyklu Wigilii (W 179). „Dreszcze czołgają się jak długie, zimne węże przez ciało moje..." - wyznaje Agaj bratu, prosząc jednocześnie o jego pocałunki (Dp 99). Wreszcie sama pożądająca i realizująca sue pożądanie kobieta przypomina gada, którego ruchy są zuinne i posuwiste. Bohater Androgyne, tuż przed ujrzeniem ukochanej, ma wrażenie, że ona „skrada się wzdłuż lasu kolumn, co uspierały sufit sali - ślizga się ostrożnie gdyby wąż" (A 389). Po chwili widzi ją w złotych bransoletach przypominających oplecione wokół jej rąk i nóg węże ${ }^{116}$. Identyfikacja uybranki z gadem staje się coraz silniejsza. W rezultacie bohater doświadcza nietypowego doznania seksualnego:

Podszedł do biurka zdziwiony - dwa ogromne kuiaty dyszały jakimś namiętnym żarem, jakąś rozkoszną pieszczotą $\mathrm{w}$ oplocie brązowego węża.

$[\ldots]$

Brązowy wąż w jego rękach począł nabierać życia i prężyć się; a naraz oślizgł mu się uzdłuż piersi, oplótł go lubieżnym, drgającym ciepłem jej ciała, tarł się o niego, znowu go obejmował i ściągał, ściągał stalową obręczą. - Ale nie! - to już nie był wąż, to była ona - czuł, jak się pierścienie jej członkóu rozluźniały i znowu ściągały w bolesnych uściskach... (A 402-403)

${ }^{115}$ Por. W. Gutouski, Mit - Eros - Sacrum, s. 63-64.

${ }^{116}$ Naga postać kobieca opleciona przez węża pojawia się także m.in. na litografii Odilona Redona z 1890 r. czy ilustracjach Williama Blake'a do Raju utraconego Miltona; to stosunkowo częsty motyu modernistycznej sztuki. 
Kobieta-wąż jest sadystką, zadającą ból suym duszącym, śmiercionośnym uściskiem. Dokonane przez Przybyszeuskiego utożsamienie wynika z faktu, że wąż jest znaną z Biblii postacią szatana, szatan zaś - jak twierdził pisarz - upodobał sobie kobietę. Stąd też płeć piękna posiada cechy biblijnego węża: przeurotność, przebiegłość i umiejętność kuszenia. I podobnie jak wąż hipnotyzuje ofiarę samym spojrzeniem.

Patrzała na niego przymrużonymi oczyma, spoza długich rzęs uybiegały lubieżne węże kuszeń i wabień [...]. (A 407)

U Przybyszewskiego, podobnie jak u innych modernistów, kobietę jako wcielenie zła jednocześnie potępia się i ubóstwia. Doskonale wyraża tę ambiwalencję jedna z czołowych scen Androgyne - bohater pragnący ukrzyżowania kochanki, widząc ją rozpiętą na krzyżu, pokornie czołga się do jej stóp i tuli ją w ramionach.

Jako maska męskości w erotycznej symbolice animalistycznej funkcjonował koń. Motyu ten zawdzięczał suoją popularność obrazowi Szał uniesień, namalowanemu przez Władysława Podkowińskiego u 1894 r. i przyjętemu w atmosferze skandalu. Przedstawia on nagą kobietę dosiadającą pędzącego karego konia i tulącą się do niego całym ciałem z przymkniętymi u upojeniu oczyma. Jej ramię oplata szyję spienionego rumaka, jej gęste rude włosy splatają się z grzywą zuierzęcia. Płótno emocjonalnie charakteryzował Kazimierz Przerwa-Tetmajer:

$\mathrm{Na}$ rozhukanym olbrzymim koniu, na jakiejś apokaliptycznej bestii rzuconej w chaos, w zamęt wichrzących się tumanów chmur i mgławic na upół leży naga kobieta, oplótłszy koniowi kark ramionami, tuląc się doń tuarzą, piersią, korpusem, cisnąc mu konuulsyjnie boki nogami. [...] szalony rumak [...] niesie tę nagą kobietę w dal, w głąb, w bezkres pożądań - w bezkres żądz zmysłowych. Ona płonie - ten rumak szalony to szaleństuo jej pragnień, uulkan jej namiętności lawą zionący i wichrem płomieni, to szał jej krwi, jej wyobraźni, jej ciała $^{117}$.

Młodopolski poeta doskonale odczytał sens uchwyconej na płótnie namiętności. Kobieta, której blade ciało uyraźnie odcina się od umaszczenia zwierzęcia oraz mroku panującego wokól, tylko pozornie jawi się jako słaba ofiara rozszalałych żądz rumaka. W rzeczywistości koń jest uyrazem jej własnych erotycznych pragnień, obrazem jej zmysłowej pasji, w której - jak wspominał Wojciech Gutouski - rozkosz przeplata się z obawą i perwersją ${ }^{118}$. Takie ułaśnie uczucia wypełniają uniesioną przez spłoszonego konia bohaterkę Śniegu.

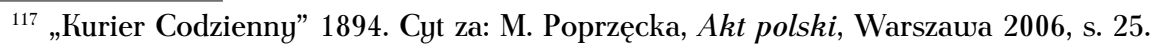

${ }^{118}$ W. Gutouski, Miłość śmierci..., s. 61. 
Byłam u śmiertelnym lęku, straciłam przytomność, a róunocześnie czułam dziunną rozkosz być niesioną przez to silne, nieokiełznane, harde, piękne zuierzę... (Ś 47)

- uspomina Bronka, odsłaniając temperament, o który nie podejrzewa jej nawet Tadeusz, szukający w żonie wyłącznie ukojenia, pocieszenia, naiuności. Podobnie jak Podkowiński, Przybyszeuski nawiązał do motyuu konia symbolizującego dynamizm życia, guałtowność pożądania, nieświadome rozbuchanie instynktów ${ }^{119}$. Niebezpieczna przygoda z koniem jest dla Bronki doświadczeniem spontaniczności i intensywności bytu, a więc wyzwoleniem od schematu, w jaki wcisnął ją Tadeusz. Jeszcze uyraźniej sens galopady jako ekwiwalentu zakazanej rozkoszy odsłonił Przybyszeuski w scenie nocnej przejażdżki, na którą zakochana Zosia namawia Adama Drzazgę. Szaleńczy pęd po stepie na najdzikszym, nieujeżdżonym ogierze ujaunia siłę namiętności młodej Krywłówny, obłąkańczo pożądającej przyrodniego brata, a jednocześnie jest próbą wyzwolenia od tej namiętności, ucieczką od zmysłowości, z którą nie sposób sobie poradzić, ucieczką od samej siebie. Podobnie jak dla Bronki, tak i dla Zosi niebezpieczne szarże na koniu oznaczają konfrontację z ułasną nieświadomością, przekroczenie ograniczeń, a jednak wyzwolenie jest zarazem autodestrukcją. Pierwiastek samozatracenia pisarz wyeksponował także w Mścicielu - Iza, rozdarta uczuciowo, „od świtu harcowała na najdzikszym źrebcu [...] - zaledwie co ujeżdżonym”, choć „to harcowanie nad urwiskiem - zbyt niebezpieczna igraszka" (Mśc 8). Jest w tym obrazie konnej jazdy element antycypujący samobójczą śmierć bohaterki, w finale dramatu rzucającej się z owego urwiska do morza.

Dynamiczny obraz pędzącego konia, kojarzony z wolnością i swobodą, nie jest u modernistów apoteozą witalności, beztroskiej zmysłowości, lecz środkiem do wyrażenia „najbardziej paradoksalnych i perwersyjnych kompleksów erotycznych" ${ }^{120}$.

Omawiając młodopolską symbolikę animalistyczną, Wojciech Gutouski zauważył, że twórcy epoki często identyfikowali seks, zuierzęcość, zatratę tożsamości i dezintegrację „ja”. Doświadczenia orgiastyczne charakteryzowała przy tym obecność różnorodnych istot monstrualnych - płazów, gadów, potworów, smoków ${ }^{121}$. Jako przykład takiego rozwiązania badacz podaje opis doznań, jakich doświadcza de la Croix w trakcie praktyk satanistycznych:

Wokół niego kłębiły się potworne płazy, wiły się wokół jego ciała wydęte cielska wężów - obiegały go wyjącym szumem ogromnych skrzydeł olbrzymie nietoperze - z mgły, która go naokół otaczała, przeglądały ślepia, ale nie jako narządy zmysłóu, ale samoistne

\footnotetext{
${ }^{119}$ Koń [hasło], [w:] J.E. Cirlot, op. cit., s. 193-194.

${ }^{120}$ W. Gutouski, Mit - Eros - Sacrum, s. 68.

${ }^{121}$ Ibidem, s. 57.
} 
jestestua na długich, cienkich nóżkach, to znowu osaczone w czołgających się brzuchach, tam znowu wyzierały z olbrzymich phallusów z krwawoczerwonych warg płciowych narządów żeńskich złe, krzyczące, wyjące, bluzgające jadem ślepia - straszliwe gryfy o ostrych dziobach krogulców rzucały się na niego wśród wściekłego wycia tych krwiożerczych ślepióu [...] - smoki, na których ludzkich, kudłatych łbach jarzyło się gromniczne światło, rzygały smrodliwą siarką, dusiły go dymem rozgotowanej smoły, u stóp jego czołgały się do wielkości wielorybów uydęte raki, potworne ropuchy rozdziawiały pyski ryczących wołów. (Ird 142)

W tym specyficznym bestiarium, wykreowanym przez szatańskie moce w celu poddania adepta „próbie chuci”, pojawiają się stwory niesamowite, na poły mityczne, jak gryf i smok, występujące w roli strażników wiedzy i samopoznania, strzegące wrót wtajemniczenia ${ }^{122}$, oraz zuierzęta dołu, kojarzone z siłami zła, ale także rozpasaną zmysłowością i płodnością: węże, raki, ropuchy ${ }^{123}$. Nietoperz, jako zwierzę nocne, również należy do stworzeń nieczystych, zuiązanych z mocami ciemności; uznawany bywa za ucielenie wampirów i czarownic, a nawet szatana (którego przedstawia się niekiedy ze skrzydłami nietoperza). Wszystkie te gady i płazy (chętnie przeciustawiane $\mathrm{w}$ modernizmie ptakom, wartościowanym pozytywnie u kontekście przestrzeni i wolności) kłębią się i wiją, wydzielają smrodliwe zapachy i nieprzyjemne dźwięki. Symbolizują przyziemne motywacje i niskie popędy, odzuierciedlają chaos, zgniliznę, rozkład. Kuintesencją bezładu i dezintegracji jest zaś obraz ożywionych męskich i żeńskich genitaliów, funkcjonujących samoistnie i wyposażonych w „ślepia”, a więc zdolność tzu. złego patrzenia. Uosabiają one potęgę chuci, a jednocześnie - poprzez groteskowe ujęcie - są wyrazem lęku przed uszechwładnym Erosem $^{124}$.

Powyższe analizy pozwalają stuierdzić, że symbolika teriomorficzna w twórczości Przybyszewskiego jest dość uboga i jednolita. Jako wyraz tendencji mizoginicznych epoki odnosi się przede uszystkim do kobiety, jawiącej się mężczyźnie jako emisariuszka bezuzględnej Natury. Odpowiadają jej takie zuierzęta, jak pantera, tygrysica, wąż, rzadziej gazela, gołębica czy mewa. Ów śuiat fauny - jak cały niemal młodopolski zuierzyniec - jest ściśle wytworem kultury. Interesująco pisał o tym zjawisku Erazm Kuźma: „zuierzęta na karty tomików weszły nie z łąk, pól, lasów, puszcz, lecz z kart innych tekstów, z obrazów, rzeźb, z ogrodów zoologicznych. Są to zuierzęta intertekstualne i intersemiotyczne" ${ }^{125}$. Figury teriomorficzne to symbole konwencjonalne, rozmyślne i metaforyczne, uprowadzone w celu

${ }^{122}$ Zob. J.E. Cirlot, op. cit., s. 153, 379; J.C. Cooper, op. cit., s. 252.

${ }^{123}$ Zob. C.J. Cooper, op. cit., s. 225-226, 230-231.

${ }^{124}$ Por. W. Gutouski, Mit - Eros - Sacrum, s. 57-58.

${ }^{125}$ E. Kuźma, Bestiaria młodopolskie, [w:] Stulecie Młodej Polski, red. M. Podraza-Kuiatkouska, Kraków 1995, s. 170. 
uwypuklenia popędów kierujących człowiekiem, obrazujące ludzką samotność oraz zatratę wartości duchowych i moralnych w świecie libidalnie zdeterminowanym.

\section{Libido wobec sfery sacrum}

Moderniści zanegowali uniwersalny charakter sacrum, uniezależniając je od wierzeń i praktyk religijnych sterowanych postanowieniami zinstytucjonalizowanego Kościoła. Uznali, że jest ono dostępne u indywidualnym, subiektywnym dośuiadczeniu weunętrznym, na które składają się osobiste, intymne emocje i doznania, również te pozaśuiadome. $\mathrm{Z}$ przekonania, że wiara nie jest tożsama z przyjęciem dogmatów i teologiczną doktryną, tajemnica transcendencji uymyka się racjonalizacji a religia uymaga uzgodnienia z kulturą i oczekiwaniami epoki, ukształtował się modernizm katolicki, będący ważnym zjawiskiem światopoglądouym przełomu XIX i XX stulecia ${ }^{126}$. Choć rozuijał się głóunie we Francji, Anglii, Niemczech i Włoszech, miał zuolenników także uśród polskich świeckich myślicieli i twórców. Interesowali się nim Marian Zdziechouski, Stanisław Brzozowski, Tadeusz Miciński, Ignacy Radliński, uynoszący dośuiadczenia metafizyczne nad akademicką scholastykę oraz formy i ceremonialne gesty, w jakich skostniał katolicyzm, opouiadający się subiektyuizacją doznań i zachowań religijnych. Postulowana interioryzacja sacrum uspółbrzmiała z typowym dla epoki kultem jednostkowego przeżycia, któremu przypisano wartości poznawcze i kulturotwórcze. Wiązała się z prześuiadczeniem, że doświadczenie religijne może się uyrażać w różnych symbolach i mitach, co prowadziło do swoistego synkretyzmu dogmatów i formuł. Chrześcijaństwo - jak zauważył Wojciech Gutouski - utraciło w Młodej Polsce pozycję religii uprzywilejowanej. Najczęściej przeciustawiano mu tradycję alternatywną, która miała charakter polemiki negatyunej, destrukcyjnej (np. Orient zamiast katolicyzmu, satanizm zamiast chrystologii) ${ }^{127}$.

\footnotetext{
${ }^{126}$ Przedstawiciele tego ruchu - wolnego od zinstytucjonalizowania i struktur - dokonali wielokierunkowej krytyki tradycji katolickiej. Zakwestionowali scholastyczne metody apologetyki, domagali się autonomii dla badań teologicznych i stosowania przy analizie Biblii tych samych kryteriów, jakie są przyjęte w naukach historycznych, zarzucali Kościołowi biurokratyczny ustrój i niezdolność do refleksji nad przemianami cywilizacyjnymi oraz kulturalnymi, pokazywali dogmaty jako twierdzenia zmienne historycznie, opouiadali się za emocjonalizacją wiary, głosili, że prawdy religijnej nie sposób wyrazić w dyskursie podporządkowanym intelektowi. Na temat modernizmu katolickiego zob. m.in. T. Lewandouski, Młodopolskie spotkania z modernizmem katolickim, [w:] Problematyka religijna w literaturze pozytywizmu i Młodej Polski, red. S. Fita, Lublin 1993, s. 197-252 oraz monograficzny numer miesięcznika „Znak” z lipca 2002 r. (nr 7).

${ }^{127}$ W. Gutouski, Wśród szyfrów transcendencji. Szkice o sacrum chrześcijańskim w literaturze polskiej $X X$ wieku, Toruń 1994, s. 17-18, 28-29.
} 
Przybyszeuski, nie angażujący się bezpośrednio w modernizm katolicki, ale z peunością z nim obeznany i surowo oceniający tradycję judeo-chrześcijańską, także przeniósł doświadczenie o charakterze religijnym w sferę ludzkiej psychiki. Pouszechny kryzys ideowy sprawil, że pisarz zajął się badaniem satanizmu, który - o czym uspominała Gabriela Matuszek - paradoksalnie stał się szansą ocalenia porządku metafizycznego i obrony przed nihilizmem ${ }^{128}$. Przekonanie o istnieniu szatana musi bowiem uwzględniać wiarę $w$ transcendencję. Założenie, że świat jest terenem starcia przeciustaunych potęg: dobra i zła, pozwoliło, jak pisze badaczka, wytłumaczyć przyczyny zła i uwolnić Boga od odpouiedzialności za uszechobecne na ziemi cierpienie ${ }^{129}$. A właśnie Boga oskarżano, przede uszystkim u pieruszej fazie epoki, o stworzenie świata, którego nieodzownymi elementami są nieszczęście i śmierć, a także ludzki grzech ${ }^{130}$. U Przybyszewskiego to szatan tworzy życie i niszczy je. Dziełem szatana jest także miłość, o której móui się: „szatańskie, piekielne runo” (Zr 251), „piekło” (Zr 178). Bóg u negatywnym, pesymistycznym kontekście został zestawiony $\mathrm{z}$ naturą $\mathrm{w}$ pieruszym poemacie pisarza:

[...] ponad zbrodniczą niesumiennością Boga-Natury, co ludzi tworzy na to, by w rozpacznym obłędzie zawodzili opętany taniec bytu -

ponad tym uszystkim panuje moja wolna, bezpłodna dusza z suym spokojem bezpoczątkowej uieczności. (Rae 94)

Wprowadzona identyfikacja nie jest wyrazem panteizmu, lecz metaforycznym porównaniem siły i metod działania. Natura jest uszechwładna niczym Bóg i - jak Bóg - tworzy ludzi po to, by cierpieli. Wyposaża ich w płeć, ale korzystanie z jej przywilejów opatrzone zostaje mianem grzechu.

Dziedzictuo chrześcijańskie - traktowane polemicznie bądź aprobatyunie - było dla modernistów jednym z ważniejszych punktów odniesienia, a Pismo Święte stało się w końcu XIX w. księgą nadzuyczaj chętnie odczytywaną na nowo $w$ poszukiwaniu nieodkrytych znaczeń. Podejmując motywy i wątki biblijne, młodopolscy artyści dokonywali najczęściej ich transformacji, reinterpretacji i transpozycji ${ }^{131}$. Podnosili je do rangi symboli, już to obrazujących degradację sfery sacrum, już to podważających prawdy wiary lub pozwalających doszukiwać się $w$ testamentowych wydarzeniach nieznanych wcześniej (na ogół niekanonicznych) sensów i archetypicznych wzorów. Inspirowane przekazem biblijnym utwory bądź ich fragmenty wyrażały niepokoje „człowieka

${ }^{128}$ G. Matuszek, Nędza świata bez Boga. O „Dzieciach szatana” Stanisława Przybyszewskiego [posłowie], [w:] S. Przybyszeuski, Dzieci szatana, Kraków 1993, s. 176.

${ }^{129}$ Ibidem, s. $176-177$.

${ }^{130}$ Zob. m.in. M. Podraza-Kuiatkouska, Obraz Boga wśród światopogladowych przemian Młodej Polski, [w:] eadem, Wolność i transcendencja.

${ }^{131}$ Przykłady tych zabiegów podaje: W. Gutouski, Mit - Eros - Sacrum, s. 159 i dalej. 
końca wieku”, głóunie natury metafizycznej, aksjologicznej i społecznej. Mogły też, poprzez jeden z bardziej śmiałych, ale i popularnych w Młodej Polsce zabiegów łączenia wyobraźni religijnej i erotycznej, uskazywać podobieństwo doświadczeń mistycznego i seksualnego, opisane przez badaczy okresu; obrazować - jak u Przybyszeuskiego - natężenie lęków związanych z płciowością i próbę ich zualczenia poprzez uwznioślenie biologii, a w efekcie przezuyciężenie nieubłaganego determinizmu i nadanie ludzkiemu życiu głębszego, metafizycznego sensu.

Podniesienie erotyki do uymiaru sacrum przebiega u młodopolskiego pisarza na kilku poziomach. Po pierusze, uyraża się u uczynieniu z chuci (popędu, chaosu) zasady istnienia. Po drugie, związane jest z ideą androgynicznego zjednoczenia, którego kochankowie mogą dostąpić poprzez zespolenie cielesne. Te duie centralne dla „miłosnego” śuviatopoglądu pisarza koncepcje - ontologicznej i kosmicznej jedni - wzmocnione zostały parafrazami słów z Ewangelii według św. Jana („Na początku było Słowo”) i Księgi Rodzaju („I stało się śuiatło”), a także stylizacją biblijną, stosowaną przede uszystkim $\mathrm{w}$ nasyconych erotyzmem scenach $\mathrm{z}$ poematów prozą. Są one - jak zauważył W. Gutouski - alternatywne wobec tradycji religijnej, ale pozostają z nią $\mathrm{w}$ dialogu ${ }^{132}$. Po trzecie wreszcie, sakralizacja Erosa wyraża się w licznych - rozgrywanych na jawie i w wyobraźni bohaterów - scenach o charakterze miłosnym i seksualnym, jak choćby w jednym z rapsodów Nad morzem, którego bohater obmywa i całuje „święte rany” na pokrwawionych stopach ukochanej (Nm 328), uyraźnie skojarzonej tu z postacią Chrystusa, obmyuającego nogi uczniom i poranionego przez guoździe od krzyża.

Autor Synagogi szatana dokonuje - przede wszystkim w poematach prozą - destrukcji symboli i motywów religijnych. Odrywa je od przyjętej wykładni teologicznej, przenosi $w$ inne konteksty i zaprzecza ich sensom. Przenosząc motyw Ukrzyżowania na grunt relacji erotycznych (Androgyne) czy kompilując wizję Sądu Ostatecznego z obrazem orgii potępieńców (De porfundis) miesza porządki sacrum i profanum, ukazując w ten sposób chaos rządzący śuiatem i człowiekiem. Nie znaczy to naturalnie, że Przybyszewski neguje sferę śuiętości, nie wierząc w jej istnienie. Raczej sytuuje ją w wymiarze osobistym, niekanonicznym. Między innymi z tego powodu wykorzystane przez pisarza elementy topiki chrześcijańskiej (jak Gehenna, Golgota, Synaj) rzadko mają samodzielną i pełną wymowę znaczeniową. Niekiedy pojawiają się uyłącznie w celu zbudowania nastroju, sugerowania podniosłości zdarzeń czy ureszcie szokowania funkcjonowaniem $w$ nietypouym kontekście ${ }^{133}$. Temu samemu służą odwołania do

\footnotetext{
${ }^{132}$ Ibidem, s. 151.

${ }^{133}$ Zob. K. Zabawa, „Kalejdoskop myśli, wrażeń i obrazów” - młodopolskie odmiany krótkiego poematu proza, Kraków 1999, s. 99.
} 
liturgii, sakramentów i obrzędów chrześcijańskich. Zaliczyć do nich należy przede uszystkim obraz wiejskiego kościółka ${ }^{134}$, wykorzystany już u $R e$ quiem aeternam. Bohater poematu, człowiek o usposobieniu dekadenta, zmagający się z dziedzictwem „martwej chuci”, podjąuszy samobójczą decyzję, widzi się nagle we unętrzu wiejskiej świątyni. Wśród blasku gromnic $\mathrm{i}$ w oparach kadzidła razem $\mathrm{z}$ wiernymi obawiającymi się zarazy ${ }^{135}$ wznosi antyfonę „Wybaw nas, Panie”. Uczucie szczęścia i błogostan, w jaki popada, przyjąuszy komunię świętą, trua zaledwie chuilę. Przerywa je Astarte, „apokaliptyczna nierządnica” wyłaniająca się z „Sodomy nieba” (Rae 90-91). Oksymoroniczne zestawienie, podające w wątpliwość czystość niebios, prowadzi do dobitnego zdewaluowania wartości sacrum. Podobnie jak skarga bohatera, który - kuszony przez boginię rozpusty - powtarza ostatnie słowa umierającego na krzyżu Chrystusa: „Boże mój, Boże, czemuś mnie opuścił". Libido, symbolizowane przez Astarte, zuycięża porządek religijny; pokonanie cielesności nie może się człowiekowi udać.

Tęskniący za ukochaną bohater $Z$ cyklu Wigilii mocą wyobraźni i pamięci róunież przenosi się do kościoła. Poróunuje swoje serce do Ciała Pańskiego, które przyjmuje podczas pieruszej komunii. Kochance nadaje zaś rolę kapłana błogosławiącego hostię:

A otóż jestem w kościele. Jestem, małe chłopię, owiany błogą świętością bóstua, strojny błogim szczęściem, utkanym z miękkich jedwabiów, u sercu grają anielskie chóry: po raz pieruszy przyjmuję Ciało Pańskie.

A moje serce staje się bóstuem odwiecznym, Ciałem Pańskim, śuiętą hostią.

- Przyjdź, weź hostią mego serca u twe miękkie ręce, przyjdź! A przybierz się u jedwabny, złotem tkany ornat kapłański, a teraz podnieś twe ręce u górę; ponad czoło uszechbytu podnieś wolno, poważnie, z świętym namaszczeniem twe przeczyste ręce. (W 174)

Pokazaniu kobiety jako istoty niepojętej i świętej służy porównanie jej do monstrancji, przed którą wierni składają pokłon, oraz do niewinnej duszy dziecka, oczyszczonej poprzez chrzest z grzechu pierworodnego.

Tylko on, on jeden istniał, a ona była jakąś śuiętą, złocistą, olbrzymią monstrancją, wzniesioną nieuidzialnymi rękoma $\mathrm{z}$ najtajniejszych głębi jego duszy. Ślepł od jej blasku... (Hs I, 73)

...Bo byłaś piękną i czystą i jasną, jak dusza dziecka, w której się święta ofiara chrztu dopełniła. (Nm 288)

${ }^{134}$ Wizja kościółka to leitmotiv twórczości Przybyszeuskiego, powracający w uielu utworach z różnych okresów. Pisarz inspirował się - jak sam podkreślał - uspomnieniem kościółka w Górze, w okolicach swojej rodzinnej usi Łojewo.

${ }^{135}$ Przybyszeuski zapamiętał z dzieciństwa epidemię cholery, która nawiedziła jego rodzinne strony. 
Ambiwalentny stosunek do kobiety znalazł natomiast wyraz w porównaniu jej do upadłego anioła. $\mathrm{Z}$ jednej strony został tu wydobyty tkwiący w niej element boskości, z drugiej zaś pisarz położył nacisk na jej diabelskość:

Bo jestem pod taką guiazdą urodzona, że sama jedyna w przepaść i w piekło wtrącić cię mogę; a sama jestem jak upadły anioł, któremu dusza się ruie u strzępy za utraconym rajem... (A 432)

Wyzwolenie od kobiety, która tylko pozornie jawi się jako anioł zdolny wznieść mężczyznę ku niebu, w istocie zaś jest nałożnicą szatana, udaje się bohaterowi Wniebowstapienia. Miejsce po niej uypełnia u sercu mężczyzny Duch Święty, zstępujący na ziemię w Zielone Świątki (notabene, jak zbadała M. Podraza-Kuiatkouska, Duch Święty jako osoba Trójcy Świętej pojawia się $\mathrm{u}$ młodopolskiej literaturze stosunkowo rzadko $\left.{ }^{136}\right)$. To mistyczne doznanie uyrażone zostało za pomocą obrazowania typowego dla doświadczenia seksualnego:

Czuł, jak jego ciało na całą ziemię się rozpościera, jak coś ze ziemi i coś z nieba ueń się przelewa, jak ramię uszechnatury ciśnie go do suego łona, aż święta krew ziemi poczęła u nim krążyć, a gorące nasienie niebios go zapładniać. (Wn 149)

Wypełnienie mocą Ducha Świętego przypomina tajemnicę androgynii; jest jednoznaczne z dostąpieniem jedności z boskością i kosmosem. Umożliwia wnieboustąpienie, do którego nie mogła doprowadzić mężczyzny kobieta.

Perwersyjne przeżycia erotyczne, sadystyczne dążenia oraz wyparte treści psychiki znalazły wyraz $\mathrm{w}$ inscenizowanych w wyobraźni bohaterów scenach ukrzyżowania partnerów ${ }^{137}$. Pociągały one modernistów, ponieważ uyrażały doświadczenia najbardziej negatywne, niszczące ${ }^{138}$, a jednocześnie fascynujące i pożądane, bo gwarantujące intensywność istnienia. Krzyż nie symbolizuje $w$ nich cierpienia i odkupienia, lecz prezentuje związek erotyzmu z występkiem; ofiarę zastępuje oksymoroniczne doznanie bolesnej rozkoszy. W halucynacyjnej projekcji bohatera Androgyne, próbującego dociec, od której kobiety otrzymał bukiet kuiatów, wisząca na krzyżu kochanka wabi i prowokuje (podobnie, co podkreślają badacze, jak na akwaforcie uwielbianego przez Przybyszeuskiego Féliciena Ropsa Kuszenie świętego Antoniego), drwiąc z mężczyzny niezdolnego do stłumienia libido. W scenie tej, jak zauważył Wojciech Gutouski, chuć zuycięża caritas i męski opór ${ }^{139}$.

\footnotetext{
${ }^{136}$ M. Podraza-Kuiatkouska, Obraz Boga..., s. 102.

${ }^{137}$ Warianty modernistycznego ukrzyżouania omawia W. Gutouski w rozdziale Motywika pasyjna w świecie młodopolskiej wyobraźni u książce Mit - Eros - Sacrum.

${ }^{138}$ Ibidem, s. 190.

${ }^{139}$ W. Gutouski, Nagie dusze..., s. 164.
} 
Ujrzał ją w krzyż rozpiętą na ścianie u całym przepychu jej piękności; ramiona jej ouiły miast naramienników złote węże, złote węże oplatały kostki nóg, a biodra opasała złota przepaska, zamknięta na łonie kwieciem lotosu, wysadzonym drogim kamieniem.

Patrzała na niego przymrużonymi oczyma; spoza długich rzęs wybiegały lubieżne węże kuszeń i wabień; kołysała się z rozkoszną pieszczotą na krzyżu [...]. (A 407)

Pisarz kilkakrotnie podkreśla szatańskość kobiety, jej sprzymierzenie z mocami zła. Ukrzyżowana nie tylko nosi bransolety u kształcie węża; nawet jej spojrzenie jest „wężowe”, kuszące i fałszywe zarazem. A jednocześnie nietypowe ozdoby oplatające ramiona i nogi kochanki odsyłają - z racji materii, z której zostały uykonane - do męki Zbawiciela (o czym Przybyszeuski zapeune nie wiedział) i $\mathrm{w}$ tym sensie są zdublowaniem obrazu ukrzyżowania. Złoty wąż owinięty wokół kobiety, której ciało układa się w kształt krzyża, przywodzi bowiem na myśl podniesionego na kiju miedzianego węża, jakiego Izraelici czcili za moc uzdrawiania ${ }^{140}$, który pod upływem lektury Nowego Testamentu stał się modelem śmierci krzyżowej Chrystusa. Interpretacja ta staje się tym bardziej dopuszczalna, że we wcześniejszej halucynacji bohatera ożywa wąż z brązu, niczym ustążka oplatający łodygi stojących w wazonie narcyzów. Tutaj brąz zastąpiony został złotem, odpowiedniejszym jako materiał dla ozdób i bardziej działającym na wyobraźnię odbiorcy, a jednocześnie wiązanym z bóstuem.

Obraz kochanki nie jest jednoznaczny. Jeśli węże stawiają ją po stronie szatana, to zakrywający jej łono lotos oznacza czystość i niewinność. (Ale lotos to także atrybut licznych bóstw, np. wyrastający $w$ mitologii indyjskiej z pępka Wisznu symbolizuje rozwój uszechświata, uydobywającego się $\mathrm{z}$ centralnego Słońca ${ }^{141}$ ). Ambiwalentny obraz kobiety przekłada się na ambiwalentne zachowanie mężczyzny. Bohater miota się między rolą kata, sadysty, pragnącego zadawać ból tej, którą pożąda, a niewolnika okazującego ukrzyżowanej czułośćc ${ }^{142}$.

Na krzyż ją ubić każę, na krzyż, poutarzał z błędnym uśmiechem.

$[\ldots]$

Pochuycili ją w ramiona, podrzucili na hebanowe drzewo krzyża; kat ujął jej ręce, podtrzymano ją $\mathrm{w}$ pasie, rozległ się stukot młota...

Lecz $\mathrm{w}$ tej chwili ryknął król z bólu, jak rozszalałe zwierzę.

Zeruał ją z krzyża, tulił jak dziecko w suych ramionach, po szatach jego ściekała krew, całował jej rany [...]... (A 410-411)

${ }^{140}$ Jako karę za nieposłuszeństwo Bóg zesłał na Izraelitów śmiercionośne węże ogniste, jednak za ustawiennictwem Mojżesza kazał sporządzić miedzianego węża i umieścić go na uysokim palu - każdy ukąszony, który na niego spojrzał, był zachowany od śmierci (zob. M. Lurker, op. cit., s. 253-254).

${ }^{141}$ Zob. Lotos [hasło], [w:] J. Cirlot, op. cit., s. 235-236; Lotos [hasło], [w:] W. Kopaliński, op. cit., s. 205-206.

${ }^{142}$ W. Gutouski, Mit - Eros - Sacrum, s. 189. 
Nieco odmienny charakter ma ukrzyżowanie ukochanej niewolnicy króla, o którym mowa u poemacie Nad morzem. W mniejszym stopniu jest ono wynikiem męskich obsesji seksualnych (konfliktu id z superego: miłosnych pragnień z obowiązkami, jakie narzuca rola władcy), a bardziej próbą przebłagania słońca, które przestało ziemię żywić, a zaczęło ją uypalać. Ukrzyżowanie zostaje wymuszone przez lud („Daj nam białą niewolnicę! Na krzyż z nią! Na krzyż! Słońcu w ofierze!” - Nm 303), a król uznaje potrzebę spełnienia żądania poddanych. I chociaż moment zawieszenia na krzyżu zostaje przemilczany, można się domyślać, że ofiara została spełniona. Jej metaforyczną, acz znaczącą zapowiedzią jest widok niewolnicy pokornie ustępującej na taras „z rękoma na krzyż” (Nm 303). Potwierdzeniem ukrzyżowania królewskiej ukochanej - jego animy, drugiego bieguna jego psychiki - jest kara spadającą na lud z ręki władcy: ukrzyżowanie tysięcy poddanych.

Transformacjom uwypuklającym dominację seksualności Przybyszeuski poddał także obraz Sądu Ostatecznego. Wpisał się tym samym na długą listę modernistów, którzy włączali w kosmiczny porządek swe dramaty egzystencjalne, by wyeksponować tragizm i absurdalność człowieczej kondycji. Apokalipsa, w zdecydowanej mierze odcięta od treści religijnych, stała się wygodnym medium katastroficznej wyobraźni epoki, wyrażającym przerażenie światem lub - jak w przypadku Przybyszeuskiego - ludzkim wnętrzem ${ }^{143}$.

Wizja dies irae nawiedza bohatera De profundis i nasila się w miarę, jak mężczyzna coraz bardziej pożąda suej siostry. Neurotyczna osobowość projektuje własne lęki, przede uszystkim obawę przed incestem, w obrazach zbliżającego się końca świata. Ich źródłem nie jest - jak wykazano we ucześniejszym podrozdziale - sama biologiczna uspólnota krwi, lecz świadomość silnego tabu kazirodztua w kulturze, a w jeszcze większej mierze wewnętrzny nakaz wierności żonie. Zarazem chaos, guałtowność i konuulsyjność Sądu Ostatecznego odpowiada intensywności uczucia między rodzeństwem, które rozpoznaje siebie wśród potępieńców. Pochodowi nie towarzyszy atmosfera skruchy i żalu za grzechy. Ludzkość śpiewa co prawda po łacinie antyfonę „Do Ciebie wzdychamy, wygnańcy, synowie Ewy. Jęcząc i płacząc na tym łez padole”, jednak zamiast błagania o litość jest wściekłość, pragnienie zemsty, potrzeba niszczenia i kopulacji, jak podczas słynnego Kasprowiczowskiego Dies irae. I jak w arcydziele katastroficznej hymniki, ludzkość podnosi bunt przeciuko niebu, oskarżając Boga (a może raczej apokaliptycznego Sędziego, którym u utworze Przybyszeuskiego jest

${ }^{143}$ Młodopolskie wersje apokalipsy omówili: H. Filipkouska, $Z$ problematyki mitu $w$ literaturze Młodej Polski, [w:] Problemy literatury polskiej lat 1890-1939, red. H. Kirchner i Z. Żabicki, Wrocław 1972, W. Gutouski, Z próżni nieba ku religii życia. Motywy chrześcijańskie w literaturze Młodej Polski, Kraków 2002, Dariusz Trześniouski, $W$ stronę człowieka. Biblia w literaturze polskiej (1863-1918), Lublin 2005. 
Chrystus) o to, że karze sue dzieci, z natury zrodzone jako grzeszne ${ }^{144}$. Co więcej, dramatyczny krzyk „Zbrodniarzu! Za co nas karzesz, zbrodniarzu?" w oryginale niemieckim wydobywa się z ust Agaj, występującej jako reprezentantka wszystkich cierpiących, zrozpaczonych, ogarniętych wewnętrznym chaosem i sądzonych za „wing niezawinione”, zaprojektowane przez Boga, który dopuścił istnienie $\mathrm{zła}^{145}$.

Kolejne odsłony wizji końca świata przeplatają się w wyobraźni bohatera z obrazami pieszczot, jakie wymienia z siostrą. Gdy tłum skanduje przeciwko Bogu, on:

[...] w niewypowiedzianej truodze rzucił się na nią - ciało jej pieniło się, zębami szarpała skórę na jego szyi, ugryzła się palcami w jego pierś. Ale był silniejszym. Żelaznym oplotem pokonał jej szał: dziki orkan burzy złamał się w długim, rzężącym jęku. (Dp 49)

Halucynacja, jakiej dośuiadcza bohater pod upływem sugestii zawartej w liście od żony i jeszcze przed pieruszym spotkaniem z Agaj, następującym po latach, powraca w końcowych partiach utworu. Mężczyzna znowu jest sam i - jak poprzednio - czyta list od połowicy. Tym razem ma już sposób na połączenie z siostrą - jest nim samobójstwo, oznaczające scalenie w żywiole wody. Jak wcześniej, pochód potępionych przypomina bezpostaciową masę „w strasznej, konwulsujnej kopulacji” (Dp 104). Uprawiające wyuzdaną miłość pary wirują wokół kobiety w szkarłatnym płaszczu, symbolizującej rozpustę i nieopanowaną chuć. Narrator następująco relacjonuje wrażenia bohatera:

Słyszał zwierzęce rżenie, jęki bolesnej męki rozrodczej; widział twarze upojone do szału ekstazą nieludzkich pragnień; widział ciała przeżarte jadem, pokryte ustrętnymi wrzodami; a u dole, gdzieś u dole ujrzał siebie samego, z krwawiącymi się, potrzaskanymi skroniami, z zaciśniętymi pięśćmi, wijącego się u przedśmiertnej agonii. (Dp 104)

Wizja ta szybko znajduje dopełnienie w samobójczym geście bohatera.

Wątki biblijne w najszerszym zakresie wykorzystał Przybyszeuski w powieściouym cyklu Dzieci nędzy. Losy i obsesje bohaterów zyskują tu analogię do dziejów postaci staro- i nowotestamentowych. Niewolnikiem i twórcą

${ }^{144}$ Łączące się z przejętym po romantykach problemem teodycei pytanie unde malum? moderniści rozstrzygali bezuzględnie, obarczając winą Boga. Natomiast przypisanie przez Przybyszeuskiego roli Sędziego Chrystusowi jest zabiegiem u Młodej Polsce uyjątkouym. Na przykład w Hymnach Kasprowicza karzący i głuchy na ludzkie wezwania Bóg-Sędzia jest uyraźnie oddzielony od postaci Chrystusa przypatrującego się człouieczej boleści (więcej nt. tego problemu zob. H. Filipkouska, op. cit. oraz D. Trześniouski, op. cit.).

${ }^{145} \mathrm{Na}$ tę ważną semantyczną różnicę między wersją niemiecką utworu a jej autorskim przekładem na język polski zuróciła uwagę Krystyna Kralkouska-Gątkouska (K. Kralkowska-Gątkouska, Zagadki „De profundis” Stanisława Przybyszewskiego, s. 157). 
tych odniesień, wynikających z głębokiej potrzeby ucieczki w życie duchowe od niezrealizowanej miłości, jest przede uszystkim Jan Krywło, mianowany przez swego brata Gustawa, fanatyka ogarniętego religijną manią o źródłach buddyjskich, wybawcą i odkupicielem win, jakie spadły na rodzeństwo Krywłów w wyniku amoralnych postępków rodzica. Bohater poddaje się sugestiom i w rezultacie widzi siebie jako coraz to nową biblijną postać, co świadczy o chwiejności i dezintegracji jego tożsamości. Najpieru przeistacza się w pretorianina - Tytusa Salustiusza - który sprzeniewierza się rozkazowi pojmania Syna Bożego, ulegając namowom żony Poncjusza Piłata, Cecylii Metelli ${ }^{146}$, pragnącej ocalić Chrystusa od męczeńskiej śmierci. Jego decyzja ma podwójne dno i wiąże się z podwójnym rozpoznaniem: ukochanej Jaduigi w Metelli i siebie samego w Jezusie. Pełne miłości spojrzenie, jakim Jadwiga-Cecylia obdarza Jana-Chrystusa, sprawia, że Krywło-Salustiusz nie jest $w$ stanie niczego kobiecie odmówić. Odnajduje Zbawiciela i nakłania go do ucieczki, proponując mu własne przebranie. Chrystus nie może jednak przystać na podobny układ, a i Tytusa przerasta rola odkupiciela, podjęta uszak nie dobrowolnie, lecz na prośbę kobiety. Chwila wahania wystarczy, by dostęp do Jezusa uzyskał Judasz, pocałunkiem wydający Mesjasza rzymskiej straży. Wtedy okazuje się, że Iskariota to także Jan, zazdrosny o uczucie ukochanej i troskę, jaką darzy ona Syna Bożego. Wydanie żydouskiego króla odbywa się uięc na podłożu rywalizacji.

W kolejnej obłąkańczej wizji Jana zmienia się obiekt owej zazdrości. Staje się nim, zamiast małżonki prokuratora Judei, Maria Magdalena namaszczająca stopy Chrystusa wonnymi olejkami.

[...] moja dusza skręciła się u strasznym skurczu bólu, gdym widział, jak złotym jedwabiem tuych włosów ocierałaś jego nogi, jak usta twe gorącymi całunki spoczywały na miejscu, przez które niezadługo rdzawe, długie, jak palec grube gwoździe przedrzeć się miały, przez te wąskie, piękne, białe stopy Boga!

$[\ldots]$

Teraz przylgnęłaś całym obliczem do jego stóp, owinęłaś nogi jego wężami twych złotych splotów - tyś zapomniała, że on Bogiem, że on ciebie nie uidzi - jak łasy kot pieścisz jego stopy i całujesz - w obie ręce ujęłaś jego białe, piękne stopy - nie czyń tego, Magdalo, nie czyń, pierś tua naga się uzdęła - pręży się twoje ciało - dreszcz przebiegł przez twój grzbiet, ściągnęły się mięśnie tuych bioder - zaprzestań Magdalo - zaprzestań! (Dn I, 122-123)

Maria Magdalena pożąda Jezusa jak kobieta pożąda mężczyzny. Jej obraz nakłada się w uyobraźni Jana na wizerunek Jadwigi i drażni nerwy bohatera. Zdrada, jakiej dopuszcza się on w jednym ze swoich wcieleń wobec Mesjasza, prowadzi na zasadzie analogii do kolejnej metamorfozy: w bratobójcę

${ }^{146}$ Cecylia Metella (2. połowa I w. p.n.e.) była u rzeczywistości żoną rzymskiego wodza Marka Krassusa. Imię żony Piłata nie pojawia się u Piśmie Świętym; późniejsza tradycja nadała jej imiona Klaudia Prokula. 
Kaina. Podstawą owej inkorporacji także jest miłość do Jadwigi - własnej bratowej. W myślach Jan tak zuraca się do jej męża, a suego brata Zdzisława, sugerując androgyniczną jedność z ukochaną:

Wybacz mi, jam umiłował oblubienicę twoją - przecz-że nie będziesz guałcił jej twoją miłością, kiedy skrzydła jej tęsknoty wokół mnie biją, a nasze ręce, co się tysiąckrotnie gubiły, błądziły, znowu się odnalazły, jak nam było od początku przeznaczone.

$[\ldots]$

I ja, Kain, zabiłem Abla. (Dn I, 112)

Jan nie posuwa się do morderstwa, jednak widzi w Zdzisławie przeszkodę na drodze do szczęścia i to uystarczy, by silnie odczuł ciążące na sobie kainowe piętno. Nawet po śmierci nieuygodnego brata i męża kochająca się para nie ma szansy na udany związek - blokują go nieszczęsne rodzinne więzy, ciążące przede uszystkim na psychice Jadwigi. Jan, ostatecznie odrzucony przez ukochaną, popełnia więc samobójstwo, topiąc się w nurtach Sekwany. W ostatnich chwilach życia zaczyna zdawać sobie sprawę z zatraty własnego „ja”, do której doprowadziła identyfikacja $\mathrm{z}$ wieloma sprzecznymi postaciami ${ }^{147}$ :

[...] coraz głośniej w nim dziunie sprzeczne myśli krzyczały i wzajem się kłóciły - i coraz silniej uczuwał już nie rozdwojenie $w$ sobie, ale jakby się na setki części był rozłupał.

Jakby dźwigał na suym karku tysiące głów, z których każda innymi myślami myślała, innym życiem żyła. (Dn I, 208)

W drugiej części dylogii Przybyszeuski poutórzył schemat rodzinnego trójkąta miłosnego: kochającego Jadwigę Adama darzy młodzieńczym uczuciem jego przyrodnia siostra Zosia, najmłodsza z rodu Krywłów. Dojrzewająca fizycznie i emocjonalnie panna nie potrafi poradzić sobie z ciężarem chorej namiętności. Zaczyna nienawidzić niegdyś uwielbianej bratowej i nie daje wiary zapewnieniom Drzazgi, jednego z wielu bękartów starego Krywły, o łączącym ich pokrewieństuie. Ujścia dla niezrealizowanej pasji szuka m.in. w nocnej galopadzie na dzikim, nieujeżdżonym ogierze, w której jako opiekun towarzyszy jej Adam, spełniający we dworze funkcje gospodarskie. Dla obojga jeźdźców szalony pęd jest symboliczną ucieczką przed własnym „ja”, przed nieujarzmionymi emocjami, „,bo straszna burza w nich się rozpętała, ta, która uszystko niszczy i szatańskim strychulcem wszelkie istnienie z niczem zrównywa" (Dn II, 125). Lęki owocują wizjami,

${ }^{147} \mathrm{~W}$. Gutouski podsumouująco stwierdza, że klęska zbawczego dzieła Jana to efekt sprzeczności: Jan „chcąc uyzwolić rodzinę spod uładzy niszczącego fatum, wyrwać ją z kołourotu zła, traktuje zarazem swą misję - niczym u scenariuszu freudouskim - jako kamuflaż własnych pragnień seksualnych”. W. Gutouski, Konstelacja Przybyszewskiego, Toruń 2008, s. 120 . 
jakie tworzy opętany obsesjami umysł. W wyobraźni Drzazgi przemierzany ułaśnie step przemienia się u scenę katastroficznego spektaklu.

Ozwał się ryk trąb, a powietrze zadrżało, jak gdyby wszechświat cały wił się w konwulsjach.

Zatrąbił pieruszy z apokaliptycznych aniołów: a stał się grad i ogień zmieszany z kruią...

Zatrąbił utóry, a uszelka trawa na dzikim stepie u ogniu stanęła [...]

I zatrąbił trzeci anioł i spadła z nieba guiazda wielka gorejąca, jako pochodnia, i widział i słyszał jednego anioła, mówiącego głosem wielkim: biada, biada mieszkającym na tej ziemi - biada domowi, dla którego głos trąb ostatnich zagrzmi. (Dn II, 126-127)

Urojenia Adama przebiegają zgodnie ze scenariuszem wzorowanym na Apokalipsie św. Jana. Bohaterami tego „prywatnego” końca świata - rozgrywanego wśród ryku trąb, trzęsienia ziemi, zaciemnienia słońca, pokrycia się księżyca krwią i spadających guiazd ${ }^{148}$ - są członkowie naznaczonego nienawiścią, grzechem, szaleństwem i degeneracją rodu Krywłów. Straszliwy sąd obejmuje na początek zalanego krwią starego Krywłę, za którym gonią Sumienie, Zgroza i Przerażenie. ,[...] będziesz męczony w ogniu i siarce przed obliczem tych, których spłodziłeś na trud i mękę i przekleństwo" - grozi mu anioł (Dn II, 128). W infernalnej przestrzeni pojawia się następnie Salomea - „wielka uszetecznica” dosiadająca „szkarłatno-czeruonej bestii rozpusty". I jak w Janowym Objawieniu nowe, święte Jeruzalem, będące symbolem odnowy świata po zagładzie, wzniesione jest na fundamentach z duunastu rodzajów kamieni szlachetnych ${ }^{149}$, podobnie w projekcji Adama Sala ozdobiona jest klejnotami nieczystości i uszeteczeństwa.

A ozdobiona była jaspisem chuci, szafirem kuszenia, szmaragdem zdrady, chalcedonem niestałości.

I ozdobiona była sardoniksem opętania, sardiuszem szału płciowego, chryzolitem przesytu, berylem zimnego okrucieństwa, topazami wyuzdanych a bezpłodnych rozkoszy, ametystami obmierzłego wstrętu, hiacyntami czystych pragnień i onyksami rozpacznych upadków. (Dn II, 129-130)

Zbigniew waży losy przeznaczonych śmierci, Gustaw proroczym głosem zuiastuje karę, jaka dosięgnie splamiony nieprawościami dom Krywłów, Zdzisław, siedzący pod krzyżem na rozstajnej drodze, przestrzega przed powrotem do Dzierżan. Jako Zuycięzcę na białym koniu, unoszącego w dal Jaduigę, widzi Drzazga Jana. Jednak przyrodni brat nie ma mocy ocalenia kogokolwiek, jest tylko „kiepskim Chrystusem”, czego dowiodły jego wcieleniowe wizje

${ }^{148} \mathrm{O}$ takich kataklizmach, zuiastujących dzień gniewu Bożego, jest mowa, gdy Baranek otwiera pieczęcie (Ap 6, 12-13).

${ }^{149} \mathrm{~W}$ Apokalipie śu. Jana duunastka jest liczbą dopełnienia. 
opisane $u$ pieruszej części dylogii. Kochająca się para upada więc $w$ przepaść i utedy Adam uśuiadamia sobie, że nieuiasta, o którą rywalizowali trzej bracia Krywło, była dla przeklętego rodu ratunkiem i pocieszeniem, „przybytkiem Bożym, w którym splamieni wszelką zbrodnią i uszeteczeństuem oczyścić się zapragnęli” (Dn II, 134). Siła zła okazuje się jednak niepokonana. Jaduiga, ostoja dobra, łagodności i życzliwości, jedyna postać tego dusznego dramatu, która przybyła z zewnątrz i którą każde z rodzeństua chciało uczynić odskocznią do lepszego życia, pada ofiarą atmosfery zbrodni i obłędu. Nawet miłość, którą ją obdarzano, niszczy ją, uysysa z niej siły życiowe. Ta tragiczna prawda unaocznia się Drzazdze w następującym obrazie:

Cały przeklęty ród Krywłów ćwiartował białą postać Jaduigi.

Rzucił się Adam Jaduidze na ratunek, ale za późno. Groby się rozstąpiły, cmentarna ziemia schłonęła ród Krywłów, z których każden miał na czole pieczęć przekleństwa, zbrodni, obłędu, potępienia - a setki rąk uciągnęło przemocą Jaduigę za sobą.

[...] tylko jeszcze Zosia tańczyła w opętanym szale na grobach... (Dn II, 137)

Te katastroficzne wizje zapowiadają śmierć Jaduigi z ręki zazdrosnej, histerycznej Zosi (upostaciowania piekielnego ducha rodu) oraz unicestwienie szlacheckiej posiadłości, którą ostatecznie Adam podpali. Ogień trawiący majątek Krywłów niszczy co prawda siedlisko zła i cierpienia, nie ma chyba jednak mocy oczyszczającej.

Silne emocje połączone z przymusem autoanalizy pozwalają bohaterom Przybyszeuskiego odkryć własne mare tenebrarum, ale też zmuszają do zmierzenia się z popędami, których realizacji domaga się natura, a które represjonuje kultura. Efektem tych egzystencjalno-erotycznych rozterek są neurozy i halucynacje. Pojawiające się w nich obrazy Sądu Ostatecznego, ukrzyżowania czy modlitewnej zadumy stanowią wyraz wyparcia nieakceptowanych społecznie potrzeb seksualnych i służą to uwzniośleniu, to znów degradacji życia uczuciowego i płciowego człowieka. Wykorzystane przez autora symbole i motywy nie odsyłają do czystych przeżyć religijnych, ale wyrażają potrzebę włączenia transcendencji w ziemskie bytowanie.

\section{Symbolika żyuiołów}

Żyuioły - zułaszcza ognia i wody - były u Młodej Polsce częstym elementem topiki miłosnej. Odnosiły się zarówno do uczucia idealistycznego, jak i niszczącego. Miały podobnie ambiwalentne znaczenie: ogień palił, ale i oczyszczał, woda symbolizowała rozkład, odrodzenie i oczyszczenie. 
Żywioły są u twórczości Przybyszeuskiego istotnym elementem obrazowania kosmicznego, ściśle powiązanego z doświadczeniem cielesności. Ciało ulega metamorfozie pod wpływem żyuiołów.

Och, ponieś $[\ldots]$

Gdzieś w bezatmosferyczne światy, gdzie kształty moje stopnieją jak młody śnieg na południouym słońcu, gdzie się z uszechświatem zleję i jak lejąca się lawa meteora w kosmiczny ocean spłynę. (Rae 81)

Śuiatło wlewa się do mego gardła, śuiatło przepala moje ciało, chłonę śuiatło, duszę się od niego - stapiam się z nim. (W 173)

Dua kruawe światła na morzu. Dua kruawe słońca, w których dwie wieczności się stopiły - to Tuoje oczy... (Nm 287)

Widziałem Cię, jak dumałaś nad brzegiem morza, rozwiana w cichych pieśniach fal [...]. $(\mathrm{Nm} 315)$

Przeistaczanie $\mathrm{u}$ żywioł, stapianie się z nim oznacza dezintegrację osobowego ,ja”, zawiera zatem element destrukcji i autodestrukcji. Niemniej mimo dramatycznego przebiegu (przepalanie ciała, duszenie się) przemiany te mają charakter pozytywny: przenoszą jednostkę na inny poziom ontologiczny, włączają ją w nieskończony rytm życia, czynią elementem wiecznego Kosmosu, nadają jej istnieniu metafizyczny sens.

Barierę między energią kosmiczną a człowiekiem znosi przede uszystkim zagęszczona symbolika Nad morzem. Kluczowe dla utworu znaczenia konstytuują się w zestawieniu żywiołu wody, reprezentowanej przez obrazy morza, z żywiołem ognia, uprowadzonego za pomocą semantyki solarnej. Bohater poematu, potężny król, to syn i wyznawca słońca, o którym mówi: „kolebka moja, matka moja, moje święte łono” (Nm 290). Cała moc uładcy wynika $\mathrm{z}$ uprzywilejowanej pozycji ulubieńca słońca, które - traktowane nie tylko jako żywioł, ale i bóstwo ${ }^{150}$ - „bezgraniczne szczęście i bogactua bez miary sypało szczodrą dłonią na syna swego" (Nm 290), czyniąc mu poddaną naturę i guarantując panowanie nad uszelkimi obszarami, gdzie docierały jego promienie. Poza upływami króla pozostaje zatem „kraj cieni i mroku” (Nm 291), skąd pochodzi przywieziona jako łup księżniczka. Dualizm światło - mrok jest dość czytelny i ugruntowany $w$ tradycji. Słońce to w utworze odpowiednik duchowej jasności, dyscypliny, moralności, porządku społecznego, intelektu; wyraz tego, co dostępne ludzkiemu poznaniu, możliwe do ogarnięcia przez świadomość. Kraina cienia oznacza ukryte podziemia duszy, sferę nieświadomego; to druga strona osobowości,

${ }^{150}$ Kult boga Słońca rozwinął się przede uszystkim w Egipcie (Słońce jako Ra czy prawe oko Horusa było bogiem najważniejszym), Azji Zachodniej, Meksyku i Peru. 
alter ego ${ }^{151}$, wobec czego staje się jasne, że ukochana niewolnica stanowi część duszy bohatera, jego animę.

Mroczna, głębinowa strefa psychiki intryguje, ponieważ odsłania nowy wymiar bytu, król pragnie więc za wszelką cenę uchronić dziewicę przed zagrażającym jej blaskiem słońca. „Kochałem Cię - Ciebie jedyną - i w strasznej truodze czuwałem nad Tobą, by mi Cię słońce nie zabiło" - wspomina (Nm 294). Sprowadza do podziemnych komnat drogocenne kamienie, które sztucznym, odbitym światłem przypominają ukochanej jej kraj. Buduje dla niej nowy świat z duunastu rodzajów klejnotów na wzór niebiańskiej Jeruzalem z wizji św. Jana, u której także element mineralny przeważa nad rajską przyrodą. Kochanka żąda jednak większego wyrzeczenia - na jej prośbę uładca przeklina patronujący mu żywioł, chroniąc się z ukochaną w wybitym kosztownościami „ciemnym grobie pałacu” (Nm 299). W akcie zemsty słońce zsyła na jego państwo mór i głód.

Wypalało zboże na polach, suszyło rzeki i jeziora, bujne pastwiska czerwieniały spalone gdyby jedna zgangrenowana rana, ciało ludu [...] odpadło, strawione ogniem, w ropiejących się ochłapach od kości [...]. ( $\mathrm{Nm} 301)$

Krwawe solarne bóstwo domaga się ofiary w celu przebłagania ${ }^{152}$. Niewolnica musi zostać umęczona, by ziemia zaczęła wydawać owoce, a uładca porzucił rolę dekadenta i „realizował się w czynie" ${ }^{153}$. Księżniczka wychodzi więc na nasłoneczniony taras, by poświęcić sue życie. „[...] stała się tak białą, że się u słońcu rozpływać zdawała [...]: U nóg mych padła bez życia" - relacjonuje król (Nm 304).

Chociaż zarówno jasność, jak i mrok mają konotacje transcendentalne, są przeciwieństwami, których nie sposób uzgodnić. Miłość nie realizuje się wyłącznie ani $w$ pod-, ani w świadomości. Świadomość i nieświadomość, kobiecość i męskość, czyn i medytacja to aspekty trudne do pogodzenia, a ich sprzeczne znaczenia uniemożliwiają uczuciowe spełnienie.

Próba miłosnej syntezy zostaje podjęta w kolejnych rapsodach poematu. Zmienia się tylko medium - tym razem jest to morze. Nierozerwalny związek kobiety i żywiołu podkreślony został metaforyczne w zainscenizowanym w wyobraźni mężczyzny rytuale zaślubin:

\footnotetext{
${ }^{151}$ Zob. Cień [hasło], [w:] J.E. Cirlot, op. cit., s. 98-99.

${ }^{152}$ Na zabójczy aspekt słońca zurócił uwagę Eliade: „Słońce pociąga za sobą, »uysysa« dusze żyjących $\mathrm{z}$ taką samą łatwością, z jaką $\mathrm{w}$ charakterze przewodnika prowadzi dusze zmarłych poprzez »słoneczne wrota« na Zachód" (M. Eliade, Traktat o historii religii, tłum. J. Wierusz-Kowalski, Warszawa 1966, s. 47).

${ }^{153}$ W. Gutouski, Nagie dusze..., s. 250.
} 
[...] z wolna rozkwita wokół Ciebie u skrami tryszczącym przepychu ślubny pierścień morza $^{154}$.

Kołysze się u Tuych stóp, odczepia się od wód, owija Cię, wznosi się kręgiem u górę, uplata się w Tue ułosy i jakby diadem, ukuty ze światła księżyca i promieni guiazd, owieńcza Twe czoło. (Nm 317-318)

Fakt, że przez zaślubiny z Oblubieńcem-morzem kobieta staje się częścią natury, jeszcze bardziej zbliża do niej narratora-bohatera. Mężczyzna odkrywa, że jest synem morza, zaś jego dusza „toć to morze samo” (Nm 327).

Teraz dopiero pojąłem, że od samego początku było we mnie i ze mną, krew mojej krwi, moje dziecko, siostra i oblubienica moja:

Morze!

I nikt tak go nie kochał, jak ja je kochałem. (Nm 324)

Mare tenebrarum zostało połączone $\mathrm{z}$ elementem kosmicznym. Indywidualność roztapia się w żywiole, a relacje osobowe (kobieta - mężczyzna) zastępuje uspólnota materii. Miłość bohatera i jego wybranki uzbudza jednak zazdrość morza, stłumioną dopiero ofiarą kobiety, która po raz kolejny oddaje swe życie żywiołowi. Uczucie nie jest mimo to niespełnione. Rzucając się $\mathrm{w}$ fale, oblubienica łączy się bowiem z ukochanym, który rozpoznał u morzu własną duszę. Pogrążenie w odmętach znamionuje pourót do preegzystencjalnej jedności ze uzględu na odrodzeńczy aspekt wody. Serce kobiety okazuje się jednocześnie sercem morza, zdolnym poruszyć jeszcze jeden żywioł - ziemię:

I serce rosło - rosło, jednym zamachem rozerwało gęstą noc i gdyby piorun wpadło do morza.

A teraz puka cała ziemia - drży - trzęsie się. Coraz głębiej wwierca się serce u jej ciemne unętrze i oto rozuiera się dno morskie i uszystka krew ziemi, uszystkie rzeki, jeziora i oceany spływają do serca ziemi. (Nm 330)

Po ziemi przychodzi pora na powietrze. Androgyniczna miłość znajduje wyraz w obrazie wzlatującego morza, unoszącego bohatera w przestworza.

${ }^{154}$ Określenie „ślubny pierścień morza” jest peryfrazą zurotu z dzieła Nietzschego Tako rzecze Zaratustra, którego fragment ukazał się w „Życiu” w 1899 r., najpraudopodobniej - jak twierdzi Bożena Wojnouska - w tłumaczeniu samego Przybyszeuskiego. Fragment ten brzmi następująco: „O, jakże bym mógł nie pożądać wieczności i ślubnego pierścienia nad pierścienie, pourotu pierścienia. Nigdym jeszcze nie spotkał kobiety, z którą bym dzieci mieć pragnął, chyba tę ukochaną, albowiem ciebie kocham, wieczności” (F. Nietzsche, Siedem pieczęci (Albo pieśń o tak i amen), „Życie” 1899, z. 1. Cyt. za: B. Wojnouska, „Nad morzem” Stanisława Przybyszewskiego. Mistyka i pteć, [w:] Stanisław Przybyszewski. W 50-lecie zgonu pisarza, red. H. Filipkowska, Wrocław 1982, s. 120). 
Za sprawą transformacji łodzi w ptaka mężczyzna odrywa się od „dna” (czyli ziemi) i uzbija ku niebiosom, ku tajemnicy ${ }^{155}$. Ten lot mocy - wywołany transfiguracją świadomości - jest doświadczeniem wolności, przekroczeniem granic poznania oraz barier cielesności, wyzwoleniem od substancjalnego ciężaru. Jest przekroczeniem przeciwieństu (kobiecości i męskości, ziemi i nieba, materii i idei, świata ludzkiego i świata boskiego), zniesieniem dwoistości właściwej kondycji ludzkiej, w celu zaznania rzeczywistości absolutnej ${ }^{156}$. Stanowi najpełniejszą i najbardziej interesującą w twórczości Przybyszeuskiego próbę syntezy pierwiastka męskiego i żeńskiego z elementem kosmicznym, transcendentnym. Jedność Ja-Ty-Żywioł sugeruje pogodzenie człowieka ze światem, syntezę seksualności i metafizyki ${ }^{157}$. Lot, będący przekroczeniem barier egzystencji, miłosnym zjednoczeniem dusz oraz ontologiczną unią z uszechnaturą, pojawia się także w Odwiecznej baśni. Wspomina o nim Sonka w rozmowie z Królem:

[...] dusza twa skrzydła rozpostrze od jednego krańca nieba do drugiego, a ja na nich płynę [...] w nieziemskim zachuycie i upojeniu, wzbijam się z tobą ponad szczyty ziemi, ponad obłoki, i płynę, i płynę, i oczy wlepiam w przeciwległe brzegi, i chłonę piękno tego innego, wiekuistego Bytu. [...] A gdy tak uzbijam się wraz z tobą wyżej i uyżej, tak że mogłabym, zda się, guiazdy z nieba strącać i rzucać je w ciemności, by w nich się u słońce jedno stopiły, wtedy czuję takie rozkosze uniebowzięcia i takie nieziemskie wyzwolenie, i tak ogarniam uszystkie światy i słońca, że wobec tego to królestwo nasze wydaje mi się tak małym, tak nikłym, że ogromem przy nim jest ten pyłek złota, jakim ma szata obsypana... (Ob 55-56)

Walor jednoczenia przypisuje morzu rodzeństwo z De profundis. Agaj snuje przed bratem wizję połączenia niemożliwego w śuiecie oficjalnej kultury, piętnującej relacje kazirodcze: „-- Patrz! Widzisz morze? Och, jakby było słodko i dobrze leżeć w twoim objęciu na jego dnie” (Dp 101). W odpowiedzi na jej słowa bohater decyduje się stopić z żywiołem utożsamionym z siostrą, która „sama stała się morzem” (Dp 104), i popełnia samobójstuo. Wyskakuje przez okno, z którego rozciąga się widok na morze, ale jego ciało nie dotyka wody. „Runął w dół” (Dp 105) - zamyka utwór narrator, obuieszczając klęskę postaci. Morze ma tutaj charakter regresywny, jest

${ }^{155}$ Motyw ulatywania i transformacji kojarzy się z wyobrażeniami duszy opuszczającej ciało. W ouych obrazach dusza często posiada skrzydła i upodabnia się do ptaka. W kulturach szamańskich kapłani za życia mogą zmieniać się w ptaka podczas magicznego lotu do innych śuiatów.

${ }_{156}$ Zob. M. Eliade, Obrazy $i$ symbole: szkice o symbolizmie magiczno-religijnym, thum. M. i P. Rodakowie, Warszawa 1998, s. 95-96.

${ }^{157}$ Zob. W. Gutouski, Nagie dusze..., s. 260. Interpretacja poematu dokonana przez badacza jest ważnym punktem odniesienia dla wszystkich kolejnych odczytań utworu. 
chaosem; pochłania, ale nie jednoczy. Od początku trudno zresztą mówić o mistycznej syntezie, skoro uczucie rodzeństua przebiega konuulsyjnie, w scenerii katastroficzno-orgiastycznych wizji.

W obu poematach to morze, jako element przejściouy i pośredniczący między sferą form (ziemia, element stały) a bezkształtnością (powietrze, gaz), ma być pierwiastkiem jednoczącym kochanków (woda rozmywa kształty, pozbawia jednostkowej tożsamości). Jednak Słońce, jako symbol nieskończoności ${ }^{158}$, także towarzyszy opisom powrotu do pierwotnej Dwój-Jedni, tj. połączenia zagubionych przed wiekami połówek - męskiej i żeńskiej. Jest ono przede uszystkim motywem przewodnim oraz istotnym elementem semantycznym Odwiecznej baśni, dramatu historycznego, którego akcja rozgrywa się „w zaraniu dziejów” (Ob 15). Funkcjonuje ono jako synonim czystych, pierwotnych wartości, takich jak piękno, dobro, prawda i oczywiście miłość (także w znaczeniu agape), i usytuowane jest w manichejskiej opozycji do ciemności, oznaczającej zło, fałsz i marność rzeczywistości ziemskiej. Reprezentantami nieskażonego świata praidei (harmonii i pełni) są miłujący się Sonka i Król, którzy - jak Prometeusz - pragną nieść ludziom ogień i światłość:

Nasze dusze królują w chwale ognia pierwotnego, z którego się wszystkie inne wyłoniły - ale tamte odbiegły w ciemnie, gdzie blask swój straciły, gdzie tarzają się u błocie, zapomniały o swej piękności - a my je z powrotem do ich ojczyzny sprowadzić mamy - w ogniu oczyścić i stopić... (Ob 57-58)

Siłę do czynu daje obojgu miłość, która jest światłem i ogniem.

Jam silniejszy teraz, bo twoja miłość płonie mi światłem jaśniejszym jak uszystkie sońca, bo miłość ku tobie takim ogniem u krui mi kipi, że nie znam żadnych trudów, których bym unieść nie zdołał, żadnych przeszkód, których bym usunąć nie był w stanie. Ciemna noc była we mnie, tyś mnie wyruała z jej odmętów na niebosięgłe wyże, z których słoneczne oblicze Boga oglądać mogłem (Ob 54)

- deklaruje Król. Miłość nie zbawi jednak świata. Więcej - żeby ją uratować, przyjdzie bohaterom od śuiata uciec.

W kontekście tych rozważań warto jeszcze raz zwrócić uwagę na cytowany już u rozprawie fragment Androgyne:

Tak!

On i ona mieli pourócić do uspólnego łona, by zlać się w to jedno ognisko, w to jedno śuięte słońce.

${ }^{158}$ Zob. W. Kopaliński, Stońce [hasło], [w:] idem, op. cit., s. 387. 
Tam się dokona cud; wielki, nieziemski cud:

będzie jednym i niepodzielnym,

będzie Bogiem uszechjedynym [...] -

odsłonią mu się niepojęte tajemnice, rozwiążą się uszystkie cele i przyczyny bytu [...]. (A 459-460)

Przybyszeuski po raz kolejny - na wzór wielu pierwotnych religii - powiązał słońce z obrazem boga. Co więcej - wszelkim emanacjom światłości przypisał boskie pochodzenie. Z tego powodu w idealistycznym, androgynicznym ujęciu kobiecie towarzyszy jasność o nieziemskim pochodzeniu. Blask wyraża ideę przebóstuienia, śuiętości kochanki, która prowadzi mężczyznę ku rzeczyuistości absolutnej i otwiera przed nim urota poznania. Żywioł ognia łączy się z żywiołem powietrza (w którym rozchodzi się światło), by objawić numinotyczny charakter owego misterium duszy ${ }^{159}$.

[...] i stało się śuiatło, dziune śuiatło [...].

I $\mathrm{w}$ tym bezświetlnym jaśnieniu widział, jak z wolna ustępowała na taras jego pałacu - Ona, Duch święty jego bytu oduiecznego, On-Ona. (A 445)

Kobieta niszcząca została natomiast interesująco utożsamiona $\mathrm{z}$ siłą ognia, powszechnego w topice erotycznej znaku pożądania seksualnego, libido $^{160}$. Na związek aktu seksualnego i pierwotnej techniki otrzymywania ognia zurócił uwagę Bachelard, poróunując „obiektywne doświadczenie pocierania dwóch kawałków drewna” oraz „bardziej pieszczotliwe pocieranie, które rozpala ukochane ciało” i argumentując, że „miłość jest pieruszą naukową hipotezą tłumaczącą obiektywną reprodukcję ognia"161. W Wyzwoleniu ogień rozpala w piecu Ada Karska. Gorące płomienie ogrzewają przemarzniętych zimową porą kochanków i obrazują łączącą ich guałtowną namiętność. „- Teraz tak napalę, że będziemy siedzieć jak u łaźni parowej” - mówi do Bieleckiego Karska, którą ,już sam widok ognia podniecal” (Mc II, 84). Moment rozpalania drewna odsłania jednocześnie demoniczną, niszczącą naturę bohaterki. Skłania ją do opowieści o kilku podpaleniach, jakich dokonała już jako nastolatka.

${ }^{159}$ Warto zurócić uuagę, że powietrze przepełnione śuiatłem stanowi w wielu obrazach religijnych tło, na którym umiejscowione są postaci świętych.

${ }_{160}$ Żar oblewający ciała partnerów jest skonwencjonalizowaną, obecną u literaturze od wieków oznaką guałtounej namiętności. Do tej metafory odwoływał się także Przybyszeuski: „Spojrzała na niego [Agaj na brata]. Tuarz jej drgała. Oczy jak zalane jakimś płomieniejącym żarem. Z wolna i chciwie wessała się oczyma w niego. Czuł, jak gorące płomienie zlewały mu się w krew" (Dp 57).

${ }^{161}$ G. Bachelard, Wyobraźnia poetycka, tłum. H. Chudak i A. Tatarkiewicz, Warszawa 1975, s. 41. 
- Widzisz, ja jestem urodzoną podpalaczką. Miałam czternaście lat, gdym po raz pieruszy opiekunowi stodołę podpaliła. [...] - ognia! więcej jeszcze ognia! - krzyczało coś we mnie. Miałam ochotę wykraść się, podpalić całą wieś na uszystkich czterech rogach, kazać pędzić bydło w ogień, by się tam na węgiel paliło i ryczało w przedśmiertnych bólach. (Mc II, 84-85)

Podobnie jak Karska, potęgę instynktu płciowego, od którego fatalnej siły nie sposób się wyzwolić, uosabia „ta trzecia” ze Śniegu - Ewa. To ona najczęściej pojawia się przy kominku, symbolizującym ciepło i bezpieczeństwo rodzinne, upatruje się w płonące drewno i podtrzymuje płomień ${ }^{162}$. Nie jest jednak strażniczką domowego ogniska, na wzór greckiej Hestii czy rzymskiej Westy, lecz jego burzycielką. Identyfikuje się z ogniem i spala Tadeusza wewnętrznie. Mówi do niego: „Rany u twoim sercu odnowiły się, lecisz w ogień jak ćma” (Ś 62). Gospodyni dworu, czyli Bronka, nie tylko ani razu nie chroni ognia przed zagaśnięciem, ale też nie zbliża się sama do paleniska. Wymienia co prawda z mężem pieszczoty przed kominkiem (siada mu na kolanach, tuli jego głowę do piersi, całuje jego oczy, bawi się jego ułosami), jednak dopiero wówczas, gdy zostaje tam podprowadzona. W tych chwilach intymności Tadeusz szuka spokoju, odpoczynku, regeneracji sił, jakie zapewnia upatrywanie się w ogień, Bronka natomiast unika ich, ponieważ buntuje się przeciuko roli ukoicielki. Rozstrojona zainteresowaniem męża dla Euy, zarzuca mu: , „...] we mnie burzy się uszystko na myśl, żem była dotychczas tylko twoim pieścidełkiem, twoją towarzyszką, z którą tak miło było gawędzić w tym piekielnym, przeklętym kątku przy kominie..." (Ś 96-97).

Rolę Bronki jako czynnika odnawiającego siły Tadeusza konstytuuje metafora śniegu. Bronka jest „białym, czystym śniegiem, który na zmarzłą grudę ziemi opadnie, ugrzeje, otuli tego trupa, dopóki nie odżyje, budzić się nie pocznie i z ciepłego już łona, z ziarn [...], nowe, świeże kiełki puszczać pocznie..." (Ś 114). Śnieg jest formą zamarzniętej wody, a kontakt z wodą „daje zawsze możliwość regeneracji: z jednej strony dlatego, że po rozpuszczeniu następują «ponowne narodziny», z drugiej zaś dlatego, że zanurzenie pomnaża potencjał życiowy i zapładnia" ${ }^{163}$. Wody mają charakter oczyszczający i odradzający: dezintegrują, niweczą formy i obmywają z win ${ }^{164}$. Tadeusz przez kontakt $\mathrm{z}$ wodą obmywa rany

${ }^{162}$ Sceny przy kominku analizował od strony gestyki bohaterów S. Mrazek, op. cit., s. 125-126. Interesujące, że Ewa, dorzucając drew do kominka, daje się uwieść hipnotycznej mocy ognia - patrzy u niego nieruchomo, nie słysząc, co się do niej mówi. Bachelard nazywał ten stan koncentracji marzeniem na jawie, możliwym dzięki dobroczynnemu działaniu ognia. Francuski filozof uskazywał też, że w kontekście ściśle seksualnym kominek uystępuje w opowiadaniach E.A. Poego (G. Bachelard, op. cit., s. 33-56).

${ }^{163}$ M. Eliade, Obrazy $i$ symbole, s. 177-178.

${ }^{164}$ Ibidem, s. 178. 
po destrukcyjnym zuiązku z femme fatale, do życia potrzebuje jednak intensywności, jaką zapeunia tylko ogień. Dlatego ulega kuszeniu Euy, zaś Bronka topi się w stawie (stanowiącym obok studni i źródła żeńską postać wody ${ }^{165}$ ). Nie bez znaczenia dla mitotwórczych znaczeń utworu jest fakt, że bohaterka oddaje sue życie wodzie stojącej i czarnej, którą moderniści - za Schopenhauerem - kojarzyli nieodmiennie ze śmiercią ${ }^{166}$. Dla Bachelarda taka posępna, uśpiona woda to śmierć, „która jest obok nas, przy nas, w nas" ${ }^{167}$, która jest naszym drugim imieniem. Utopienie w niej ( $w$ przeciwieństwie do zanurzenia $w$ wodzie żywej, płynącej, bieżącej) jest niczym innym jak ruchem w dół, autodestrukcją. Nie otwiera perspektyw odrodzeńczych i reintegracyjnych, ponieważ nie konotuje upływu czasu, a więc zmian. Staw czy jezioro reprezentują chwilę, która jest jednocześnie wiecznością, i unaoczniają śmierć jako zawsze obecną.

Symbolika żywiołów jest u Przybyszeuskiego pełna dynamiki. Potęguje zagadkowość, grozę i transcendentalny wymiar świata oraz łączy życie ludzkie z rytmem kosmicznym. Przede uszystkim jednak służy wyrażeniu najgłębszych, najwewnętrzniejszych przeżyć, zobrazowaniu sensu i przebiegu zarówno miłości androgynicznej, jak i destrukcyjnej. Ogień to siła niszcząca, ale także - w postaci słońca i światła - ewokująca absolut, pożądany stan boskości i poznania. Woda to amorficzność, na przemian stwarzająca szansę odnowy, to znów grożąca utratą tożsamości; to życie i mogiła. To także matecznik psychiki, obszar nieświadomego. Zułaszcza szerokie, dynamiczne morze (odbierane przeważnie w aspekcie męskim ${ }^{168}$ ) pojawia się u Przybyszeuskiego jako synonim „nagiej duszy", jako znak tego, co niewyrażalne, wykraczające poza świadome ego, stanowiące obszar niestłumionych przez kulturę mistycznych doznań. Metaforyka mare tenebrarum pojawia się uprost w dramacie Miasto, gdzie mówi się o Leszku: ,jego dusza jak dno morza, nic na nim dojrzeć nie można - niezgłębiona" (Mto 53). W takim znaczeniu symbolika morza występowała również w pismach publicystycznych autora Synagogi szatana:

Poza ciasnym kółkiem śuiadomych stanów naszego Ja jest ocean weunętrzny, morze tajni i zagadek, kędy się wichrzą dziwaczne burze, są tam kryjówki Sezama pełne nieprzebranych skarbów i cudów, i rzeczy u słowa nieujętych ${ }^{169}$.

${ }^{165}$ Zob. M. Lurker, op. cit., s. 354-355.

${ }^{166}$ J. Tuczyński, Schopenhauer a Młoda Polska, Gdańsk 1969, s. 169.

${ }^{167}$ G. Bachelard, op. cit., s. 146.

${ }_{168}$ Zob. J. Tuczyński, op. cit., s. 169.

${ }^{169}$ S. Przybyszeuski, $O$ „nowa” sztukę, [w:] idem, Wybór pism, s. 150. 


\section{Przestrzenie erotycznej uolności}

Postulat penetracji sfer psychiki oraz próba dotarcia do tego, co ukryte w nieświadomości, oznaczają odurót od mimetycznej funkcji literatury, a zatem od realistyczno-naśladowczych sposobów ujmowania świata. Zakorzenienie akcji utworów w konkretnych warunkach historycznych i geograficznych, silnie obecne w literaturze pozytywizmu, moderniści traktowali jako ograniczającą konwencję. Starali się ją przezuyciężyć, odrzucając dyktat czasu i przestrzeni jako głóunych kategorii opisu rzeczywistości ${ }^{170}$. Przybyszewski jako jeden z pieruszych twórców młodopolskich pisał, że „sztuka jest odtworzeniem tego, co jest wiecznym, niezależnym od wszelkich zmian lub przypadkowości, niezawisłym ani od czasu, ani od przestrzeni" ${ }^{171}$. Rok, miesiąc czy dzień nie mają większego znaczenia dla rozwoju wykreowanych przez pisarza uydarzeń, choć już przeszłość w irracjonalny sposób upływa na teraźniejszośćc ${ }^{172}$. Miejsce akcji jest w zasadzie obojętne (podobnie jak u Maeterlincka), podawane marginesowo i ogólnie, np. w didaskaliach Złotego runa: „Pokój jadalny. Stół zastawiony do śniadania. Umeblowanie wytuorne" (Zr 171). Taką quasi-empiryczną ${ }^{173}$, prawdopodobną, ale ubogą w szczegóły przestrzeń czytelnik odnajduje u De profundis, Homo sapiens, Krzyku, Synach ziemi, dramacie Dla szczęścia oraz całym Pentateuchu, podporządkouanym wizyjności.

Choć konwencjonalne miejsce nie odpowiada charakterowi młodopolskiej miłości, Przybyszeuski chętnie umieszczał bohaterów w tradycyjnym salonie,

\footnotetext{
${ }^{170} \mathrm{O}$ kategoriach czasu i przestrzeni zob. tom Czas i przestrzeń $w$ prozie polskiej XIX i XX wieku, red. C. Niedzielski i J. Spein, Toruń 1990.

${ }^{171}$ S. Przybyszeuski, Confiteor, [w:] idem, Wybór pism, s. 140.

${ }^{172}$ Ulubioną porą roku Przybyszeuskiego, jak uszystkich modernistów, była jesień. Odpowiadała ona doskonale nastrojom dekadenckim, poczuciu schyłkowości i rozkładu, kojarzyła się ze smutkiem, pesymizmem, powolnym umieraniem. Ta pora roku stanowi tło dla tragicznych wydarzeń Ślubów i Dzieci szatana, jesień spędzoną uspólnie z kochanką wspomina król z rapsodu Nad morzem. O wiele częściej jednak buduje ona nastrój i jest poetyckim ekwiwalentem stanów psychicznych; obrazuje to, co dzieje się w życiu, związkach i w duszy bohaterów:

A po olbrzymiej sali rozeszło się gdyby łkanie jesiennego deszczu, gdyby zaduszne tchnienie grobowych tajemnic [...]. (A 447)

Dziuny nastrój u tym pokoju [mówi Zdżarski do Heleny]. Jesień. Jesień. Niedługo zaczną się deszcze. A to straszna rzecz, gdy deszcz całymi dniami na szybach jęczy. (Dszcz 39)

[...] u nas u domu jesień - jesień, pochmurne dnie, deszcze, zżółkłe liście... [mówi Irena do męża]. (Zr 187)

Wiosna jako pora roku, u której budzą się namiętności, stała się natomiast tłem dla romansu Falka i Maryt (Homo sapiens).

${ }^{173}$ Posługuję się tu terminem Krystyny Kralkowskiej-Gątkouskiej, użytym w jej pracy Antymimesis $i$ wizja. Typy konstrukcji przestrzeni w powieściach Stanisława Przybyszewskiego, [w:] Przełom antypozytywistyczny w polskiej świadomości kulturowej końca XIX w., red. T. Bujnicki i J. Maciejeuski, Wrocław 1986, s. 131-161.
} 
mieszkaniu czynszowej kamienicy czy wielkomiejskiej kawiarni. Obszar ładu społecznego, u którym żyją, wyznacza jednak duszące ich granice. Guałtowne uczucia i głęboka potrzeba ekspresji kontrastują z uporządkowaną przestrzenią oficjalnej kultury. Namiętności nie da się stłumić przyjętymi normami moralności mieszczańskiej, najlepszą scenerię stanowi dla niej kraina wolności; czy to rzeczywista - w postaci egzotycznych krajów - czy imaginacyjna. Właśnie to transgresujne ujęcie przestrzeni, z nietypowymi i odległymi kulturowo dekoracjami w tle uczuć, będzie przedmiotem niniejszej analizy.

Perspektywę wkroczenia na nieznane terytorium otwiera uysunięta przez jedno z kochanków propozycja uspólnej dalekiej podróży ${ }^{174}$. Do takiego wojażu namawia Przesłauski Irenę u Złotym runie:

Chcesz, powiozę cię u Pireneje... tam takie maleńkie miasteczko, przyczepione, przylepione do olbrzymiej skały - pomyśl, przylepione, tak jak wioska kafrów przyczepiona do szczytów dziewiczych drzew w dziewiczych lasach - chcesz, powiozę cię nad brzeg Tajo - tam miasto wymarłe - miasto śmierci... chcesz, zawiozę cię w piekielne żary Afryki albo do dżungli indyjskich. (Zr 201)

Przesłauski nie mówi o miejscach atrakcyjnych turystycznie, dostarczających zwiedzającym pożywki intelektualno-artystycznej. Przeciwnie - pragnie zabrać ukochaną daleko od cywilizacji, w rejony dzikie, odludne, działające na wyobraźnię swą pierwotnością i osobliwością. Nie oferuje podróży dla rozrywki czy ze snobizmu, lecz uskazuje możliwość odrzucenia zasad społecznych, ograniczających człowieka żyjącego w kulturze Zachodu. Swą opowieścią o egzotycznych zakątkach świata i ich skarbach (białych pawiach, rzadkich kamieniach szlachetnych) uwodzi Rembouską, która boi się jeszcze realizacji suych pragnień. Irena, w obawie, że mogłaby ulec, co jakiś czas przerywa Przesłauskiemu, usiłując zmusić go do milczenia: „Jak ja się ciebie lękam...”, „Och, jakiś ty straszny!” „Cicho, na Boga, cicho, bo oszaleję” (Zr 201-202). Dla niej zgoda na wyjazd $\mathrm{z}$ kochankiem oznacza $\mathrm{z}$ jednej strony pogwałcenie reguł uspółżycia małżeńskiego, a więc skazę etyczną, z drugiej zaś - niebezpieczną wolność od norm zbiorowych, które wszak konstytuują jednostkę.

„Zamorską" podróż służącą izolacji od kontekstu społecznego projektuje także Jan Czerkaski. Powraca ona niczym leitmotiv na kartach Synów zie$m i$. Jej zamysł nakłada się na rzeczywistą wyprowadzkę Hanki od męża i dziecka; w ten sposób staje się metaforą życiouego przełomu, rezygnacji z usankcjonowanego społecznie trybu życia, uycofania z obszaru nakazów i wartości kolektywnych.

${ }^{174}$ Młodopolskie projekty takich dalekich podróży uymienia W. Gutouski, Mit - Eros - Sacrum, s. 43. 
- Hanka, pojedziesz ze mną? - Jest morze, które zamarza zimą, taka bezgraniczna, biała róunina. Weźmiemy sanki, ja otulę cię mym płaszczem, takim szerokim, króleuskim płaszczem gronostajouym, na sercu mym cię ogrzeję. A potem konie poniosą nas po tej zamarzłej, trupiej róuninie, po lodach i śniegu aż hen, tam, gdzie kraj tysiąca jezior i wieczna wiosna i ciepło, i jasne noce. (Sz I, 146)

Zastanawiające, że w suych dywagacjach Czerkaski mocniej akcentuje nie cel, a etap podróży. Szerzej opisuje przestrzeń mijaną niż miejsce, do którego ostatecznie chce powieść Hankę. Owa kraina szczęśliwości do końca pozostanie niekonkretna, osadzona bardziej w sferze mitu czy baśni niż konkretnych realiach geograficznych.

- To będzie nasza podróż poślubna - szeptał.

Tam, tam, poprzez tę pustynię śnieżną, tam gdzie kraina tysiąca jezior, kraj wodospadów i lasów dziewiczych, kraj wiecznej wiosny, z dala, z dala od tej strasznej malarii, która tu wszystkim suym jadem krew rozkłada... (Sz I, 154)

Niebezpieczeństwo, trud i nieuygody podróży przez oblodzone morze (nasuwające skojarzenia z surowym pejzażem Północy) podkreśla też Hanka:

[...] widziała, jak pędzą jakąś bezkresną, śnieżną, trupią róuniną, jakby poprzez olbrzymie, białe wieko, które człowieka żywcem pogrzebanego przytłacza. (Sz I, 169)

Biel pejzażu nie jest symbolem zaślubin, jak chciałby Czerkaski, lecz śmierci. Ma trupi odcień, wokół zaś panuje „cisza cmentarna” (Sz I, 153). Ten ponury krajobraz jest obrazouym ekwiualentem rozterek i niepokojów Hanki, pragnącej oddać się ukochanemu mężczyźnie, lecz dręczonej rozbudzonym instynktem macierzyńskim oraz poczuciem winy wobec dobrego i szlachetnego człouieka, który ją poślubił. Napięcie między pragnieniem a obowiązkiem sprawia, że śnieg przykrywający morze uydaje się Hance wiekiem trumny, grobem, u którym żyucem pogrzebała suego męża i który ją także pochłonie. Próbując uyciszyć emocje kochanki, Czerkaski opowiada jej o dziewiczej, nieujarzmionej przez człouieka krainie, u której jej uroda w pełni rozkwitnie:

Dla nas grobem nie będzie, dla nas stanie się ciężką, mrozem, bólem i straszną męką ściętą drogą do krain wiecznej wiosny, do krainy tysiąca jezior, w których twa piękność odbijać się będzie, do kraju dziewiczych lasów, które nad twą złocistą głóuką cień suój rozwachlarzą, do kraju miękkich, wilgotnych wrzosów, w których twoje ciało spocznie, gdy je upał słoneczny zmęczy, do kraju złotych piasków, w których gdy już o uszystkim zapomnisz, tuoje bose nóżki po kostki grzęznąć będą. (Sz I, 170)

Wizja egzotycznych obszarów upaja Hankę, jak w Złotym runie hipnotyzowała Rembowską. Jednak Czerkaski sam nie ufa swoim słowom. Pragnie 
wierzyć, że odnajdą Ultima Thule - jak u średniowieczu nazywano północną krainę wyznaczającą kraniec znanego śuiata - ale obraz bajecznej krainy wiecznej wiosny zakłóca świadomość, że

[...] tam pod tą skorupą lodu szaleje i kłębi się morze ciemności. Lada chwila wraz z Hanką w przepaść runąć może. Tam w dali w otchłań bezdenną... (Sz I, 175)

Daleka podróż pozostaje u sferze przenośni, marzenia o lepszym świecie, mitu. Nie zostaje zrealizowana ani w Złotym runie, ani w Synach ziemi. Hanka i Czerkaski uyprowadzają się do maleńkiej miejscowości głęboko w Poznańskiem i tam próbują stworzyć namiastkę domu ${ }^{175}$. Baśniowość zastępują sielskością budowaną z elementów polskiego krajobrazu.

[...] tu nikt nie chodzi, taki spokój, siądziemy obok siebie, będziemy patrzeć u ciche guiazdy - słuchać rechotania żab - a są tu żaby?

- Są gdzieś stauy nieduże u pobliżu.

- A koniki polne też są?

- O, pełno ich na łąkach naduiślańskich.

- To piękna muzyka - prawda? I słowiki są?

- Tu ułaśnie się gnieżdżą...

$[\ldots]$

- Tak, tak - szeptał - będziemy tu żyli, jak dwoje króleuskich dzieci... tylko ty i ja. Od lat tysięcy tęskni ludzkość za baśnią, a z nami się ten cud dokonał. (Sz II, 180)

Przed demonami przeszłości, lękami i sumieniem nie da się jednak uciec. Hanka musi wrócić w obszar norm społecznych, by odzyskać córkę. Nowy dom na krótko więc staje się dla zakochanych oazą spokoju i azylem przed śuiatem.

O tym, że przestrzeń społeczna nie jest dobrym miejscem nie tylko dla rozwoju miłości, ale i dla leczenia zadanych przez nią ran, świadczy reakcja Tadeusza, który zmęczony burzliwym związkiem z Ewą przez dwa lata włóczył się po świecie, m.in. polując u Afryce na tygrysy (Śnieg). Dla niego, podobnie jak dla Rembouskiej i Przesłauskiego oraz Czerkaskiego i Hanki, przestrzeń ładu jest - jak pisze Wojciech Gutouski - „fizycznie bliska, ale emocjonalnie obca, jest antywartością”, ponieważ niszczy autonomię uczućc $^{176}$.

W podróż po Włoszech zabiera za to kochankę niespełniony artysta - Henryk Bielecki. Przybyszeuski najwięcej uwagi pośuięca epizodoui weneckiemu tej uyprawy, demaskującemu fałszywe motywacje „mocnego człowieka”. Pobyt $\mathrm{w}$ Wenecji to rodzaj randki à rebours. Miejsce pielgrzymek zakochanych

${ }^{175}$ Wyjazd z miasta i odosobnienie w letniskowej miejscowości dające możliwość przemiany i wewnętrzną swobodę przedstawił także Leo Belmont w powieści $W$ wieku nerwowym.

${ }^{176}$ W. Gutouski, Mit - Eros - Sacrum, s. 42. 
i miłosnych tête à tête nie jest bowiem $\mathrm{w}$ powieści przestrzenią romantycznych doznań. Bielecki nie zamierza uwieść Łucji. Pod pozorem pokazania jej wielkiego świata uywozi ją, by sprytnie się jej pozbyć i na zawsze pogrzebać tajemnicę fałszerstwa manuskryptów, którego się dopuścił. Wenecja to nie miłość, lecz śmierć. Dlatego Szumska podświadomie reaguje lękiem i niepokojem. Czarna gondola, do której wsiadają, uydaje jej się trumną, a miarowe uderzenia wioseł o wodę i majaczące $u$ nocy cienie gondolierów napawają ją strachem: „- Siedzimy jak w jakiejś trumnie - szepnęła cicho - jakbyśmy na cmentarz jechali” (Mc I, 259). „Miała wrażenie, że tu w mrokach nocy trupy wywożą, by za dnia żywych nie straszyć" - informuje narrator (Mc I, 257), kilkakrotnie akcentujący także „śmiertelne” znużenie Łucji ${ }^{177}$.

Kolejnym punktem tej podróży jest nadmorska prowincja La Spezia, gdzie Bielecki pozoruje wypadek na łodzi, w czasie którego topi nieuygodną kochankę. Miejsce uybiera nieprzypadkowo. Jako człowiek z ambicjami literackimi, choć bez talentu, uie doskonale, że ułaśnie tam u czasie sztormu utopił się angielski poeta romantyzmu Percy Shelley, i pragnie otrzeć się o jego wielkość, wystylizować swoje życie na poemat, skoro nie jest w stanie go napisać.

Chociaż krajobraz polskich łąk i pól - inspirowany pejzażem rodzinnych Kujaw autora - często poutarza się we uspomnieniach bohaterów Przybyszeuskiego, pisarz zadziwiająco rzadko umieszcza swoje postacie na łonie natury. Tym bardziej warto przyjrzeć się fragmentowi Synów ziemi, w którym Czerkaski i Hanka spacerują po lesie. Przybyszewski nie dostarcza oczywiście czytelnikom dokładnych, realistycznych opisów, stwarzających iluzję oglądania wycinka rzeczywistości; nie byłoby zresztą sensu analizowanie ich w tym miejscu. Bardziej interesująco przedstawia się dokonana przez autora psychizacja krajobrazu. Otóż niemal natychmiast, gdy kochankouie wkraczają do lasu, niebo zaciąga się burzouymi chmurami. „Hankę szarpnęło jakieś niemiłe przeczucie”, a mimo to „coraz głębiej zapuszczali się u las” (Sz II, 14). W pewnym momencie jest już za późno, by wrócić przed nawałnicą. Ale owo „za późno” (Sz II, 15) ma szerszy zakres znaczeniowy: oznacza konsekwencje, jakie nieuchronnie musi ponieść para, zdecydowawszy się na uspólne życie. Burza w przyrodzie jest zatem zapowiedzią burzy $w$ życiu bohaterów. Pozorny spokój kochanków, którzy obiecują sobie zapomnieć o przeszłości, rozpada się bardzo szybko. Szukając schronienia przed deszczem, ukrywają się $\mathrm{w}$ wykopanym $\mathrm{w}$ ziemi dole, spełniającym rolę szałasu druala, do którego po chuili trafia także zabłąkane, przemoknięte dziecko. „Maleńkie, upiorne widmo, trzęsące się od deszczu i zimna” (Sz II, 19) jest jak chodzący wyrzut sumienia - przypomina Hance o córeczce, którą

${ }^{177}$ Podobny obraz pojawia się u poezji Antoniego Langego, gdzie śmierć jest „czarną gondolą, która niby sen po bazaltach kanałouych sunie” (A. Lange, Rozmyślania II, [w:] idem, Rozmyślania, Kraków 1906, s. 48). 
pozostawiła przy porzuconym mężu. Wędróuka po lesie (obszarze poza kulturą) to uyprawa u głąb nieświadomości, symboliczna konfrontacja z własnymi lękami i pragnieniami. Jej sens wzmocnił Przybyszewski dodatkowo opisem spotkania w podziemnej grocie, symbolizującej głębie psychiki, ale też typowo żeński aspekt ziemi, a mianowicie macicę Matki Ziemi ${ }^{178}$, a więc macierzyństwo.

Sposobem zdobycia kontroli nad własną psychiką jest zwrot ku temu, co świadome, uyrażający się $\mathrm{u}$ radości z posiadania ogrodu ${ }^{179}$.

Po uczorajszej burzy pouitało ją [Hankę] niebo jasne, głębokie, przeczyste. Z ogrodu płynęła słodka woń przez jedną noc tuż pod oknami rozkwitłych, bogatych rzędów białych lilii; dalej zuieszały się z gęstego listowia okiście białych i liliowych bzów, z ciemnej zieleni kasztanów świeciły srebrne i czerwone świece u górę strzelającego kwiecia. Krzewy paproci, którymi obsadziła klomby, wczoraj jeszcze zuiędłe i prawie zamierające, dziś podnosiły sue jasne pióropusze, śuieże, rozłożyste, niemal u mig rozbujałe.

Dawno, już dawno nie czuła takiej pełni sił i jędrnej, chciwej życia młodości... (Sz II, 62)

Przyroda uspółgra tu z ludzkim nastrojem i odczuwaniem świata. Rozkwita, bo i Hanka nastawiona jest do życia optymistycznie. Bohaterka pragnie kreować przestrzeń wokół siebie, by dokonać jej sakralizacji, zadomowić się $w$ niej i wytworzyć poczucie bycia na swoim miejscu. Marzy o niemal rajskim ogrodzie, który zapewniłby jej życiu idealną harmonię i odizolował od nacisku kultury i jej norm, który byłby namiastką podróży, o jakiej uspominał wcześniej Czerkaski.

- I chciałabym mieć ogrody - mówiła, jak do siebie, a głos jej brzmiał jak śpieu cichej, smętnej kołysanki, - ogrody, pełne oaz i zagajnych uysp, porośniętych cyprysami, cedrami, a na nich winny się kołysać przedziune ptaki gdzieś z Peru, Ekuadoru, Meksyku, bo tam tylko są ptaki, na których uidok człowiek ślepnie od blasku i przepychu baru - kołysać się winny i śnić dalekie, dalekie sny, tak, jak my naszą najrychlejszą młodość śnimy [...]...

Och! chciałabym mieć ogrody z cichymi łąkami na brzegach mnóstwa stawów, z wodą czystszą od górskiej krynicy, a na nich stada nieruchomych, w tępej zadumie stężałych flamingów [...] a na olbrzymich murach żywopłotu przechadzałyby się białe pawie - tak - białe, bo te tylko są piękne: jedne wlokące sue ogony, jak biały, atłasouy tren ślubnej sukni oblubienicy - inne z rozpostartym kołem ogromnych piór [...]... (Sz II, 66)

Wymarzony ogród Hanki nie ma uymowy erotycznej, jak klomby róż posadzone dla Jadwigi przez Adama Drzazgę. Egzotyczna flora i fauna są elementem stylizacji życia na baśń, upiększenia go, odcięcia od upływów społecznych, które zawsze zakłócają miłosne relacje.

${ }^{178}$ Zob. Estetyka czterech żywiołów. Ziemia, woda, ogień, powietrze, red. K. Wilkoszeuska, Kraków 2002, s. 54.

${ }^{179} \mathrm{O}$ ogrodzie jako symbolu świadomości była już mowa w podrozdziale Erotyczne florarium. 
Modernistyczny opis krajobrazu nie służy - jak zostało powiedziane - celom mimetycznym, ale wywołaniu odpowiedniego nastroju, który koresponduje ze stanem emocjonalnym bohaterów. Pejzaż wokół majątku Szelutów jest dziki i posępny, bo mieszkańcy dworu uwikłani są w tragiczne wydarzenia, uplątani w kołowrót miłości i śmierci, niechcianych uczuć i samobójstw. Didaskalia przed pieruszym aktem Mściciela informują: „widok na uzburzone morze, falujące u stóp wysoko, w kształt półksiężyca piętrzącego się wybrzeża, którego ściany, prostopadle prawie spadające $u$ morze, wykazują u jednym miejscu szeroką rozpadlinę, w rodzaju przepaścistego, głębokiego parouu. Widać dokładnie uruisko, porosłe skarłowaciałymi, potwornie pouygginanymi sosnami" (Mśc 7). Wszystkie postaci w różnych momentach akcji zuracają się ku widocznej za oknem przepaści, semantyzując ją i przygotowując czytelnika (widza) na tragiczny finał dramatu.

Zmiana scenerii następuje zawsze $w$ wizjach czy snach postaci przepełnionych niezrealizowaną energią seksualną. Perwersyjne pragnienia pobudzają imaginację. I tak bohater Requiem aeternam widzi się w wiejskim kościółku, atakowany przez „apokaliptyczną nierządnicę”, zaś bohater $D e$ profundis, marząc o Agaj, przenosi się w przestrzeń apokaliptycznej orgii. Chaos, transgresja, sceneria katastroficzna i sabatowa to odpowiedź na ograniczające wymogi ethosu. Podobnie bohater Androgyne wciela się w rolę władcy nieokreślonego uschodniego kraju, upaja zapachem egzotycznych roślin oraz widokiem najpiękniejszych dziewic.

Zeusząd ścieśniała się przestrzeń, z odległych dali biegła ku niemu, zuężała się i ścieśniała wokół niego, okoliła go murem i ujrzał się w jakiejś tajemniczej sali, coś w kształt świątyń eleuzyńskich, w których się odbywały dziune misteria; coś w kształt hali, w której półbogi germańskich północy miewały w świetle zórz polarnych sue tajne narady; [...] to znouu widział się w gotyckiej kaplicy książęcej warouni, gdzie świętokradzcy mnisi odbywali wśród najdzikszych orgii obłąkanych potępieńców na ciele nagiej kobiety swe sabathy szatańskie. (A 405)

Bohater nieustannie balansuje na granicy upadku i chaosu. W scenerii orgii może wyrazić swoje potrzeby, nawet jeśli oznacza ona dezintegrację „ja”, czyli niepoutarzalnej osobowości. Ale najbardziej interesująca jest przestrzeń, do której przenosi się w drugiej części utworu. Androgynicznej jedności poszukuje mianowicie u należącym do przodków Alkazarze, mieście martwym, przypominającym „straszny, olbrzymi grób katakomb” (A 437). Wykuty u skale, pełen zakamarków, ma strukturę labiryntu symbolizującego tajemnice podśuiadomości ${ }^{180}$, nieodkryty obszar duszy oraz - co zauważył

${ }^{180}$ Metaforyką korytarzy, krypt, lochów i labiryntów w odniesieniu do podśuiadomości Przybyszeuski posługiwał się kilkakrotnie. W artykule programouym pisał: „Są w naszej duszy dziunie splątane i pouikłane krużganki, grobouce uspomnień życia przed życiem, podziemne kurytarze, do których nigdy jeszcze nie unikło światło” (S. Przybyszeuski, O „nowa” sztukę, [w:] idem, Wybór pism, s. 150). W Synach ziemi Hanka, zawieszona emocjonalnie 
W. Gutouski - duchową stagnację, zmarnowane dziedzictwo, dekadencką samotnośćc ${ }^{181}$. Jest cmentarzyskiem; zaprzecza życiu, a więc i miłości. Wzbudza grozę i lęk.

Znał uprawdzie uszystkie zaułki, ulice i uliczki, znał ich skręty i sploty, ich krzyżowania i rozstaje; [...] a pomimo tego czuł jakąś tajemną grozę i przestrach, że mógłby się zabłąkać, lata całe błądzić u tym labiryncie i nigdy już z niego nie wyjść.

A nie było nikogo, kto by mu mógł pokazać drogę, bo miasto było martue. (A 437)

Na obraz Alkazaru wyobraźnia bohatera nakłada wizję szalejącego morza, które guałtownie wznosi się ku niebu i łączy z nim, by następnie ożywić miasto potopem suych wód. Żywioł oczyszcza jak za czasów Noego; odradza przestrzeń, przeobraża ją nieomal w raj utracony.

To było jego miasto, ale inne, nie $\mathrm{z}$ tego świata.

Od stóp Alkazaru wiły się ponad białymi dachami ulic olbrzymie pnie winnych latorośli. Wyrastały z fundamentów Alkazaru, rozrastały się nad całym miastem, pokryły wszystkie ulice, rozgałęziały się w olbrzymim bogactuie; a całe miasto wydawało się jedną czarouną winnicą. (A 442)

Znakiem zmartwychustania staje się symbolizujący młodość i życie wieczne krzew winny. Wskrzeszone miasto nie jest jednak hymnem ku czci płodności natury, lecz apoteozą imaginacji. Bujnie rozwinięta flora, świadectwo życia, jest bowiem sztuczna ${ }^{182}$ :

Pnie były z brązu, liście z delikatnej blachy miedzianej, grona winne z ciemno-niebieskiego kamienia. [...] wyprysła i rozlała się tęcza uszelkiego kruszcu i nagich pokładów drogiego kamienia [...], wił się w spiralach i parabolach, w dzikich splotach lianów i spouviciach winnych latorośli zielony golf omszałej miedzi. (A 443, 454)

Twórczy akt uyobraźni zbliża bohatera do mistycznej chwili, w której dusza przenika uszelkie tajemnice i „w przepych własnej nagości patrzy" (A 445). Ożywiona w wyniku osobliwej psychomachii przestrzeń ${ }^{183}$ sprzyja zjednoczeniu z wytęsknioną kochanką, skoro i ona - jako część

między uczuciem do Czerkaskiego a rolą matki, we śnie „błądziła po jakichś ciemnych korytarzach, po mrocznych gankach, po skąpo oświetlonych schodach u górę, na dół, tam i z powrotem - przebiegła kilkakrotnie cały gmach, a może kręciła się tylko w kółko" (Sz II, 112). O symbolice architektonicznej w powiązaniu z ludzką psychiką pisała M. Podraza-Kuiatkowska, Symbolizm i symbolika..., s. 229-233.

${ }^{181}$ W. Gutouski, Nagie dusze..., s. 255.

${ }^{182}$ Por. W. Gutouski, Mit - Eros - Sacrum, s. 48

${ }^{183}$ Kreacja krajobrazu przybiera uymiar katastroficzny: morze płonie, planety pękają, z ziemi bucha płynny metal, uybuchają gejzery kamieni, łańcuchy górskie ścierają się ze sobą. 
duszy bohatera, jej najtajniejsza głębia - jest kreacją, projekcją męskiej podświadomości. W odpowiednio przeobrażonej scenerii, u blasku światła o nienaturalnym źródle, może pojawić się On-Ona. Imaginacja wypełnia krajobraz życiem i umożliwia doprowadzenie do syntezy Ja z Ty. Wyraźny u tej kreacji element genezyjski sugeruje podobieństwo działań człowieka i Boga, nadaje poczynaniom ludzkim podniosły charakter. Jednocześnie Alkazar jako miasto odrodzone jest alternatywą dla modernistycznych wizji antyurbanistycznych: miasta-molocha, miasta-labiryntu, miasta-potwora, jakie uprowadził Przybyszeuski u dramacie Miasto oraz powieści $K r z y k^{184}$.

Do pokładów psychiki ludzkiej odsyłają również symbole architektoniczne w poemacie Nad morzem. Podobnie jak w Androgyne, którego bohater najpierw ogląda miasto z uyżyn, a dopiero później zstępuje u jego zaułki, mamy tu do czynienia ze schodzeniem w głąb obiektu, odpowiadającym próbie dotarcia pod powierzchnię świadomości (zadziwiające, jak niedaleko był Przybyszeuski od psychologii głębi Junga). Władca krainy słońca dla suej ukochanej niewolnicy buduje bowiem w podziemiach pałacu komnaty wypełnione najkosztowniejszymi klejnotami. Jak bohater Androgyne kreuje obszar, w którym kobieta - jego anima ${ }^{185}$ - może żyć. To jednocześnie obszar konfrontacji $\mathrm{z}$ ułasną duszą. Bogato zdobione drogimi kamieniami unętrza, do których się schodzi, symbolizują miejsce poznania ostatecznej prawdy, spełnienia ideału, osiągnięcia doskonałej syntezy; oznaczają elementy stałe, wieczne, w przeciwieństuie do podlegającej przemianom natury ${ }^{186}$. U Przybyszewskiego, który - podobnie jak Tadeusz Miciński - interesował się zarówno symboliką drogich kamieni,

${ }^{184}$ Tytułowe miasto z dramatu Przybyszewskiego jest wartością u skali wieków, jako rodowe dziedzictuo, piękno, pełnia i tradycja, „nierozerwalny łańcuch mijających i tych, które przyjść mają, pokoleń" (Mto 75), niszczy natomiast jednostki - walczące o nie, lecz niemogące sprostać uładaniu nim. „O miasto! Przeklęte miasto! Zażarty, mściuy, nieubłagany Molochu, który mnie za życia chcesz pochłonąć!” - skarży się Kinga (Mto 80). „Miasto, którego tak pożądałem chciwie, czemuż zualasz się na moje piersi? Czemuż stałoś mi się zmorą, czemu zmysły moje mącisz i sen mi odbierasz, i drżącą truogą me serce napełniasz?" - rozpaczliuie pyta Mścisław (Mto 106). Miasto jako potwór i labirynt ulic, poróunane do ohydnej stonogi i prostytutki, jest bohaterem Krzyku. Obciążone ładunkiem negatyunym pojawia się u najsłynniejszych autorów epoki: Reymonta, Zapolskiej, Berenta, a nawet Orzeszkowej (zułaszcza u powieści Australczyk; 1896). Kazimierz Przerwa-Tetmajer określał je jako przestrzeń, u której dominują „brud”, „otchłanie bólu”, „poszarpane serca, trzewia, dusze” (K. Tetmajer, Obłoki nad miastem, [u:] Poezje wybrane, oprac. J. Krzyżanouski, Wrocław 1968, s. 100). Obrazowi miasta poświęcony został tom Miasto - kultura - literatura. Wiek XIX, red. J. Data, Gdańsk 1993. Zob. też I. Maciejeuska, Wielkie miasto w prozie okresu Młodej Polski a problemy naturalizmu, [w:] Problemy literatury polskiej okresu pozytywizmu, seria 3, red. E. Jankouski, J. Kulczycka-Saloni, Wrocław 1984.

${ }^{185}$ Klejnot znajdujący się $\mathrm{w}$ posiadaniu dziewicy lub księżniczki kojarzony jest z Jungowską animą (zob. Klejnoty [hasło], [w:] J.E. Cirlot, op. cit., s. 178-180).

${ }^{186}$ M. Podraza-Kuiatkouska, Symbolizm i symbolika..., s. 236-237, 240. 
jak i ich związkiem z ciałami niebieskimi, odpowiadają atmosferze androgynicznej jedności.

Z Indii przywiozły moje okręty olbrzymie diamenty, pyszne i czarne jak skamieniałe śuiatło $[\ldots]$.

Z Grecji przysłano niebieskie szafiry [...].

Kapłankom Galów wydarto ich śuięte szmaragdy [...].

Asyryjskim Hakumim odebrano podstępem i przemocą chryzolity [...].

$\mathrm{Z}$ nieznanych krajów przywlekli niewolnicy moi nieprzebrane skarby: czarne agaty [...], zielone hiacynty [...] i ciemne jak otchłań jantary [...]. (Nm 295-296)

Budulec podziemnych komnat przypomina fundamenty opisanego w Apokalipsie św. Jana Nowego Jeruzalem, będącego symbolem przymierza Boga z ludźmi i przywoływanego - ze względu na funkcję reintegracji świata oraz połączenie logosu z energią życiową - jako analogia także dla Alkazaru z Androgyne $e^{187}$.

A mur uzniesiony był z jaspisu, a samo miasto ze złota czystego podobnego do szkła czystego. A fundamenty muru miasta ozdobione są różnymi drogimi kamieniami. Fundament pieruszy jaspisem, drugi szafirem, trzeci chalcedonem, czuarty szmaragdem, piąty sardoniksem, szósty kruaunikiem, siódmy chryzolitem, ósmy berylem, dziewiąty topazem, dziesiąty chryzoprazem, jedenasty hiacyntem, duunasty ametystem. A duanaście bram to duanaście pereł, każda z osobna brama była z jednej perły ${ }^{188}$.

Podziemie z drogich kamieni oznacza u Przybyszeuskiego - podobnie jak u Piśmie Śuiętym - osiągnięcie pełni, doskonałości duchowej w nowej rzeczywistości ${ }^{189}$, jest miejscem ucieczki we własne wnętrze, alternatywnym obszarem wolności.

Przestrzenie egzotyczne, imaginacyjne, transgresyjne ściśle uspółgrają w utworach Przybyszewskiego z koncepcją miłości. Wyrażają przekonanie o uszechwładzy chuci bądź budują nastrój sprzyjający odtworzeniu Dwój-Jedni. Sytuuje je pisarz w opozycji do regionów kultury, regulowanych przez ethos, i wartościuje dodatnio jako miejsca realizacji wolności i autonomizacji erotyki. W zakresie formalnym ich wprowadzenie jest elementem przekraczania granic tworzywa literackiego, zgodnie z tezą, że nowa sztuka ma rozsadzić dotychczasowe struktury, by dotrzeć do pierwotnych przeżyć.

${ }^{187}$ Zurócił na to uwage W. Gutouski, Mit - Eros - Sacrum, s. 92.

${ }^{188}$ Pismo Święte Nowego Testamentu, ustęp i komentarz ks. E. Dąbrouski, Warszawa 1949, s. 974-975.

${ }^{189}$ Zob. W. Kopaliński, Kamienie drogocenne [hasło], [w:] idem, op. cit., s. 138. 



\section{Zakończenie}

Doświadczenie miłości jest $\mathrm{w}$ twórczości Stanisława Przybyszeuskiego tożsame z poszukiwaniem - a nawet próbą ocalenia - sensu egzystencji. Pozwala zajrzeć pod podszewkę bytu, do głębokich pokładów ludzkiej psychiki. Ujmując erotykę jako potęgę, której źródła tkwią w nieśuiadomości, młodopolski autor zbliżał się do teorii Freuda, w przeciwieństwie do austriackiego psychoanalityka rozumiał jednak, że seksualność spełnia wielorakie funkcje - z kosmologiczną na czele - a zatem blisko jej do hierofanii. Dlatego u podstaw jego obrazu miłości zdaje się leżeć horror vacui. Aby odsunąć widmo egzystencjalnej i postegzystencjalnej pustki, Przybyszeuski wypracował i konsekwentnie rozwijał własną erotologię, której gnoseologiczną podstawę stanowi marzenie o uszechjedności uraz z implikowaną przezeń koncepcją androgynii.

Miłość to w istocie monotemat twórczości Przybyszeuskiego. Od jego ciężaru nie jest wolny nawet tom opowiadań wojennych Powrót (1916) - oficer Nieczuja z Pojednania bierze przecież udział $w$ działaniach na froncie wschodnim, by odpokutować i wymierzyć sobie karę za uwiedzenie i doprowadzenie do samobójstwa siostry przyjaciela. Paradoksalnie, znacząca jest nieobecność miłości w $K r z y k u^{1}$. Jej brak koresponduje bowiem z modernistyczną tendencją przedstawiania duszy artysty jako rozdartej między duiema niemożliwymi do uzgodnienia sprzecznościami: sztuką a uczuciem do kobiety odbierającym zdolność kreacji (sprzeczności te dezintegrują życie Borouskiego w Próchnie Berenta czy Relskiego z Karykatur Kisieleuskiego). Oblubienica bohatera, artysty malarza, to sztuka; nierozerwalność tego związku i uyłączność przedmiotu ukochania symbolizuje ślubny pierścionek, jaki - w geście błogosławieństua czy przekleństwa - wsunęła na palec syna umierająca matka. Gasztowt wśród wielu tematów malował co prauda "głód żądzy i rozuścieczonej chuci" (K 84), a w podrzędnej kawiarni oglądał wyuzdany, imitujący kopulację taniec, jednak „żadne erotyczne uczucie nie skalało jego duszy" (K 77). Niepodległy nigdy miłosnym imperatywom, wykorzystuje jednakże miłość jako narzędzie wymuszania podległości.

${ }^{1}$ Zurócił mi na to uwagę W. Gutouski. Temu naznaczonemu brakiem aspektowi utworu poświęciła też fragment (tytułując go Powieść niemiłosna?) G. Matuszek w książce Stanisław Przybyszewski - pisarz nowoczesny. 
Powściąga obrzydzenie do kobiety oraz własnej i cudzej płciowości, by złudną grą konwencjonalnych wyrazów uczucia i pustych deklaracji doprowadzić oszukaną prostytutkę do samobójstwa, podczas którego poutórnie usłyszy krzyk będący istotą życia, „syntezą ulicy”. Krzyk ten, wyrażający tajemnice istnienia i komplet człowieczych doświadczeń - bólu, zbrodni, rozkoszy - ma być inspiracją dla najuspanialszego z obrazów Gasztowta, symbolizującego i wyrażającego całość egzystencji.

- Miłość, miłość kazała mi Cię szukać! [...].

Teraz jął wyrzucać z siebie bezładnie najgorętsze słowa miłości, bełkotał, chuytał ją za ręce, ciągnął ku sobie, przemógł zuycięsko fizyczny ustręt, jaki w nim dotyk jej ciała wywoływał, uszystko w sobie zdusił, by tylko jej krzyk posłyszeć [...] (K 169-170).

Manipulacji Gasztouta podlega przedstawicielka płatnej miłości, rozdająca sue ciało każdemu, kto chętnie za nie zapłaci, a więc reprezentantka tego wymiaru życia, który bohater konsekwentnie neguje. Jej śmierć, oznaczająca zniszczenie kobiecości dla sztuki, jest tylko przypieczętowaniem od początku deklarowanej postawy bohatera. Gasztowt na moment staje się cynicznym uwodzicielem, lecz jest to uwodzenie ku śmierci przez miłość-kłamstwo.

Jako jeden z pierwszych twórców Przybyszewski przełamał seksualne tabu obowiązujące w polskiej literaturze, ale jego znaczenie polega przede wszystkim na tym, że dostrzegł w erotyzmie akt poznawczy i kreacyjny oraz wpisał go w nurt energii kosmicznej. Pragnął uwolnić człowieczą seksualność od balastu obłudnej świętoszkowatości, sprowadzającej aktywność erotyczną do obowiązku reprodukcji. Pojmując miłość jako moment szczególnego napięcia, gwałtownych olśnień i mistycznych iluminacji otwierających nowe poziomy egzystencji, nadał jej sens metafizyczny i podniósł do rangi problemu filozoficzno-moralnego. Dokonał sakralizacji płci, uznał popęd płciowy za praelement i pratworzywo bytu oraz czynnik umożliwiający ujawnienie „nagiej duszy”, czyli najintymniejszych sfer ludzkiej osobowości. Wykorzystywał zatem temat miłości, by mówić o człowieku i odległych rejonach jego świadomości (notabene, uprowadzenie nowego typu bohatera - o nowej wrażliwości i strukturze życia psychicznego - zapowiadało przeobrażenia formalne $u$ prozie duudziestowiecznej). Ta penetracja demaskowała zaś jednostkę przełomu wieków jako neurotyczną, zdominowaną przez dekadenckie poczucie pustki i osamotnienia. Młodopolski erotyzm jest bowiem uwikłany w determinizm, któremu Przybyszeuski usiłował nadać sens teleologiczny. Wiąże się z lękiem przed ułasną płciowością i przed życiem seksualnym - jako zagrażającym sferze duchowej - w ogóle. Konotuje mizoginizm, jako że uosobieniem natury niszczącej uczynili moderniści kobietę, oskarżając ją o działanie na szkodę rodu męskiego poprzez nastawienie na realizację wyłącznie celów biologicznych. 
Podleganie prawom gatunku i bezwzględnej natury wywołuje poczucie dyskomfortu i bunt, zułaszcza że pożądanie seksualne wchodzi u konflikt z normami społecznymi i etyką. Stąd wynika rozdarcie między przymusem postępowania wbrew etosowi i immanentnie tkwiącej w człowieku moralności a poczuciem wing i odpowiedzialności za własne, choć bezwolnie popełniane, czyny. $\mathrm{O}$ ile $\mathrm{w}$ dramacie greckim człowiek był zabawką $\mathrm{w}$ rękach bogów, u Przybyszeuskiego jest zabawką chuci, a także losu, fatum, które go dosięga niczym kara za niezawinioną winę ${ }^{2}$ To sprawia, że uwikłani w miłość bohaterowie są postaciami tragicznymi, ponoszą klęskę, a żaden ze zuiązków nie jest szczęśliuy. Synonimami miłości są smutek, ból, tęsknota, a przede uszystkim cierpienie. Nastawienie na przeżycie i upojenie, a nie na partnera, nie pozwala mówić o prawdziwym uczuciu. W relacjach kobieta - mężczyzna brakuje przyjaźni, szacunku, troski o drugą osobę, toczy się natomiast walka o dominację. Słuszność ma Gabriela Matuszek, gdy zauważa, że pisarz zdaje się być bliski stuierdzeniu Denisa de Rougemonta, iż absolutna miłość jest złudzeniem, marzeniem niemożliwym do spełnienia w naszej kulturze ${ }^{3}$.

Przybyszeuskiemu bliska była tradycja manichejska, według której miłość jest zausze walką na linii soma-psyche. Jednak jego utwory nie dotyczą klasycznego rozdarcia człowieka między ideą miłości a żądzami cielesnymi. Problemem jest raczej konstatacja, że bliskość fizyczna to nie uybór, możliwość otwierająca perspektywy, lecz imperatyw biologiczny, nakaz chuci działającej na rzecz przedłużenia gatunku.

Konieczność poddania się nakazom natury sprawia, że bohaterowie mają osobowości zdezintegrowane, oscylujące między miłością a nienawiścią, dręczone przez koszmary i halucynacje. Od przestrzeni oficjalnej kultury i ładu społecznego uciekają $w$ śmiałe wizje erotyczne, na przemian spokojne i gwałtowne, z sadyzmem, orgią, nekrofilią i kazirodztwem włącznie. Pożądanie seksualne powoduje rozpad uporządkowanego świata, ujawniając tkwiące w człowieku pierwiastki agresji. Miłość młodopolska jest - co szokowało czytelników - paroksyzmem, ekstazą; polega na intensyfikacji doznań, cechuje ją doloryzm. Znalazło to wyraz w języku - zdania pytające i wykrzyknienia odzwierciedlające krzyk duszy są krótkie, litanijne ukształtowanie tekstu świadczy o silnych emocjach. Skrajne, wyostrzone do ostateczności przeżycia pochodziły jednak z najgłębszych sfer psychiki. Stały się wyrazem „nagiej duszy”, nie mogły więc podlegać ualoryzacji pod względem etycznym.

${ }^{2}$ Zob. I. Sławińska, Tragedia $w$ epoce Młodej Polski. Z zagadnień struktury dramatu, Toruń 1948, s. 37.

${ }^{3}$ D. de Rougemont, Miłość a świat kultury zachodniej, tłum. L. Eustachiewicz, Warszawa 1999. Zob. G. Matuszek, Wstęp, [w:] S. Przybyszeuski, Synagoga szatana i inne eseje, oprac. i tłum. z niem. G. Matuszek, Kraków 1995, s. 29. 
Przekroczenie barier płci i ciała oraz ograniczeń ontologicznych i poznawczych zapeuniał mit Androgyne. Dokonujące się na poziomie cielesnym i duchowym odtworzenie Duój-Jedni, do której dążą uszyscy bohaterowie, miało doprowadzić do wewnętrznej harmonii i pełni. Ta koncepcja potwierdza, że miłość jest wyjściem $\mathrm{z}$ siebie $\mathrm{w}$ innego, a więc przezuyciężeniem samotności. Jednak w zderzeniu ludzkiego istnienia ze zobiektywizowaną i uspołecznioną rzeczywistością miłość okazuje się tragiczna i nierzadko wiąże ze śmiercią. Dualizm jest nie do pokonania u granicach naszego świata. Warunkiem spełnienia jest zatem transcendowanie, wyjście poza granice egzystencji, ku temu, co uyższe. Miłość jest taką transgresją. Ostateczne zualczenie samotności następuje tylko w integracji androgynicznej, przy czym dla artystów XIX-wiecznych androgynia oznacza przede wszystkim przekształcenie natury, ontyczno-antropologiczną przemianę jednostki. Stopniowo pojęcie to bywa jednak coraz częściej rozumiane jako niezgoda na sztucznie wznoszone podziały między płciami. Odnosi się do zintegrowania $w$ psychice indywiduum stylów zachowań i cech osobowości, które tradycyjnie uważa się za wyłącznie męskie lub wyłącznie kobiece. W modernizmie właśnie tkuią źródła uspółczesnego pojmowania androgynii jako umiejętności zachowania równowagi między uyróżnikami i wartościami przypisywanymi obu płciom oraz zdolności ich godzenia w postępowaniu jednostki. W ten sposób pozostaje Przybyszewski stale obecny w naszym myśleniu o płci. 


\section{Wykaz skrótów najczęściej cytowanych utworów Stanisława Przybyszeuskiego}

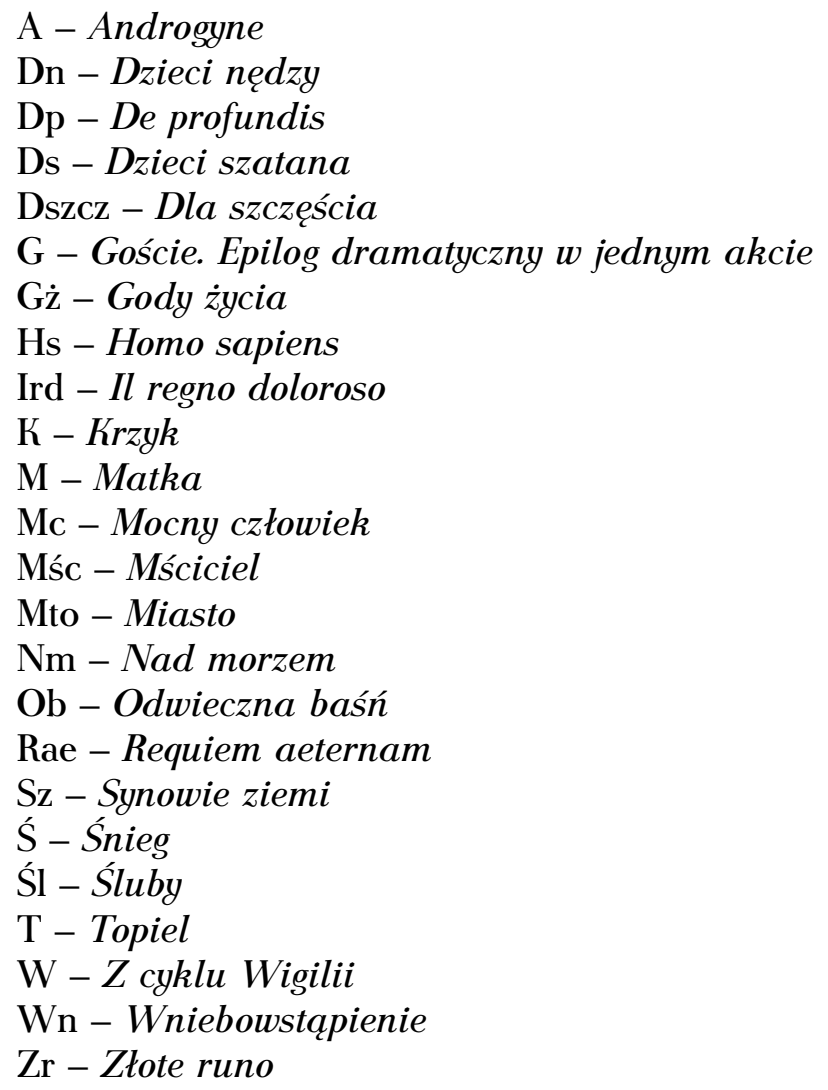





\section{Bibliografia}

\section{Bibliografia podmiotowa}

\section{Poematy}

S. Przybyszeuski, Androgyne, [w:] idem, Poematy proza, wybór i oprac.

G. Matuszek, Kraków 2003.

S. Przybyszeuski, Na tym padole ptaczu, [w:] idem, Poematy proza.

S. Przybyszeuski, Nad morzem, [w:] idem, Poematy proza.

S. Przybyszeuski, Requiem aeternam, [w:] idem, Poematy proza.

S. Przybyszeuski, Wniebowstapienie, [w:] idem, Poematy proza.

S. Przybyszeuski, $Z$ cyklu Wigilii, [w:] idem, Poematy proza.

\section{Dramaty}

S. Przybyszeuski, Dla szczęścia, Lwów 1900.

S. Przybyszeuski, Gody życia, Warszawa 1910.

S. Przybyszeuski, Goście. Epilog dramatyczny w jednym akcie, [w:] idem, Taniec miłości i śmierci, Luóu 1901.

S. Przybyszeuski, Matka, Warszawa 1902.

S. Przybyszeuski, Miasto, Kraków 1914.

S. Przybyszeuski, Mściciel, Warszawa 1927.

S. Przybyszeuski, Odwieczna baśń, Lwów 1906.

S. Przybyszeuski, Śluby, Wilno 1923.

S. Przybyszeuski, Śnieg, Warszawa 1987.

S. Przybyszeuski, Topiel, Warszawa 1912.

S. Przybyszeuski, Złote runo, [w:] idem, Wybór pism, oprac. R. Taborski, Wrocław 1966, s. 170-281.

\section{Pouieści}

S. Przybyszeuski, De profundis, Lwóu 1929.

S. Przybyszewski, Dzieci nędzy, Kraków 1913.

II część Dzieci nędzy (pt. Adam Drzazga), Kraków 1914. 
S. Przybyszeuski, Dzieci szatana, Kraków 1993.

S. Przybyszewski, Homo sapiens (cz. I - Na rozstaju, cz. II - Po drodze, cz. III - $W$ malstromie), Warszawa 1923.

S. Przybyszeuski, Krzyk, Lwów 1917.

S. Przybyszeuski, Il regno doloroso, Kraków 2003.

S. Przybyszeuski, Mocny człowiek (cz. II - Wyzwolenie, cz. III - Święty gaj), Warszawa 1923.

S. Przybyszewski, Synowie ziemi (cz. II - Dzień sqdu, cz. III - Zmierzch), Luów 1923.

\section{Teksty dyskursyune}

S. Przybyszeuski, Confiteor, [w:] idem, Wybór pism.

S. Przybyszeuski, Frontispice, [w:] idem, De profundis, Lwów 1929.

S. Przybyszeuski, Moi wspótcześni. Wśród obcych, Warszawa 1926.

S. Przybyszeuski, Moi wspótcześni, Warszawa 1959.

S. Przybyszeuski, Moralność a sztuka - „Alraune”, „Gazeta Wieczorna” 1917, nr 3705.

S. Przybyszeuski, Na drogach duszy, wyd. 2, Warszawa 1902.

S. Przybyszewski, Na marginesie tworu Ewersa, Lwów 1917.

S. Przybyszewski, Naokoło śmierci, Warszawa 1921.

S. Przybyszewski, $O$ dramacie i scenie, [w:] idem, Wybór pism.

S. Przybyszeuski, $O$O „nowa” sztuke, [w:] idem, Wybór pism.

S. Przybyszeuski, Przyczynek do etyki ptci, „Nasz Kraj” 1908, z. 9.

S. Przybyszewski, Synagoga Szatana. Przyczynek do psychologii czarownicy, Warszawa 1902.

S. Przybyszeuski, Synagoga szatana i inne eseje, oprac. i tłum. z niem. G. Matuszek, Kraków 1995.

S. Przybyszeuski, Szlakiem duszy polskiej, Poznań 1920.

S. Przybyszewski, Z psychologii jednostki twórczej, tłum. S. Helsztyński, [w:] idem, Wybór pism.

\section{Listy}

S. Przybyszeuski, Listy, oprac. S. Helsztyński, t. 1, Warszawa 1937.

S. Przybyszeuski, Listy, oprac. S. Helsztyński, t. 2, Warszawa 1938.

S. Przybyszewski, Listy, oprac. S. Helsztyński, t. 3, Warszawa 1954. 


\section{Bibliografia przedmiotowa}

\section{Opracowania dotyczące Przybyszeuskiego i jego epoki}

1. Ardens [Józef Koterbski], Wrogowie kobiety, „Biblioteka Warszawska" 1905 , t. 4, z. 1, s. 61-86.

2. G. Bąbiak, Między Berlinem, Praga a Warszawa. Przybyszewski - Procházka - Przesmycki, [w:] Czytanie modernizmu, red. M. Olszewska i P. Bąbiak, Warszawa 2004, s. 11-26.

3. E. Boniecki, Modernistyczny dramat ciała. Maria Komornicka, Warszawa 1998.

4. E. Boniecki, Struktura „nagiej duszy”. Studium o Stanisławie Przybyszewskim, Warszawa 1993.

5. G. Borkouska, Pteć jako skaza: Przybyszewski i Natkowska, [w:] Nowa świadomość ptci w modernizmie, red. G. Ritz, C. Binswanger, C. Scheide, Kraków 2000.

6. M. Bourkane, Stanisław Przybyszewski wobec wybranych aspektów filozofii genezyjskiej Stowackiego, „Pamiętnik Literacki” 2005, z. 3, s. 67-88.

7. E. Boyé, U kolebki modernizmu. Estetyczne poglady na tamach krakowskiego „Życia”, Kraków 1922.

8. S. Brzozouski, O Stanisławie Przybyszewskim, „Wiadomości Literackie" 1928, nr 18, s. 3.

9. Z. Bytkouski, Stanisław Przybyszewski, Lwów 1902.

10. P. Chmielouski, Najnowsze prady w poezji naszej, Warszawa 1901.

11. B. Chołuj, Gdyby nie miłość... Rzecz o utopii Stanisława Przybyszewskiego, [w:] Ciało, pteć, literatura, red. M. Hornung, M. Jędrzejczak, T. Korsak, Warszawa 2001.

12. K. Czachouski, Obraz wspólczesnej literatury polskiej 1884-1933, t. 1, Luów 1934.

13. Czas i przestrzeń w prozie polskiej XIX i XX wieku, red. C. Niedzielski i J. Spein, Toruń 1990.

14. A.B. Cyps, Stanistaw Przybyszewski od antynaturalisty do mistyka, Łódź 1923.

15. B. Cywiński, Rodowody niepokornych, Warszawa 1971.

16. Czytanie modernizmu, red. M. Olszewska i P. Bąbiak, Warszawa 2004.

17. G. Daniłouski, Jawnogrzesznica przed sadem, „Świat” 1913, nr 28, s. 9-10.

18. M. Dąbrouska, Piewca niedojrzałości duchowej, „Wiadomości Literackie" 1928, nr 18.

19. J. Detko, Znaczenie naturalizmu, „Miesięcznik Literacki” 1976, nr 4.

20. P. Dybel, Literatura jako histeria. O „Requiem aeternam” Stanisława Przybyszewskiego, „Przegląd Artystyczno-Literacki” 2000, nr 5, s. 116-133.

21. P. Dybel, Urwane ścieżki. Przybyszewski - Freud - Lacan, Kraków 2000. 
22. J. Dynak, Przybyszewski. Dzieje legendy i autolegendy, Wrocław 1994.

23. J. Dynak, Nasi dekadenci. Literackie konterfekty Przybyszewskiego, [w:] Młoda Polska. Legendy $i$ światopoglady, red. T. Bujnicki, Katowice 1983, s. $106-130$.

24. Erjot [Roman Jungiewicz], Z teki modernisty, „Kolce” 1902, nr 3.

25. L. Eustachiewicz, Dramaturgia Młodej Polski. Próba monografii dramatu z lat 1890-1918, Warszawa 1982.

26. W. Feldman, Wspótczesna literatura polska 1864-1918, t. 2, Kraków 1985.

27. I. Filipczak, Eryk Falk - geniusz zła czy obłąkany neurastenik? („Homo sapiens” Stanisława Przybyszewskiego), „Acta Universitatis Lodziensis. Folia Litteraria Polonica" 2005, z. 7.

28. H. Filipkowska, Z problematyki mitu w literaturze Młodej Polski, [w:] Problemy literatury polskiej lat 1890-1939, red. H. Kirchner i Z. Żabicki, Wrocław 1972.

29. H. Galle, Kronika literacka, „Biblioteka Warszauska” 1913, t. 3, s. 543-545.

30. M. Głowiński, Ekspresja i empatia. Studia o młodopolskiej krytyce literackiej, Kraków 1997.

31. M. Głowiński, Powieść młodopolska. Studium z poetyki historycznej, Kraków 1997.

32. Z. Goczołowa, Składnia powieści Stanisława Przybyszewskiego, Lublin 1975.

33. A. Górski, Młoda Polska, „Życie” 1898, nr 15, 16, 18, 19, 24, 25.

34. Z. Greń, Nie więcej, czyli o Przybyszewskim, [w:] idem, Rok 1900. Szkice o dramacie zapomnianym, Kraków 1969.

35. W. Grubiński, I tak, i nie, „Kurier Warszauski” 1931, nr 271, s. 8.

36. W. Gutouski, Chuć przeciw duszy narodu. O kompleksach polskich i erotyce modernizmu, „Acta Universitatis Nicolai Copernici” 1986, t. 28.

37. W. Gutouski, Konstelacja Przybyszewskiego, Toruń 2008.

38. W. Gutouski, Miłość śmierci i energia rozkładu. O młodopolskiej wyobraźni nekrofilskiej, „Pamiętnik Literacki” 1989, R. 80, z. 1, s. 37-71.

39. W. Gutouski, Mit Androgyne w poematach proza Stanisława Przybyszewskiego, „Acta Universitatis Nicolai Copernici” 1993, s. 67-87.

40. W. Gutouski, Mit - Eros - Sacrum. Sytuacje młodopolskie, Bydgoszcz 1999.

41. W. Gutouski, Młodopolskie inicjacje, „Ruch Literacki” 2002, z. 2, s. $121-133$.

42. W. Gutouski, Nagie dusze i maski (O młodopolskich mitach miłości), Kraków 1992.

43. W. Gutouski, Pasje wyobraźni. Szkice o literaturze romantyzmu i Młodej Polski, „Prace Wydziału Filologiczno-Filozoficznego”, t. 33, z. 2, Toruń 1991. 
44. W. Gutouski, Pokusy nicości i tajemnice Petni. Młodopolskie obrazy eschatologii, [w:] W kreggu Młodej Polski. Prace ofiarowane M. PodrazieKwiatkowskiej, red. M. Stala, F. Ziejka, Kraków 2001, s. 13-46.

45. W. Gutouski, Wśród szyfrów transcendencji. Szkice o sacrum chrześcijańskim w literaturze polskiej $X X$ wieku, Toruń 1994.

46. W. Gutouski, $Z$ próżni nieba ku religii życia. Motywy chrześcijańskie w literaturze Młodej Polski, Kraków 2002.

47. S. Helsztyński, Meteory Młodej Polski, Kraków 1969.

48. S. Helsztyński, Przybyszewski, Warszawa 1973.

49. W. A. Herget, Źródła filozoficzne twórczości Przybyszewskiego, „Nowa Reforma” 1915, nr 281, s. 1-2.

50. P. Hultberg, Styl wczesnej prozy fabularnej Wacława Berenta, tłum. I. Sieradzki, Wrocław 1969.

51. A. Hutnikiewicz, „Być meteorem, to istotna moja tęsknota”, „Przegląd Artystyczno-Literacki" 1995, nr 3, s. 16-19.

52. A. Hutnikiewicz, Stanisław Przybyszewski. Legenda i rzeczywistość, [w:] idem, Portrety $i$ szkice literackie, s. 41-56.

53. K. Irzykouski, Czyn i słowo. Glossy sceptyka, Lwów 1913.

54. J. Iwaszkiewicz, Przybyszewski klasyk, „Życie Warszawy” 1966, nr 261. 55. W. Jabłonouski, Wrażenia literackie II, „Głos” 1899, $\mathrm{nr} 2$, s. 506-510.

56. M. Jankowiak, Funkcja mitu w prozie Przybyszewskiego i Berenta, [w:] Problemy literatury polskiej lat 1890-1939, red. H. Kirchner i Z. Żabicki, Wrocław 1972.

57. T. Jeske-Choiński, Nowoczesna kobieta, Warszawa 1917.

58. T. Jeske-Choiński, Seksualizm w powieści polskiej, Warszawa 1914.

59. W. Kaczmarek, Złamane pieczęcie Księgi. Inspiracje biblijne w dramaturgii Młodej Polski, Lublin 1999.

60. P. Kawalec, Stanisław Przybyszewski w czeskim świecie literackim, Kraków 2007.

61. Z. Klimajówna, Nazwiska bohaterów powieści S. Przybyszewskiego „Roczniki Humanistyczne" 1967, z. 1.

62. K. Kolińska, Córka smutnego szatana, Warszawa 1993.

63. K. Kolińska, $W$ kręgu smutnego szatana, [w:] eadem, Parnas $w$ Oborach, Warszawa 2000.

64. K. Kolińska, Stachu, jego kobiety, jego dzieci, Kraków 1978.

65. S. Kołaczkouski, Twórcze fermenty, „Wiadomości Literackie” 1928, nr 18 , s. 1 .

66. J. Kostecki, Wybory lekturowe abonentów warszawskich wypożyczalni prywatnych na przetomie lat 80. i 90. XIX w., [w:] Przetom antypozytywistyczny w polskiej świadomości kulturowej końca XIX w., red. T. Bujnicki, J. Maciejeuski, Wrocław 1986. 
67. K. Kralkouska-Gątkouska, Antymimesis i wizja. Typy konstrukcji przestrzeni w powieściach Stanisława Przybyszewskiego, [w:] Przełom antypozytywistyczny w polskiej świadomości kulturowej końca XIX w., red. T. Bujnicki i J. Maciejeuski, Wrocław 1986, s. 131-161.

68. K. Kralkouska-Gątkouska, Matki, córki, mentorzy. O dyskursie edukacyjnym $i$ emancypacyjnym w prozie XIX wieku, [w:] Przez dwa stulecia. In memoriam Artur Hutnikiewicz, Toruń 2006.

69. K. Kralkowska-Gątkouska, Świat postaci w powieściach Stanisława Przybyszewskiego, [w:] Młoda Polska. Legendy i światopoglady, red. T. Bujnicki, Katowice 1983.

70. K. Kralkouska-Gątkouska, Zagadki „De profundis” Stanisława Przybyszewskiego (Autoprzekład autoerotycznej powieści), [w:] Topika erotyczna w przekładzie, red. P. Fast, Katowice 1994.

71. M. Krassouski, Przybyszewski, moderna i postmodernizm, „Wiadomości Kulturalne" 1995, nr 46, s. 1, 4.

72. M. Krzymuska, Stanisław Przybyszewski, jego poezja i filozofia, [w:] eadem, Studia literackie, Warszawa 1903.

73. L. Krzywicki, Ludożerstwo i szał krwiożerczo-erotyczny, „Prawda” 1887. Przedruk [w:] idem, Artykuty $i$ rozprawy 1886-1888, Dzieła, t. 3, Warszawa 1959.

74. L. Krzywicki, Stanistaw Przybyszewski, [w:] idem, Wspomnienia, oprac. J. Wilhelmi, t. 2, Warszawa 1958.

75. L. Krzywicki, Wilkołactwo. Szkic psychiatryczno-antropologiczny, „Prawda" 1888. Przedruk [w:] idem, Artykuty $i$ rozprawy 1886-1888, Dzieła, t. 3, Warszawa 1959.

76. W. Kubacki, Rzecz o Przybyszewskim, [w:] idem, Lata terminowania. Szkice literackie 1932-1962, s. 173-199.

77. M. Kuncewiczowa, Fantasia alla polacca, Warszawa 1982.

78. M. Kuncewiczowa, Przybyszewski - dekadent czy wizjoner?, „Literatura" 1975 , nr 26, s. 8-9.

79. J. Lorentowicz, „Synowie ziemi” Przybyszewskiego, „Kurier Codzienny” 1904, nr 281, s. 2.

80. A. Lubaszeuska, Życie - Śmierci doskonałość. Młodopolska antropologia śmierci i literacki świat wartości, Kraków 1995.

81. B. Lutomski, Kobieta i kobiecość, „Tygodnik Ilustrowany” 1901, nr 38.

82. W. Lutosłauski, Bańki mydlane. Poglad krytyczny na tak zwany satanizm nagich a pijanych dusz, Kraków 1899.

83. K. Łuczyński, Dwujęzyczna twórczość Stanisława Przybyszewskiego (1892-1900), Kielce 1982.

84. I. Maciejeuska, Wielkie miasto w prozie okresu Młodej Polski a problemy naturalizmu, [w:] Problemy literatury polskiej okresu pozytywizmu, seria 3, red. E. Jankouski, J. Kulczycka-Saloni, Wrocław 1984. 
85. A.Z. Makowiecki, Kłamstwa kompensacyjne autobiografizmu - Stanistaw Przybyszewski, [w:] Autobiografizm - przemiany, formy, znaczenia, red. H. Gosk i A. Zieniewicz, Warszawa 2001, s. 104-113.

86. A.Z. Makowiecki, Przybyszewski, [w:] idem, Trzy legendy literackie, Warszawa 1980.

87. A.Z. Makowiecki, Ten wyuzdany fin de siècle..., [w:] idem, Wokót modernizmu. Szkice, Warszawa 1985, s. 167-181.

88. G. Matuszek, Der geniale Pole? Niemcy o Stanisławie Przybyszewskim (1892-1992), Kraków 1996.

89. G. Matuszek, Incest w literaturze przełomu XIX i XX wieku, [w:] Zrozumieć płeć II: studia interdyscyplinarne, red. A. Kuczyńska i E.K. Dzikouska, Wrocław 2004.

90. G. Matuszek, Jak czytano powieści „wielkiego demoralizatora”, „Pamiętnik Literacki" 1985, R. 76, z. 2, s. 35-48.

91. G. Matuszek, Kultura contra natura? O mizoginizmie minionego fin de siècle'u, [w:] W kręgu Młodej Polski, red. M. Stala, F. Ziejka, Kraków 2001, s. $47-60$.

92. G. Matuszek, Melancholik, mistyk, narcystyczny kochanek, samotny homo dolorosus [ustęp], [w:] S. Przybyszeuski, Poematy proza, oprac. G. Matuszek, Kraków 2003.

93. G. Matuszek, Seksualizm i androgynizm. O erotyce w twórczości Stanisława Przybyszewskiego, „Rocznik Kasprowiczouski” 1990.

94. G. Matuszek, Stanisław Przybyszewski - pisarz nowoczesny. Eseje i proza - próba monografii, Kraków 2008.

95. I. Matuszewski, Stowacki i nowa sztuka (modernizm), oprac. S. Sandler, Warszawa 1965.

96. Młodopolski świat wyobraźni. Studia i eseje, red. M. Podraza-Kwiatkowska, Kraków 1977.

97. B. Mazan, Wczesne dramaty Aleksandra Świętochowskiego. Niewinni, Ojciec Makary, Piękna, Łódź 1991.

98. B. Mazan, $Z$ obrazów Chin i Chińczyków w piśmiennictwie polskim drugiej połowy XIX wieku. „Chińskie cienie” w „Lalce” Bolestawa Prusa, [w:] Pozytywizm i negatywizm. My $i$ wy po stu latach, red. B. Mazan, Łódź 2005.

99. Miasto - kultura - literatura. Wiek XIX, red. J. Data, Gdańsk 1993.

100. A. Moskwin, Stanisław Przybyszewski w kulturze rosyjskiej końca XIX - poczatku XX wieku, Warszawa 2007.

101. S. Mrazek, Gestyka w dramatach Stanisława Przybyszewskiego, [w:] idem, Środki ekspresji pozastownej $w$ dramatach Staffa, Tetmajera i Przybyszewskiego, Kraków 1980, s. 109-141.

102. Z. Nałkouska, Moralność Przybyszewskiego, „Wiadomości Literackie" 1928 , nr 18, s. 6. 
103. A. Niemojeuski, Prorok wykolejeńców, „Głos” 1902, nr 5, s. 67-68.

104. Nowa świadomość ptci w modernizmie, red. G. Ritz, C. Binswanger, C. Scheide, Kraków 2000.

105. A. Nowaczyński, Przybysz, „ABC” 1933, nr 221, 222.

106. J. Nowiński, Stanisław Przybyszewski, Warszawa 1902.

107. E. Piasecka, „Dolina mroku”. Groza i niesamowitość w prozie polskiej lat 1890-1918, Opole 2006.

108. M. Podraza-Kwiatkouska, Literatura Młodej Polski, Warszawa 1992.

109. M. Podraza-Kuiatkouska, Somnambulicy - dekadenci - herosi. Studia i eseje o literaturze Młodej Polski, Kraków 1985.

110. M. Podraza-Kuiatkouska, Symbolizm i symbolika w poezji Młodej Polski, Kraków 2001.

111. M. Podraza-Kuiatkouska, Schopenhauer i chuć, „Teksty” 1974, z. 2, s. 25-35.

112. M. Podraza-Kuiatkouska, Wolność i transcendencja. Studia i eseje o Młodej Polsce, Kraków 2001.

113. M. Popiel, Wzniostość - retoryka cierpienia (O prozie Stanisława Przybyszewskiego), „Ruch Literacki” 1996, R.: 37, z. 1, s. 37-49.

114. Problematyka religijna $w$ literaturze pozytywizmu $i$ Młodej Polski, red. S. Fita, Lublin 1993.

115. Problemy literatury polskiej lat 1890-1939, red. H. Kirchner i Z. Żabicki, Wrocław 1972.

116. Programy i dyskusje literackie okresu Młodej Polski, oprac. M. Podraza-Kuiatkouska, Wrocław 2000.

117. W. Presser, Stanisław Przybyszewski. Studium literackie, Lwów 1903.

118. J. Ratajczak, Umrzeć z miłości. Szkice o romansach mtodopolskich, Wrocław 1999.

119. H. Ratuszna, Wieczność w człowieku. O młodopolskiej świadomości śmierci w twórczości Stanisława Przybyszewskiego, Toruń 2005.

120. Recenzja teatralna ze Złotego runa, „Śmigus” 1901, nr 7.

121. A. Rogalski, Przybyszewski filozof - moralista, Poznań 1946.

122. A. Rogalski, Stanisław Przybyszewski. Próba rewizji twórczości, [w:] idem, Literatura i cywilizacja. Eseje $i$ studia, Warszawa 1956, s. 42-55.

123. E. Rzewuska, Dramaturgia Przybyszewskiego i ekspresionizm, [w:] Jan August Kisielewski i problemy dramatu młodopolskiego, red. E. Łoch, Rzeszów 1980.

124. W. Rzymouski, Cud Magdaleny, „Prawda” 1913, nr 14, s. 7-11.

125. M. Sadlik, „Konfesje samotnych”. W kręgu prozy spowiedniczej 1884-1914, Kraków 2004.

126. D. Samborska-Kukuć, Narcyz w masce tragicznej. Sobowtór jako eksterioryzacja duszy w opowiadaniu Leo Belmonta „Tamten człowiek”, „Pamiętnik Literacki” 2005, z. 3. 
127. A. Sawicka, Dagny Juel Przybyszewska. Fakty i legendy, Gdańsk 2006.

128. D. Siwicka, „Naga dusza” $i$ eksperyment egzystencjalny, „Pamiętnik Literacki" 1987, z. 1, s. 155-163.

129. M. Schluchter, Stanislaw Przybyszewski und seine deutschsprachigen Prosawerke 1892-1899, Ludwigsburg/Württ 1969.

130. H. Schmid, Znaczenie Stanisława Przybyszewskiego dla rozwoju eksperymentalnego teatru Wsiewołoda E. Meyerholda, „Ruch Literacki” R. 31:1990, z. 6, s. 419-433.

131. R. Shenfeld, Obecność Stanisława Przybyszewskiego $w$ literaturze hebrajskiej na przetomie XIX i XX wieku, [w:] Stulecie Młodej Polski, red. M. Podraza-Kuiatkouska, Kraków 1995, s. 377-390.

132. H. Sienkiewicz, Odpowiedź na ankietę w sprawie dramatu modernistycznego, „Kurier Teatralny” 1903, nr 55; przedr. Pisma zapomniane i nie wydane. Z polecenia rodziny wydat I. Chrzanowski, Lwów 1922.

133. I. Sikora, „Asfodele - liany - tuberozy...”. O mtodopolskiej egzotyce florystycznej, [w:] idem, Łabędź i lira. Studia i szkice o literaturze Młodej Polski, Zielona Góra 2001.

134. I. Sikora, Symbolika kwiatów w poezji Młodej Polski, Szczecin 1987.

135. I. Sikora, Wstep, [w:] W kręgu Salome i Astarte. Młodopolskie wiersze miłosne, oprac. I. Sikora, Wrocław 1993.

136. I. Sławińska, August Strindberg i wczesny ekspresjonizm polski, [w:] eadem, Moja gorzka europejska ojczyzna, Warszawa 1988.

137. I. Sławińska, Tragedia w epoce Młodej Polski. Z zagadnień struktury dramatu, Toruń 1948.

138. L. Sokół, Metafizyka ptci: Strindberg, Weininger $i$ Witkacy, „Pamiętnik Literacki" R. 76: 1985, z. 4.

139. B. Spannhake, „Nietzsche byt jak rumak najszlachetniejszej rasy, ale źle ujeżdżony”. Przybyszewskiego (naturalistyczna) interpretacja Nietzschego, [w:] Friedrich Nietzsche i pisarze polscy, red. W. Kunicki, Poznań 2002.

140. M. Stala, Pejzaż człowieka. Młodopolskie myśli i wyobrażenia o duszy, duchu i ciele, Krakóu 1994.

141. Stanisław Przybyszewski. W 50-lecie zgonu pisarza, red. H. Filipkowska, Wrocław 1982.

142. Stulecie Młodej Polski, red. M. Podraza-Kwiatkouska, Kraków 1995.

143. M. Stykowa, Teatralna recepcja Maeterlincka w okresie Młodej Polski, Wrocław 1980.

144. A. Sucharska, Stanisław Przybyszewski. Mitość: „Rozślizłe prześcieradto moich uczuć”, „Metafora” 1992, nr 5, s. 7-13.

145. A. Sygietyński, Porachunki. Neosoteryzm, „Gazeta Polska” 1899, nr 133.

146. W. Szczepański, Nowy indeks książek zakazanych, Kraków 1903. 
147. J.N. Szuman, Wyznanie wiary modernisty, „Głos” 1900, $\mathrm{nr} 35$, s. $557-558$.

148. B. Szymańska, Mistycy i pesymiści. Przeżycia i uczucia jako wartości w filozofii polskiego modernizmu, Wrocław 1991.

149. R. Taborski, Trzech dramatopisarzy modernistycznych. Przybyszewski - Kisielewski - Szukiewicz, Warszawa 1965.

150. J. Tomkowski, Młoda Polska, Warszawa 2001.

151. D. Trześniouski, „A trwanie twoje jest, jak śmierć, na zawsze - coraz straszniejsze i krwawsze...”. Modernistyczny wizerunek Salome, „Pamiętnik Literacki" 2001, z. 1, s. 7-31.

152. D. Trześniouski, $W$ stronę człowieka. Biblia w literaturze polskiej (1863-1918), Lublin 2005.

153. J. Tuczyński, Schopenhauer a Młoda Polska, Gdańsk 1969.

154. J. Tynecki, Eros rozczłonkowany (albo Prus wobec Androgyne), [w:] idem, Światopogląd pozytywizmu. Wybór pism, Łódź 1996, s. 249-269.

155. T. Walas, Ku otchłani (dekadentyzm w literaturze polskiej 1890-1905), Krakóu 1986.

156. T. Weiss, Polski wzorzec archicygana: Stanisław Przybyszewski, [w:] idem, Cyganeria Młodej Polski, Kraków 1970, s. 63-77.

157. K. Wyka, Modernizm polski, wyd. 2. zmien. i powiększ., Kraków 1968.

158. X, Hymn do losu, „Diabeł” 1899, nr 5.

159. K. Zabawa, „Kalejdoskop myśli, wrażeń i obrazów” - mtodopolskie odmiany krótkiego poematu proza, Kraków 1999.

160. M. Zdziechouski, Ptazy a ptaki, [w:] Programy $i$ dyskusje literackie okresu Młodej Polski, oprac. M. Podraza-Kuiatkowska, Wrocław 2000.

161. Ze sportu, „Diabel” 1900, nr 16, s. 3.

162. J. Zieliński, Pierwsze zdanie „Homo sapiens”, „Teksty” 1977, nr 4.

163. T. Żeleński (Boy), Blaski i nędze mowy polskiej, „Wiadomości Literackie" 1928, nr 30.

164. T. Żeleński (Boy), Ludzie żywi, Pisma, t. 3, Warszawa 1956.

165. T. Żeleński (Boy), Smutny szatan, [w:] idem, Szkice o literaturze niemoralnej, Warszawa 1990.

166. T. Żeleński (Boy), Wstęp, [w:] Młoda Polska. Wybór poezji, oprac. T. Żeleński, Wrocław 1947.

167. T. Żeleński (Boy), Znaszli ten kraj?, Kraków 1962.

\section{Inne opracouania historycznoliterackie}

\section{i teoretycznoliterackie}

1. A. Czyż, Mortęska, Drużbicki i lilie mistyczne. Symbolika roślinna w prozie polskiej wczesnego baroku, [w:] Literacka symbolika roślin, oprac.

A. Martuszeuska, Gdańsk 1997. 
2. T. Hargreaves, Androgyny in Modern Literature, New York 2005.

3. E. Hoffmann-Piotrouska, „Naga dusza” Mickiewicza-towiańczyka (przyczynek do mistycznej antropologii poety), „Przegląd Humanistyczny” 2002, z. 2, s. 71-79.

4. Kobiety w literaturze, oprac. L. Wiśnieuska, Bydgoszcz 1999.

5. E. Kraskouska, Dwujęzyczność a problemy przekładu, [w:] Miejsca wspólne. Szkice o komunikacji literackiej i artystycznej, red. E. Balcerzan i S. Wysłouch, Warszawa 1985.

6. Literacka symbolika roślin, red. A. Martuszewska, Gdańsk 1997.

7. Literacka symbolika zwierzat, red. A. Martuszewska, Gdańsk 1993.

8. Literatura wobec niewyrażalnego, red. W. Bolecki, E. Kuźma, Warszawa 1998.

9. K. Mrówka, Androgyn, Szczecin 2005.

10. M. Piwińska, Miłość romantyczna, Kraków-Wrocław 1974.

Prace filozoficzne, socjologiczne, religioznawcze i kulturoznawcze

1. G. Bachelard, Wyobraźnia poetycka, tłum. H. Chudak i A. Tatarkieuicz, Warszawa 1975.

2. E. Badinter, Tożsamość mężczyzny, tłum. G. Przewłocki, Warszawa 1993.

3. Bestiariusz, tłum. R. Sasor, Kraków 2005.

4. S. Borzym, Obecność ryzyka. Szkice z filozofii powszechnej, Warszawa 1998.

5. H. Buczyńska-Garewicz, Metafizyczne rozważania o czasie, Kraków 2003.

6. R. Caillois, Modliszka, [w:] idem, Odpowiedzialność i styl. Eseje, tłum. K. Dolatouska, Warszawa 1967.

7. E. Cioran, Zły demiurg, tłum. I. Kania, Kraków 1995.

8. K. Darwin, $O$ wyrazie uczuć u człowieka $i$ zwierzat, t. 6 Dziet wybranych, red. R. Wojtusiak, tłum. Z. Majlert, K. Zaćwilichouska, Warszawa 1959.

9. B. Dobroczyński, Idea nieświadomości w polskiej myśli psychologicznej przed Freudem, Kraków 2005.

10. K. Du Prel, Spirytyzm, tłum. S. Brzozouski, Warszawa 1908.

11. E. Durkheim, Samobójstwo, tłum. K. Wakar, Warszawa 2006.

12. B. Dybouski, O kwestii kobiecej ze stanowiska nauk przyrodniczych, Lwóu 1897.

13. M. Eliade, Obrazy i symbole: szkice o symbolizmie magiczno-religijnym, tłum. M. i P. Rodakowie, Warszawa 1998.

14. M. Eliade, Sacrum, mit, historia. Wybór esejów, tłum. A. Tatarkiewicz, Warszawa 1987.

15. M. Eliade, Traktat o historii religii, tłum. J. Wierusz-Koualski, Warszawa 1966.

16. Estetyka czterech żywiołów. Ziemia, woda, ogień, powietrze, red. K. Wilkoszeuska, Kraków 2002. 
17. Ewangelia wedtug Tomasza, [w:] Apokryfy Nowego Testamentu, t. 1, red. M. Starowieyski, Lublin 1986.

18. U. Frevert, Maż $i$ niewiasta, niewiasta $i$ maż. O różnicach ptci $w$ czasach nowoczesnych, przeł. A. Kopacki, Warszawa 1997.

19. D. Gilmore, Mizoginia, czyli męska choroba, tłum. J. Margański, Kraków 2003.

20. M. Głowiński, Mity przebrane, Kraków 1994.

21. M. Gołaszeuska, Imiona miłości, Kraków 1992.

22. H. Hofstätter, Symbolizm, tłum. S. Błaut, Warszawa 1987.

23. J. Huizinga, Jesień Średniowiecza, tłum. T. Brzostouski, Warszawa 1967.

24. M. Janion, Salome tańczy, [w:] eadem, Żyjac tracimy życie. Niepokojace tematy egzystencji, Warszawa 2001, s. 289-300.

25. M. Janion, Wampir. Biografia symboliczna, Gdańsk 2004.

26. A.Kępiński, Psychopatologia nerwic, Kraków 2002.

27. S. Kijaczko, Wobec bycia. Filozoficzny problem samobójstwa, Opole 2005.

28. R. Krafft-Ebing, Zboczenia umysłowe na tle zaburzeń ptciowych. Psychopatia sexualis, tłum. A. Fabian, Warszawa 1908.

29. L. Krzywicki, Ludożerstwo i szał krwiożerczo-erotyczny, „Prawda” 1887.

30. L. Krzywicki, Wilkołactwo. Szkic psychiatryczno-antropologiczny, „Prawda" 1888 .

31. Z. Kuderouicz, Nietzsche, Warszawa 1979.

32. E. Kuryluk, Salome, albo o rozkoszy, Kraków 1976.

33. E. Lévinas, Całość i nieskończoność. Eseje o zewnętrzności, tłum. M. Kowalska, Warszawa 2002.

34. C. Lombroso, Miłość u obłąkanych, tłum. M.W. [Wacłau Moraczeuski? Mamert Wikszemski?], Warszawa 1894.

35. M. Lurker, Przestanie symboli $w$ mitach, kulturach $i$ religiach, tłum. R. Wojnakouski, Kraków 1994.

36. P. Mantegazza, Wiek nerwowy, tłum. J. Wollerner, Złoczów 1890.

37. J. Marx, Idea samobójstwa w filozofii, Warszawa 2003.

38. R. May, Miłość $i$ wola, tłum. H. i P. Śpiewakowie, Warszawa 1978.

39. J.S. Mill, Poddaństwo kobiet, tłum upoważnione przez autora, Toruń 1870. 40. J.S. Mill, Utylitaryzm; O wolności, przeł. M. Ossouska, A. Kurlandzka, Warszawa 2006.

41. L. Miodoński, Nieświadome w idealizmie niemieckim, [w:] Nieświadomość to odrębne królestwo..., red. I. Błocian, R. Saciuk, Toruń 2003.

42. F. Nietzsche, Ecce homo, thum. L. Staff, Warszawa 1909.

43. F. Nietzsche, Poza dobrem i złem, tłum. S. Wyrzykouski, Warszawa 1907.

44. F. Nietzsche, Tako rzecze Zaratustra, thum. W. Berent, Warszawa 1907.

45. F. Nietzsche, Wiedza radosna, przeł. L. Staff, Warszawa 1910-1911. 
46. M. Nordau, Miłość, tłum. W.L., Warszawa 1903.

47. J. Ochorowicz, Miłość, zbrodnia, wiara i moralność. Kilka studiów z psychologii kryminalnej, Warszawa 1870.

48. J. Ortega y Gasset, Portret Salome, [w:] idem, Szkice o miłości, thum. K. Kamyszewa, Warszawa 1989, s. 151-158.

49. M. Ossouska, Moralność mieszczańska, Wrocław 1985.

50. Pismo Święte Nowego Testamentu, ustęp i komentarz ks. E. Dąbrouski, Warszawa 1949.

51. Owidiusz, Przemiany, tłum. B. Kiciński, Kraków 2002.

52. Platon, Uczta, oprac. i tłum. W. Wituicki, Warszawa 1984.

53. M. Poprzęcka, Akt polski, Warszawa 2006.

54. T. Ribot, Logika uczuć, tłum. K. Błeszyński, Kraków 1921.

55. R. Rolheiser, The Holy Longing, New York 1999.

56. D. de Rougemont, Miłość a świata kultury zachodniej, thum. L. Eustachiewicz, Warszawa 1999.

57. J.-P. Roux, Krew. Mity, symbole, rzeczywistość, tłum. M. Perek, Kraków 1994.

58. N.J. Saunders, Dusze zwierzat, tłum. Z. Daleuski, Warszawa 1996.

59. A. Schopenhauer, Metafizyka miłości płciowej, wybór i tłum. A. Pańta, Gdańsk 1995.

60. A. Schopenhauer, Metafizyka życia i śmierci, thum. J. Marzęcki, Łódź 1995.

61. K. Starczeuska, Wzory miłości w kulturze Zachodu, Warszawa 1975.

62. W. Tatarkiewicz, Historia filozofii, 3 t., Warszawa 2003.

63. E. Trillat, Historia histerii, tłum. Z. Podgórska-Klawe, E. Jamrozik, Wrocław 1993.

64. A. Tytkouska, Lilith: polskie dziedzictwo hebrajskiego mitu, [w:] Mity, mitologie, mityzacje nie tylko w literaturze, red. L. Wiśnieuska, Bydgoszcz 2005, s. 109-118.

65. M. Uliński, Kobieta i mężczyzna. Dzieje refleksji filozoficzno-społecznej, Kraków 2001.

66. O. Weininger, Płeć i charakter, tłum. O. Ortwin, Warszawa 1994.

67. T. Weiss, Fryderyk Nietzsche w piśmiennictwie polskim lat 1890-1914, Wrocław 1961.

68. M.A. Zawadzki, Przewodnik zakochanych, czyli Jak zdobyć szczęście w miłości i powodzenie u kobiet, Warszawa 2007.

\section{Słouniki, encyklopedie, leksykony}

1. C.J. Cela, Stownik erotyzmu, tłum. K. Adamska, Warszawa 2002.

2. J.E. Cirlot, Stownik symboli, przeł. I. Kania, Kraków 2006.

3. J.C. Cooper, Zwierzęta symboliczne i mityczne, tłum. A. Kozłouska-Ryś, L. Ryś, Poznań 1998. 
4. A. Cotterell, Stownik mitów świata, tłum. W. Ceran, M. Dąbrouska, Katowice 1996.

5. Encyklopedia powszechna S. Orgelbranda, 28 t., Warszawa 1859-1869.

6. Encyklopedia powszechna z ilustracjami i mapami S. Orgelbranda, 18 t., Warszawa 1898-1904.

7. W. Kopaliński, Stownik symboli, Warszawa 1991.

8. Księga ilustrowana wiadomości pożytecznych. Popularny podręcznik encyklopedyczny z dziedziny..., Warszawa 1899.

9. J. Laplanche, J. Pontalis, Stownik psychoanalizy, tłum. E. Modzeleuska i E. Wojciechouska, Warszawa 1996.

10. Podręczna encyklopedia powszechna, red. A. Wiślicki, 6 t., Warszawa 1895-1901.

11. D. Sharp, Leksykon pojęć i idei C.G. Junga, tłum. J. Prokopiuk, Wrocław 1998.

12. Słownik języka polskiego, red. J. Karłowicz, A. Kryński, W. Niedźwiedzki, 8 t., Warszawa 1900-1927.

13. Stownik literatury polskiej XIX w., red. J. Bachórz i A. Kowalczykowa, Wrocław 2002.

\section{Utwory literackie}

1. A. Asnyk, Poezje zebrane, ustęp Z. Mocarska-Tycowa, Toruń 2000.

2. Ch. Baudelaire, Sztuka romantyczna. Dzienniki poufne, thum. A. Kijouski, Warszawa 1971.

3. L. Belmont, $W$ wieku nerwowym, Warszawa 1928.

4. R. Dehmel, Poezje, tłum. A. Spaet, Lwów 1933.

5. H.H. Ewers, Alraune. Dzieje istoty żyjącej, tłum. J. Przybyszewska, Lwów 1917.

6. T. Gautier, Panna de Maupin, tłum. T. Żeleński (Boy), Warszawa 1958.

7. W. Grubiński, Na rubieży, Kraków 1906.

8. J.-K. Huysmans, Na wspak, tłum. J. Rogoziński, Warszawa 1976.

9. J.A. Kisielewski, $W$ sieci, Kraków 2002.

10. M. Komornicka, Szkice, Warszawa 1894.

11. M. Kulikouska, $Z$ dziejów duszy, Kraków 1911.

12. A. Lange, Rozmyślania, Kraków 1906.

13. M. Maeterlinck, Confession de poete, „L'art Moderne” 1891, z. 23.

14. T. Miciński, Pieśń triumfującej miłości, [w:] idem, Poematy prozą, Kraków 1985.

15. A. Mombert, Śnienie twórcy, tłum. S. Przybyszeuski, „Znicz” 1903.

16. T. Nalepiński, Kazia, Kraków-Warszawa 1927.

17. H. Orlicz-Garlikouska, Żar, Warszawa 1921.

18. B. Prus, Lalka, oprac. J. Bachórz, t. 1-2, Wrocław 1991. 
19. B. Prus, Ze wspomnień cyklisty, [w:] idem, Dzieła, red. Z. Szweykouski, Warszawa 1948, t. 24.

20. D. Przybyszeuska, Kiedy słońce zachodzi, Warszawa 1902.

21. D. Przybyszeuska, Krucze gniazdo, Warszawa 1902.

22. J. Schlaf, Wiosna, tłum. S. Przybyszeuski, Lwów 1907.

23. E. Słoński, Wśród szronu, Warszawa 1910.

24. M. Srokowski, Kult ciała. Dziennik człowieka samotnego, Lwów 1920 [reprint Spółdzielni Wydawniczo-Księgarskiej w Opolu 1990].

25. K. Tetmajer, Otchtań. Fantazja psychologiczna, Warszawa 1901.

26. K. Tetmajer, Poezje, Warszawa 1980.

27. K. Tetmajer, Poezje wybrane, oprac. J. Krzyżanouski, Wrocław 1968.

28. L. Tołstoj, Sonata Kreutzerowska, tłum. M. Leśnieuska, Warszawa 1987.

29. O. Wilde, Portret Doriana Graya, tłum. M. Feldmanowa, Wrocław 1996.

30. S. Żeromski, Dzieje grzechu, Kraków 2005.

31. E. Żmijeuska, Dola, Warszawa 1959. 